\title{
VARIASI SPASIAL-TEMPORAL HIDROGEOKIMIA DAN SIFAT ALIRAN UNTUK KARAKTERISASI SISTEM KARST DINAMIS DI SUNGAI BAWAH TANAH BRIBIN, KABUPATEN GUNUNG KIDUL, DIY
}

\section{Disertasi}

\section{Program Studi Geografi}

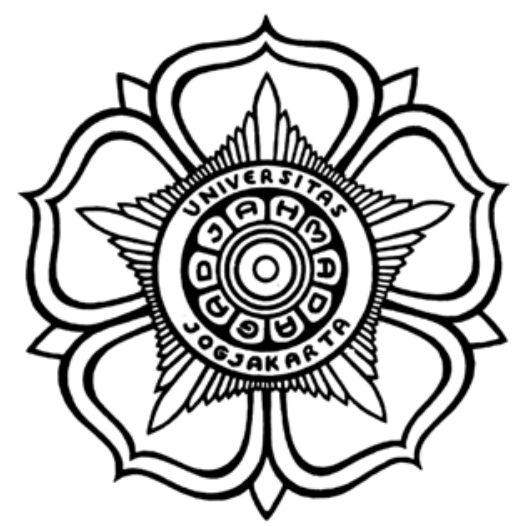

Oleh:

Tjahyo Nugroho Adji 05/1729/PS

PROGRAM PASCA SARJANA

FAKULTAS GEOGRAFI

UNIVERSITAS GADJAH MADA

YOGYAKARTA 2010 


\title{
VARIASI SPASIAL-TEMPORAL HIDROGEOKIMIA DAN SIFAT ALIRAN UNTUK KARAKTERISASI SISTEM KARST DINAMIS DI SUNGAI BAWAH TANAH BRIBIN, KABUPATEN GUNUNG KIDUL, DIY
}

\author{
Disertasi untuk memperoleh \\ Derajat Doktor dalam Ilmu Geografi pada \\ Universitas Gadjah Mada
}

\author{
Dipertahankan di hadapan \\ Dewan Penguji Program Pasca Sarjana \\ Fakultas Geografi \\ Universitas Gadjah Mada \\ Pada tanggal: 21 Desember 2009
}

Oleh:

Tjahyo Nugroho Adji

Lahir
di Magelang, 28 Januari 1972 


\section{PERNYATAAN}

Dengan ini saya menyatakan bahwa dalam Disertasi ini tidak terdapat karya yang pernah diajukan untuk memperoleh gelar kesarjanaan di suatu Perguruan Tinggi, dan sepanjang pengetahuan saya juga tidak terdapat karya atau pendapat yang pernah ditulis atau diterbitkan oleh orang lain, kecuali yang secara tertulis diacu dalam naskah ini dan disebutkan dalam daftar pustaka.

Yogyakarta, Februari 2009

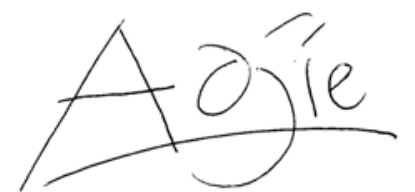

Tjahyo Nugroho Adji 


\section{HALAMAN PERंSETUJUAN DISERTASI}

\section{VARIASI SPASIAL-TEMPORAL HIDROGEOKIMIA DAN SIFAT ALIRAN UNTUK KARAKTERISASI SISTEM KARST DINAMIS DI SUNGAI BAWAH TANAH BRIBIN, KABUPATEN GUNUNG KIDUL, DIY}

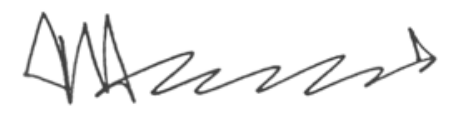

Prof. Dr. Sudarmadji, M.Eng.Sc Tanggal..2.9-01-2010 Promotor

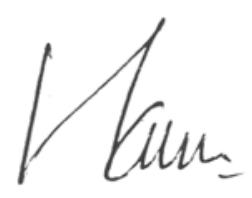

Prof. Dr. Suratman, M.Sc Ko-promotor Tanggal...

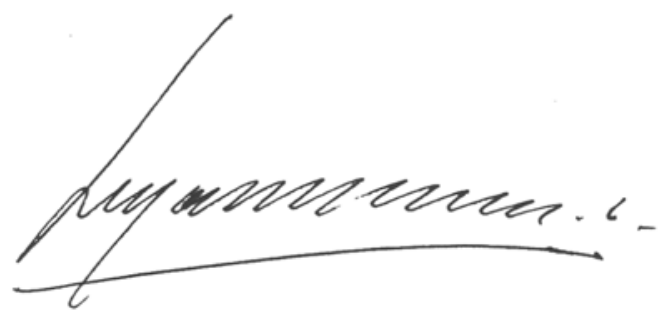

Dr. Ir. Heru Hendrayana, M.Sc Tanggal. $02-02-2010$ Ko-promotor 


\section{INTISARI}

Penelitian ini dilakukan pada kawasan bertopografi karst, yaitu daerah tangkapan Sungai Bawah Tanah (SBT) Bribin yang secara administratif terletak di Kabupaten Gunungkidul, Propinsi Daerah Istimewa Yogyakarta. Tujuan dari penelitian ini adalah: (1) menganalisis variasi spasial dan temporal karakteristik dan persentase aliran dasar (PAD) SBT Bribin; (2) mengevaluasi karakter hidrogeokimia SBT Bribin dan mencari hubungan dengan sifat alirannya; (3) mengkarakterisasi kondisi Sistem Karst Dinamis (SKD) SBT Bribin yang didekati dengan paramater tingkat agresivitas air terhadap batuan gamping dan hubungannya dengan kondisi paramater SKD SBT Bribin sepanjang tahun.

Untuk mengetahui karakteristik aliran dan PAD, tiga alat pencatat fluktuasi muka air SBT dipasang di hulu, hilir, dan bocoran SBT Bribin selama satu tahun, dan pengukuran debit aliran dilakukan untuk memperoleh kurva hubungan debit dan tinggi muka air SBT. Kemudian, dilakukan pemisahan aliran dasar dengan cara digital filtering untuk menghitung besarnya PAD setelah sebelumnya dihitung nilai konstanta resesi aliran diffuse, fissure, dan conduitnya. Untuk mengetahui karakter hidrogeokimia SBT, sebanyak 120 sampel air diambil dan dianalisis sepanjang tahun di SBT Bribin yang meliputi air tetesan gua, air hujan, dan air SBT. Scatter plot antar parameter hidrogeokimia kemudian dilakukan untuk mengetahui hubungan antara PAD dan hidrogeokimia, serta untuk mengetahui proses hidrogeokimia yang terjadi. Selanjutnya, untuk mengetahui tingkat agresivitas air SBT dilakukan analisis Indeks Kejenuhan terhadap mineral kalsit, sedangkan hubungan antar parameter SKD pada gua di bagian hulu dan hilir dilakukan untuk mengkarakterisasi kondisi SKD sepanjang SBT Bribin.

Hasil penelitian menunjukkan bahwa terdapat perbedaan karakteristik aliran sungai bawah tanah secara temporal dan spasial di SBT Bribin karena adanya perbedaan sifat akuifer karst untuk melepaskan komponen aliran diffuse, fissure, dan conduit. Hal ini mengakibatkan adanya perbedaan karakteristik PAD di sepanjang SBT Bribin. Selanjutnya, karakteristik PAD berpengaruh terhadap karakter hidrogeokimia sungai bawah tanah terutama pada musim kemarau. Pada musim hujan, hidrogeokimia sungai bawah tanah lebih dipengaruhi oleh kejadian banjir yang mengakibatkan turunnya PAD karena adanya proses pengenceran oleh air hujan (dilution by precipitation) yang menaikkan kandungan $\mathrm{CO}_{2}$ dalam air. Secara umum, gua di hilir SBT Bribin lebih bersifat agresif untuk melarutkan batuan gamping dibandingkan gua di daerah hulu karena adanya perbedaan sifat pelorongan gua, dimana bagian hilir mempunyai sifat pelorongan terbuka sehingga selalu ada pasokan gas karbondioksida untuk mendukung proses pelarutan.

Kata kunci: Sifat aliran, diffuse, fissure, conduit, hidrogeokimia, agresivitas 


\begin{abstract}
This research is conducted in karst area, which is particularly enclosed by Bribin Underground River Catchment, Gunungkidul Regency. The objectives of this study are: (1) to understand spatial and temporal variation of flow characteristic as well as Diffuse Flow Proportion (PAD) of Bribin River; (2) to assess hydrogeochemistry and to recognize the relationship between hydrogeochemistry and flow characteristics of Bribin River, and (3) to define water agressivity of Bribin River with respect to carbonate mineral and to express the components of Karst Dynamic System (KDS) one-year behavior.

To define flow characteristic and PAD, three water level data loggers are installed within upper, lower and the leakage point along Bribin River continued by discharge measurement with the purpose of attaining stage-discharge rating curve. Afterwards, PAD is defined by conducting digital filtering baseflow separation approach after calculation of diffuse, fissure, and conduit recession constant. Next, to figure out hydrogeochemical condition, 120 sample of karst water are analyzed including rain, underground-river, and drip water. After that, scatter plots between hydrogeochemical parameters are conducted to achieve the correlation between PAD and hydrogeochemistry as well as to figure out hydrogeochemical processes to occur. Subsequently, Saturation Indices analysis with respect to calcite mineral and KDS components correlation is carried out to define karst water agressivity and its manners along flowpath of Bribin River.

The research's result demonstrates that there is spatial and temporal differentiation of flow characteristics along Bribin River attributable to the comportment of karst aquifer toward discharging its diffuse, fissure, or conduit flow components, which consequence to the dissimilarity of PAD distribution along Bribin River. Accordingly, PAD characteristics result to dry season hydrogeochemical condition of Bribin River. However, wet season hydrogeochemical condition is more influenced by means of dilution by precipitation process within flood events, which exaggerates $\mathrm{CO}_{2}$ content of water. Generally, the upper-stream cave tend to more aggressive in dissolving limestone, contrast to down-steam cave that be inclined to precipitate carbonate mineral as a result of their differentiation of cavities configuration. In addition, down-stream cave is characterized by open system cavities, subsequent to the $\mathrm{CO}_{2}$ discharge to preserve dissolution process.
\end{abstract}

Keywords : Flow characteristic, diffuse, fissure, conduit, hydrogeochemistry, aggressivity 


\section{KATA PENGANTAR}

Segala puji bagi Allah Subhanahu wa ta'ala, kita memuji-Nya, kita mohon pertolongan-Nya, kita mohon ampunan-Nya, dan kita berlindung kepada-Nya dari keburukan jiwa-jiwa dan amalan-amalan kami. Barang siapa yang diberi pertunjuk oleh Allah, maka tiada seorangpun yang bisa menyesatkannya, dan barang siapa disesatkan oleh Allah, maka tidak ada seorangpun yang bisa menunjukinya. Sebaikbaik perkataan adalah Kitab Allah, untuk itu penulis sangat menyadari bahwa hanya karena hidayah-Nya dan ijin-Nya-lah, disertasi yang mencoba mengurai sekelumit ilmu yang diturunkan melalui proses karstifikasi ini dapat terselesaikan. Semoga ilmu tersebut dapat memberikan manfaat dan kebaikan serta amalan yang baik bagi penulis.

Disertasi ini merupakan upaya penulis untuk mengungkap karakteristik aliran, hidrogeokimia, serta hubungannya terhadap tingkat agresivitas air karst untuk melarutkan batuan gamping dan perilaku komponen-komponen Sistem Karst Dinamis (SKD) sepanjang SBT Bribin. SBT Bribin dipilih atas dasar kedudukannya sebagai salah satu sungai bawah tanah dengan debit yang besar di kawasan karst Gunung Sewu, Kabupaten Gunung Kidul, serta adanya upaya akhir-akhir ini untuk memanfaatkannya secara lebih optimal. Dengan data-data primer terkait sifat aliran dan sifat kimia komponen sungai bawah tanah selama satu tahun, maka penelitian ini menghasilkan hubungan baik secara spasial maupun temporal antara sifat aliran dan hidrogeokimia yang berpengaruh terhadap sifat air dalam melarutkan batuan gamping di daerah penelitian.

Penulis menyadari bahwa selama penyelesaian kuliah S3 dan penulisan disertasi ini telah didukung dan dibantu oleh berbagai pihak. Untuk itu penulis juga tidak lupa mengucapkan banyak terima kasih kepada:

1. Rektor Universitas Gadjah Mada, Direktur Sekolah Pasca Sarjana, Dekan Fakultas Geografi, dan Ketua Jurusan Geografi Lingkungan yang telah mendorong dan sekaligus memberikan ijin penulis untuk menempuh disertasi;

2. Prof. Dr. Sudarmadji, M.Eng. Sc., Prof. Dr. Suratman Woro Suprodjo M.Sc, dan Dr. Heru Hendrayana M.Sc selaku promotor utama dan promotor pendamping 
yang telah memberikan dukungan, bimbingan, dan semangat selama penelitian dan penyelesaian disertasi;

3. Tim Penilai kelayakan disertasi ini yaitu Prof. Dr. Sutikno, Prof. Dr. Ir. Sari Bahagiarti, M.Sc, dan Dr. M. Pramono Hadi, M.Sc. yang telah memberikan masukan-masukan berharga bagi perbaikan disertasi ini, serta Prof. Dr. R. Rijanta, M.Sc selaku Ketua Tim Penguji;

4. Kedua orang tuaku Djamijoen dan Sri Hardiyah yang dengan penuh kasih sayang memelihara saya sejak kecil hingga sekarang, serta Ibunda Satirah yang telah memberi dorongan mental dan fasilitas basecamp lapangan pada penulis untuk menyelesaikan disertasi ini;

5. Istriku tercinta Wiwin Rahmanti, S.E.Akt., M.Com., yang selalu mendorong dan memberikan dukungan moral maupun material dalam menempuh dan penyelesaian disertasi. Anak-anakku tersayang M. Alif Al Tsaqiif, Zalfa Sabilathifa, Laila Az Zahra, Fathimah Az Zahra yang juga telah memberikan semangat melalui keceriaannya.

Pihak-pihak lain seperti, Zaenuri Putro Utomo S.Si., dan Arie Purwanto yang telah membantu penyiapan data, pengolahan data, dan kerja lapangan. Teman-teman pemerhati kawasan karst Dr. Eko Haryono, M.Si., Dra. Widyastuti M.T., Bagus Yulianto A.Md, Sunu Wijanarko, Cahyo Rahmadi, S.Si. serta teman-teman dari ASC yang membantu instalasi alat-alat pengukuran sungai bawah tanah yaitu Imam, Dicky, Uji, Anggit, Iyek, Abe Rodhial, dan lain-lain. Ucapan terima kasih juga penulis sampaikan kepada seluruh staf pengajar Fakultas Geografi UGM, laboran terutama dari Laboratorium Geohidrologi, Bapak Lili Ismangil, serta Badi Hariadi dan M. Misqi yang banyak membantu mendesain dan memasang alat ukur di lapangan, pegawai perpustakaan, Mahasiswa Pecinta Alam Fakultas Geografi UGM (GEGAMA), PDAM Gunung Kidul dan segenap pihak yang tidak dapat tersebut semuanya dalam tulisan ini karena keterbatasan tempat.

Yogyakarta, Februari 2009

Tjahyo Nugroho Adji 


\section{DAFTAR ISI}

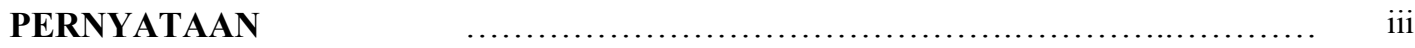

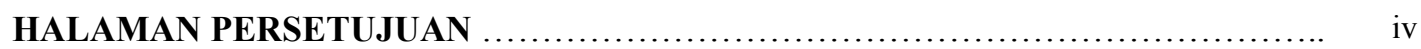

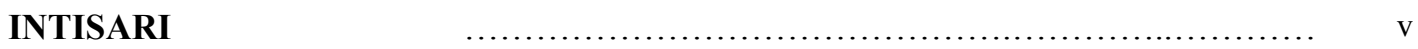

ABSTRACK $\quad$.

KATA PENGANTAR $\quad$.

DAFTAR ISI $\quad$.

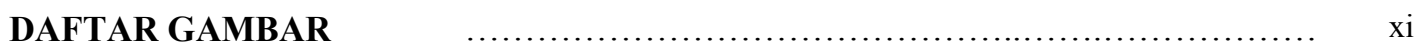

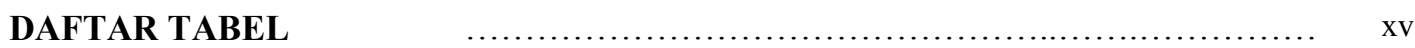

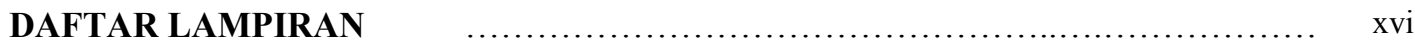

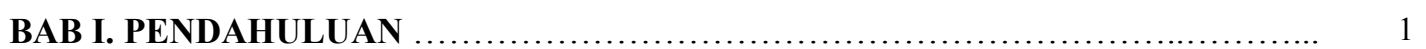

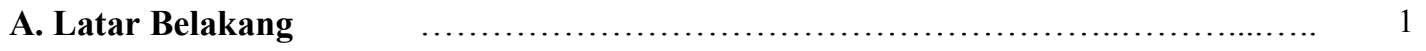

B. Permasalahan $\quad$............................................................... 5

C. Tujuan dan Sasaran Penelitian $\quad$...................................................... 7

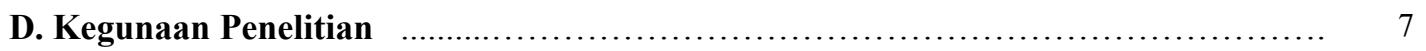

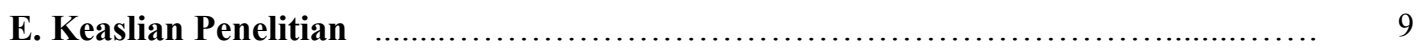

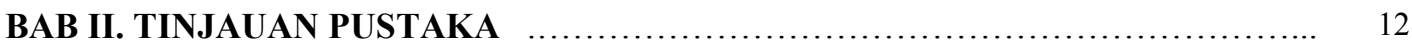

A. Telaah Pustaka $\quad$............................................................ 12

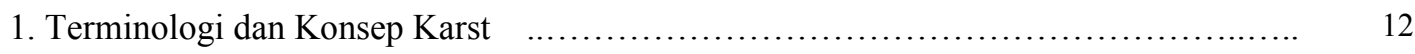

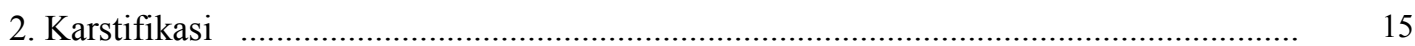

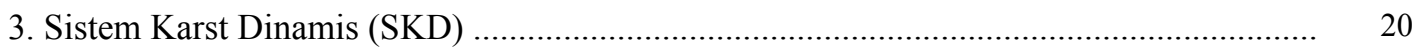

4. Akuifer dan Sifat Aliran Karst ............................................................................... 21

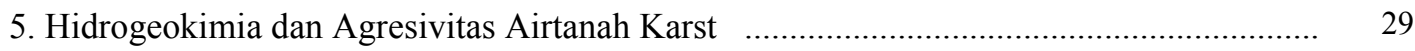

6. Kondisi Sistem Sungai Bawah Tanah Bribin-Baron ........................................................ 34

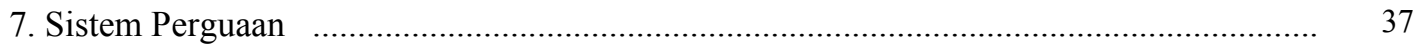

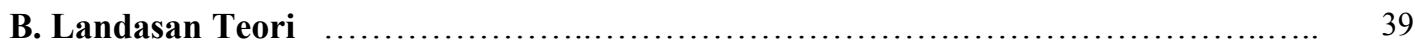

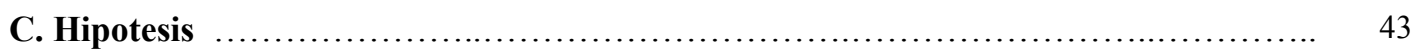

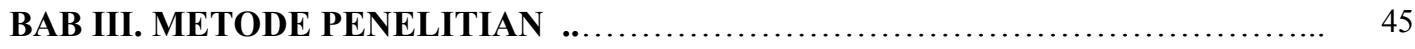

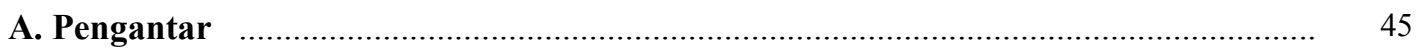

B. Batasan Ruang Lingkup Penelitian ..................................................................... 46

C Pemilihan Batas-Batas Daerah Penelitian ............................................................... 47

D. Data yang Dikumpulkan

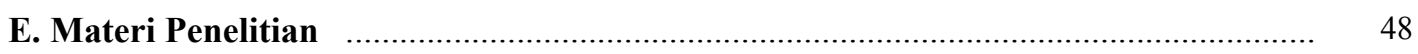

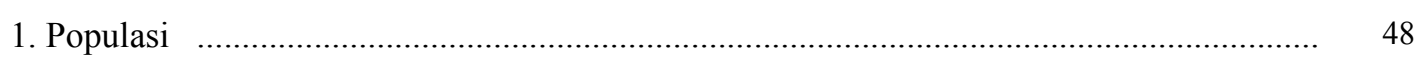

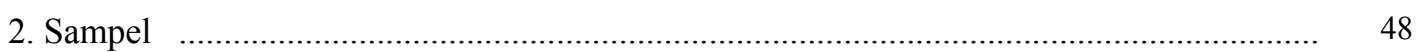

3. Bahan Penelitian ……...................................................................................... 49

4. Alat Penelitian …..................................................................................... 50 


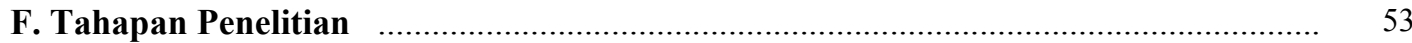

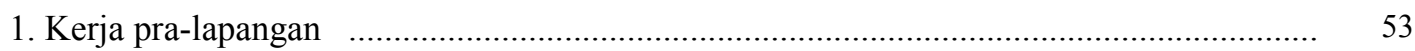

2. Kerja lapangan

3. Kerja pasca lapangan $\quad$................................................................................................... 57

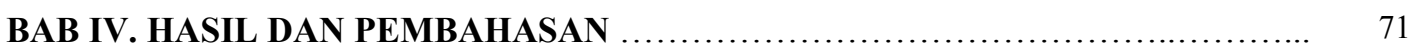

A. Deskripsi Singkat Daerah Penelitian .................................................................

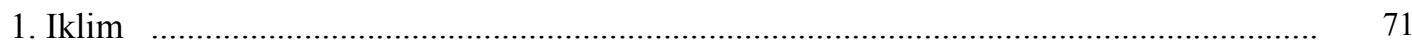

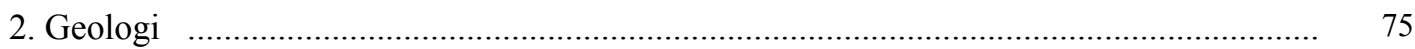

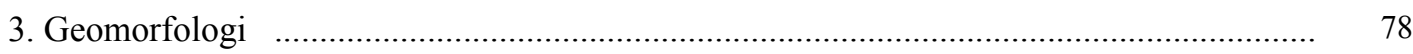

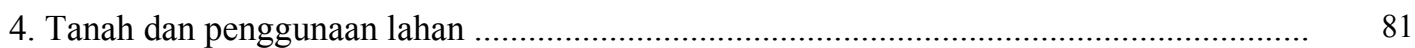

B. Variasi Spasial dan Temporal Karakteristik Aliran dan PAD SBT Bribin ............... 83

1. Variasi temporal aliran Inlet Sungai Pentung-Luweng Jomblangan $\quad$...................................

2. Variasi temporal aliran di Gua Gilap …….................................................................... 86

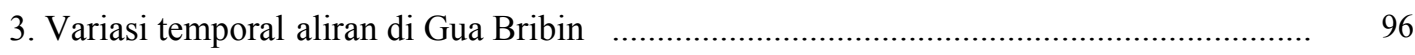

4. Variasi temporal aliran di Gua Ngreneng f.................................................................... 103

5. Pembahasan variasi spasial dan temporal Karakteristik Aliran SBT Bribin .................... 110

C. Variasi Spasial dan Temporal Hidrogeokimia SBT Bribin ..................................... 119

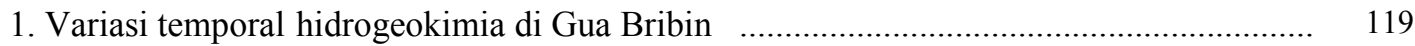

2. Variasi temporal hidrogeokimia di Sungai Pentung, Luweng Jomblangan, Gua Gilap, dan Gua, Ngreneng ................................................................................................ 139

3. Pembahasan variasi spasial dan temporal hidrogeokimia SBT Bribin dan hubungannya dengan sifat alirannya ........................................................................... 154

D. Variasi dan Karakter Spasial dan Temporal Agresivitas Airtanah di SBT Bribin dan Hubungannya Antar Parameter SKDnya ………............................................. 169

1. Variasi dan karakter spasial dan temporal agresivitas air SBT Bribin $\quad$.............................. 169

2. Karakter dan hubungan parameter SKD Air SBT Bribin hulu-hilir..................................... 174

E. Temuan Konsep dan Teori: Variasi Sifat Aliran, Hidrogeokimia, dan Perilaku Sistem Karst Dinamis (SKD) di SBT Bribin ……................................................. 195

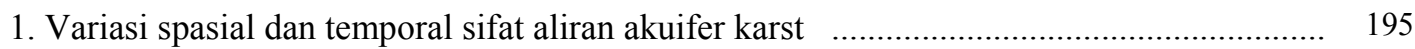

2. Variasi spasial dan temporal hidrogeokimia dan hubungannya dengan sifat aliran akuifer karst ................................................................................................. 197

3. Karakter SKD di SBT Bribin atas nilai agresivitas sungai bawah tanah dan hubungan

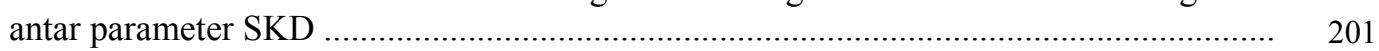

4. Kemanfatan, keterbatasan metode dan dialog teori hasil penelitian ................................ 202

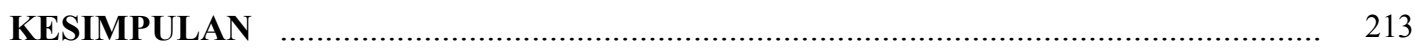

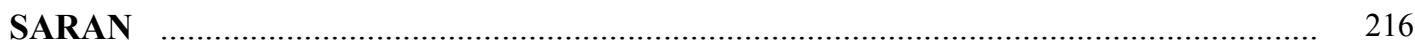

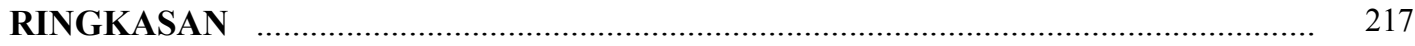

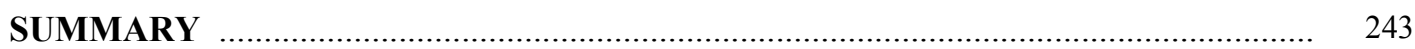

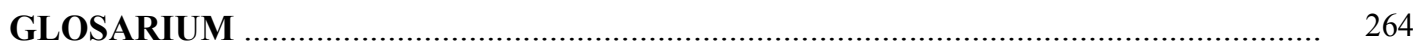

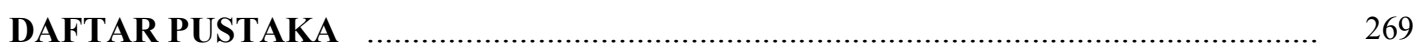

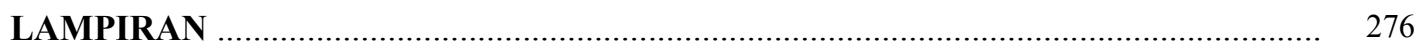




\section{DAFTAR GAMBAR}

Gambar 1.1. Kubah Sinusoidal, Ciri Utama kegelkarst Gunung Sewu..................................... 1

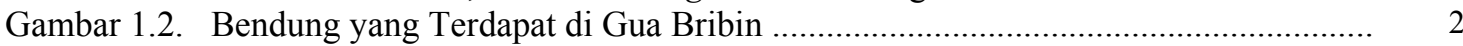

Gambar 1.3. Sistem Sungai Bawah Tanah (SBT) Bribin ............................................................. 3

Gambar 2.1. Perpindahan Massa Melalui Interface Udara/Air Dan Udara/Batuan ....................................................................................... 18

Gambar 2.2. Proses 1 Sampai Dengan 3 Pelarutan Batuan Gamping ........................................ 19

Gambar 2.3. Proses pelarutan karbonat yang diikuti oleh pembentukan

Gambar 2.4. Model Konseptual Sistem Aliran Airtanah Pada Akuifer Karst ............................. 22

Gambar 2.5. Diffuse, Mixed dan Conduit di Akuifer Karst ........................................................ 24

Gambar 2.6. Sistem Aliran Diffuse dan Sistem Aliran Conduit ................................................ 25

Gambar 2.7. Tiga Sub-Sistem Bertingkat yang Menghasilkan Perbedaan

Gambar 2.8. Model Konseptual Akuifer Karst

Gambar 2.9. Sistem Sungai Bawah Tanah Bribin-Baron .......................................................... 36

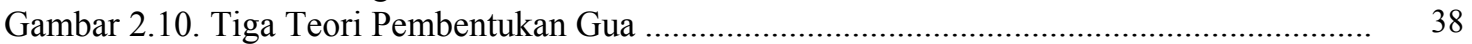

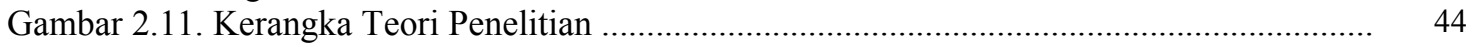

Gambar 3.1. Pertimbangan Sampling Daerah Penelitian ......................................................... 51

Gambar 3.2. Penakar Hujan Otomatik ................................................................................. 55

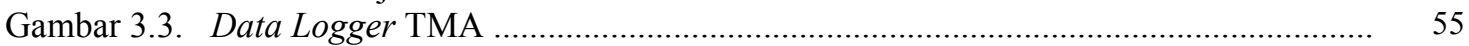

Gambar 3.4. Pengambilan Sampel Air Sungai Bawah Tanah ................................................ 56

Gambar 3.5. Pengukuran Debit Aliran Dengan Current Meter ................................................... 56

Gambar 3.6. Pengukuran pH, suhu, DHL, dan Eh lapangan .................................................... 57

Gambar 3.7. Pelepasan Simpanan Air Akuifer Sebagai Komponen Aliran ................................ 59

Gambar 3.8. Pemisahan Aliran Dasar Dengan Metode digital filtering....................................... 60

Gambar 3.9. Tabulasi Untuk Membedakan Komposisi Komponen Aliran ................................. 62

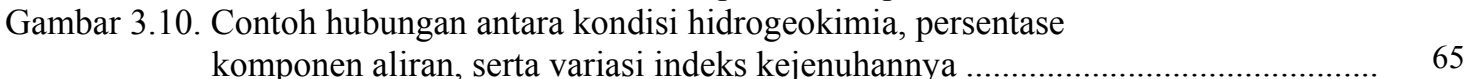

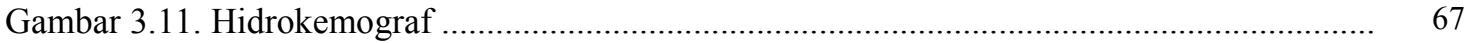

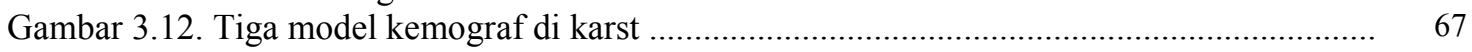

Gambar 3.13. Hubungan Antara Fluks Komposisi Kimia dan Debit .......................................... 69

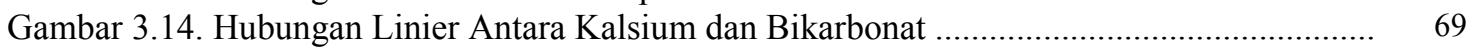

Gambar 3.15. Diagram Alir Metodologi Penelitian ....................................................................

Gambar 4.1. Perubahan Iklim Jaman Kuarter Sejak 190.000 Tahun BP di Pulau Jawa dan Sekitarnya .........................................................................

Gambar 4.2. Distribusi Temporal Rata-Rata Suhu dan Kelembaban di Stasiun

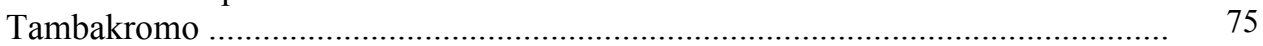

Gambar 4.3. Kolom Stratigrafi Pegunungan Selatan Jawa Tengah .......................................... 77

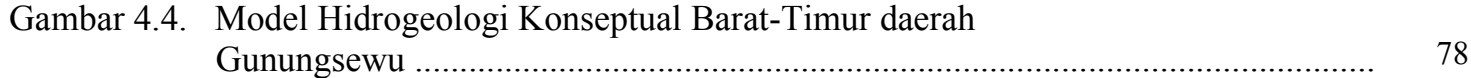

Gambar 4.5. Kenampakan Kegel Karst Gunungsewu .............................................. 79

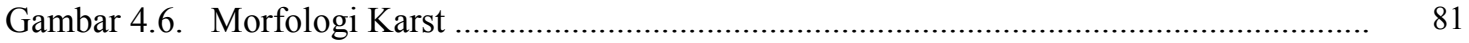

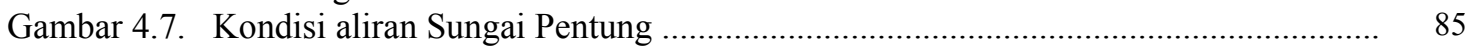

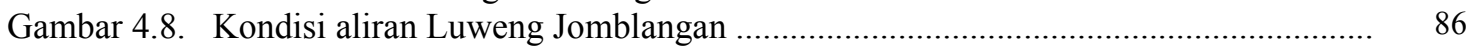

Gambar 4.9. Kondisi Aliran Gua Gilap ............................................................................ 86

Gambar 4.10. Hubungan Tinggi Muka Air Dan Debit di Gua Gilap ............................................ 88

Gambar 4.11. Variasi Debit Dasar Gua Gilap periode 1 Mei 2006-30 April 2007.......................... 88

Gambar 4.12a. Kejadian Resesi Banjir-Banjir Terpilih Gua Gilap ............................................ 91

Gambar 4.12b. Kejadian Resesi Banjir-Banjir Terpilih Gua Gilap ........................................... 92 
Gambar 4.13. Fluktuasi Aliran Dasar Gua Gilap periode 1 Mei 2006-30 April 2007................... 94

Gambar 4.14. Pemasangan AWLR di Gua Bribin, dan water level data logger .......................... 97

Gambar 4.15. Hubungan Tinggi Muka Air Dan Debit di Gua Bribin ......................................... 98

Gambar 4.16. Variasi Debit Aliran Gua Bribin Periode 1 Mei 2006-30 April 2007

Gambar 4.17a. Kejadian Resesi Banjir-Banjir Terpilih Gua Bribin .....

Gambar 4.17b. Lanjutan Kejadian Resesi Banjir-Banjir Terpilih Gua Bribin

Gambar 4.18. Fluktuasi Aliran Dasar Gua Bribin Periode 1 Mei 2006-30 April 2007

Gambar 4.19. Kondisi Aliran di Gua Ngreneng, dan Instalasi Stasiun Aliran

Gambar 4.20. Hubungan Tinggi Muka Air dan Debit di Gua Ngreneng

Gambar 4.21. Variasi Debit Aliran Gua Ngreneng Periode 1 Mei 2006-30 April 2007

Gambar 4.22. Kejadian Resesi Banjir-Banjir Terpilih Gua Ngreneng

Gambar 4.23. Fluktuasi Aliran Dasar Gua Ngreneng Periode 1 Mei 2006-30 April 2007

Gambar 4.24. Rasio Aliran Dasar Bulanan Sepanjang SBT Bribin Mei 2006-

Gambar 4.25. Variasi Spasial dan Temporal Pelepasan Aliran oleh Akuifer Karst di SBT Bribin ....

Gambar 4.26. Hidrokemograf Gua Bribin Sepanjang Tahun

Gambar 4.27. Variasi Debit, Persentase Aliran Dasar, $\log \mathrm{PCO}_{2}$ dan Persentase Kalsium dan Bikarbonat Gua Bribin Sepanjang Tahun Scatter plot Hubungan DHL-Kalsium dan DHL-Bikarbonat

Gambar 4.28. Scatter plot Hubungan DHL-K
Gua Bribin Musim Kemarau

Gambar 4.29. Scatter Plot Ion Natrium dan Klorida Gua Bribin Musim Kemarau

Gambar 4.30. Scatter Plot Hubungan PAD-Kalsium dan PAD-Bikarbonat Gua Bribin Musim Kemarau

Gambar 4.31. Scatter plot Log $\mathrm{PCO}_{2}$-Kalsium dan Log $\mathrm{PCO}_{2}$-Bikarbonat Musim Kemarau di Gua Bribin

Gambar 4.32. Scatter plot Hubungan Aliran Dasar-Debit Aliran Gua Bribin pada Kejadian Banjir 22-23 Februari 2007 dan pada Kejadian Banjir 19 Maret 2008

Gambar 4.33. Scatter Plot Hubungan Aliran Dasar-log $\mathrm{PCO}_{2}$ di Gua Bribin dan Aliran Dasar-Kalsium Pada Kejadian Banjir 22-23 Februari 2007

Gambar 4.34. Scatter Plot Hubungan Aliran Dasar-log $\mathrm{PCO}_{2}$ di Gua Bribin dan Aliran Dasar-Bikarbonat pada Kejadian Banjir 19 Maret 2007

Gambar 4.35. Scatter Plot Ion Natrium dan Klorida pada Kejadian Banjir 22-23 Februari 2008 dan pada Kejadian Banjir 19 Maret 2007

Gambar 4.36. Scatter Plot Hubungan Aliran Dasar-Debit Aliran Gua Bribin Musim Hujan

Gambar 4.37. Scatter Plot Hubungan Aliran Dasar-Kalsium dan Aliran Dasar-Bikarbonat

Gambar 4.38. Scatter Plot Hubungan Aliran Dasar dan Tekanan Parsial Gas

Karbondioksida Gua Bribin Sepanjang Musim Hujan

Gambar 4.39. Variasi DHL Sepanjang Tahun Gua Bribin

Gambar 4.40. Hubungan DHL dan Kalsium Terlarut dan DHL Bikarbonat Terlarut 
Gambar 4.41. Scatter Plot Hubungan Aliran Dasar-Debit Aliran Gua Bribin

Sepanjang Tahun

Gambar 4.42. Hubungan DHL dan Kalsium Terlarut dan DHL Bikarbonat

Terlarut Gua Bribin Sepanjang Tahun

Gambar 4.43. Hubungan DHL dan Kalsium Terlarut dan DHL Bikarbonat

Terlarut di Sungai Pentung Sepanjang Tahun

Gambar 4.44. Hubungan DHL dan Kalsium Terlarut dan DHL Bikarbonat

Terlarut di Luweng Jomblangan Sepanjang Tahun ....

Gambar 4.45. Hubungan DHL dan Kalsium Terlarut dan DHL Bikarbonat

Terlarut di Gua Gilap Sepanjang Tahun

Gambar 4.46. Hubungan DHL dan Kalsium Terlarut dan DHL Bikarbonat Terlarut di Gua Ngreneng Sepanjang Tahun

Gambar 4.47. Scatter Plot Ion Natrium dan Klorida Sungai Pentung dan Luweng Jomblangan Sepanjang Tahun

Gambar 4.48. Scatter Plot Ion Natrium dan Klorida Gua Gilap dan Gua Ngreneng Sepanjang Tahun

Gambar 4.49. Hubungan Debit dan PAD Sungai Pentung Sepanjang Tahun

Gambar 4.50. Hubungan Debit dan PAD (Baseflow) Gua Gilap Sepanjang Tahun

Gambar 4.51. Hubungan Debit dan PAD (Baseflow) Gua Ngreneng Sepanjang Tahun

Gambar 4.52. Hubungan PAD-Kalsium Terlarut dan PAD-Bikarbonat Terlarut di Sungai Pentung Sepanjang Tahun

Gambar 4.53. Hubungan PAD-Kalsium Terlarut dan PAD-Bikarbonat Terlarut di Gua Gilap Sepanjang Tahun

Gambar 4.54. Hubungan PAD-Kalsium Terlarut dan PAD-Bikarbonat Terlarut di Gua Ngreneng Sepanjang Tahun

Gambar 4.55. Hubungan PAD-Tekanan Parsial Gas Karbondioksida Sepanjang Tahun di Sungai Pentung .....

Gambar 4.56. Hubungan PAD-Tekanan Parsial Gas Karbondioksida Sepanjang Tahun di Gua Gilap

Gambar 4.57. Hubungan PAD-Tekanan Parsial Gas Karbondioksida Sepanjang Tahun di Gua Ngreneng

Gambar 4.58. Hubungan Nilai Log $\mathrm{PCO}_{2}$-Kalsium Terlarut dan Nilai Log $\mathrm{PCO}_{2}$-Bikarbonat Terlarut di Sungai Pentung Sepanjang Tahun

Gambar 4.59. Hubungan Nilai Log $\mathrm{PCO}_{2}$-Kalsium Terlarut dan Nilai Log $\mathrm{PCO}_{2}$-Bikarbonat Terlarut di Luweng Jomblangan Sepanjang Tahun

Gambar 4.60. Hubungan Nilai Log $\mathrm{PCO}_{2}$-Kalsium Terlarut dan Nilai Log $\mathrm{PCO}_{2}$-Bikarbonat Terlarut di Gua Gilap Sepanjang Tahun ....

Gambar 4.61. Hubungan Nilai Log $\mathrm{PCO}_{2}$-Kalsium Terlarut dan Nilai Log $\mathrm{PCO}_{2}$-Bikarbonat Terlarut di Gua Ngreneng Sepanjang Tahun

Gambar 4.62. Hubungan Kalsium dan DHL Gua-Gua di SBT Bribin pada Musim Kemarau

Gambar 4.63. Hubungan Bikarbonat-DHL Gua-Gua di SBT Bribin pada Musim Kemarau

Gambar 4.64. Hubungan Kalsium dan DHL Gua-Gua di SBT Bribin pada Musim Hujan

Gambar 4.65. Hubungan Bikarbonat dan DHL Gua-Gua di SBT Bribin pada 
Gambar 4.66. Hubungan Debit dan Persentase Aliran Dasar (PAD) Gua-Gua di SBT Bribin pada Musim Kemarau

Gambar 4.67. Hubungan Debit dan Persentase Aliran Dasar (PAD) Gua-Gua di SBT Bribin pada Musim Hujan

Gambar 4.68. Hubungan Kalsium Terlarut dan Persentase Aliran Dasar (PAD)

Gua-Gua di SBT Bribin pada Musim Kemarau

Gambar 4.69. Hubungan Bikarbonat Terlarut dan Persentase Aliran Dasar (PAD) Gua-Gua di SBT Bribin pada Musim Kemarau

Gambar 4.70. Hubungan Kalsium Terlarut dan Persentase Aliran Dasar (PAD) Gua-Gua di SBT Bribin pada Musim Hujan

Gambar 4.71. Hubungan Bikarbonat Terlarut dan Persentase Aliran Dasar

(PAD) Gua-Gua di SBT Bribin pada Musim Hujan

Gambar 4.72. Variasi Spasial dan Temporal Hidrogeokimia di SBT Bribin

Gambar 4.73. Variasi Temporal Nilai Indeks Kejenuhan (SI) Gua-Gua di SBT Bribin

Gambar 4.74. Hubungan SI Kalsit dan $\log \mathrm{P}_{\mathrm{CO} 2}$ di Gua Gilap pada Musim Kemarau

Gambar 4.75. Hubungan SI Kalsit dan $\log \mathrm{P}_{\mathrm{CO} 2}$ di Gua Gilap pada Musim Hujan

Gambar 4.76. Hubungan SI Kalsit dan log Kalsium di Gua Gilap pada Musim Kemarau

Gambar 4.77. Hubungan SI Kalsit dan log Kalsium di Gua Gilap pada Musim Hujan

Gambar 4.78. Hubungan SI kalsit dan pH di Gua Gilap pada Musim Kemarau

Gambar 4.79. Hubungan SI kalsit dan pH di Gua Gilap pada Musim Hujan

Gambar 4.80. Hubungan SI Kalsit dan $\log \mathrm{P}_{\mathrm{CO} 2}$ di Gua Bribin pada Musim Kemarau

Gambar 4.81. Hubungan SI Kalsit dan $\log \mathrm{P}_{\mathrm{CO} 2}$ di Gua Bribin pada Musim Hujan

Gambar 4.82. Hubungan SI Kalsit dan log Kalsium di Gua Bribin pada Musim Kemarau

Gambar 4.83. Hubungan SI Kalsit dan log Kalsium di Gua Bribin pada Musim Hujan

Gambar 4.84. Hubungan SI Kalsit dan pH di Gua Bribin pada Musim Kemarau

Gambar 4.85. Hubungan SI Kalsit dan pH di Gua Bribin pada Musim Hujan

Gambar 4.86. Konseptual Model SKD di SBT Bribin pada Musim Kemarau

Gambar 4.87. Konseptual Model SKD di SBT Bribin pada Musim Hujan

Gambar 4.88. Variasi Spasial dan Temporal Kondisi Pelepasan Komponen Aliran Akuifer Karst di SBT Bribin 


\section{DAFTAR TABEL}

Tabel 1.1. Perbandingan Penelitian Dengan Penelitian Sejenis .............................................. 10

Tabel 2.1. Karakteristik Aliran Akuifer Karst ....................................................................... 27

Tabel 3.1. Kondisi Lokasi Pengambilan Sampel di Daerah Penelitian .................................... 49

Tabel 3.2. Data Primer Penelitian .............................................................................. 53

Tabel 3.3. Fase Pelarutan Atas Dasar Nilai SI ........................................................................... 64

Tabel 4.1. Curah Hujan Rata-Rata Bulanan di Daerah Penelitian Periode

Tahun 1947-2000 ...........................................................................

Tabel 4.2. Tekanan Udara, Suhu, dan Kelembapan (RH) di Daerah Penelitian .......................

Tabel 4.4. Hasil Pengukuran Debit Aliran Gua Gilap ............................................................... 8

Tabel 4.5. Konstanta Resesi, $T_{p}$ dan $T_{b}$ Hidrograf Banjir Terpilih Gua Gilap ......................... 93

Tabel 4.6. Rasio Aliran Dasar dan Total Aliran Tiap Bulan Gua Gilap .................................. 95

Tabel 4.7. Rasio Aliran Dasar dan Total Aliran pada Kejadian Banjir Terpilih

Gua Gilap ............................................................................................ 96

Tabel 4.8. Hasil Pengukuran Debit Aliran Gua Bribin ........................................................ 97

Tabel 4.9. Konstanta Resesi, $T_{p}$ dan $T_{b}$ Hidrograf Banjir Terpilih Gua Bribin ....................... 100

Tabel 4.10. Rasio Aliran Dasar dan Total Aliran Tiap Bulan Gua Bribin ................................. 103

Tabel 4.11. Rasio Aliran Dasar dan Total Aliran pada Kejadian Banjir 104

Terpilih Gua Bribin ........................................................................... $\quad 104$

Tabel 4.12. Hasil Pengukuran Debit Aliran Gua Ngreneng ...................................................... 105

Tabel 4.13. Konstanta Resesi, $T_{p}$ dan $T_{b}$ Hidrograf Banjir Terpilih Gua $\ldots$

Tabel 4.14. Rasio Aliran Dasar dan Total Aliran Tiap Bulan Gua Ngreneng ............................. 109

Tabel 4.15. Rasio Aliran Dasar dan Total Aliran Kejadian Banjir Terpilih Gua Ngreneng ..................................................................................... 109

Tabel 4.16. Ringkasan Julat Nilai Konstanta Resesi dan Paramater Banjir SBT Bribin ............ 111

Tabel 4.17. Kondisi Komponen Aliran Akuifer Karst Atas Dasar Perbandingan
Angka Paramater Hidrograf Banjir .................................................................. 115

Tabel 4.18. Persentase Aliran Dasar (PAD) Saat Kejadian Banjir ........................................... 117

Tabel 4.19. Posisi Sampling Hidrogeokimia SBT Bribin ......................................................... 119

Tabel 4.20. Komposisi Kimia Sampel Air Gua Bribin Sepanjang Tahun ................................. 120

Tabel 4.21. Kondisi dan Variasi Proses Hidrogeokimia di Gua Bribin Sepanjang

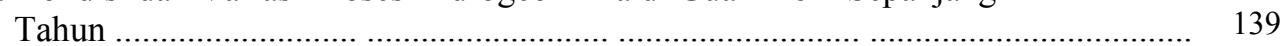

Tabel 4.22. Komposisi Kimia Sampel Air Sungai Pentung Sepanjang Tahun ........................... 140

Tabel 4.23. Komposisi Kimia Sampel Air Luweng Jomblangan Sepanjang Tahun .................. 140

Tabel 4.24. Komposisi Kimia Sampel Air Gua Gilap Sepanjang Tahun ................................... 141

Tabel 4.25. Komposisi Kimia Sampel Air Gua Ngreneng Sepanjang Tahun ............................ 142

Tabel 4.26. Kondisi dan Variasi Proses Hidrogeokimia di Sungai Pentung, Luweng 153 Tabel 4.27. Hubungan dan tingkat determinasi $\left(\mathrm{R}^{2}\right)$ DHL vs Kalsium dan
Bikarbonat Sepanjang SBT Bribin Pada Musim Kemarau ......................................

Tabel 4.28. Rerata Persentase Aliran Dasar Saat Pengambilan Sampel pada Musim Hujan

Tabel 4.29. Hubungan dan Tingkat Determinasi $\left(\mathrm{R}^{2}\right)$ Antara DHL-Kalsium dan DHL Karbonat di SBT Bribin pada Musim Hujan

Tabel 4.30. Hubungan dan Tingkat Determinasi $\left(\mathrm{R}^{2}\right)$ antara PAD-Debit di Sepanjang SBT Bribin pada Musim Kemarau ....................................................... 
Tabel 4.31. Hubungan dan Tingkat Determinasi $\left(\mathrm{R}^{2}\right)$ antara PAD-Debit di Sepanjang SBT Bribin pada Musim Hujan

Tabel 4.32. Hubungan dan Tingkat Determinasi $\left(\mathrm{R}^{2}\right)$ antara PAD-Kalsium dan

PAD- Karbonat Di Sepanjang SBT Bribin pada Musim Kemarau

Tabel 4.33. Hubungan dan Tingkat Determinasi $\left(\mathrm{R}^{2}\right)$ antara PAD-Kalsium dan

PAD- Karbonat di Sepanjang SBT Bribin pada Musim Hujan

Tabel 4.34. Distribusi Nilai SI di SBT Bribin

Tabel 4.35. Distribusi Nilai Paramater SKD SBT Bribin pada Musim Kemarau ................ 175

Tabel 4.36. Distribusi Nilai Paramater SKD SBT Bribin pada Musim Hujan .......................... 175

Tabel 4.37. Hubungan SI Kalsit dan $\log \mathrm{P}_{\mathrm{CO} 2}$ di Gua Gilap .............................................. 178

Tabel 4.38. Hubungan SI Kalsit dan log Kalsium di Gua Gilap (hulu) .................................. 181

Tabel 4.39. Hubungan SI Kalsit dan pH di Gua Gilap (hulu) ............................................. 183

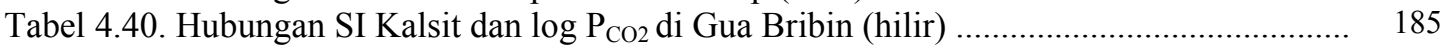

Tabel 4.41. Hubungan SI Kalsit dan log Kalsium di Gua Bribin (hilir) ................................. 188

Tabel 4.42. Hubungan SI Kalsit dan pH di Gua Bribin (hilir) ............................................ 191

Tabel 4.43. Sifat Pelepasan Komponen Aliran Diffuse, Hubungannya dengan

PAD, Jenis Pelorongan Gua dan Sifat Agresivitasnya

Tabel 4.44. Faktor-faktor Yang Berpengaruh Terhadap Hidrograf Aliran pada GuaGua di SBT Bribin

\section{DAFTAR LAMPIRAN}

Lampiran 1. Variasi Spasio-Temporal Hidrogeokimia SBT Bribin

Lampiran 2. Kondisi dan Hubungan Antar Parameter SKD di Hulu dan Hilir SBT Bribin Musim Kemarau

Lampiran 3. Kondisi dan Hubungan Antar Parameter SKD di Hulu dan Hilir 


\section{BAB I. PENDAHULUAN}

\section{A. Latar Belakang}

Perserikatan Bangsa-Bangsa (PBB) memperkirakan persediaan air sekitar 25\% penduduk dunia berasal dari akuifer air karst (Ko, 1984). Di Indonesia, luas kawasan karst mencapai hampir 20\% dari total luas wilayah (Balazs, 1968). Sementara itu, wilayah selatan Provinsi Daerah Istimewa Yogyakarta (DIY) hampir seluruhnya merupakan kawasan karst yang dikenal sebagai karst Gunung Sewu yang mencakup dua wilayah administrasi yaitu sebagian besar wilayah Kabupaten Gunungkidul dan wilayah Kabupaten Bantul dalam persentase yang sangat kecil.

Karst Gunung Sewu yang diperkenalkan pertama kali oleh Danes (1910) dan Lehmann (1936) dicirikan dengan berkembangnya kubah karst (kegelkarst), yaitu bentukan positif yang tumpul, tidak terjal atau sering diistilahkan kubah sinusoidal (Gambar 1.1). Kegelkarst oleh Sweeting (1972) dikategorikan sebagai bagian dari tipe karst tropis.

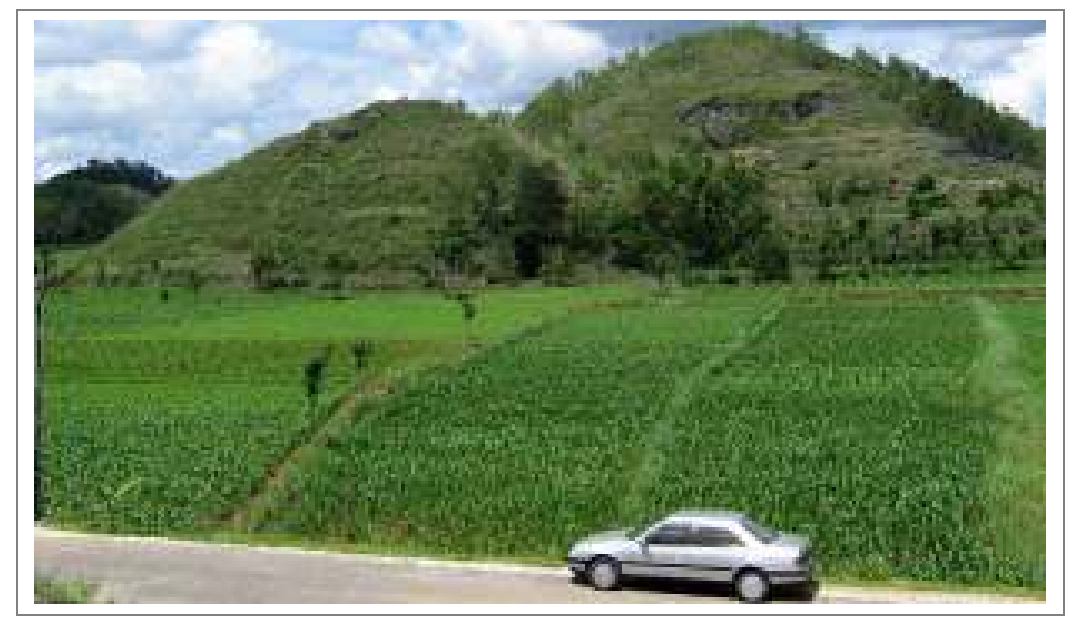

Gambar 1.1. Kubah Sinusoidal, Ciri Utama Kegelkarst Gunung Sewu (skala 1:125)

Kawasan karst Gunung Sewu dikenal sebagai daerah yang sulit air karena perkembangan lorong conduit yang mengontrol sungai bawah tanah mempunyai 
kedalaman hingga 100 meter di bawah permukaan tanah atau lebih, sehingga sumberdaya air yang ada sulit untuk dimanfaatkan. Salah satu sistem sungai bawah tanah yang mempunyai debit aliran cukup besar sepanjang tahun adalah sistem sungai bawah tanah Bribin-Baron, yang menurut pengukuran debit aliran oleh MacDonald dan Partners (1984) mencapai 8000 liter/detik di bagian muara. Sistem sungai bawah tanah ini merupakan salah satu sistem sungai utama di kawasan karst Gunung Sewu. Sungai Bawah Tanah (SBT) Bribin pada hulu sistem ini merupakan sungai bawah tanah yang mempunyai debit aliran paling besar dan menjadi tumpuan pemenuhan air domestik masyarakat yang tinggal di kawasan karst Gunungsewu. Sungai bawah tanah ini dapat dimasuki salah satunya di Gua Bribin yang merupakan gua utama pada sistem ini (Gambar 1.2).

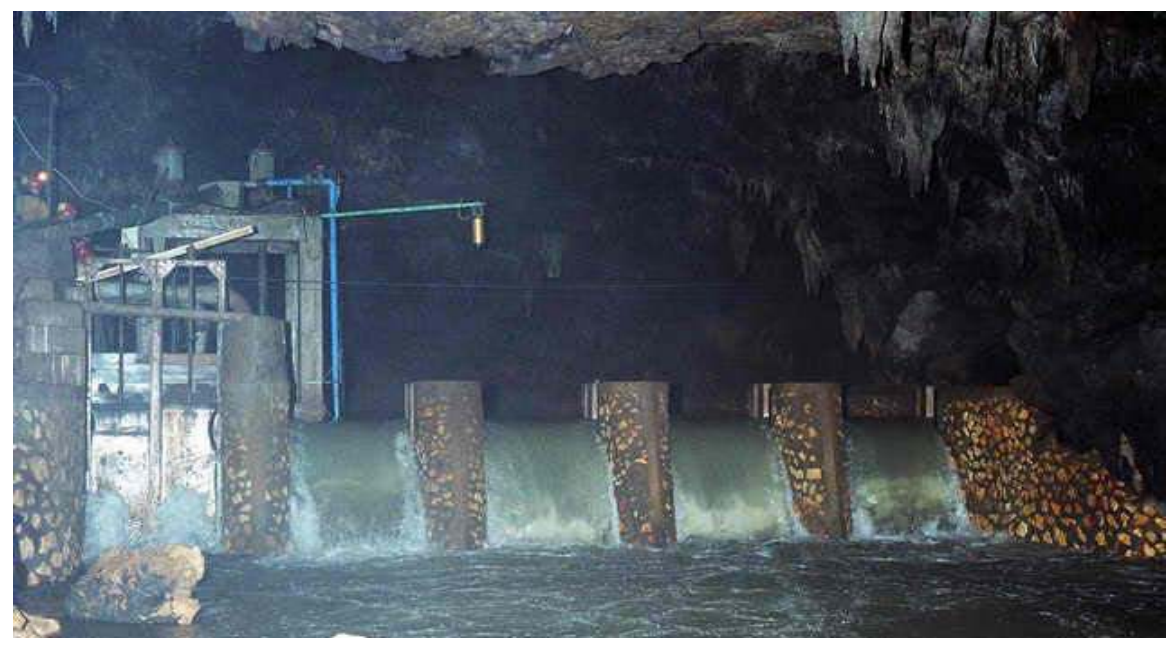

Gambar 1.2. Bendung yang Terdapat di Gua Bribin (skala 1:100)

Pada gua ini, debit minimum terukur di musim kemarau sekitar 1500 liter/detik, sementara pada musim penghujan, debit puncak dapat mencapai lebih dari 2000 liter/detik (MacDonald dan Partners, 1984). Penelitian oleh Fakultas Kehutanan (1993) menyebutkan bahwa dari total debit yang dijumpai pada Sungai Bawah Tanah (SBT) Bribin, baru sekitar 80 liter/detik yang sudah dimanfaatkan dan didistribusikan 
untuk memenuhi kebutuhan domestik penduduk sekitar. Ditinjau dari sisi demografi, jumlah orang yang tergantung dari suplai air sistem sungai bawah tanah ini lebih dari 200.000 orang, sehingga kedudukan Gua Bribin ini menjadi penting sebagai penyedia sumber air bersih. Gambar 1.3. menunjukkan sistem SBT Bribin sebagai suatu sistem sungai.

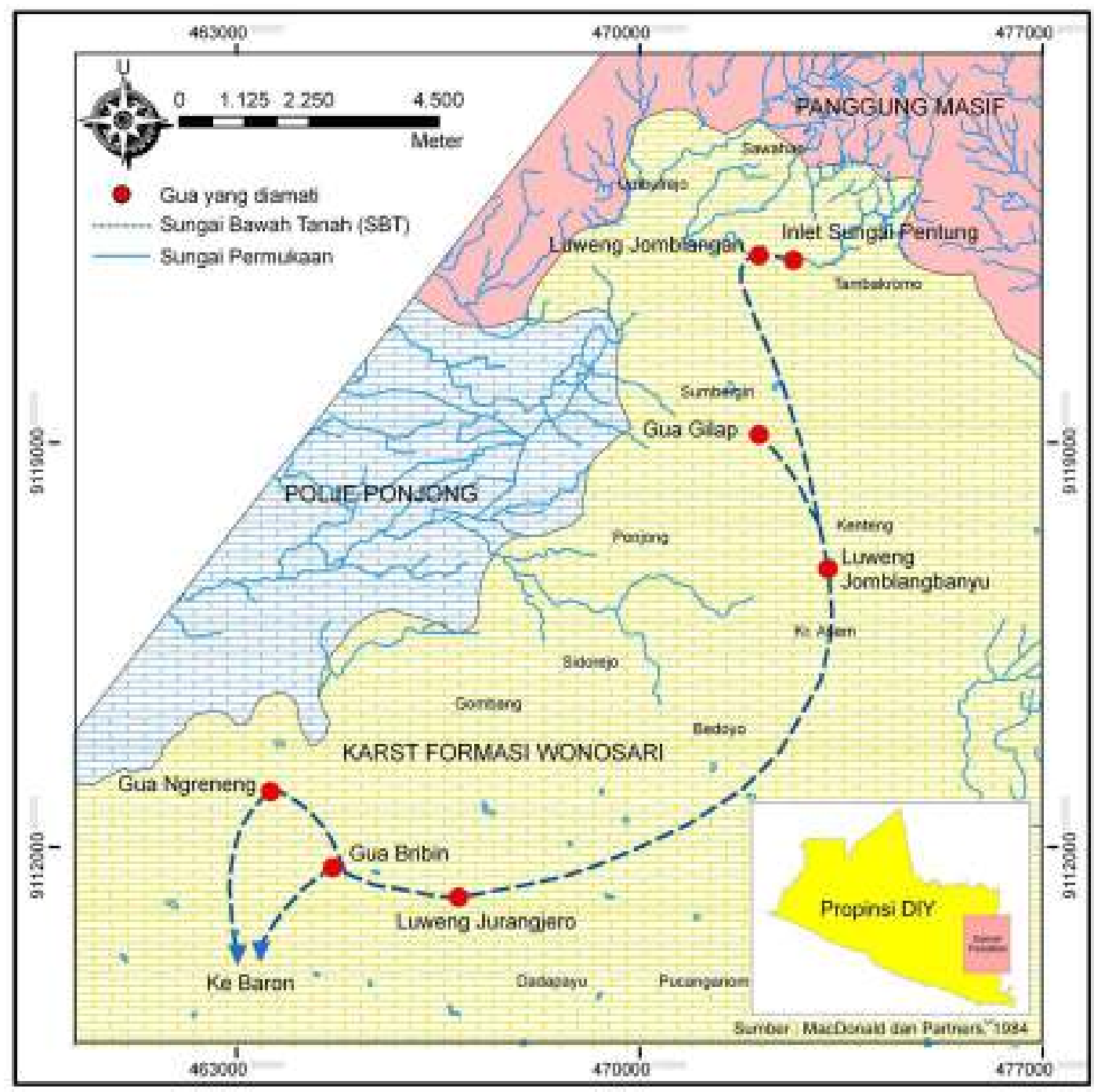

Gambar 1.3. Sistem Sungai Bawah Tanah (SBT) Bribin (MacDonald dan Partners, 1984)

Istilah Karst Dynamic System atau Sistem Karst Dinamis (SKD) yang pertama kali dikenalkan oleh Daoxian (2005) sebenarnya bukan merupakan istilah 
baru. Bogli (1960, 1980), Sweeting (1972), Trudgill (1985), dan Ford dan Williams (1992), menjelaskan istilah ini sebagai suatu sistem yang di dalamnya terjadi proses yang dinamis antara $\mathrm{H}_{2} \mathrm{O}, \mathrm{CO}_{2}$ dan $\mathrm{CaCO}_{3}$ yang dikontrol oleh karakteristik akuifer batuan gamping. White (1988), Ford dan Williams (1992), Smart dan Hobbes (1986) serta Gillieson (1996) secara prinsip membagi karakteristik aliran pada SKD menjadi tiga yaitu: (a)aliran lorong (conduit); (b)celah (fissure), dan (c)rembesan (diffuse). Ketiga sifat aliran ini mempunyai karakteristik dan sumber yang berbeda dan berkaitan erat dengan 4 (empat) komponen utama imbuhan akuifer.

Karena sifat pelorongannya yang anisotropis, penelitian untuk mengungkapkan sifat dan karakteristik akuifer karst di suatu kawasan umumnya dilakukan dengan pendekatan induktif. Salah satu pendekatan induktif yang dapat digunakan adalah pendekatan hidrogeokimia yang berasumsi bahwa komposisi kimia airtanah karst merupakan cerminan dari proses yang berlangsung dalam akuifer karst (Mudry, 2004). Metode ini dapat dikombinasikan dengan kajian sifat aliran sungai bawah tanah dan merupakan metode yang dianggap paling representatif karena mampu mendeskripsikan sistem media penyimpan airtanah karst, termasuk sifat aliran pada akuifer berbatuan gamping yang berkorelasi dengan sifat kimia airtanah karst, seperti yang dilakukan oleh Liu, et al. (2004a dan 2004b), Etfimi (2005), Wang dan Luo (2001), Anthony, et al. (1997) serta Raeisi dan Karami (1997). Selanjutnya, Martin et al. (2002) dan Karimi et al. (2004) mengungkapkan bahwa interaksi antara diffuse flow dan conduit flow yang berperan banyak terhadap pelebaran celah pada batuan karbonat, ternyata juga dipicu oleh kadar agresivitas airtanah karst, sedangkan Taylor dan Greene (2001) mengungkapkan bahwa untuk mengkarakterisasi akuifer karst secara detail diperlukan pendekatan kuantitatif. 


\section{B. Permasalahan}

Pada periode tahun 2004 s.d. 2009 ini, kerjasama antara Pemerintah Provinsi Daerah Istimewa Yogyakarta (DIY), Kabupaten Gunung Kidul, Badan Tenaga Atom Nasional, Kementerian Negara Riset dan Teknologi, Federal Misnistry and Education-Universitas Kalsruhe, Jerman sudah menyelesaikan proyek pemboran dan membuat bendung bawah tanah sistem mikrohidro dengan ketinggian $6 \mathrm{~m}$ dan luas $15 \mathrm{~m}^{2}$ yang terletak sekitar $1 \mathrm{~km}$ pada arah downstream bendungan Bribin (lama). Bendungan baru ini diharapkan dapat menghasilkan listrik sebesar 250 s.d. $300 \mathrm{KW}$ yang kemudian akan digunakan untuk meningkatkan kapasitas pelayanan kepada masyarakat menjadi dua kali lipat dari sebelumnya. Melihat uraian tersebut, harapan terhadap kelangsungan sumberdaya airtanah SBT Bribin sangat besar mengingat besarnya investasi yang dikeluarkan. Hanya saja, selama ini belum ditemukan penelitian terkait dengan kondisi aliran Sungai Bawah Tanah Bribin dan akuifer karst dan proses hidrogeokimia yang mengontrol perkembangan SBT Bribin ini, sehingga muncul permasalahan-permasalahan penelitian sebagai berikut:

1. Bagaimanakah variasi spasial dan temporal sifat aliran SBT Bribin yang tercermin dari pelepasan aliran akuifer karst dan persentase aliran dasar (PAD) di SBT Bribin sepanjang tahun;

2. Bagaimanakah variasi spasial dan temporal kondisi hidrogeokimia di SBT Bribin dan bagaimanakah hubungannya dengan sifat alirannya sepanjang tahun;

3. Bagaimanakah karakteristik Sistem Karst Dinamis (SKD) di SBT Bribin yang didekati dengan tingkat agresivitas untuk melarutkan batuan gamping dan bagaimanakah hubungannya dengan perilaku parameter SKD sepanjang tahun.

Untuk menjawab tiga pertanyaan di atas, maka atas dasar latar belakang yang sudah diungkapkan, pendekatan hidrogeokimia yang dikombinasikan dengan kajian 
sifat aliran sungai bawah tanah pada SBT Bribin merupakan metode yang paling cocok karena komposisi kimia airtanah karst dan karakteristik aliran SBT merupakan cerminan dari proses pelarutan dan sifat pelepasan komponen aliran akuifer karst yang berlangsung searah aliran airtanah. Selain itu, pendekatan ini dipilih karena metode investigasi air bawah tanah seperti yang dapat dilakukan di kawasan nonkarst sangat sulit dilakukan mengingat sifat akuifer karst yang bersifat heterogen dan anisotropis. Atas dasar pemikiran dan permasalahan di atas, maka penulis memilih judul disertasi yaitu: "Variasi Spasial-Temporal Hidrogeokimia dan Sifat Aliran untuk Karakterisasi Sistem Karst Dinamis (SKD) pada Sungai Bawah Tanah (SBT) Bribin, Kabupaten Gunung Kidul, DIY”.

Berkaitan dengan judul penelitian tersebut, Strahler (1973) menjelaskan bahwa fokus kajian geografi fisik adalah live layer, yaitu mintakat dangkal di daratan atau lautan yang di dalamnya terdapat sebagian besar makluk hidup (biosphere), termasuk di dalamnya adalah hydrosphere yang menjelaskan tentang fenomena air dalam bentuk gas, cair atau padat. Pernyataan ini mengandung pengertian bahwa penelitian hidrologi pada suatu sungai bawah tanah, dalam hal ini adalah SBT Bribin merupakan bagian dari penelitian Geografi Fisik. Selanjutnya, kedudukan penelitian ini dalam lingkup permasalahan geografi yang lebih luas adalah untuk menjelaskan perbedaan fenomena hidrologi dan hidrogeokimia sebagai salah satu obyek material dalam ilmu Geografi Fisik, pada beberapa titik pengamatan di SBT Bribin pada suatu daerah tangkapan hujan -'Geography is concerned with the description and explanation of the areal differentiation of the earth surface' (Harvey, 1969). Penelitian ini menurut Bintarto dan Hadisumarno (1987), Haggett (1975), dan Yunus (2008) dapat dikategorikan dalam penelitian geografis karena penelitian ini bertujuan untuk memperoleh pemahaman mengenai perbedaan kondisi hidrologi dalam suatu ruang yaitu daerah tangkapan hujan SBT Bribin, serta mengkajinya dari 
hulu ke hilir (spasial) yang bertujuan untuk membedakan karakteristik tiap-tiap titik gua pada SBT Bribin yang dibedakan antara musim hujan dan kemarau (temporal) serta mengkaitkannya antara titik (gua-gua) dengan menggunakan parameter tertentu.

\section{Tujuan dan Sasaran Penelitian}

Tujuan penelitian ini adalah sebagai berikut:

1. mengevaluasi variasi spasial-temporal karakteristik dan persentase aliran dasar (PAD) di SBT Bribin;

2. mengkaji hubungan antara variasi spasial-temporal karakter hidrogeokmia SBT Bribin dengan sifat alirannya;

3. mengkarakterisasi Sistem Karst Dinamis (SKD) SBT Bribin berdasarkan tingkat agresivitas air terhadap batugamping dan hubungannya dengan parameter SKD.

Dalam rangka mencapai tujuan-tujuan penelitian tersebut, maka sasaran utama penelitian ini adalah: (1) fluktuasi debit aliran SBT Bribin dari hulu ke hilir sepanjang tahun; (2) PAD SBT Bribin dari hulu ke hilir sepanjang tahun; (3) karakteristik resesi akuifer karst dalam melepaskan komponen air; (4) hidrogeokimia aliran SBT Bribin; tetesan ornamen dan air hujan; (5) agresivitas air SBT Bribin untuk melarutkan batuan karbonat; dan (6) perilaku parameter SKD sepanjang tahun.

\section{Kegunaan Penelitian}

\section{Untuk ilmu pengetahuan}

Secara umum, penelitian ini merupakan penelitian untuk mengungkap secara lebih rinci tentang karakteristik aliran dan proses hidrogeokimia secara spasial yang terjadi di SBT Bribin dalam kurun waktu satu tahun. Sementara itu, secara khusus penelitian ini bermanfaat untuk: (1) mengungkap hubungan antara variabel-variabel yang berpengaruh terhadap kondisi aliran di SBT Bribin dari hulu ke hilir sepanjang 
tahun; (2) mengungkap hubungan SBT Bribin dengan kondisi hidrogeokimianya. Dengan kata lain, ciri-ciri hidrogeokimia dan tingkat pelarutan batuan karbonat oleh aliran air SBT Bribin atas dasar variasi komponen alirannya akan terlihat sepanjang tahun dan juga secara spasial dari hulu ke hilir. Selain itu; (3) penelitian ini juga mengevaluasi peran dan karakteristik dari parameter SKD terhadap proses pelarutan yang selama ini terjadi di SBT Bribin, sehingga dengan informasi hubungan antara kondisi aliran dan hidrogeokimia sungai bawah tanah, maka karakteristik akuifer karst yang selama ini tidak mungkin disurvei secara langsung di lapangan dapat dijelaskan atas dasar sifat proses hidrogeokimia dan komponen aliran yang dominan dari hulu ke hilir secara time series.

\section{Manfaat praktis}

Selain manfaat yang telah disebutkan, manfaat praktis dari penelitian ini adalah untuk: (1) mengetahui variasi spasial dan temporal potensi SBT Bribin dalam hal pelepasan komponen aliran karst; (2) mengetahui tipologi gua dengan debit andalan (PAD) yang stabil sepanjang tahun, serta hubungannya dengan kondisi kualitas airnya; dan (3) memperoleh gambaran tentang wilayah konservasi terhadap simpanan air pada daerah tangkapan SBT Bribin secara spasial yang dapat mengacu pada kondisi aliran dan karakter dari SKD di SBT Bribin. Dari manfaat-manfaat praktis yang sudah disebutkan di atas, maka hasil dari penelitian ini dapat digunakan sebagai acuan pengelolaan sumberdaya air yang berkelanjutan di SBT Bribin dalam beberapa aspek yaitu ketersediaan debit andalan pada musim kemarau, kondisi kualitas air untuk keperluan pemenuhan kebutuhan domestik masyarakat, dan potensi terjadinya pencemaran dari permukaan ke dalam sistem SBT Bribin, serta rekomendasi tentang konservasi daerah tangkapannya. 


\section{E. Keaslian Penelitian}

Perbandingan penelitian ini dengan penelitian lain yang sejenis ditunjukkan pada Tabel 1.1. Dalam hal lokasi penelitian, beberapa penelitian sebelumnya yang dapat diacu diantaranya adalah Danes (1910), Lehmann (1936), MacDonald dan Partners (1984), Urushibara dan Yoshino (1995), Kusumayuda et al. (2000), serta Haryono dan Day (2004). Hanya saja, penelitian mengenai hidrogeokimia dan sifat komponen aliran sungai bawah tanah di kawasan karst Gunung Sewu belum pernah dilakukan. Penelitian mengenai hidrogeokimia karst di Indonesia yang dijumpai pada umumnya berkisar pada kondisi kualitas air untuk air minum serta kandungan pencemar, dan bukan untuk mengetahui tingkat agresivitas airtanah karst dan prosesproses hidrogeokimia yang terjadi, apalagi untuk mengkaji sifat komponen alirannya. Penelitian mengenai karakteristik hidrograf satuan di Gua Bribin pernah dilakukan oleh Suryanta (2001), tetapi skala waktunya pendek dan tidak dihubungkan dengan karakteristik hidrogeokimia. Selain itu, penelitian tersebut mengambil asumsi bahwa batas-batas daerah tangkapan SBT Bribin sudah terdefinisi dengan benar.

Dalam hal metode, penelitian ini menggunakan metode atau gabungan metode dari beberapa peneliti yang melakukan studi karst dengan menggunakan metode hidrogeokimia. Variabel yang digunakan kurang lebih sama dengan penelitian yang dilakukan oleh Liu, et al. (2004a; 2004b) dan Anthony, et al. (1997), namun variasi temporal yang dilakukan pada penelitian ini lebih panjang serta lokasi penelitian yang lebih luas dan bervariasi. Metode analisis yang digunakan merupakan gabungan dari beberapa metode yang dilakukan oleh Etfimi (2005), Raesi dan Karami (1997), serta Wang dan Luo (2001). Sementara itu, kerangka waktu pengambilan sampel yang akan digunakan mengacu pada Currens (1999), dengan sedikit modifikasi. 
Tabel 1.1. Perbandingan Penelitian dengan Penelitian Sejenis

\begin{tabular}{|c|c|c|c|c|}
\hline No & Peneliti, Tahun, Judul & Tujuan Utama & Metode & Hasil \\
\hline 1 & $\begin{array}{l}\text { MacDonald dan Partners } \\
\text { (1984), Greater Jogjakarta, } \\
\text { Study Report }\end{array}$ & $\begin{array}{l}\text { Mempelajari sistem bawah } \\
\text { tanah karst dan } \\
\text { menginventarisasi } \\
\text { sumberdaya airnya }\end{array}$ & $\begin{array}{l}\text { Survei lapangan } \\
\text { (pemetaan gua-gua, tracer } \\
\text { test) }\end{array}$ & $\begin{array}{l}\text { Peta sebaran gua-gua, } \\
\text { sistem SBT, dan kondisi } \\
\text { kualitas-kuantitas airnya }\end{array}$ \\
\hline 2 & $\begin{array}{l}\text { Kusumayuda et al. (2000), } \\
\text { Fractal analysis of the Oyo } \\
\text { River, cave system, and } \\
\text { topography of the Gunungsewu } \\
\text { karst area, Central Java, } \\
\text { Indonesia }\end{array}$ & $\begin{array}{l}\text { Menghitung dan } \\
\text { membandingkan dimensi } \\
\text { fractal lembah pada berbagai } \\
\text { litologi dan struktur serta } \\
\text { antara lembah permukaan } \\
\text { dan lorong gua }\end{array}$ & $\begin{array}{l}\text { Analisis peta dan box- } \\
\text { counting }\end{array}$ & $\begin{array}{l}\text { Dimensi fraktal lembah } \\
\text { Oyo bervariasi pada setiap } \\
\text { segmen yang dikontrol } \\
\text { oleh litologi dan struktur } \\
\text { geologi ; dimensi fraktal } \\
\text { alur gua persentaseonal } \\
\text { terhadap dimensi fractal } \\
\text { topografi permukaan }\end{array}$ \\
\hline 3 & $\begin{array}{l}\text { Fakultas Kehutanan, (1993), } \\
\text { Penyusunan Arahan } \\
\text { Konservasi Tanah dan Air di } \\
\text { Daerah Tangkapan Air Gua } \\
\text { Bribin Kabupaten. Gunung } \\
\text { Kidul DIY }\end{array}$ & $\begin{array}{l}\text { Menyusun arahan konservasi } \\
\text { yang tepat untuk DTA Bribin }\end{array}$ & Survey lapangan & $\begin{array}{l}\text { Peta dugaan sistem aliran } \\
\text { sekunder dan primer SBT } \\
\text { Bribin atas dasar compass } \\
\text { surveying pada gua-gua } \\
\text { terlingkup DTA Bribin }\end{array}$ \\
\hline 4 & $\begin{array}{l}\text { Haryono dan Day (2004), } \\
\text { Landform differentiation within } \\
\text { the Gunung Kidul Kegel karst, } \\
\text { Java, Indonesia }\end{array}$ & $\begin{array}{l}\text { Membuktikan bahwa } \\
\text { anggapan selama ini bahwa } \\
\text { topografi karst GunungSewu } \\
\text { adalah semata-mata } \\
\text { Kegelkarst adalah terlalu } \\
\text { sederhana }\end{array}$ & $\begin{array}{l}\text { Analisis kelurusan, doline, } \\
\text { lembah, bukit karst dari } \\
\text { foto udara }\end{array}$ & $\begin{array}{l}\text { Bahwa sebenarnya } \\
\text { geomorfologi karst } \\
\text { Gunung Sewu dapat } \\
\text { diklasifikasikan menjadi } 3 \\
\text { tipe yaitu labirinth, } \\
\text { polygonal, dan tower karst }\end{array}$ \\
\hline 5 & $\begin{array}{l}\text { Liu, et al. (2004), South China } \\
\text { Karst Aquifer Storm-Scale } \\
\text { Hydrochemistry }\end{array}$ & $\begin{array}{l}\text { Mencari hubungan antara air, } \\
\text { atmosfer dan akuifer } \\
\text { gampingan }\end{array}$ & $\begin{array}{l}\text { Pengukuran sifat fisik dan } \\
\text { kimia, } \mathrm{SI}, \mathrm{PCO}_{2} \\
\text { Analisis statistik }\end{array}$ & $\begin{array}{l}\text { Terdapat } 2 \text { proses utama } \\
\text { saat banjir yaitu } \\
\text { pengenceran oleh air } \\
\text { hujan dan interaksi antara } \\
\text { air-batuan-gas }\end{array}$ \\
\hline 6 & $\begin{array}{l}\text { Wang, et al. (2001), } \\
\text { Geostatistical and geochemical } \\
\text { analysis of surface water } \\
\text { leakage into groundwater on a } \\
\text { regional scale: a case study in } \\
\text { the Liulin karst system }\end{array}$ & $\begin{array}{l}\text { Mengetahui transfer massa } \\
\text { kimia pada sistem yang } \\
\text { diindikasi terpengaruh oleh } \\
\text { bocoran sungai permukaan }\end{array}$ & $\begin{array}{l}\text { Geostatistik } \\
\text { Geokimia } \\
\text { Analisis SI } \\
\text { Analisis kesetimbangan } \\
\text { massa (invers model) }\end{array}$ & $\begin{array}{l}\text { Mixing merupakan proses } \\
\text { yang dominan } \\
\text { Pelarutan dolomit juga } \\
\text { merupakan proses yang } \\
\text { dominan daripada } \\
\text { pelarutan kalsit }\end{array}$ \\
\hline 7 & $\begin{array}{l}\text { Raeisi dan Karami, } 1997 . \\
\text { Hydrochemographs of Berghan } \\
\text { karst spring as indicators of } \\
\text { aquifer characteristics }\end{array}$ & $\begin{array}{l}\text { Mengkarakteristik } \\
\text { komponen akuifer karst } \\
\text { secara hidrokimia }\end{array}$ & $\begin{array}{l}\text { Pemisahan komponen } \\
\text { aliran } \\
\text { Pengukuran } \\
\text { hidrogeokimia } \\
\text { Analisis chemograf, } \\
\mathrm{SI}_{\mathrm{PCO}}\end{array}$ & $\begin{array}{l}\text { Ada pola rasio yang } \\
\text { menarik antara komponen } \\
\text { aliran secara time-series, } \\
\text { tiap komponen } \\
\text { mempunyai karakteristik } \\
\text { hidrokimia yang } \\
\text { signifikan } \\
\end{array}$ \\
\hline 8 & $\begin{array}{l}\text { Karimi, H., Raeisi , E., Zare, } \\
\text { M. (2003), Hydrodynamic } \\
\text { behavior of the Gilan karst } \\
\text { spring, west of Zagros, Iran }\end{array}$ & $\begin{array}{l}\text { Menghitung persentase } \\
\text { komponen aliran mataair } \\
\text { karst selama satu tahun dan } \\
\text { mengkorelasikannya dengan } \\
\text { kondisi hidrokimianya }\end{array}$ & $\begin{array}{l}\text { Analisis chemograf } \\
\text { Analisis SI, } \mathrm{PCO}_{2} \\
\text { Memisahkan komponen } \\
\text { aliran }\end{array}$ & $\begin{array}{l}\text { Kontribusi conduit musim } \\
\text { kemarau menurunkan nilai } \\
\text { koefisien resesi, karena } \\
\text { pengaruh bentuk DAS } \\
\text { yang panjang dan sempit, } \\
\text { mengakibatkan durasi } \\
\text { hujan jauh lebih kecil dari } \\
\text { time lag-nya, sehingga } \\
\text { nilai EC kemarau turun }\end{array}$ \\
\hline 9 & $\begin{array}{l}\text { Currens, (1999), A sampling } \\
\text { plan for conduit flow karst } \\
\text { springs, minimizing sampling } \\
\text { cost and maximizing statistical } \\
\text { utility }\end{array}$ & $\begin{array}{l}\text { Membuat acuan minimal } \\
\text { waktu sampling pada aliran } \\
\text { konduit }\end{array}$ & $\begin{array}{l}\text { Mengkombinasikan } \\
\text { berbagai waktu minimal } \\
\text { pengambilan sampel }\end{array}$ & $\begin{array}{l}\text { Sampling } 2 \text { mingguan } \\
\text { cukup untuk mewakili } \\
\text { aliran conduit dengan } \\
\text { perubahan yang cepat } \\
\text { dalam skala waktu setahun }\end{array}$ \\
\hline
\end{tabular}




\begin{tabular}{|c|c|c|c|c|}
\hline 10 & $\begin{array}{l}\text { Adji (2009), Variasi Spasial- } \\
\text { Temporal Hidrogeokimia dan } \\
\text { Sifat Aliran } \\
\text { Karakterisasi Sistem } \\
\text { Dinamis (SKD) pada } \\
\text { Bawah Tanah (SBT) Bribain, } \\
\text { Kabupaten Gunung Kidul, DIY. }\end{array}$ & $\begin{array}{l}\text { Mengetahui variasi } \\
\text { temporal-spasial komponen } \\
\text { aliran Mengevaluasi kondisi } \\
\text { hidrogeokimia Menghitung } \\
\text { tingkat agresivitas air dan } \\
\text { perilaku parameter SKD }\end{array}$ & $\begin{array}{l}\text { Pemisahan komponen } \\
\text { aliran } \\
\text { Analisis resesi banjir } \\
\text { Pengukuran } \\
\text { Hidrogeokimia } \\
\text { Analisis chemograf } \\
\text { Analisis } \mathrm{SI}_{\mathrm{PCO}} \\
\text { Analisis spasial- temporal }\end{array}$ & $\begin{array}{l}\text { Terdapat variasi spasial } \\
\text { dan temporal pada } \\
\text { karakteristik aliran, } \\
\text { hidrogeokimia dan } \\
\text { agresivitas di SBT Bribin, } \\
\text { dan terdapatnya hubungan } \\
\text { antara sifat aliran dan } \\
\text { hidrogeokimia dan } \\
\text { karakteristik SKD di SBT } \\
\text { Bribin }\end{array}$ \\
\hline
\end{tabular}

Sumber : telaah pustaka oleh penulis (2006)

Secara metodologis, penelitian ini menggunakan pendekatan spasial yaitu membandingkan kondisi aliran, hidrogeokimia dan tingkat agresivitas air untuk melarutkan batugamping pada suatu ruang yaitu daerah tangkapan hujan SBT Bribin, sehingga mendapatkan hasil karakteristik yang berbeda pada masing-masing titik yang diamati di SBT Bribin dari hulu ke hilir. Penelitian ini membandingkan kondisi aliran, hidrogeokimia dan tingkat agresivitas air untuk melarutkan batugamping selama satu tahun dan dibedakan antara musim kemarau dan musim penghujan, sehingga diperoleh variasi temporal dan spasial perbedaan proses-proses yang berpengaruh pada kondisi aliran. Di samping itu, evaluasi terhadap kondisi hidrogeokimia serta kajian hubungannya dengan sifat aliran akan menjawab karakteristik sifat sistem hidrologi SBT Bribin dari hulu ke hilir. Selanjutnya, penelitian ini juga mengkarakterisasi bagaimanakah sifat agresivitas air untuk melarutkan batugamping dan mengkaji hubungannya dengan parameter SKD di SBT Bribin. 


\section{BAB II. TINJAUAN PUSTAKA}

\section{A. Telaah Pustaka}

\section{Terminologi dan Konsep Karst}

Ahli geomorfologi menggunakan karst sebagai istilah untuk medan dengan batuan gamping yang dicirikan oleh drainase permukaan yang langka, solum tanah yang tipis dan hanya setempat-setempat, terdapatnya cekungan-cekungan tertutup (doline), serta keberadaan sistem drainase bawah tanah yang lebih dominan dibandingkan dengan sistem aliran permukaan (Summerfield, 1991). Sementara itu, Ford dan Williams (1992) mendefinisikan istilah karst secara lebih umum sebagai medan dengan karakteristik hidrologi dan bentuklahan yang diakibatkan oleh kombinasi dari batuan yang mudah larut (soluble rock) dan mempunyai porositas sekunder yang berkembang baik. Proses karstifikasi secara kimiawi adalah terjadinya reaksi antara zat padat yang mengandung mineral karbonat, zat cair atau air yang mengandung unsur-unsur terlarut tertentu, dan gas atau udara yang berisi gas karbondioksida (White, 1988). Lebih jauh lagi, proses yang terjadi pada sistem karst, menurut Daoxian (2005) merupakan bagian dari siklus karbon, air dan kalsium di bumi yang terjadi pada batas antar fase (interface) antara hidrosfer, atmosfer, dan litosfer.

Istilah "karst" pada mulanya diambil dari suatu nama tempat Krs di Slovenia (sekarang terletak di baratlaut Yugoslavia), merupakan suatu tipikal dari lahan gersang yang berbatu (Short dan Blair, 1986). Ahli sejarah juga mengatakan wilayah tersebut dekat dengan Kota Trieste, Italia. Dari tipikal kata Indo-Eropa, "kar" atau "karra" atau dalam bahasa Italia adalah "carso" yang berarti batu kemudian berevolusi menjadi kars atau kras (Bahasa Jerman). Selanjutnya, karst dipakai secara 
ilmiah dan dikenal secara luas untuk mendeskripsikan suatu bentang alam hasil proses pelarutan yang biasanya terjadi pada suatu wilayah yang berbatuan gamping. Pada dunia pendidikan, istilah karst pertama kali dipakai dalam bidang ilmu kebumian di sekolah-sekolah geografi dan geologi di Wina Austria, sekitar pertengahan abad 19 (Sweeting, 1972; Ford dan Williams, 1992). Telaahan pustaka dari Sweeting (1972), Bogli (1980), Trudgill (1985), White (1988) menyebutkan bahwa karst sebenarnya tidak hanya dapat terbentuk pada batuan gamping, tetapi juga dapat berkembang pada batugaram dan gipsum. Namun, sebagian besar karst berkembang di kawasan berbatuan gamping, karena singkapannya yang lebih luas dibanding batugaram dan gipsum.

Ciri utama kawasan karst di permukaan (eksokarst) adalah terdapatnya cekungan-cekungan tertutup yang dikenal sebagai dolin. Apabila dolin saling menyatu membentuk uvala. Di beberapa tempat, dolin dapat terisi air membentuk danau dolin. Kenampakan permukaan daerah karst selain dolin dan uvala adalah polje, ponor, pinnacle, dan menara karst, atau kubah karst. Kombinasi dolin dan kubah menyebabkan panorama karst menjadi unik dengan bukit-bukit yang terhampar luas. Selain itu, menurut Ford dan Cullingford (1976), keunikan lain dari kawasan karst adalah ciri-ciri bawah permukaan (endokarst) yaitu keberadaan gua dan sungai bawah tanah. Gua-gua tersebut pada umumnya bertingkat dengan ukuran kurang dari satu meter hingga ratusan meter persegi dengan bentuk vertikal miring maupun horisontal. Gua-gua karst hampir semuanya dihiasi dengan ornamen (speleothem) yang sangat beragam dari mulai yang sangat kecil (helectite) hingga yang sangat besar (column) dengan bentuk dan warna yang bervariasi.

Hampir di setiap pulau di Indonesia memiliki batuan gamping, tapi tidak semuanya terkartsifikasi menjadi kawasan karst. Menurut Balazs (1968) terdapat 17 
lokasi yang dapat dikategorikan sebagai kawasan karst. Karst di Indonesia seperti yang ditulis oleh Balazs (1971) tersebar di sebagian besar pulau-pulau, namun demikian tidak semuanya berkembang dengan baik. Di antara kawasan karst tersebut, terdapat dua kawasan karst yang paling baik dan dianggap sebagai prototipe dari karst daerah tropis, yaitu karst Maros dan Gunung Sewu. Lebih khusus lagi, Karst Gunung Sewu, yang pertama kali diperkenalkan oleh Lehmann (1936) termasuk dalam tipe Kegelkarst, dicirikan dengan berkembangnya kubah-kubah karst yang berbentuk kerucut (connical). Karst Gunung Sewu juga dicirikan dengan bentukan dolin yang pada setiap musim penghujan selalu terisi air yang kemudian disebut telaga, dengan jumlah ratusan. Luas karst Gunung Sewu mencapai sekitar $3300 \mathrm{~km}^{2}$ yang meliputi Provinsi DIY, Jawa Tengah, dan Jawa Timur. Istilah karst Gunung Sewu sebagai Kegelkarst ini dikuatkan oleh Flathe dan Pfeiffer (1965), serta Balazs (1968 \& 1971), Verstappen (1969), dan Waltham, et al. (1983). Bahkan, Balazs (1968) mengkonfirmasikan bahwa bukit connical di kawasan ini berjumlah lebih dari 40.000 buah dengan kepadatan sekitar 30 bukit $/ \mathrm{km}^{2}$.

Penelitian-penelitian lain terkait kondisi geomorfologi karst Gunung Sewu diantaranya adalah oleh Haryono dan Day (2004), Ahmad, dkk (2005), Srijono dan Aldilla (2006) yang mengungkapkan bahwa karst Gunung Sewu bukan semata-mata merupakan kegelkarst, tetapi mempunyai variasi yang lebih detail terkait dengan konfigurasi parameter-paramater lembah dan kerucut karstnya. Selain itu, penelitian terkini oleh Haryono (2008) mengungkapkan bahwa proses pelarutan bukan merupakan satu-satunya proses yang dominan, akan tetapi terdapat peranan proses fluvial yang berperan dalam perkembangan topografi karst Gunung Sewu. 


\section{Karstifikasi}

Secara umum, karstifikasi sering disebut sebagai proses solusional karena proses kimia yang dominan adalah pelarutan (dissolution) batugamping oleh air yang kaya akan gas karbondioksida. Bentuklahan yang dihasilkan oleh proses ini secara geomorfologis disebut sebagai bentang alam karst. Jankowski (2001) mengungkapkan bahwa ada dua syarat utama suatu formasi karst dapat terbentuk karena proses pelarutan oleh air yaitu sifat air yang melalui karst harus tidak jenuh (undersaturated) terhadap batuan gamping, dan air tersebut harus mampu mentransport produk hasil pelarutan ke tempat lain. Kondisi air yang cocok untuk pelarutan batuan gamping ini adalah air freatik dan juga air hujan (meteoric water) yang kaya akan $\mathrm{CO}_{2}$. Air ini biasa masuk ke batuan gamping secara gravitasi dan kemudian mampu membentuk lorong-lorong solusional. Lebih jauh lagi Jankowski (2001) menjelaskan bahwa untuk memperoleh air yang bersifat tidak jenuh terhadap batuan gamping ada beberapa mekanisme yang sering terjadi pada airtanah karst yaitu perubahan suhu, percampuran (mixing) dengan air yang mempunyai sifat lain, terjadinya banjir di permukaan yang menyebabkan imbuhan yang cepat dan bersifat tidak jenuh, dan meningkatnya kondisi keasaman air sepanjang aliran airtanah. Lebih jauh lagi Jankowski (2001) mengemukakan bahwa terdapat empat faktor yang dapat mempercepat proses pelarutan di daerah karst, di antaranya adalah sebagai berikut:

a) Perubahan suhu airtanah karst. Menurunnya suhu air akan mempercepat proses pelarutan khususnya pada akuifer karst berbatuan gamping $\left(\mathrm{CaCO}_{3}\right)$ karena terkait dengan jumlah gas karbondioksida yang terlarut dalam air, yang oleh banyak ahli karst di dunia dapat diidentifikasi dengan mengukur tekanan parsial gas tersebut. Dari hasil observasi lapangan dan percobaan di laboratorium, terungkap bahwa tekanan gas karbondioksida akan naik seiring dengan 
turunnya suhu air. Di lapangan turunnya suhu air tersebut terkait juga dengan masukan komponen aliran yang biasanya berasal dari sistem terbuka (open system) yang kaya akan gas karbondioksida.

b) Derajat keasaman $(\mathrm{pH})$ air. Reaksi pertama pada perpindahan massa dan reaksi kimia antar fase udara-air pada karstifikasi mensyaratkan bahwa air yang asam akan terjadi bila gas karbondioksida masuk ke air dan membentuk senyawa asam dengan $\mathrm{H}_{2} \mathrm{O}$ menjadi $\mathrm{H}_{2} \mathrm{CO}_{3}$, sehingga dapat dikatakan bahwa semakin kecil $\mathrm{pH}$ air, maka akan semakin cepat proses pelarutan atau membuat air dalam keadaan belum jenuh (undersaturated) terhadap batugamping. Besar kecilnya tingkat keasaman ini tentunya tergantung dari tipe aliran yang dominan pada sungai bawah tanah, apakah termasuk conduit yang mempunyai sistem terbuka (open system) ataukah diffuse yang miskin oleh gas karbondioksida (closed system).

c) Pengaruh dari ion lain. Pada sistem SKD, ion mayor selain $\mathrm{Ca}^{2+}$ dan $\mathrm{HCO}^{3-}$ biasanya juga terlarut dalam air, biasanya $\mathrm{Mg}^{2+}$ mempunyai proporsi yang cukup tinggi, sementara $\mathrm{SO}_{4}{ }^{2-}$ biasanya terlarut dalam jumlah yang kecil. Ion alkali bahkan sering dijumpai pada sistem ini jika lokasinya dekat dengan laut atau danau yang asin di daerah kering/arid. Pengaruh ion-ion tersebut adalah terhadap kemudahan untuk melarutkan batuan gamping (solubility). Sebagai contoh, penambahan $0,1 \%$ larutan $\mathrm{NaCl}$ (ion lain) meningkatkan pelarutan sebesar $10-20 \%$. Sementara itu, penambahan ion sejenis $\left(\mathrm{Ca}^{2+}\right.$ dan $\left.\mathrm{HCO}_{3}^{-}\right)$ searah aliran airtanah akan memperlambat tingkat pelarutan.

d) Adanya percampuran (mixing) dengan komponen air lain, walaupun masingmasing sudah jenuh (supersaturated) terhadap batuan gamping. Teori percampuran (mixing) pertama kali diperkenalkan oleh Bogli (1960) yaitu jika 
ada dua air karst yang sama-sama sudah jenuh terhadap kalsit, maka jika bercampur akan menghasilkan air yang agresif terhadap batuan gamping Contohnya adalah adanya tenaga mekanis karena ada dua air yang bercampur memiliki tekanan parsial gas $\mathrm{CO}_{2}$ yang berbeda. Sebagai contoh, perkembangan gua terjadi sangat cepat pada zone sedikit di bawah muka air, dimana terjadi percampuran antara air vadose yang jenuh $\mathrm{CO}_{2}$ dan air freatik yang mempunyai gas $\mathrm{CO}_{2}$ sedikit dan sudah jenuh terhadap $\mathrm{CaCO}_{3}$ akan menghasilkan air yang agresif (undersaturated) terhadap mineral kalsit. Contoh yang lain adalah ketika terjadi percampuran dengan air laut yang sudah sangat jenuh terhadap mineral kalsit akan berubah menjadi sangat agresif untuk melarutkan ketika bercampur dengan air karst yang sudah jenuh pula.

Selanjutnya, Dreybort dan Gabrovsek (2003), mengungkapkan bahwa pelarutan batugamping akan berjalan lambat jika konsentrasi gas karbondioksida pada airtanah karst mempunyai konsentrasi yang kecil (di bawah $10^{-4} \mathrm{mmol} / \mathrm{cm}^{3}$ ). Sebaliknya, proses pelarutan akan meningkat drastis jika kandungan karbondioksida dalam air berjumlah signifikan. Bogli (1980) menyatakan bahwa air yang cocok untuk melarutkan batuan gamping adalah air freatik dan air hujan (meteoric water) yang kaya akan gas karbondioksida yang masuk ke batuan gamping dengan cara perpindahan massa melalui interface udara-air-batuan yang selanjutnya dikenal sebagai sistem $\mathrm{CO}_{2}-\mathrm{H}_{2} \mathrm{O}-\mathrm{CaCO}_{3}$. Dewasa ini, sistem tersebut lebih dikenal sebagai terminologi baru yaitu Karst Dynamic System (KDS) yang selanjutnya diterjemahkan menjadi Sistem Karst Dinamis atau SKD. Bogli (1980) juga menjelaskan bahwa pada proses pelarutan batuan gamping oleh air hujan dari udara dan jatuh ke permukaan menyebabkan terjadinya banyak proses fisik dan kimia yang melibatkan unsur gas, cair dan padatan yang menyebabkan perpindahan massa dan reaksi antara fase-fase udara, air, dan batuan seperti yang diilustrasikan pada Gambar 2.1. 


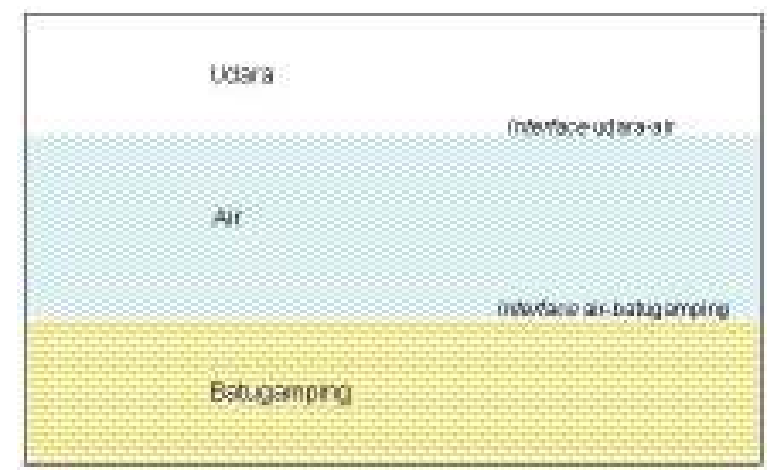

Gambar 2.1. Perpindahan Massa Melalui Interface Udara/Air Dan Udara/Batuan (Bogli, 1980)

Pada umumnya, proses yang terjadi pada interface/batas adalah transfer massa dan difusi, sementara reaksi kimia lebih dominan terjadi di air. Selanjutnya, jika memperhatikan Gambar 2.2. tampak bahwa sistem perpindahan massa yang terjadi pada sistem karbonat yang dikenal sebagai sistem $\mathrm{CO}_{2}-\mathrm{H}_{2} \mathrm{O}-\mathrm{CaCO}_{3}$, menurut Bogli (1980) mempunyai tahapan proses, yaitu:

(1) ketika terjadi hujan, gas karbondioksida $\left(\mathrm{CO}_{2}\right)$ di atmosfer masuk ke dalam air melalui proses difusi

(2) kemudian, air yang mengandung $\mathrm{CO}_{2}$ bersenyawa membentuk asam karbonat (carbonic acid) dengan reaksi kimia $\mathrm{CO}_{2}$ (di air) $+\mathrm{H}_{2} \mathrm{O} \longrightarrow \mathrm{H}_{2} \mathrm{CO}_{3}$, sehingga dapat dikatakan bahwa gas karbondioksida larut dalam air

(3) karena $\mathrm{H}_{2} \mathrm{CO}_{3}$ merupakan asam kuat, maka dapat mengalami dissociation (perpecahan) yaitu yang pertama $\mathrm{H}_{2} \mathrm{CO}_{3} \longrightarrow \mathrm{HCO}_{3}{ }^{-}+\mathrm{H}^{+}$dan yang kedua adalah $\mathrm{HCO}_{3}^{-} \longrightarrow \mathrm{CO}_{3}{ }^{2-}+\mathrm{H}^{+}$dengan proporsi yang kecil dibawah $\mathrm{pH} 8,4$ sehingga dapat diabaikan. 

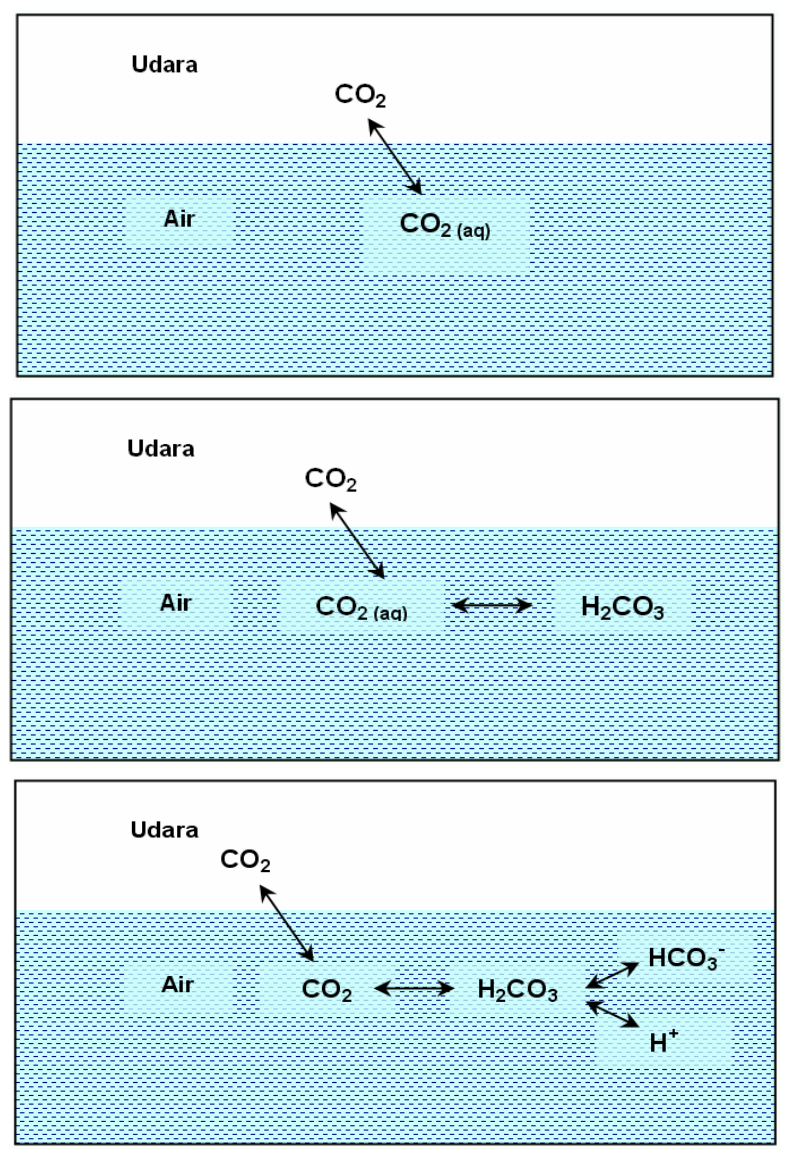

Gambar 2.2. Proses 1 Sampai Dengan 3 Pelarutan Batuan Gamping (Bogli, 1980)

Kemudian, proses selanjutnya adalah :

(4) ketika air dan batuan gamping berinteraksi, terjadi pelepasan ion dan kemudian terjadi reaksi pelarutan batugamping $\mathrm{CaCO}_{3} \longrightarrow \mathrm{Ca}^{2+}+\mathrm{CO}_{3}^{-}$

(5) selanjutnya, $\mathrm{CO}_{3}^{-}$bergabung dengan ion $\mathrm{H}^{+}$yang lepas pada reaksi (3) sehingga $\mathrm{CO}_{3}{ }^{2-}+\mathrm{H}^{+} \longleftrightarrow \mathrm{HCO}_{3}^{-}$

Untuk ilustrasi, proses (4) dan (5) disajikan pada Gambar 2.3. 

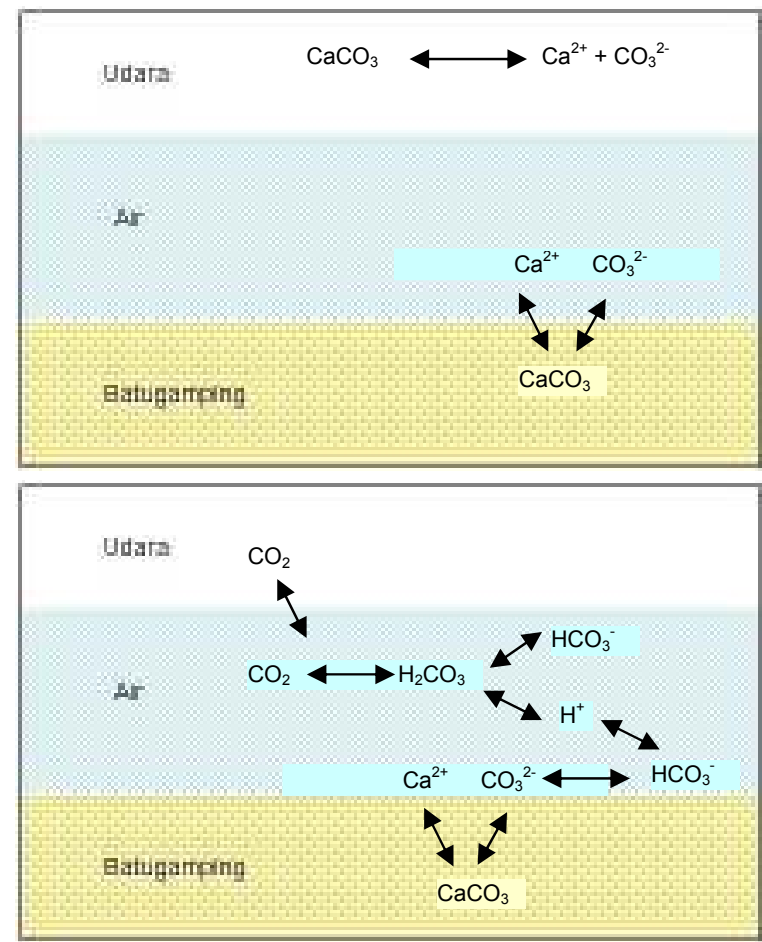

Gambar 2.3. Proses Pelarutan yang Diikuti oleh Pembentukan Bikarbonat (Bogli, 1980)

Dari proses di atas terlihat bahwa semakin banyak karbondioksida yang terlarut dalam air, maka semakin mudah pula air itu untuk melarutkan batuan gamping pada kondisi termodinamika ( $\mathrm{pH}$ dan suhu) yang sama (Appelo dan Postma, 1994), sehingga dapat disimpulkan bahwa transfer gas $\mathrm{CO}_{2}$ memegang peranan penting dalam proses karstifikasi.

\section{Sistem Karst Dinamis (SKD)}

Istilah SKD atau dalam Bahasa Inggrisnya adalah Karst Dynamic System (KDS) yang dipublikasikan pertama kali oleh Daoxian (2005) sebenarnya bukan merupakan istilah baru. Para ahli sebenarnya sudah memperkenalkan istilah ini, hanya saja bukan dengan istilah SKD ini, diantaranya adalah Bogli (1960; 1980), Sweeting (1972), Trudgill (1985), dan Ford dan Williams (1992). Semua publikasi di atas sepakat bahwa peranan dari gas $\mathrm{CO}_{2}$ dalam proses pelarutan/karstifikasi adalah 
sangat penting daripada hanya berkutat pada hubungan antara air dan batuan karst saja. SKD terdiri dari fase gas, padat, dan cair. Fase padatan didominasi oleh berbagai macam batuan gamping yang mempunyai rekahan yang membentuk jaringan. Fase cairan adalah air di karst yang mengandung unsur-unsur utama berupa $\mathrm{Ca}^{2+}, \mathrm{Mg}^{2+}, \mathrm{HCO}^{3-}, \mathrm{CO}_{3}{ }^{2-}, \mathrm{H}^{+}$, dan karbondioksida terlarut dalam air. Antara air dan padatan terdapat batas imajiner yang ketebalannya dikontrol oleh kondisi air dan sifat alirannya. Sementara itu, fase gas yang paling utama adalah gas karbondioksida, baik itu di atmosfer maupun di dalam air (Daoxian, 2005). SKD merupakan sistem terbuka karena berkembangnya lorong conduit di akuifer karst yang terhubung langsung ke permukaan melalui sinkhole. Sifatnya akan berubah dengan sangat cepat tergantung dari kondisi masing-masing fase, sehingga skala waktu perubahannya tidak harus selalu tergantung musim, tetapi dapat harian, jam-jaman, bahkan lebih singkat lagi. Pola dan perilaku dari SKD dapat diidentifikasi dengan mencari hubungan mutual antara suhu, $\mathrm{pH}, \mathrm{Ca}^{2+}$ atau $\mathrm{HCO}^{3-}$, dan karbondioksida (Daoxian, 2005).

\section{Akuifer dan sifat aliran karst}

Akuifer adalah suatu formasi batuan yang mampu menyimpan dan mengalirkan airtanah dalam jumlah yang cukup pada suatu kondisi kemiringan hidraulik tertentu (Acworth, 2001). Sementara itu, perdebatan apakah formasi karst dapat dikategorikan sebagai suatu akuifer sudah berlangsung lama. Akan tetapi, jika dilihat bahwa karst juga mampu menyimpan dan mengalirkan airtanah dalam jumlah yang cukup, maka formasi karst dapat disebut sebagai suatu akuifer (Ford dan Williams, 1992). Perbedaan utama di akuifer karst dibandingkan dengan akuifer pada bentang alam non-karst adalah berkembangnya porositas sekunder yang merupakan hasil dari proses sekunder (pelarutan). Sementara itu, akuifer di kawasan non-karst 
didominasi oleh porositas primer berupa rongga antar butir batuan yang bersifat homogen.

Sebagai akuifer yang berbatuan gamping, proses utama yang mengontrol karakteristik dan aliran pada akuifer karst adalah proses pelarutan (dissolution). Dreybort dan Gabrovsek (2003), mengungkapkan bahwa cepat atau lambatnya proses pelarutan batuan gamping salah satunya tergantung dari besar kecilnya konsentrasi gas karbondioksida pada aliran airtanah karst. Selain itu faktor lain yang mengontrol adalah jenis pelorongan pada akuifer karst yang bersifat terbuka atau tertutup (Freeze dan Cherry, 1979). White (2004) mengungkapkan bahwa secara prinsip, sistem aliran airtanah bawah permukaan di akuifer karst paling tidak terdiri dari 4 (empat) komponen aliran utama, seperti yang diilustrasikan pada Gambar 2.4.

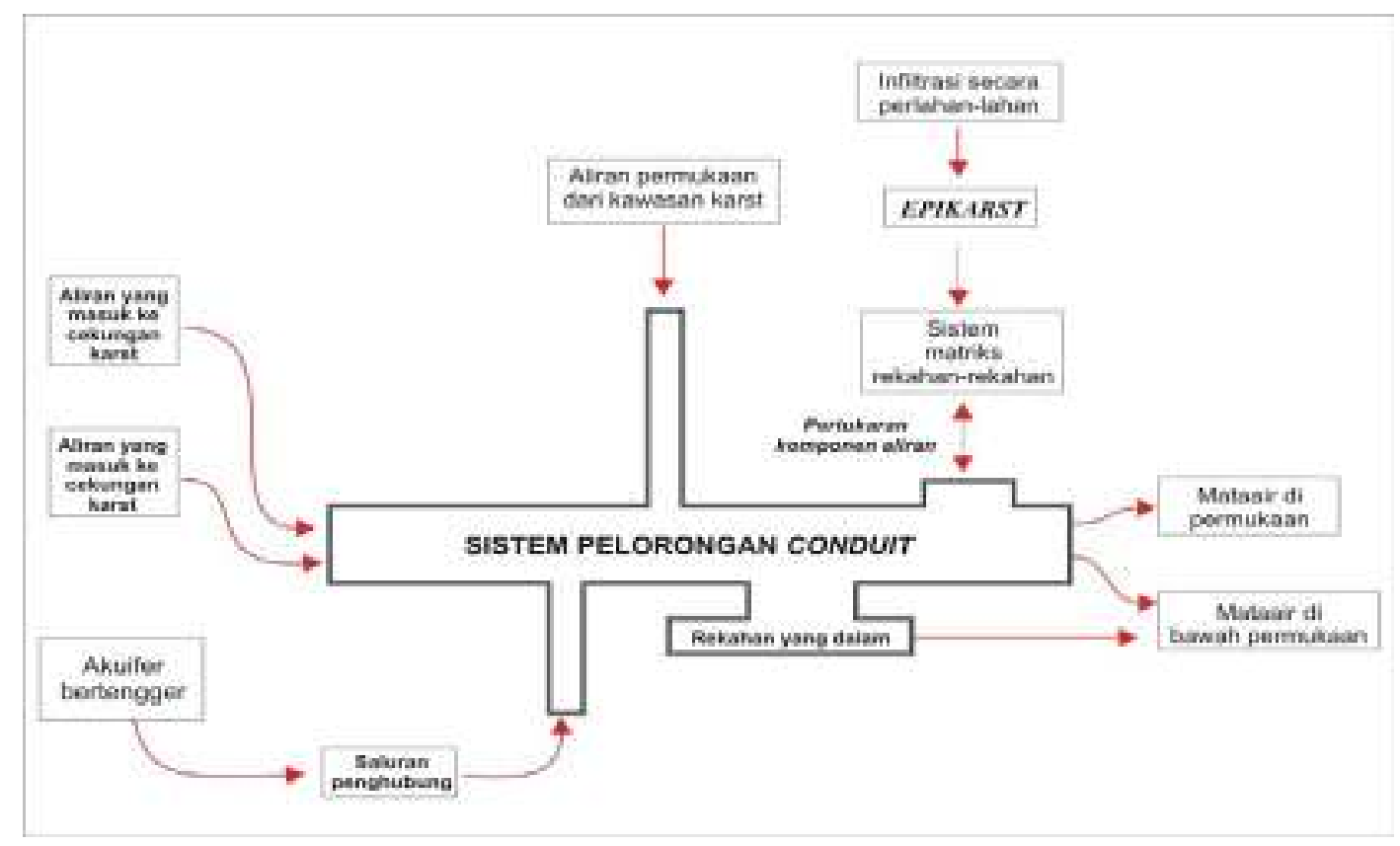

Gambar 2.4. Model Konseptual Sistem Aliran Airtanah pada Akuifer Karst (White, 2004)

Berdasarkan Gambar 2.4. dapat dijelaskan bahwa 4 komponen utama imbuhan akuifer karst adalah: 
a. allogenic recharge: yaitu aliran permukaan berupa sungai yang masuk ke akuifer karst melalui ponor (swallow hole);

b. internal runoff: yaitu aliran permukaan dan hujan yang jatuh ke suatu cekungan karst tertutup dan kemudian masuk ke akuifer karst melalui sinkhole atau ponor;

c. diffuse infiltration: yaitu air hujan yang jatuh ke permukaan tanah dan terinfiltrasi secara perlahan-lahan melalui pori-pori tanah yang mampu disimpan dalam kurun waktu mingguan pada zone epikarst sebelum kemudian turun ke bawah melalui rekahan atau matriks batuan menuju ke muka airtanah;

d. imbuhan dari akuifer yang bertengger (perched aquifer): yaitu imbuhan yang berasal dari akuifer lokal yang berada di atas akuifer karst yang kemudian dapat mencapai muka airtanah karst secara perlahan-lahan melaui sistem rekahan yang tersedia.

Dua hal ekstrim yang terdapat pada akuifer karst menurut White (1988) adalah adanya sistem aliran rembesan (diffuse) dan saluran (conduit), yang ditegaskan pula oleh Domenico dan Schwarts (1990). Menurut Gillieson (1996), terdapat satu lagi sistem aliran di akuifer karst yang dikenal sebagai sistem celah (fissure). Ilustrasi dari sistem aliran yang berkembang di akuifer karst disajikan pada Gambar 2.5.

Perbedaan lain antara daerah karst dan non-karst adalah zonasi vertikal di kawasan karst yang mempunyai dua mintakat, yaitu mintakat epikarst dan endokarst. Mintakat epikarst adalah bagian atas perlapisan batuan di permukaan karst yang mengalami proses pelarutan yang intensif (Ford dan Williams, 1992; Drew, 1995). Mintakat ini menurut Doerfliger dan Zwahlen (1995), dapat dibagi lagi menjadi dua 
bagian, yaitu bagian permukaan dan tanah permukaan (cutaneous zone), bagian regolith dan bagian yang mengalami pelebaran rekahan akibat pelarutan (subcutaneous zone).

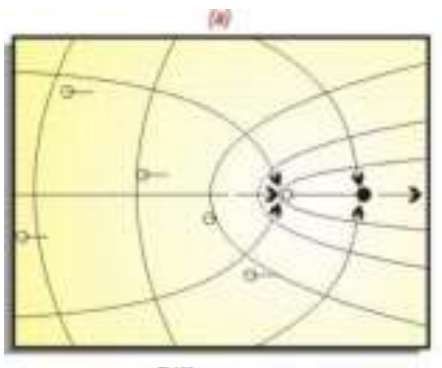

Difuse

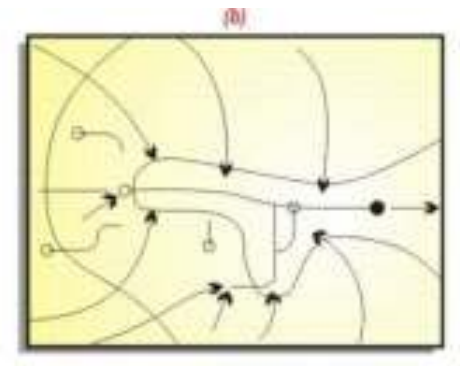

Mixed

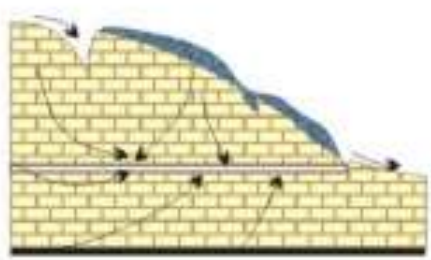

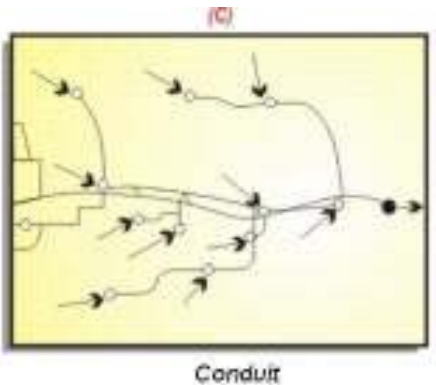

Conduit

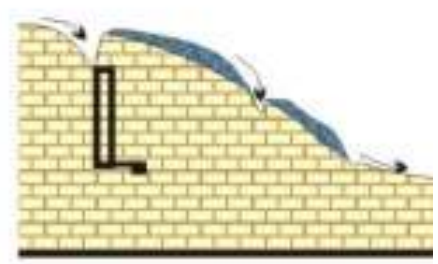

Gambar 2.5. Diffuse, Mixed dan Conduit di Akuifer Karst (Domenico dan Schwartz, 1990)

Seperti disajikan pada Gambar 2.5, akuifer di daerah karst dapat didominasi oleh aliran diffuse atau conduit. Komponen-komponen aliran sungai bawah tanah pada mulanya berasal dari permukaan tanah, dan diasumsikan memiliki tiga komponen daerah tangkapan air yaitu: dari formasi karst itu sendiri, daerah lain nonkarst yang berdekatan (contoh: aliran allogenic), dan masukan dari bagian atas formasi karst (misal: sungai yang masuk/tertelan) atau masukan langsung secara vertikal dari akuifer yang bertengger diatasnya. Jika ada hujan, maka sebagian hujan akan terevapotranspirasikan dan sisanya akan masuk ke akuifer karst sebagai limpasan allogenic, limpasan internal dan infiltrasi rekahan-rekahan kecil (diffuse infiltration).

Hujan yang masuk harus menjenuhkan tanah dan zone rekahan serta epikarst sebelum masuk ke zona vadose. Kemudian, sungai yang tertelan dan masuk melalui 
ponor pada lembah dan dolin biasanya langsung membentuk lorong conduit dan dapat berkembang sebagai saluran terbuka atau pipa-pipa vadose. Selain itu, air yang dialirkan dari daerah tangkapan hujan atau dari akuifer yang bertengger di atas formasi karst (jika ada) biasanya akan langsung menuju zone vadose melalui loronglorong vertikal. Akhirnya, aliran tersebut dapat bergabung dengan lorong conduit dari tempat lain, dan ada pula yang menjadi mataair bila kondisi topografi memungkinkan (Gambar 2.5). Sementara itu, imbuhan yang mempunyai sifat diffuse bergerak secara seragam ke bawah melalui rekahan-rekahan yang tersedia (fissure). Jika sistem diffuse berkembang baik, maka dapat dipastikan bahwa proses infiltrasi pada zona epikarst berlangsung dengan baik. Pada karst yang berkembang baik, diffuse sudah menjadi satu sistem dengan conduit (mixed) dan memasok aliran airnya ke lorong-lorong conduit. Gambar 2.6 menunjukkan perbedaan tipe aliran antara sistem diffuse dan conduit.

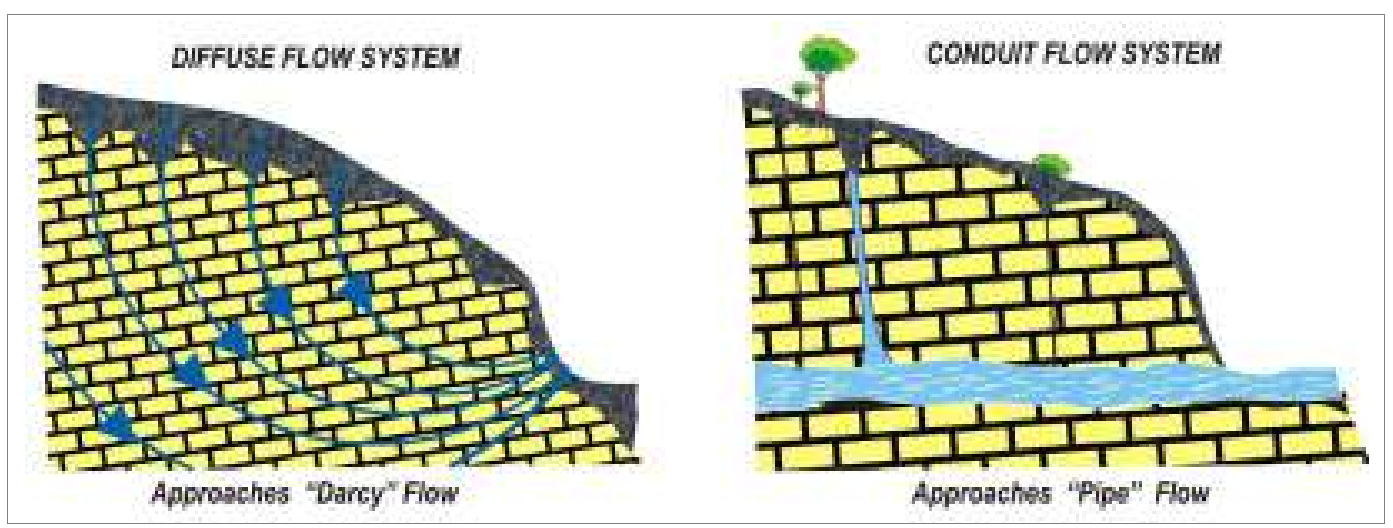

Gambar 2.6. Sistem Aliran Diffuse (kiri) dan Conduit (White, 1988)

Selanjutnya, White (1988) membagi akuifer karst menjadi 3 model konseptual atas dasar sifat alirannya sebagai berikut.

a. Diffuse-flow karst aquifer atau akuifer dengan sistem aliran dominan diffuse. Akuifer ini tidak memiliki aktivitas pelarutan yang baik, sehingga dapat dikategorikan sebagai akuifer homogen dan sistem alirannya mendekati 
hukum Darcy (Gambar 2.6). Akuifer ini biasanya terdapat pada akuifer batugamping yang tidak mudah larut, misalnya dolomit. Air bergerak sepanjang rekahan-rekahan kecil yang hanya sedikit terpengaruh oleh aktivitas pelarutan. Jika terdapat gua, biasanya kecil dan tidak berhubungan satu sama lain. Keluaran air biasanya juga hanya memiliki debit dalam jumlah yang kecil sebagai mataair atau rembesan. Ciri yang lain adalah, muka airtanah dapat dengan mudah didefinisikan dan karena sebagian imbuhan melalui fracture, maka fluktuasinya tidak terlalu besar dan kedudukan muka airtanahnya (water table) dapat sedikit di atas muka airtanah regional.

b. Free-flow karst aquifer. Akuifer ini juga memiliki aliran tipe diffuse, tetapi lorong-lorong hasil pelarutan lebih dominan dimana sebagian besar aliran adalah melalui lorong-lorong conduit yang ada. Airtanah karst pada akuifer ini sangat terkontrol oleh distribusi dan arah dari lorong-lorong tersebut. Gambar 2.6 mengilustrasikan bahwa pendekatan hukum aliran yang digunakan pada kondisi ini adalah pipe flow karena sebagian besar air terdapat pada lorong-lorong conduit yang diibaratkan mempunyai bentuk seperti pipa dengan diameter tertentu. Oleh karena itu, kecepatan aliran diidentikkan dengan kecepatan aliran saluran permukaan (misal: sungai). Sifat alirannya adalah turbulen, bukan laminer. Pada akuifer ini, mataair dapat mempunyai respon yang sangat cepat terhadap hujan dan mempunyai sifat hidrograf aliran yang sama dengan sungai permukaan.

c. Confined-flow karst aquifer atau akuifer karst yang berada di bawah batuan dengan nilai permeabilitas yang sangat kecil. Sistem aliran akuifer ini sangat dikontrol oleh lapisan di atasnya, walaupun memiliki lorong-lorong solusional. 
Selanjutnya, publikasi oleh Martin, et al. (2002) mengungkapkan bahwa interaksi antara diffuse flow dan conduit flow yang berperan banyak terhadap pelebaran celah pada batuan gamping, ternyata juga dipicu oleh kadar agresivitas airtanah karst, sedangkan Taylor dan Greene (2001) mengungkapkan bahwa untuk mengkarakterisasi akuifer karst secara detail diperlukan pendekatan kuantitatif. Pendekatan kuantitatif ini berfungsi untuk mendeskripsikan secara integral sistem aliran di akuifer karst dibandingkan sistem konvensional seperti penggunaan hukum Darcy dan tracer test. Publikasi lain oleh Smart dan Hobbes (1986) mengungkapkan bahwa terdapat satu lagi komponen aliran di aliran karst yaitu seperti yang disebut oleh Gillieson (1996) sebagai fissure. Tabel 2.1 dan Gambar 2.7 menyajikan hubungan antara karakteristik aliran dan kondisi daerah tangkapannya.

Tabel 2.1. Karakteristik Aliran Akuifer Karst (Smart dan Hobbes,1986)

\begin{tabular}{|l|l|l|l|}
\hline Tipe aliran & \multicolumn{1}{|c|}{ Karakteristik } & \multicolumn{1}{c|}{$\begin{array}{c}\text { Kondisi Daerah } \\
\text { Tangkapan }\end{array}$} & \multicolumn{1}{c|}{ Simpanan } \\
\hline Conduit & $\begin{array}{l}\text { - Perpipaan (streamsink) } \\
\text { - Sangat cepat dan sensitif } \\
\text { terhadap hujan }\end{array}$ & $\begin{array}{l}\text { - Banyak cekungan } \\
\text { dengan sinkhole dan } \\
\text { ponor }\end{array}$ & $\begin{array}{l}\text { Rendah dan hanya pada saat } \\
\text { musim hujan }\end{array}$ \\
\hline Fissure & $\begin{array}{l}\text { Percelahan } \\
\text { - Respon sedang terhadap hujan }\end{array}$ & $\begin{array}{l}\bullet \text { Fracture } \\
\bullet \text { Joint }\end{array}$ & Sedang dan perenial musiman \\
\hline Diffuse & $\begin{array}{l}\bullet \text { Fracture } \\
\bullet \text { Menyebar }\end{array}$ & Besar dan sepanjang tahun \\
\hline
\end{tabular}

Lebih jauh lagi, publikasi oleh Perrin (2003) menjelaskan terdapat 4 subsistem dalam akuifer karst, yaitu:

a) sub-sistem infiltrasi, ketika imbuhan akuifer bersifat autogenik, allogenik, diffuse, atau terkonsentrasi;

b) sub-sistem tanah dan zona epikarst, dimana sebagian air infiltrasi tersimpan;

c) sub-sistem zone tidak jenuh yang dihubungkan dengan sub-sistem epikarst menuju zona freatik melalui rekahan-rekahan vertikal; 
d) sub-sistem freatik atau zona jenuh, merupakan zona dengan jaringan conduit yang mempunyai permeabilitas tinggi atau rendah dengan kapasitas penyimpanan yang tinggi, keempat sub sistem ini diilustrasikan pada Gambar 2.8 .

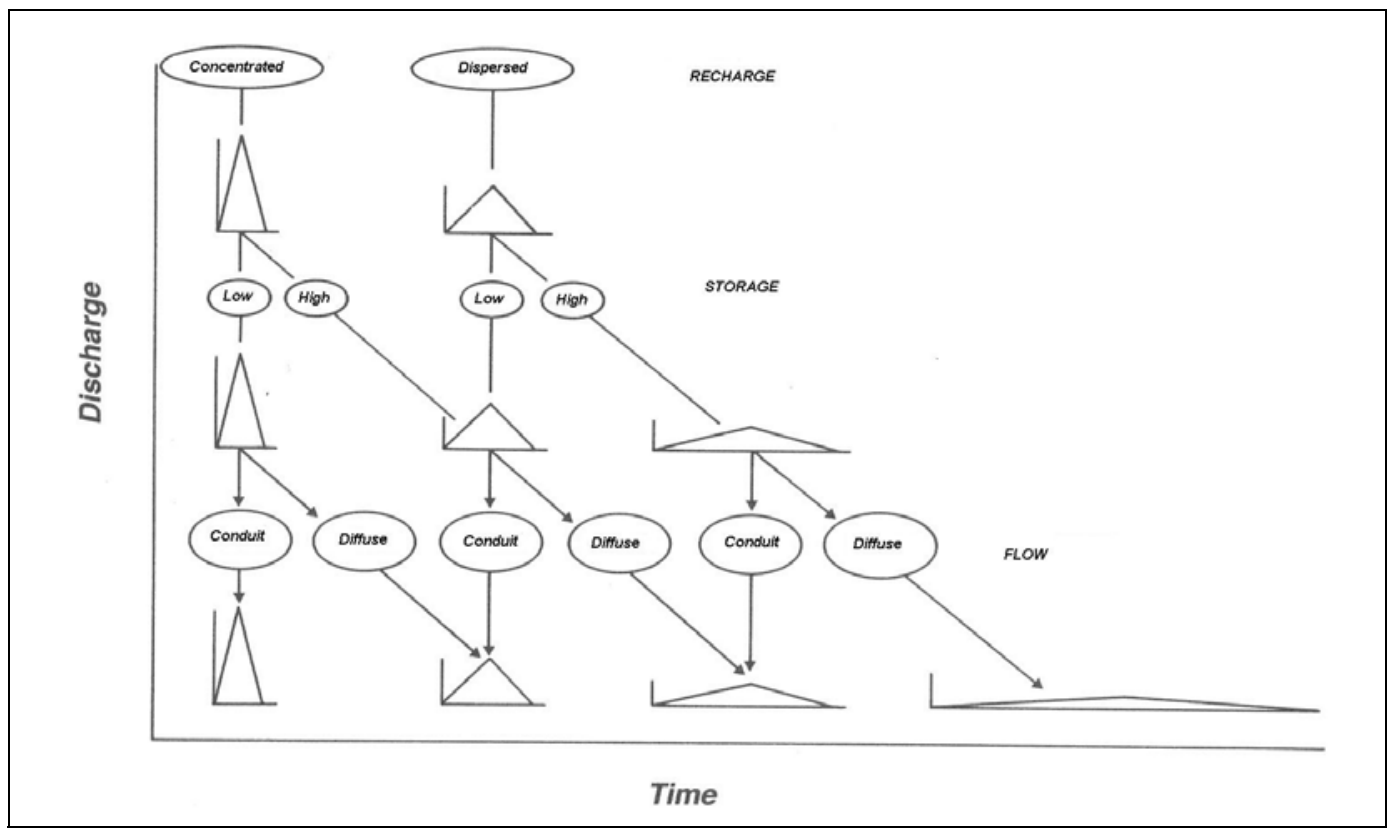

Gambar 2.7. Tiga Sub-Sistem Bertingkat yang Menghasilkan Perbedaan Hidrograf Aliran pada Mataair Karst Menurut Smart dan Hobbes (1986)

Dari 4 sub-sistem tersebut, Perrin (2003) kemudian membedakannya menjadi

3 sistem yang mempunyai perbedaan utama, yaitu:

a) batuan dengan permeabilitas yang rendah pada zona freatik sebenarnya merupakan volume dari lorong-lorong fissure atau saluran-saluran besar yang terhubung dengan saluran pengatus (sungai bawah tanah);

b) aliran dasar pada sungai bawah tanah sebenarnya berasal dari zona dengan permeabilitas rendah atau dari zone epikarst;

c) air yang berperan dalam saat banjir di sungai bawah tanah dapat berasal dari beberapa sumber yang berbeda, di antaranya adalah infiltrasi yang terkonsentrasi 
(point recharge), aliran diffuse dan air yang tersimpan pada zona permeabilitas rendah, epikarst, simpanan conduit, air infiltrasi, lengas tanah, dan campuran dari beberapa yang sudah disebutkan.

\section{Hidrogeokimia dan Agresivitas Airtanah Karst}

Komposisi kimia airtanah pada suatu wilayah sangat tergantung dari interaksi antara airtanah dan mineral penyusun batuan dengan proses utama berupa pelarutan (dissolution). Menurut Appelo dan Postma (1993), terdapat tiga fase yang berkatian dengan proses ini yaitu (1) kondisi air tidak jenuh (undersaturated), sehingga masih mampu untuk melarutkan mineral batuan; (2) kondisi seimbang (equilibrium), proses pelarutan sudah berhenti, dan; (3) kondisi air sudah jenuh (supersaturated) sehingga terjadi proses pengendapan (precipitation).

Reaksi airtanah dengan batuan gamping merupakan proses yang sangat penting terhadap komposisi kimia airtanah di akuifer karst (Appelo dan Postma, 1993). Sementara itu, kandungan gas karbondioksida dalam airtanah merupakan hal yang sangat penting terhadap agresivitas airtanah terhadap batuan gamping. Secara umum reaksi antara airtanah yang mengandung $\mathrm{CO}_{2}$ dan batuan gamping adalah sebagai berikut:

$$
\mathrm{CaCO}_{3}+\mathrm{CO}_{2}+\mathrm{H}_{2} \mathrm{O} \longleftrightarrow \mathrm{Ca}^{2+}+2 \mathrm{HCO}_{3}^{-}
$$

Jika terdapat $\mathrm{CO}_{2}$ yang cukup dalam air, maka reaksi pelarutan (dissolution) akan berlangsung, sehingga airtanah dikategorikan sebagai agresif terhadap batuan gamping. Sebaliknya, jika jumlah $\mathrm{CO}_{2}$ tidak cukup maka akan terjadi proses pengendapan (precipitation). Airtanah karst yang agresif biasanya terdapat pada sistem yang terbuka (open system) dimana tersedia $\mathrm{CO}_{2}$ yang cukup, karena tekanan 
parsial $\mathrm{CO}_{2}$ terjaga sebagai akibat adanya reaksi oksidasi dari material organik, respirasi dari akar tumbuhan, serta adanya transfer gas $\mathrm{CO}_{2}$ dari tanah dan atmosfer.

Faktor lain yang dapat mempercepat proses pelarutan adalah masuk atau bercampurnya air yang mengandung cukup gas $\mathrm{CO}_{2}$. Proses ini dikenal sebagai proses percampuran (mixing) yang pertama kali diperkenalkan oleh Bogli (1960) sebagai teori yang dikenal sebagai Mixing Theory. Contoh paling baik dari proses ini adalah ketika air laut bertemu dengan air tawar yang mengakibatkan air menjadi bersifat sangat agresif terhadap batuan gamping seperti yang diungkapkan oleh Plummer (1975).

Jankowski dan Jacobson (1991) mendeskripsikan airtanah karst yang mempunyai tekanan parsial gas karbondioksida $\left(\mathrm{PCO}_{2}\right)$ tinggi bertemu dengan air laut dengan $\mathrm{PCO}_{2}$ yang rendah mengakibatkan berkembangnya lorong-lorong solusional di sekitar pantai. Anthony, et al. (1997), melakukan investigasi awal dengan tujuan untuk mengetahui hubungan antara variasi temporal (seasonal changes) dan kondisi hidrogeokimia di Logdson River, Mammoth Cave, Kentucky. Dari penelitian ini terungkap bahwa faktor terpenting terhadap kondisi agresivitas airtanah karst adalah kandungan gas karbondioksida atau yang dalam penelitian ini dinyatakan dalam tekanan parsial gas karbondioksida $\left(\mathrm{PCO}_{2}\right)$ yang terpengaruh oleh kondisi tanah, batuan dasar dan proses organik dalam gua. Hasil yang diperoleh mengindikasikan bahwa perubahan musim panas dan dingin membawa pengaruh yang signifikan terhadap agresivitas airtanah karst. 


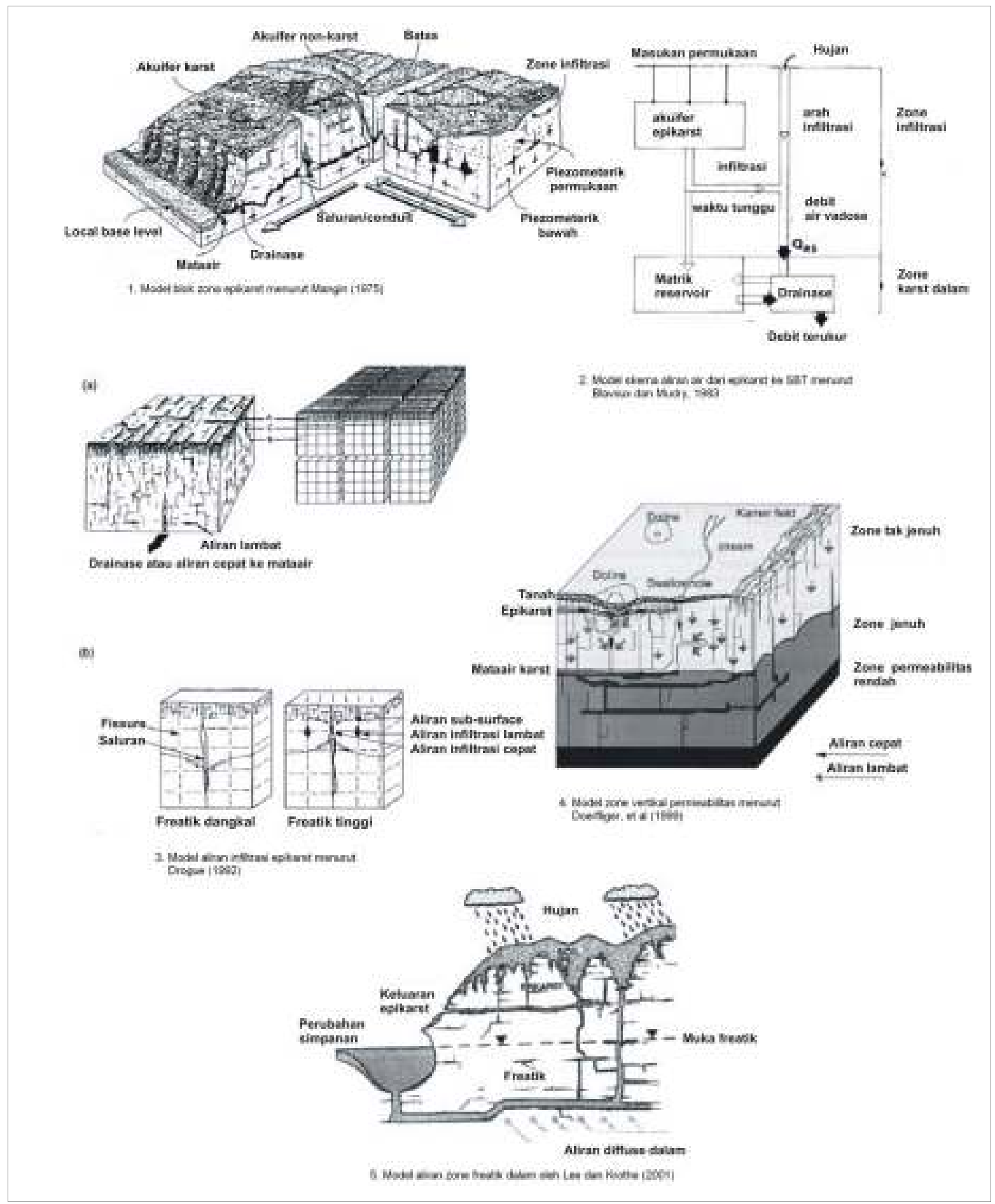

Gambar 2.8. Model Konseptual Akuifer Karst (1. Mangin, 1975, 2. Blavoux dan Mudry, 1983, 3. Drogue, 1992, 4. Doerfliger, et al, 1999, 5. Lee dan Krothe, 2001 dalam Perrin, 
Liu, et al. (2004b), berpendapat bahwa untuk mengetahui kondisi hidrogeokimia di daerah karst tidak cukup melakukan studi yang hanya difokuskan pada hubungan antara air dan batuan (water-rock interaction) saja, tetapi dibutuhkan pengetahuan komprehensif terhadap efek dari variabel dari $\mathrm{CO}_{2}$ yang terdapat pada sistem akuifer. Penelitian ini dilakukan pada saat hujan puncak dengan tujuan untuk mengetahui variasi temporal komposisi kimia dan agresivitas airtanah karst. Hasil penelitian menunjukkan bahwa terdapat hubungan linier antara ion dominan $\left(\mathrm{Ca}^{2+}\right.$ dan $\mathrm{HCO}_{3}{ }^{-}$) dan daya hantar listrik tercatat, sementara $\mathrm{PCO}_{2}$ air diffuse jauh lebih tinggi pada saat banjir puncak dibandingkan saat tidak terjadi banjir. Lebih jauh lagi analisis nilai indeks kejenuhan atau Saturation Indices (SI) terhadap mineral kalsit menunjukkan bahwa pada saat banjir nilai SI terhadap kalsit adalah rendah. Pada waktu yang bersamaan $\mathrm{PCO}_{2}$ air conduit tinggi dan SI terhadap kalsit juga rendah, yang mengindikasikan bahwa airtanah karst masih bersifat agresif. Penelitian ini kemudian berpendapat bahwa paling tidak kita harus mengetahui dua proses ketika banjir, yaitu hubungan antara batuan dan air (water-rock interaction) dan rembesan dari air hujan (dilution by precipitation), sementara untuk air bertipe diffuse atau fissure, mengkaji water-rock interaction saja sudah cukup. Selain itu, terungkap pula bahwa air bertipe diffuse yang bertipe jenuh (supersaturated) terhadap mineral kalsit dapat berubah menjadi sangat agresif ketika terjadi hujan diatas $100 \mathrm{~mm} /$ beberapa jam.

Karimi, et al. (2004) meneliti variasi hidrodinamik dari mataair karst Gilan di Iran. Parameter fisik dan kimia airtanah yang diukur meliputi DHL, suhu air, $\mathrm{pH}$, dan ion mayor pada interval waktu dua mingguan. Analisis yang dipakai adalah analisis indeks kejenuhan (SI) terhadap kalsit, dolomit, dan gipsum serta tekanan parsial dianalisis dengan bantuan perangkat lunak WATEQF. Hasil dari analisis hidrograf satuan dan pemisahan aliran dasar (baseflow), serta perhitungan konstanta resesi 
menunjukkan bahwa tipe aliran dasar didominasi oleh tipe diffuse, sementara pada debit puncak didominasi oleh aliran conduit. Selanjutnya, debit puncak berlangsung ketika aliran conduit didekat mataair menaikkan debit mataair Gilan, sementara aliran conduit yang bersal dari lokasi yang jauh mencapai mataair pada saat periode resesi. Lebih jauh lagi, peranan aliran conduit pada saat musim kemarau membuat parameter fisik seperti DHL berkurang di daerah hilir, terutama pada daerah tangkapan hujan yang sempit dan panjang karena durasi hujan jauh lebih sedikit daripada waktu tundanya (time-lag).

Salah satu pendekatan untuk mengidentifikasi karakteristik akuifer karst adalah dengan melakukan analisis hidrokemograf, seperti yang dideskripsikan oleh Raeisi dan Karami (1997). Pada penelitian ini, mereka melakukan monitoring terhadap parameter-parameter Daya Hantar Listrik (DHL), pH, dan suhu di mataair karst Berghan, Iran dengan interval pengukuran setiap 20 hari selama periode 32 bulan, termasuk juga menganalisis komposisi kimia mataair karst ini atas dasar unsur mayor terlarut. Mereka juga menghitung debit mataair Berghan pada saat periode resesi setiap 3 minggu selama periode penelitian mereka. Tekanan parsial gas karbondioksida dianalisis dengan bantuan software WATEQF. Hasil penelitian menunjukkan bahwa komponen baseflow mendominasi seluruh total aliran mataair masing-masing sebesar $71,5 \%, 100 \%$, dan $66,2 \%$ secara berurutan pada periode resesi pertama, kedua, dan pada saat musim hujan. Sementara itu, nilai DHL, pH, suhu dan nilai indeks kejenuhan terhadap mineral kalsit tidak menunjukkan variasi yang signifikan. Kesimpulan dari studi ini adalah bahwa daerah tangkapan mataair Berghan didominasi oleh tipe aliran diffuse, dengan bukti berupa adanya imbuhan autogenik, breksi akuifer dan pebedaan yang kecil pada variasi hidrograf resesi. 
Wang dan Luo (2001) menghitung transfer massa di sungai bawah tanah pada sistem karst Liulin, Cina Baratdaya. Penelitian ini bertujuan untuk menghitung agresivitas airtanah karst setelah terjadinya kebocoran pada sistem airtanah karst oleh aliran permukaan. Untuk mengevaluasi secara kuantitatif transfer massa hidrogeokimia secara spasial, Wang dan Luo menggunakan teknik inverse model dengan batuan perangkat lunak NETPATH. Hasil pemodelan menunjukkan bahwa percampuran dua komponen airtanah karst merupakan faktor utama yang menyebabkan adanya variasi transfer massa hidrogeokimia, sementara pelarutan dolomit lebih dominan daripada pelarutan kalsit.

\section{Kondisi Sistem Sungai Bawah Tanah Bribin-Baron}

Sistem sungai bawah tanah Bribin-Baron pertama kali diperkenalkan oleh MacDonald dan Partners (1984). Sistem ini secara lebih detail dapat dibagi lagi menjadi beberapa sistem, diantaranya adalah sistem Bribin bermula dari Sungai Pentung yang masuk ke ponor di daerah Sawah Ombo, Tambakromo, yang kemudian ditemukan lagi di Luweng Jomblangan, kemudian di Gua Gilap, Luweng Jomblangbanyu, Luweng Jurang Jero, dan terakhir di Gua Bribin, dengan debit yang semakin besar ke arah hilir (Fakultas Kehutanan, 1993). Gua-gua yang sudah disebutkan di atas membentuk satu sistem sungai bawah tanah yang selanjutnya oleh MacDonald dan Partners (1984) disebut sebagai Sungai Bawah Tanah (SBT)

\section{Bribin.}

Debit terukur Bribin dapat mencapai lebih dari 2000 lt/detik pada musim penghujan, dan sekitar 1500 1t/detik pada saat musim kemarau. Sistem yang lain yang diungkap oleh MacDonald dan Partners (1984) adalah sistem Suci-Grubug yang kemudian muncul di mataair Baron. Detail kondisi sistem sungai bawah tanah Bribin-Baron disajikan pada Gambar 2.9. 
Gambar 2.9 menunjukan bahwa selain beberapa sistem atau sub-sistem yang sudah dikemukakan di atas, masih terdapat beberapa sistem lagi seperti sistem Semuluh dan sistem Buhputih. Selain itu terdapat pula daerah tangkapan air sungai permukaan yang masuk dan berpotensi memasok recharge sistem Bribin-Baron ini, seperti dari Sungai Suci, Petung, dan Tegoan. Dari fakta-fakta tersebut, maka penelitian mengenai variasi kondisi hidrogeokimia airtanah karst di SBT Bribin (Gua Bribin dianggap sebagai outlet) yang menjadi bagian dari sistem Bribin-Baron baik secara spasial maupun temporal sangat menarik untuk dikaji dengan melihat kenyataan banyaknya luweng atau ponor yang merupakan imbuhan dari sistem sungai bawah tanah ini.

Jika dilihat dari permukaan (eksokarst), daerah penelitian adalah bentang alam karst yang diduga merupakan daerah tangkapan hujan bagi SBT Bribin. Batas ini secara tegas di sebelah barat merupakan Polje Ponjong, sementara batas sebelah utara merupakan Panggung Masif yang berbatuan vulkanik. Gua Bribin dianggap sebagai outlet di sebelah selatan sehingga dapat disebut sebagai batas daerah tangkapan bagian selatan. Selanjutnya, batas sebelah timur belum dapat didefinisikan secara tegas karena belum adanya penelitian lanjutan setelah MacDonald dan Partners (1984), sedangkan alur SBT Bribin dari hulu ke hilir mengacu atas dasar metode pelacakan kimia (tracer test) oleh MacDonald dan Partners (1984).

Sampai saat ini masih merupakan tanda tanya seberapa besar kontribusi dari ponor, sungai permukaan, maupun aliran tipe diffuse dan conduit terhadap total aliran di SBT Bribin secara spasial dan temporal. Selain itu, model hidrogeokimia untuk mengetahui variasi agresivitas airtanah karst pada sistem ini juga menarik untuk diungkap. Dalam hal kualitas air, penelitian oleh MacDonald dan Partners (1984), 
Adji (2007), dan Fakultas Kehutanan (1993) mengkonfirmasi bahwa secara hidrogeokimia, unsur-unsur terlarut dalam air di SBT Bribin tidak melebihi baku mutu untuk air minum yang disyaratkan, meskipun secara biologis, kandungan bakteri E-Coli dapat melebihi batas yang disyaratkan.

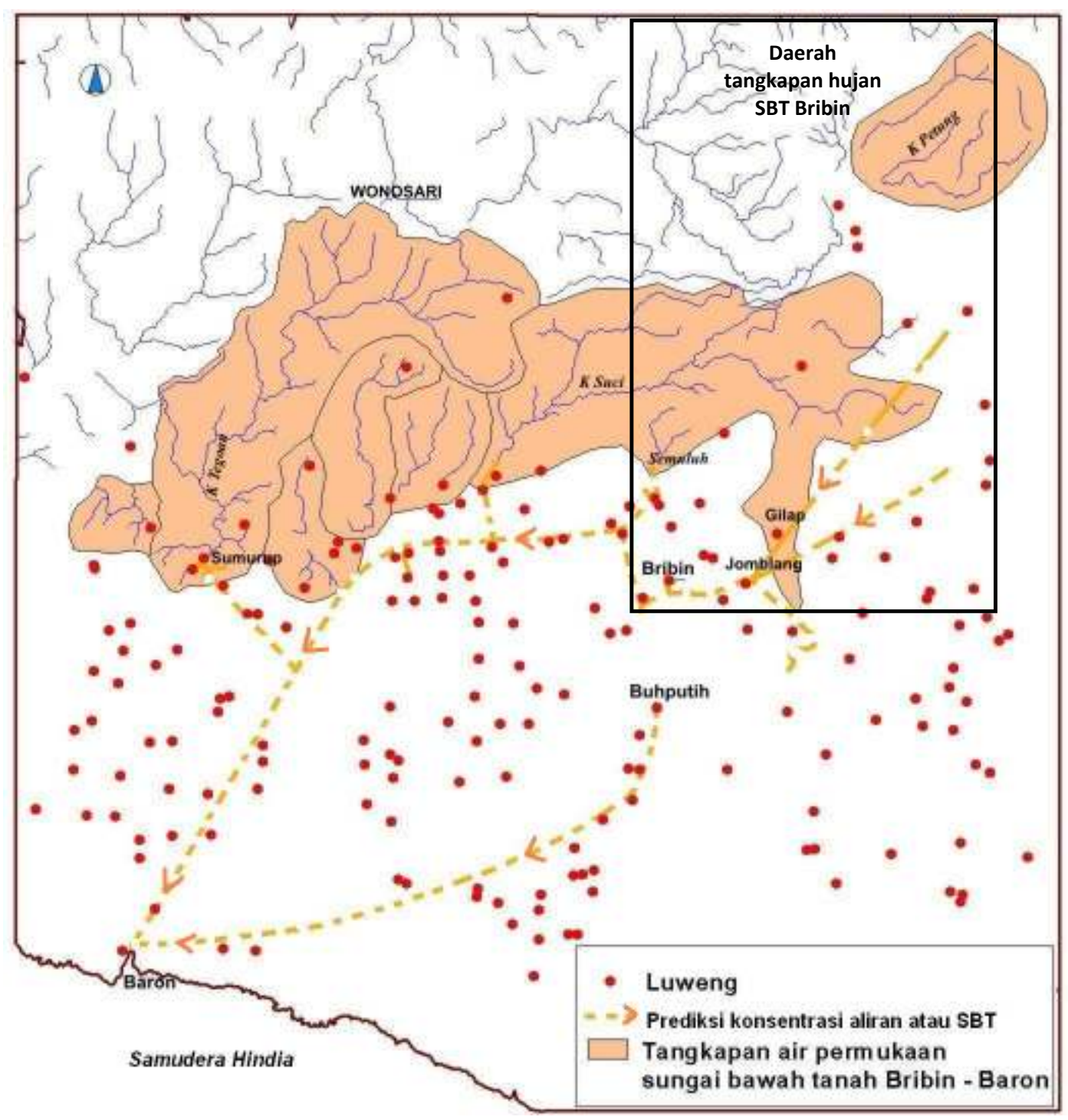

Gambar 2.9. Sistem Sungai Bawah Tanah Bribin-Baron (MacDonald dan Partners, 1984) 


\section{Sistem Perguaan}

Menurut Ford dan Cullingford (1976), gua karst didefinisikan sebagai ruang alamiah di dalam bumi yang kebanyakan memiliki ruangan-ruangan dan loronglorong yang merupakan hasil proses pelarutan batuan gamping. Kadang-kadang, lorong-lorong tersebut membentuk jaringan dengan gua lain yang berdekatan dan dikenal sebagai sistem perguaan. Jika sistem tersebut terisi aliran air maka dikenal sebagai sungai bawah tanah. Secara umum dikenal 3 teori pembentukan gua, yaitu:

\section{a. Teori vadose}

Teori ini menyatakan bahwa sebagian besar volume gua terjadi akibat ekskavasi oleh aliran gua menuju muka airtanah bebas. Air yang berasal dari suatu input yang besar kemudian mengalir menuruni zone vadose atau tak jenuh menuju muka airtanah, yang telah terbentuk oleh beberapa proses sebelumnya pada keadaan sebelum gua itu terbentuk.

\section{b.Teori deep phreatic}

Jika perkembangan pemeabilitas sekunder datang dari masukan air yang merupakan pelarut batuan gamping pada kondisi muka airtanah yang stabil pada suatu periode yang panjang, maka banyak saluran gua yang berkembang jauh di bawah muka airtanah.

\section{c.Teori water table}

Teori ini mengemukakan bahwa gua terbentuk pada saat air yang tersaring (percolated water) dari vadose yang mengalir menuju muka airtanah membentuk gua di sekitar tempat yang dangkal pada batas freatik. Oleh karenanya, gua berkembang di sepanjang wilayah ini. Ilustrasi ketiga teori tersebut disajikan pada Gambar 2.10. 


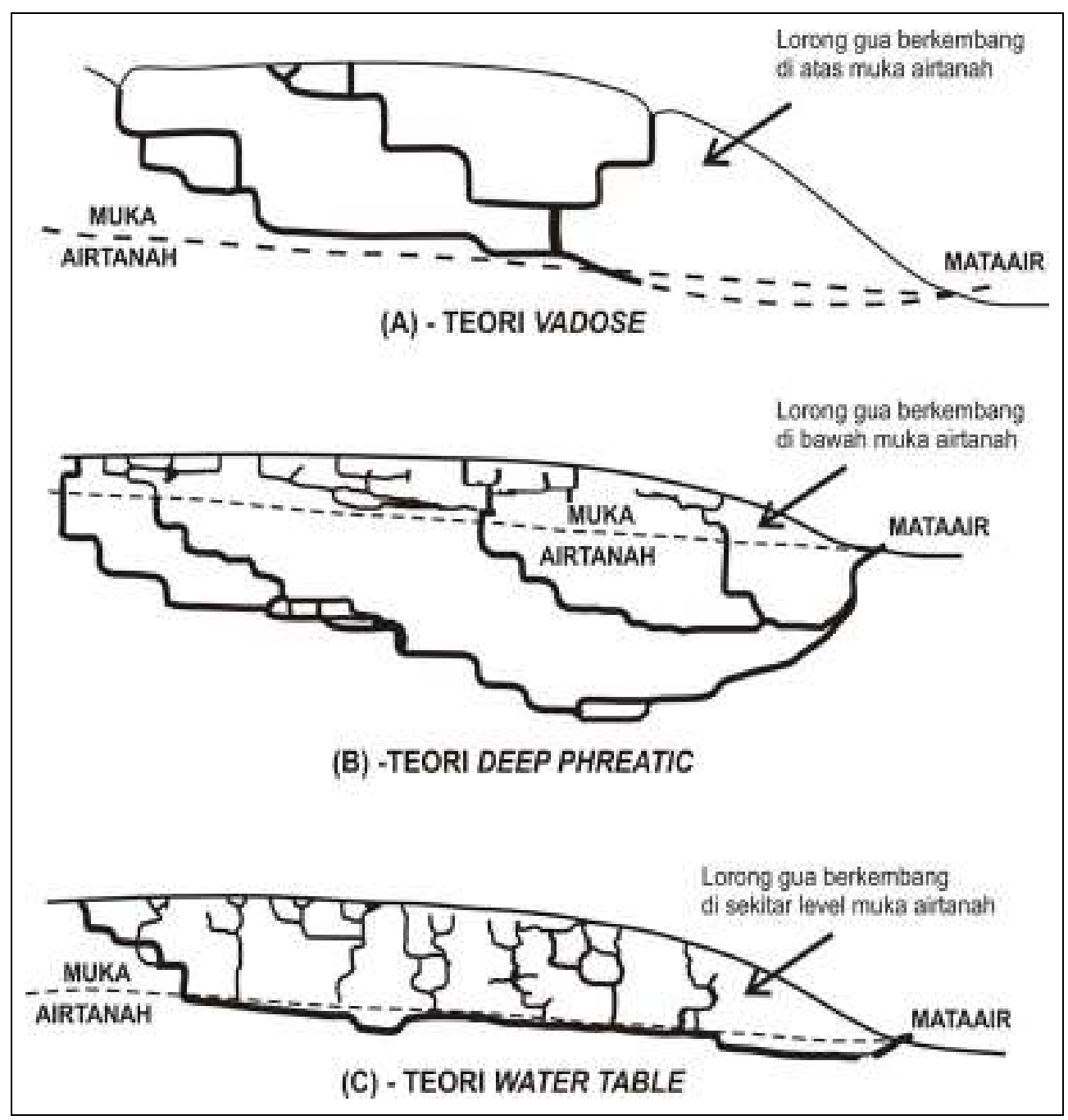

Gambar 2.10. Tiga Teori Pembentukan Gua (Ford dan Ewers, 1978)

Adji dan Nurjani (1999), memetakan 39 gua yang diindikasikan tercakup dalam daerah tangkapan hujan SBT Bribin. Lebih jauh lagi dijelaskan bahwa persebaran posisi gua-gua yang dijumpai tidak terdistribusi merata berdasarkan cakupan luasan daerah tangkapan SBT Bribin, tetapi tersebar secara tidak teratur. Gua-gua di daerah penelitian atas dasar bentuk lorongnya dibedakan menjadi dua yaitu (i) gua horisontal, yaitu gua dengan lorong mendatar atau kemiringan yang landai, tidak terlalu terjal, dan dapat dimasuki tanpa bantuan peralatan khusus; (ii) gua vertikal atau sering disebut luweng, yaitu gua yang mempunyai mulut gua 
dengan lorong tegak lurus, dan hanya dapat dimasuki dengan peralatan khusus. Dari 39 gua, 21 di antaranya adalah gua vertikal. Lebih jauh lagi, beberapa gua mempunyai lorong yang panjang dan kadang-kadang merupakan pintu masuk dari sungai permukaan (point recharge), yang biasanya berhubungan dengan gua-gua lain dan membentuk sistem perguaan. Atas dasar sistem perguaan ini, kemudian gua-gua di daerah penelitian dapat dikelompokkan menjadi:

a) gua pada aliran primer, yaitu gua yang mempunyai aliran pada aliran utama SBT Bribin dan biasanya mempunyai debit air yang cukup besar;

b) gua pada aliran sekunder, yaitu gua yang memiliki aliran sebagai sub aliran yang bergabung dengan aliran primer SBT Bribin;

c) gua yang tidak mempunyai sistem, yaitu gua-gua yang walaupun mempunyai aliran air, tetapi karena beberapa hal belum dapat disebut memiliki sistem perguaan, walaupun mungkin juga terhubung dengan SBT Bribin.

\section{B. Landasan Teori}

Karst adalah suatu istilah untuk medan yang merupakan hasil dari proses pelarutan batugamping. Ciri-ciri utama kawasan karst, diantaranya adalah lebih dominannya aliran bawah permukaan, dan sangat minimnya aliran permukaan. Secara kimiawi, proses pembentukan karst atau karstifikasi adalah terjadinya reaksi antara zat padat yang mengandung mineral karbonat, zat cair atau air yang mengandung unsur-unsur terlarut tertentu, dan gas atau udara yang berisi gas karbondioksida. Dalam hal ini peranan dari gas karbondioksida menjadi sangat penting, karena bila gas karbondioksida yang terlarut dalam air besar, maka proses pelarutan akan berjalan dengan intensif, demikian pula sebaliknya. 
Secara umum sumber utama komponen airtanah karst dapat dibagi menjadi 4, yaitu: (1) aliran permukaan (sungai) yang masuk ke akuifer karst melalui ponor, dikenal sebagai imbuhan allogenic; (2) aliran permukaan dan hujan yang jatuh ke suatu cekungan karst tertutup dan kemudian masuk ke akuifer karst melalui sinkhole atau ponor, dikenal sebagai internal runoff; (3) air hujan yang jatuh ke permukaan tanah dan kemudian terinfiltrasi secara perlahan-lahan melalui pori-pori tanah, dikenal sebagai diffuse infiltration; dan (4) imbuhan dari akuifer di atas batuan gamping, bila ada. Komponen-komponen tersebut mempunyai peranan sendirisendiri terhadap karstifikasi yang berlangsung karena sifat dan kedudukannya yang berbeda-beda, termasuk kandungan gas karbondioksidanya.

Secara sederhana, tipe aliran pada komponen airtanah karst dapat dibagi menjadi dua yaitu tipe saluran (conduit) dan tipe rembesan (diffuse), atau campuran antara keduanya (mixed). Hal tersebut dapat digunakan untuk mengkategorikan dua sistem akuifer yang berkembang di daerah karst yaitu sistem diffuse-flow karst aquifer atau akuifer dengan sistem aliran dominan rembesan; atau sistem free-flow karst aquifer yang didominasi oleh lorong-lorong conduit. Secara prinsip para ahli karst membagi sifat aliran pada akuifer karst menjadi tiga komponen yaitu aliran saluran/lorong (conduit), celah (fissure), dan rembesan (diffuse), sehingga jika karakteristik pelepasan komponen-komponen aliran tersebut dapat diketahui, maka tingkat perubahan atau pelebaran pelorongan karst yang mengontrol banyak sedikitnya aliran dasar saat kemarau akan dapat diprediksi.

Sifat akuifer karst dapat dijelaskan karakteristiknya jika diketahui berapa besar perbandingan antara komponen aliran diffuse dan conduitnya. Selain itu, perilaku akuifer dalam melepaskan komponen-komponen alirannya secara temporal, khususnya pada saat kejadian banjir merupakan cerminan dari kondisi jaringan percelahan yang ada di akuifer. 
Sistem Karst Dinamis (SKD) adalah sistem yang terdiri dari 3 fase yang dibatasi oleh interface yaitu fase-fase $\mathrm{CO}_{2}-\mathrm{HCO}_{3}-\mathrm{H}_{2} \mathrm{O}$. SKD dapat berupa sistem terbuka (open system) sehingga sepanjang waktu akan mengalami perubahan interaksi antar fase yang sangat cepat, karena masing-masing fase yang terhubung oleh lobang-lobang conduit. SKD juga dapat merupakan sistem yang cenderung tertutup (closed system), sehingga pada suatu waktu proses pelarutan dapat tidak berlangsung atau berlangsung secara lambat. Pola dan perilaku dari SKD dapat diidentifikasi dengan mencari hubungan mutual antara paramater SKD diantaranya adalah agresivitas air untuk melarutkan batgamping (SI), $\mathrm{pH}, \mathrm{HCO}_{3}{ }^{-}$, dan gas karbondioksida.

Karakterisasi akuifer karst oleh sebagian besar hidrolog dianggap tidak mudah karena sifatnya yang heterogen dan anisotropis. Karena keunikan sifat akuifer serta komponen alirannya, maka hampir semua penelitian hidrologi di akuifer karst tidak menggunakan metode penelitian yang bersifat deduktif (mengunakan distribusi sifat permukaan untuk mengkarakterisasi sifat alirannya), tetapi lebih cenderung menggunakan sifat penelitian dengan metode survai induktif pada sungai bawah tanah, atau air tetesan pada gua.

Salah satu pendekatan ilmiah yang dapat menjelaskan proses aliran airtanah karst dan reaksi yang terjadi adalah pendekatan hidrogeokimia. Pendekatan hidrogeokimia airtanah adalah ilmu interdisipliner yang membahas karakter kimia air di lingkungan bawah permukaan tanah. Di daerah karst, pendekatan ini dipakai untuk mendeskripsikan sifat dan distribusi sistem aliran pada akuifer karst yang unik, karena pendekatan lain sangat sulit dilakukan. Pendekatan hidrogeokimia merupakan metode yang dianggap paling representatif karena komposisi kimia airtanah karst merupakan cerminan dari proses pelarutan yang berlangsung searah aliran airtanah 
karst. Selain itu, metode investigasi air bawah tanah seperti yang dapat dilakukan di kawasan non-karst sangat sulit dilakukan mengingat akuifer karst yang bersifat heterogen dan anisotropis. Pendekatan hidrogeokimia karst ini juga dianggap mampu untuk mendeskripsikan sistem media penyimpan airtanah karst, termasuk mengetahui besar kecilnya sifat agresivitas air untuk melarutkan batuan gamping.

SBT Bribin merupakan salah satu sistem sungai bawah tanah yang dominan di daerah karst Gunung Sewu, karena sistem perguaannya yang sudah diketahui dan melewati beberapa gua yang dapat dimonitor perilakunya dengan pemasangan alat tertentu pada gua-gua tersebut. Potensi debit sungai ini tergolong cukup besar dan kelangsungan dari sumberdaya air sistem ini sangat diharapkan untuk kelangsungan penduduk yang hidup di sekitarnya. Dengan kenyataan ini, sangat menarik untuk dikaji bagaimana peranan dari komponen aliran, baik itu diffuse, fissure, dan conduit terhadap perkembangan endokarst di daerah penelitian, termasuk bagaimana hubungannya dengan variasi spasial dan temporal dari proses pelarutan yang berlangsung, serta lebih jauh lagi bagaimana peranannya terhadap perilaku SKD sepanjang SBT Bribin secara time-series selama kurang lebih 1 tahun. Pemahaman mengenai perbedaan kondisi hidrologi dalam hal ini adalah SBT Bribin yang mencakup karakteristik aliran, hidrogeokimia, serta agresivitasnya serta hubungannya dengan karakteristik SKDnya dalam suatu ruang yaitu daerah tangkapan hujan SBT Bribin, merupakan pendekatan utama dalam kajian geografi, dan bertujuan untuk membedakan karakteristik tiap-tiap titik pengamatan secara spasial dan temporal serta mengkaitkannya antara titik pengamatan. Penelitian ini diharapkan dapat menjawab bagaimanakah sifat aliran SBT Bribin yang didekati dengan fluktuasi debit aliran dan persentase aliran dasarnya secara temporal dalam lingkup daerah tangkapan, hubungan sifat aliran dengan kondisi hidrogeokimianya, serta karakteristik SKD-nya sepanjang tahun yang didekati dengan sifat air untuk 
melarutkan batuan gamping yang terjadi secara spasial (hulu-hilir) dan temporal (1 tahun). Kerangka teori penelitian ini disajikan pada Gambar 2.11.

\section{Hipotesis}

Dari telaah pustaka dan landasan teori yang disampaikan, maka penelitian ini mengajukan hipotesis sebagai berikut:

1. Persentase Aliran Dasar (PAD) pada musim kemarau semakin besar ke arah hilir, sementara pada saat musim hujan (kejadian banjir), besarnya PAD berkurang, meskipun PAD di bagian hilir tetap lebih besar.

2. Pada musim kemarau, hubungan PAD dan hidrogeokimia cenderung lebih kuat pada gua di bagian hilir, sementara pada musim penghujan hubungannya bervariasi tergantung besar kecilnya PAD tiap kejadian banjir yang variasinya mengikuti sifat banjir yang terjadi.

3. Pada musim kemarau, agresivitas airtanah karst untuk melarutkan batuan gamping semakin kecil ke arah hilir karena PADnya semakin besar, sementara pada saat musim hujan bervariasi tergantung dari sifat banjir yang terjadi. 


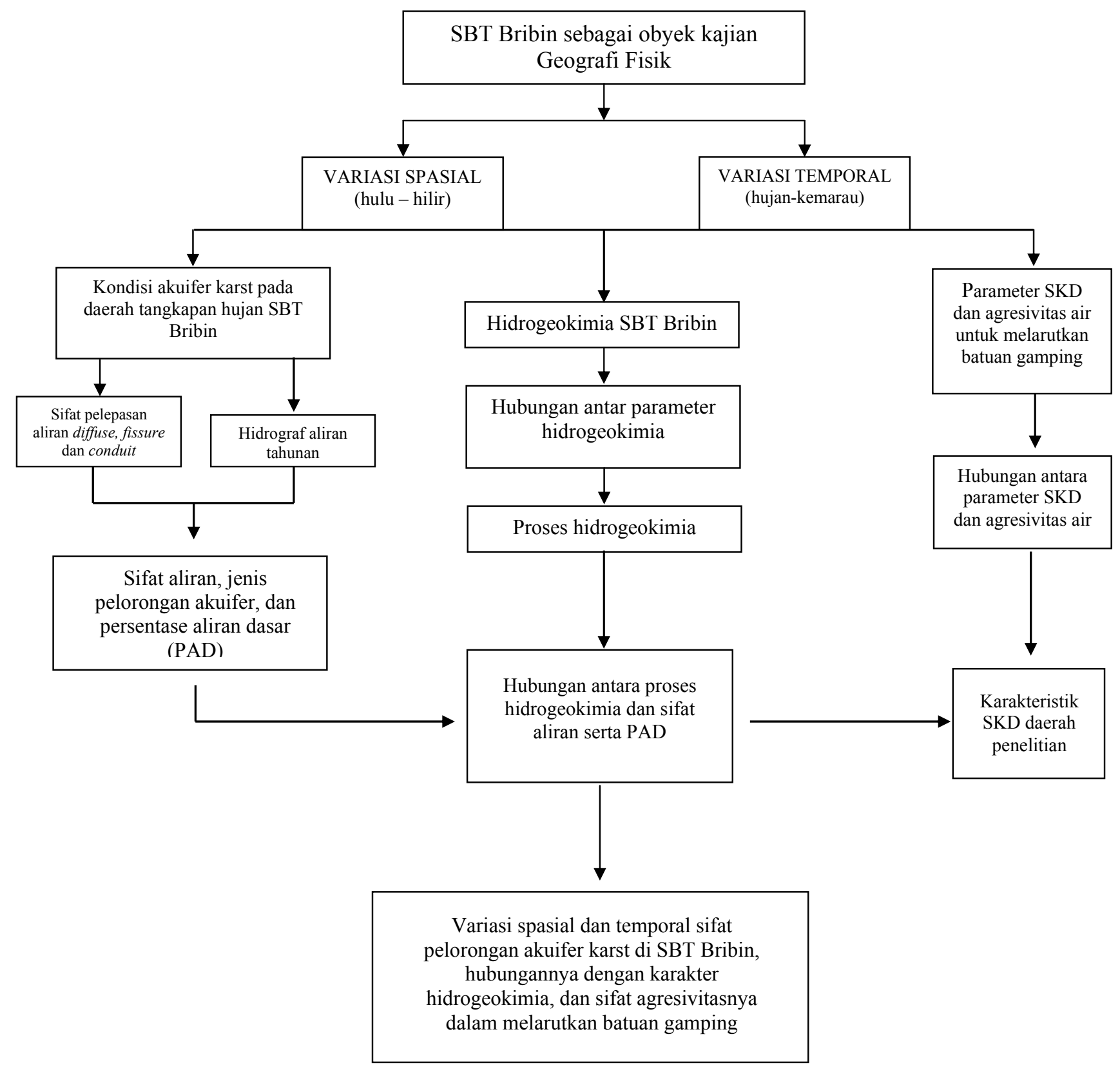

Gambar 2.11. Kerangka Teori Penelitian 


\section{BAB III. METODE PENELITIAN}

\section{A. Pengantar}

Akuifer karst mempunyai sifat anisotropis (karakteristik porositas ke segala arah tidak sama) yaitu terkontrol oleh persebaran conduit dan tidak terdapatnya korelasi homogen dan gradual antara permukaan dan bawah permukaan, sehingga hampir semua penelitian hidrologi di akuifer karst tidak menggunakan metode penelitian yang bersifat deduktif (menggunakan distribusi sifat permukaan untuk mengkarakterisasi sifat alirannya), untuk menarik kesimpulan karakteristik insitu tetapi lebih cenderung menggunakan metode induktif dengan sifat penelitian yang mendekati Quasi-Experimental Research (Dane, 1990). Quasi-Experimental Research merupakan bagian dari Experimental Research yang merupakan tingkatan tertinggi dari suatu riset, karena banyaknya data yang diperoleh di lapangan dan bukan semata menggunakan metode Conceptual Research yang menggabungkan teori-teori yang ada untuk menarik suatu kesimpulan tertentu. Tipe QuasiExperimental riset ini dipilih atas dasar sulitnya pada beberapa faktor atau kondisi yang tidak dapat disurvai secara langsung seperti pengaruh mineral batuan, tebal dan perlapisan batuan karbonat pada akuifer, kandungan $\mathrm{CO}_{2}$ pada akuifer, jaringan retakan dan conduit di akuifer yang di lapangan tidak dapat dikorelasikan secara langsung dengan obyek utama penelitian ini, yaitu sungai bawah tanah. Selain itu, karena penelitian ini memakan waktu yang panjang, maka desain penelitian ini dikenal sebagai Time Series Design of Quasi-Experimental Research. Menurut Dane (1990), metode pengambilan data yang paling sesuai dan jamak dilakukan oleh peneliti dengan metode ini adalah Field-Survey Research atau penelitian berbasis data hasil riset di lapangan, yang pada penelitian ini menggunakan alat-alat 
pengukuran dan pencatatan data secara time series. Lebih jauh lagi diungkapkan bahwa tipe penelitian Quasi-Experimental dengan survai lapangan secara temporal biasanya menggunakan metode induktif untuk mendeskripsikan suatu sistem di alam. Meskipun demikian, pada akhirnya penarikan kesimpulan secara umum pada penelitian ini juga mengambil teori-teori dasar karst dan teori-teori hasil riset, sehingga dapat pula dalam hal ini penelitian ini bersifat deduktif.

Pendekatan sampling hidrogeokimia secara induktif (spasial dan temporal) diharapkan akan mampu mendeskripsikan sistem hidrologi karst dari eksokarst dan endokarst, dengan mengabaikan beberapa parameter di dalam akuifer itu sendiri seperti halnya karakteristik zona epikarst, lorong-lorong conduit serta besarnya tekanan gas karbondioksida di dalam tanah. Selain itu faktor manusia, topografi, dan vegetasi di permukaan yang sebenarnya mempunyai andil dalam siklus hidrologi karst juga diabaikan.

\section{B. Batasan Ruang Lingkup Penelitian}

Penelitian ini dilakukan dengan survai lapangan secara berkala pada beberapa titik yang dapat dijangkau dalam ruang lingkup daerah tangkapan hujan SBT Bribin. Penelitian ini adalah penelitian yang menggunakan pendekatan deduktif dalam pengambilan kesimpulan yang terkait dengan kondisi di tempat lain, tetapi bersifat induktif dalam konteks penarikan kesimpulan terkait sifat aliran dan proses hidrogeokimia di akuifer karst daerah penelitian yang tidak semuanya dapat dianalisis dengan pendekatan deduktif karena sifatnya yang anisotropis, sehingga tidak selalu ada korelasi antara kondisi permukaan dan bawah permukaan (Ford dan William, 1992). Keterbatasan penggunaan metode deduktif dalam penelitian ini diantaranya adalah tidak memungkinkan mengkaitkan kondisi permukaan dan bawah permukaan karst karena adanya ketidakselarasan akuifer karst yang didominasi 
beraneka ragam retakan. Selain itu, pendekatan deduktif untuk mengkaji hidrogeokimia dan sifat aliran sungai bawah tanah belum pernah dijumpai pada telaahan pustaka yang dilakukan. Metode induktif dengan pendekatan hidrogeokimia dan kondisi aliran pada sungai bawah tanah hingga saat ini masih dianggap sebagai metode yang paling mungkin untuk mendeskripsikan proses yang terjadi pada akuifer karst, sehingga beberapa parameter permukaan yang secara teori berhubungannya dengan kondisi bawah permukaan karst diabaikan pada penelitian ini, misalnya: mineral penyusun akuifer karst, penggunaan lahan, geomorfologi karst, kandungan $\mathrm{CO}_{2}$ pada akuifer, kandungan $\mathrm{CO}_{2}$ pada zone epikarst karena pengaruh organisme, serta kondisi retakan di akuifer.

\section{Pemilihan Batas-Batas Daerah Penelitian}

Batas daerah penelitian adalah estimasi semua wilayah permukaan yang merupakan daerah tangkapan hujan SBT Bribin, seperti yang sudah dijelaskan pada Gambar 1.6. Sementara itu, Gua Bribin dianggap sebagai outlet SBT Bribin yang hulunya adalah Sungai Pentung yang hilang ke beberapa ponor di daerah Sawah Ombo, Tambakromo, kemudian dapat ditemukan lagi di Luweng Jomblangan, kemudian di Gua Gilap, Luweng Jomblangbanyu, Luweng Jurang Jero, dan terakhir di Gua Bribin dengan satu sistem bocoran yang dapat dijumpai di Gua Ngreneng. Sistem SBT Bribin yang dideskripsikan alurnya ini sesuai dengan hasil uji tracer yang dilakukan oleh MacDonald dan Partners (1984).

\section{Data yang Dikumpulkan}

Cakupan kegiatan pada penelitian ini dapat meliputi pengambilan dan pengumpulan data primer dan sekunder yang rinciannya adalah sebagai berikut. 
1. Data tinggi muka air SBT Bribin (Sungai Pentung, Gua Gilap, Gua Bribin, Gua Ngreneng), untuk monitoring fluktuasi dan pembuatan rating curve;

2. Data debit sungai bawah tanah Bribin (Sungai Pentung, Gua Gilap, Gua Bribin, Gua Ngreneng), untuk karakterisasi sifat aliran;

3. Data hidrokimia sungai bawah tanah Bribin (Sungai Pentung, Gua Gilap, Gua Bribin, Gua Ngreneng, Luweng Jomblangan), untuk karakterisasi proses yang ada di akuifer;

4. Data hidrokimia tetesan ornamen gua-gua di SBT Bribin (Gua Bribin dan Gua Gilap), untuk karakterisasi proses yang ada di akuifer;

5. Data hidrokimia hujan di daerah tangkapan SBT Bribin (Stasiun Tambak Romo, Karang Asem, dan Dadapayu), untuk karakterisasi proses air pada kondisi tidak jenuh.

\section{E. Materi Penelitian}

\section{Populasi}

Populasi yang menjadi obyek kajian adalah sungai bawah tanah dan gua yang tercakup dalam daerah tangkapan SBT Bribin. Selanjutnya sampel yang akan mewakili populasi adalah gua yang dilewati oleh SBT Bribin saja dari hulu ke hilir.

\section{Sampel}

Sampel utama yang akan diambil dalam penelitian ini adalah sampel air yang mencakup air sungai bawah tanah dan air tetesan ornamen gua-gua yang dilewati oleh SBT Bribin dan memungkinkan untuk dijangkau (spesifik). Kerangka sampling pada penelitian ini adalah purposive sampling. Sampel sungai bawah tanah pada guagua yang dilewati SBT Bribin dibagi lagi menjadi dua kriteria, yaitu gua-gua dengan 
sungai bawah tanah yang memungkinkan untuk dipasang alat pencatat tinggi muka air dan gua-gua yang tidak memungkinkan untuk dipasang alat pencatat tinggi muka air. Sementara itu, sampel tetesan dilakukan pada gua-gua yang mempunyai tetesan yang dapat diambil sampelnya. Pada Tabel 3.1 ditunjukkan lokasi dan kriteria sampling di daerah penelitian yang dilewati oleh SBT Bribin, dan Gambar 3.1. menunjukkan ilustrasi lokasi persebaran sampling dan peralatan pengukur lainnya.

Tabel 3.1. Kondisi Lokasi Pengambilan Sampel di Daerah Penelitian

\begin{tabular}{|c|c|c|c|c|c|c|}
\hline No & Nama Gua & Koordinat lokasi & $\begin{array}{c}\text { Alat Pencatat } \\
\text { Tinggi muka air }\end{array}$ & $\begin{array}{c}\text { Sampling } \\
\text { hidrogeokimia }\end{array}$ & $\begin{array}{c}\text { Sampling } \\
\text { tetesan }\end{array}$ & Keterangan \\
\hline 1 & Inlet Sungai Pentung & 49 M 472674;9122165 & Tidak & $\mathrm{Ya}$ & Tidak & \multirow{2}{*}{$\begin{array}{l}\text { Tidak memungkinkan alat } \\
\text { pencatat TMA dan tidak ada } \\
\text { air tetesan }\end{array}$} \\
\hline 2 & Luweng Jomblangan & 49 M 472076;9122244 & Tidak & Ya & Tidak & \\
\hline 3 & Gua Gilap & 49 M 472076;9119137 & $\mathrm{Ya}$ & $\mathrm{Ya}$ & $\mathrm{Ya}$ & $\begin{array}{l}\text { Dapat dipasang alat pencatat } \\
\text { TMA, sampling hidrogeokimia } \\
\text { tetesan dan SBT }\end{array}$ \\
\hline 4 & Luweng Jomblangbanyu & 49 M 473272;9116826 & Tidak & Tidak & Tidak & \multirow{2}{*}{$\begin{array}{l}\text { Sangat sulit dijangkau dan } \\
\text { tidak memungkinkan } \\
\text { membawa peralatan mencapai } \\
\text { sungai bawah tanah }\end{array}$} \\
\hline 5 & Luweng Jurangjero & 49 M 466857;9111128 & Tidak & Tidak & Tidak & \\
\hline 6 & Gua Bribin & 49 M 464666;9111646 & $\mathrm{Ya}$ & Ya & $\mathrm{Ya}$ & $\begin{array}{l}\text { Dapat dipasang alat pencatat } \\
\text { TMA, sampling hidrogeokimia } \\
\text { tetesan dan SBT }\end{array}$ \\
\hline 7 & Gua Ngreneng & 49 M 463590;9112961 & $\mathrm{Ya}$ & $\mathrm{Ya}$ & Tidak & $\begin{array}{l}\text { Dapat dipasang alat pencatat } \\
\text { TMA, sampling hidrogeokimia } \\
\text { SBT }\end{array}$ \\
\hline
\end{tabular}

Selanjutnya, jumlah sampel air sungai dan tetesan pada masing-masing lokasi diambil tiap bulan sekali kecuali pada saat musim hujan dilakukan beberapa kali pada lokasi sampling yang mempunyai alat pencatat tinggi muka air dengan mengikuti kenaikan tinggi muka air (level base) sungai bawah tanah.

\section{Bahan Penelitian}

Bahan utama penelitian ini adalah sampel air pada sungai bawah tanah dan tetesan ornamen gua yang lokasi dan kondisinya sudah dijelaskan pada Tabel 3.1. Selain itu, bahan utama lain adalah sampel air hujan pada waktu-waktu tertentu. Selain itu, bahan penunjang lain yang diperlukan adalah Peta Rupa Bumi (RBI) 
daerah penelitian skala 1:25.000 tahun 1998 daerah Semanu dan Ponjong, lembar 1407-633, 1408-311, 1408-312, 1407-634, dan 1407-635, untuk pembatasan daerah penelitian dan survai di lapangan, foto udara B/W daerah Ponjong, Semanu dan Eromoko tahun 1999, untuk delineasi batas topografi karst daerah penelitian, serta peta tematik sungai bawah tanah dan sebaran gua oleh MacDonald dan Partners (1984), untuk penentuan lokasi sampling dan pemasangan alat ukur. Sementara itu, materi penelitian disajikan pada Tabel 3.2.

\section{Alat Penelitian}

Pada penelitian ini, peralatan yang digunakan dapat dibagi menjadi tiga kriteria, yaitu (1) peralatan yang digunakan untuk pra-lapangan yang umumnya menggunakan alat-alat untuk interpretasi peta, delineasi, serta interpretasi foto udara daerah penelitian. Alat-alat tersebut diantaranya adalah: stereoskop cermin, komputer, kurvimeter dan planimeter; (2) peralatan yang dipakai untuk pengukuran dan pengambilan data di lapangan yaitu :

a) stereoskop cermin untuk interpretasi foto udara;

b) notebook/komputer untuk mengolah data dan men-download data hujan dan aliran di lapangan);

c) perangkat lunak untuk pemodelan hidrogeokimia (AQUACHEM);

d) Hobo Water Level Data Logger (3 buah), untuk mencatat fluktuasi tinggi muka air sungai bawah tanah;

e) Automatic Water Level Recorder (1 buah), untuk mencatat fluktuasi tinggi muka air sungai bawah tanah; 


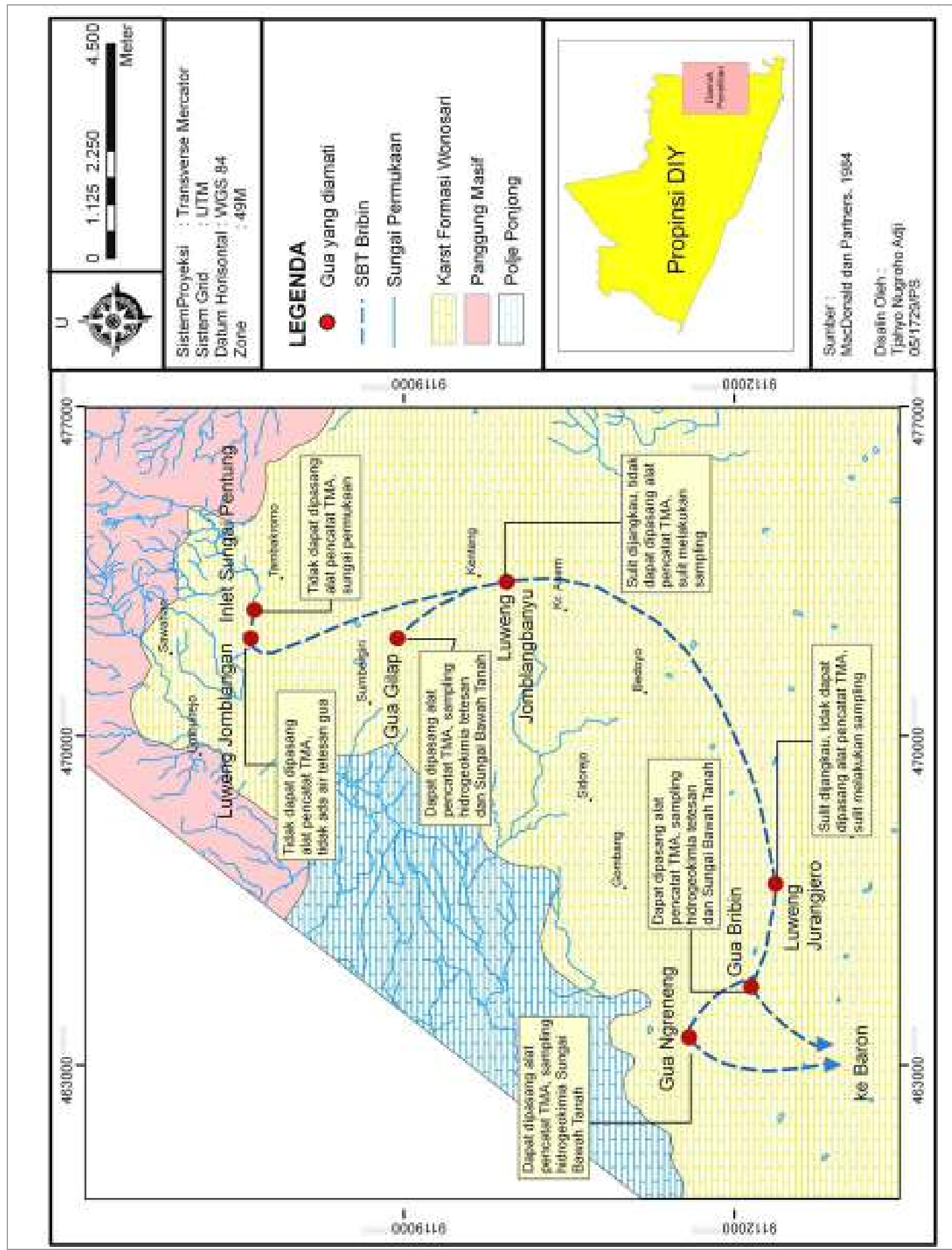

Gambar 3.1. Pertimbangan Sampling Daerah Penelitian 
f) Mini Station Data Logger untuk mencatat data hujan, suhu, kelembaban, dan tekanan udara;

g) kompas Brunton dan Silva (2 buah), untuk orientasi di lapangan;

h) Single Rope Techniques (SRT) set untuk masuk ke gua vertikal;

i) Global Positioning System (GPS) (1 buah), untuk menentukan posisi di lapangan;

j) botol sampel (20 buah), untuk mengambil sampel air sungai bawah tanah, tetesan, dan hujan;

k)Electrical Conductivity meter (1 buah), untuk mengukur daya hantar listrik air;

1) $\mathrm{pH}$ meter (1 buah), untuk mengukur derajat keasaman air;

m) penakar hujan manual (2 buah), untuk mencatat data hujan;

n) penakar hujan otomatis (2 buah), untuk mencatat data hujan;

o) alat sampling mineralogi (1 set), untuk mengambil sampel mineral;

p) kamera digital ( 1 buah), untuk dokumentasi;

q) meteran ( 2 buah), untuk mengaukur tinggi muka air sungai bawah tanah;

r) current meter untuk menghitung kecepatan aliran (1 buah); 
Tabel 3.2. Data Primer Penelitian

\begin{tabular}{|c|c|c|c|}
\hline No & Jenis Data & Parameter & $\begin{array}{l}\text { Sumber dan Cara } \\
\text { Pengambilan Data }\end{array}$ \\
\hline 1 & $\begin{array}{l}\text { Hidrokimia Air Sungai Bawah Tanah } 1 \\
\text { tahun }\end{array}$ & $\begin{array}{l}\mathrm{Ca}^{2+}, \mathrm{Mg}^{2+}, \mathrm{Na}^{+}, \mathrm{K}^{+}, \mathrm{Cl}^{-}, \mathrm{SO}_{4}^{2-} \text {, dan } \\
\mathrm{HCO}_{3}^{-} \cdot \mathrm{pH}, \mathrm{DHL}, \mathrm{Suhu}\end{array}$ & $\begin{array}{l}\text { Pengukuran lapangan dan } \\
\text { laboratorium }\end{array}$ \\
\hline 2 & $\begin{array}{l}\text { Hidrokimia Air Tetesan Ornamen Gua } 1 \\
\text { tahun }\end{array}$ & $\begin{array}{l}\mathrm{Ca}^{2+}, \mathrm{Mg}^{2+}, \mathrm{Na}^{+}, \mathrm{K}^{+}, \mathrm{Cl}^{-}, \mathrm{SO}_{4}{ }^{2-}, \text { dan } \\
\mathrm{HCO}_{3}^{-} \cdot \mathrm{pH}, \mathrm{DHL}, \mathrm{Suhu}\end{array}$ & $\begin{array}{l}\text { Pengukuran lapangan dan } \\
\text { laboratorium }\end{array}$ \\
\hline 3 & Data curah hujan 1 tahun & Tebal hujan, durasi, intensitas & $\begin{array}{l}\text { Pemasangan alat dan } \\
\text { pencatatan data hujan }\end{array}$ \\
\hline 4 & Data Iklim 1 tahun & Kelembaban, suhu, tekanan udara & $\begin{array}{l}\text { Pemasangan alat dan } \\
\text { pencatatan data }\end{array}$ \\
\hline 4 & Hidrokimia Air Hujan & $\begin{array}{l}\mathrm{Ca}^{2+}, \mathrm{Mg}^{2+}, \mathrm{Na}^{+}, \mathrm{K}^{+}, \mathrm{Cl}^{-}, \mathrm{SO}_{4}{ }^{2-}, \text { dan } \\
\mathrm{HCO}_{3}^{-} \cdot \mathrm{pH}, \mathrm{DHL}, \mathrm{Suhu}\end{array}$ & $\begin{array}{l}\text { Pengukuran lapangan dan } \\
\text { laboratorium }\end{array}$ \\
\hline 5 & $\begin{array}{l}\text { Fluktuasi } 1 \text { tahun tinggi muka airtanah } \\
\text { dan debit Sungai Bawah Tanah }\end{array}$ & $\begin{array}{l}\text { Tinggi muka air dalam satuan meter } \\
\text { (m), dan debit aliran dalam satuan lt/dt }\end{array}$ & $\begin{array}{l}\text { Pengukuran dan pencatatan } \\
\text { lapangan }\end{array}$ \\
\hline 6 & $\begin{array}{l}\text { Fluktuasi } 1 \text { tahun intesitas tetesan } \\
\text { ornamen gua }\end{array}$ & Intensitas dalam $\mathrm{ml} /$ menit & $\begin{array}{l}\text { Pengukuran dan pencatatan } \\
\text { lapangan }\end{array}$ \\
\hline
\end{tabular}

Kemudian, (3) peralatan yang digunakan untuk kegiatan analisis dan pasca lapangan adalah peralatan-peralatan yang terdapat di Laboratorium Hidrologi dan Kualitas Air Fakultas Geografi UGM, serta seperangkat komputer yang dibantu dengan perangkat lunak untuk analisis hidrogeokimia airtanah di antaranya adalah program Rockworks 99, dan Aquachem.

\section{F. Tahapan Penelitian}

\section{Kerja pra-lapangan}

a) Identifikasi dan delineasi daerah penelitian; tahapan identifikasi ini menyangkut pembatasan daerah penelitian dengan maksud untuk menentukan batas geografis yang melingkupi obyek yang akan diteliti. Delineasi ini termasuk juga penentuan obyek-obyek yang akan diteliti, utamanya adalah posisi gua dan jalur SBT Bribin. 
b) Penentuan posisi titik-titik pengambilan sampel air; tidak semua gua yang dilewati jalur sungai bawah tanah digunakan sebagai titik sampel. Lokasi pengambilan sampel yang ditentukan adalah pada masukan sungai permukaan yang masuk ke SBT Bribin, serta beberapa gua yang dapat mewakili sebaran spasial sistem ini dari hulu sampai hilir, seperti yang sudah disajikan pada Tabel 3.1.

c) Penentuan posisi alat pengukur tinggi muka air sepanjang SBT Bribin; tidak semua gua yang dilalui SBT Bribin dipasang alat pengukur Tinggi Muka Air (Hobo water level data logger). Hal ini disebabkan karena instalasi alat pengukur Tinggi Muka Air (TMA) di sungai bawah tanah tidak sederhana dan membutuhkan ketrampilan khusus mengingat sulitnya medan dan tidak adanya cahaya alami. Penentuan lokasi alat pengukur TMA selanjutnya tergantung dari faktor-faktor kondisi segmen sungai yang memungkinkan, posisi spasial yang dapat mewakili hulu-hilir, keamanan, dan kemudahan akses.

d) Penentuan posisi alat penakar hujan; mengingat sulitnya menentukan daerah tangkapan hujan yang ideal untuk bentang alam karst, maka posisi penakar hujan akan ditentukan berdasarkan pada luasan daerah penelitian dan keterwakilan terhadap topografi dari hulu ke hilir. Posisi penakar hujan, alat pencatat TMA dan titik-titik pengambilan sampel pada penelitian ini sudah disajikan pada Gambar 3.1. 


\section{Kerja lapangan}

a) Pemasangan alat pencatat curah hujan dan pencatatan data hujan selama 1 tahun ( \pm 3 titik), seperti yang disajikan pada Gambar 3.2.
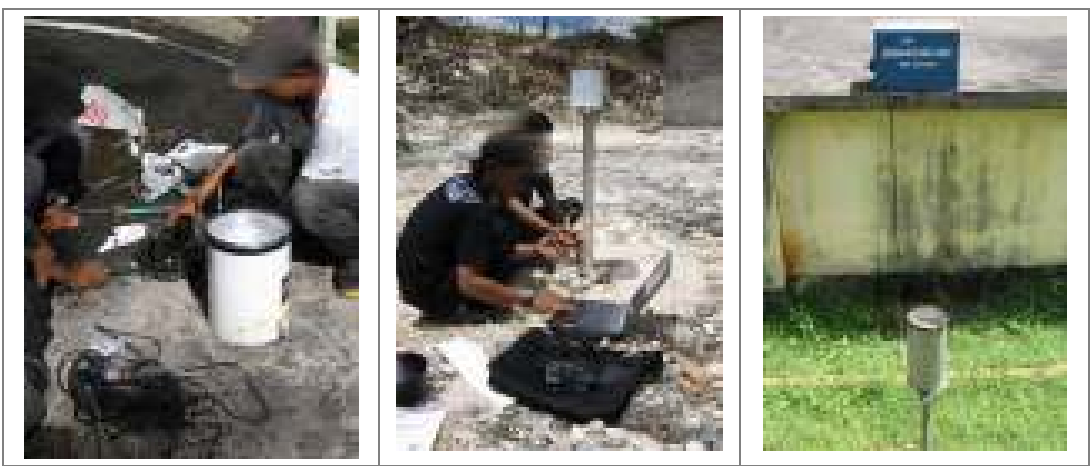

Gambar 3.2. Penakar Hujan Otomatik Tipe Castella (hulu DAS Bribin-kiri); OnsetHOBO RG3M (tengah DAS Bribin-tengah); Semi Otomatik (hilir DAS Bribin-kanan)

b) Pemasangan water level data logger atau Automatic Water Level Recorder (AWLR) untuk pencatatan TMA selama 1 tahun ( \pm 3 titik), seperti yang disajikan pada Gambar 3.3.

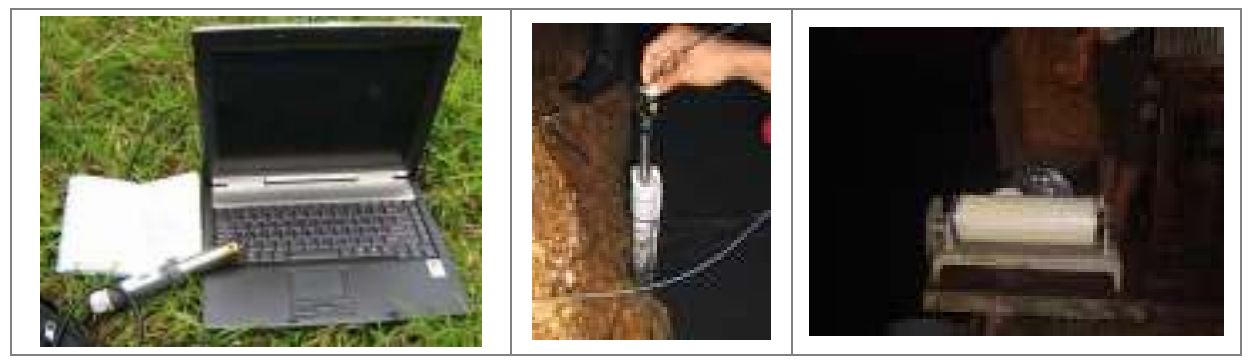

Gambar 3.3. Data Logger TMA yang Dipasang di Gua Gilap (kiri); Instalasi Stasiun Aliran di Gua Ngreneng (tengah); Automatic Water Level Recorder -AWLR di Gua Bribin (kanan)

c) Pencatatan data TMA dilakukan setiap 30 menitan dan pengambilan sampel air SBT dan tetesan setiap 1 bulan 1 kali mengacu pada penelitian Currens (1999) dengan kondisi aquifer karst seperti pada daerah penelitian dengan tipe mixed antara diffuse dan conduit, pada semua titik sampling dan pengambilan sampel dan pengukuran intensitas tetesan ornamen gua untuk mewakili hidrogeokimia air diffuse seperti yang disajikan pada Gambar 3.4. 
d) Pengukuran kecepatan aliran dan penampang basah pada semua lokasi yang dipasang alat pencatat TMA pada saat debit puncak, debit menengah, dan debit minimum untuk keperluan pembuatan Stage Discharge Rating Curve $( \pm 3$ titik), seperti yang disajikan pada Gambar 3.5.

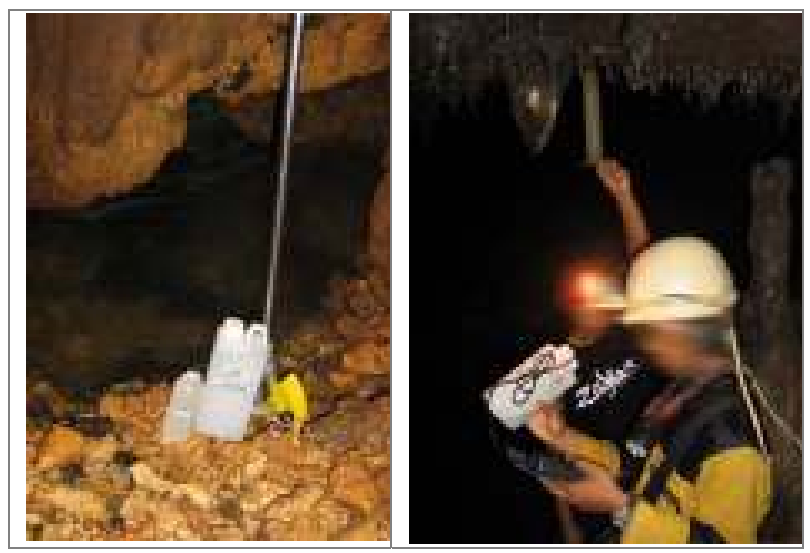

Gambar 3.4. Pengambilan Sampel Air Sungai Bawah Tanah di Gua Ngreneng (kiri) dan Tetesan Ornamen di Gua Bribin (kanan)

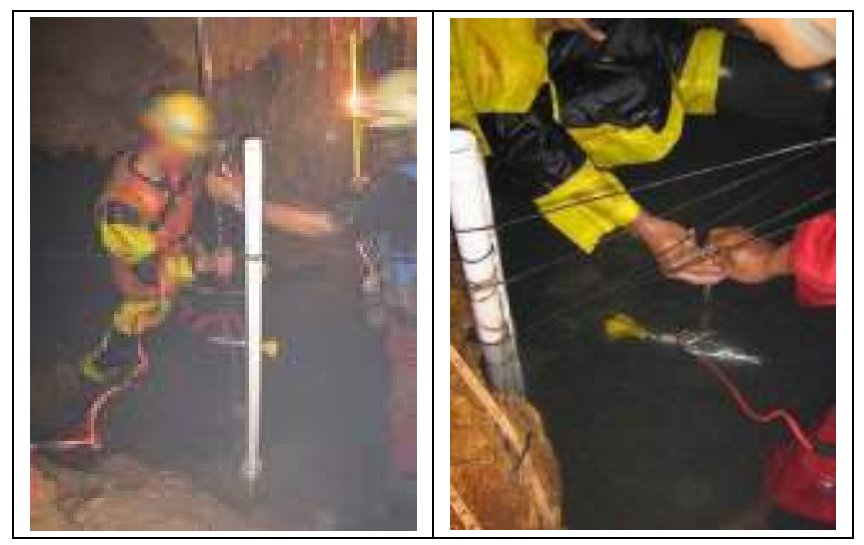

Gambar 3.5. Pengukuran Debit Aliran dengan Current Meter di Gua Gilap (Kiri) dan Gua Ngreneng (Kanan)

e) Pengambilan sampel air dengan intensitas yang rapat untuk mengkarakterisasi dinamika SKD pada saat kejadian banjir pada kondisi yang memungkinkan.

f) Pengambilan sampel air hujan untuk uji kualitas air di daerah tangkapan hujan SBT Bribin. 
g) Pengukuran pH, suhu, Daya Hantar Listrik (DHL), dan Eh lapangan setiap pengambilan sampel, seperti yang disajikan pada Gambar 3.6.

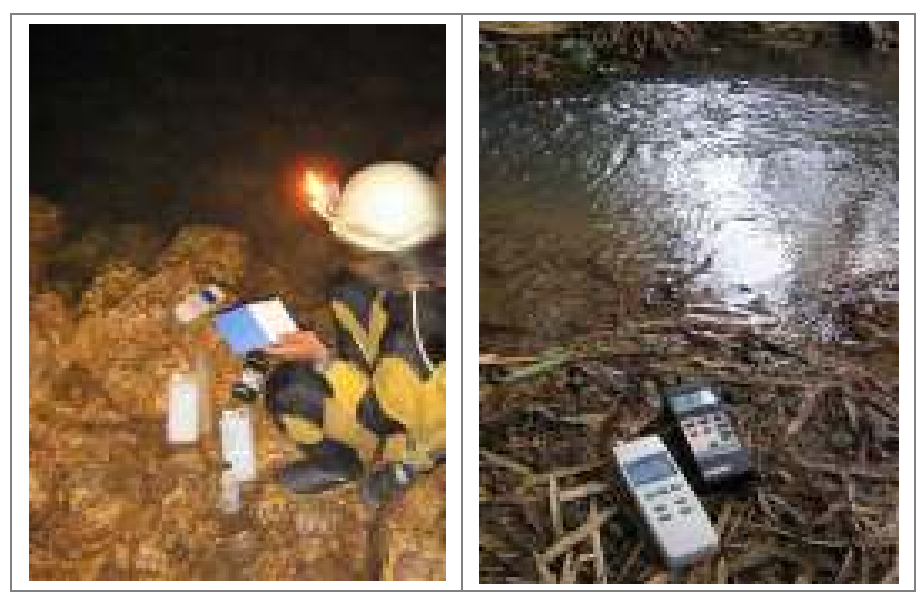

Gambar 3.6. Pengukuran pH, Suhu, DHL, dan Eh Lapangan Setiap Pengambilan Sampel

\section{Kerja pasca lapangan}

Kegiatan pasca lapangan merupakan kegiatan analisis data yang dilakukan untuk memverifikasi data pengukuran dan pengambilan sampel, analisis variabelvariabel SKD, analisis spasial dan temporal untuk mencapai tujuan penelitian, yang meliputi :

a. Analisis spasial dan temporal dari hulu ke hilir sifat komponen aliran dan PAD SBT Bribin sepanjang tahun, untuk membuktikan hipotesis ke-1, yaitu dengan prosedur-prosedur:

i) Analisis regresi antara data TMA dan debit terukur untuk membuat Stage Discharge Rating Curve. Cara yang dipakai adalah cara sederhana berupa regresi linier dengan jumlah sampel kecil (Schulz, 1976).

ii) Analisis Hidrograf. Analisis hidrograf yang dibuat adalah hidrograf tinggi muka air (stage hydrograph), hidrograf aliran (annual discharge hydrograph) 
sepanjang tahun, dan hidrograf banjir (flood hydrograph). Hidrograf-hidrograf ini kemudian disajikan secara grafikal sepanjang tahun atau pada saat banjir puncak dengan skala tertentu, kemudian dilakukan analisis data grafik hidrograf aliran per kejadian banjir terpilih yang meliputi rising limb, crest dan recession limb, serta sifat-sifat yang menyertainya seperti time to rise, time of base, timelag, dan peak discharge.

iii) Menghitung konstanta resesi dari kurva resesi (Gambar 3.7-atas) merupakan bagian dari suatu hidrograf banjir pada sungai bawah tanah setelah tidak ada hujan, sehingga debit aliran turun atau akuifer melepaskannya komponen alirannya.yaitu yang merupakan bagian dari suatu hidrograf banjir (Gambar 3bawah) pada SBT setelah tidak ada hujan, sehingga debit aliran turun atau akuifer melepaskannya komponen alirannya. Formula untuk menghitung konstanta resesi adalah:

$$
Q_{t}=Q_{0} e^{-\alpha t}
$$

\section{Keterangan:}

$Q_{t}$ is adalah debit aliran pada waktu $t, Q_{0}$ adalah debit awal pada segmen resesi, dan $\alpha$ adalah suatu konstanta. Selanjutnya, $e^{-\alpha}$ pada rumus (1) dapat diganti dengan $k$, yang oleh hidrolog dikenal sebagai konstanta resesi (recession constant atau depletion factor), yang jamak digunakan sebagai indikator keberlangsungan aliran dasar (Nathan dan McMahon, 1990). Kemudian, nilai k dibandingkan dengan klasifikasi resesi sungai bawah tanah karst oleh Worthington (1991, dalam Giliesson, 1996).

iv) Analisis pemisahan aliran dasar (baseflow separation) dan perhitungan aliran langsung sepanjang tahun. Metode pemisahan aliran dasar menggunakan automated base flow separation by digital filtering method (Eckhardt, 2005), 
yaitu mencari nilai digital filtering atas dasar nilai konstanta resesi pada kejadian hidrograf sepanjang tahun (Gambar 3.8), yang kemudian dihubungkan dengan nilai base flow indices (BFI) di akuifer karst, rumus yang digunakan adalah :

$$
q_{b(i)}=\frac{\left(1-B F I_{\text {max }}\right) a q_{b(i-1)}+(1-a) B F I_{\text {max }} q_{i}}{1-a B F I_{\text {max }}}
$$

\section{Keterangan:}

$q_{b(i)}$ adalah baseflow pada saat $i, q_{b(i-1)}$ adalah baseflow pada waktu sebelumnya $i-1, q_{i}$ adalah total aliran pada waktu $i$, a adalah konstanta resesi dan $B F I_{\max }$ adalah baseflow maksimum yang dapat diukur atau diketahui.

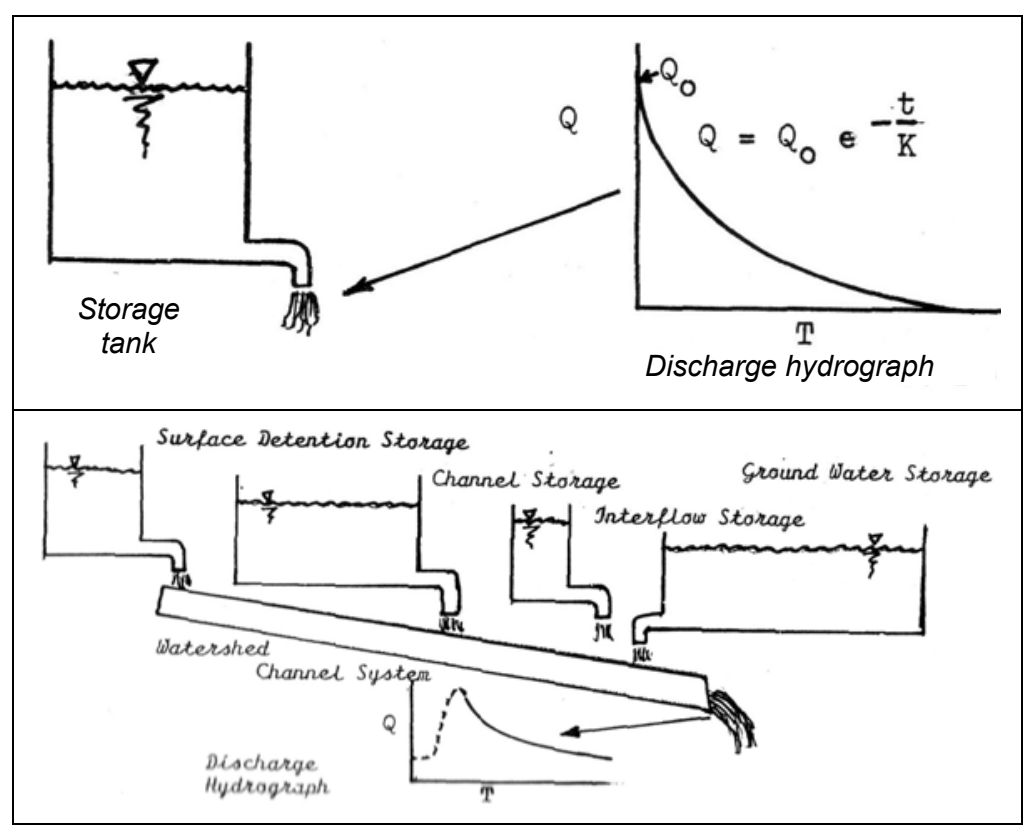

Gambar 3.7. Pelepasan Simpanan Air Akuifer Sebagai Komponen Aliran (Schulz, 1976) 


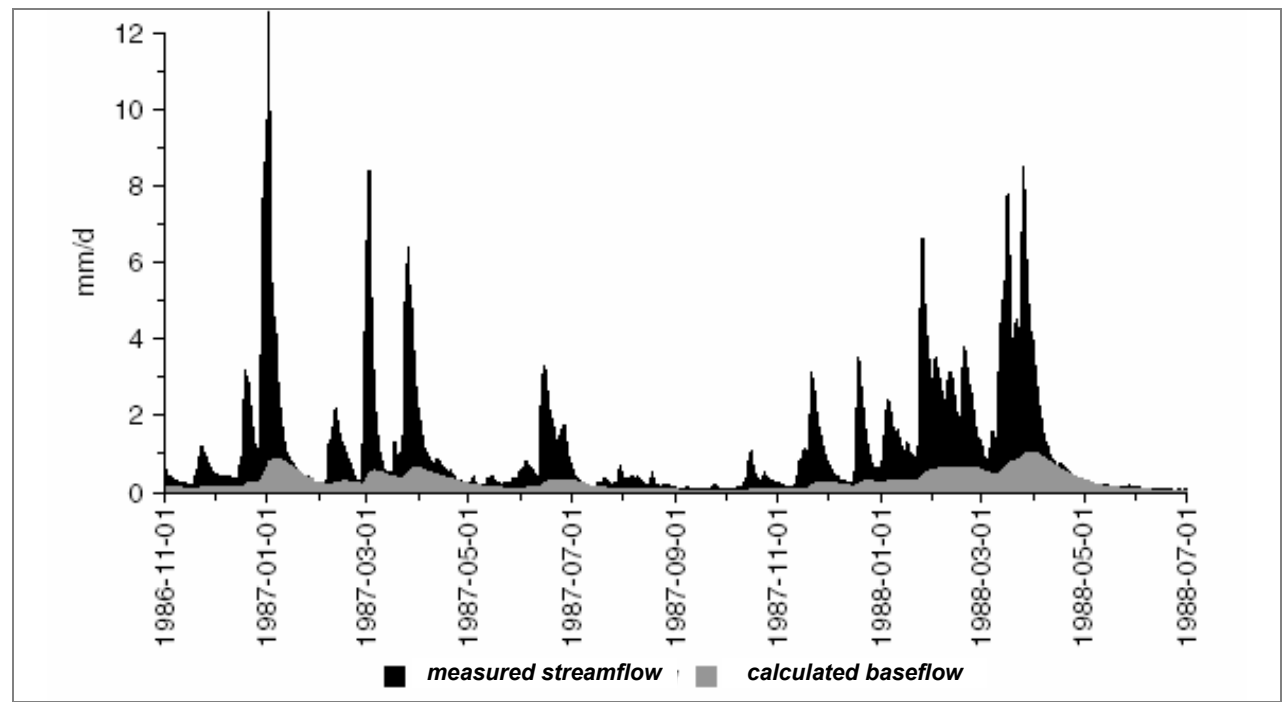

Gambar 3.8. Pemisahan Aliran Dasar dengan Metode Digital Filtering (Eckhardt, 2005)

Analisis-analisis tersebut dilakukan secara spasial pada lokasi-lokasi yang dipasang peralatan pencatat tinggi muka air, seperti yang contohnya disajikan pada Gambar 3.9. Pada prosedur ini hipotesis pertama terbukti jika PAD musim kemarau gua di bagian hilir lebih besar dari gua di bagian hulu, dan besarnya PAD disebabkan oleh perbedaan nilai konstanta resesi aliran dasar dari akuifer karst. Sementara itu, pada saat musim hujan besar kecilnya PAD lebih tergantung dari nilai konstanta resesi aliran conduit.

b. Analisis Variasi Temporal dan Spasial Hidrogeokimia dan Agresivitas Air SBT Bribin, merupakan prosedur lanjutan untuk membuktikan hipotesis ke-2 dan ke-3, melalui prosedur-prosedur:

i) Analisis kimia sampel di laboratorium meliputi kation $\mathrm{Ca}^{2+}, \mathrm{Mg}^{2+}, \mathrm{Na}^{+}, \mathrm{K}^{+}$, dan anion $\mathrm{Cl}^{-}, \mathrm{SO}_{4}{ }^{2-}$, dan $\mathrm{HCO}_{3}{ }^{-}$. Metode analisis yang digunakan meliputi : metode volumetri untuk unsur $\mathrm{Ca}^{2+}, \mathrm{Mg}^{2+}, \mathrm{CO}_{3}^{-}$dan $\mathrm{SO}_{4}{ }^{2-} ;$ metode spektrofotometri untuk unsur $\mathrm{HCO}_{3}{ }^{-}$; metode flamefotometri untuk unsur $\mathrm{Na}^{+}$ dan $\mathrm{K}^{+}$. 
ii)Analisis Charge Balance Calculation. Karena kondisi alami dari larutan elektrolit dalam air, maka jumlah dari ion negatif dan ion positif dalam meq/l haruslah sama, sehingga jika proses pengambilan sampel, pengawetan, dan analisis di laboratorium itu benar, maka kondisi tersebut harus dipenuhi (Appelo dan Postma, 1994). Pada analisis sampel air di laboratorium sebelum dianalisis lebih lanjut, hasil analisis dihitung tingkat akurasinya dengan perhitungan tingkat penyimpangan kesetimbangan reaksi (charge balance error). Berdasarkan konsentrasinya, perhitungan tingkat penyimpangan kesetimbangan reaksi dituliskan sebagai berikut :

$$
\begin{gathered}
\left(\mathrm{Na}^{+}\right)+\left(\mathrm{K}^{+}\right)+2\left(\mathrm{Ca}^{2+}\right)+2\left(\mathrm{Mg}^{2+}\right)=\left(\mathrm{Cl}^{-}\right)+\left(\mathrm{HCO}_{3}{ }^{-}\right)+2\left(\mathrm{SO}_{4}{ }^{2-}\right) \text { sehingga : } \\
\sum z m c=\sum z m a \ldots \ldots \ldots \ldots \ldots \ldots \ldots \ldots \ldots \ldots \ldots \ldots \ldots \ldots \ldots \ldots \ldots \ldots \ldots \ldots \ldots \ldots \ldots \ldots \ldots
\end{gathered}
$$

Keterangan:

$$
\begin{array}{ll}
\mathrm{z} & =\text { Valensi ion; } \\
\sum \mathrm{Mc} & =\text { Molalitas kation; } \\
\sum \mathrm{ma} & =\text { Molalitas anion. }
\end{array}
$$

Perhitungan ini menunjukkan jumlah ion positif yang bereaksi harus sama dengan jumlah ion negatif yang bereaksi. Jika terjadi penyimpangan dari perhitungan, dipastikan telah terjadi kesalahan analisis pada penentuan konsentrasi atau terdapat salah satu ion dengan konsentrasi tinggi yang tidak termasuk dalam analisis. Jika ditunjukkan dalam persentase maka :

$$
E=\frac{\sum z m c-\sum z m a}{\sum z m c+\sum z m a} \times 100
$$

E adalah tingkat penyimpangan kesetimbangan reaksi dalam \%, bila tidak terdapat kesalahan maka $\mathrm{E}$ adalah 0 atau unsur kation dan unsur anion 
membentuk kesetimbangan. Tingkat persentase penyimpangan yang masih dapat diterima adalah 5\% (Jankowski, 2001).

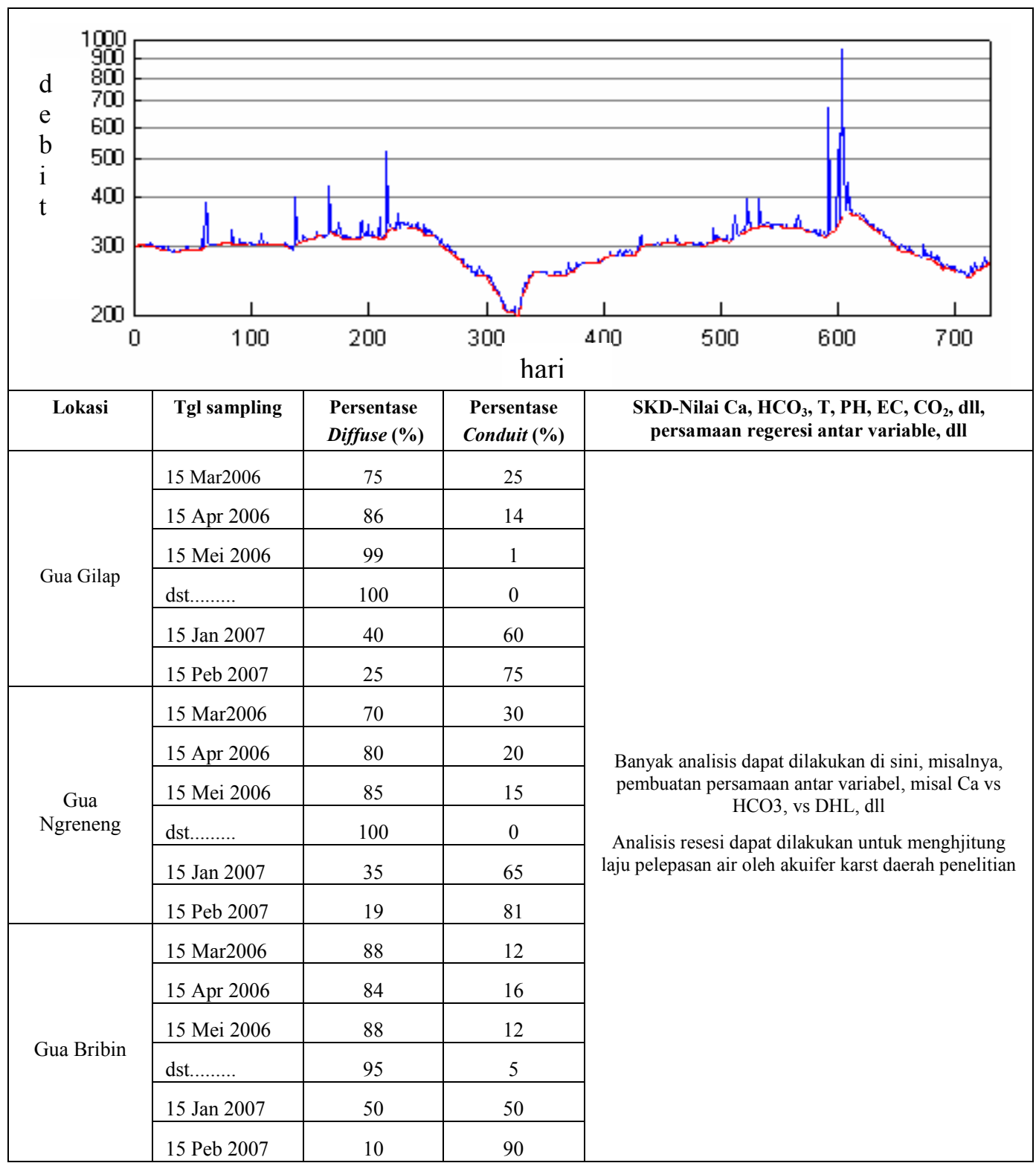

Gambar 3.9. Contoh Tabulasi Untuk Membedakan Komposisi Komponen Aliran

iii) Analisis tipe kimia airtanah karst. Penentuan tipe kimia airtanah dimaksudkan untuk mengetahui jenis kation dan anion yang dominan. Atas dasar simplisitas dan homogenitas daerah penelitian, maka metode yang dipilih 
adalah penentuan tipe kimia airtanah oleh Szczukariew - Priklonski (Alekin, 1970). Metode klasifikasi tipe kimia airtanah ini didasarkan pada kandungan anion dan kation yang terkandung lebih dari $20 \%$ dari total kandungan anion dan kation dalam meq/l. Tipe airtanah dalam metode ini dilambangkan dengan kandungan anion di awal, kemudian diikuti kandungan kation di belakang berdasar kerterdapatannya. Dari ke-7 unsur utama yang dianalisis dalam klasifikasi, dapat diperoleh berbagai macam kombinasi tipe kimia.

iv) Analisis Indeks Kejenuhan. Analisis Indeks Kejenuhan atau Saturation Indices (SI) dilakukan untuk mengetahui sifat air sampel terhadap tingkat pelarutan batuan karbonat (agresivitas air) terutama terhadap $\mathrm{CaCO}_{3}$, dibantu dengan software Netpath (Plummer, et al., 1991) dengan formulasi sebagai berikut.

$$
\begin{aligned}
& {\left[\mathrm{CO}_{3}{ }^{-}\right]\left[\mathrm{Ca}^{2+}\right]} \\
& \text { SI } \mathrm{CaCO}_{3}=\log 10 \\
& \text {---------------- } \\
& \mathrm{Ksp} \mathrm{CaCO}_{3}
\end{aligned}
$$

\section{$\underline{\text { Keterangan: }}$}

$\left[\mathrm{CO}_{3}{ }^{-}\right]$adalah aktivitas ion karbonat;

$\left[\mathrm{Ca}^{2+}\right]$ adalah aktivitas ion kalsium;

$\mathrm{Ksp} \mathrm{CaCO}_{3}$ adalah solubility product kalsit $=10^{-8,48}$.

Selanjutnya, Jankowski (2001) menambahkan bahwa hubungan antara mineral dan komposisi kimia airtanah yang ditunjukkan oleh nilai SI tersebut dapat dipakai untuk mengetahui fase pelarutan atau pengendapan yang terjadi di akuifer karst (Tabel 3.3). Bila sampel mineral diambil searah aliran airtanah dari hulu ke hilir, maka akan diketahui perubahan nilai SI terhadap nilai equilibriumnya atau kesetimbangannya. 
Tabel 3.3. Fase Pelarutan Atas Dasar Nilai SI

\begin{tabular}{|l|l|l|}
\hline \multicolumn{1}{|c|}{ Nilai SI } & \multicolumn{1}{c|}{ Klasifikasi } & \multicolumn{1}{c|}{ Proses Hidrogeokimia } \\
\hline Negatif $(<0)$ & Tidak jenuh (undersaturated) & Masih mampu melarutkan kalsit \\
\hline 0 & Seimbang (equilibrium) & Setimbang \\
\hline Positif $(>0)$ & Jenuh (supersaturated) & Mengkristal /membentuk padatan (solid) \\
\hline
\end{tabular}

v) Analisis $\mathrm{PCO}_{2}$ (partial pressure of carbondioxide) yang diasumsikan sudah mencapai equilibrium terhadap sampel air (Stumn dan Morgan, 1981; Drever, 1988; White, 1988) pasa semua sampel, dengan rumus, dan dibantu dengan software Wateq-4f (Ball dan Nordstorm, 1991), dengan formula:

$$
\mathrm{P}_{\mathrm{CO} 2}=\left[\mathrm{HCO}_{3}^{-}\right]\left[\mathrm{H}^{+}\right] / \mathrm{K}_{1} \mathrm{~K}_{\mathrm{CO} 2}
$$

\section{Keterangan:}

$\mathrm{PCO}_{2}$ adalah tekanan (sebagian) gas karbondioksida dalam air;

$\left[\mathrm{HCO}_{3}^{-}\right]$adalah aktivitas ion bikarbonat;

$\left[\mathrm{H}^{+}\right]$adalah aktivitas ion hidrogen;

$\mathrm{K}_{1}$ adalah kesetimbangan konstant reaksi pelarutan pada suhu $25^{\circ} \mathrm{C}$;

$\mathrm{K}_{\mathrm{CO} 2}$ adalah kesetimbangan konstant gas $\mathrm{CO}_{2}$ di air pada $25^{\circ} \mathrm{C}$.

Analisis-analisis di atas dilakukan secara spasial dari hulu ke hilir dan secara temporal, seperti yang diilustrasikan pada Gambar 3.10.

c. Analisis terhadap perilaku komponen SKD, hubungan antar parameter SKD, dan hubungan dengan hidrogeokimia-aliran dasar di daerah penelitian, untuk membuktikan hipotesis ke-2 dan ke-3, melalui prosedur-prosedur: 


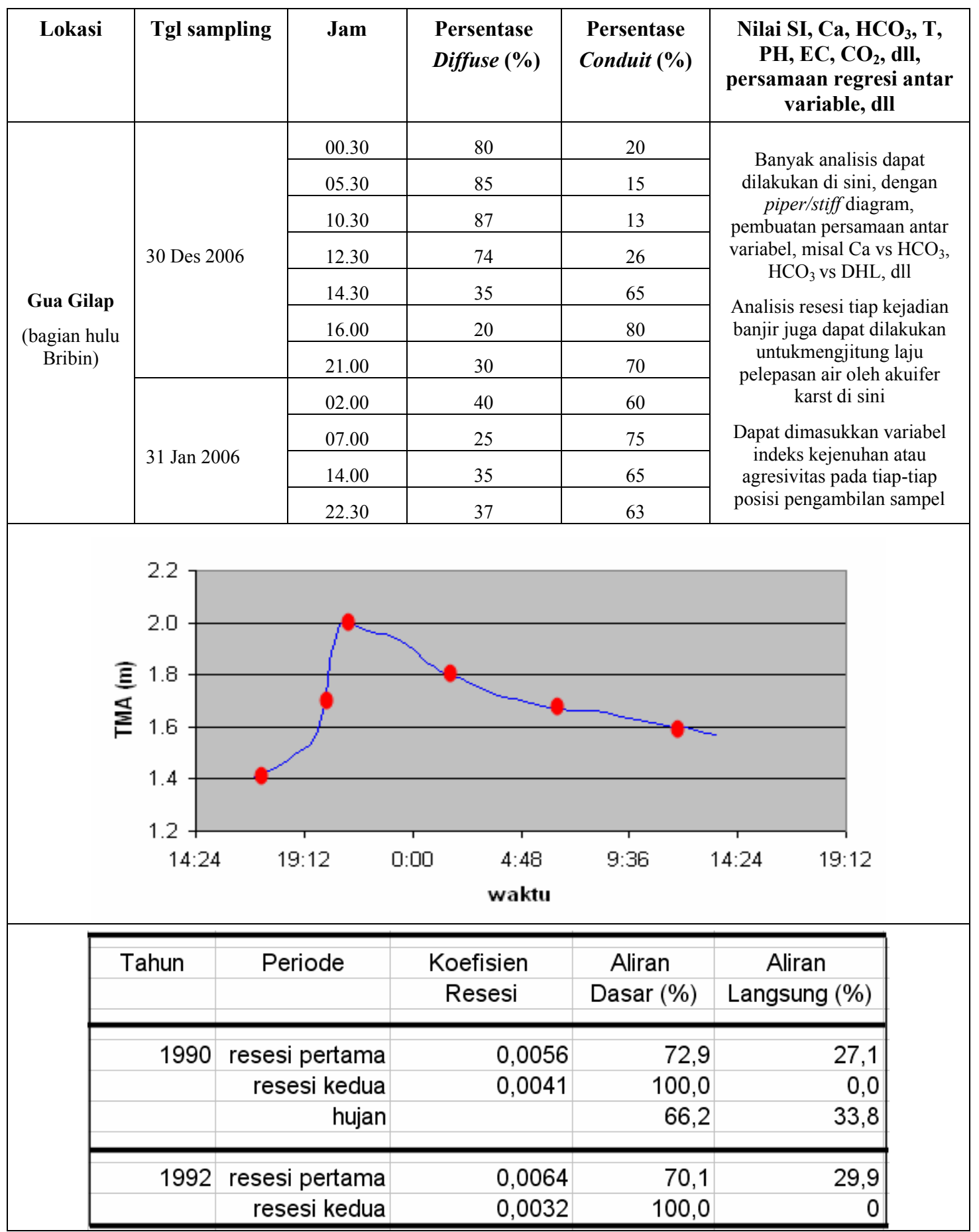

Gambar 3.10. Contoh Hubungan Antara Kondisi Hidrogeokimia, Persentase Komponen Aliran, Serta Variasi Indeks Kejenuhannya untuk Menguji Hipotesis 2 dan 3 
i) Analisis Hidrogeokimia bulanan selama 1 tahun (longterm);

ii) Analisis Hidrogeokimia pada saat hujan puncak atau banjir (Flood-StormScale Hidrogeochemistry). Pada beberapa kali kejadian banjir dan hujan, dilakukan pengambilan sampel setiap 1 atau 2 jam yang diikuti analisis hidrogeokimia seperti yang sudah dipaparkan di atas dengan tujuan untuk mengetahui perubahan parameter SKD;Analisis longterm dan storm-scale hydrochemograph (Gambar 3.11) untuk mencari hubungan antar faktor-faktor yang berpengaruh terhadap SKD di daerah penelitian yaitu meliputi parameterparameter $\mathrm{pH}$, suhu, hujan, $\mathrm{P}_{\mathrm{CO} 2}$, kalsium dan bikarbonat, yang kemudian disajikan secara spasial dari hulu ke hilir. Selanjutnya, Plagnes dan Balakowicz (2001) menyimpulkan keterdapatan tiga model kemograf pada sungai bawah tanah karst (Gambar 3.12), yaitu : (i) komposisi kimia air sepanjang waktu hampir sama pada saat hidrograf mulai naik. Komposisi terlarut kemudian naik sedikit, dan TDS kembali kepada kondisi saat sebelum banjir; (ii) air dengan komposisi mineral lebih banyak muncul pada saat kenaikan hidrograf, kemudian turun sampai di bawah komposisi sebelum banjir, dan pada resesi kemudian kembali ke posisi awal; (iii) bervariasi secara teratur sesuai variasi hidrograf alirannya. 


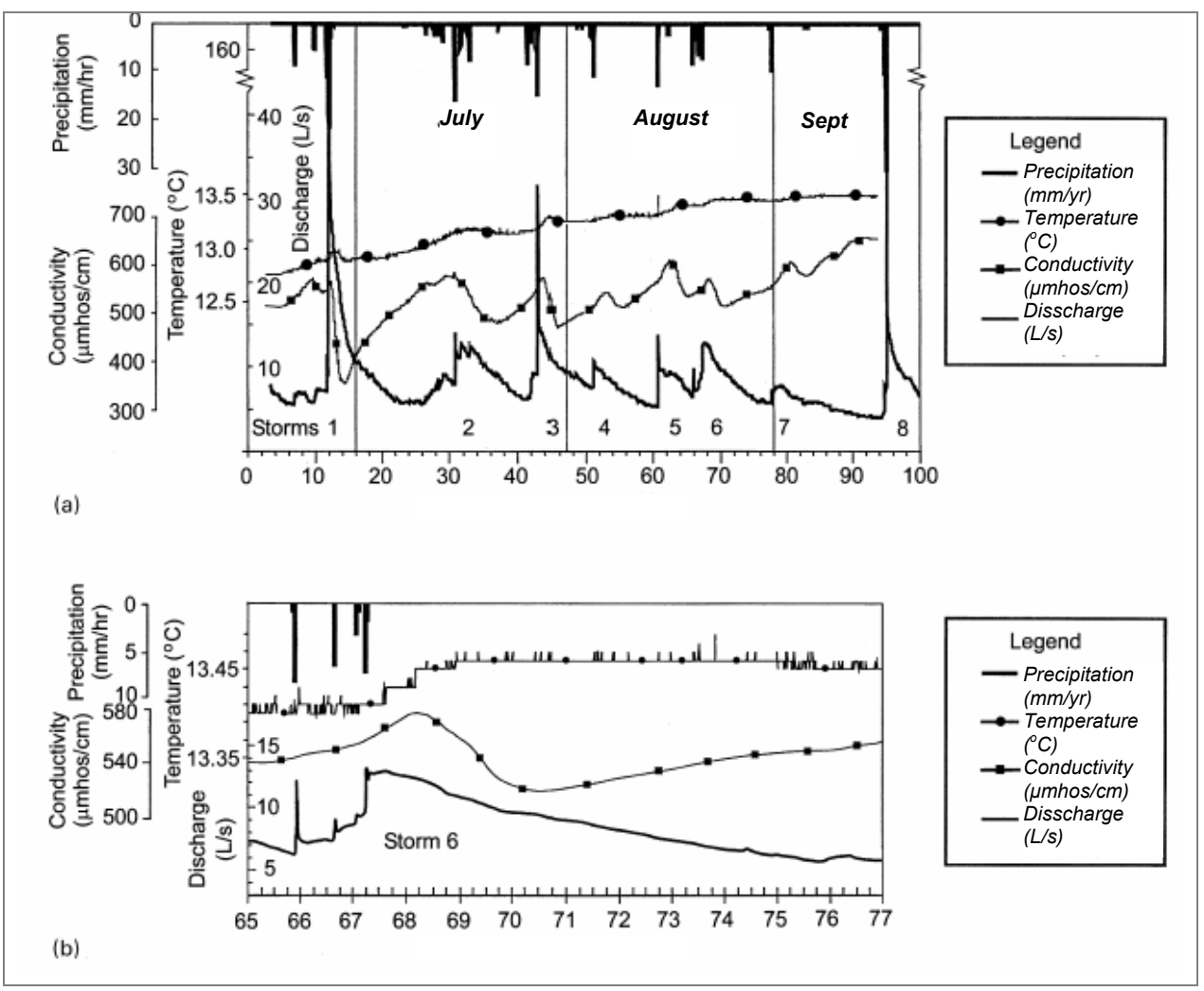

Gambar 3.11. Hidrokemograf (Desmarais dan Rojstaczer, 2001)

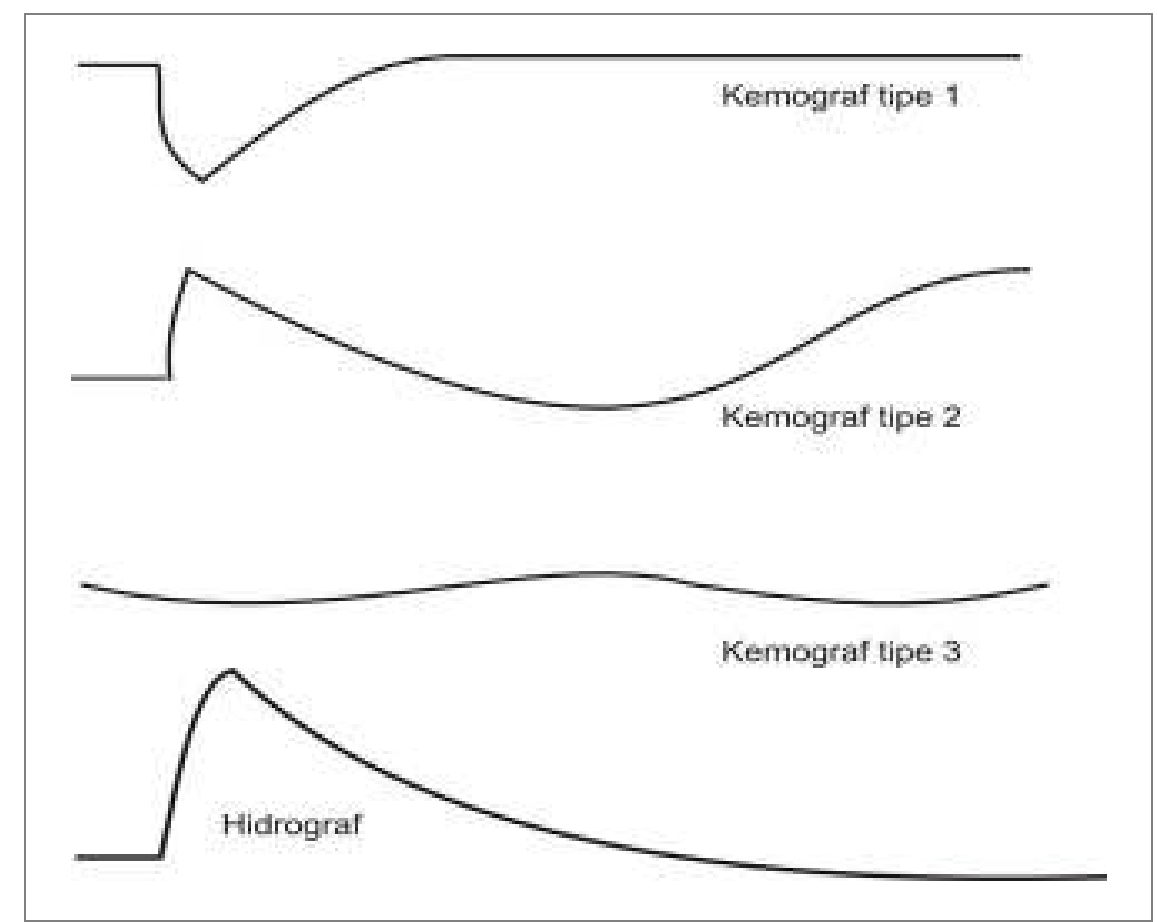

Gambar 3.12. Tiga Model Kemograf di Akuifer Karst (Plagnes dan Balakowicz, 2001) 
iii) Menghubungkan variasi sifat hidrogeokimia selama satu tahun dan pada saat hujan puncak dengan sifat komponen aliran (diffuse-conduit) pada waktu yang bersamaan dengan waktu pengambilan sampel untuk mengidentifikasi prosesproses hidrogeokimia yang terjadi dengan cara membuat scatter plot dengan jumlah sampel kecil (non-discrete parameter), yaitu:(i) hubungan debitkonsentrasi (Gambar 3.13); (ii) hubungan linier antara kalsium dan bikarbonat secara time series pada masing-masing titik sampling (Gambar 3.14); (iii) hubungan DHL-kalsium dan karbonat; (iv) scatter plot natrium dan klorida; (v) hubungan aliran dasar-debit aliran ; (vi) hubungan aliran dasar $\log \mathrm{PCO}_{2}$; dan (vii) hubungan aliran dasar-kasium dan bikarbonat;

iv) Menganalisis perilaku paramater SKD pada air hujan, air tetesan dan air sungai bawah tanah dan mencari hubungan antara agresivitas air (nilai Indeks kejenuhan) dengan $\mathrm{pH}$, kalsium terlarut, dan tekanan parsial gas karbondioksida.

Pada prosedur ini hipotesis kedua terbukti jika hubungan antara PAD dan parameter hidrogeokimia gua di bagian hilir mempunyai hubungan yang lebih kuat pada saat musim kemarau dibandingkan pada musim hujan. Sementara itu, hubungan pada saat musim hujan tergantung dari sifat parameter hidrograf dan pelepasan komponen aliran oleh akuifer karst. Hipotesis ketiga dapat dibuktikan dengan membandingkan nilai agresivitas gua musim kemarau di bagian hilir dan hulu yang mempunyai nilai PAD berbeda, sedangkan saat musim hujan dapat dibandingkan pula nilai agresivitas gua di hulu dan hilir pada saat kejadian banjir.

Selanjutnya, diagram alir metode penelitian disajikan pada Gambar 3.15. 


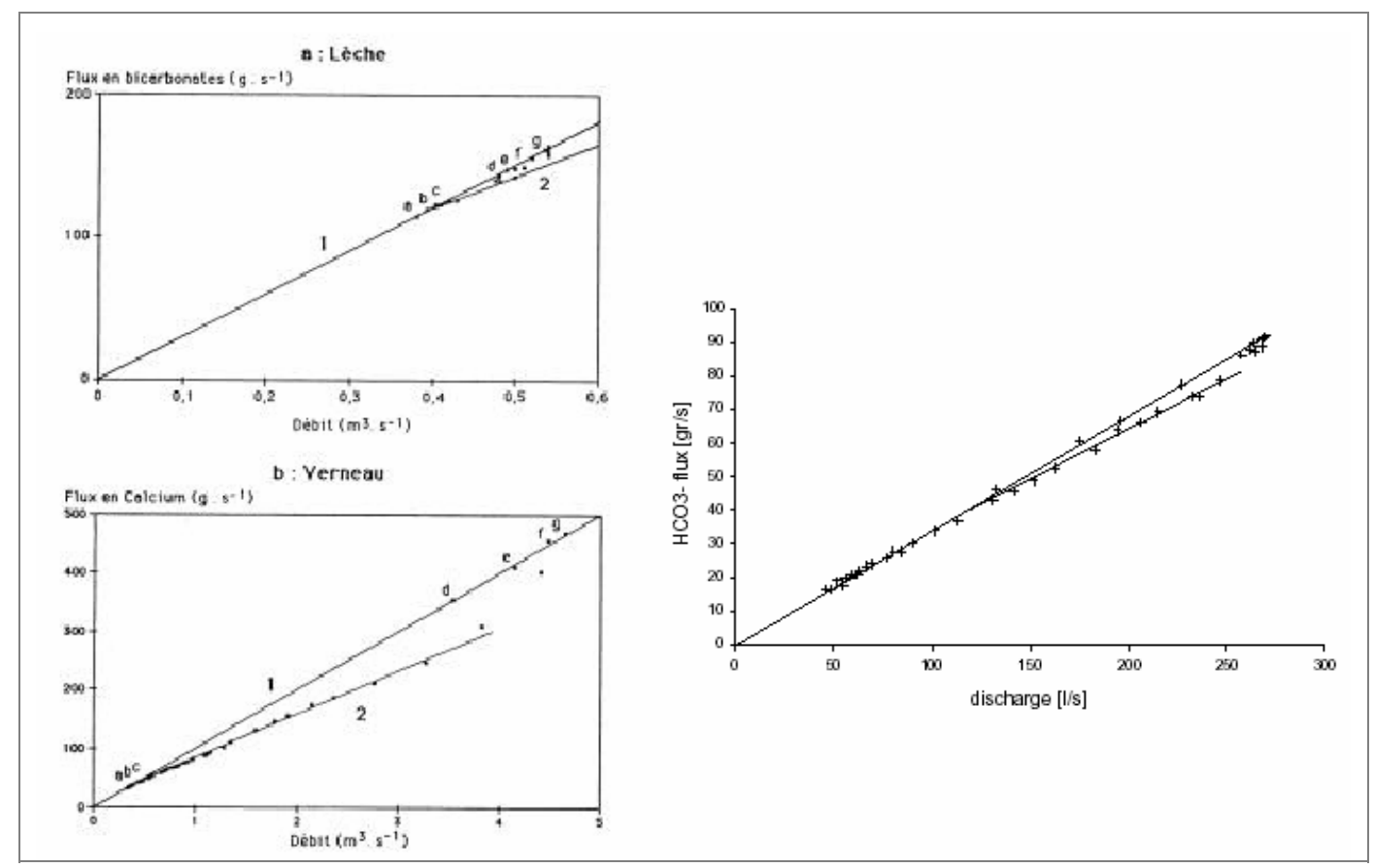

Gambar 3.13. Hubungan Antara Fluks Komposisi Kimia dan Debit (Mudry, 1990)

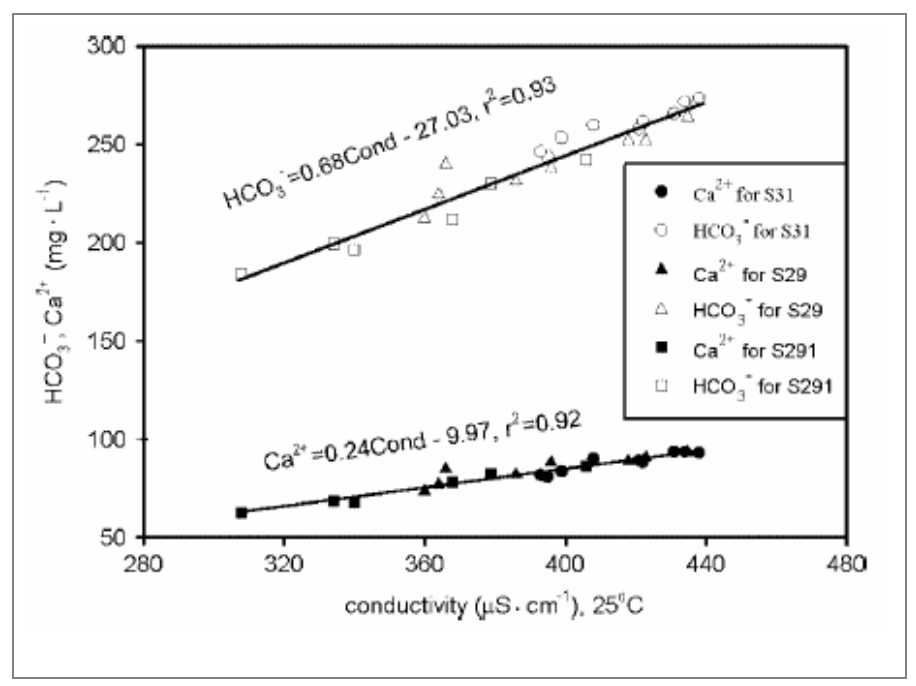

Gambar 3.14. Hubungan Linier antara Kalsium dan Bikarbonat (Liu, et al, 2004a) 


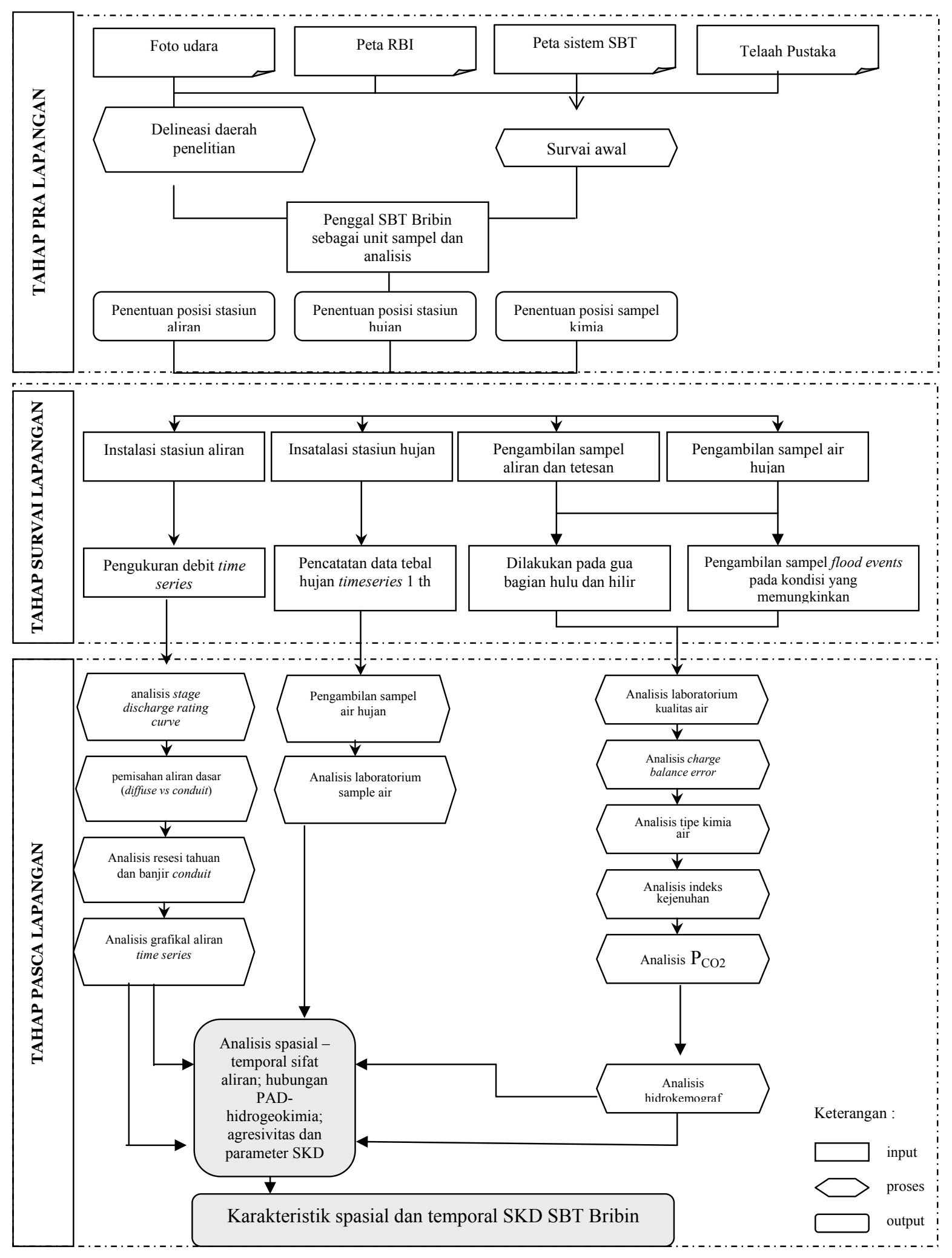

Gambar 3.15. Diagram Alir Metode Penelitian 


\section{BAB 4. \\ HASIL DAN PEMBAHASAN \\ A. Deskripsi Daerah Penelitian}

\section{Iklim}

Kondisi iklim terutama hujan dan suhu berpengaruh terhadap komponen masukan air secara kualitas yang berhubungan dengan kondisi hidrokimia airtanah pada daerah karst. Tidak begitu banyak penelitian terkait kondisi iklim di karst Gunung Sewu. Penelitian paling mutakhir tentang kondisi iklim di Gunungsewu di antaranya dilakukan oleh Verstappen (1997) dan Urushibara-Yoshino dan Yoshino (1997). Penelitian-penelitian sebelumnya terkait iklim pada periode Kuarter di sekitar wilayah penelitian (Pulau Jawa) dilakukan oleh Urushibara-Yoshino (1995), Verstappen (1975; 1994), Dam (1994), Morley (1982), dan Budel (1975). Selanjutnya, rangkuman tentang perubahan iklim selama periode Kuarter di Pulau Jawa dan sekitarnya ditunjukkan pada Gambar 4.1.

Deskripsi iklim lampau Pulau Jawa yang dilontarkan oleh Dam (1994) mengkonfirmasikan bahwa pada sekitar 126.000 sampai dengan 107.000 tahun BP (Before Present), iklim di Jawa mengalami periode hangat dengan temperatur sekitar $1-2^{\circ} \mathrm{C}$ lebih hangat dari kondisi iklim sekarang. Melalui analisis polen di sekitar Cekungan Bandung, Dam menjelaskan bahwa terjadi periode iklim yang lebih dingin dan kering pada sekitar 81.000 tahun BP sampai 17.000 tahun BP. Deskripsi ini juga didukung oleh Budel (1975) dan Verstappen (1975) yang menyatakan bahwa pada saat itu (periode glasial akhir), kondisi iklim di Indonesia lebih dingin sekitar $1-2^{\circ} \mathrm{C}$ dari saat ini. Urushibara-Yoshino dan Yoshino (1997) dan Verstappen (1997) merangkum perubahan iklim di Pulau Jawa dan sekitarnya sejak 190.000 tahun BP (Gambar 4.1.) yaitu sebagai berikut: 

a. $190.000-127.000$ BP : lebih hangat dan lembab dari kondisi saat ini;
b.120.000-60.000 BP $\quad$ : masih cenderung lebih hangat dari saat ini;
c. $60.000-12.000 \mathrm{BP} \quad$ : lebih dingin dan kering;
d. $12.000-10.000 \mathrm{BP} \quad$ : suhu menghangat;
e. $12.000-10.000 \mathrm{BP} \quad$ : kenaikan muka air laut;
f. $10.000-9.500 \mathrm{BP} \quad$ : hangat dan basah (sekitar $3,6^{\circ} \mathrm{C}$ lebih hangat);
g. $9.500-5.000 \mathrm{BP} \quad$ : sedikit lebih hangat dari sekarang;
h. $5.000-3.000 \mathrm{BP} \quad$ : jauh lebih lembab dari sekarang;
i. $3000-1.800 \mathrm{BP} \quad$ : sangat kering;
j. awal AD - saat ini $\quad$ : kondisi sekarang;

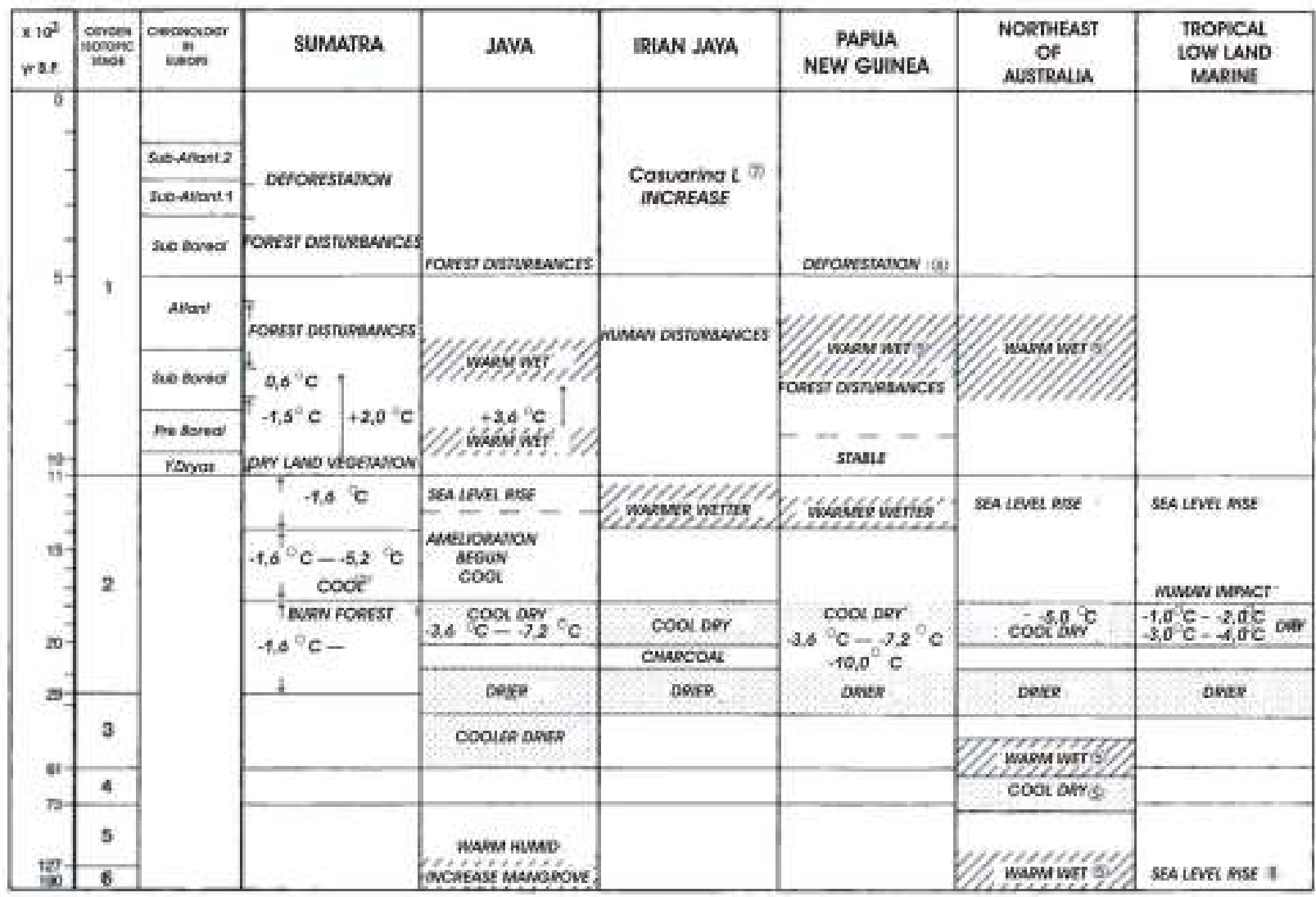

Gambar 4.1. Perubahan Iklim Jaman Kuarter Sejak 190.000 Tahun BP di Pulau Jawa dan Sekitarnya (Urushibara-Yoshino dan Yoshino,1997) 
Dari deskripsi perubahan iklim lampau ini terlihat bahwa tidak terdapat perbedaan suhu dan kelembapan secara mencolok (hanya pada kisaran 3-4 ${ }^{\circ} \mathrm{C}$ ) karena posisi daerah yang terletak dekat garis katulistiwa. Deskripsi iklim pada masa sekarang dapat diketahui dari publikasi-publikasi oleh oleh Adji dan Nurjani (1999), Suryanta (2001), MacDonalds dan Partners (1984), BMG (2000, dalam Sutikno dan Tanudirjo, 2006), serta Fakultas Kehutanan UGM (1993).Menurut BMG (2000) dalam Sutikno dan Tanudirjo (2006), suhu rata-rata bulanan di daerah karst Gunungsewu berkisar antara $22,12^{\circ} \mathrm{C}$ sampai dengan $26,97^{\circ} \mathrm{C}$. Besarnya curah hujan bulanan di daerah penelitian yang didasarkan pada data di 12 stasiun penakar hujan yaitu Semanu, Tepus, Rongkop, Panggang, Ngawen, Nglipar, Playen, Wonosari, Karangmojo, Patuk dan Semin yang tercatat selama sekitar 50 tahun, ditunjukkan pada Tabel 4.1.

Tabel 4.1. Curah Hujan Rata-Rata Bulanan di Daerah Penelitian Periode Tahun 1947-2000

\begin{tabular}{|l|r|}
\hline \multicolumn{1}{|c|}{ Bulan } & Curah Hujan (mm/bulan) \\
\hline Januari & 361 \\
\hline Pebruari & 364 \\
\hline Maret & 328 \\
\hline April & 182 \\
\hline Mei & 99 \\
\hline Juni & 83 \\
\hline Juli & 57 \\
\hline Agustus & 44 \\
\hline September & 38 \\
\hline Oktober & 123 \\
\hline November & 224 \\
\hline Desember & 14 \\
\hline
\end{tabular}

Sumber : BMG (2000, dalam Sutikno dan Tanudirjo, 2006) 
Pada penelitian ini, dipasang 3 stasiun penakar hujan yang diletakkan di hulu, tengah dan hilir DAS Bawah Tanah Bribin. Disamping 3 stasiun penakar hujan tersebut, dipasang juga stasiun iklim mini yang dapat mengamati kelembaban, suhu dan tekanan udara tiap setengah jam 1 kali. Ringkasan rata-rata parameter iklim bulanan pada stasiun tersebut disajikan pada Tabel 4.2 .

Tabel 4.2. Tekanan Udara, Suhu, dan Kelembapan (RH) di Daerah Penelitian

\begin{tabular}{|l|r|r|r|}
\hline \multicolumn{1}{|c|}{ Bulan } & $\begin{array}{c}\text { Tekanan Udara } \\
\text { (mbar) }\end{array}$ & \multicolumn{1}{c|}{$\begin{array}{c}\text { Suhu } \\
\mathbf{(} \mathbf{0} \mathbf{C})\end{array}$} & RH (\%) \\
\hline Mei 2006 & 954,8 & 26,3 & 87,2 \\
\hline Juni 2006 & 955,3 & 25,3 & 83,0 \\
\hline Juli 2006 & 956,2 & 24,8 & 79,0 \\
\hline Agustus 2006 & 956,1 & 25,6 & 71,7 \\
\hline September 2006 & 956,3 & 26,3 & 70,4 \\
\hline Oktober 2006 & 956,5 & 27,6 & 69,5 \\
\hline November 2006 & 954,4 & 27,8 & 75,2 \\
\hline Desember 2006 & 953,6 & 26,0 & 90,6 \\
\hline Januari 2007 & 954,8 & 26,1 & 90,3 \\
\hline Pebruari 2007 & 954,3 & 25,5 & 91,1 \\
\hline Maret 2007 & 953,1 & 25,0 & 90,1 \\
\hline April 2007 & 954,4 & 25,4 & 90,6 \\
\hline
\end{tabular}

Sumber : pengukuran lapangan (2006-2007)

Distribusi kelembapan bulanan dan suhu bulanan rerata disajikan pada Gambar 4.2. Selain itu, pembahasan tentang distribusi hujan di daerah penelitian akan dibahas pada subbab selanjutnya karena akan dikaitkan dengan kondisi aliran dan hidrogeokimia SBT Bribin secara aktual. 


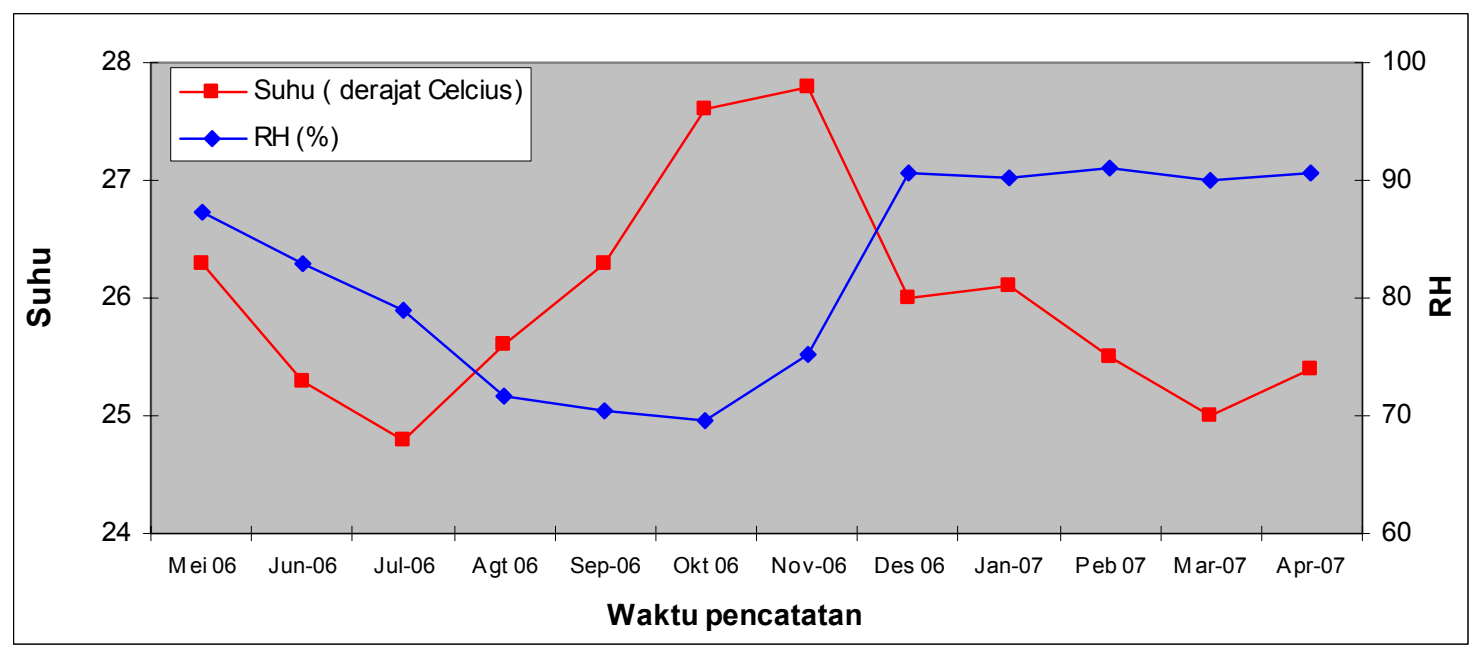

Gambar 4.2. Distribusi Temporal Rata-Rata Suhu dan Kelembapan di Stasiun Tambakromo

\section{Geologi}

Pengetahuan tentang kondisi geologi daerah karst terkait secara erat dengan kondisi hidrogeokimia sungai bawah tanah, terutama adalah jenis batuan dan struktur geologi. Secara regional, jika dilihat bahwa batugamping menempati daerah yang dibatasi oleh Sungai Oyo di bagian utara dan Samudera Hindia di sebelah selatan, maka oleh Samodra (2005), dan Suyoto (1994) dalam Kusumayudha (2005) stratigrafi batugamping di Kabupaten Gunung Kidul terfokus pada tiga formasi yaitu Formasi Oyo, Formasi Wonosari, dan Formasi Kepek, yang penjelasannya adalah sebagai berikut:

a. Formasi Oyo, tersusun oleh oleh batugamping pasiran yang strukturnya berlapis, kalkarenit, batupasir gampingan, dan batupasir napalan-tufaan. Formasi ini berumur sekitar Miosen Tengah. Hubungan antara Formasi Oyo dan Formasi Wonosari (batugamping terumbu) di bagian atasnya, maka sebagian Formasi Oya menjari dengan Formasi Wonosari; 
b. Formasi Wonosari, terusun dari batugamping berlapis, batugamping masif, dan batugamping terumbu. Ciri khusus pada formasi ini ini adalah dominasi porositas sekunder berupa rongga-ronga hasil pelarutan. Formasi ini kadangkadang menunjukkan hubungan selaras di atas Formasi Oyo, sedangkan di tempat lain hubungannya tidak selaras atau menjari;

c. Formasi Kepek, tersusun dari perselingan antara lempung, napal pasiran, dan batugamping berlapis. Formasi ini diendapkan pada lingkungan laut dangkal dan berumur Miosen akhir hingga Pliosen. Formasi Kepek dan Formasi Wonosari mempunyai hubungan selaras di satu tempat, dan menjari di banyak tempat. Oleh Suyoto (1994) dalam Kusumayudha (2005), Formasi Oyo, Kepek, dan Wonosari dianggap sebagai satu kelompok formasi yang diberi nama Kelompok Gunungsewu (Gambar 4.3.).

Ketiga formasi batuan tersebut di lapangan menunjukkan ciri-ciri bentangalam batugamping yang berbeda-beda pula. Dari pengamatan lapangan dan dari peta geologi oleh MacDonald dan Partners (1984), serta deskripsi oleh Bemmelen (1970), Rahardjo et al. (1977), Toha, dkk. (1994), Surono, dkk.(1992), Kusumayudha (2005), dan Samodra (2005), dapat disimpulkan bahwa seluruh daerah penelitian tercakup ke dalam Formasi Wonosari. 


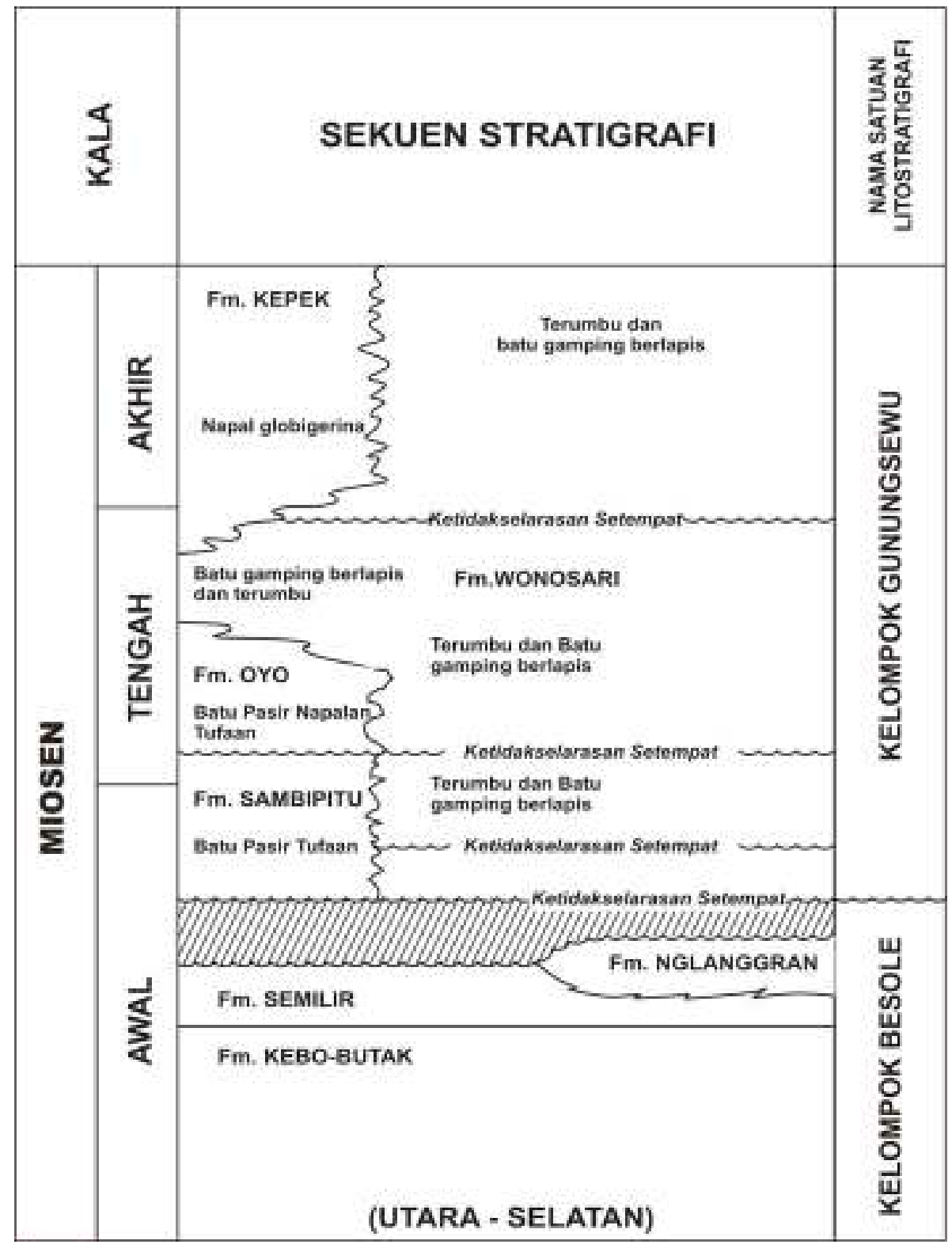

Gambar 4.3. Kolom Stratigrafi Pegunungan Selatan Jawa Tengah (Suyoto, 1994, dalam Kusumayudha, 2005)

Jika dilihat dari aspek strukturnya, maka menurut hasil interpretasi foto udara skala 1:50.000 maupun citra ERS skala 1:1.000.000 yang dilakukan oleh Kusumayudha (2005), jurus struktur retakan yang terdiri dari kekar, sesar, dan rekahan di daerah Gunungsewu mempunyai arah umum jurus struktur kekar atau sesar barat laut-tenggara dan timur laut-barat daya. Adanya struktur-struktur tersebut 
kemudian membagi kawasan ini menjadi blok-blok yang dibatasi oleh sesar-sesar yang turut mengatur sistem hidrogeologi karena terciptanya konfigurasi rendahan dan tinggian (Kusumayudha, 2005). Daerah penelitian berupa daerah tangkapan hujan SBT Bribin termasuk pada bagian Subsistem Hidrogeologi Wonosari-Baron yang mempunyai konfigurasi batuan dasar (batuan vulkanik) seperti graben yang mempunyai arah sekitar timur laut - barat daya (Gambar 4.4.).

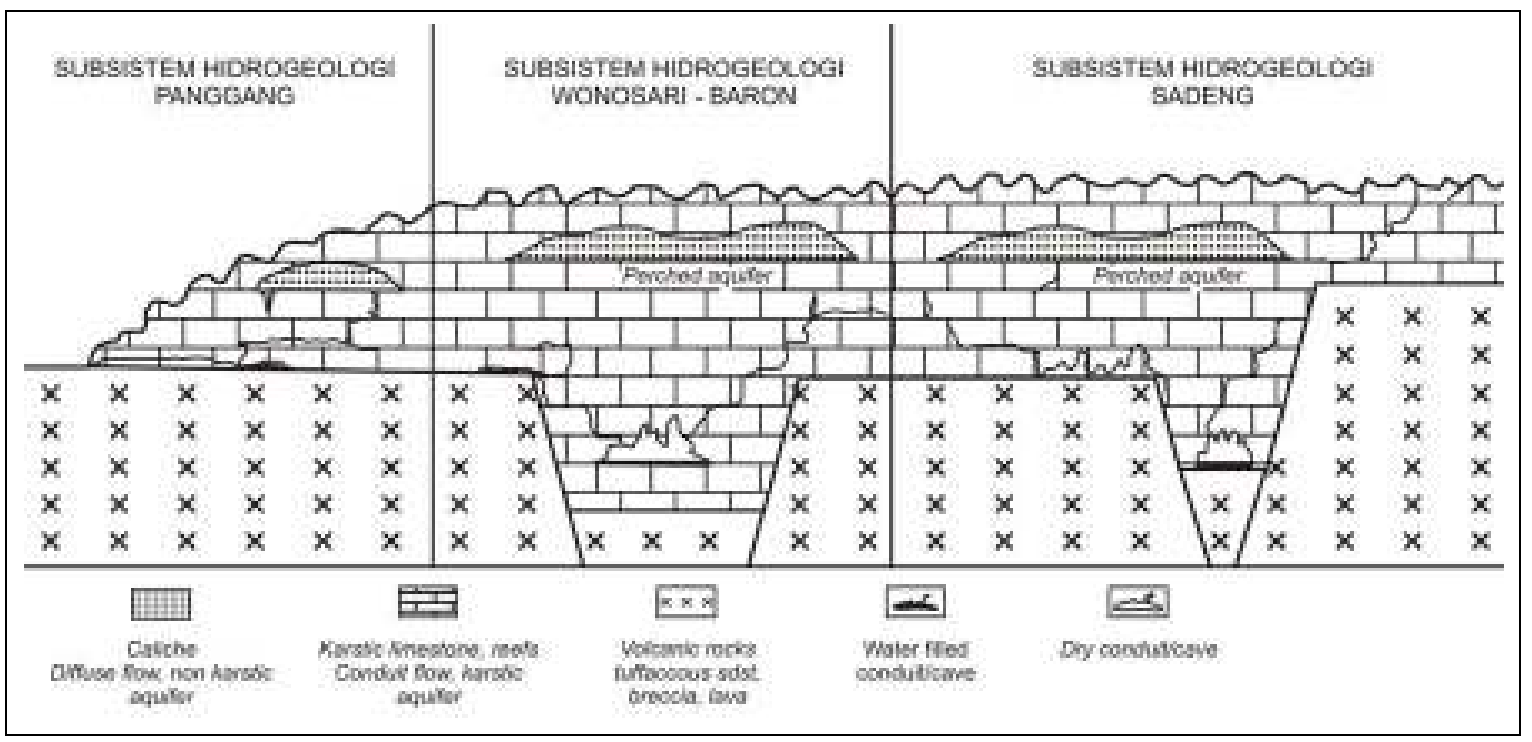

Gambar 4.4. Model Hidrogeologi Konseptual Barat-Timur daerah Gunungsewu (Kusumayudha, 2005)

\section{Geomorfologi}

Pengetahuan tentang perbedaan tipe geomorfologi karst di daerah penelitian penting untuk diungkapkan karena adanya hubungan dengan intensitas tingkat pelarutan batuan gamping (Haryono, 1999). Pendapat tentang tipe geomorfologi karst Gunung Sewu pertama kali digaungkan oleh Lehmann (1936) yang mendeskripsikan bahwa karst Gunung Sewu bertipe connical atau kegel, dicirikan oleh bukit-bukit sinusioidal yang diselingi di antaranya oleh cekungan-cekungan dan saling berhubungan, dan jika dilihat dari atas akan kelihatan seperti bentukan berupa bintang. Beberapa geomorfolog lain yang menguatkan pendapat Lehmann adalah 
Flathe dan Pfeiffer (1965); Balazs (1968;1971); Verstappen (1969), dan Waltham et al. (1983). Bahkan, Balazs (1968) mengkonfirmasikan bahwa jumlah bukit di kawasan ini berjumlah lebih dari 40.000 buah dengan kepadatan sekitar 30 bukit $/ \mathrm{km}^{2}$. Kegel karst menurut Sweeting (1972) sebenarnya merupakan bagian dari tipe karst tropis. Kegel karst sering pula disebut sebagai cone karst atau cockpit karst. Kegel karst ini dicirikan oleh kumpulan bukit-bukit berbentuk kerucut yang sambung menyambung. Sela antar bukit kerucut membentuk cekungan dengan bentuk seperti bintang yang dikenal dengan cockpit. Cockpit seringkali membentuk pola kelurusan sebagai akibat kontrol kekar atau sesar. Depresi atau cockpit yang terkontrol kekar atau sesar ini oleh Lehmann (1936) disebut gerichteter karst (karst oriente). Gambar 4.5. menyajikan contoh karst tipe Kegel.

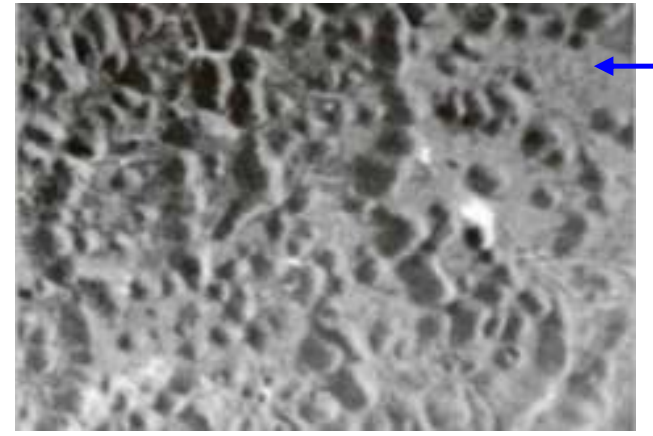

(a)

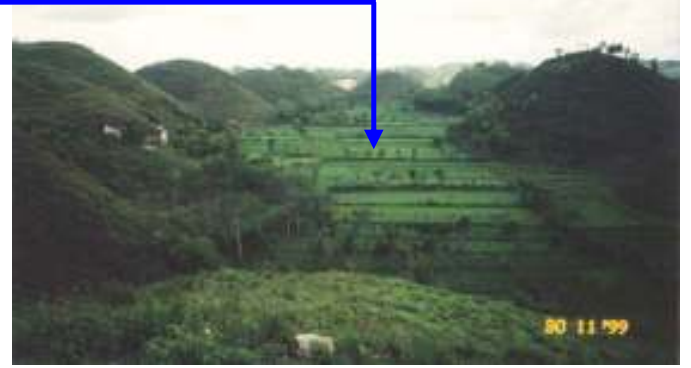

(b)

Gambar 4.5. Kenampakan Kegel Karst Gunungsewu dari Foto Udara (a) dan Lapangan (bfoto oleh Haryono, 1999)

Tidak banyak penelitian terkini yang berkaitan dengan geomorfologi karst

Gunung Sewu. Penelitian seperti Urushibara-Yoshino dan Yoshino (1997) lebih menekankan pada adanya pengaruh kondisi paleoklimat terhadap perkembangan karst Gunung Sewu. Selanjutnya, penelitian geomorfologi semi-detail salah satunya adalah oleh Ahmad, dkk (2005) yang mendeskripsikan secara mayor geomorfologi karst antara telaga Sanglen dan Telaga Kamal yaitu daerah antara Cekungan 
Wonosari yang tersusun oleh batugamping berlapis ke arah selatan pada Pegunugan Seribu yang tersusun oleh batugamping masif.

Penelitian geomorfologi detail kawasan karst ini secara lebih komprehensif dipublikasikan oleh Haryono dan Day (2004). Menurut mereka, pengklasifikasian karst Gunung Sewu semata sebagai kegel karst adalah terlalu disederhanakan. Selanjutnya disebutkan bahwa terdapat distribusi tipe karst yang lebih komprehensif di kawasan ini yaitu (1) morfologi karst labirin; (2) morfologi karst poligonal, dan (3) morfologi karst tower. Dari hasil pengamatan lapangan, geomorfologi bagian utara sampai tengah didominasi oleh morfologi karst tower, sementara bagian selatan lebih didominasi oleh tipe morfologi karst poligonal.

Tipe morfologi karst poligonal dominan pada bagian selatan daerah penelitian (sekitar Kecamatan Semanu). Menurut White (1988) karst poligonal dicirikan oleh dolin atau cekungan-cekungan yang berhubungan antara satu dengan yang lain. Dengan demikian semua cekungan sudah dapat dikatakan membentuk dolin yang saling bersambungan. Jika dilihat rasionya, maka rasio antara luas area dolin dengan luas daerah karst mendekati satu. Sebenarnya, morfologi tipe karst inilah yang paling cocok mewakili kegel karst, karena bukit antar dolin di wilayah ini relatif membulat yang oleh Flathe dan Pfeiffer (1965) disebut sinusoidal. Hasil pengukuran morfometri cockpit oleh Haryono dan Day (2004) mendeskripsikan bahwa lebar dasar cockpit dapat mencapai 120 meter, sementara dolin tunggal mempunyai lebar sekitar 70 meter.

Morfologi karst tower mengandung dua pengertian, yaitu (i) bahwa tower karst haruslah mempunyai dinding yang vertikal dan terjal (White, 1988; Trudgill, 1985); (ii) pendapat kedua lebih condong kepada proses karstifikasi bahwa yang dapat disebut sebagai karst tower adalah tidak harus berdinding terjal dan tinggi, 
tetapi munculnya keberadaan bukit-bukit sisa di tengah-tengah lembah-lembah dengan luasan lembah yang lebih luas daripada luasan wilayah bukit karst (Ford dan Williams,1992). Jika mengacu pada uraian kedua ini, maka sebagian wilayah karst di sekitar Bedoyo, Kecamatan Ponjong yang merupakan bagian terbesar dari daerah penelitian dapat diklasifikasikan sebagai Karst tipe tower. Pada wilayah tersebut, cekungan tertutup sangat minim dijumpai, dan dolin sudah berhubungan satu sama lain tanpa pembatas topografi (Haryono, dkk, 2001). Selanjutnya, oleh Haryono dan Day (2004), karst ini disebut sebagai residual cone karst yang dari foto udara terlihat sebagai dataran planasi dengan kubah-kubah karst di tengahnya. Morfologi karst tower ini merupakan kelanjutan dari perkembangan karst poligonal. Gambaran dari karst tipe polygonal dan tower disajikan pada Gambar 4.6.

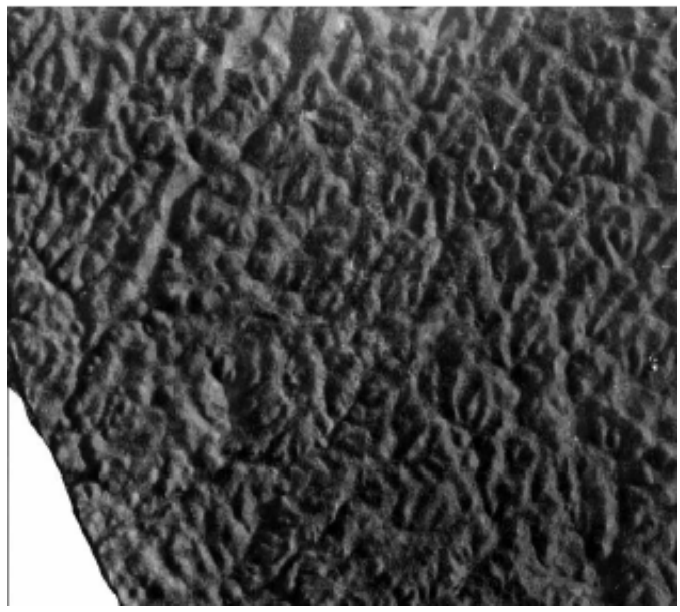

(a)

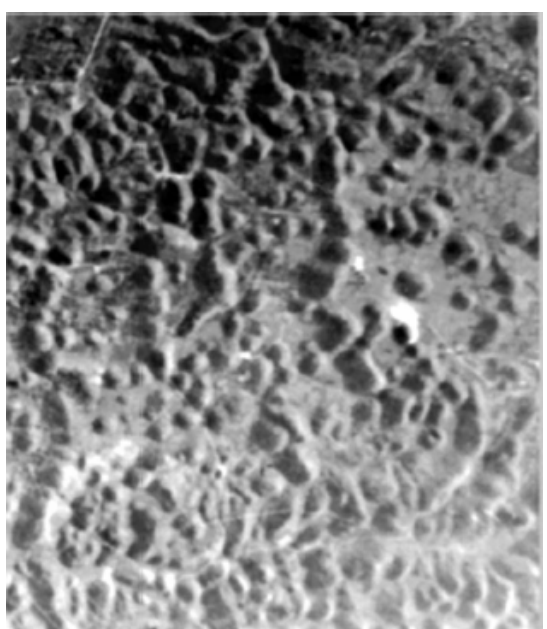

(b)

Gambar 4.6. Morfologi Karst Poligonal (a) dan Karst Tower (b), dilihat dari Foto Udara (Haryono dan Day, 2004)

\section{Tanah dan Penggunaan Lahan}

Deskripsi jenis tanah di daerah penelitian dapat dipergunakan untuk mengetahui perbedaan jenis tanah yang berkembang pada topografi bukit karst. Selain itu, sifat tanah akan berpengaruh pula terhadap interaksi air dan tanah pada 
zone epikarst dan banyak sedikitnya sedimen pada SBT yang berpengaruh terhadap kekeruhan air. Tanah di daerah penelitian digolongkan terutama sebagai Entisols, Inceptisols, Alfisols (Wiyono et al, 2006) dan Vertisols (Agusman et al, 2006). Mulyanto (2006) melaporkan bahwa di kawasan karst Gunung Sewu tanah-tanah merah dengan warna yang lebih merah dari HUE 5 YR cukup dominan. Sebaran luas tanah ini dijumpai terutama di atas Formasi Wonosari yang tersusun atas batuan terumbu massif packstone. Entisols dijumpai di bagian puncak dan lereng (dome) perbukitan karst. Solum tanah pada bagian puncak dan lereng dangkal $(0-20 \mathrm{~cm})$ dan makin kearah lembah (doline) makin tebal. Alfisols terutama yang dijumpai pada lembah (dolin) dapat mempunyai ketebalan (solum) lebih dari $2 \mathrm{~m}$ (Wiyono et al, 2006). Pada puncak dan lereng perbukitan, profil tanah biasanya terdiri dari satu lapisan umumnya berwarna coklat sampai coklat gelap, tekstur debuan sampai pasiran, struktur remah sampai gumpal membulat halus, konsistensi gembur, perakaran halus banyak, fragmen batuan banyak menumpang langsung di atas batuan gamping terumbu. Alfisols dan Inceptisols dijumpai terutama pada dolin dimana solum tanah cukup tebal, terdiri atas beberapa lapisan berwarna kekuningan sampai kemerahan. Vertisols dijumpai terbatas berkembang di atas batuan gamping bioklastis pada bentang lahan cekungan atau datar, atau di atas batuan napalan (Mulyanto, 2006).

Pola pemanfaatan lahan yang relatif kurang produktif dijumpai pada daerah penelitian. Berdasarkan hasil penelitian oleh Bappeda Gunung Kidul (2007), penggunaan lahan di daerah penelitian didominasi oleh tegalan yaitu mencapai hampir 80\%, kemudian penggunaan lahan persawahan sekitar 6\% dan sisanya sekitar $15 \%$ adalah permukiman, pekarangan, hutan, dan lahan kosong. 


\section{B.Variasi Spasial dan Temporal Karakteristik Aliran dan PAD SBT Bribin}

SBT Bribin dideskripsikan oleh MacDonalds dan Partners (1984) dimulai dari sebuah sungai permukaan yaitu Sungai Pentung yang masuk ke dalam tanah pada beberapa sinkhole di kawasan Sawahombo. Sungai ini kemudian muncul sebagai cenote/karst window di Luweng Jomblangan, yang selanjutnya dijumpai lagi di Gua Gilap, Luweng Jomblang Banyu, Luweng Jurangjero, dan terakhir muncul di Gua Bribin. Pada penggal antara Luweng Jurang Jero dan Gua Bribin, disebutkan bahwa sungai ini mempunyai percabangan atau bocoran keluar yang dapat dijumpai di Gua Ngreneng. Atas dasar kesulitan di lapangan, maka sampling pengukuran debit dan instalasi alat pencatat Tinggi Muka Air tidak dapat dilakukan pada semua tempat yang disebutkan diatas seperti yang sudah disajikan pada Tabel 3.1.

\section{Variasi temporal aliran inlet Sungai Pentung-Luweng Jomblangan}

Sungai Pentung mempunyai DAS yang meluas dari Panggung Masif di sebelah utara daerah penelitian sampai dengan daerah perbatasan antara topografi vulkanik dan karst di daerah Tambakromo. Pada DAS ini, mayoritas batuannya berupa batuan vulkanik (breksi andesit), dengan simpanan airtanah pada akuifer terbatas dengan koefisien aliran besar, sehingga bersifat intermitten atau bahkan ephemeral, yaitu sungai yang mengalirkan air hanya pada waktu musim hujan, sedangkan pada musim kemarau alirannya sangat kecil atau bahkan tidak ada alirannya, dikarenakan minimnya suplai aliran dasar dari akuifer. Pengukuran debit sesaat Sungai Pentung selama periode satu tahun (Maret 2006 sampai dengan Mei 2007) dilakukan sebanyak 13 kali pengukuran, seperti yang disajikan pada Tabel 4.3. dan diilustrasikan pada Gambar 4.7. 
Tabel 4.3. Kondisi Debit Aliran Sesaat Sungai Pentung

\begin{tabular}{|r|l|r|r|r|}
\hline No & \multicolumn{1}{|c|}{ Tanggal } & Jam & Debit (It/dt) & Hujan harian (mm) \\
\hline 1 & 21-Maret-06 & $10: 00$ & 887,44 & 63 \\
\hline 2 & 28-April-06 & 14.00 & 168,78 & 0 \\
\hline 3 & 22-Mei-06 & 15.05 & 87,36 & 18,5 \\
\hline 4 & 21-Juni-06 & 10.00 & 62,22 & 0 \\
\hline 5 & 20-Juli-06 & 10.30 & 23,25 & 0 \\
\hline 6 & 23-Agustus-06 & 10.00 & 4,06 & 0 \\
\hline 7 & 21-September-06 & 10.00 & 2,25 & 0 \\
\hline 8 & 16-November-06 & 10.00 & $0(\mathrm{kering})$ & 0 \\
\hline 9 & 21-Desember-06 & 10.30 & 3,32 & 57,5 \\
\hline 10 & 1-Februari-07 & 14.30 & 5,50 & 5 \\
\hline 11 & 6-Maret-07 & 15.00 & 6,55 & 16 \\
\hline 12 & 22-April-07 & 10.00 & 147,00 & 66 \\
\hline 13 & 20-Mei-07 & 10.30 & 513,70 & 45 \\
\hline
\end{tabular}

Sumber : pengukuran lapangan dan analisis (tahun 2006-2007)

Dari Tabel 4.3 terlihat bahwa meskipun data pengukuran ini tidak dapat sepenuhnya mewakili data perilaku timeseries debit Sungai Pentung, tetapi dapat terlihat bahwa sungai ini mengalami kekeringan atau mempunyai debit sesaat yang kecil pada waktu periode bulan-bulan tidak turun hujan. Debit minimum dijumpai pada bulan-bulan Agustus 2006 sampai dengan. Maret 2007, sedangkan debit-debit maksimum dijumpai pada bulan Maret-April 2006. Distribusi debit aliran yang disajikan pada Tabel 4.3. tidak dapat mewakili perilaku debit secara timeseries, karena secara umum Sungai Pentung ini mempunyai debit puncak sesaat setelah terjadi hujan, yang kemudian mengalami penurunan debit yang cepat karena sifat batuan di daerah ini. Sifat batuan di daerah ini yang berupa batuan vulkanik tua memungkinkan terjadinya limpasan permukaan yang tinggi, dan penyimpanan air di dalam akuifer yang rendah. 


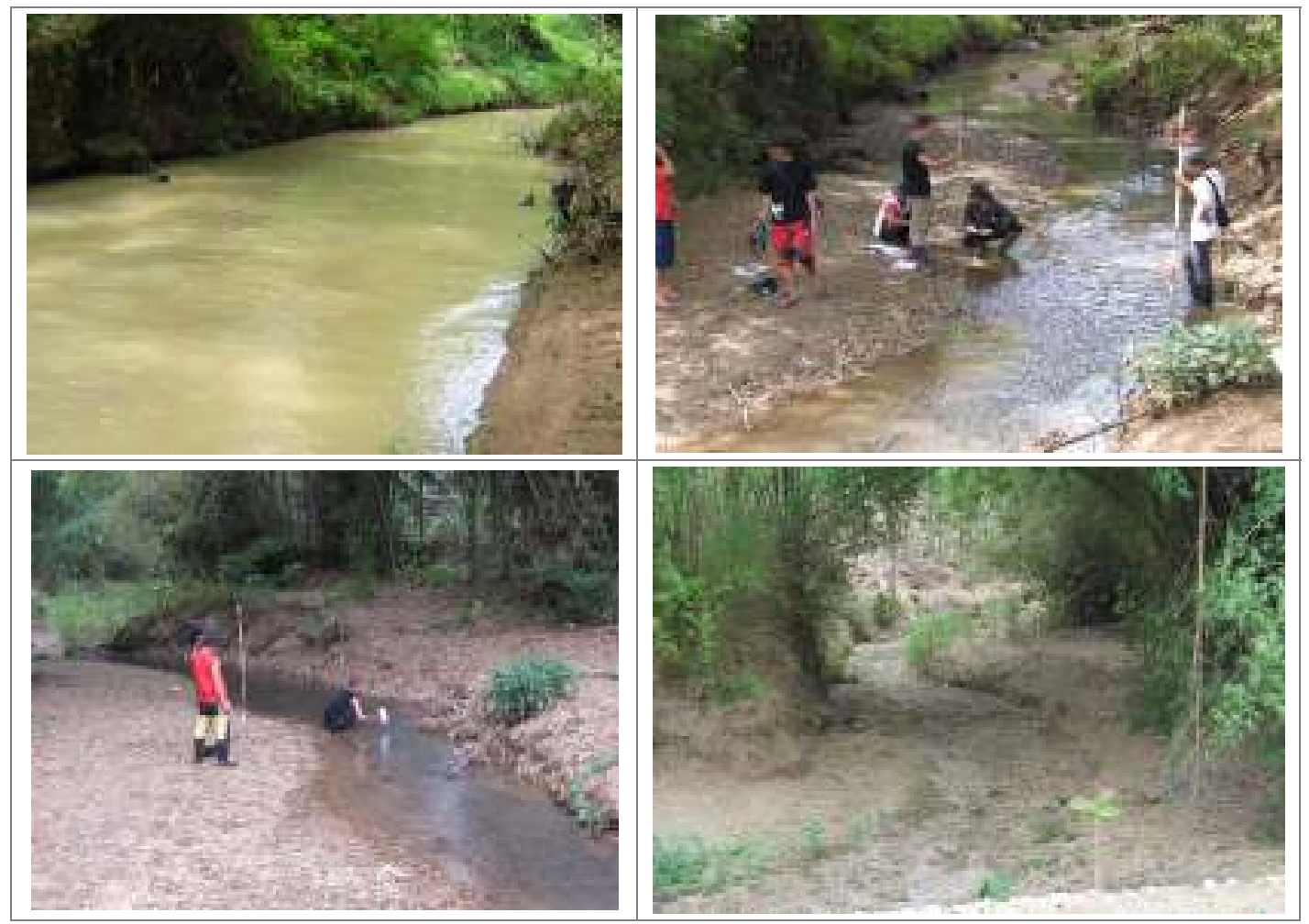

Gambar 4.7. Kondisi aliran Sungai Pentung (1) kiri atas-21 Maret 2006;(2) kanan atas-28 April 2006;(3)kiri bawah-22 Mei 2006;(4)kanan bawah-16 November 2006

Kondisi aliran permukaan Sungai Pentung yang merupakan inlet SBT Bribin ini berpengaruh terhadap kondisi aliran SBT Bribin. Sebagai contoh, debit pada inlet Sungai Pentung pada 21 Maret 2006 yang airnya keruh dengan kisaran sekitar 900 liter/detik ternyata berpengaruh pula terhadap pemunculan pertama Sungai Bribin di Luweng Jomblangan yang airnya juga keruh, dan secara visual debitnya dapat dibedakan jika dibandingkan dengan kondisi pada 28 April 2006, saat debit Sungai Pentung berkisar pada 170 lt/detik. Sebagai ilustrasi, kondisi aliran di Luweng Jomblangan pada kedua waktu pengukuran disajikan pada Gambar 4.8. 


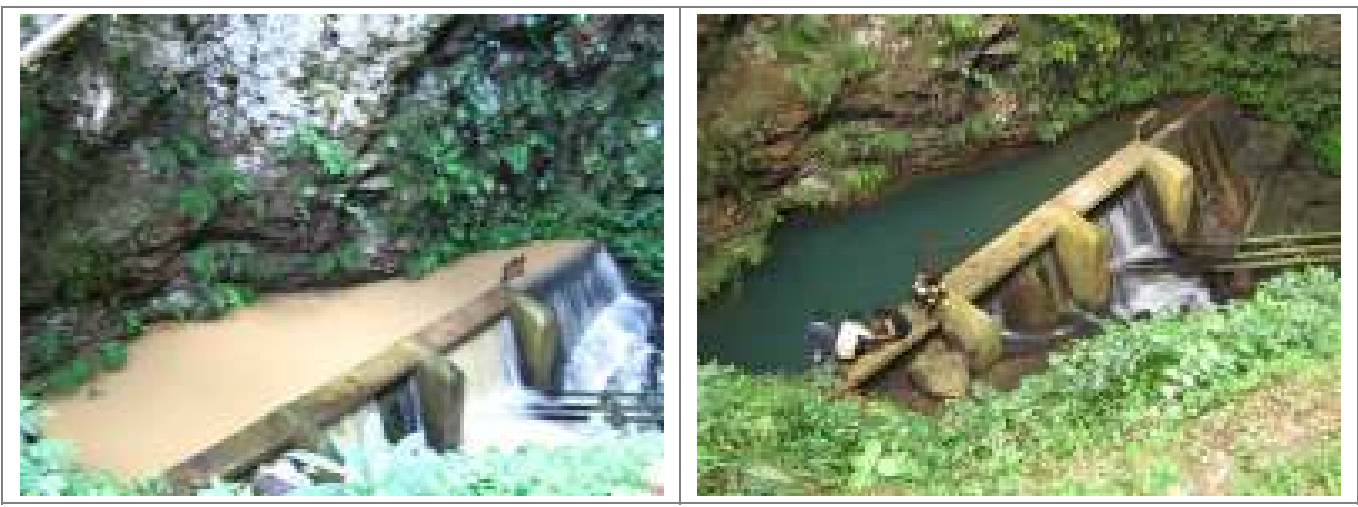

Gambar 4.8. Kondisi aliran Luweng Jomblangan 21 Maret 2006 (musim hujan-kiri) dan 28 April 2006 (awal kemarau-kanan)

\section{Variasi temporal aliran di Gua Gilap}

\section{a. Hubungan tinggi muka air dan debit Gua Gilap}

Gua Gilap merupakan pemunculan kedua dari Sungai Bribin setelah Luweng Jomblangan. Gua ini sering disebut sebagai "song" (Jawa-pen), karena bentuk guanya yang horisontal dan berada pada suatu collapse doline yang berukuran besar dengan diamater sekitar 200 meter. Beda tinggi antara puncak lembah dan muka air sungai di Gua Gilap mencapai sekitar 100 meter. Gua Gilap selalu berair sepanjang tahun (perenial) dan mempunyai morfometri alur sungai yang memungkinkan untuk dipasang alat pencatat tinggi muka air (water level data logger), sehingga kondisi aliran sepanjang tahun dapat tercatat (Gambar 4.9).

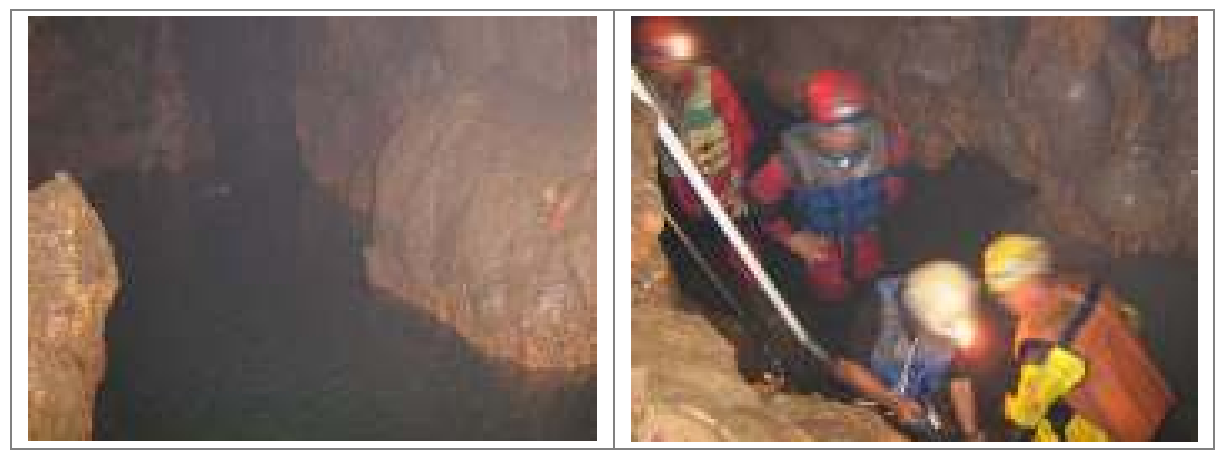

Gambar 4.9. Kondisi Aliran Gua Gilap (kiri) dan Instalasi Alat Pengukur Tinggi Muka Air 
Untuk memperoleh variasi debit tahunan, diperlukan kurva hubungan tinggi muka air dan debit (stage discharge rating curve), yang dicari dengan melakukan pengukuran debit aliran pada saat debit kecil, rata-rata, dan besar, dari April 2006 sampai dengan Maret 2007, dan disajikan pada Tabel 4.4. Dari data hasil pengukuran tersebut dibuat kurva regresi (Gambar 4.10). Hubungan antara tinggi muka air dan debit aliran di Gua Gilap dinyatakan sebagai:

$$
y=7,9129 e^{2,7173 x}
$$

\section{Keterangan:}

y adalah debit aliran (liter/detik) dan x adalah tinggi muka air (m)

Tabel 4.4. Hasil Pengukuran Debit Aliran Gua Gilap

\begin{tabular}{|r|r|r|r|}
\hline No & \multicolumn{1}{|c|}{ Tanggal } & TMA (m) & Debit aliran (liter/detik) \\
\hline 1 & $28 / 4 / 06$ & 1,32 & 294,10 \\
\hline 2 & $23 / 5 / 06$ & 0,72 & 44,52 \\
\hline 3 & $21 / 6 / 06$ & 0,57 & 35,24 \\
\hline 4 & $19 / 7 / 06$ & 0,34 & 25,23 \\
\hline 5 & $24 / 8 / 06$ & 0,16 & 17,26 \\
\hline 6 & $21 / 9 / 06$ & 0,09 & 8,91 \\
\hline 7 & $16 / 11 / 06$ & 0,08 & 6,93 \\
\hline 8 & $21 / 12 / 06$ & 0,15 & 12,99 \\
\hline 9 & $22 / 3 / 07$ & 0,99 & 122,51 \\
\hline
\end{tabular}

Sumber : Pengukuran lapangan 2006-2007

Hasil kurva hubungan tinggi muka air di Gua Gilap dengan debit alirannya tidak mempunyai hubungan linier karena sifat aliran sungai bawah tanah yang cenderung turbulen dan bukan laminer seperti halnya yang dijumpai pada sungai permukaan. Selanjutnya, rumus (6) digunakan untuk menghitung debit aliran sepanjang tahun pada alat pencatat tinggi muka air yang dipasang di Gua Gilap. Tinggi muka air yang tercatat di Gua Gilap mempunyai interval pencatatan tiap 30 
menit. Hasil penggambaran variasi debit aliran Gua Gilap selama satu tahun (Mei 2006 sampai dengan April 2007) disajikan pada Gambar 4.11

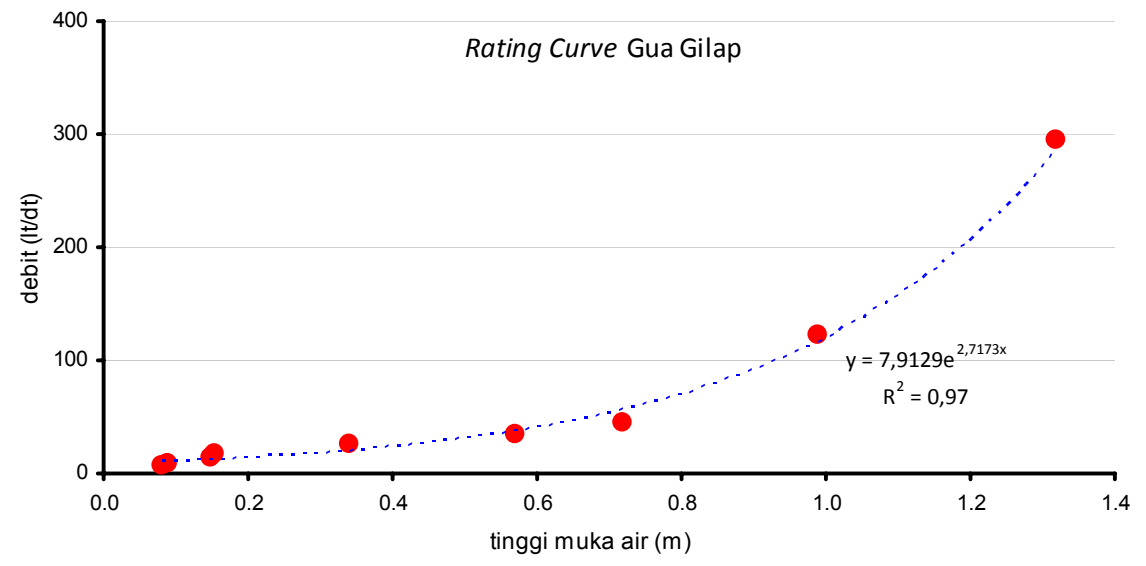

Gambar 4.10. Hubungan Tinggi Muka Air Dan Debit di Gua Gilap

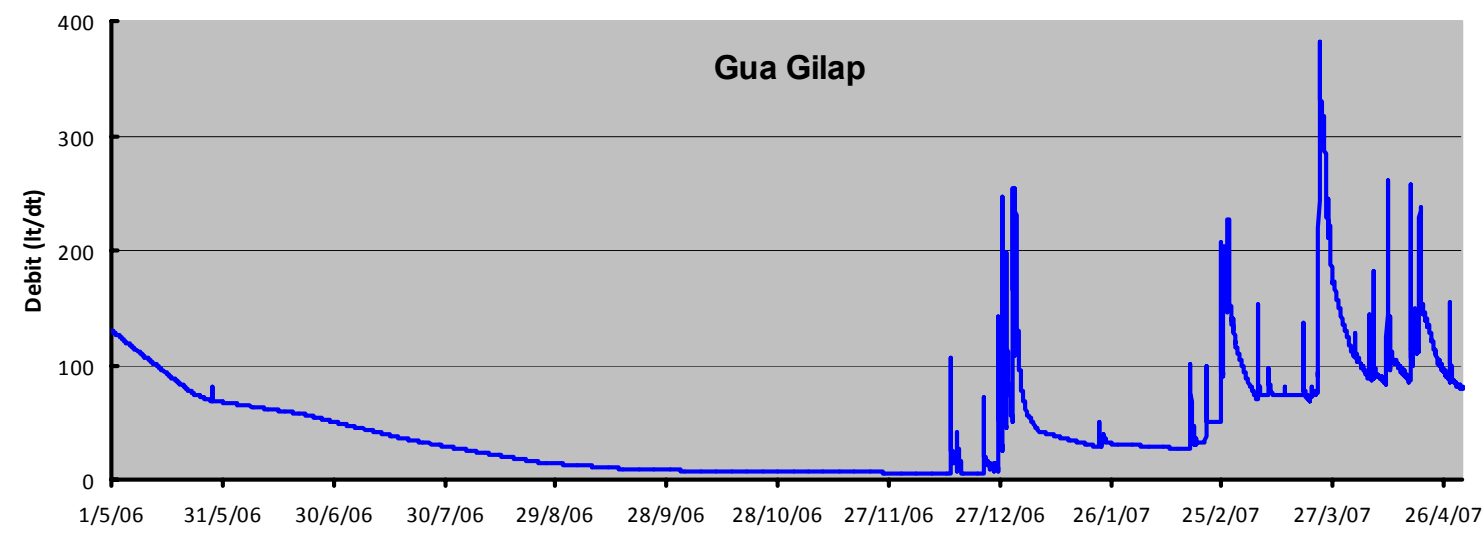

Gambar 4.11. Variasi Debit Aliran Gua Gilap Periode 1 Mei 2006-30 April 2007

Pada penelitian ini, kondisi debit aliran Gua Gilap diasumsikan mewakili SBT Bribin bagian atas, karena posisinya ada di sebelah hulu daerah tangkapan hujan SBT Bribin. Menurut MacDonald and Partners (1984), sepanjang tahun Gua Gilap selalu dialiri air dan memiliki debit minimum sebesar sekitar 6 liter/detik yang terjadi pada puncak musim kemarau. Hasil pencatatan dari 1 Mei 2006 sampai dengan 30 April 2007 menunjukkan bahwa debit minimum dijumpai pada tanggal 7-8 
Desember 2006, sebesar 3 liter/detik. Periode tanpa kejadian hujan yang diindikasikan dengan tidak terdapatnya kenaikan debit aliran terjadi dari tanggal 30 Mei sampai dengan 8 Desember 2006. Pada rentang waktu tersebut, secara teori tidak ada kejadian hujan sehingga komponen pengisi aliran sungai bawah tanah didominasi oleh aliran diffuse, terutama pada periode bulan Agustus-Desember 2006.

Periode banjir (flood pulse period) dimulai sejak tanggal 13 Desember 2006 sampai akhir masa pencatatan (30 April 2007). Pada kurun waktu tersebut tercatat 41 kali kejadian banjir yang merupakan efek dari terjadinya hujan pada daerah tangkapan Gua Gilap. Beberapa banjir yang cukup besar dua diantaranya adalah yang terjadi pada tanggal 31 Desember 2006, dengan debit puncak sebesar 252 liter/detik pada pukul 07.00 WIB, dan banjir pada tanggal 23 Maret 2007, pukul 08.30 dengan debit puncak mencapai 380 liter/detik.

\section{b. Konstanta Resesi Hidrograf Banjir Gua Gilap}

Konstanta resesi (recession constant atau depletion factor) dapat digunakan untuk mengetahui karakteristik akuifer karst dalam melepaskan komponenkomponen aliran sungai bawah tanah. Model yang dipakai adalah model tangki (tank model) yang dikenalkan oleh Schulz (1976). Aplikasi model resesi ini dapat digunakan untuk menghitung nilai konstanta resesi saluran/conduit $\left(\mathrm{K}_{\mathrm{c}}\right)$, konstanta resesi aliran antara/fissure $\left(\mathrm{K}_{\mathrm{i}}\right)$, dan konstanta aliran dasar/baseflow $\left(\mathrm{K}_{\mathrm{b}}\right)$.

Pada gua-gua yang dilewati sungai bawah tanah sistem Bribin termasuk salah satunya adalah Gua Gilap, terjadi puluhan kali banjir pada periode satu musim hujan, sedangkan analisis tidak dilakukan pada semua kejadian banjir. Pemilihan banjir yang dianalisis didasarkan pada keterwakilan nilai waktu dari puncak banjir sampai aliran normal ( $\mathrm{T}_{\mathrm{b}}=$ time to baseflow) sehingga banjir-banjir yang kecil atau sangat 
pendek dapat diabaikan karena secara matematis tidak valid jika dipaksakan diukur konstanta resesinya (Schulz,1976). Konstanta resesi banjir terpilih pada berbagai komponen aliran dicari dengan persamaan:

$$
Q(t)=Q\left(t_{0}\right) e^{-k\left(t-t_{0}\right)}
$$

$\mathrm{k}$ adalah konstanta resesi pada suatu sistem akuifer, $\mathrm{t}$ adalah waktu pada debit ke $\mathrm{t}$, dan $t_{0}$ adalah waktu pada debit awal resesi. Kemudian jika pada skala semi-log rumus ini dianggap linier, maka:

$$
\begin{gathered}
\ln Q(t)=-k\left(t-t_{o}\right)+\ln Q\left(t_{o}\right) \ldots \ldots \ldots \ldots \ldots \ldots \ldots \ldots(8), \text { atau } \\
k=-1 / t-t_{o} \ln \left(Q_{t} / Q_{o}\right) \quad \ldots \ldots \ldots \ldots \ldots \ldots \ldots \ldots \ldots(9)
\end{gathered}
$$

Dari 41 kejadian banjir kemudian terpilih 16 kejadian banjir yang debitnya mencukupi dan waktu resesinya cukup panjang sesuai yang disyaratkan oleh Schulz (1976). Selanjutnya, grafik tiap kejadian banjir terpilih yang sudah dipisahkan komponen aliran dasarnya (baseflow) pada skala logaritma disajikan pada Gambar 4.12.a. dan 4.12.b.

Dari Gambar 4.12. a. dan 4.12.b. tampak bahwa masing-masing kejadian banjir memiliki karakteristik kurva resesi yang berbeda-beda, terlihat dari bentuk kurva resesi yang dikenali dari debit puncak menuju ke aliran dasar. Perbedaan tersebut terlihat dalam paramater waktu resesi dari debit puncak menuju aliran dasar (time to baseflow $=\mathrm{T}_{\mathrm{b}}$ ), dan waktu dari aliran dasar menuju debit puncak (time to peak $=\mathrm{T}_{\mathrm{p}}$ ). Selain itu, kemiringan kurva resesi juga terlihat berbeda-beda pada tiap kejadian banjir yang diakibatkan faktor perbedaan karakteristik hujan pada daerah tangkapan yang tidak selalu seragam secara spasial dari waktu ke waktu (Schulz,1976). Akibatnya, hal ini berpengaruh pada hasil perhitungan nilai konstanta resesi banjir $\mathrm{K}_{\mathrm{c}}, \mathrm{K}_{\mathrm{i}}$, maupun $\mathrm{K}_{\mathrm{b}}$ (Tabel 4.5.). 

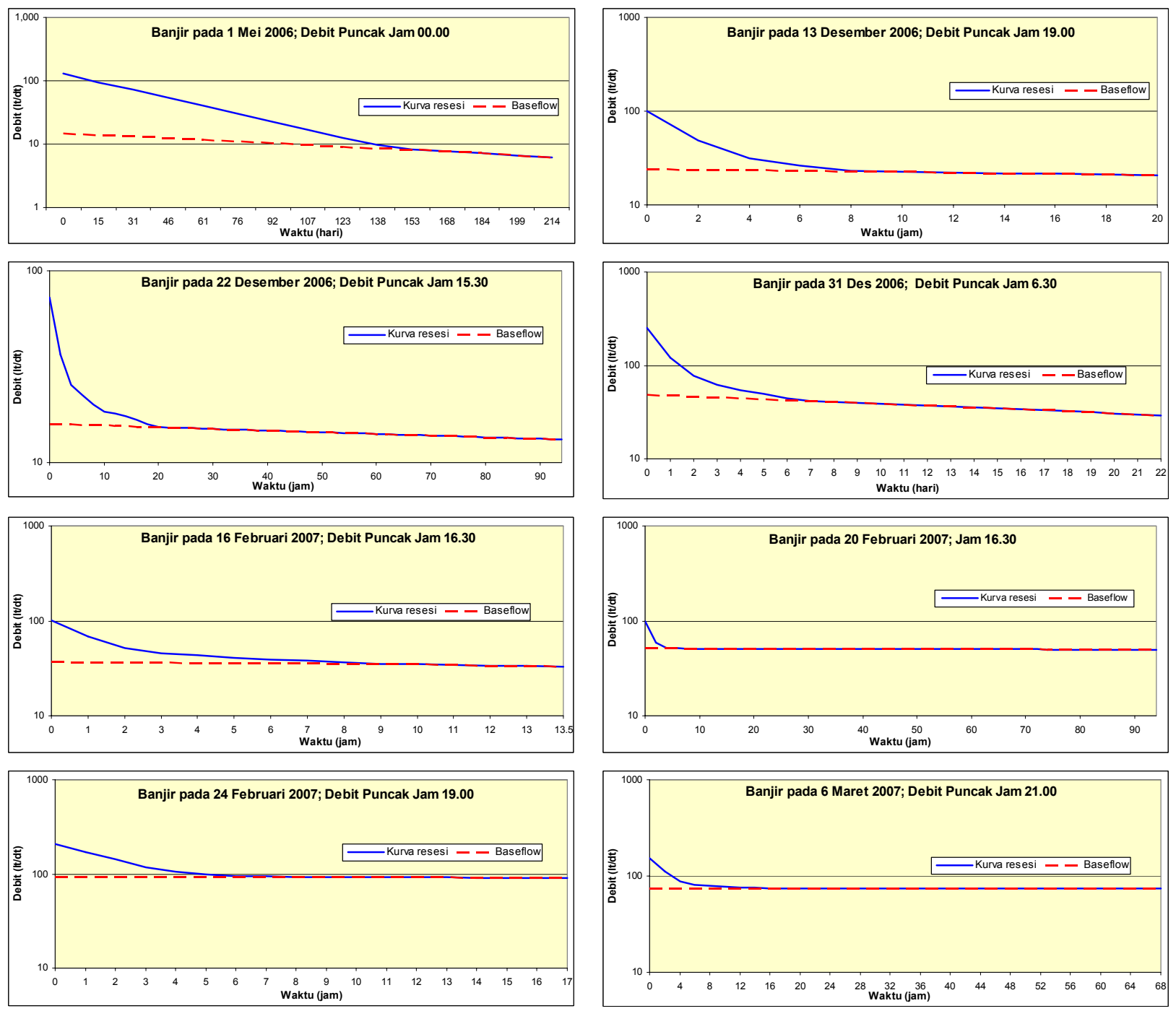

Gambar 4.12.a. Kejadian Resesi Banjir-Banjir Terpilih Gua Gilap

Secara umum, Nathan and McMahon (1990) menjelaskan bahwa julat nilai konstanta resesi untuk saluran $\left(\mathrm{K}_{\mathrm{c}}\right)$ adalah 0,2-0,8; aliran antara $\left(\mathrm{K}_{\mathrm{i}}\right)$ adalah 0,7-0,94; dan aliran dasar $\left(\mathrm{K}_{\mathrm{b}}\right)$ berkisar $0,93-0,995$. Dari perhitungan yang sudah disajikan pada Tabel 4.5. diketahui bahwa nilai $\mathrm{K}_{\mathrm{c}}$ periode banjir di Gua Gilap mempunyai julat antara $0,14-0,88$ dengan nilai rerata sebesar 0,463 , sedangkan nilai $\mathrm{K}_{\mathrm{i}}$ berjulat 0,39-0,92 dengan rerata 0,767 , dan julat konstanta resesi aliran dasar $\left(\mathrm{K}_{\mathrm{b}}\right)$ menunjukkan variasi antara 0,94-0,99 dengan nilai rata-rata sebesar 0,996. 
Pembahasan mengenai nilai konstanta resesi banjir akan disajikan pada subbab berikutnya dan akan dilakukan analisis secara spasial antara ketiga gua yang memiliki stasiun aliran (Gua Gilap, Gua Bribin, dan Gua Ngreneng).
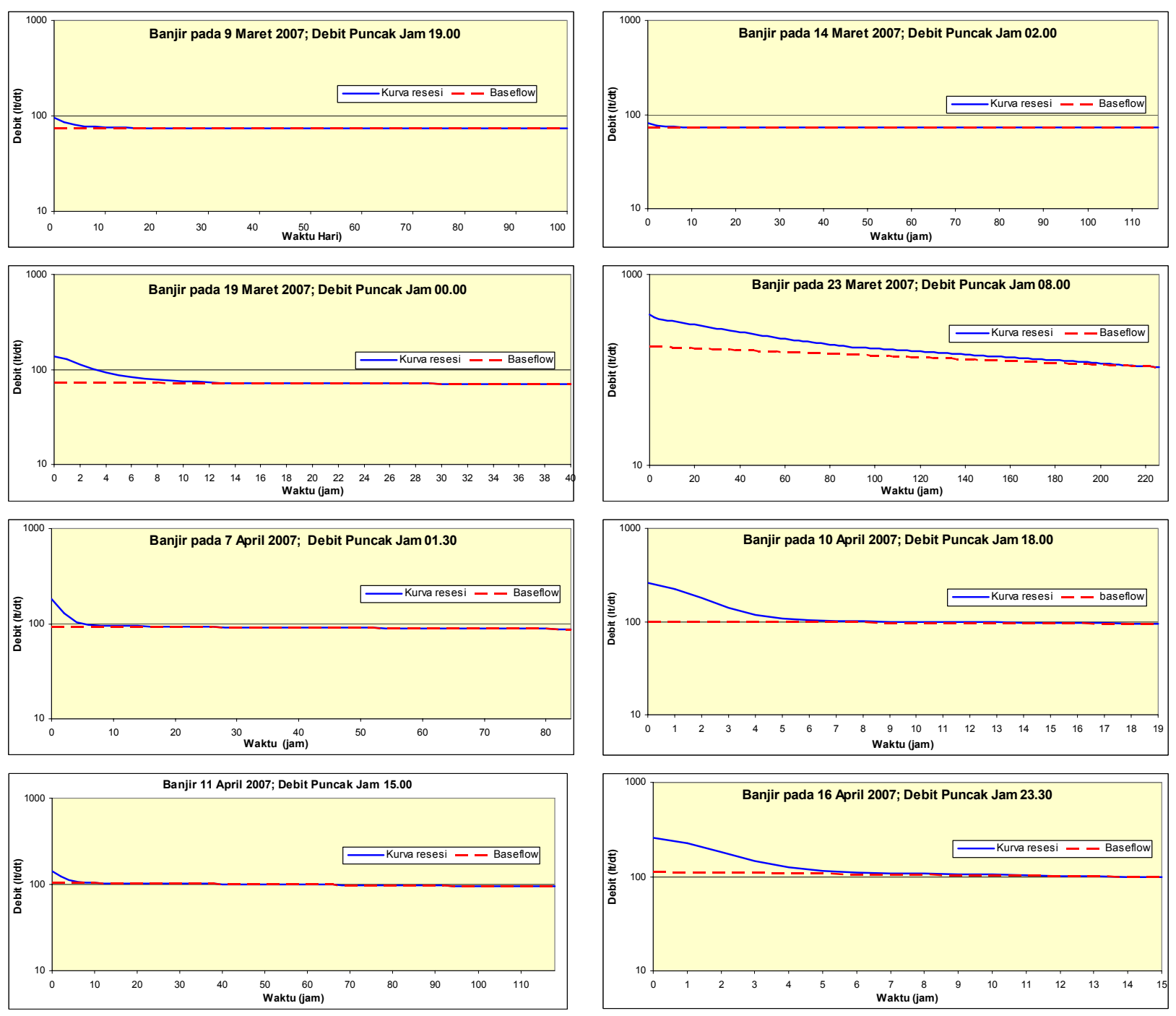

Lanjutan Gambar 4.12.b. Kejadian Resesi Banjir-Banjir Terpilih Gua Gilap 
Tabel 4.5. Konstanta Resesi, $T_{p}$ dan $T_{b}$ Hidrograf Banjir Terpilih Gua Gilap

\begin{tabular}{|r|r|r|r|r|r|r|r|r|}
\hline \multirow{2}{*}{ No } & \multicolumn{2}{|c|}{ Waktu } & $\begin{array}{c}\text { Debit } \\
\text { puncak(It/dt) }\end{array}$ & $\begin{array}{c}\text { Kr Baseflow } \\
\left(\mathbf{K}_{\mathbf{b}}\right)\end{array}$ & $\begin{array}{c}\text { Kr Interflow } \\
\left(\mathbf{K}_{\mathbf{i}}\right)\end{array}$ & $\begin{array}{c}\text { Kr channel } \\
\left(\mathbf{K}_{\mathbf{c}}\right)\end{array}$ & $\begin{array}{c}\mathbf{T}_{\mathbf{p}} \\
(\mathbf{j a m})\end{array}$ & $\begin{array}{c}\mathbf{T}_{\mathbf{b}} \\
(\mathbf{j a m})\end{array}$ \\
\hline 1 & \multicolumn{1}{|c|}{$13 / 12 / 06$} & $19: 00$ & 99,5 & 0,992 & 0,609 & 0,374 & 3,5 & 12 \\
\hline 2 & $22 / 12 / 06$ & $15: 30$ & 72,7 & 0,998 & 0,838 & 0,428 & 1,5 & 22 \\
\hline 3 & $31 / 12 / 06$ & $06: 30$ & 254,3 & 0,978 & 0,621 & 0,144 & 4 & 186 \\
\hline 4 & $16 / 2 / 07$ & $16: 30$ & 101,2 & 0,993 & 0,733 & 0,178 & 1,5 & 10 \\
\hline 5 & $24 / 2 / 07$ & $19: 00$ & 208,0 & 0,998 & 0,737 & 0,395 & 3 & 14 \\
\hline 6 & $26 / 2 / 07$ & $18: 00$ & 227,4 & 0,941 & 0,749 & 0,197 & 3 & 192 \\
\hline 7 & $6 / 3 / 07$ & $21: 00$ & 153,4 & 0,999 & 0,876 & 0,256 & 3 & 24 \\
\hline 8 & $9 / 3 / 07$ & $19: 00$ & 96,7 & 0,999 & 0,829 & 0,567 & 2 & 20 \\
\hline 9 & $14 / 3 / 07$ & $02: 00$ & 81,1 & 0,999 & 0,619 & 0,002 & 2 & 10 \\
\hline 10 & $19 / 3 / 07$ & $00: 00$ & 137,3 & 0,998 & 0,759 & 0,326 & 2 & 14 \\
\hline 11 & $21 / 3 / 07$ & $08: 00$ & 100,5 & 0,999 & 0,660 & 0,541 & 5 & 7 \\
\hline 12 & $23 / 3 / 07$ & $08: 00$ & 381,4 & 0,997 & 0,889 & 0,522 & 4,5 & 24 \\
\hline 13 & $7 / 4 / 07$ & $01: 30$ & 182,6 & 0,999 & 0,926 & 0,503 & 2,5 & 8 \\
\hline 14 & $10 / 4 / 07$ & $18: 00$ & 261,6 & 0,997 & 0,922 & 0,327 & 3,5 & 7 \\
\hline 15 & $11 / 4 / 07$ & $15: 00$ & 142,7 & 0,999 & 0,725 & 0,678 & 2 & 10 \\
\hline 16 & $16 / 4 / 07$ & $23: 30$ & 258,4 & 0,991 & 0,918 & 0,781 & 5,5 & 15 \\
\hline
\end{tabular}

Sumber : Pengukuran lapangan dan analisis data tahun 2006-2007

Perhitungan nilai time to peak $\left(\mathrm{T}_{\mathrm{p}}\right)$ yaitu lama waktu yang dibutuhkan oleh aliran sungai bawah tanah dari debit normal untuk mencapai puncak banjir di Gua Gilap berkisar antara 1,5 sampai dengan 5 jam sejak hujan mulai turun di daerah tangkapan dengan rata-rata waktu adalah sekitar 3 jam untuk mencapai banjir puncak, dengan rerata waktu resesi yang diperlukan dari puncak banjir untuk mencapai aliran dasar $\left(\mathrm{T}_{\mathrm{b}}\right)$ adalah sekitar 36 jam.

\section{c. Pemisahan Aliran Dasar Gua Gilap}

Pemisahan aliran dasar dilakukan untuk mengetahui persentase komponen aliran yang mensuplai aliran SBT tergantung dari kondisi pelepasan komponen air dari akuifer karst. Dua jenis aliran yang dipisahkan adalah (1) aliran langsung dan aliran antara (conduit-fissure); dan (2) aliran dasar (diffuse flow). Karena panjangnya data debit tiap 30 menit secara time series selama periode satu tahun pemasangan alat di Gua Gilap, maka digunakan cara pemisahan aliran dasar secara otomatis yaitu 
model automated base flow separation by digital filtering method yang dikembangkan oleh Eckhardt (2005), seperti yang sudah dijelaskan pada Rumus (3). Data utama yang diperlukan adalah data konstanta resesi aliran dasar Gua Gilap $\left(\mathrm{K}_{\mathrm{b}}\right)$ atau oleh Eckhhardt disebut digital filtering yang nilai reratanya adalah sebesar 0,996. Nilai $\mathrm{BFI}_{\max }$ yang digunakan adalah 0,8 karena sifat akuifer karst yang porus dan alirannya menahun (Eckhardt, 2005). Hasil pemisahan aliran dasar Gua Gilap disajikan pada Gambar 4.13. dan persentase bulanannya disajikan pada Tabel 4.6.

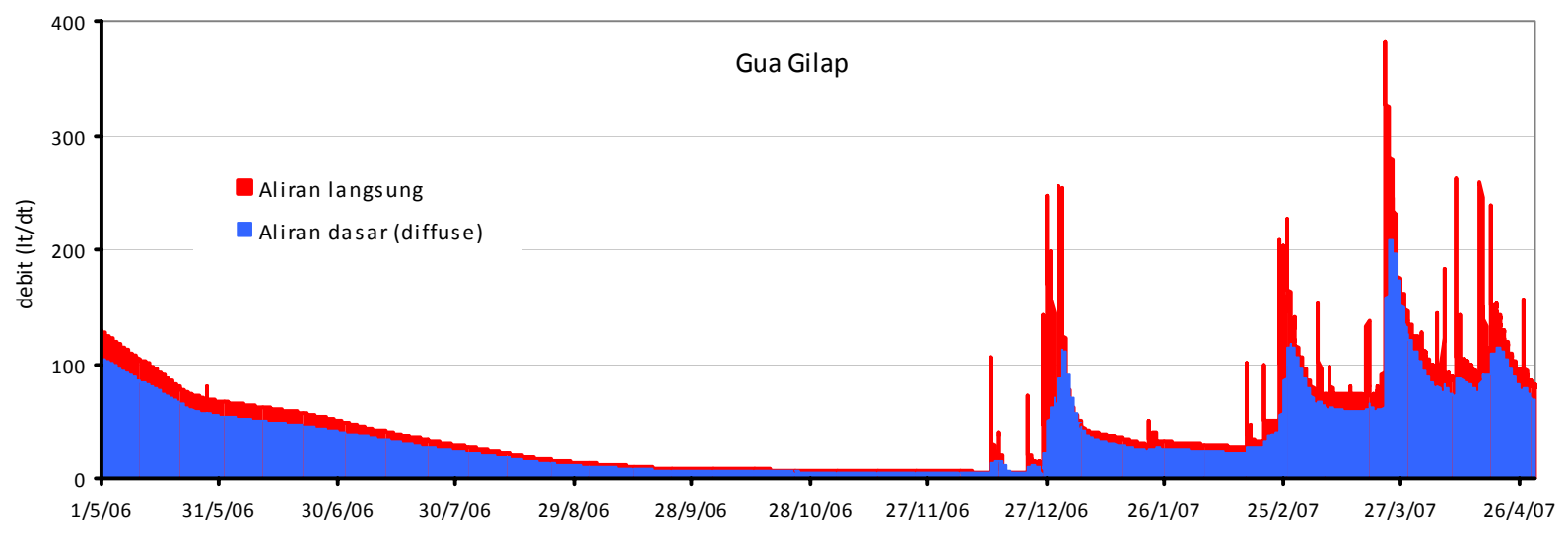

Gambar 4.13. Fluktuasi Aliran Dasar Gua Gilap periode 1 Mei 2006-30 April 2007

Dari perhitungan rasio total aliran dasar bulanan terhadap total aliran (Tabel 4.6), tampak bahwa secara umum nilai rasionya mendekati angka sekitar $80 \%$. Hal ini disebabkan oleh sifat pelepasan aliran akuifer karst yang didominasi oleh retakan bertipe diffuse. Jika dibedakan antara musim penghujan dan kemarau, terlihat perbedaan mengecilnya dominasi diffuse flow yang diakibatkan oleh adanya banjir yang memicu pelepasan komponen aliran conduit menuju sungai bawah tanah. Jika dicermati karakteristik temporalnya, nampak bahwa semakin menuju ke puncak musim kemarau, dominasi aliran dasar semakin besar karena berkurangnya aliran conduit dan fissure yang dilepaskan oleh akuifer karst di sekitar Gua Gilap. 
Tabel. 4.6. Rasio Aliran Dasar dan Total Aliran Tiap Bulan Gua Gilap

\begin{tabular}{|c|l|c|c|}
\hline No & \multicolumn{1}{|c|}{ Bulan } & Rasio (\%) & musim \\
\hline 1 & Mei 2006 & 80,41 & kemarau \\
\hline 2 & Juni 2006 & 80,47 & kemarau \\
\hline 3 & Juli 2006 & 80,93 & kemarau \\
\hline 4 & Agustus 2006 & 81,66 & kemarau \\
\hline 5 & September 2006 & 81,77 & kemarau \\
\hline 6 & Oktober 2006 & 82,09 & kemarau \\
\hline 7 & November 2006 & 82,36 & kemarau \\
\hline 8 & Desember 2007 & 80,11 & hujan \\
\hline 9 & Januari 2007 & 84,86 & hujan \\
\hline 10 & Februari 2007 & 77,49 & hujan \\
\hline 11 & Maret 2007 & 82,94 & hujan \\
\hline 12 & April 2007 & 82,85 & hujan \\
\hline
\end{tabular}

Sumber : hasil analisis data 2006-2007

Rasio aliran dasar dan total aliran pada musim penghujan pada bulan-bulan tertentu menunjukkan angka yang lebih kecil dibandingkan pada musim kemarau, dan mempunyai kecenderungan membesar seiring dengan berakhirnya musim hujan (Maret-April 2007). Sebagai contoh rasio pada bulan Februari 2007 menunjukkan angka $77,49 \%$ yang berarti total alirannya terpengaruh kontribusi dari aliran conduit. Rasio yang disajikan pada Tabel 4.6 merupakan nilai rata-rata bulanan, sehingga tidak menunjukkan rasio per kejadian hujan. Rasio aliran dasar dan total aliran tiap kejadian banjir terpilih di Gua Gilap disajikan pada Tabel 4.7.

Rasio komponen aliran diffuse pada saat banjir terhadap total aliran Gua Gilap sangat berbeda dengan rasio bulanannya. Pada awal sampai tengah musim hujan, rasio selalu kurang dari $60 \%$ yaitu berkisar antara $45-58 \%$, bahkan pada kejadian banjir pertama kali (13 Desember 2006), rasio menunjukkan angka yang kecil yaitu 45,08\%. Hal ini mengindikasikan bahwa akuifer karst belum menambah pasokan komponen diffuse flow menuju sungai, sementara pasokan conduit flow dari permukaan karst menjadi dominan saat kejadian banjir. Dari waktu ke waktu 
kecenderungan rasio diffuse flow mengalami peningkatan, kecuali pada kejadian banjir yang sangat besar (23 Maret 2007). Selanjutnya, semakin mendekati akhir musim hujan rasio aliran dasar akan kembali mendekati kisaran $80 \%$.

Tabel. 4.7. Rasio Aliran Dasar dan Total Aliran pada Kejadian Banjir Terpilih Gua Gilap

\begin{tabular}{|r|c|r|r|r|c|}
\hline \multirow{2}{*}{ No } & \multicolumn{2}{|c|}{ Waktu banjir } & Debit puncak & Rasio & Periode \\
& (liter/detik) & (\%) & hujan \\
\hline 1 & $13 / 12 / 06$ & $19: 00$ & 99,5 & 45,08 & Awal \\
\hline 2 & $22 / 12 / 06$ & $15: 30$ & 72,7 & 55,52 & Awal \\
\hline 3 & $31 / 12 / 06$ & $06: 30$ & 254,3 & 57,75 & Awal \\
\hline 4 & $16 / 2 / 07$ & $16: 30$ & 101,2 & 57,25 & Tengah \\
\hline 5 & $24 / 2 / 07$ & $19: 00$ & 208,0 & 51,25 & Tengah \\
\hline 6 & $26 / 2 / 07$ & $18: 00$ & 227,4 & 58,55 & Tengah \\
\hline 7 & $6 / 3 / 07$ & $21: 00$ & 153,4 & 79,91 & Akhir \\
\hline 8 & $9 / 3 / 07$ & $19: 00$ & 96,7 & 78,18 & Akhir \\
\hline 9 & $14 / 3 / 07$ & $02: 00$ & 81,1 & 78,92 & Akhir \\
\hline 10 & $19 / 3 / 07$ & $00: 00$ & 137,3 & 72,75 & Akhir \\
\hline 11 & $21 / 3 / 07$ & $08: 00$ & 100,5 & 77,20 & Akhir \\
\hline 12 & $23 / 3 / 07$ & $08: 00$ & 381,4 & 50,88 & Akhir \\
\hline 13 & $7 / 4 / 07$ & $01: 30$ & 182,6 & 70,33 & Akhir \\
\hline 14 & $10 / 4 / 07$ & $18: 00$ & 261,6 & 62,94 & Akhir \\
\hline 15 & $11 / 4 / 07$ & $15: 00$ & 142,7 & 76,30 & Akhir \\
\hline 16 & $16 / 4 / 07$ & $23: 30$ & 258,4 & 73,80 & Akhir \\
\hline
\end{tabular}

Sumber : hasil analisis data 2006-2007

\section{Variasi temporal aliran di Gua Bribin}

\section{a. Hubungan tinggi muka air dan debit di Gua Bribin}

Gua Bribin pada penelitian ini dianggap sebagai pemunculan terakhir Sungai Bribin sebelum akhirnya muncul sebagai resurgence di Pantai Baron. Pada gua ini, lorong gua bertemu dengan Sungai Bribin akan dijumpai bendung untuk pengambilan air, sehingga di tempat ini relatif mudah untuk memasang alat pencatat tinggi muka air (Gambar 4.14.). 


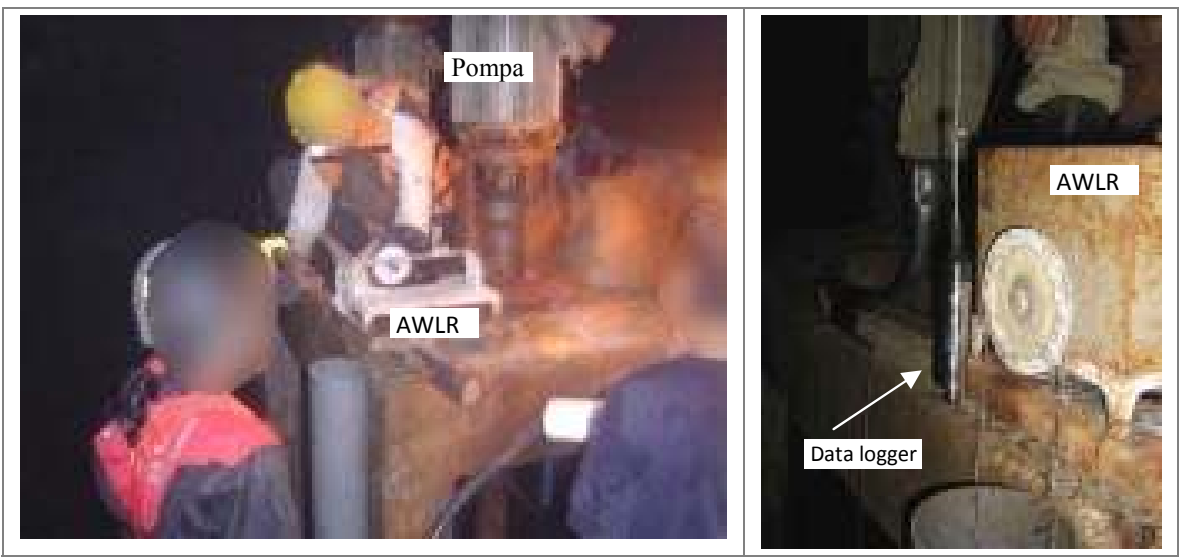

Gambar 4.14. Pemasangan AWLR di Gua Bribin (kiri), dan water level data logger (kanan)

Analisis kurva hubungan tinggi muka air dan debit dilakukan dengan menggunakan kurva yang sudah dipublikasikan oleh Suryanta (2001), yang data pengukurannya disajikan pada Tabel 4.8. dan grafiknya ditunjukkan pada Gambar 4.15 .

Tabel 4.8. Hasil Pengukuran Debit Aliran Gua Bribin

\begin{tabular}{|r|r|r|r|}
\hline \multicolumn{1}{|c|}{ No } & $\begin{array}{c}\text { Tanggal } \\
\text { pengukuran }\end{array}$ & $\begin{array}{c}\text { Tinggi muka } \\
\text { air }(\mathbf{m})\end{array}$ & $\begin{array}{c}\text { Debit aliran } \\
\text { (liter/detik) }\end{array}$ \\
\hline 1 & $18 / 1 / 00$ & 0,98 & 1297,19 \\
\hline 2 & $28 / 1 / 00$ & 1,06 & 1277,65 \\
\hline 3 & $5 / 2 / 00$ & 1,61 & 1939,94 \\
\hline 4 & $20 / 2 / 00$ & 1,37 & 1605,24 \\
\hline 5 & $23 / 2 / 00$ & 1,27 & 1480,61 \\
\hline 6 & $4 / 3 / 00$ & 1,10 & 1346,78 \\
\hline 7 & $8 / 3 / 00$ & 0,80 & 1001,15 \\
\hline 8 & $13 / 3 / 00$ & 1,33 & 1571,08 \\
\hline 9 & $18 / 3 / 00$ & 0,80 & 923,67 \\
\hline 10 & $22 / 3 / 00$ & 0,97 & 1176,54 \\
\hline 11 & $27 / 3 / 00$ & 1,36 & 1732,06 \\
\hline 12 & $1 / 4 / 00$ & 0,86 & 1027,89 \\
\hline 13 & $10 / 4 / 00$ & 0,87 & 979,63 \\
\hline 14 & $25 / 4 / 00$ & 1,44 & 1743,91 \\
\hline 15 & $30 / 4 / 00$ & 0,94 & 1123,09 \\
\hline
\end{tabular}

Sumber : Suryanta (2001) 


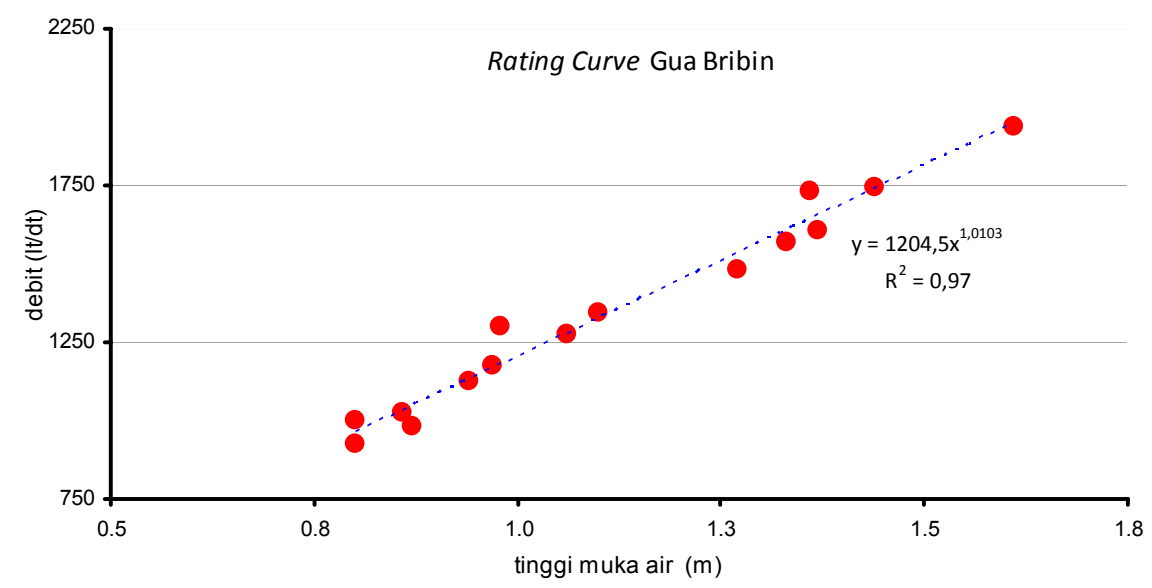

Gambar 4.15. Hubungan Tinggi Muka Air Dan Debit di Gua Bribin

Rumus lengkung aliran di Gua Bribin adalah :

$$
y=1204,5 x^{1,0103}
$$

\section{Keterangan:}

y adalah debit aliran (liter/detik) dan x adalah tinggi muka air (m).

Rumus tersebut digunakan untuk menghitung debit aliran sepanjang tahun pada alat pencatat tinggi muka air yang dipasang di Gua Bribin, dengan tinggi muka airnya dicatat tiap interval waktu 30 menit. Hasil penggambaran variasi debit aliran Gua Bribin selama satu tahun disajikan pada Gambar 4.16.

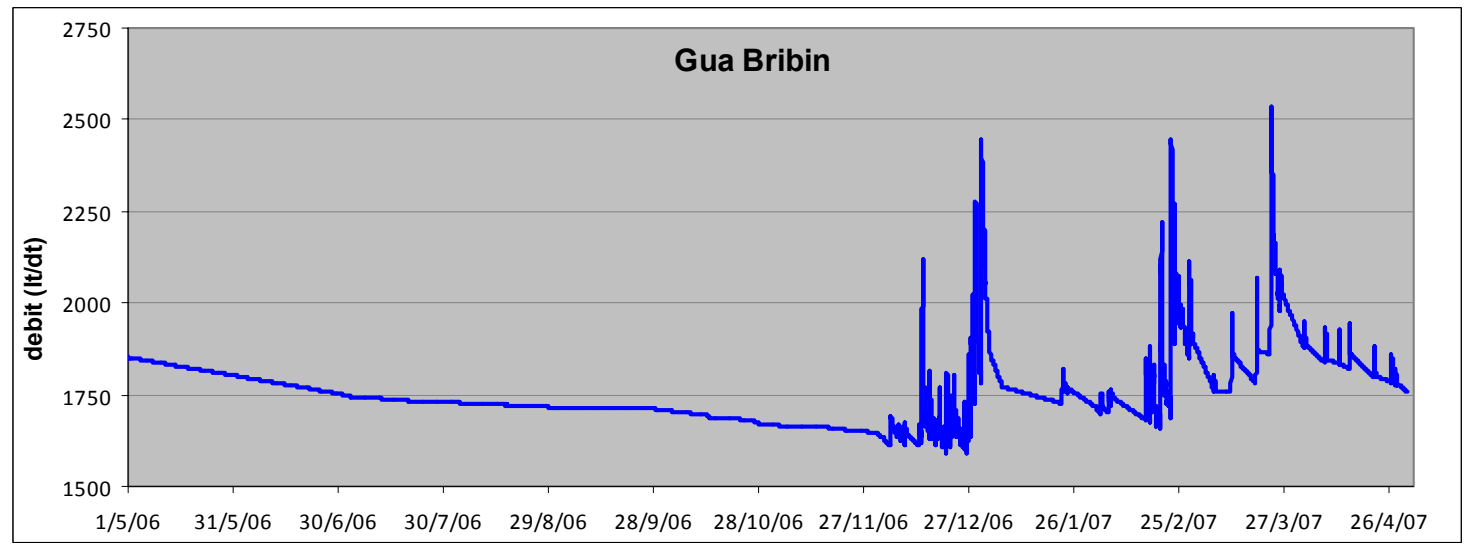

Gambar 4.16. Variasi Debit Aliran Gua Bribin Periode 1 Mei 2006-30 April 2007 
Pencatatan debit pada periode 1 Mei 2006 sampai dengan 30 April 2007 menunjukkan bahwa debit minimum terjadi pada 4 Desember 2006 yaitu sekitar 1630 liter/detik, sedangkan puncak banjir terbesar tercatat pada 23 Maret 2007 sebesar 2520 liter/detik. Periode aliran dasar terjadi antara Juni dan Desember 2006, sedangkan periode banjir dimulai sejak 4 Desember 2006 sampai akhir masa pencatatan (30 April 2007), dan masih menunjukkan kecenderungan berlanjut. Pada kurun waktu tersebut tercatat sekitar 58 kali kejadian banjir yang merupakan efek dari terjadinya hujan pada daerah tangkapan. Beberapa banjir yang cukup besar diantaranya terjadi pada tanggal 30 Desember 2006, dengan debit puncak sebesar 2443 liter/detik pada pukul 17.00 WIB, kejadian banjir pada tanggal 22 Maret 2007, pukul 21.00 dengan debit puncak mencapai 2440 liter/detik, serta banjir pada 23 Maret 2007, pukul 12.30 sebesar 2520 liter/detik.

\section{b. Konstanta resesi hidrograf banjir di Gua Bribin}

Sungai bawah tanah di Gua Bribin mengalami total 58 kali kejadian banjir, selama periode Mei 2007 sampai dengan April 2008 yang kemudian dipilih 12 kejadian banjir yang mempunyai debit besar dan waktu resesi yang cukup untuk dibuat model perhitungan konstanta resesinya. Grafik tiap kejadian banjir terpilih yang sudah dipisahkan komponen aliran dasarnya (baseflow) disajikan pada Gambar 4.17. Pada grafik tersebut disajikan skala normal mengingat rata-rata debit banjir yang berkisar antara 1600 sampai dengan 2300 liter/detik, akan tidak terlihat jika disajikan pada skala logaritmik. Sementara itu, perhitungan nilai konstanta resesi banjir $\mathrm{K}_{\mathrm{c}}, \mathrm{K}_{\mathrm{i}}$, maupun $\mathrm{K}_{\mathrm{b}}$ sungai bawah tanah di Gua Bribin disajikan pada Tabel 4.9.

Dari perhitungan yang disajikan pada Tabel 4.9. diketahui bahwa nilai $\mathrm{K}_{\mathrm{c}}$ priode banjir di Gua Bribin mempunyai julat antara 0,002-0,519 dengan rerata sebesar 0,332. Nilai $\mathrm{K}_{\mathrm{i}}$ berjulat 0,002-0,95 dengan rerata 0,825, sedangkan julat 
konstanta resesi aliran dasar $\left(\mathrm{K}_{\mathrm{b}}\right)$ tidak begitu menunjukkan variasi dengan nilai ratarata sebesar 0,998 . Selanjutnya, perhitungan nilai time to peak $\left(T_{p}\right)$ yaitu lama waktu yang dibutuhkan oleh aliran sungai bawah tanah pada debit normal untuk mencapai puncak banjir di Gua Bribin berkisar antara 2 sampai dengan 9,5 jam sejak hujan mulai turun di daerah tangkapan dengan rata-rata waktu adalah 5,5 jam, sedangkan rerata waktu resesi yan g diperlukan dari puncak banjir mencapai aliran dasar $\left(T_{b}\right)$ sekitar 36 jam.

Tabel 4.9. Konstanta Resesi, $T_{p}$ dan $T_{b}$ Hidrograf Banjir Terpilih Gua Bribin

\begin{tabular}{|c|c|c|c|c|c|c|c|c|}
\hline \multirow{2}{*}{ No } & \multicolumn{2}{|c|}{ Waktu } & \multirow{2}{*}{$\begin{array}{c}\text { Debit puncak } \\
\text { (liter/detik) }\end{array}$} & \multirow{2}{*}{$\begin{array}{c}\text { Kr Baseflow } \\
\left(\mathbf{K}_{\mathrm{b}}\right)\end{array}$} & \multirow{2}{*}{$\begin{array}{c}\text { Kr Interflow } \\
\left(\mathrm{K}_{\mathrm{i}}\right)\end{array}$} & \multirow{2}{*}{$\begin{array}{c}\text { Kr channel } \\
\left(\mathbf{K}_{\mathbf{c}}\right)\end{array}$} & \multirow{2}{*}{$\begin{array}{c}\mathbf{T}_{\mathbf{p}} \\
(\mathbf{j a m})\end{array}$} & \multirow{2}{*}{$\begin{array}{c}T_{\mathbf{b}} \\
(\mathbf{j a m})\end{array}$} \\
\hline & Tanggal & jam & & & & & & \\
\hline 1 & $6 / 12 / 06$ & $22: 30$ & 1667,8 & 0.999 & 0.767 & 0.646 & 4.5 & 11 \\
\hline 2 & $7 / 12 / 06$ & 23:00 & 1660,5 & 0.998 & 0.668 & 0.018 & 6.5 & 124 \\
\hline 3 & $13 / 12 / 06$ & $19: 30$ & 2120,5 & 0.995 & 0.667 & 0.445 & 5.5 & 13 \\
\hline 4 & $29 / 12 / 06$ & $00: 30$ & 2273,2 & 0.999 & 0.929 & 0.502 & 9.5 & 5 \\
\hline 5 & $30 / 12 / 06$ & $17: 00$ & 2445,6 & 0.998 & 0.698 & 0.304 & 7.5 & 168 \\
\hline 6 & $16 / 2 / 07$ & 18:00 & 1884,9 & 0.997 & 0.950 & 0.001 & 4.5 & 13 \\
\hline 7 & $22 / 2 / 07$ & 21:00 & 2440,7 & 0.996 & 0.869 & 0.273 & 6.5 & 17 \\
\hline 8 & $23 / 2 / 07$ & 20:00 & 2272,0 & 0.999 & 0.897 & 0.435 & 6 & 18 \\
\hline 9 & $28 / 2 / 07$ & 01:30 & 2113,2 & 0.999 & 0.908 & 0.300 & 2 & 24 \\
\hline 10 & $7 / 3 / 07$ & 05:00 & 1805,6 & 0.999 & 0.779 & 0.292 & 4 & 9 \\
\hline 11 & $7 / 4 / 07$ & 22:00 & 1936,1 & 0.999 & 0.912 & 0.242 & 4 & 16 \\
\hline 12 & $27 / 4 / 07$ & $20: 00$ & 1819,0 & 0.999 & 0.850 & 0.519 & 5 & 14 \\
\hline
\end{tabular}

Sumber : Pengukuran lapangan dan analisis data tahun 2006-2007

\section{c. Pemisahan aliran dasar Gua Bribin}

Data utama untuk pemisahan aliran dasar diperoleh dari perhitungan konstanta resesi aliran dasar Gua Bribin $\left(\mathrm{K}_{\mathrm{b}}\right)$ yang nilai reratanya adalah sebesar 0,998. Sementara itu, nilai $\mathrm{BFI}_{\max }$ yang dipergunakan adalah sama dengan nilai di Gua Gilap yaitu sebesar 0,8. Selanjutnya, hasil pemisahan aliran dasar Gua Bribin disajikan pada Gambar 4.18. dan rincian persentase bulanannya disajikan pada Tabel 4.10. 

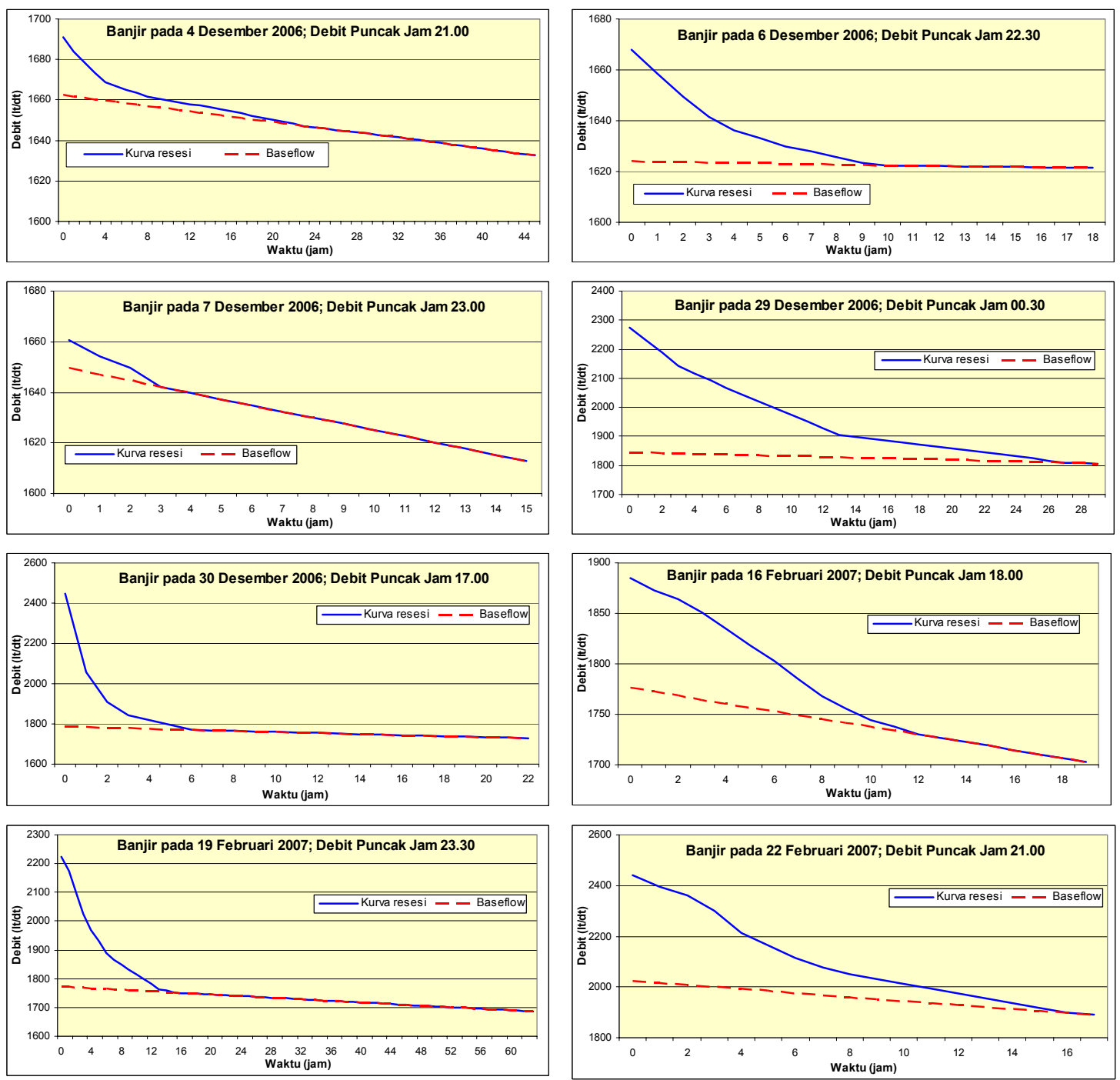

Gambar 4.17a. Kejadian Resesi Banjir-Banjir Terpilih Gua Bribin

Persentase bulanan rasio aliran dasar dan aliran total di Gua Bribin menunjukkan angka yang tinggi yaitu pada kisaran 97-99\%, artinya terdapat dominasi aliran dasar sebagai komponen aliran pengisi sungai bawah tanah. Pada musim kemarau, rasio aliran menunjukkan kecenderungan yang semakin meningkat dari bulan Mei sampai dengan November 2006, dan mencapai rasio terbesar pada November 2006 yaitu sebesar 99,40\%. Dimulainya musim hujan pada Desember 
2006 menyebabkan turunnya persentase aliran dasar menjadi dari sekitar 99\% menjadi dibawah 97\% yang kemudian berfluktuasi selama bulan-bulan musim penghujan (Januari-April 2007), dengan kisaran yang selalu lebih kecil dari kisaran pada bulan-bulan di musim kemarau. Rasio aliran dasar dan total aliran tiap kejadian banjir terpilih di Gua Bribin disajikan pada Tabel 4.11.

Dari 12 kali kejadian banjir terpilih di Gua Bribin, rata-rata rasio komponen aliran dasar dan total aliran sekitar 90,36\%, lebih kecil dari rata-rata rasio bulanannya, yang disebabkan oleh kontribusi aliran conduit pada waktu kejadian banjir. Persentase aliran dasar terkecil saat banjir dijumpai pada banjir berdebit puncak besar, diantaranya banjir pada 22 Februari 2007 dengan debit puncak sebesar 2440,7 liter/detik yang mempunyai persentase aliran dasar sebesar 81,81\% dan banjir pada 29 Desember 2006 (debit puncak $=2273,2$ liter/dt) dengan persentase aliran dasar sebesar $77,72 \%$. Selain itu, persentase aliran dasar relatif bertambah besar pada kejadian banjir saat akhir musim hujan karena mengecilnya debit aliran langsung dari permukaan karst.
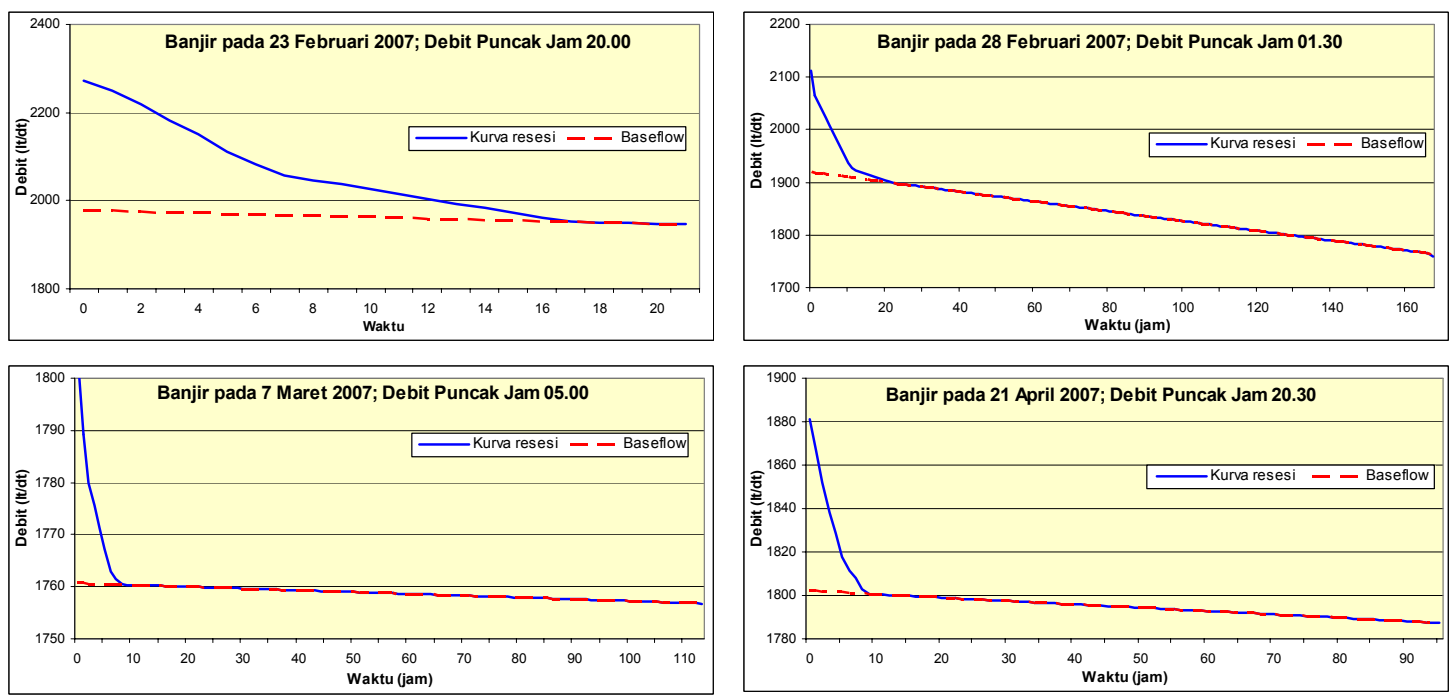

Lanjutan Gambar 4.17b. Kejadian Resesi Banjir-Banjir Terpilih Gua Bribin 


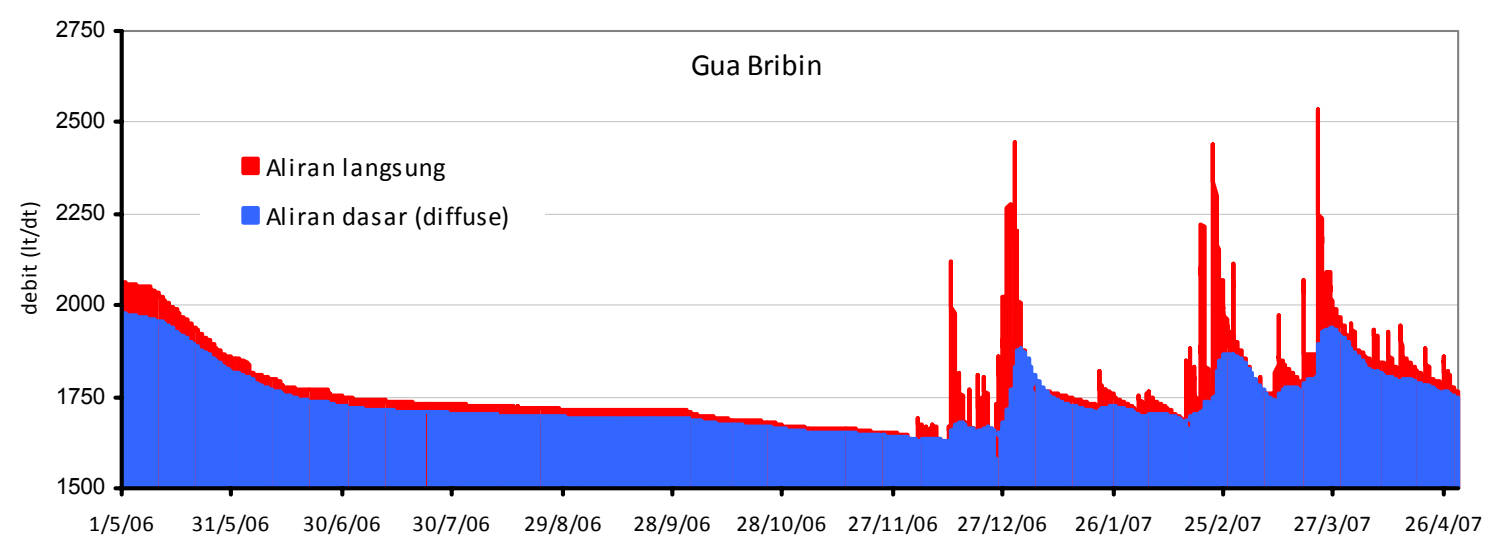

Gambar 4.18. Fluktuasi Aliran Dasar Gua Bribin Periode 1 Mei 2006-30 April 2007

Tabel. 4.10. Rasio Aliran Dasar dan Total Aliran Tiap Bulan Gua Bribin

\begin{tabular}{|c|l|r|c|}
\hline No & \multicolumn{1}{|c|}{ Bulan } & Rasio (\%) & Musim \\
\hline 1 & Mei 2006 & 97,03 & kemarau \\
\hline 2 & Juni 2006 & 98,40 & kemarau \\
\hline 3 & Juli 2006 & 98,53 & kemarau \\
\hline 4 & Agustus 2006 & 98,64 & kemarau \\
\hline 5 & September 2006 & 98,70 & kemarau \\
\hline 6 & Oktober 2006 & 99,14 & kemarau \\
\hline 7 & November 2006 & 99,40 & kemarau \\
\hline 8 & Desember 2007 & 97,44 & hujan \\
\hline 9 & Januari 2007 & 98,87 & hujan \\
\hline 10 & Februari 2007 & 97,22 & hujan \\
\hline 11 & Maret 2007 & 97,07 & hujan \\
\hline 12 & April 2007 & 98,26 & hujan \\
\hline
\end{tabular}

Sumber : hasil analisis data 2006-2007

\section{Variasi temporal aliran di Gua Ngreneng}

\section{a. Hubungan tinggi muka air dan debit Gua Ngreneng}

Dari hasil tracer test oleh MacDonald and Partners (1984), diketahui bahwa Gua Ngreneng adalah pemunculan sungai bawah tanah yang diyakini sebagai bocoran dari sungai utama Bribin. Gua ini terletak pada suatu cekungan bekas doline 
yang mempunyai beda tinggi sekitar 50 meter antara dasar sungai dan permukaan lembahnya. Sungai di Gua Ngreneng ini selalu berair sepanjang tahun dan pada saat musim hujan debit sungai dapat menjadi sangat tinggi karena pintu masuk gua ini juga berfungsi sebagai sinkhole aliran permukaan di sekitar cekungan gua ini yang mengakibatkan tingginya pasokan aliran permukaan. Di gua ini dipasang alat pencatat tinggi muka air sungai seperti yang diilustrasikan pada Gambar 4.19. Hasil pengukuran debit di Gua Ngreneng disajikan pada Tabel 4.12.

Tabel. 4.11. Rasio Aliran Dasar dan Total Aliran pada Kejadian Banjir Terpilih Gua Bribin

\begin{tabular}{|r|r|r|r|r|c|}
\hline No & \multicolumn{2}{|c|}{ Waktu banjir } & \multicolumn{1}{c|}{$\begin{array}{c}\text { Debit } \\
\text { puncak } \\
\text { (liter/detik) }\end{array}$} & $\begin{array}{c}\text { Rasio } \\
\mathbf{( \% )}\end{array}$ & $\begin{array}{c}\text { Periode } \\
\text { hujan }\end{array}$ \\
\hline 1 & $6 / 12 / 06$ & $22: 30$ & 1667,8 & 98,38 & Awal \\
\hline 2 & $7 / 12 / 06$ & $23: 00$ & 1660,5 & 99,02 & Awal \\
\hline 3 & $13 / 12 / 06$ & $19: 30$ & 2120,5 & 86,16 & Awal \\
\hline 4 & $29 / 12 / 06$ & $00: 30$ & 2273,2 & 77,72 & Awal \\
\hline 5 & $30 / 12 / 06$ & $17: 00$ & 2445,6 & 82,69 & Awal \\
\hline 6 & $16 / 2 / 07$ & $18: 00$ & 1884,9 & 92,29 & Tengah \\
\hline 7 & $22 / 2 / 07$ & $21: 00$ & 2440,7 & 81,81 & Tengah \\
\hline 8 & $23 / 2 / 07$ & $20: 00$ & 2272,0 & 84,51 & Tengah \\
\hline 9 & $28 / 2 / 07$ & $01: 30$ & 2113,2 & 89,91 & Tengah \\
\hline 10 & $7 / 3 / 07$ & $05: 00$ & 1805,6 & 99,05 & Akhir \\
\hline 11 & $7 / 4 / 07$ & $22: 00$ & 1936,1 & 95,50 & Akhir \\
\hline 12 & $27 / 4 / 07$ & $20: 00$ & 1819,0 & 97,25 & Akhir \\
\hline
\end{tabular}

Sumber : hasil analisis data 2006-2007
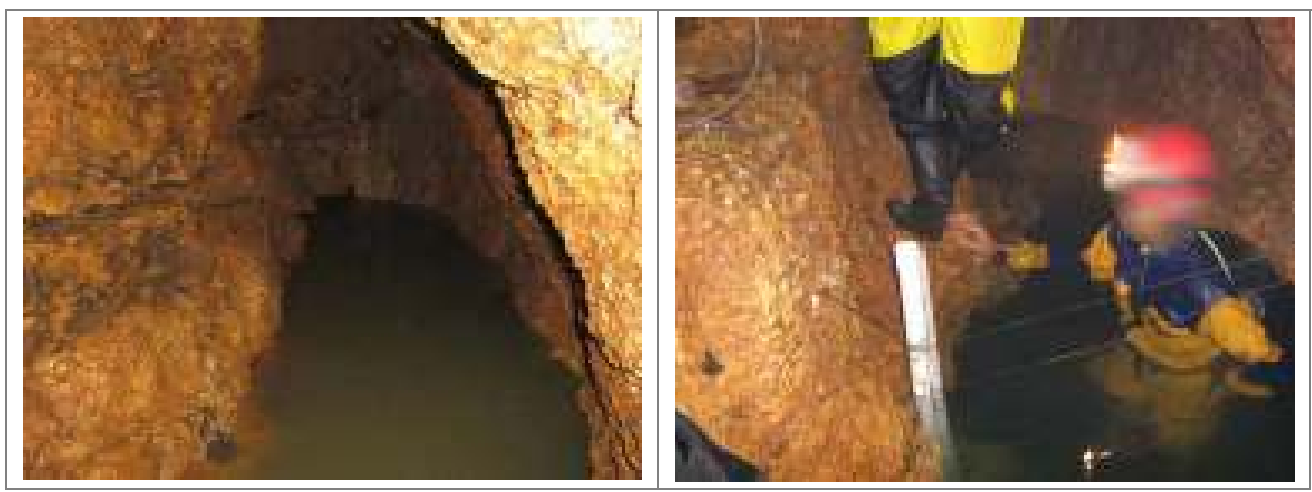

Gambar 4.19. Kondisi Aliran di Gua Ngreneng (kiri), dan Instalasi Stasiun Aliran (kanan) 
Tabel 4.12. Hasil Pengukuran Debit Aliran Gua Ngreneng

\begin{tabular}{|r|r|r|r|}
\hline No & $\begin{array}{c}\text { Tanggal } \\
\text { pengukuran }\end{array}$ & \multicolumn{1}{c|}{$\begin{array}{c}\text { Tinggi muka } \\
\text { air }(\mathbf{m})\end{array}$} & $\begin{array}{c}\text { Debit aliran } \\
\text { (liter/detik) }\end{array}$ \\
\hline 1 & $20 / 4 / 06$ & 1,80 & 545,96 \\
\hline 2 & $26 / 4 / 06$ & 1,61 & 488,33 \\
\hline 3 & $22 / 5 / 06$ & 1,21 & 283,11 \\
\hline 4 & $22 / 6 / 06$ & 1,17 & 263,61 \\
\hline 5 & $19 / 7 / 06$ & 0,97 & 219,00 \\
\hline 6 & $23 / 8 / 06$ & 0,71 & 140,71 \\
\hline 7 & $20 / 9 / 06$ & 0,62 & 123,57 \\
\hline 8 & $15 / 11 / 06$ & 0,38 & 75,73 \\
\hline 9 & $20 / 12 / 06$ & 0,43 & 100,61 \\
\hline
\end{tabular}

Sumber : Pengukuran lapangan 2006-2007

Selanjutnya, dari data tersebut dibuat kurva regresi (Gambar 4.20) hubungan antara tinggi muka air dan debit aliran di gua Ngreneng, berupa persamaan :

$$
y=49,164 e^{1.343 x}
$$

\section{Keterangan:}

y adalah debit aliran (liter/detik) dan x adalah tinggi muka air (m)

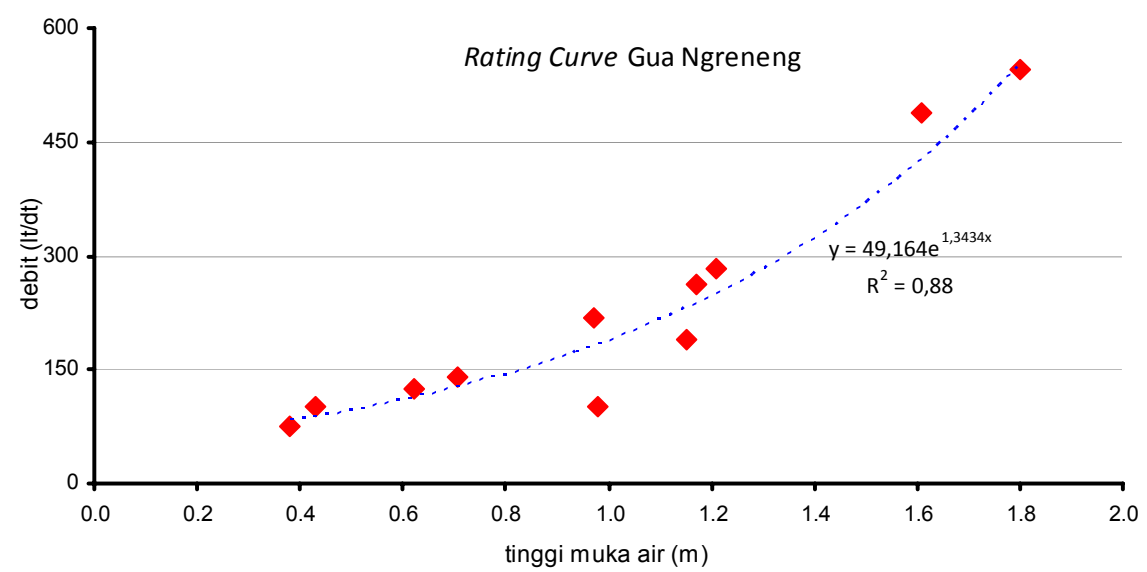

Gambar 4.20. Hubungan Tinggi Muka Air dan Debit di Gua Ngreneng

Rumus yang diperoleh tersebut digunakan untuk menghitung debit aliran sepanjang tahun berdasarkan pada tinggi muka air yang tercatat pada alat dengan interval waktu 30 menit. Hasil penggambaran variasi debit aliran Gua Ngreneng selama satu tahun pencatatan disajikan pada Gambar 4.21. 


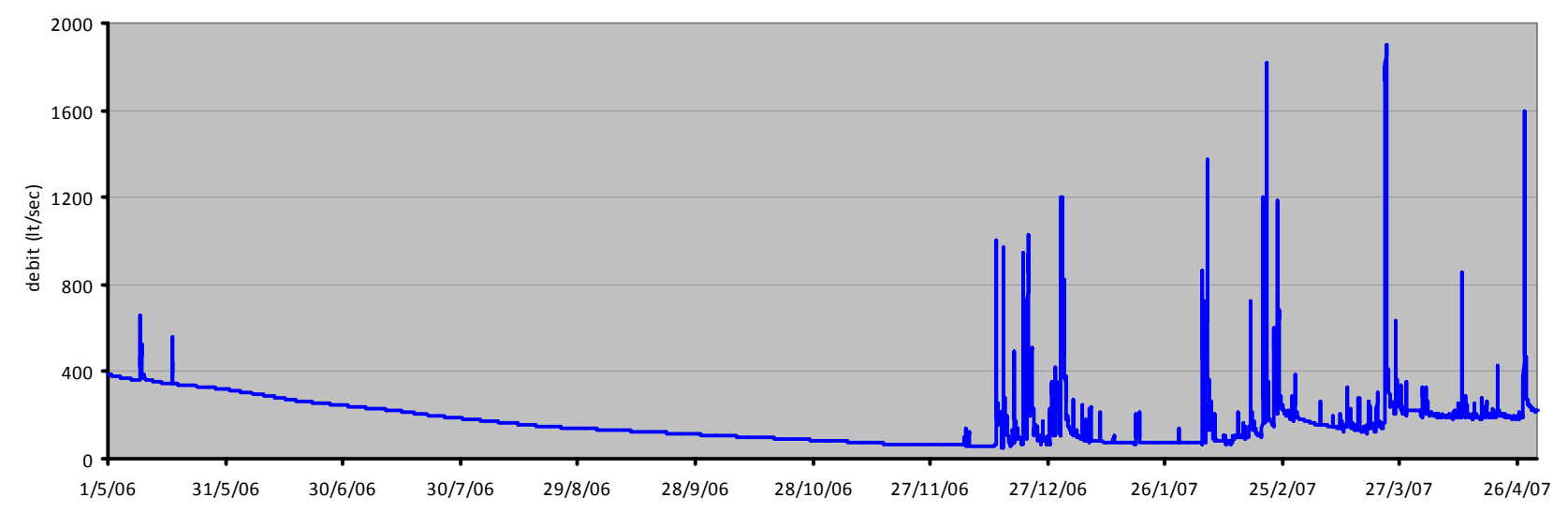

Gambar 4.21. Variasi Debit Aliran Gua Ngreneng Periode 1 Mei 2006-30 April 2007

Pencatatan dari 1 Mei 2006 sampai dengan 30 April 2007 menunjukkan bahwa periode tanpa banjir dimulai pada 18 Mei 2006 sampai dengan 6 Desember 2006, dengan debit aliran minimum sekitar 60 liter/detik. Banjir pertama kali terjadi pada 6 Desember 2006 dengan debit puncak sebesar 143,24 liter/detik. Selanjutnya, periode banjir-banjir yang cukup besar dimulai pada 13 Desember 2006 dan sampai akhir masa pencatatan terjadi sekitar 62 kali kejadian banjir. Beberapa banjir besar diantaranya terjadi pada 20 Februari 2007, pukul 20.00 dengan debit puncak sebesar 1788,86 liter/detik dan banjir pada 23 Maret 2007 pukul 09.30 dengan debit puncak sebesar 1905,3 liter/detik.

\section{b. Konstanta Resesi Hidrograf Banjir Gua Ngreneng}

Dari 62 kali kejadian banjir, terpilih 8 kejadian banjir yang mempunyai debit besar dan waktu resesi yang cukup panjang untuk dibuat model perhitungan konstanta resesinya. Hasil perhitungan nilai konstanta resesi banjir $\mathrm{K}_{\mathrm{c}}, \mathrm{K}_{\mathrm{i}}$, maupun $\mathrm{K}_{\mathrm{b}}$ sungai bawah tanah di Gua Ngreneng disajikan pada Tabel 4.13. Sementara itu, grafik pada skala logaritma tiap kejadian banjir terpilih yang sudah dipisahkan komponen aliran dasarnya (baseflow) disajikan pada Gambar 4.22. 
Tabel 4.13. Konstanta Resesi, $T_{p}$ dan $T_{b}$ Hidrograf Banjir Terpilih Gua Ngreneng

\begin{tabular}{|c|c|c|c|c|c|c|c|c|}
\hline \multirow{2}{*}{ No } & \multicolumn{2}{|c|}{ Waktu } & \multirow{2}{*}{$\begin{array}{c}\text { Debit } \\
\text { puncak(lt/dt) }\end{array}$} & \multirow{2}{*}{$\begin{array}{c}\text { Kr Baseflow } \\
\left(K_{\mathbf{b}}\right)\end{array}$} & \multirow{2}{*}{$\begin{array}{c}\text { Kr Interflow } \\
\left(\mathbf{K}_{\mathbf{i}}\right)\end{array}$} & \multirow{2}{*}{$\begin{array}{c}\mathbf{K r} \\
\text { channel } \\
\left(\mathbf{K}_{\mathbf{c}}\right)\end{array}$} & \multirow{2}{*}{$\begin{array}{c}\mathbf{T}_{\mathbf{p}} \\
(\mathbf{j a m})\end{array}$} & \multirow{2}{*}{$\begin{array}{c}\mathbf{T}_{\mathbf{b}} \\
(\mathrm{jam})\end{array}$} \\
\hline & Tanggal & Jam & & & & & & \\
\hline 1 & $13 / 12 / 06$ & 19:30 & 1005,2 & 0,9991 & 0,9247 & 0,2792 & 6 & 9 \\
\hline 2 & $15 / 12 / 06$ & $18: 30$ & 882,1 & 0,9881 & 0,8595 & 0,2442 & 7 & 14 \\
\hline 3 & $18 / 12 / 06$ & 13:30 & 454,6 & 0,9933 & 0,9643 & 0,2786 & 2,5 & 20 \\
\hline 4 & $20 / 12 / 06$ & $18: 30$ & 947,5 & 0,9900 & 0,8769 & 0,1882 & 3,5 & 16 \\
\hline 5 & $22 / 12 / 06$ & $20: 30$ & 514,2 & 0,9985 & 0,9712 & 0,2674 & 7,5 & 62 \\
\hline 6 & $5 / 2 / 07$ & 17:00 & 1373,0 & 0,9910 & 0,7362 & 0,4048 & 4 & 240 \\
\hline 7 & $19 / 2 / 07$ & $20: 30$ & 890,2 & 0,9779 & 0,7762 & 0,2510 & 5 & 19 \\
\hline 8 & $20 / 2 / 07$ & $20: 00$ & 1788,9 & 0,9968 & 0,9034 & 0,7480 & 4 & 43 \\
\hline
\end{tabular}

Sumber : Pengukuran lapangan dan analisis data tahun 2006-2007

Dari perhitungan yang disajikan pada Tabel 4.13. diketahui bahwa nilai $\mathrm{K}_{\mathrm{c}}$ periode banjir di Gua Ngreneng mempunyai julat antara 0,188-0,748 dengan nilai rerata sebesar 0,333 , nilai $\mathrm{K}_{\mathrm{i}}$ berjulat $0,732-0,971$ dengan rerata 0,877 , dan, julat konstanta resesi aliran dasar $\left(\mathrm{K}_{\mathrm{b}}\right)$ menunjukkan variasi antara 0,978 sampai dengan 0,999 dengan nilai rata-rata sebesar 0,992 . Perhitungan nilai time to peak $\left(\mathrm{T}_{\mathrm{p}}\right)$ yaitu lama waktu yang dibutuhkan oleh aliran sungai bawah tanah pada debit normal untuk mencapai puncak banjir di Gua Ngreneng berkisar antara 2,5 sampai dengan 7,5 jam dengan rerata 4,5 jam. Sementara itu, rerata waktu resesi yang diperlukan dari puncak banjir untuk mencapai aliran dasar $\left(\mathrm{T}_{\mathrm{b}}\right)$ adalah sekitar 16 jam.

\section{c. Pemisahan Aliran Dasar Gua Ngreneng}

Data untuk pemisahan aliran dasar diperoleh dari perhitungan konstanta resesi aliran dasar Gua Ngreneng $\left(K_{b}\right)$ yang nilai reratanya adalah sebesar 0,992, dengan nilai $\mathrm{BFI}_{\max }$ yang digunakan adalah sama seperti nilai di Gua Gilap dan Bribin, yaitu sebesar 0,8 . Hasil pemisahan aliran dasar Gua Ngreneng disajikan pada Gambar 4.23. dan rincian persentase bulanannya disajikan pada Tabel 4.14. 

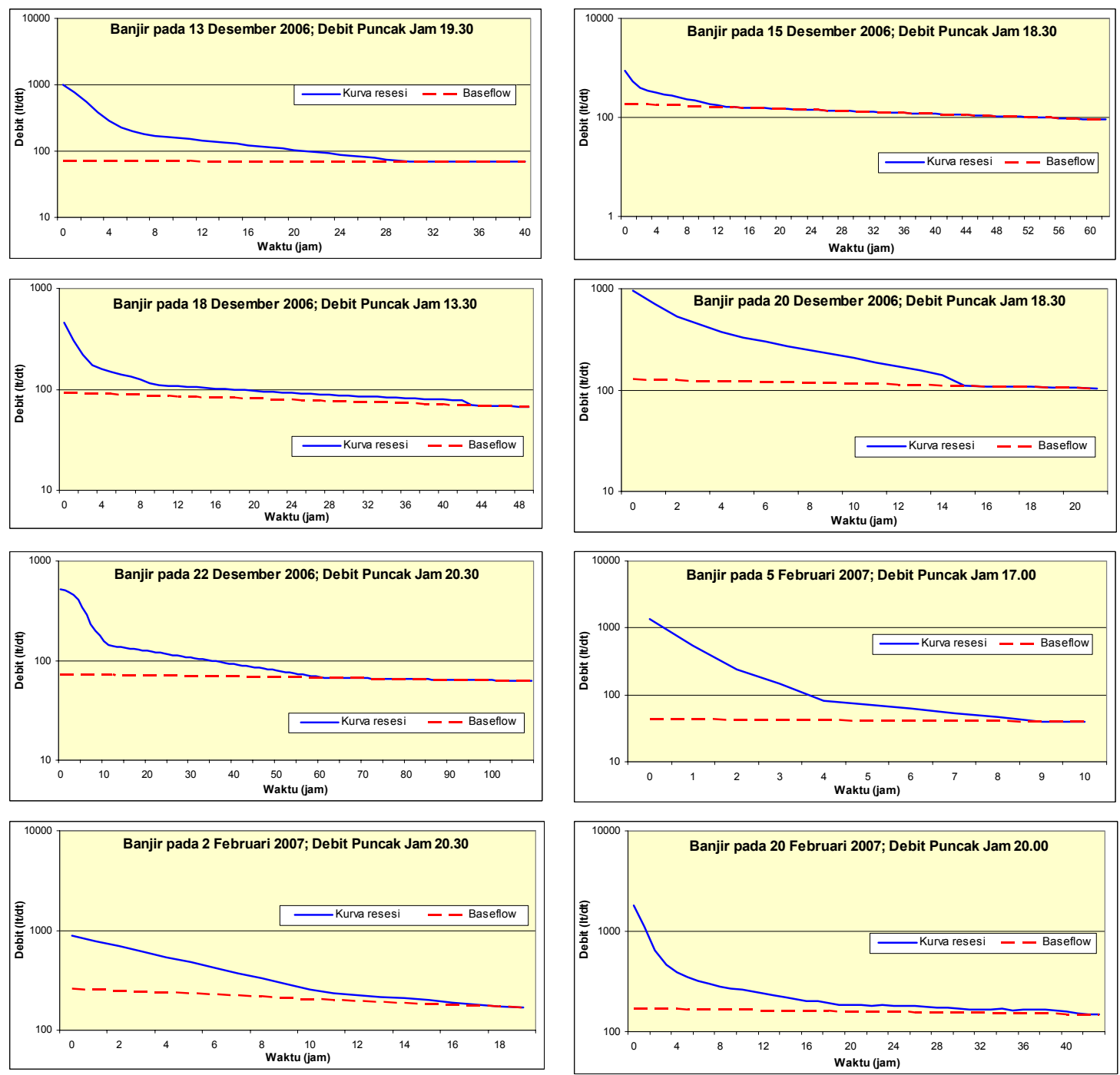

Gambar 4.22. Kejadian Resesi Banjir-Banjir Terpilih Gua Ngreneng

Persentase bulanan rasio aliran dasar dan aliran total di Gua Ngreneng menunjukkan angka sekitar $80 \%$, dan semakin meningkat pada periode banjir menjadi 81-83 \%. Dimulainya musim hujan pada Desember 2006 tidak menyebabkan persentase aliran dasar menjadi berkurang, seperti yang terjadi pada gua Gilap dan Bribin, tetapi malah menunjukkan peningkatan, walaupun tidak signifikan (sekitar 1-2 \%). Rasio aliran dasar dan total aliran tiap kejadian banjir terpilih di Gua Ngreneng disajikan pada Tabel 4.15. 


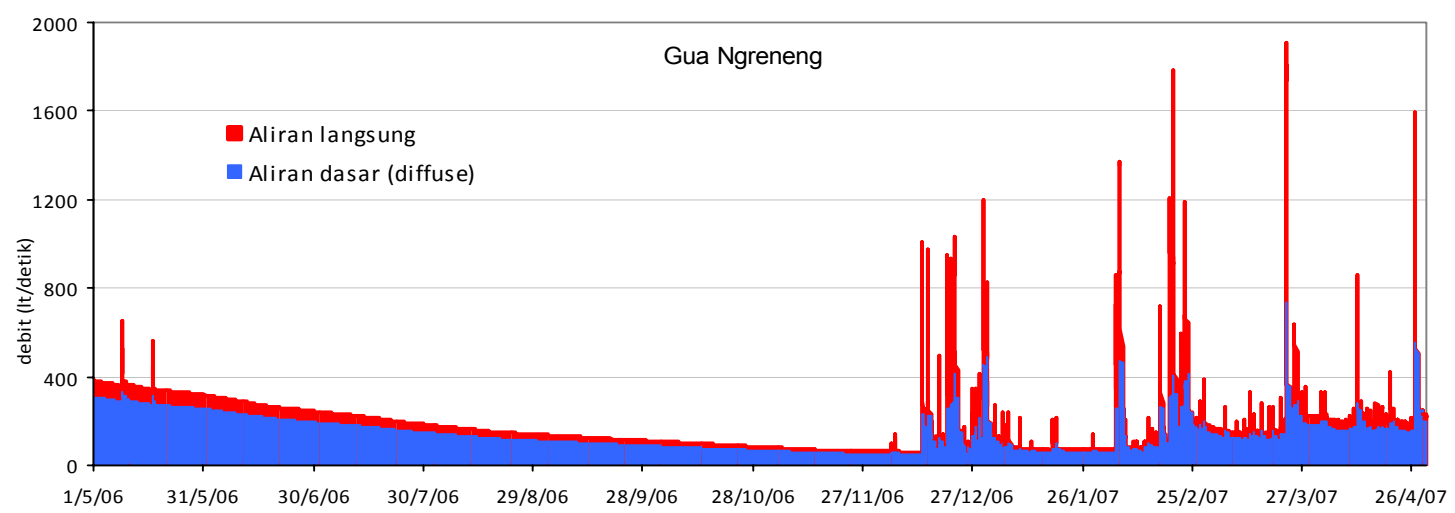

Gambar 4.23.Fluktuasi Aliran Dasar Gua Ngreneng Periode 1 Mei 2006-30 April 2007

Tabel. 4.14. Rasio Aliran Dasar dan Total Aliran Tiap Bulan Gua Ngreneng

\begin{tabular}{|c|l|r|c|}
\hline No & \multicolumn{1}{|c|}{ Bulan } & Rasio (\%) & Musim \\
\hline 1 & Mei 2006 & 80,35 & kemarau \\
\hline 2 & Juni 2006 & 80,36 & kemarau \\
\hline 3 & Juli 2006 & 80,37 & kemarau \\
\hline 4 & Agustus 2006 & 80,38 & kemarau \\
\hline 5 & September 2006 & 80,38 & kemarau \\
\hline 6 & Oktober 2006 & 80,38 & kemarau \\
\hline 7 & November 2006 & 80,38 & kemarau \\
\hline 8 & Desember 2007 & 81,78 & hujan \\
\hline 9 & Januari 2007 & 82,93 & hujan \\
\hline 10 & Februari 2007 & 83,48 & hujan \\
\hline 11 & Maret 2007 & 82,41 & hujan \\
\hline 12 & April 2007 & 81,78 & hujan \\
\hline
\end{tabular}

Sumber : Hasil analisis data 2006-2007

Tabel. 4.15. Rasio Aliran Dasar dan Total Aliran Kejadian Banjir Terpilih Gua Ngreneng

\begin{tabular}{|c|c|c|c|c|c|}
\hline No & \multicolumn{2}{|c|}{ Waktu } & \multirow{2}{*}{$\begin{array}{c}\text { Debit puncak } \\
\text { (liter/detik) }\end{array}$} & \multirow{2}{*}{$\begin{array}{c}\text { Rasio } \\
(\%)\end{array}$} & \multirow{2}{*}{$\begin{array}{l}\text { Periode } \\
\text { hujan }\end{array}$} \\
\hline & Tanggal & Jam & & & \\
\hline 1 & $13 / 12 / 06$ & $19: 30$ & 1005,2 & 41,43 & Awal \\
\hline 2 & $15 / 12 / 06$ & $18: 30$ & 882,1 & 44,68 & Awal \\
\hline 3 & $18 / 12 / 06$ & $13: 30$ & 454,6 & 50,85 & Awal \\
\hline 4 & $20 / 12 / 06$ & $18: 30$ & 947,5 & 43,88 & Awal \\
\hline 5 & $22 / 12 / 06$ & $20: 30$ & 514,2 & 44,68 & Awal \\
\hline 6 & $5 / 2 / 07$ & $17: 00$ & 1373,0 & 45,68 & Tengah \\
\hline 7 & $19 / 2 / 07$ & $20: 30$ & 890,2 & 40,79 & Tengah \\
\hline 8 & $20 / 2 / 07$ & $20: 00$ & 1788,9 & 59,77 & Tengah \\
\hline
\end{tabular}

Sumber : Pengukuran lapangan dan analisis data tahun 2006-2007 
Rasio komponen aliran diffuse pada saat banjir terhadap total aliran Gua Ngreneng sangat berbeda dengan rasio bulanannya. Pada awal musim hujan, julat rasio selalu berada dibawah angka $50 \%$ yaitu berkisar antara $41-50 \%$, bahkan pada kejadian banjir pertama kali (13 Desember 2006), rasio menunjukkan angka yang kecil yaitu 41,43 \%. Hal ini mengindikasikan bahwa akuifer karst belum menambah pasokan komponen diffuse flow menuju sungai, sementara pasokan conduit flow dari permukaan karst menjadi dominan saat kejadian banjir. Dari waktu ke waktu kecenderungan rasio diffuse flow saat banjir di Gua Ngreneng menunjukkan peningkatan, dengan angka maksimum sebesar 59,77 \% pada kejadian banjir tanggal 20 Februari 2007.

\section{Pembahasan variasi spasial dan temporal karakteristik aliran SBT Bribin}

Pembahasan kondisi karakteristik aliran di SBT Bribin akan difokuskan pada kemunculan SBT Bribin di Gua Gilap, Gua Bribin, dan Gua Ngreneng, karena hanya tiga lokasi tersebut yang memungkinkan untuk dipasang stasiun pencatat karakteristik aliran. Kondisi aliran di Inlet Sungai Pentung dan Luweng Jomblangan sudah secara ringkas dideskripsikan pada subbab sebelumnya dan tidak mungkin dibahas secara rinci karena tidak tersedianya data aliran secara time series, seperti yang diperoleh di Gua Gilap, Bribin, dan Ngreneng. Pembahasan karakteristik aliran akan dibagi menjadi 2 topik yaitu (a) konstanta resesi aliran-paramater hidrograf banjir dan (b) komposisi komponen aliran yang mengisi sungai bawah tanah.

\section{a. Konstanta Resesi (K), waktu menuju puncak banjir $\left(T_{p}\right)$, dan waktu menuju aliran dasar $\left(\mathbf{T}_{\mathbf{b}}\right)$}

Konstanta resesi yang dibahas pada sub bab ini dibagi menjadi 3 (tiga) yaitu (i) konstanta resesi untuk komponen aliran saluran-conduit $\left(\mathrm{K}_{\mathrm{c}}\right)$; (ii) komponen aliran 
antara-fissure $\left(\mathrm{K}_{\mathrm{i}}\right)$; dan (iii) komponen aliran dasar-diffuse $\left(\mathrm{K}_{\mathrm{b}}\right)$. Selanjutnya, perbandingan nilai konstanta resesi antar tiga gua dapat memberikan gambaran mengenai karakteristik akuifer karst untuk melepaskan ketiga komponen air yang dimilikinya. Sementara itu, parameter hidrograf aliran yang juga dibahas adalah waktu menuju puncak banjir $\left(\mathrm{T}_{\mathrm{p}}\right)$ yang mampu memberikan gambaran terhadap seberapa cepat respon akuifer karst untuk mengimbuh sungai bawah tanah. Parameter ini tentu saja terkait dengan konstanta resesi masing-masing komponen aliran. Demikian juga dengan parameter waktu menuju aliran dasar $\left(T_{b}\right)$ yang mempunyai hubungan erat terutama dengan konstanta resesi aliran dasar $\left(\mathrm{K}_{\mathrm{b}}\right)$. Nilai paramater-parameter tersebut pada tiga gua sepanjang aliran SBT Bribin disajikan pada Tabel 4.16.

Tabel 4.16. Ringkasan Julat Nilai Konstanta Resesi Dan Paramater Banjir SBT Bribin

\begin{tabular}{|l|c|c|c|c|c|}
\hline \multicolumn{1}{|c|}{ Nama gua } & $\mathbf{K}_{\mathbf{c}}$ & $\mathbf{K}_{\mathbf{i}}$ & $\mathbf{K}_{\mathbf{b}}$ & $\mathbf{T}_{\mathbf{p}}(\mathbf{j a m})$ & $\mathbf{T}_{\mathbf{b}}(\mathbf{j a m})$ \\
\hline Gua Gilap & $\begin{array}{c}0,14-0,88 \\
(\text { predominan=0,463) }\end{array}$ & $\begin{array}{c}0,39-0,92 \\
(\text { predominan=0,767) }\end{array}$ & $\begin{array}{c}0,94-0,99 \\
\text { (predominan=0,996) }\end{array}$ & $\begin{array}{c}1,5-5 \\
\text { (predominan=3,03) }\end{array}$ & $\begin{array}{c}7-192 \\
\text { (predominan=36,7) }\end{array}$ \\
\hline Gua Bribin & $\begin{array}{c}0,02-0,519 \\
\text { (predominan=0,332) }\end{array}$ & $\begin{array}{c}0,002-0,95 \\
\text { (predominan=0,825) }\end{array}$ & $\begin{array}{c}0,98-0,99 \\
(\text { predominan=0,998) }\end{array}$ & $\begin{array}{c}2-9,5 \\
\text { (predominan=5,5) }\end{array}$ & $\begin{array}{c}5-192 \\
\text { (predominan=36,3) }\end{array}$ \\
\hline $\begin{array}{l}\text { Gua } \\
\text { Ngreneng }\end{array}$ & $\begin{array}{c}0,188-0,748 \\
\text { (predominan=0,333) }\end{array}$ & $\begin{array}{c}0,732-0,971 \\
\text { (predominan=0,877) }\end{array}$ & $\begin{array}{c}0,978-0,999 \\
\text { (predominan=0,992) }\end{array}$ & $\begin{array}{c}2,5-7,5 \\
\text { (predominan=4,5) }\end{array}$ & $\begin{array}{c}9-240 \\
\text { (predominan=16,8) }\end{array}$ \\
\hline
\end{tabular}

$* \mathrm{~K}_{\mathrm{c}}=$ konstanta resesi conduit; $\mathrm{K}_{\mathrm{i}}=$ konstanta resesi fissure; $\mathrm{K}_{\mathrm{b}}=$ konstanta resesi diffuse

$* \mathrm{~T}_{\mathrm{p}}=$ time to peak; $\mathrm{T}_{\mathrm{b}}=$ time to baseflow

Dari ringkasan data yang disajikan pada Tabel 4.16, terlihat bahwa variasi nilai konstanta resesi untuk komponen aliran diffuse, fissure, dan conduit pada tiga gua di SBT Bribin sangat tinggi. Rata-rata nilai konstanta resesi aliran diffuse $\left(\mathrm{K}_{\mathrm{b}}\right)$ tertinggi adalah di Gua Bribin $(0,998)$ dengan variasi nilai $\mathrm{K}_{\mathrm{b}}$ kecil yang mengindikasikan bahwa terdapat dominasi diffuse flow pasca banjir pada skala waktu yang pendek maupun panjang. Hal ini terbukti dengan tidak pernah keringnya Gua Bribin pada puncak musim kemarau dengan debit minimum masih di atas 1600 
liter/detik. Gua Gilap mempunyai rerata konstanta resesi diffuse yang lebih kecil dibanding yang ditemukan di Gua Bribin, dengan variasi nilai sepanjang musim banjir cukup besar (0,94-0,99), dengan rerata sebesar 0,996. Konstanta resesi diffuse di Gua Ngreneng menunjukkan angka rerata terkecil, yaitu sebesar 0,992. Melihat angka-angka tersebut, dapat diindikasikan bahwa Gua Ngreneng melepaskan aliran dasar (diffuse) lebih cepat dibanding kedua gua yang lain. Fakta ini didukung pula dengan nilai waktu menuju aliran dasar $\left(\mathrm{T}_{\mathrm{b}}\right)$ di Gua Ngreneng yang lebih singkat yaitu sekitar 16,8 jam dibandingkan dengan Gua Gilap dan Bribin yaitu masingmasing 36,7 dan 36,3 jam pasca banjir puncak.

Selanjutnya, nilai konstanta resesi untuk komponen aliran saluran atau conduit $\left(\mathrm{K}_{\mathrm{c}}\right)$ menunjukkan bahwa Gua Ngreneng, Gilap, dan Bribin mempunyai resesi yang curam dengan nilai rata-rata selama periode banjir dibawah 0,5. Menurut Schulz (1976), nilai resesi saluran yang kecil mempunyai karakteristik pelepasan komponen aliran conduit yang lebih cepat dibanding jika nilai $\mathrm{K}_{\mathrm{c}}$ nya lebih besar. Gua Ngreneng mempunyai nilai rata-rata $K_{c}$ yang kecil $(0,333)$ karena pada saat-saat hujan puncak memperoleh aliran permukaan setempat (lokasi gua ini yang berada pada suatu cekungan). Selain itu, sebagai aliran bocoran dari SBT Bribin, nilai $\mathrm{K}_{\mathrm{c}}$ di Gua Ngreneng juga terpengaruh oleh aliran Gua Bribin. Apabila melihat nilai waktu menuju puncak banjir $\left(\mathrm{T}_{\mathrm{p}}\right)$, Gua Ngreneng yang terletak di daerah tangkapan bagian hilir dan merupakan bocoran dari SBT Bribin, seharusnya mempunyai waktu menuju puncak banjir yang relatif sama dengan yang dimiliki oleh Gua Bribin. Tetapi, gua ini mempunyai $T_{p}$ yang 1 jam lebih cepat dari yang dimiliki oleh Gua Bribin. Hal ini berkaitan erat dengan morfologi Gua Ngreneng yang merupakan point recharge dari sungai bawah tanah. Sementara itu, Gua Gilap yang berlokasi di bagian hulu daerah tangkapan mempunyai nilai $\mathrm{K}_{\mathrm{c}}$ dan $\mathrm{T}_{\mathrm{p}}$ yang relatif lebih cepat dibanding yang dijumpai di Gua Ngreneng dan Gua Bribin. 
Nilai konstanta resesi fissure atau aliran antara $\left(\mathrm{K}_{\mathrm{i}}\right)$ pada tiga gua di daerah penelitian tidak menunjukkan perbedaan yang cukup berarti dengan julat yang hampir seimbang $(0,767-0,877)$, berarti pola fissure (retakan berukuran menengah) pada akuifer karst daerah tangkapan SBT Bribin hampir identik. Gua Gilap mempunyai rerata nilai $\left(\mathrm{K}_{\mathrm{i}}\right)$ yang paling rendah $(0,767)$, sementara Gua Bribin memiliki angka yang identik dengan yang dijumpai di Gua Ngreneng (bocoran SBT Bribin) yaitu 0,825 di Gua Bribin dan 0,877 di Gua Ngreneng.

Melihat angka-angka terkait konstanta resesi pada berbagai komponen aliran dan parameter hidrograf banjir lainnya $\left(T_{p}\right.$ dan $\left.T_{b}\right)$, tampak bahwa Gua Gilap yang terletak pada SBT Bribin bagian hulu mempunyai respon yang paling cepat terhadap hujan $\left(\mathrm{T}_{\mathrm{p}}=3\right.$ jam$)$, karena letaknya berada di bagian hulu daerah tangkapan, meskipun mempunyai rerata nilai $\mathrm{K}_{\mathrm{b}}$ yang cukup tinggi $(0,996)$ jika dibandingkan yang dijumpai di Gua Ngreneng, sehingga masih tergolong baik dalam melepaskan air dari akuifer karst. Sementara itu, Gua Ngreneng yang memiliki nilai $\mathrm{K}_{\mathrm{b}}$ terkecil $(0,992)$, ternyata memiliki nilai waktu menuju puncak banjir $\left(\mathrm{T}_{\mathrm{p}}\right)$ yang relatif lama, tetapi mempunyai nilai $\mathrm{T}_{\mathrm{b}}$ yang cepat $(16,8$ jam) yang mengindikasikan bahwa Gua Ngreneng mempunyai sifat akuifer yang lebih cepat melepaskan komponen aliran dasar (diffuse) dan terpengaruh oleh fungsi Gua Ngreneng sebagai pengatus aliran permukaan langsung (point recharge) dari cekungan-cekungan di sekitarnya. Dari fakta ini terlihat bahwa kontrol morfologi permukaan berupa sinkhole berperan dalam mempengaruhi karakteristik parameter hidrograf banjir di Gua Ngreneng. Ringkasan kondisi paramater hidrograf banjir dan konstanta resesi di daerah penelitian disajikan pada Tabel 4.17.

Dari data dan karakteristik yang disajikan pada Tabel 4.17. dapat disimpulkan bahwa sungai di Gua Bribin mempunyai simpanan aliran dasar (aliran mantap) yang 
paling besar dan simpanan tersebut dilepaskan paling perlahan-lahan dibanding yang ditemukan di Gua Ngreneng dan Gua Gilap. Daerah hulu tangkapan hujan SBT Bribin yang diwakili oleh Gua Gilap juga menunjukkan tingkat pelepasan aliran dasar (baseflow) yang lambat, sehingga berkontribusi positif bagi kelangsungan debit SBT Bribin pada musim kemarau. Hanya saja, karena letaknya di bagian hulu, maka respon terhadap banjir termasuk yang paling cepat, dan debit aliran mantap pada musim kemarau tergolong kecil. Sementara itu, Gua Ngreneng yang secara teori letaknya berdekatan dan merupakan bocoran dari SBT Bribin, mempunyai sifat pelepasan akuifer yang berbeda dengan yang ditemukan di Gua Bribin. Selain itu, karakteristik banjirnya sangat dipengaruhi oleh morfologinya sebagai suatu point recharge cekungan-cekungan karst di sekitarnya.

\section{b. Persentase aliran dasar-PAD (diffuse flow)}

Persentase antara debit aliran dasar yang dipisahkan dari hidrograf banjir dibagi dengan debit total aliran dapat digunakan untuk mengkarakterisasikan simpanan atau potensi akuifer untuk mengimbuh sungai bawah tanah sepanjang tahun. Selanjutnya, ilustrasi perubahan persentase aliran dasar bulanan pada gua-gua di sepanjang aliran SBT Bribin disajikan pada Gambar 4.24.

Secara umum, rasio aliran dasar bulanan pada ketiga gua menunjukkan pola yang hampir sama, yaitu meningkat secara perlahan-lahan ketika menuju puncak musim kemarau, kemudian berfluktuasi pada saat musim hujan dengan kecenderungan rasio yang lebih kecil dibanding pada saat musim hujan karena pengaruh meningkatnya kontribusi aliran conduit saat hujan. Gambar 4.24. menunjukkan bahwa secara spasial, semakin ke arah hilir, kecenderungan rasio aliran dasar terhadap aliran total (PAD) adalah meningkat (Gilap<Bribin). Selain itu, Gua 
Bribin mempunyai komposisi rasio yang paling tinggi (>95\%) jika dibandingkan dengan Gua Ngreneng dan Gua Gilap yaitu hanya pada kisaran $80 \%$.

Tabel 4.17. Kondisi Komponen Aliran Akuifer Karst Atas Dasar Perbandingan Angka Paramater Hidrograf Banjir

\begin{tabular}{|c|c|c|c|}
\hline $\begin{array}{l}\text { Paramater } \\
\text { hidrograf }\end{array}$ & $\begin{array}{l}\text { Sungai bawah } \\
\text { tanah }\end{array}$ & Perbandingan & Karakteristik \\
\hline $\mathrm{K}_{\mathrm{b}}=0,996$ & \multirow{5}{*}{ Gilap } & $\begin{array}{l}>\text { Ngreneng } \\
<\text { Bribin }\end{array}$ & $\begin{array}{l}\text { - akuifer melepaskan aliran diffuse lebih cepat daripada GUA Bribin } \\
\text { tapi lebih lambat daripada GUA Ngreneng } \\
\text { - fungsi retakan kecil (diffuse) masih lebih baik dari GUA Ngreneng }\end{array}$ \\
\hline $\mathrm{K}_{\mathrm{i}}=0,767$ & & $\begin{array}{l}<\text { Ngreneng } \\
<\text { Bribin }\end{array}$ & $\begin{array}{l}\text { - simpanan air pada retakan berukuran menengah (fissure) paling cepat } \\
\text { dilepaskan dibanding di GUA Bribin dan Ngreneng }\end{array}$ \\
\hline $\mathrm{K}_{\mathrm{c}}=0,463$ & & $\begin{array}{l}>\text { Ngreneng } \\
>\text { Bribin }\end{array}$ & $\begin{array}{l}\text { - simpanan air pada retakan berukuran besar (conduit) paling lama } \\
\text { dilepas oleh akuifer } \\
\text { - luasan daerah tangkapannya paling kecil dibanding GUA Bribin dan } \\
\text { Ngreneng }\end{array}$ \\
\hline $\mathrm{T}_{\mathrm{p}}=3,03 \mathrm{jam}$ & & $\begin{array}{l}<\text { Ngreneng } \\
<\text { Bribin }\end{array}$ & - jarak tangkapan hujan paling dekat karena berada di bagian hulu \\
\hline $\mathrm{T}_{\mathrm{b}}=36,7 \mathrm{jam}$ & & $\begin{array}{l}>\text { Ngreneng } \\
>\text { Bribin }\end{array}$ & $\begin{array}{l}\text { - simpanan diffuse lama dilepas oleh akuifer } \\
\text { - retakan conduit belum berkembang sebaik GUA Bribin dan } \\
\text { Ngreneng }\end{array}$ \\
\hline $\mathrm{K}_{\mathrm{b}}=0,998$ & \multirow{5}{*}{ Bribin } & $\begin{array}{l}>\text { Ngreneng } \\
>\text { Gilap }\end{array}$ & $\begin{array}{l}\text { - potensi simpanan diffuse paling baik karena paling lama dilepas oleh } \\
\text { akuifer } \\
\text { - debit masih besar di musim kemarau }\end{array}$ \\
\hline $\mathrm{K}_{\mathrm{i}}=0,825$ & & $\begin{array}{l}<\text { Ngreneng } \\
>\text { Gilap }\end{array}$ & $\begin{array}{l}\text { - simpanan pada retakan fissure relatif paling baik (hampir sama } \\
\text { dengan di Ngreneng }\end{array}$ \\
\hline $\mathrm{K}_{\mathrm{c}}=0,332$ & & $\begin{array}{l}<\text { Ngreneng } \\
<\text { Gilap }\end{array}$ & $\begin{array}{l}\text { - adanya point recharge saat hujan yang mengimbuh langsung ke } \\
\text { sungai, sehingga konstanta resesi saluran besar }\end{array}$ \\
\hline $\mathrm{T}_{\mathrm{p}}=5,5 \mathrm{jam}$ & & $\begin{array}{l}>\text { Ngreneng } \\
>\text { Gilap }\end{array}$ & - luas tangkapan hujan paling besar \\
\hline $\mathrm{T}_{\mathrm{b}}=36,3 \mathrm{jam}$ & & $\begin{array}{l}>\text { Ngreneng } \\
<\text { Gilap }\end{array}$ & $\begin{array}{l}\text { - komponen aliran conduit dan diffuse sama-sama dominan pada saat } \\
\text { banjir } \\
\text { - simpanan diffuse lama dilepas oleh akuifer } \\
\end{array}$ \\
\hline $\mathrm{K}_{\mathrm{b}}=0,992$ & \multirow{5}{*}{ Ngreneng } & $\begin{array}{l}<\text { Gilap } \\
<\text { Bribin }\end{array}$ & $\begin{array}{l}\text { - akuifer melepaskan komponen aliran diffuse paling cepat dibanding } \\
\text { GUA Gilap dan Bribin }\end{array}$ \\
\hline $\mathrm{K}_{\mathrm{i}}=0,877$ & & $\begin{array}{l}>\text { Gilap } \\
>\text { Bribin }\end{array}$ & - simpanan pada retakan fissure paling lama dilepas oleh akuifer \\
\hline $\mathrm{K}_{\mathrm{c}}=0,333$ & & $\begin{array}{l}<\text { Gilap } \\
>\text { Bribin }\end{array}$ & $\begin{array}{l}\text { - mulut gua merupakan point recharge aliran permukaan saat hujan } \\
\text { - merupakan bocoran dari S. Bribin sehingga nilainya hampir identik }\end{array}$ \\
\hline $\mathrm{T}_{\mathrm{p}}=4,5 \mathrm{jam}$ & & $\begin{array}{l}>\text { Gilap } \\
<\text { Bribin }\end{array}$ & $\begin{array}{l}\text { - seharusnya nilainya identik dengan di Bribin, tetapi terpengaruh } \\
\text { aliran langsung ke mulut gua pada saat kejadian hujan }\end{array}$ \\
\hline $\mathrm{T}_{\mathrm{b}}=16,8 \mathrm{jam}$ & & $\begin{array}{l}<\text { Gilap } \\
<\text { Bribin }\end{array}$ & $\begin{array}{l}\text { - simpanan aliran dasar paling cepat dilepas oleh akuifer } \\
\text { - retakan conduit kemungkinan sudah dominan }\end{array}$ \\
\hline
\end{tabular}

$* \mathrm{~K}_{\mathrm{c}}=$ konstanta resesi conduit $; \mathrm{K}_{\mathrm{i}}=$ konstanta resesi fissure; $\mathrm{K}_{\mathrm{b}}=$ konstanta resesi diffuse

$* \mathrm{~T}_{\mathrm{p}}=$ time to peak; $\mathrm{T}_{\mathrm{b}}=$ time to baseflow

Fakta lain yang menarik adalah kenyataan bahwa pola kecenderungan rasio

aliran dasar bulanan di Gua Ngreneng pada saat musim hujan menunjukkan

kecenderungan meningkat, sementara di Gua Gilap dan Bribin memiliki pola 
kecenderungan menurun. Adanya anomali penurunan aliran dasar pada Bulan Februari 2007 di Gua Gilap disebabkan bulan ini merupakan bulan puncak di daerah hulu (daerah lain puncak hujan bukan pada bulan ini), yang mengakibatkan dominasi aliran conduit di Gua Gilap lebih besar dibanding bulan-bulan yang lain.

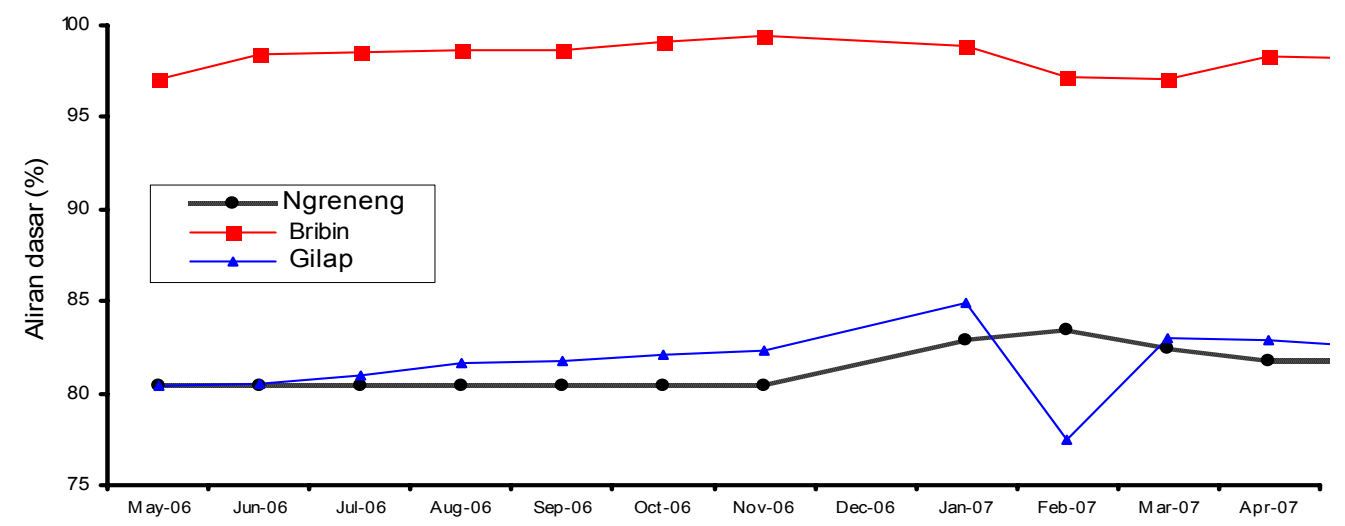

Gambar 4.24. Rasio Aliran Dasar Bulanan Sepanjang SBT Bribin Mei 2006 - April 2007

Fakta ini memperkuat argumentasi sebelumnya bahwa karena morfologi mulut Gua Ngreneng merupakan sinkhole dari cekungan karst, maka dominasi aliran conduit hanya sesaat $\left(\mathrm{K}_{\mathrm{c}}\right.$ dan $\mathrm{T}_{\mathrm{b}}$ kecil), sehingga jika dirata-rata dalam sebulan terlihat bahwa peran aliran conduit di gua ini kecil yang menyebabkan rasio aliran dasarnya justru meningkat. Tetapi, jika analisis rasio aliran dasar ini dilakukan pada saat kejadian banjir saja, maka persentase aliran dasar pada semua gua menunjukkan cenderung menurun yang menunjukkan adanya penambahan kontribusi komponen aliran conduit yang besar (Tabel 4.18).

Secara rerata Gua Ngreneng memiliki komposisi aliran dasar yang paling sedikit, yaitu berkisar pada angka 46,5\%. Hal ini menunjukkan bahwa penambahan aliran dasar (diffuse) pada saat kejadian banjir jauh lebih sedikit dibawah penambahan aliran langsung (conduit), sebagai akibat morfologi mulut Gua Ngreneng yang berfungsi sebagai sebuah sinkhole. 
Gua Bribin ternyata memiliki rerata jumlah aliran dasar yang tidak berbeda jauh jika dibandingkan dengan persentase bulanannya. Hal ini mengindikasikan dominasi aliran dasar di Gua Bribin lebih baik dibanding dua gua lainnya, sehingga sesuai dengan hipotesis pertama. Sementara itu, rasio saat banjir di Gua Gilap memiliki rerata nilai sebesar $65,41 \%$, lebih sedikit dibanding rasio bulanannya tetapi lebih signifikan dengan yang ditemukan di Gua Ngreneng. Hal ini menunjukkan bahwa pola retakan conduit di Gua Gilap belum begitu berkembang dibandingkan dengan yang dijumpai di Gua Ngreneng. Secara konseptual, variasi spasial dan temporal pelepasan komponen aliran sepanjang SBT Bribin disajikan pada Gambar 4.25 .

Tabel. 4.18. Persentase Aliran Dasar (PAD) Saat Kejadian banjir

\begin{tabular}{|c|c|c|c|c|c|c|c|c|c|}
\hline \multirow{3}{*}{ No } & \multicolumn{3}{|c|}{ Gua Gilap } & \multicolumn{3}{|c|}{ Gua Bribin } & \multicolumn{3}{|c|}{ Gua Ngreneng } \\
\hline & \multicolumn{2}{|c|}{ Waktu } & \multirow{2}{*}{$\begin{array}{c}\text { PAD } \\
(\%)\end{array}$} & \multicolumn{2}{|c|}{ Waktu } & \multirow{2}{*}{$\begin{array}{c}\text { PAD } \\
\text { (\%) }\end{array}$} & \multicolumn{2}{|c|}{ Waktu } & \multirow{2}{*}{$\begin{array}{c}\text { PAD } \\
(\%)\end{array}$} \\
\hline & Tanggal & jam & & Tanggal & jam & & Tanggal & jam & \\
\hline 1 & $13 / 12 / 06$ & 19:00 & 45,08 & $6 / 12 / 06$ & $22: 30$ & 98,38 & $13 / 12 / 06$ & $19: 30$ & 41,43 \\
\hline 2 & $22 / 12 / 06$ & $15: 30$ & 55,52 & $7 / 12 / 06$ & $23: 00$ & 99,02 & $15 / 12 / 06$ & $18: 30$ & 44,68 \\
\hline 3 & $31 / 12 / 06$ & $06: 30$ & 57,75 & $13 / 12 / 06$ & $19: 30$ & 86,16 & $18 / 12 / 06$ & $13: 30$ & 50,85 \\
\hline 4 & $16 / 2 / 07$ & $16: 30$ & 57,25 & $29 / 12 / 06$ & $00: 30$ & 77,72 & $20 / 12 / 06$ & $18: 30$ & 43,88 \\
\hline 5 & $24 / 2 / 07$ & 19:00 & 51,25 & $30 / 12 / 06$ & $17: 00$ & 82,69 & $22 / 12 / 06$ & $20: 30$ & 44,68 \\
\hline 6 & $26 / 2 / 07$ & $18: 00$ & 58,55 & $16 / 2 / 07$ & $18: 00$ & 92,29 & $5 / 2 / 07$ & $17: 00$ & 45,68 \\
\hline 7 & $6 / 3 / 07$ & $21: 00$ & 79,91 & $22 / 2 / 07$ & $21: 00$ & 81,81 & $19 / 2 / 07$ & $20: 30$ & 40,79 \\
\hline 8 & $9 / 3 / 07$ & 19:00 & 78,18 & $23 / 2 / 07$ & $20: 00$ & 84,51 & $20 / 2 / 07$ & $20: 00$ & 59,77 \\
\hline 9 & $14 / 3 / 07$ & 02:00 & 78,92 & $28 / 2 / 07$ & $01: 30$ & 89,91 & & & \\
\hline 10 & $19 / 3 / 07$ & 00:00 & 72,75 & $7 / 3 / 07$ & 05:00 & 99,05 & & & \\
\hline 11 & $21 / 3 / 07$ & 08:00 & 77,20 & $7 / 4 / 07$ & $22: 00$ & 95,50 & & & \\
\hline 12 & $23 / 3 / 07$ & 08:00 & 50,88 & $27 / 4 / 07$ & $20: 00$ & 97,25 & & & \\
\hline 13 & $7 / 4 / 07$ & $01: 30$ & 70,33 & & & & & & \\
\hline 14 & $10 / 4 / 07$ & $18: 00$ & 62,94 & & & & & & \\
\hline 15 & $11 / 4 / 07$ & 15:00 & 76,30 & & & & & & \\
\hline 16 & $16 / 4 / 07$ & $23: 30$ & 73,80 & & & & & & \\
\hline \multicolumn{3}{|c|}{ Rerata PAD } & 65,41 & & & 90,36 & & & 46,47 \\
\hline
\end{tabular}

Sumber : hasil analisis data 2006-2007 


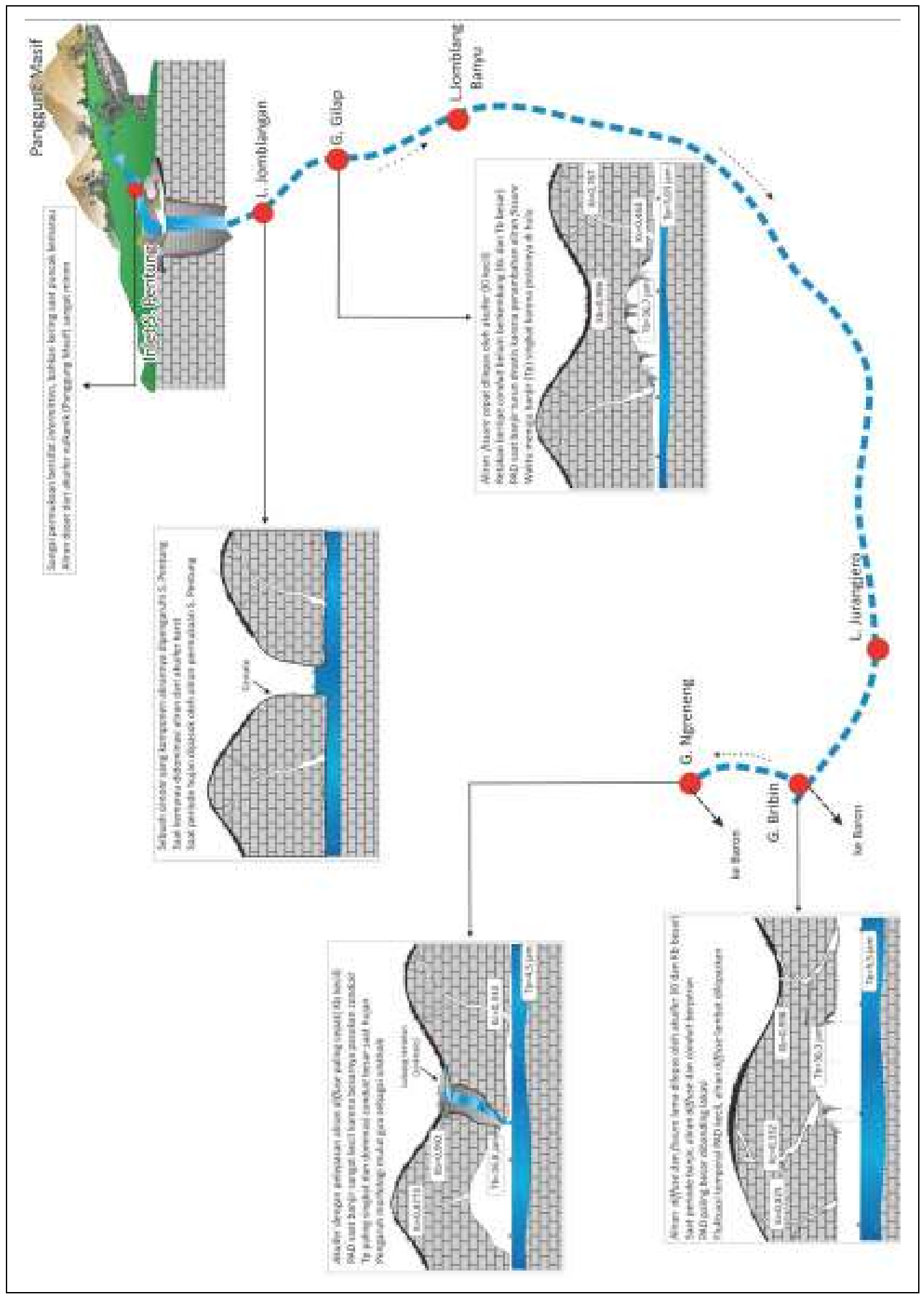

Gambar 4.25. Variasi Spasial dan Temporal Pelepasan Aliran Akuifer Karst di SBT Bribin 


\section{Variasi Spasial dan Temporal Karakter Hidrogeokimia SBT Bribin dan Hubungannya dengan Sifat Alirannya}

Hasil dan pembahasan terkait karakter hidrogeokimia sepanjang aliran SBT Bribin didasarkan atas analisis data hasil sampling pada titik-titik yang mewakili distribusi keruangan SBT Bribin dari hulu ke hilir yang selanjutnya disajikan pada Tabel 4.19. Pada sub bab ini karakter hidrogeokimia di Gua Bribin akan dibahas tersendiri, atas dasar banyaknya jumlah sampel yang diambil, bahkan memungkinkan pengambilan sampel pada saat banjir puncak yang tidak mungkin diambil pada guagua yang lain.

Tabel 4.19. Posisi Sampling Hidrogeokimia SBT Bribin

\begin{tabular}{|l|l|c|c|c|}
\hline No & \multicolumn{1}{|c|}{ Nama lokasi } & Koordinat UTM & Posisi & $\begin{array}{c}\text { Alat pencatat } \\
\text { tinggi muka air }\end{array}$ \\
\hline 1 & Inlet Sungai Pentung & 49 M 472674;9122165 & hulu & tidak ada \\
\hline 2 & Luweng Jomblangan & 49 M 472076;9122244 & hulu & tidak ada \\
\hline 3 & Gua Gilap & 49 M 472076;9119137 & hulu & ada \\
\hline 4 & Gua Bribin & 49 M 464666;9111646 & hilir & ada \\
\hline 5 & Gua Ngreneng & 49 M 463590;9112961 & bocoran & ada \\
\hline 6 & Tetesan Gua Gilap & 49 M 472076;9119137 & hulu & tidak ada \\
\hline 7 & Tetesan Gua Bribin & 49 M 464666;9111646 & hilir & tidak ada \\
\hline
\end{tabular}

\section{Variasi temporal karakter hidrogeokimia di Gua Bribin}

Karakteristik Hidrogeokimia di Gua Bribin sepanjang tahun secara temporal dapat dibagi menjadi periode pengukuran yaitu: (i) pada saat musim kemarau yang diwakili sebanyak 8 kali pengukuran pada kurun waktu Maret 2006 sampai dengan November 2006; (ii) pada 2 kali kejadian banjir yaitu banjir 22-23 Februari 2007 dan 19 Maret 2007; dan (iii) pada saat musim hujan bukan pada saat kejadian banjir. Data lengkap hasil pengukuran paramater kualitas air dan analisis laboratorium air sungai bawah tanah di Gua Bribin disajikan pada Tabel 4.20, dan hidrokemografnya disajikan pada Gambar 4.26. dan 4.27. 
Tabel 4.20. Komposisi Kimia Sampel Air Gua Bribin Sepanjang Tahun

\begin{tabular}{|c|c|c|c|c|c|c|c|c|c|c|c|c|c|c|}
\hline \multicolumn{2}{|c|}{ Waktu } & \multirow{2}{*}{$\begin{array}{c}\text { DHL } \\
(\mu \mathrm{mhos} / \mathrm{cm})\end{array}$} & \multirow{2}{*}{$\mathbf{p H}$} & \multirow{2}{*}{$\begin{array}{c}\text { Suhu } \\
\left({ }^{\circ} \mathrm{C}\right)\end{array}$} & \multirow{2}{*}{ Eh } & \multirow{2}{*}{$\begin{array}{c}\mathrm{Ca}^{2+} \\
(\mathrm{mg} / \mathrm{l})\end{array}$} & \multirow{2}{*}{$\begin{array}{l}\mathrm{Mg}^{2+} \\
(\mathrm{mg} / \mathrm{l})\end{array}$} & \multirow{2}{*}{$\begin{array}{c}\mathrm{Na}^{+} \\
(\mathrm{mg} / \mathrm{l})\end{array}$} & \multirow{2}{*}{$\begin{array}{c}\mathrm{K}^{+} \\
(\mathrm{mg} / \mathrm{l})\end{array}$} & \multirow{2}{*}{$\begin{array}{c}\mathrm{HCO}_{3}^{-} \\
(\mathrm{mg} / \mathrm{l})\end{array}$} & \multirow{2}{*}{$\underset{(\mathrm{mg} / \mathrm{l})}{\mathrm{Cl}^{-}}$} & \multirow{2}{*}{$\begin{array}{l}\mathrm{SO}_{4}{ }^{2-} \\
(\mathrm{mg} / \mathrm{l})\end{array}$} & \multirow{2}{*}{$\begin{array}{l}\text { Debit } \\
\text { (l/dt) }\end{array}$} & \multirow{2}{*}{$\begin{array}{l}\text { PAD } \\
\text { (\%) }\end{array}$} \\
\hline tanggal & jam & & & & & & & & & & & & & \\
\hline \multicolumn{15}{|c|}{ Musim kemarau } \\
\hline $23 / 3 / 06$ & 11:00 & 486 & 6,96 & 27,3 & 0,004 & 86,13 & 3,40 & 3,10 & 1,50 & 242,02 & 7,40 & 5,28 & 2118,5 & 93,4 \\
\hline $26 / 4 / 06$ & $12: 30$ & 491 & 6,99 & 27,2 & 0,000 & 91,78 & 8,90 & 15,50 & 8,80 & 245,30 & 9,10 & 8,17 & 2057,0 & 95,6 \\
\hline $22 / 5 / 06$ & 12:00 & 493 & 7,07 & 27,1 & 0,002 & 93,90 & 16,50 & 2,50 & 1,30 & 258,11 & 5,50 & 7,68 & 1971,5 & 97,7 \\
\hline $20 / 6 / 06$ & $10: 30$ & 497 & 7,17 & 27,1 & 0,009 & 97,24 & 16,20 & 2,90 & 0,90 & 264,22 & 12,50 & 14,41 & 1770,2 & 98,3 \\
\hline $19 / 7 / 06$ & $9: 30$ & 507 & 7,28 & 27,1 & $-0,020$ & 98,84 & 8,70 & 2,80 & 0,70 & 265,44 & 7,40 & 12,01 & 1734,9 & 98,5 \\
\hline $22 / 8 / 06$ & $9: 30$ & 508 & 7,37 & 27,1 & $-0,023$ & 104,14 & 13,20 & 2,90 & 0,80 & 267,88 & 3,70 & 12,49 & 1722,7 & 98,6 \\
\hline $20 / 9 / 06$ & $9: 30$ & 509 & 7,38 & 27,2 & $-0,038$ & 109,78 & 13,70 & 3,10 & 1,10 & 271,02 & 7,40 & 13,45 & 1714,1 & 98,7 \\
\hline $15 / 11 / 06$ & $10: 30$ & 511 & 7,39 & 27,2 & 0,009 & 110,27 & 18,80 & 3,10 & 1,10 & 278,02 & 5,50 & 12,97 & 1666,7 & 99,3 \\
\hline \multicolumn{15}{|c|}{ Banjir 22-23 Februari 2007} \\
\hline $22 / 2 / 07$ & $16: 30$ & 443 & 6,48 & 27,0 & 0,011 & 40,00 & 2,90 & 0,11 & 2,50 & 104,01 & 10,30 & 2,90 & 1693,4 & 100,0 \\
\hline $22 / 2 / 07$ & $18: 30$ & 453 & 6,46 & 26,7 & 0,008 & 33,60 & 7,30 & 0,09 & 2,00 & 120,01 & 7,70 & 3,20 & 1777,5 & 97,0 \\
\hline $22 / 2 / 07$ & $21: 00$ & 461 & 6,89 & 26,8 & $-0,014$ & 32,67 & 7,00 & 0,14 & 3,20 & 125,01 & 6,80 & 3,20 & 2440,7 & 71,0 \\
\hline $22 / 2 / 07$ & $22: 30$ & 469 & 6,97 & 26,8 & $-0,016$ & 31,66 & 5,90 & 0,15 & 3,50 & 110,21 & 14,00 & 2,20 & 2372,2 & 73,5 \\
\hline $23 / 2 / 07$ & $0: 00$ & 466 & 7,01 & 26,8 & $-0,017$ & 30,66 & 2,30 & 0,11 & 2,50 & 99,34 & 14,00 & 1,90 & 2298,9 & 76,3 \\
\hline $23 / 2 / 07$ & $2: 00$ & 440 & 7,03 & 26,9 & $-0,019$ & 30,40 & 6,80 & 0,12 & 2,80 & 102,01 & 14,00 & 2,20 & 2165,7 & 81,4 \\
\hline $23 / 2 / 07$ & 5:00 & 380 & 6,83 & 26,4 & $-0,007$ & 33,20 & 7,20 & 0,12 & 2,80 & 114,01 & 10,00 & 2,20 & 2050,9 & 86,4 \\
\hline $23 / 2 / 07$ & $7: 30$ & 351 & 6,89 & 26,4 & -0 & 35,40 & 30 & 0,12 & 2,80 & 126,01 & 10,00 & 1,20 & 2008,1 & 88,5 \\
\hline $23 / 2 / 07$ & $11: 00$ & 358 & 6,97 & 26,5 & $-0,015$ & 38,40 & 7,70 & 0,12 & 2,80 & 149,01 & 12,00 & 1,50 & 1947,1 & 91,6 \\
\hline $23 / 2 / 07$ & 14:00 & 370 & 6,94 & 26,6 & $-0,013$ & 34,20 & 9,20 & 0,10 & 2,40 & 124,01 & 13,00 & 1,10 & 1891,0 & 94,4 \\
\hline \multicolumn{15}{|c|}{ Banjir 19 Maret 2007} \\
\hline $19 / 3 / 07$ & $0: 00$ & 490 & 6,42 & 27,0 & 0,016 & 52,10 & 7,30 & 0,16 & 3,60 & 189,92 & 15,10 & 0,16 & 1798,3 & 98,1 \\
\hline $19 / 3 / 07$ & $1: 00$ & 491 & 6,57 & 26,9 & 0,007 & 69,10 & 13,10 & 0,14 & 3,30 & 223,71 & 13,30 & 0,08 & 1821,4 & 96,8 \\
\hline $19 / 3 / 07$ & $2: 00$ & 492 & 6,64 & 26,9 & 0,003 & 74,40 & 11,10 & 0,17 & 3,80 & 247,41 & 9,50 & 0,11 & 1908,1 & 92,5 \\
\hline $19 / 3 / 07$ & 3:00 & 493 & 6,65 & 26,9 & 0,002 & 63,70 & 11,20 & 0,15 & 3,50 & 250,52 & 9,50 & 0,10 & 2033,8 & 86,9 \\
\hline $19 / 3 / 07$ & $4: 00$ & 493 & 6,69 & 26,9 & 0,002 & 55,80 & 13,00 & 0,16 & 3,70 & 251,31 & 11,40 & 0,06 & 2069,2 & 85,5 \\
\hline $19 / 3 / 07$ & $6: 00$ & 492 & 6,89 & 27,0 & $-0,011$ & 76,30 & 9,10 & 0,17 & 3,80 & 252,02 & 13,30 & 0,07 & 2044,8 & 86,8 \\
\hline $19 / 3 / 07$ & 8:00 & 474 & 6,97 & 27,5 & $-0,017$ & 70,00 & 8,00 & 0,14 & 3,20 & 253,41 & 13,30 & 0,08 & 2004,5 & 88,8 \\
\hline 19/3/07 & 11:00 & 480 & 7,05 & 27,8 & $-0,017$ & 76,30 & 7,70 & 0,13 & 3,00 & 255,02 & 9,50 & 0,11 & 1927,6 & 92,5 \\
\hline \multicolumn{15}{|c|}{ Musim hujan bukan pada saat kejadian banjir } \\
\hline $6 / 2 / 07$ & $19: 30$ & 482 & 6,73 & 27,0 & 0,003 & 34,50 & 16,20 & 4,40 & 2,10 & 184,01 & 8,90 & 9,40 & 1738,2 & 97,99 \\
\hline $20 / 2 / 07$ & $10: 00$ & 408 & 6,53 & 26,8 & 12,00 & 37,80 & 14,80 & 3,20 & 1,10 & 176,01 & 15,00 & 6,20 & 1814,1 & 95,53 \\
\hline $2 / 3 / 07$ & $11: 00$ & 478 & 6,53 & 26,9 & 0,009 & 46,50 & 3,30 & 2,80 & 1,50 & 153,01 & 9,50 & 2,90 & 1865,8 & 99,04 \\
\hline $9 / 3 / 07$ & $10: 30$ & 491 & 6,58 & 26,9 & 0,008 & 50,20 & 9,10 & 2,80 & 1,80 & 197,01 & 11,40 & 3,10 & 1758,9 & 99,63 \\
\hline $16 / 3 / 07$ & $14: 30$ & 485 & 6,69 & 27,0 & 0,002 & 52,40 & 12,40 & 4,40 & 1,40 & 240,02 & 9,50 & 2,90 & 1809,0 & 98,11 \\
\hline $26 / 3 / 07$ & $21: 00$ & 476 & 6,34 & 26,8 & $-0,017$ & 50,10 & 15,60 & 3,30 & 1,30 & 203,01 & 15,60 & 3,70 & 2018,2 & 96,01 \\
\hline $30 / 3 / 07$ & $21: 00$ & 488 & 6,14 & 27,5 & $-0,024$ & 48,80 & 15,40 & 3,60 & 1,80 & 191,01 & 13,80 & 5,60 & 1935,3 & 98,61 \\
\hline
\end{tabular}

Sumber : pengukuran lapangan dan analisis laboratorium tahun 2006-2007 


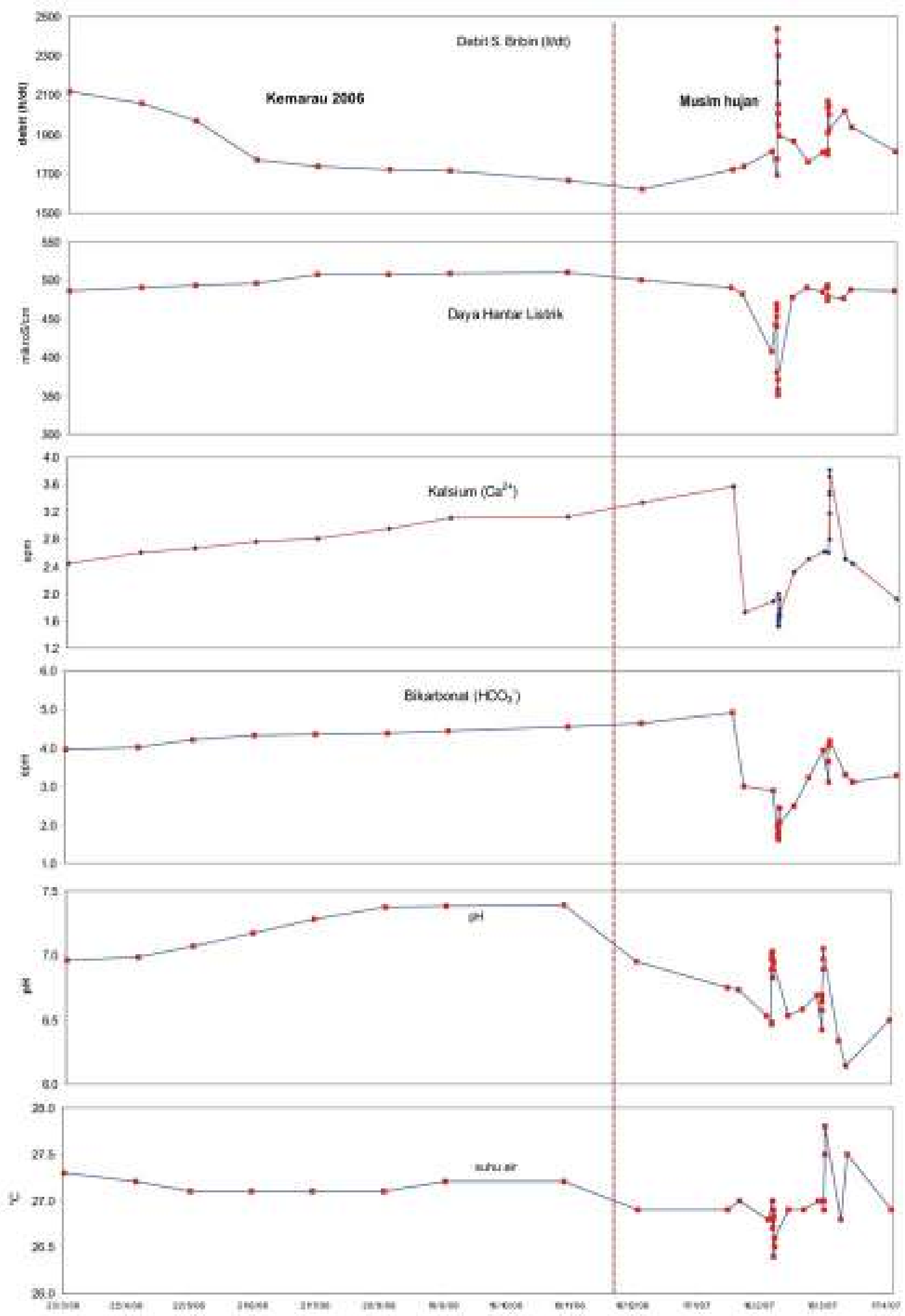

Gambar 4.26. Hidrokemograf Gua Bribin Sepanjang Tahun (sumbu x tidak diskalakan) 


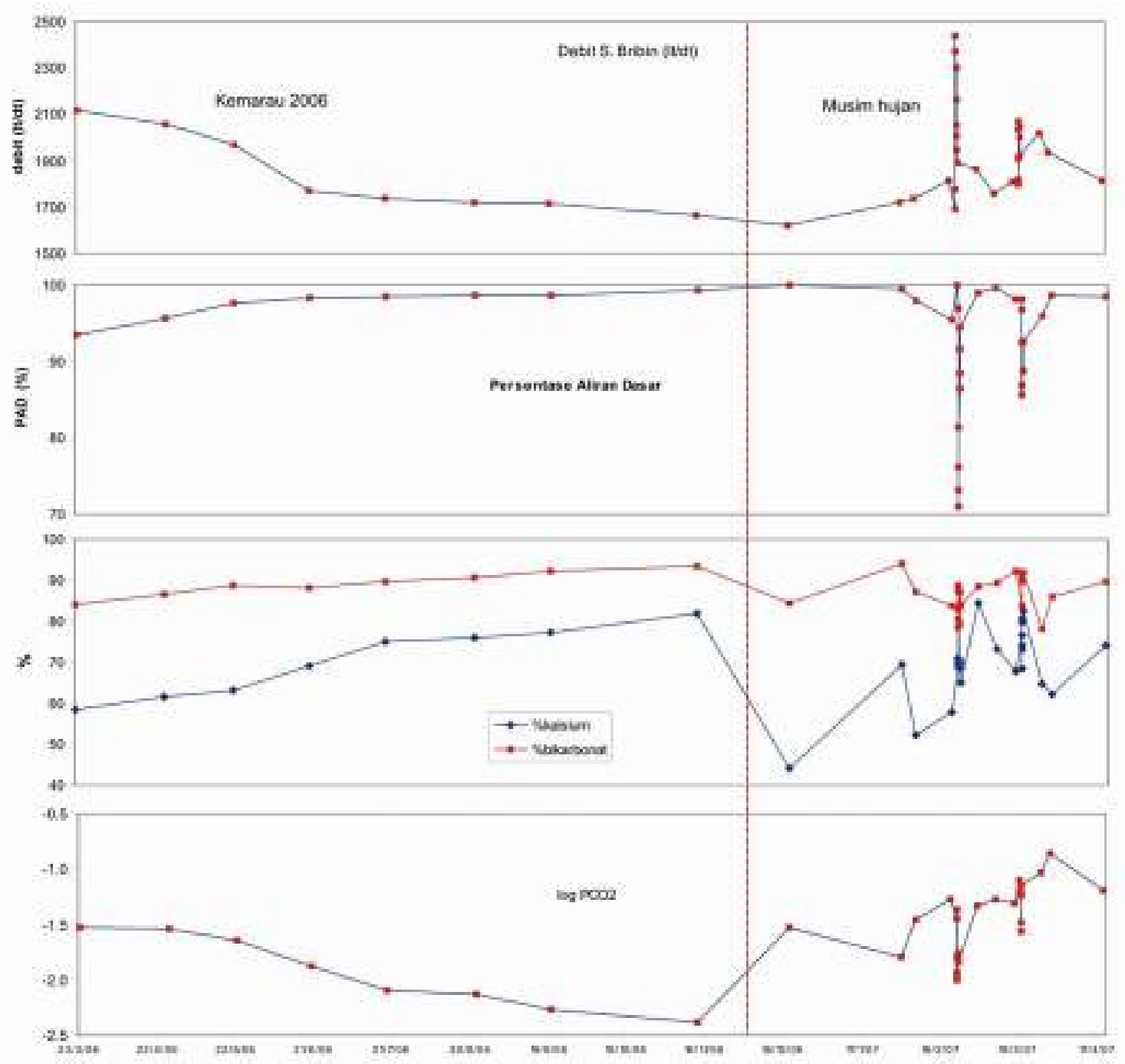

Gambar 4.27. Variasi Debit, Persentase Aliran Dasar, $\log \mathrm{PCO}_{2}$ dan Persentase Kalsium dan Bikarbonat Gua Bribin Sepanjang Tahun (sumbu x tidak diskalakan)

Pada saat akhir hujan menuju musim kemarau, sungai bawah tanah menunjukkan penurunan debit aliran menuju ke kondisi dominasi aliran dasar (diffuse flow), yang oleh Raeisi dan Karami (1997) disebut sebagai kondisi resesi. Pada periode ini, kandungan unsur terlarut utama di sungai bawah tanah yaitu kalsium dan bikarbonat sedikit demi sedikit mengalami kenaikan karena pelepasan diffuse flow sebagai air infiltrasi yang telah jenuh melarutkan mineral karbonat pada akuifer karst dari zone epikarst dan minimnya aliran conduit (Ford and Williams, 
1992). Scatter plot DHL-kalsium dan DHL-bikarbonat saat kemarau menunjukkan hubungan yang positif antara kenaikan DHL terhadap kalsium dan bikarbonat, dengan nilai $\mathrm{R}^{2}=0,89$ untuk DHL-kalsium dan $\mathrm{R}^{2}=0,87$ untuk DHL-bikarbonat (Gambar 4.28.). Hubungan yang yang kuat ini menunjukkan adanya interaksi antara air dan batuan (water-rock interaction) pada dominasi diffuse flow. Selanjutnya, scatter plot $\left(\mathrm{Na}^{+}-\mathrm{Cl}^{-}\right)$juga digunakan untuk mengetahui percampuran atau mixing pada sungai bawah tanah dengan asumsi bahwa air hujan mempunyai rasio 1:1 antara ion natrium dan klorida dalam satuan miliequivalent per liter (epm), seperti yang disajikan pada Gambar 4.29.
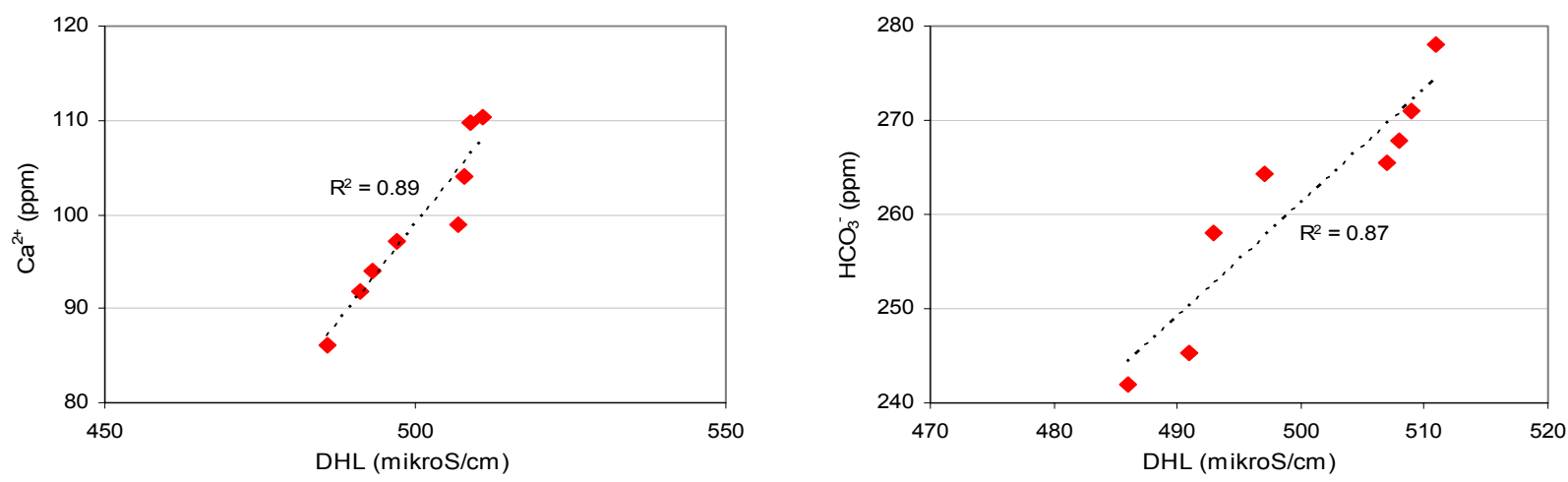

Gambar 4.28. Scatter Plot Hubungan DHL-Kalsium (kiri) dan DHL-Bikarbonat (kanan) Gua Bribin Musim Kemarau

Dari Gambar 4.29. terlihat bahwa sampel-sampel pada akhir musim hujan mempunyai posisi yang lebih dekat kepada garis rasio 1:1 yang menunjukkan adanya sisa-sisa pengaruh air hujan melalui proses dilution by precipitation (Liu, et al, 2004a). Sementara itu, posisi sampel pada bulan-bulan puncak kemarau dan akhir kemarau cenderung menjauh ke selah kiri dari garis rasio 1:1 yang menunjukkan lebih intensifnya proses water-rock interaction. Dari Gambar 4.28 terlihat pula evolusi dominasi air hujan yang semakin berkurang seiring pergantian musim dari akhir musim hujan-puncak kemarau-akhir kemarau, yang secara teoritis digantikan oleh aliran diffuse. 


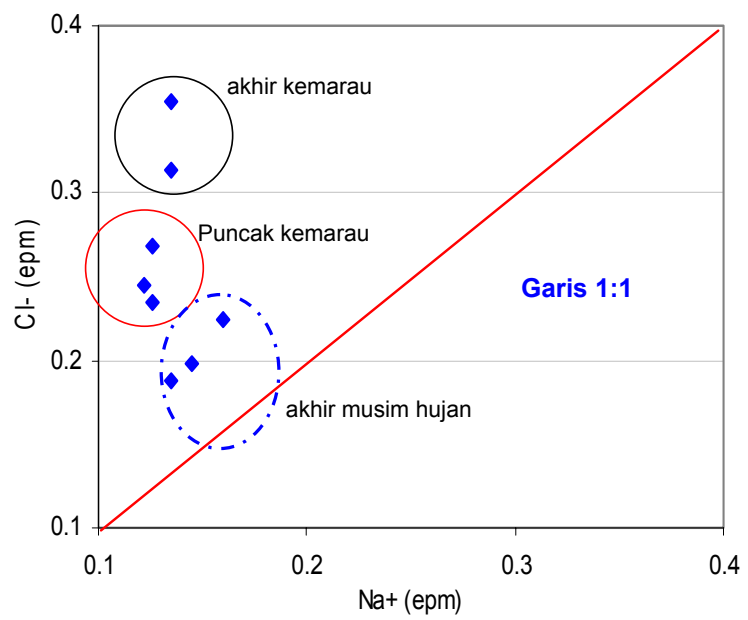

Gambar 4.29. Scatter Plot Ion Natrium dan Klorida Gua Bribin Musim Kemarau

Hal yang sama juga ditunjukkan dengan pada scatter plot antara persentase aliran dasar (PAD) dan unsur-unsur dominan terlarut, yang mempunyai hubungan determinasi cukup besar (Gambar 4.30), seperti yang dijelaskan oleh Etfimi (2005) dan Liu, et al.(2004b). Pada saat musim kemarau ini, di Gua Bribin juga terlihat adanya penurunan gradual tekanan parsial gas karbondioksida yang mempunyai hubungan determinasi $\left(\mathrm{R}^{2}\right)$ yang cukup kuat dengan kenaikan kandungan kalsium dan karbonat dalam air seperti yang disajikan pada Gambar 4.31.
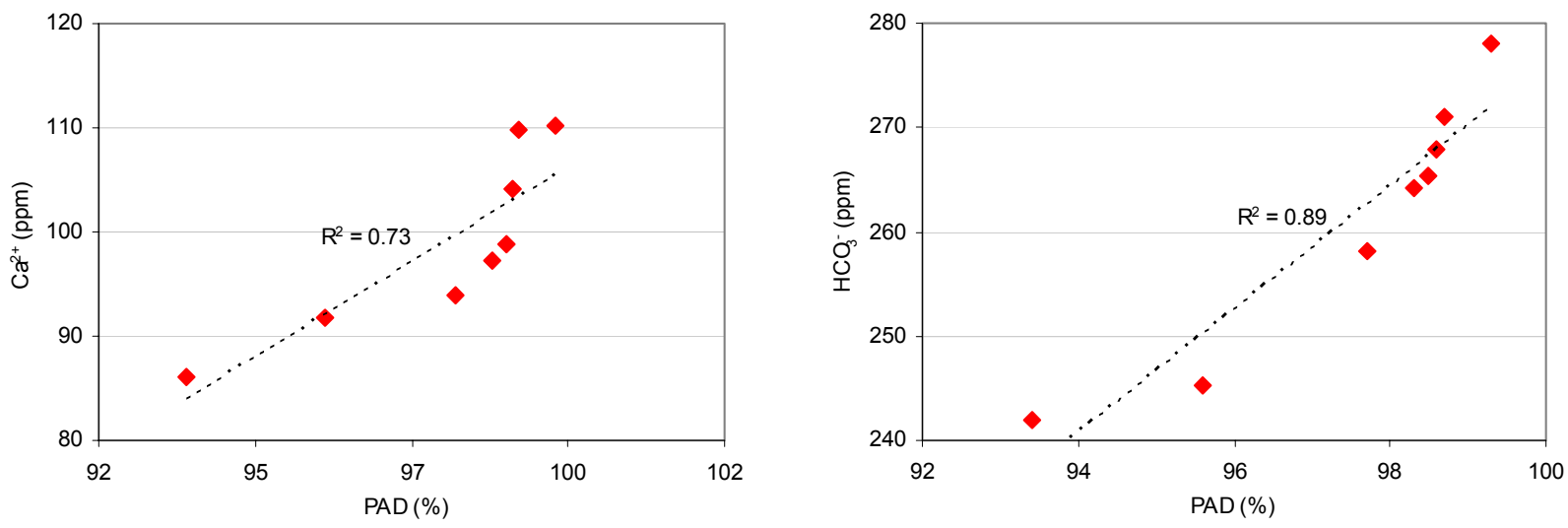

Gambar 4.30. Scatter Plot Hubungan PAD-Kalsium (kiri) dan PAD-Bikarbonat (kanan) Gua Bribin Musim Kemarau 

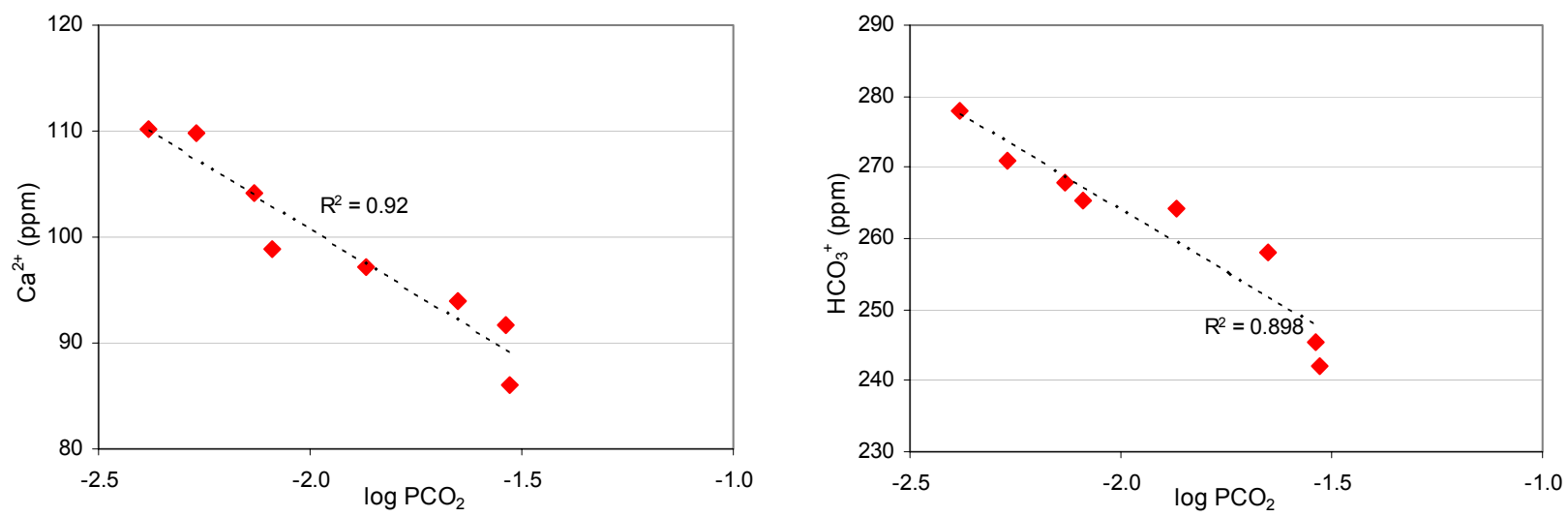

Gambar 4.31. Scatter Plot Log $\mathrm{PCO}_{2}$-Kalsium (Kiri) Dan Log $\mathrm{PCO}_{2}$-Bikarbonat (Kanan) Musim Kemarau di Gua Bribin

Dari kemograf kejadian banjir yang disajikan, terlihat bahwa aliran diffuse turun jika terjadi kenaikan debit aliran pada kejadian banjir 22-23 Februari 2007, atau dengan kata lain persentase aliran dasar menurun seiring dengan naiknya debit aliran menuju debit puncak. Sementara itu, respon aliran diffuse pada banjir 19 Maret 2007 juga memiliki pola dan kecenderungan yang sama Dari fenomena pada dua kali kejadian banjir di Gua Bribin tersebut dapat dijelaskan bahwa persentase aliran diffuse mempunyai kecenderungan turun seiring dengan peningkatan debit aliran menuju debit puncak dan kemudian sedikit demi sedikit meningkat sesaat setelah melewati debit puncak, yang hubungan scatter plot-nya disajikan pada Gambar 4.32.
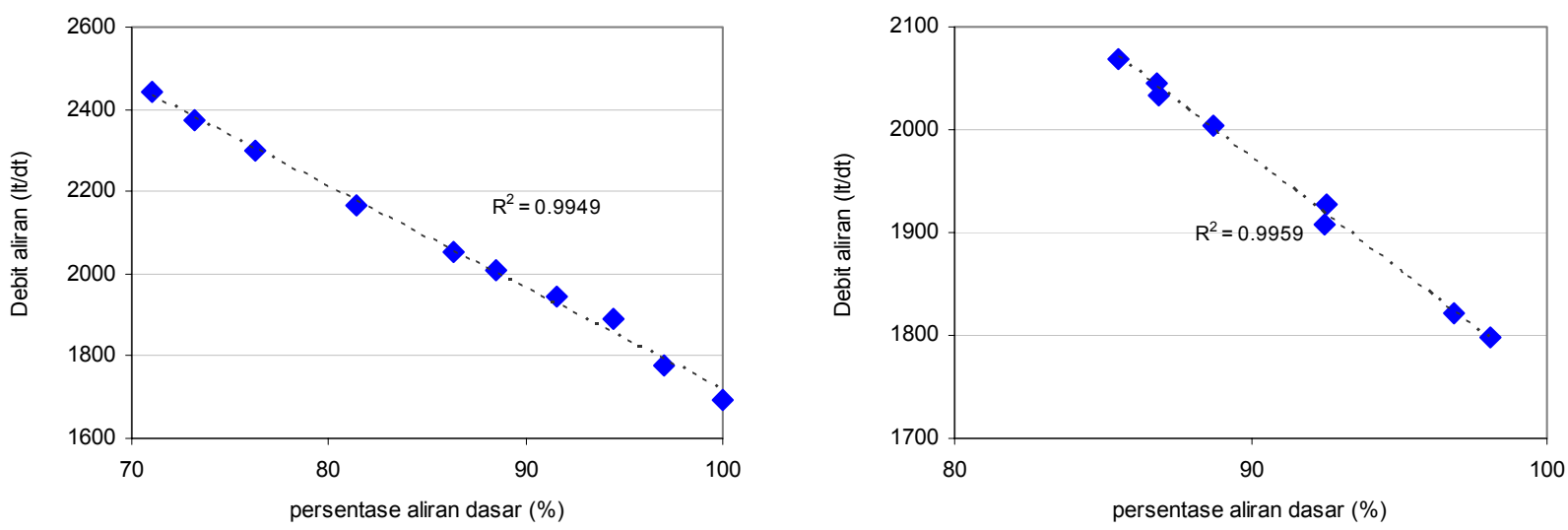

Gambar 4.32. Scatter Plot Hubungan Aliran Dasar-Debit Aliran Gua Bribin pada Kejadian Banjir 22-23 Februari 2007 (kiri) dan pada Kejadian Banjir 19 Maret 2008 (kanan) 
Dari Gambar 4.32. terlihat bahwa terdapat hubungan negatif antara debit aliran dan persentase aliran dasar pada kedua kejadian banjir, bahkan nilai determinasinya $\left(\mathrm{R}^{2}\right)$ mencapai angka 0,995 dan 0,996 pada kejadian banjir pertama dan kedua. Hal ini disebakan turunnya persentase aliran diffuse dari akuifer karst yang tergantikan atau tercampurkan oleh komponen air hujan yang berasal dari dari zona permukaan karst. Pada periode turunnya persentase aliran dasar terjadi proses pengenceran oleh air hujan (dilution by precipitation) seiring dengan naiknya debit sungai Bribin. Kemudian, tingginya hubungan antara kenaikan debit dan penurunan persentase aliran diffuse dan sebaliknya, menunjukkan bahwa sungai bawah tanah di daerah penelitian mempunyai lorong conduit yang sudah berkembang baik.

Jika dilihat dari variasi perubahan nilai $\log \mathrm{PCO}_{2}$, maka dapat dijelaskan bahwa terdapat perbedaan kecenderungan variasi nilai log $\mathrm{PCO}_{2}$ dan debit aliran pada banjir 22-23 Februari 2007 dan banjir 19 Maret 2007. Pada kejadian banjir yang pertama (puncak musim hujan), variasi nilai log $\mathrm{PCO}_{2}$ pada saat aliran menuju debit puncak (naik perlahan-lahan) menunjukkan kecenderungan penurunan, bahkan masih berlanjut sampai beberapa saat pasca debit puncak terlewati. Penurunan nilai menunjukkan bahwa tekanan parsial gas karbondioksida dalam air masih terpengaruh oleh sisa-sisa aliran diffuse dan fissure yang terdorong oleh air hujan yang datang sesudahnya, sehingga mempunyai kecenderungan menurun secara perlahan-lahan. Hal ini sesuai yang dijelaskan oleh Vesper dan White (2003), Raeisi dan Karami (1997), serta Liu, et al. (2004b). Selanjutnya, pada permulaan periode resesi, nilai $\log \mathrm{PCO}_{2}$ menunjukkan kenaikan yang signifikan meskipun belum mampu mencapai kondisi seperti pada saat kondisi resesi sebelum banjir karena adanya proses percampuran (mixing) antar komponen-komponen aliran karst (diffuse, fissure, conduit). Sementara itu, pola nilai $\log \mathrm{PCO}_{2}$ pada kejadian banjir 19 Maret 2007 yang sudah memasuki periode akhir musim hujan menunjukkan variasi yang 
mempunyai hubungannya lebih kecil terhadap variasi aliran dasar. Dari variasi persentase aliran dasar dan nilai $\log \mathrm{PCO}_{2}$ pada dua kali kejadian banjir tersebut, maka dapat dijelaskan bahwa pada fase kejadian banjir terdapat pengaruh interaksi antara air-gas-batuan yang lebih mendominasi dibandingkan dengan proses waterrock interaction saja seperti yang terjadi di musim kemarau, meskipun pada kejadian banjir pertama menunjukkan kecenderungan proses air-gas-batuan yang lebih tinggi dibanding kejadian banjir kedua. Hal ini menunjukkan pergeseran kecenderungan dominasi proses air-gas-batuan kearah air-batuan saja. Kecenderungan ini selanjutnya dapat diperkuat dengan mencermati variasi unsur utama terlarut dan daya hantar listrik dan jika dibandingkan dengan hubungan aliran dasar dan tekanan parsial gas karbondioksida.

Variasi nilai DHL pada kejadian banjir pertama dan kedua mempunyai kesamaan dengan model kemograf yang dideskripsikan oleh Plagnes (2001). Plagnes menjelaskan bahwa kandungan unsur terlarut dalam air sedikit demi sedikit naik ketika debit aliran naik menuju debit puncak (rising limb), kemudian baru disusul oleh air yang terencerkan oleh air hujan yang sedikit kandungan unsur terlarutnya (proses dilution by precipitation) dan mencapai puncak beberapa saat setelah debit puncak (DHL turun), kemudian perlahan-lahan naik kembali menuju kondisi air sebelum hujan. Jika jenis percelahan pada akuifer Sungai Bribin hanya didominasi oleh tipe percelahan besar (conduit) saja, maka air hujan akan sangat cepat dan mempunyai ritme yang sama dengan kenaikan debit. Sungai bawah tanah di Gua Bribin mempunyai simpanan fissure dan diffuse pada rekahan sedang dan kecil yang tinggi unsur terlarutnya, kemudian terdorong oleh air conduit yang menyebabkan DHL mengalami kenaikan terlebih dahulu, kemudian baru disusul oleh dominasi air hujan (DHL turun). 
Kandungan kalsium pada kejadian banjir 22-23 Februari 2007 mempunyai kecenderungan menurun seiring dengan naiknya aliran menuju debit puncak, sedangkan bikarbonat mempunyai kecenderungan yang hampir sama dengan DHL. Selanjutnya, jika dilakukan analisis scatter plot antara persentase aliran dasar dan kalsium serta $\log \mathrm{PCO}_{2}$, maka akan diketahui bahwa masing-masing proses yaitu water-rock interaction dan air-water-rock interaction pada saat banjir mempunyai kontribusi yang hampir seimbang, dengan nilai $\mathrm{R}^{2}$ sekitar 0,5 (Gambar 4.33). Hal ini berbeda dengan hubungan negatif yang ditunjukkan pada hubungan nilai log $\mathrm{PCO}_{2}$ dan aliran dasar pada saat musim kemarau.
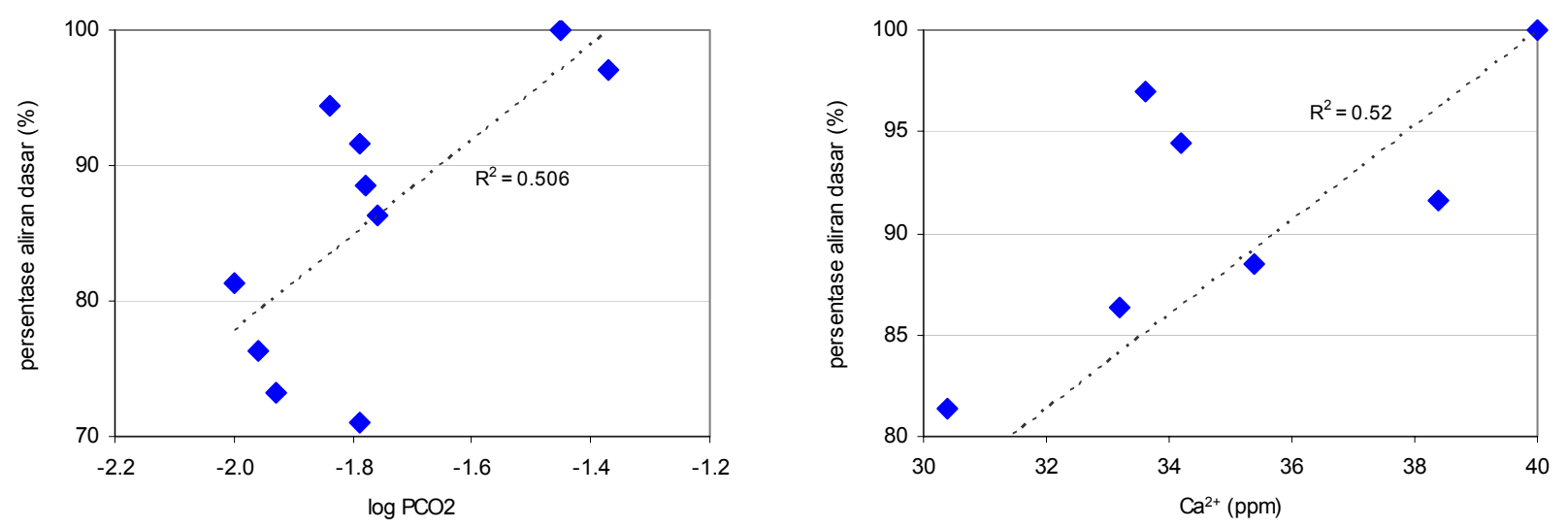

Gambar 4.33. Scatter Plot Hubungan Aliran Dasar-log $\mathrm{PCO}_{2}$ di Gua Bribin (kiri) dan Aliran Dasar-Kalsium (kanan) Pada Kejadian Banjir 22-23 Februari 2007

Kejadian banjir pada 19 Maret 2007 menunjukkan bahwa kenaikan aliran dasar selaras dengan penurunan kandungan bikarbonat terlarut dalam air (nilai $\mathrm{R}^{2}=0,63$ ) yang ditunjukkan pada Gambar 4.34. Hal ini berbeda dengan yang terjadi pada kejadian banjir pertama dimana pada kejadian banjir kedua ini aliran diffuse dan fissure di sungai sudah mulai stabil dan secara umum aliran conduit yang datang ketika ada kejadian hujan langsung dapat mengencerkan air sungai bawah tanah, sehingga tidak terdapat selisih waktu yang lama antara puncak banjir dan penurunan kandungan bikarbonat. Pengaruh tekanan parsial gas karbondioksida pada saat banjir 
masih mempunyai determinasi rendah $\left(\mathrm{R}^{2}=0,36\right)$, sehingga perannya sudah berkurang dibanding kejadian banjir 22-23 Februari 2008. Hal ini berkaitan dengan mulai berkurangnya intensitas hujan yang sudah masuk periode akhir musim hujan.

Variasi $\mathrm{pH}$ dan suhu di Gua Bribin saat kejadian banjir sangat berbeda jika dibandingkan dengan pada saat musim kemarau. Pada saat musim kemarau, $\mathrm{pH}$ dan suhu cenderung naik seiring penurunan debit aliran atau naiknya persentase aliran dasar, sementara itu pada saat kejadian banjir, $\mathrm{pH}$ dan suhu berfluktuasi seiring dengan fluktuasi debit aliran pada hidrograf banjir. Variasi $\mathrm{pH}$ dan suhu pada hidrograf banjir sungai karst secara teoritis lebih tergantung kepada jenis dominasi komponen aliran pada saat pengukuran.
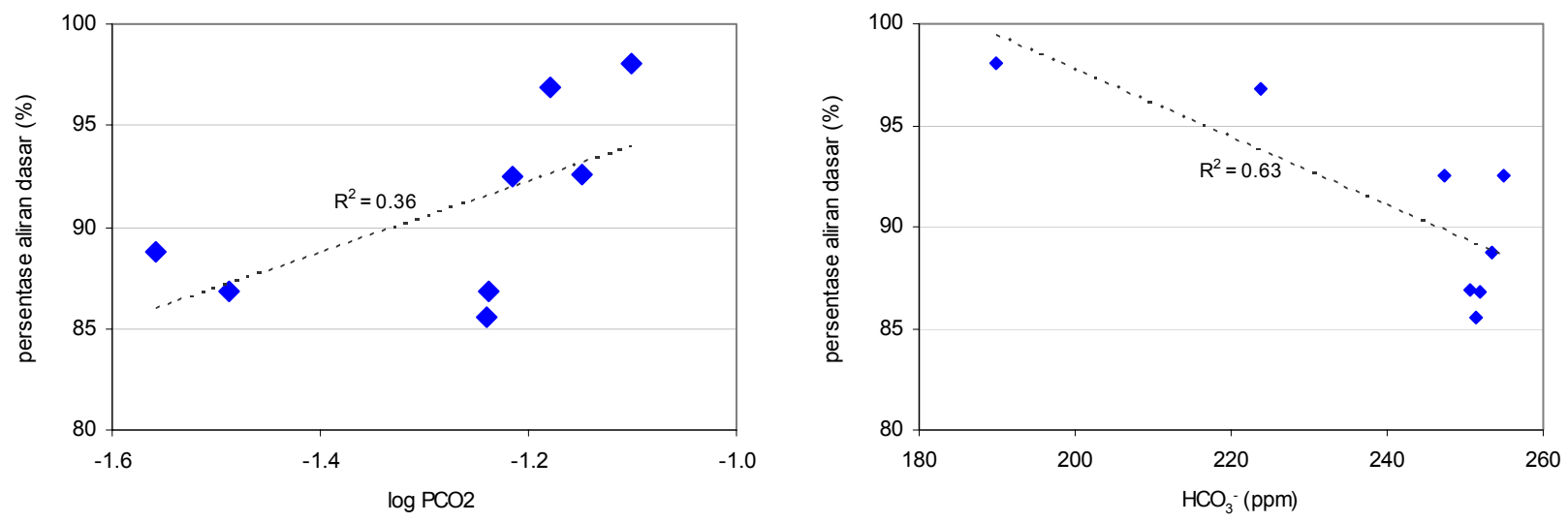

Gambar 4.34. Scatter Plot Hubungan Aliran Dasar-log $\mathrm{PCO}_{2}$ di Gua Bribin (kiri) dan Aliran Dasar-Bikarbonat (kanan) pada Kejadian Banjir 19 Maret 2007

Scatter plot $\left(\mathrm{Na}^{+}-\mathrm{Cl}^{-}\right)$pada dua kali kejadian banjir disajikan pada Gambar 4.35. Rasio ion natrium-klorida pada saat-saat puncak banjir dan sesaat sesudahnya menunjukkan rasio yang mendekati rasio air hujan (1:1), sementara posisi sampel yang paling jauh dari garis rasio 1:1 adalah pada saat periode resesi sebelum kejadian banjir. Selanjutnya, posisi sampel-sampel pada periode resesi setelah banjir terletak di antara posisi puncak banjir dan pra-banjir. 

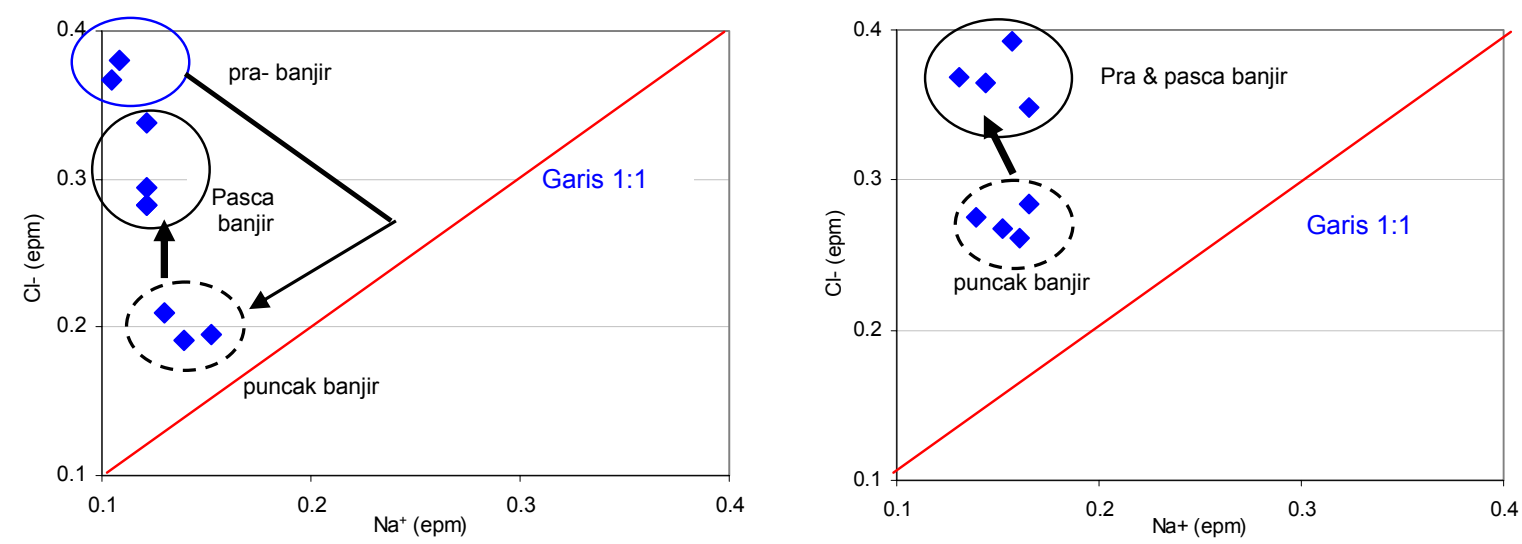

Gambar 4.35. Scatter Plot Ion Natrium dan Klorida pada Kejadian Banjir 22-23 Februari 2008 (kiri) dan pada Kejadian Banjir 19 Maret 2007 (kanan)

Dari fenomena tersebut dapat dijelaskan bahwa kenaikan debit atau penurunan persentase aliran dasar membuat rasio ion natrium-klorida mendekati rasio air hujan yang menunjukkan dimulainya dominasi komponen aliran conduit melalui proses dilution by precipitation pada sungai bawah tanah, sedangkan pada periode resesi setelah banjir, perlahan-lahan rasionya meningkat dan mulai menjauhi garis 1:1. Sampel-sampel pada periode resesi sebelum banjir mempunyai rasio natrium- klorida yang jauh dari rasio air hujan, yang menunjukkan dominasi proses water-rock interaction karena dominasi komponen aliran diffuse dan fissure. Kemudian, fenomena menarik ditunjukkan oleh rasio ion natrium klorida pada kejadian banjir 19 Maret 2007, dimana rasio pada saat puncak banjir cukup jauh menyimpang dari garis $1: 1$, sedangkan rasio pada saat pra dan pasca banjir tidak menunjukkan perbedaan yang berarti. Hal ini dapat dijelaskan karena kejadian banjir yang kedua ini sudah memasuki akhir musim kemarau, sehingga persentase aliran dasar yang cukup kaya mineral terlarut lebih mendominasi dibanding pada saat kejadian banjir yang pertama. Konsekuensinya, rasio ion natrium-klorida pada saat puncak banjir lebih besar dibanding pada saat kejadian banjir yang pertama, atau jika diplot dalam grafik akan mempunyai posisi relatif menjauh dari garis rasio 1:1. 
Sementara itu, rasio periode resesi setelah dan sesudah banjir tidak begitu terpengaruh adanya kejadian banjir.

Jika diamati sepanjang musim hujan, parameter DHL, suhu, dan unsur terlarut dalam air pada saat banjir bervariasi dan cenderung berkurang, sehingga dapat dikatakan bahwa musim hujan menyebabkan terjadinya variasi unsur terlarut dalam air. Pada awal dan akhir musim hujan nilai DHL dan suhunya air hampir mirip, yaitu pada kisaran $500 \mathrm{mS} / \mathrm{cm}$, dan $27^{\circ} \mathrm{C}$. Hal ini membuktikan bahwa komponen aliran diffuse mempunyai peran yang dominan pada saat-saat tidak terjadi banjir. Hal yang berbeda ditunjukkan pada kandungan unsur kalsium dan bikarbonat serta nilai $\mathrm{pH}$ yang masih belum mencapai kondisi awal dan memungkinkan pengenceran sungai bawah tanah masih terjadi oleh komponen aliran fissure tetapi tidak begitu mempengaruhi nilai DHL dan suhu air.

Jauh berbeda dengan yang terjadi pada musim kemarau, variasi tekanan parsial gas karbondioksida sangat bervariasi sepanjang musim hujan. Sementara itu, persentase aliran dasar mempunyai hubungan terbalik dengan variasi debit, seperti yang terjadi pada saat kejadian banjir, meskipun dengan nilai $\mathrm{R}^{2}$ yang lebih kecil yaitu sebesar 0,91 (Gambar 4.36.). Dari Gambar 4.36, tampak bahwa terjadi sedikit penyimpangan hubungan aliran dasar dan debit yang terjadi pada saat awal maupun akhir musim hujan. Hal ini dapat dijelaskan bahwa pada masa tersebut terjadi perubahan dominasi komponen aliran karena adanya time lag (waktu jeda) aliran fissure dan diffuse untuk mengimbuh sungai bawah tanah ketika terjadi hujan yang intensitasnya lebih kecil dibandingkan saat puncak musim hujan (nilai $\mathrm{R}^{2}=0,99$ ). Hubungan antara aliran dasar dan ion-ion kalsium dan bikarbonat serta aliran dasartekanan parsial gas karbondioksida disajikan pada Gambar 4.37. dan Gambar 4.38. 


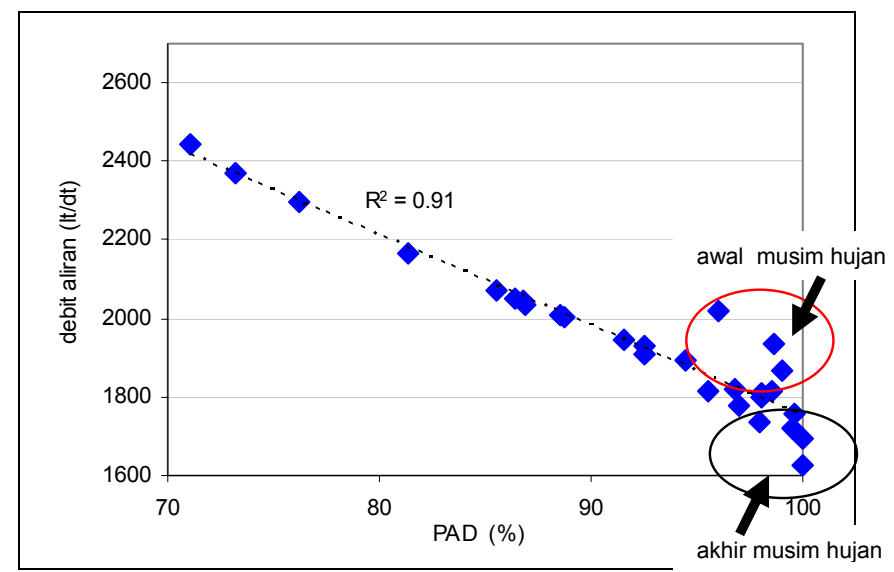

Gambar 4.36. Scatter Plot Hubungan Aliran Dasar-Debit Aliran Gua Bribin Musim Hujan

Dari Gambar 4.37. terlihat bahwa terdapat pengelompokan sampel atas dasar karakteristik penggalan kejadian banjir (puncak banjir dan resesi) maupun waktu pada awal atau akhir musim hujan, meskipun secara umum hubungan $\left(\mathrm{R}^{2}\right)$ antara persentase aliran diffuse dan kandungan kalsium-bikarbonat adalah lemah. Hal ini disebabkan oleh tingginya variasi PAD saat kejadian banjir. Pada plotting kalsium dan bikarbonat vs. aliran diffuse, terlihat bahwa kandungan unsur terlarut pada awal musim penghujan memiliki persentase aliran diffuse dan kalsium yang lebih tinggi dari semua sampel lainnya, karena adanya pengenceran oleh air hujan.
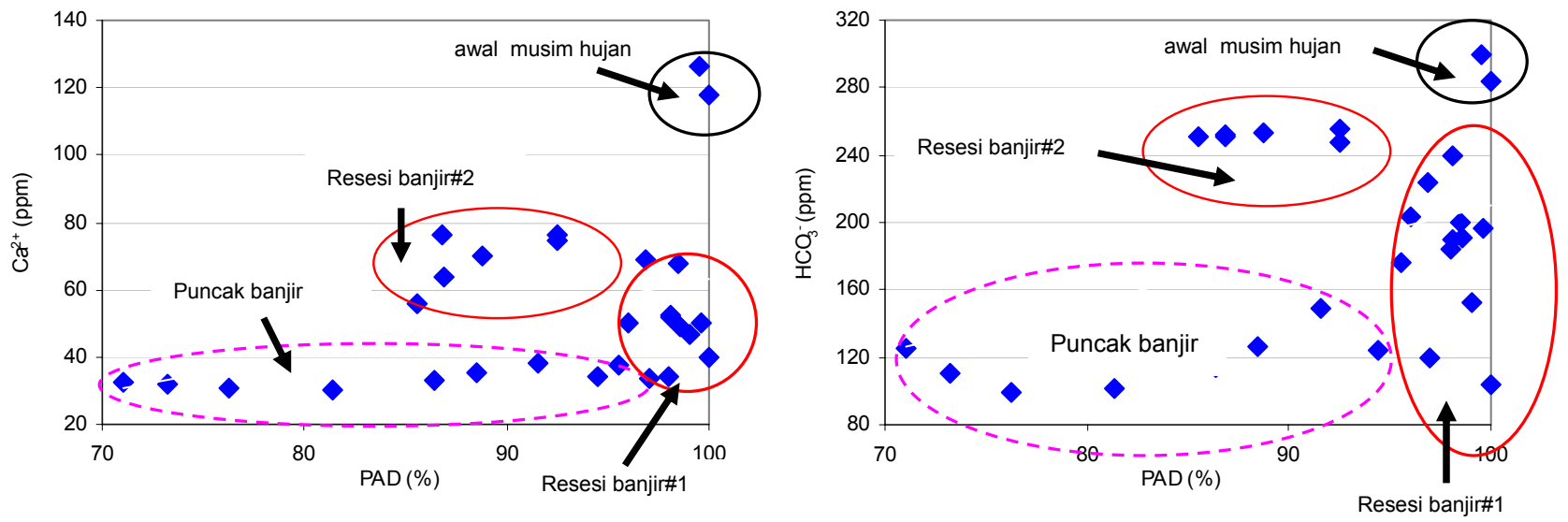

Gambar 4.37. Scatter Plot Hubungan Aliran Dasar-Kalsium (kiri) Dan Aliran DasarBikarbonat (kanan) 


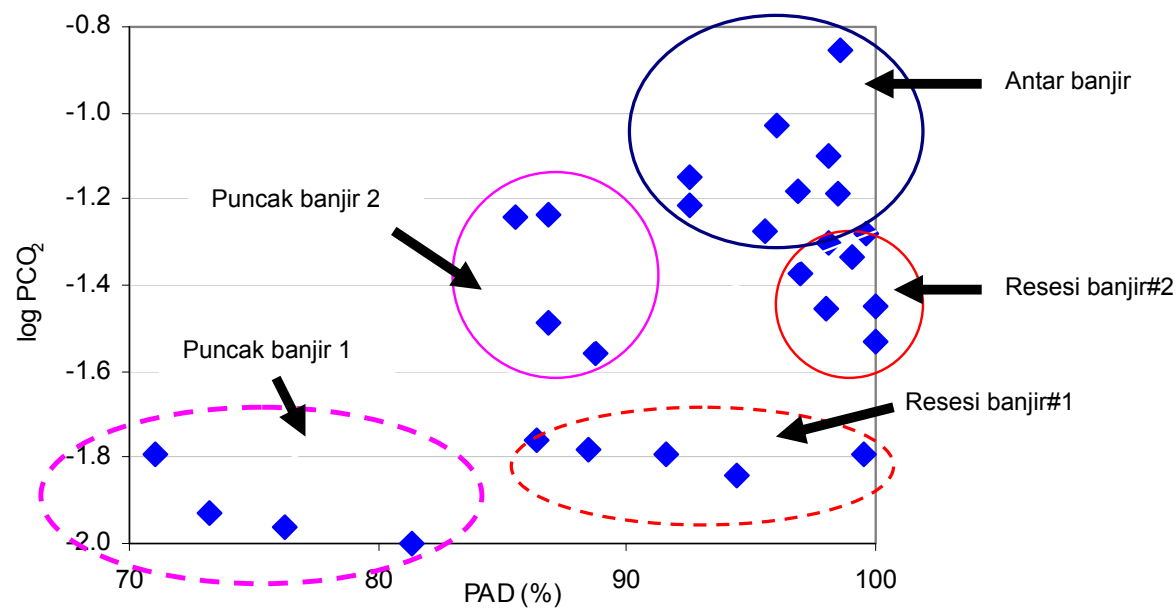

Gambar 4.38. Scatter Plot Hubungan Aliran Dasar dan Tekanan Parsial Gas Karbondioksida Gua Bribin Sepanjang Musim Hujan

Sementara itu, sampel-sampel pada saat puncak banjir memiliki persentase aliran diffuse dan kandungan unsur terlarut paling kecil. Fenomena lain yang menarik adalah bahwa sampel-sampel pada kondisi resesi banjir 22-23 Februari 2007 mempunyai kandungan unsur kalsium dan bikarbonat terlarut yang lebih kecil dibanding kejadian banjir 19 Maret 2007, meskipun persentase aliran diffusenya relatif sama. Hal ini menunjukkan bahwa simpanan airtanah pada akuifer karst sudah cukup terpasok oleh air hujan, sehingga meningkatkan persentase aliran diffuse dan fissure yang relatif lebih jenuh terhadap mineral karbonat yang sudah mengalami proses water-rock interaction, sehingga meningkatkan persentase aliran dasar pada kejadian banjir 19 Maret 2007 (akhir musim hujan).

Pada musim hujan, terdapat hubungan yang positif antara tekanan parsial gas karbondioksida dalam air dan persentase aliran dasar meskipun nilai $\mathrm{R}^{2}$ kecil. Secara rinci, pada kondisi sekitar puncak banjir 22-23 Februari 2007 dicirikan dengan nilai $\log \mathrm{PCO}_{2}$ yang kecil dan persentase aliran diffuse yang kecil pula, sangat berbeda 
dengan puncak banjir 19 Maret 2007 yang mempunyai nilai log $\mathrm{PCO}_{2}$ dan persentase aliran diffuse yang lebih besar. Bahkan, nilai log $\mathrm{PCO}_{2}$ dan persentase aliran pada puncak banjir kedua masih lebih besar dibanding pada sampel-sampel saat resesi banjir yang pertama. Pada kondisi stabil (tanpa banjir) pada musim hujan mempunyai persentase aliran dasar dan nilai log $\mathrm{PCO}_{2}$ yang relatif lebih besar dibandingkan pada saat banjir. Hal ini menunjukkan bahwa variasi nilai log $\mathrm{PCO}_{2}$ terjadi pada saat musim hujan, dan berhubungan dengan persentase aliran dasarnya, sehingga proses interaksi air-gas-batuan lebih dominan dibanding interaksi airbatuan saja.

Sepanjang tahun, variasi unsur terlarut dalam air pada musim kemarau lebih linier dibanding yang terjadi pada saat musim penghujan atau bahkan pada saat kejadian banjir. Sebagai contoh kandungan unsur terlarut yang didekati dengan parameter Daya Hantar Listrik (DHL) menunjukkan kenaikan gradual atau secara perlahan-lahan dengan kisaran nilai yang tidak terlalu besar yaitu antara 486 sampai dengan $511 \mu \mathrm{S} / \mathrm{cm}$. Pada saat-saat awal musim hujan, nilai DHL turun jauh dan bervariasi dengan kisaran nilai yang besar $(511-460 \mu \mathrm{S} / \mathrm{cm})$, dan bahkan pada saat banjir nilai DHL bervariasi antara 460 sampai dengan $370 \mu \mathrm{S} / \mathrm{cm}$, sebuah variasi yang cukup besar. Pada saat akhir musim penghujan, nilai DHL mulai stabil dan menunjukkan variasi yang tidak begitu besar 480 sampai dengan $486 \mu \mathrm{S} / \mathrm{cm}$. Hasil pengukuran nilai DHL yang lebih detail (1 mingguan), disajikan pada Gambar 4.39.

Dari grafik-grafik yang sudah disajikan sebelumnya, baik variasi DHL bulanan maupun mingguan, terlihat bahwa variasi nilai DHL terjadi saat musim hujan atau pada saat kejadian banjir yang mempunyai fluktuasi dominasi komponen aliran, sehingga kemudian dapat diasumsikan bahwa variasi DHL dikontrol oleh variasi komponen aliran pada sungai bawah tanah. Hal ini terlihat pada penjelasan- 
penjelasan sebelumnya bahwa tidak terdapat hubungan yang kuat antara persentase aliran dasar (PAD) dan kalsium atau bikarbonat pada saat kejadian hujan atau pada saat kejadian banjir, lain halnya dengan yang terjadi pada saat musim kemarau (determinasi tinggi). Hubungan antara DHL dan kalsium/bikarbonat sampel-sampel sepanjang tahun disajikan pada Gambar 4.40.

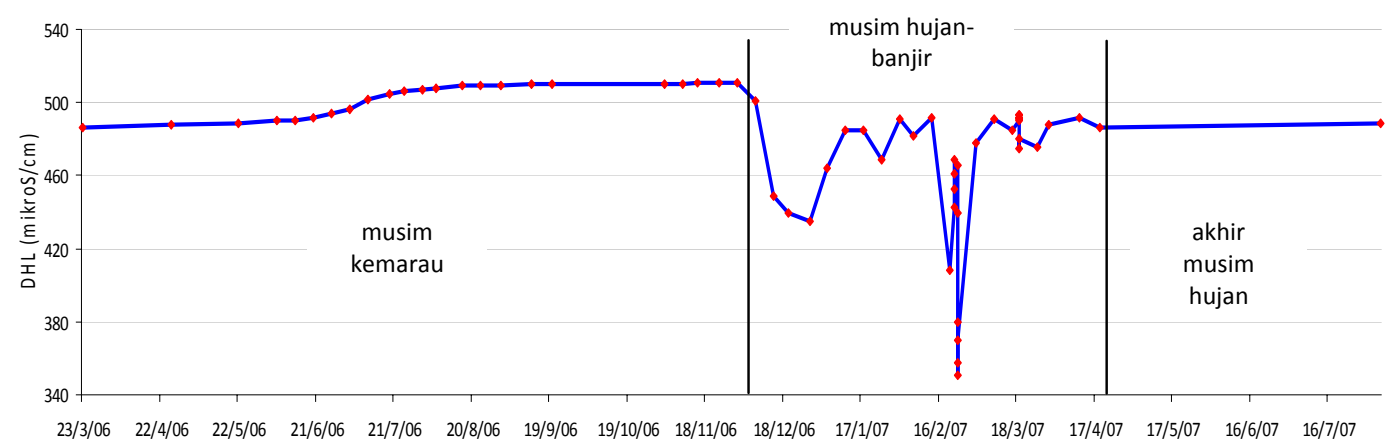

Gambar 4.39. Variasi DHL Sepanjang Tahun Gua Bribin (sumbu x tidak diskalakan)

Jika dilihat sepanjang tahun, pada grafik hubungan antara DHL dan kalsium/bikarbonat terlarut terdapat lima kelompok yang mencirikan kondisi sungai bawah tanah pada saat pengambilan sampel, yaitu:

a) Kondisi hidrogeokimia yang dicirikan dengan nilai DHL sedang dan nilai $\mathrm{Ca}^{2+}$ dan $\mathrm{HCO}_{3}^{-}$kecil, yaitu pada saat sebelum dan saat kejadian puncak banjir 22-23 Februari 2008.

b) Kondisi hidrogeokimia yang dicirikan dengan nilai DHL kecil dan nilai $\mathrm{Ca}^{2+}$ dan $\mathrm{HCO}_{3}^{-}$kecil, yaitu pada saat setelah kejadian puncak banjir 22-23 Februari 2008.

c) Karakter hidrogeokimia yang dicirikan dengan nilai DHL tinggi dan nilai $\mathrm{Ca}^{2+}$ dan $\mathrm{HCO}_{3}^{-}$kecil, yaitu pada saat antar banjir 22-23 Februari dan 19 maret 2007 
d) Karakter hidrogeokimia yang dicirikan dengan nilai DHL tinggi dan nilai $\mathrm{Ca}^{2+}$ dan $\mathrm{HCO}_{3}{ }^{-}$sedang, yaitu pada saat kejadian banjir 19 Maret 2007

e) Karakter hidrogeokimia yang dicirikan dengan nilai DHL tinggi dan nilai $\mathrm{Ca}^{2+}$ dan $\mathrm{HCO}_{3}{ }^{-}$tinggi, yaitu pada saat musim kemarau

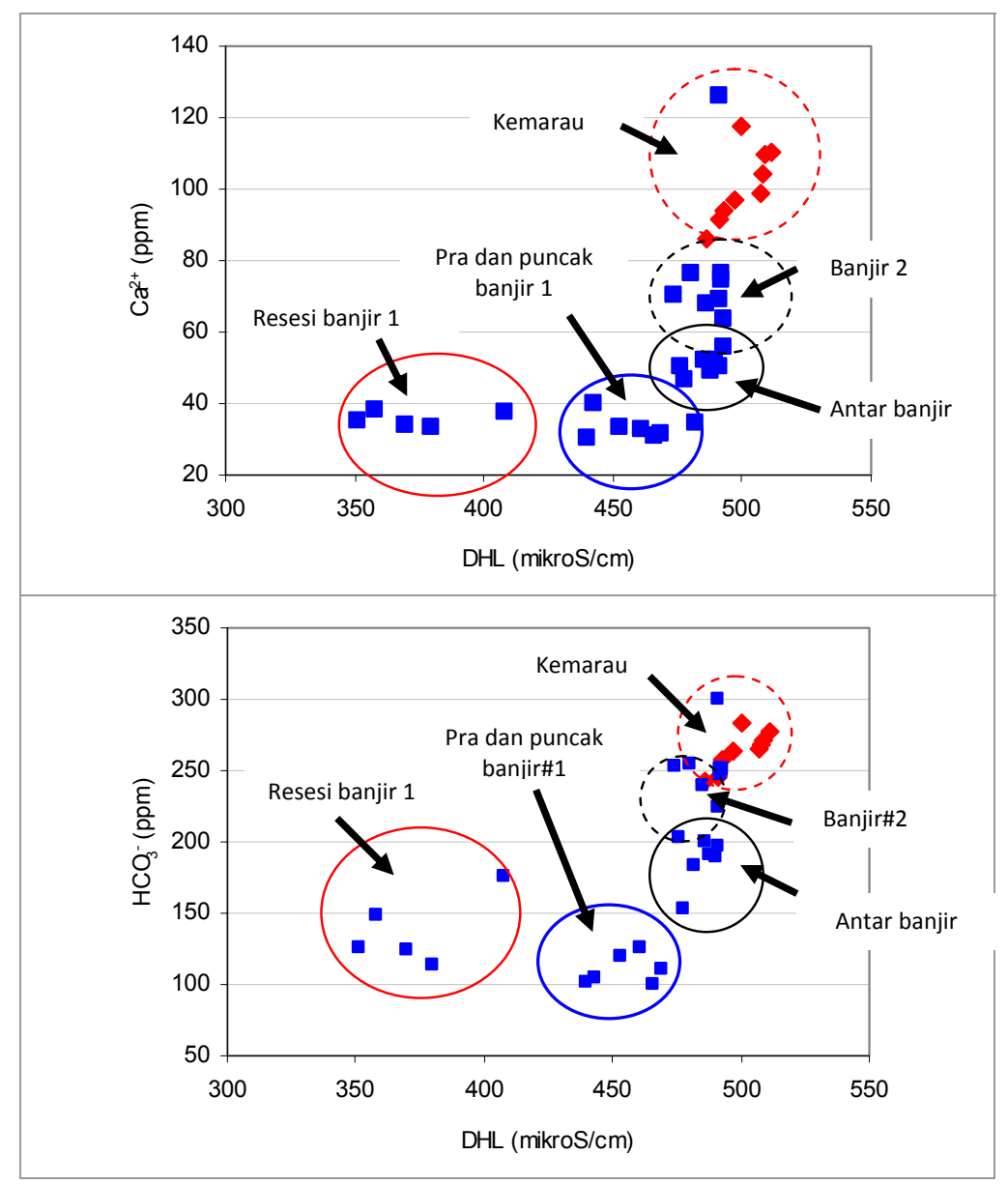

Gambar 4.40. Hubungan DHL dan Kalsium Terlarut (atas) dan DHL Bikarbonat Terlarut (bawah)

Secara umum kondisi aliran sungai di Gua Bribin mencirikan hubungan terbalik antara persentase aliran diffuse dan debit aliran, meskipun hubungannya tidak sebesar yang ditemukan pada masing-masing kejadian banjir atau musimmusim terperinci, seperti yang sudah dijelaskan pada pembahasan sebelumnya 
(Gambar 4.41). Selanjutnya, scatter plot aliran dasar versus unsur utama terlarut yaitu kalsium dan karbonat disajikan pada Gambar 4.42.

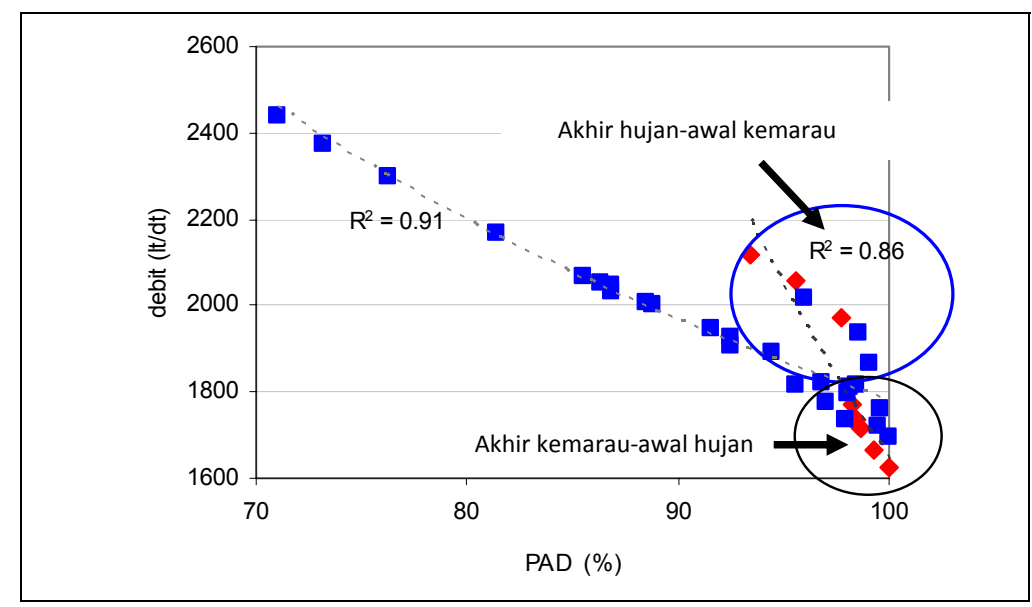

Gambar 4.41. Scatter Plot Hubungan Aliran Dasar-Debit Aliran Gua Bribin Sepanjang Tahun

Persentase aliran dasar (PAD) mempunyai hubungan terbalik dengan variasi debit, meskipun dengan nilai $\mathrm{R}^{2}$ yang lebih kecil $(0,83)$. Seperti halnya yang terjadi sepanjang musim hujan, tampak bahwa terjadi sedikit penyimpangan hubungan aliran dasar dan debit yang terjadi pada saat akhir kemarau dan akhir musim hujan. Hal ini dapat dijelaskan bahwa pada masa tersebut terjadi perubahan dominasi komponen aliran karena adanya time lag (waktu jeda) aliran komponen aliran fissure dan diffuse. Hal yang sama dijumpai pula pada scatter plot aliran dasar versus unsur utama terlarut yaitu kalsium dan karbonat (Gambar 4.42), yaitu hubungan yang kuat $\left(\mathrm{R}^{2}\right.$ besar) ditunjukkan pada musim kemarau (menunjukkan proses water-rock interaction dominan) sementara pada saat kejadian banjir dan musim hujan menunjukkan adanya proses lain yaitu dilution by precipitation, sehingga nilai $\mathrm{R}^{2}$ kecil. Ringkasan variasi proses hidrogeokimia di Gua Bribin disajikan pada Tabel 4.21 . 


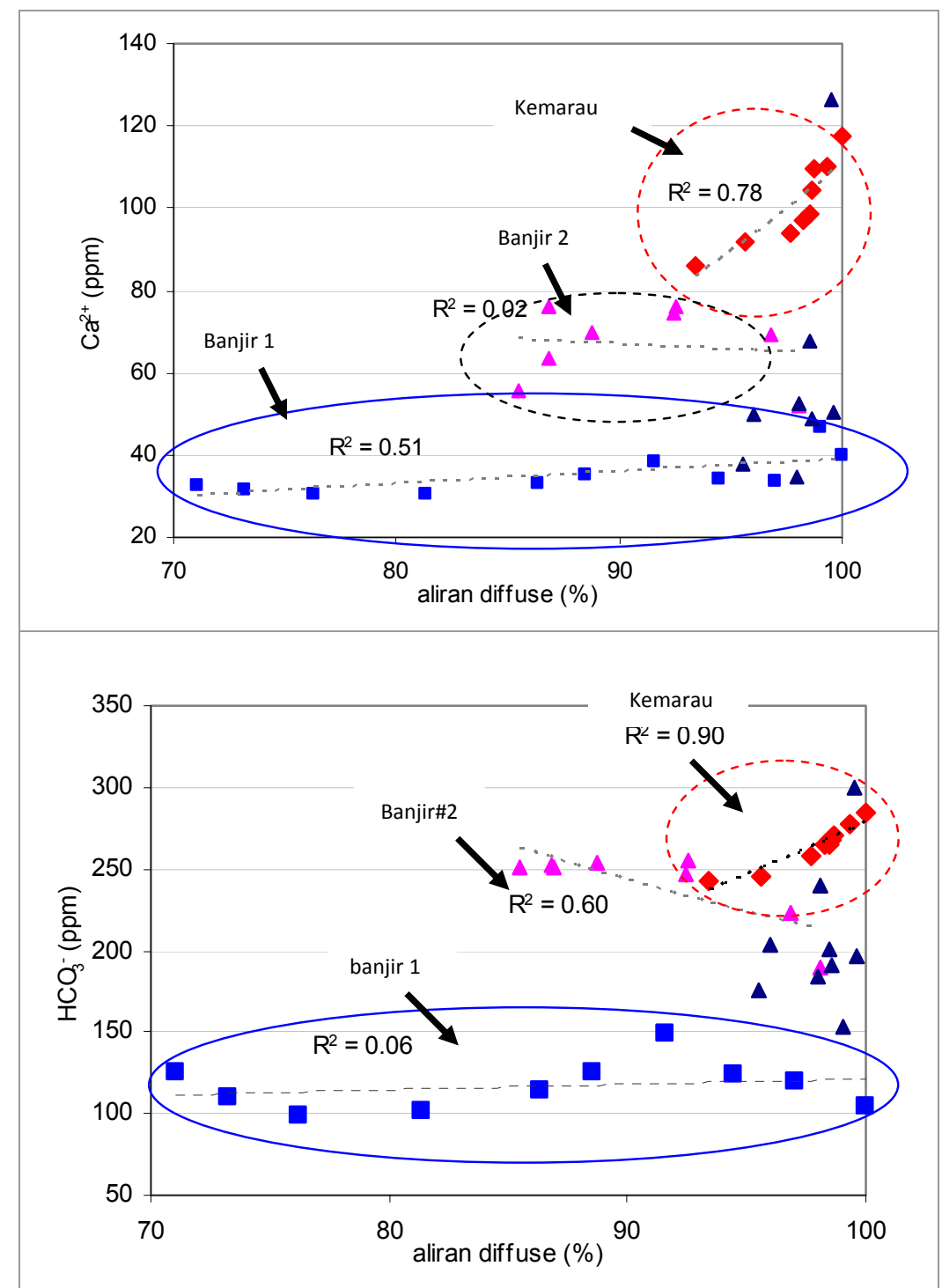

Gambar 4.42. Hubungan DHL dan Kalsium Terlarut (Atas) dan DHL Bikarbonat Terlarut (Bawah) Gua Bribin Sepanjang Tahun 
Tabel 4.21. Karakter dan Variasi Proses Hidrogeokimia di Gua Bribin Sepanjang Tahun

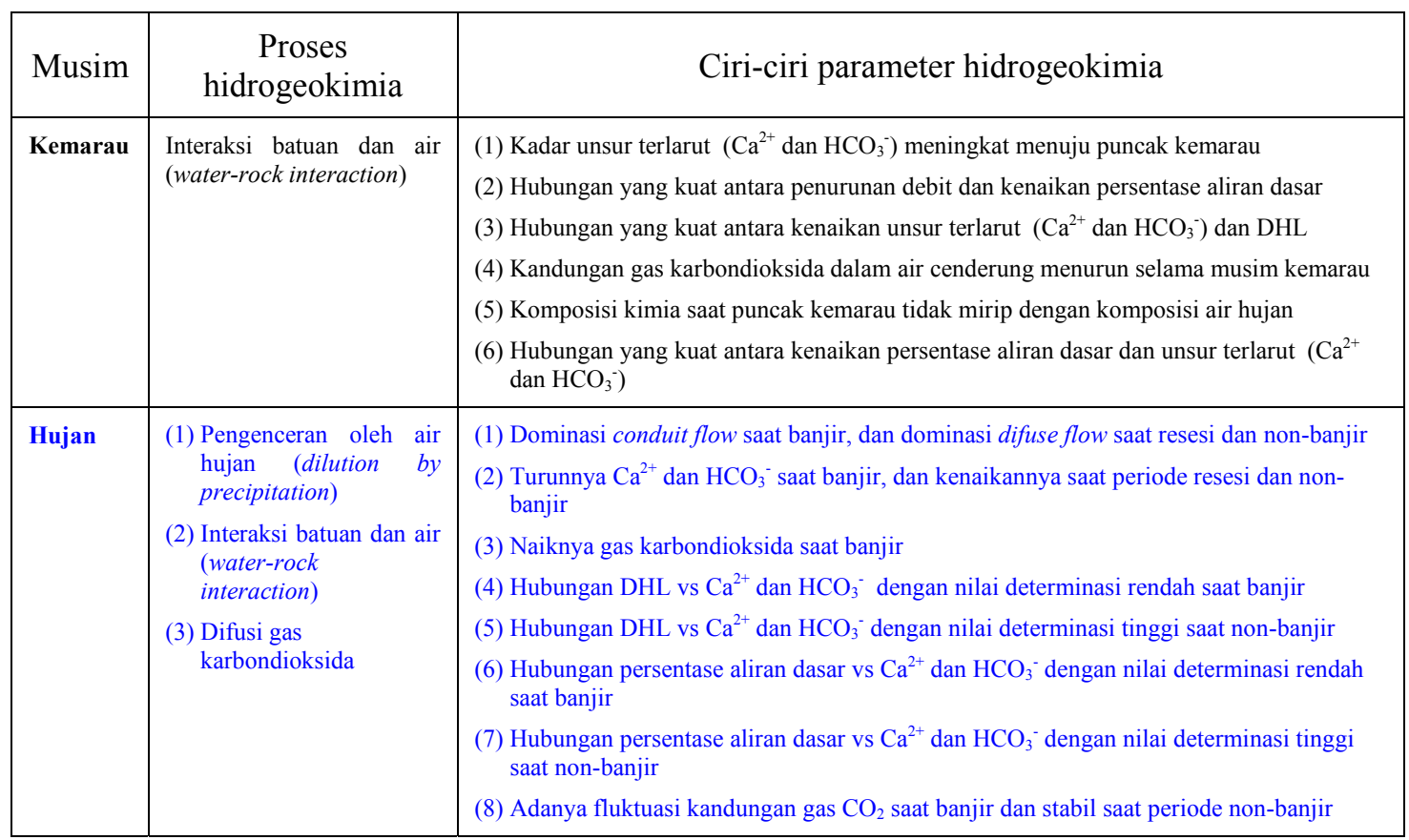

\section{Variasi temporal karakter hidrogeokimia di Sungai Pentung, Luweng Jomblangan, Gua Gilap, dan Gua Ngreneng}

Karakteristik hidrogeokimia di Sungai Pentung, Luweng Jomblangan, Gua

Gilap, dan Gua Ngreneng secara temporal diwakili oleh pengambilan sampel musim kemarau pada kurun waktu Maret 2006 sampai dengan November 2006 dan musim hujan pada periode Desember 2006 sampai dengan April 2007. Hasil analisis laboratorium terhadap sampel air tersebut selanjutnya disajikan pada Tabel 4.22., Tabel 4.23, 4.24, dan 4.25, dan itu hidrokemografnya disajikan pada Lampiran 1. 
Tabel 4.22. Komposisi Kimia Sampel Air Sungai Pentung Sepanjang Tahun

\begin{tabular}{|c|c|c|c|c|c|c|c|c|c|c|c|c|c|c|}
\hline \multicolumn{2}{|c|}{ Waktu } & \multirow{2}{*}{$\begin{array}{c}\text { DHL } \\
(\mu \mathrm{mhos} / \mathrm{cm})\end{array}$} & \multirow{2}{*}{ pH } & \multirow{2}{*}{$\begin{array}{c}\text { Suhu } \\
\left({ }^{\circ} \mathrm{C}\right)\end{array}$} & \multirow{2}{*}{ Eh } & \multirow{2}{*}{$\begin{array}{c}\mathrm{Ca}^{2+} \\
(\mathrm{mg} / \mathrm{l})\end{array}$} & \multirow{2}{*}{$\begin{array}{l}\mathrm{Mg}^{2+} \\
(\mathrm{mg} / \mathrm{l})\end{array}$} & \multirow{2}{*}{$\begin{array}{c}\mathrm{Na}^{+} \\
(\mathrm{mg} / \mathrm{l})\end{array}$} & \multirow{2}{*}{$\begin{array}{c}\mathbf{K}^{+} \\
(\mathrm{mg} / \mathrm{l})\end{array}$} & \multirow{2}{*}{$\begin{array}{r}\mathrm{HCO}_{3}^{-} \\
(\mathrm{mg} / \mathrm{l})\end{array}$} & \multirow{2}{*}{$\begin{array}{c}\mathrm{Cl}^{-} \\
(\mathrm{mg} / \mathrm{l})\end{array}$} & \multirow{2}{*}{$\begin{array}{l}\mathrm{SO}_{4}{ }^{2-} \\
(\mathrm{mg} / \mathrm{l})\end{array}$} & \multirow{2}{*}{$\begin{array}{l}\text { Debit } \\
\text { (l/dt) }\end{array}$} & \multirow{2}{*}{$\begin{array}{l}\text { PAD } \\
(\%)\end{array}$} \\
\hline tanggal & jam & & & & & & & & & & & & & \\
\hline $21 / 3 / 06$ & $10: 00$ & 187 & 7.57 & 26.20 & -0.060 & 45.30 & 3.30 & 4.10 & 1.70 & 143.01 & 9.20 & 6.50 & 887.44 & 10.1 \\
\hline $28 / 4 / 06$ & 14:00 & 288 & 7.84 & 25.00 & -0.051 & 50.30 & 11.90 & 7.10 & 2.80 & 169.01 & 16.00 & 13.70 & 168.78 & 82.9 \\
\hline $22 / 5 / 06$ & $15: 50$ & 268 & 7.92 & 26.3 & -0.055 & 52.10 & 14.00 & 3.80 & 1.50 & 207.01 & 7.40 & 11.90 & 87.36 & 100.0 \\
\hline $21 / 6 / 06$ & $10: 15$ & 324 & 8.05 & 24.8 & -0.064 & 50.30 & 10.70 & 10.80 & 2.20 & 222.01 & 5.50 & 13.80 & 62.22 & 100.0 \\
\hline $20 / 7 / 06$ & $10: 30$ & 330 & 8.07 & 23.8 & -0.06 & 52.30 & 12.70 & 11.50 & 2.90 & 233.02 & 6.50 & 14.90 & 23.25 & 100.0 \\
\hline $23 / 8 / 06$ & $10: 00$ & 358 & 8.08 & 24.1 & -0.062 & 59.50 & 13.40 & 12.10 & 1.50 & 236.02 & 9.20 & 10.40 & 4.06 & 100.0 \\
\hline $21 / 9 / 06$ & $10: 00$ & 505 & 8.42 & 26 & -0.095 & 65.60 & 11.40 & 8.40 & 1.50 & 237.02 & 9.30 & 12.40 & 2.25 & 100.0 \\
\hline $16 / 11 / 06$ & $12: 45$ & kering & kering & kering & kering & kering & kering & kering & kering & kering & kering & kering & 0.0 & 0.0 \\
\hline $21 / 12 / 06$ & $10: 30$ & 239 & 7.96 & 26.3 & -0.05 & 32.00 & 6.90 & 3.00 & 0.80 & 125.01 & 7.90 & 8.40 & 3.32 & 100.0 \\
\hline $1 / 2 / 07$ & $14: 30$ & 300 & 8.21 & 30.8 & -0.07 & 49.10 & 15.40 & 4.60 & 1.10 & 231.02 & 7.60 & 8.80 & 5.50 & 100.0 \\
\hline $22 / 3 / 07$ & $10: 30$ & 246 & 7.75 & 25.2 & -0.052 & 42.70 & 12.50 & 5.00 & 1.40 & 155.01 & 22.50 & 3.50 & 147.00 & 40.8 \\
\hline $20 / 4 / 07$ & $10: 00$ & 146 & 6.95 & 25.7 & -0.018 & 45.00 & 11.60 & 3.60 & 1.50 & 156.01 & 20.60 & 7.20 & 513.70 & 17.5 \\
\hline
\end{tabular}

Sumber : pengukuran lapangan dan analisis laboratorium tahun 2006-2007

Tabel 4.23. Komposisi Kimia Sampel Air Luweng Jomblangan Sepanjang Tahun

\begin{tabular}{|c|c|c|c|c|c|c|c|c|c|c|c|c|}
\hline \multicolumn{2}{|c|}{ Waktu } & \multirow{2}{*}{$\begin{array}{c}\text { DHL } \\
(\mu \mathrm{mhos} / \mathrm{cm})\end{array}$} & \multirow{2}{*}{ pH } & \multirow{2}{*}{$\begin{array}{l}\text { Suhu } \\
\left({ }^{\circ} \mathrm{C}\right)\end{array}$} & \multirow{2}{*}{ Eh } & \multirow{2}{*}{$\begin{array}{c}\mathrm{Ca}^{2+} \\
(\mathrm{mg} / \mathrm{l})\end{array}$} & \multirow{2}{*}{$\begin{array}{l}\mathrm{Mg}^{2+} \\
(\mathrm{mg} / \mathrm{l})\end{array}$} & \multirow{2}{*}{$\begin{array}{c}\mathrm{Na}^{+} \\
(\mathrm{mg} / \mathrm{l})\end{array}$} & \multirow{2}{*}{$\begin{array}{c}\mathrm{K}^{+} \\
(\mathrm{mg} / \mathrm{l})\end{array}$} & \multirow{2}{*}{$\begin{array}{l}\mathrm{HCO}_{3}^{-} \\
(\mathrm{mg} / \mathrm{l})\end{array}$} & \multirow{2}{*}{$\underset{(\mathrm{mg} / \mathrm{l})}{\mathrm{Cl}^{-}}$} & \multirow{2}{*}{$\begin{array}{l}\mathrm{SO}_{4}{ }^{2-} \\
(\mathrm{mg} / \mathrm{l})\end{array}$} \\
\hline tanggal & jam & & & & & & & & & & & \\
\hline $21 / 3 / 06$ & $14: 40$ & 215 & 7.10 & 26.6 & -0.021 & 44.66 & 4.50 & 3.20 & 1.70 & 158.01 & 9.20 & 4.00 \\
\hline $28 / 4 / 06$ & $13: 30$ & 312 & 7.09 & 26.6 & -0.014 & 59.30 & 3.10 & 10.80 & 4.10 & 197.01 & 7.40 & 6.40 \\
\hline $22 / 5 / 06$ & $16: 00$ & 478 & 7.09 & 26.3 & -0.006 & 62.10 & 9.60 & 3.80 & 1.50 & 247.02 & 7.40 & 11.90 \\
\hline $21 / 6 / 06$ & $10: 35$ & 484 & 7.1 & 26.6 & -0.005 & 71.90 & 10.70 & 4.60 & 1.20 & 286.02 & 5.50 & 10.30 \\
\hline $20 / 7 / 06$ & 11:00 & 500 & 7. & 3 & & & .80 & 70 & 1.40 & & 40 & 1.40 \\
\hline $23 / 8 / 06$ & $10: 30$ & 504 & 7.13 & 26 & -0.013 & 76.90 & 11.60 & 4.60 & 1.90 & 304.02 & 7.40 & 11.20 \\
\hline $21 / 9 / 06$ & $10: 30$ & 506 & 7.37 & 26.4 & -0.047 & 139.01 & 1.40 & 4.60 & 1.30 & 395.03 & 7.40 & 15.40 \\
\hline $16 / 11 / 06$ & $11: 00$ & 508 & 7.38 & 26.4 & -0.048 & 140.01 & 3.40 & 4.60 & 1.30 & 397.03 & 7.40 & 15.40 \\
\hline $21 / 12 / 06$ & 11:00 & 408 & 6.63 & 25.8 & 0.018 & 110.01 & 5.80 & 4.30 & 1.20 & 356.02 & 9.50 & 10.40 \\
\hline $1 / 2 / 07$ & 15:00 & 463 & 6.99 & 27.7 & -0.009 & 98.20 & 15.40 & 3.90 & 1.30 & 334.02 & 3.80 & 10.50 \\
\hline $22 / 3 / 07$ & $11: 00$ & 292 & 6.62 & 25.9 & 0.001 & 74.40 & 11.30 & 4.60 & 1.20 & 232.02 & 19.20 & 5.40 \\
\hline $20 / 4 / 07$ & 11:00 & 238 & 6.55 & 25.4 & 0.002 & 42.80 & 11.70 & 2.90 & 1.70 & 154.01 & 10.80 & 7.20 \\
\hline
\end{tabular}

Sumber : pengukuran lapangan dan analisis laboratorium tahun 2006-2007

\section{a. Analisis hidrokemograf}

Sungai Pentung yang merupakan sungai permukaan yang masuk ke dalam sinkhole di daerah Sawahombo mempunyai sifat variasi temporal unsur terlarut berbeda dengan sungai bawah tanah. Pada sungai bawah tanah dijumpai fluktuasi yang lebih tegas pada musim hujan, tetapi di Sungai Pentung, fluktuasi yang dijumpai tidak terlalu tegas pada musim kemarau maupun pada saat musim 
penghujan. Hal yang sama juga dijumpai di Luweng Jomblangan, kerena lokasinya yang berdekatan dengan Sungai Pentung, yaitu fluktuasi DHL dan unsur terlarut yang dijumpai mirip dengan yang ada di Sungai Pentung, terutama rendahnya nilai DHL pada musim hujan, yaitu pada kisaran $200 \mu \mathrm{mhos} / \mathrm{cm}$, meskipun saat puncak musim kemarau mencapai nilai $500 \mu \mathrm{mhos} / \mathrm{cm}$, sama dengan yang dijumpai di sungai bawah tanah yang lain.

Tabel 4.24. Komposisi Kimia Sampel Air Gua Gilap Sepanjang Tahun

\begin{tabular}{|c|c|c|c|c|c|c|c|c|c|c|c|c|c|c|}
\hline \multicolumn{2}{|c|}{ Waktu } & \multirow{2}{*}{$\begin{array}{c}\text { DHL } \\
(\mu \mathrm{mhos} / \mathrm{cm})\end{array}$} & \multirow{2}{*}{ pH } & \multirow{2}{*}{$\begin{array}{c}\text { Suhu } \\
\left({ }^{\circ} \mathrm{C}\right)\end{array}$} & \multirow{2}{*}{ Eh } & \multirow{2}{*}{$\begin{array}{c}\mathrm{Ca}^{2+} \\
(\mathrm{mg} / \mathrm{l})\end{array}$} & \multirow{2}{*}{$\begin{array}{l}\mathrm{Mg}^{2+} \\
(\mathrm{mg} / \mathrm{l})\end{array}$} & \multirow{2}{*}{$\begin{array}{c}\mathrm{Na}^{+} \\
(\mathrm{mg} / \mathrm{l})\end{array}$} & \multirow{2}{*}{$\begin{array}{c}\mathrm{K}^{+} \\
(\mathrm{mg} / \mathrm{l})\end{array}$} & \multirow{2}{*}{$\begin{array}{l}\mathrm{HCO}_{3}^{-} \\
(\mathrm{mg} / \mathrm{l})\end{array}$} & \multirow{2}{*}{$\underset{(\mathrm{mg} / \mathrm{l})}{\mathrm{Cl}^{-}}$} & \multirow{2}{*}{$\begin{array}{l}\mathrm{SO}_{4}{ }^{2-} \\
(\mathrm{mg} / \mathrm{l})\end{array}$} & \multirow{2}{*}{$\begin{array}{l}\text { Debit } \\
\text { (l/dt) }\end{array}$} & \multirow{2}{*}{$\begin{array}{l}\text { PAD } \\
\text { (\%) }\end{array}$} \\
\hline tanggal & jam & & & & & & & & & & & & & \\
\hline $23 / 3 / 06$ & $16: 30$ & 471 & 7.06 & 26.4 & -0.006 & 50.56 & 3.50 & 2.50 & 1.40 & 178.0 & 7.80 & 7.00 & 343.8 & 73.5 \\
\hline $28 / 4 / 06$ & $18: 30$ & 493 & 7.18 & 26.4 & -0.011 & 52.68 & 6.50 & 13.60 & 5.20 & 204.0 & 11.20 & 7.80 & 294.1 & 78.8 \\
\hline $23 / 5 / 06$ & $12: 50$ & 501 & 7.23 & 26.2 & -0.016 & 54.11 & 16.20 & 90 & 1.20 & 217.0 & 5.50 & 11.80 & 74.4 & 80.5 \\
\hline $21 / 6 / 06$ & $12: 15$ & 502 & 7.42 & 26.0 & -0.027 & 55.50 & 13.00 & 3.00 & 0.90 & 223.7 & 7.40 & 3.50 & 57.3 & 80.8 \\
\hline $20 / 7 / 06$ & $12: 40$ & 503 & 7.48 & 26.0 & -0.062 & 57.01 & 7.60 & 3.10 & 1.30 & 228.2 & 7.40 & 11.20 & 34.7 & 82.1 \\
\hline $23 / 8 / 06$ & $13: 30$ & 504 & 8.16 & 25.9 & -0.064 & 58.11 & 8.90 & 2.80 & 1.00 & 232.0 & 5.50 & 11.80 & 15.7 & 82.5 \\
\hline $21 / 9 / 06$ & $13: 30$ & 505 & 8.42 & 26.0 & -0.095 & 63.65 & 4.80 & 3.60 & 1.10 & 242.2 & 9.30 & 11.80 & 8.5 & 82.7 \\
\hline $16 / 11 / 06$ & $12: 45$ & 505 & 8.42 & 26.2 & -0.097 & 68.08 & 6.80 & 3.60 & 1.30 & 265.0 & 3.70 & 10.40 & 6.6 & 83.3 \\
\hline $21 / 12 / 06$ & $13: 00$ & 489 & 7.12 & 25.9 & -0.008 & 39.20 & 5.00 & 3.20 & 1.10 & 8.50 & 8.50 & 145 & 5.43 & 84.22 \\
\hline $22 / 1 / 07$ & 18:00 & 345 & 6.84 & 25.8 & -0.015 & 33.80 & 4.00 & 2.80 & 1.00 & 7.40 & 6.70 & 122 & 50.42 & 47.98 \\
\hline $26 / 2 / 07$ & $21: 30$ & 273 & 6.52 & 25.5 & -0.016 & 31.80 & 3.10 & 1.70 & 1.00 & 7.20 & 5.80 & 110 & 180.77 & 62.65 \\
\hline $22 / 3 / 07$ & 13:00 & 485 & 7.01 & 26.1 & -0.019 & 36.90 & 6.10 & 2.10 & 1.00 & 8.10 & 2.80 & 131 & 74.07 & 81.75 \\
\hline $22 / 4 / 07$ & $14: 30$ & 482 & 6.85 & 26.0 & -0.015 & 42.70 & 6.30 & 2.20 & 1.80 & 8.60 & 6.30 & 154 & 121.0 & 88.50 \\
\hline
\end{tabular}

Sumber : pengukuran lapangan dan analisis laboratorium tahun 2006-2007

Seperti halnya yang dijumpai di Gua Bribin, saat akhir hujan menuju musim kemarau, SBT di Luweng Jomblangan, Gua Gilap, dan Gua Ngreneng menunjukkan penurunan debit aliran menuju ke kondisi dominasi aliran dasar (diffuse flow), yang ditandai dengan kenaikan unsur terlarut dalam air karena pelepasan diffuse flow sebagai air infiltrasi yang telah jenuh melarutkan mineral karbonat pada akuifer karst. Ketika memasuki periode hujan, maka dominasi aliran dasar berkurang dan berfluktuasi tergantung pada periode banjir yang terjadi. Pola yang mirip dengan yang ditemukan di Gua Bribin juga ditunjukkan pada variasi temporal nilai kalsium dan bikarbonat terlarut yang cenderung meningkat perlahan-lahan pada musim 
kemarau dan kemudian turun drastis pada puncak musim hujan dan kemudian meningkat lagi pada akhir musim hujan 2007.

Tabel 4.25. Komposisi Kimia Sampel Air Gua Ngreneng Sepanjang Tahun

\begin{tabular}{|c|c|c|c|c|c|c|c|c|c|c|c|c|c|c|}
\hline \multicolumn{2}{|c|}{ Waktu } & \multirow{2}{*}{$\underset{(\mu \mathrm{mhos} / \mathrm{cm})}{\mathrm{DHL}}$} & \multirow{2}{*}{ pH } & \multirow{2}{*}{$\begin{array}{c}\text { Suhu } \\
\left({ }^{\circ} \mathrm{C}\right)\end{array}$} & \multirow{2}{*}{ Eh } & \multirow{2}{*}{$\begin{array}{c}\mathrm{Ca}^{2+} \\
(\mathrm{mg} / \mathrm{l})\end{array}$} & \multirow{2}{*}{$\begin{array}{c}\mathrm{Mg}^{2+} \\
(\mathrm{mg} / \mathrm{l})\end{array}$} & \multirow{2}{*}{$\begin{array}{c}\mathrm{Na}^{+} \\
(\mathrm{mg} / \mathrm{l})\end{array}$} & \multirow{2}{*}{$\begin{array}{c}\mathrm{K}^{+} \\
(\mathrm{mg} / \mathrm{l})\end{array}$} & \multirow{2}{*}{$\begin{array}{l}\mathrm{HCO}_{3}^{-} \\
(\mathrm{mg} / \mathrm{l})\end{array}$} & \multirow{2}{*}{$\underset{(\mathrm{mg} / \mathrm{l})}{\mathrm{Cl}^{-}}$} & \multirow{2}{*}{$\begin{array}{l}\mathrm{SO}_{4}{ }^{2-} \\
(\mathrm{mg} / \mathrm{l})\end{array}$} & \multirow{2}{*}{$\begin{array}{l}\text { Debit } \\
\text { (l/dt) }\end{array}$} & \multirow{2}{*}{$\begin{array}{l}\text { PAD } \\
(\%)\end{array}$} \\
\hline tanggal & jam & & & & & & & & & & & & & \\
\hline $23 / 3 / 06$ & $14: 00$ & 480 & 6.93 & 27.8 & 0.003 & 71.7 & 1.1 & 3 & 1.7 & 246 & 7.4 & 6 & 490.5 & 75.55 \\
\hline $26 / 4 / 06$ & $15: 30$ & 493 & 6.94 & 27.7 & 0.001 & 71.9 & 6.3 & 11.2 & 6.7 & 280 & 9.2 & 8.9 & 488.3 & 78.75 \\
\hline $22 / 5 / 06$ & $16: 30$ & 498 & 6.98 & 27.5 & -0.001 & 73.1 & 7.3 & 11 & 1.1 & 286 & 7.4 & 9.6 & 335 & 80.21 \\
\hline $20 / 6 / 06$ & $12: 30$ & 504 & 7.03 & 27.7 & -0.004 & 75.2 & 8.6 & 3 & 0.8 & 288 & 7.2 & 7 & 261.7 & 80.32 \\
\hline $19 / 7 / 06$ & 12:00 & 507 & 7.04 & 27.6 & -0.007 & 75.4 & 10.4 & 2.7 & 0.9 & 290.2 & 7.4 & 11.9 & 205.5 & 81.06 \\
\hline $22 / 8 / 06$ & $12: 30$ & 507 & 7.05 & 27.5 & -0.007 & 76.6 & 8.8 & 2.7 & 1.1 & 290.2 & 5.5 & 12.9 & 146.3 & 81.27 \\
\hline $20 / 9 / 06$ & $12: 30$ & 507 & 7.11 & 27.6 & -0.032 & 77.1 & 8.3 & 3.5 & 1.1 & 292 & 5.7 & 12.5 & 119.4 & 81.71 \\
\hline 15/11/06 & $12: 30$ & 508 & 7.12 & 27.5 & -0.022 & 78.1 & 8 & 3.5 & 1.1 & 293 & 3.7 & 15.4 & 69.8 & 81.95 \\
\hline $20 / 12 / 06$ & $12: 30$ & 465 & 6.80 & 27.4 & 0.010 & 23.60 & 22.10 & 3.40 & 1.90 & 7.50 & 8.70 & 178 & 65.43 & 100.00 \\
\hline $1 / 2 / 07$ & $12: 30$ & 485 & 6.92 & 27.4 & 0.004 & 39.88 & 10.90 & 3.40 & 1.20 & 7.60 & 12.40 & 174 & 72.85 & 80.59 \\
\hline $23 / 2 / 07$ & $9: 30$ & 418 & 6.85 & 27.4 & -0.010 & 30.40 & 8.00 & 3.70 & 2.00 & 10.00 & 1.10 & 120 & 231.11 & 100.00 \\
\hline $30 / 3 / 07$ & 9:00 & 487 & 6.61 & 27.5 & -0.002 & 40.80 & 10.50 & 4.20 & 1.70 & 12.50 & 8.30 & 171 & 223.39 & 80.33 \\
\hline $20 / 4 / 07$ & 9:00 & 484 & 6.55 & 27.4 & 0.002 & 42.30 & 12.50 & 3.40 & 1.80 & 12.90 & 8.50 & 167 & 202.672 & 82.27 \\
\hline
\end{tabular}

Sumber : pengukuran lapangan dan analisis laboratorium tahun 2006-2007

\section{b. Scatter plot DHL-unsur dominan terlarut}

Scatter plot DHL-unsur dominan terlarut di Sungai Pentung, Luweng Jomblangan, Gua Gilap, dan Gua Ngreneng disajikan pada Gambar 4.43, 4.44, 4.45, dan 4.46.

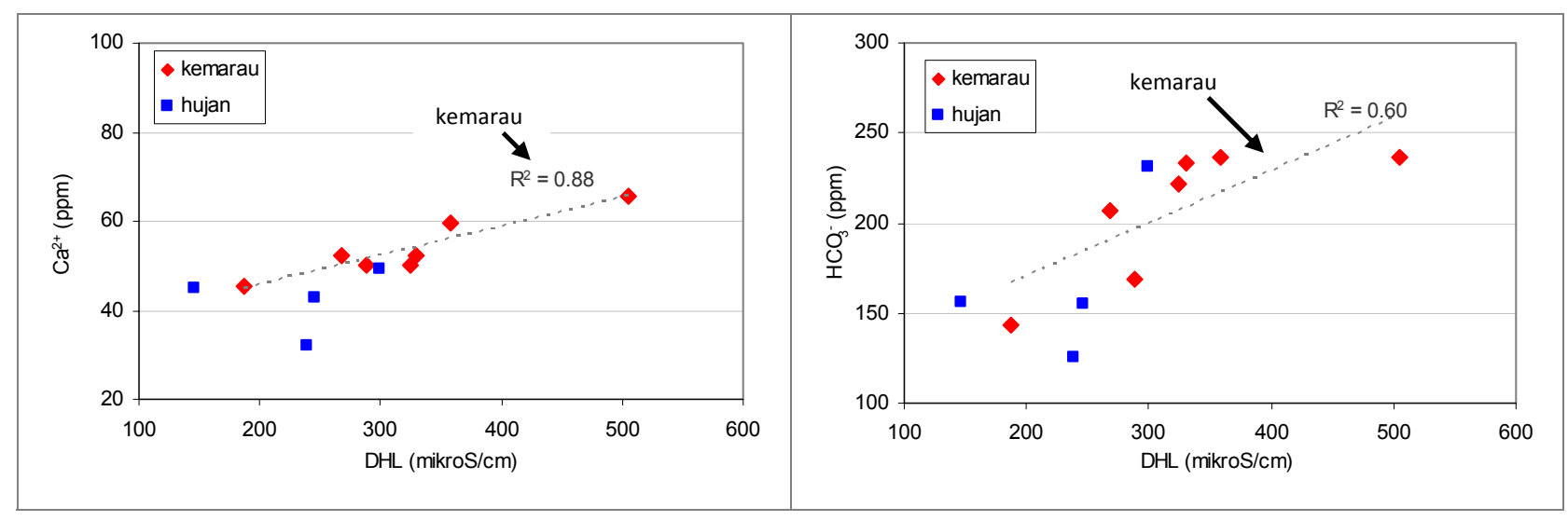

Gambar 4.43. Hubungan DHL dan Kalsium Terlarut (kiri) dan DHL Bikarbonat Terlarut (kanan) di Sungai Pentung Sepanjang Tahun 


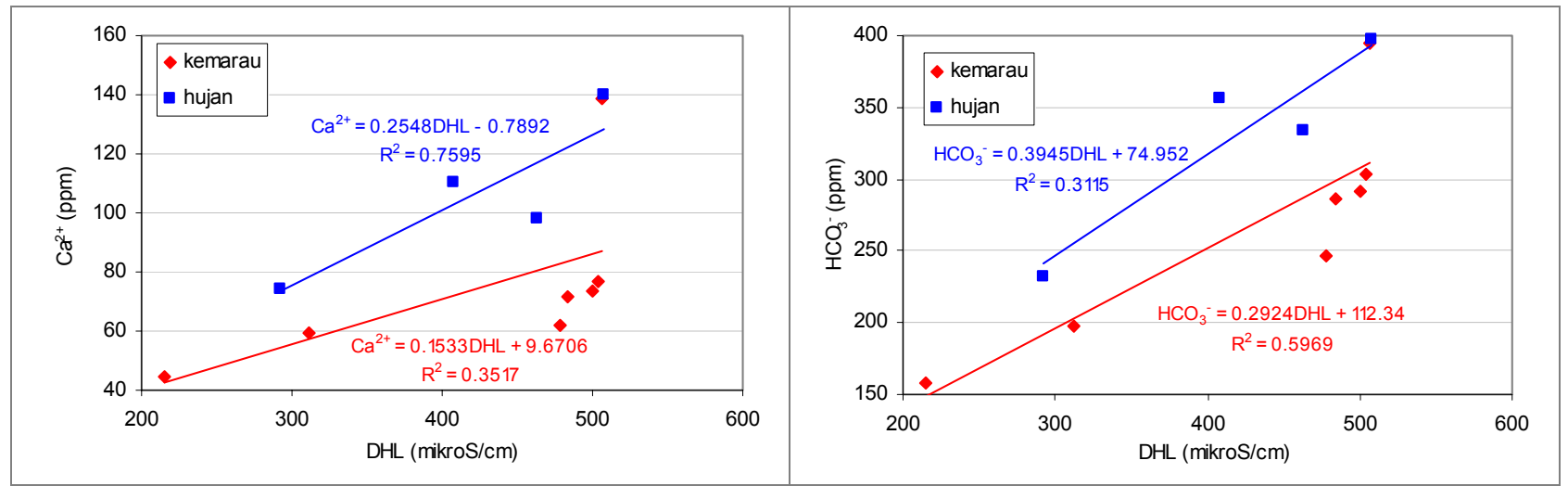

Gambar 4.44. Hubungan DHL dan Kalsium Terlarut (kiri) dan DHL Bikarbonat Terlarut (kanan) di Luweng Jomblangan Sepanjang Tahun
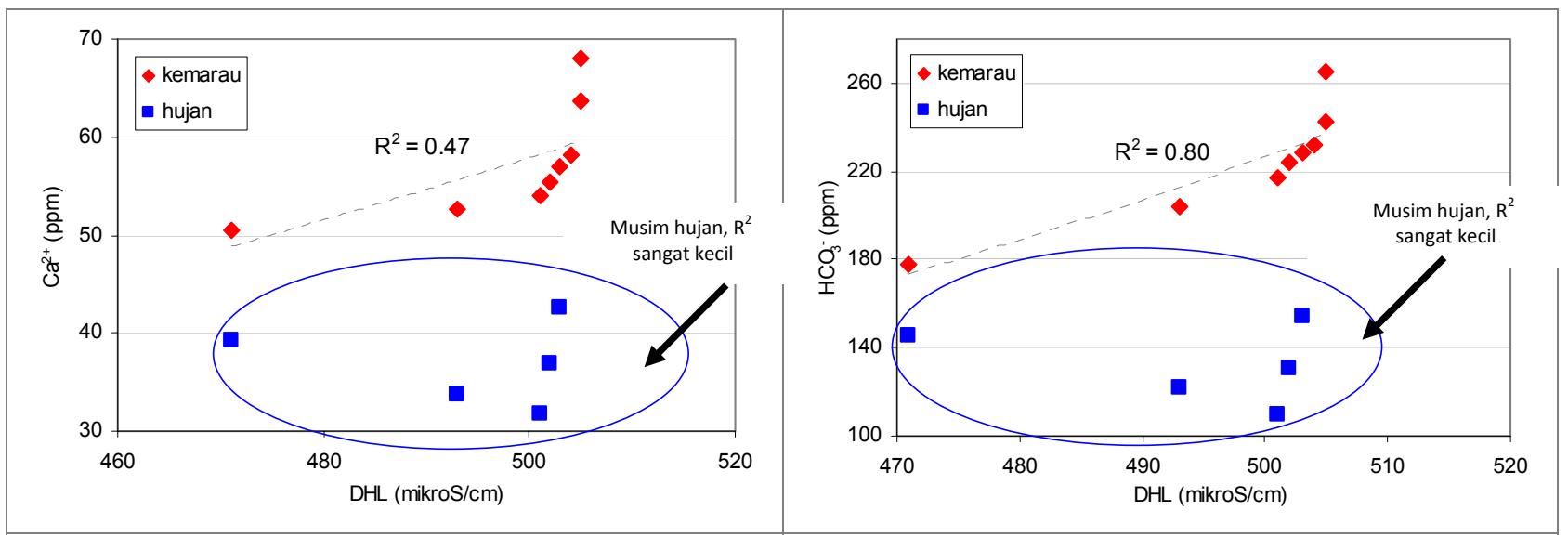

Gambar 4.45. Hubungan DHL dan Kalsium Terlarut (kiri) dan DHL Bikarbonat Terlarut (kanan) di Gua Gilap Sepanjang Tahun
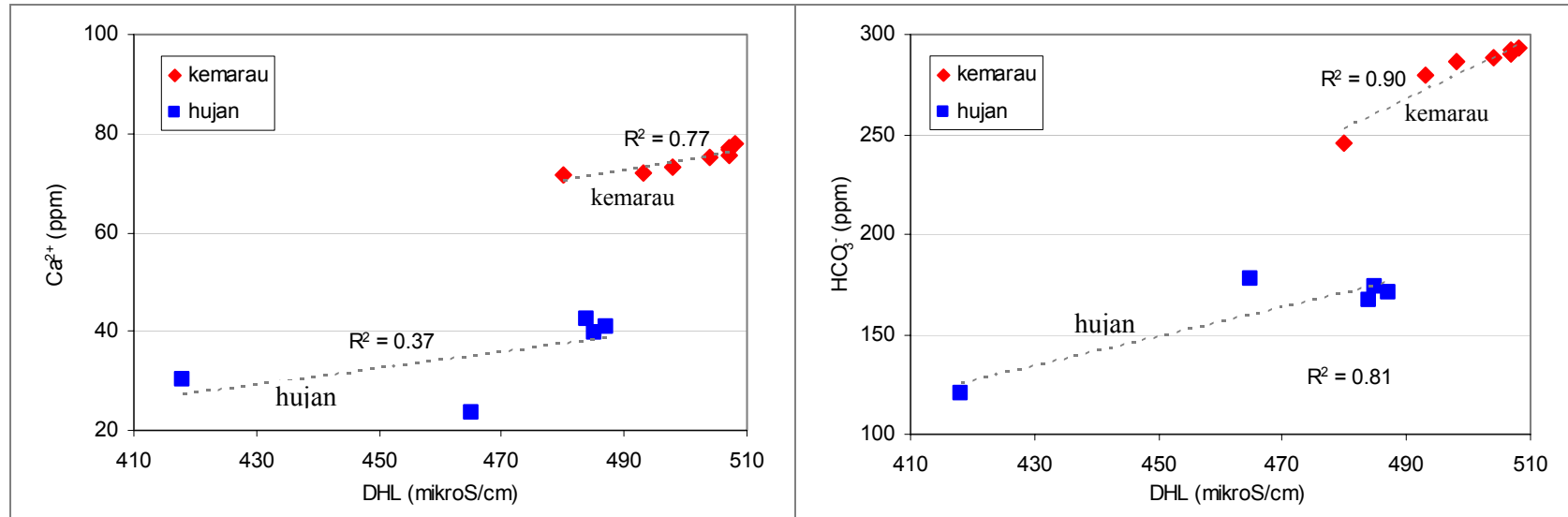

Gambar 4.46. Hubungan DHL dan Kalsium Terlarut (kiri) dan DHL Bikarbonat Terlarut (kanan) di Gua Ngreneng Sepanjang Tahun 
Dari Gambar 4.43, 4.44, 4.45, dan 4.46. terlihat bahwa hubungan antara DHL dan kalsium atau bikarbonat sebagain besar pada musim kemarau mempunyai hubungan positif, dengan nilai determnasi $\left(\mathrm{R}^{2}\right)$ sebesar $70 \%$, bahkan lebih. Sebaliknya, hubungan yang ditemukan pada musim penghujan adalah negatif. Hal ini mengindikasikan bahwa hubungan positif hasil proses water-rock interaction lebih dominan terjadi pada saat musim kemarau, yaitu saat terjadi dominasi diffuse flow dibandingkan pada saat musim hujan yang terpengaruh oleh aliran dari sistem conduit, sehingga terjadi mekanisme percampuran (mixing) antar komponen aliran dan proses dilution by precipitation. Dari gambar-gambar tersebut tersebut juga terlihat bahwa nilai kalsium dan bikarbonat terlarut serta DHL pada saat musim kemarau jauh lebih besar dari yang dijumpai pada saat musim penghujan.

Hal yang agak sedikit berbeda dijumpai di Luweng Jomblangan, yaitu nilai $\mathrm{R}^{2}$ tidak sebesar yang ditemukan gua-gua yang lain, terutama pada saat musim kemarau. Hal ini dapat dimungkinkan karena komponen aliran di Luweng Jomblangan merupakan campuran dari sungai permukaan dan akuifer karst yang mempunyai fase kejenuhan mineral karbonat yang berbeda pada proses water-rock interaction.

\section{c. Scatter plot natrium-klorida}

Scatter plot natrium-klorida di Sungai Pentung, Luweng Jomblangan, Gua Gilap, dan Gua Ngreneng disajikan pada Gambar 4.47. dan Gambar 4.48. Analisis scatter plot antara $\mathrm{Na}^{+}$dan $\mathrm{Cl}^{-}$menunjukkan bahwa terjadi pemisahan posisi pada plotting secara tegas yaitu sampel-sampel musim hujan dan awal kemarau mempunyai posisi relatif mendekati garis rasio 1:1 Sementara itu, pengukuran pada bulan-bulan September dan November 2006 (puncak kemarau) menunjukkan posisinya yang berada paling jauh dari garis rasio 1:1, yang menunjukkan kuatnya 
proses water-rock interaction karena melemahnya dominasi air hujan dan digantikan oleh komponen aliran dasar dari akuifer karst.
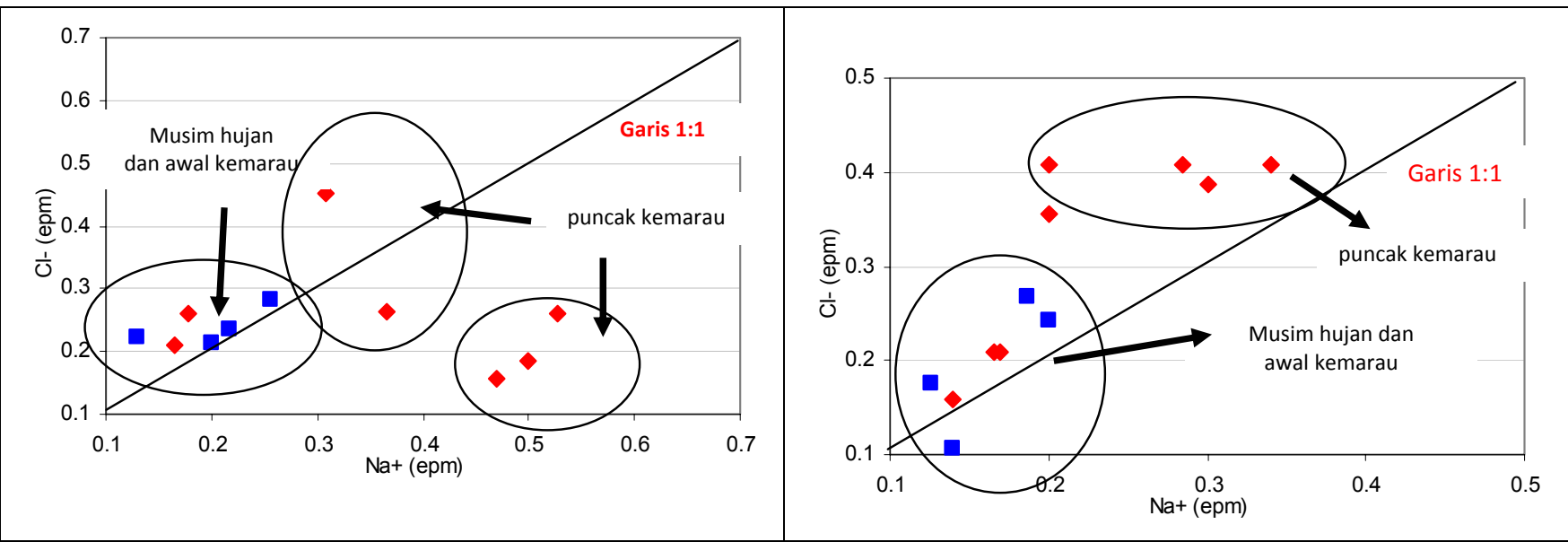

Gambar 4.47. Scatter Plot Ion Natrium dan Klorida Sungai Pentung (kiri) dan Luweng Jomblangan (kanan) Sepanjang Tahun
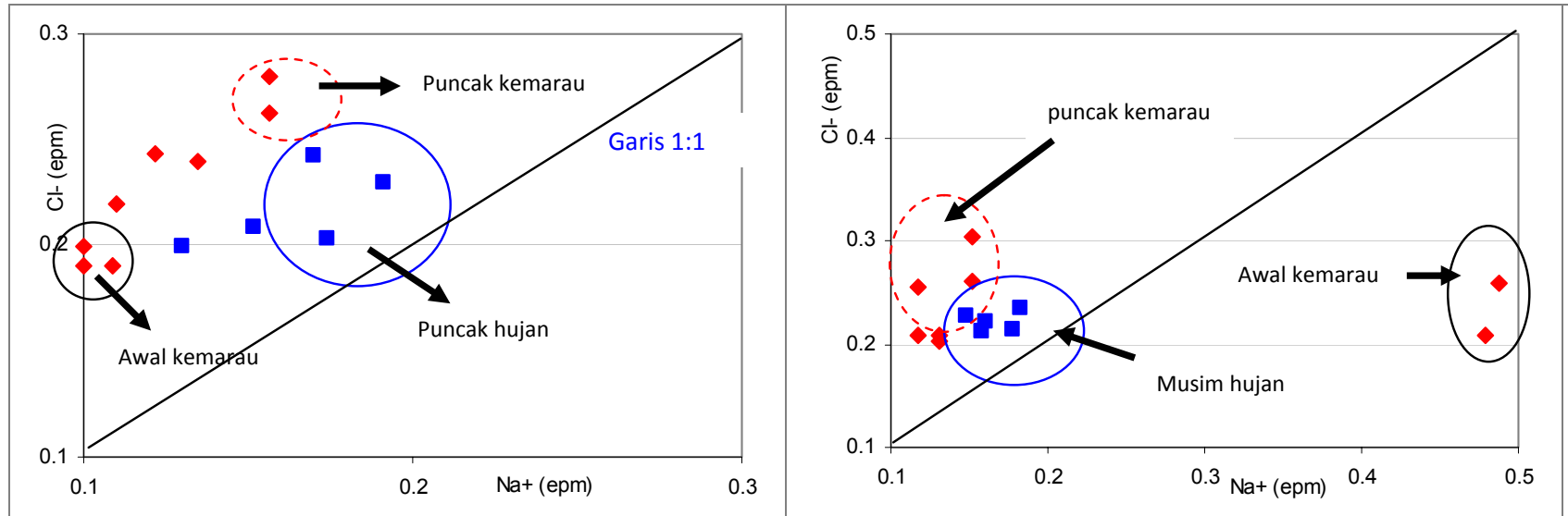

Gambar 4.48. Scatter Plot Ion Natrium dan Klorida Gua Gilap (kiri) Dan Gua Ngreneng (kanan) Sepanjang Tahun

\section{d. Scatter plot PAD-debit aliran}

Scatter plot PAD-debit aliran di Sungai Pentung, Gua Gilap, dan Gua

Ngreneng disajikan pada Gambar 4.49, 4.50, 4.51. 


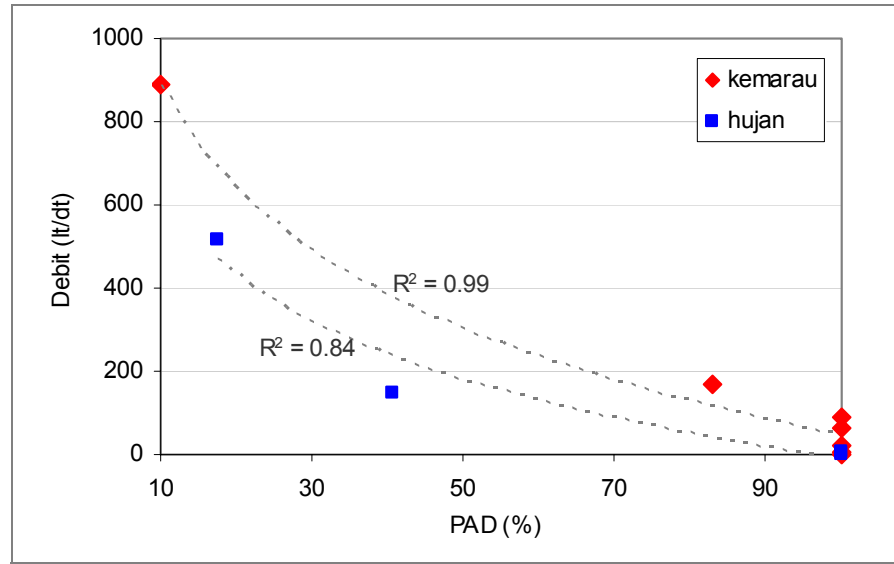

Gambar 4.49. Hubungan Debit dan PAD (Baseflow) Sungai Pentung Sepanjang Tahun

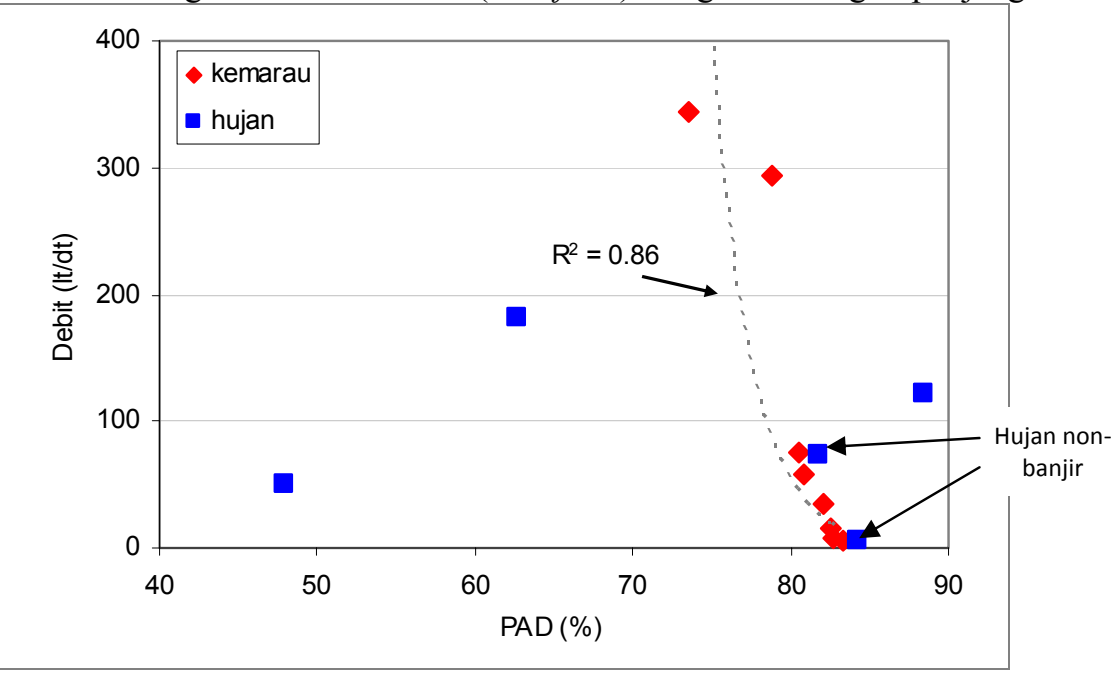

Gambar 4.50. Hubungan Debit dan PAD Gua Gilap Sepanjang Tahun

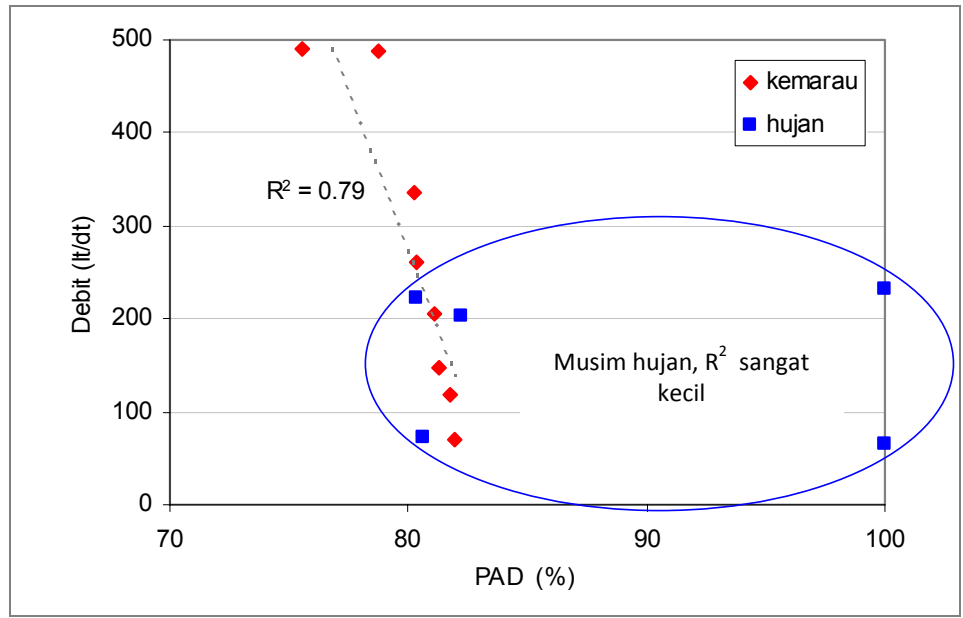

Gambar 4.51. Hubungan Debit dan PAD (Baseflow) Gua Ngreneng Sepanjang Tahun 
Penurunan debit aliran meningkatkan persentase aliran diffuse. Hubungan negatif ini juga terjadi pada saat musim hujan meskipun hubungannya kecil. Meskipun demikian, di Gua Gilap terdapat dua sampel musim hujan yang terletak dekat pada garis linier hubungan debit-PAD musim kemarau. Dua sampel tersebut diambil pada saat musim hujan bukan pada saat kejadian banjir (awal dan akhir musim hujan), sehingga mengindikasi adanya proses water-rock interaction. Di Sungai Pentung terlihat bahwa terdapat hubungan yang kuat antara penurunan debit dan kenaikan runoff di aliran Sungai Pentung (hubungan negatif) terutama pada saat musim kemarau $\left(\mathrm{R}^{2}=0,99\right)$. Karena pengaruh limpasan permukaan dikontrol oleh kejadian hujan, determinasi antara debit dan PAD saat musim penghujan sedikit mengalami penurunan, yaitu $\left.\mathrm{R}^{2}=0,84\right)$.

\section{e. Scatter plot PAD-unsur dominan terlarut}

Scatter plot PAD-debit aliran di Sungai Pentung, Gua Gilap, dan Gua Ngreneng disajikan pada Gambar 4.52, 4.53, 4.54.
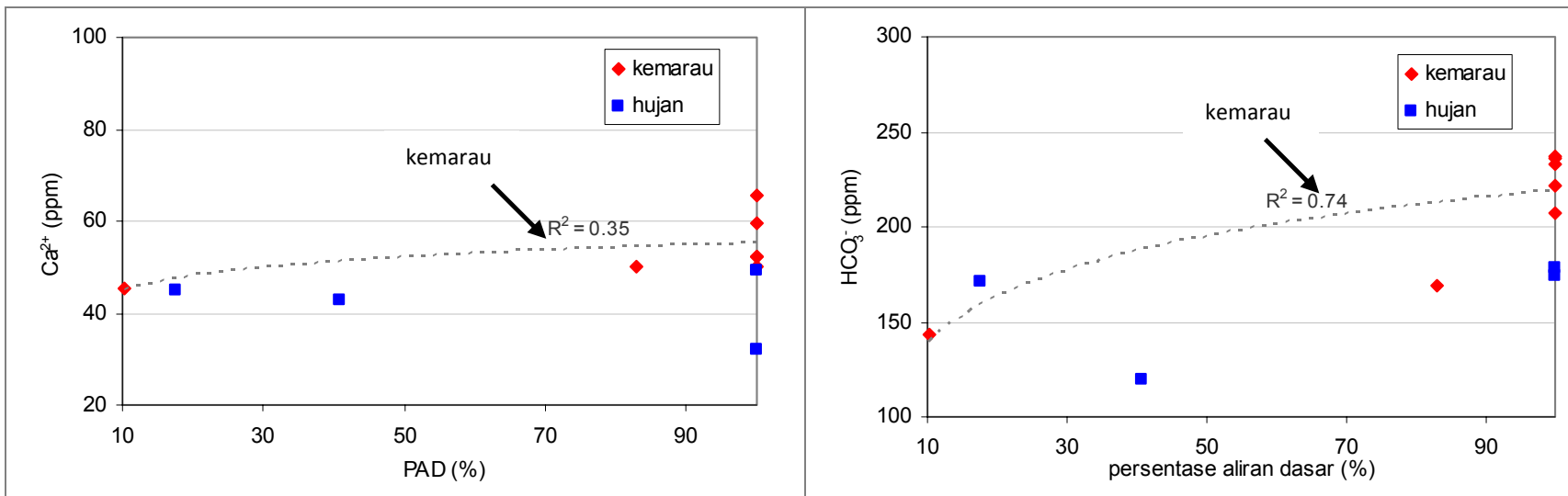

Gambar 4.52. Hubungan PAD-Kalsium Terlarut (kiri) dan PAD-Bikarbonat Terlarut (kanan) di Sungai Pentung Sepanjang Tahun 

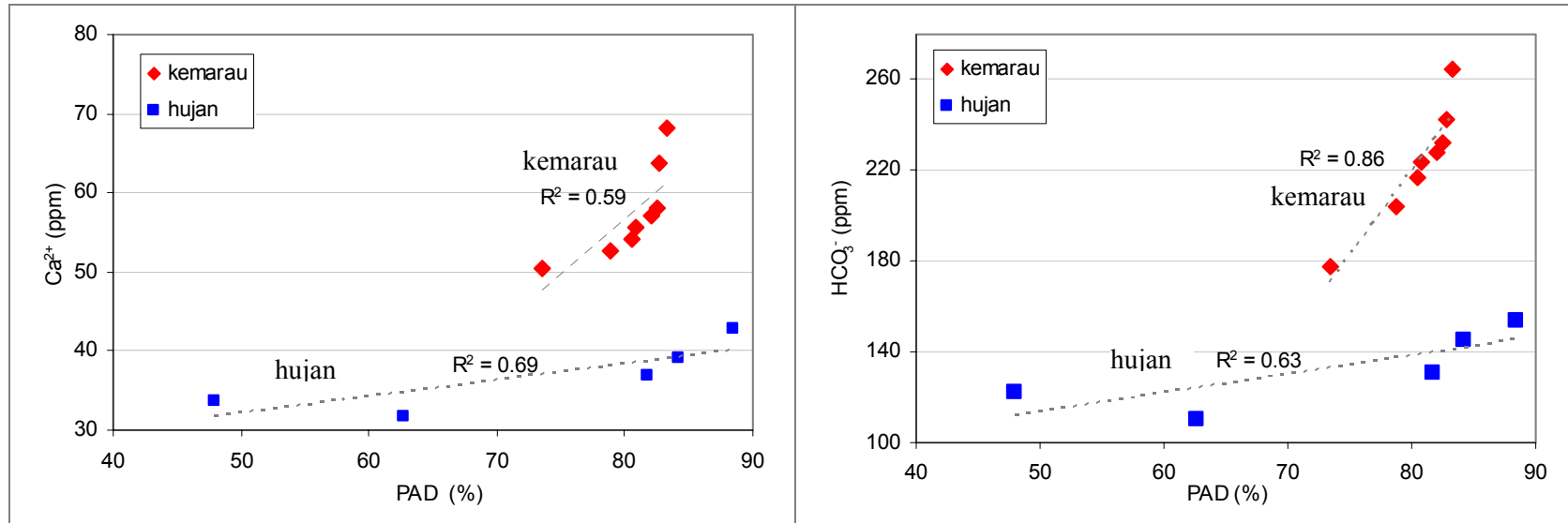

Gambar 4.53. Hubungan PAD-Kalsium Terlarut (kiri) dan PAD-Bikarbonat Terlarut (kanan) di Gua Gilap Sepanjang Tahun
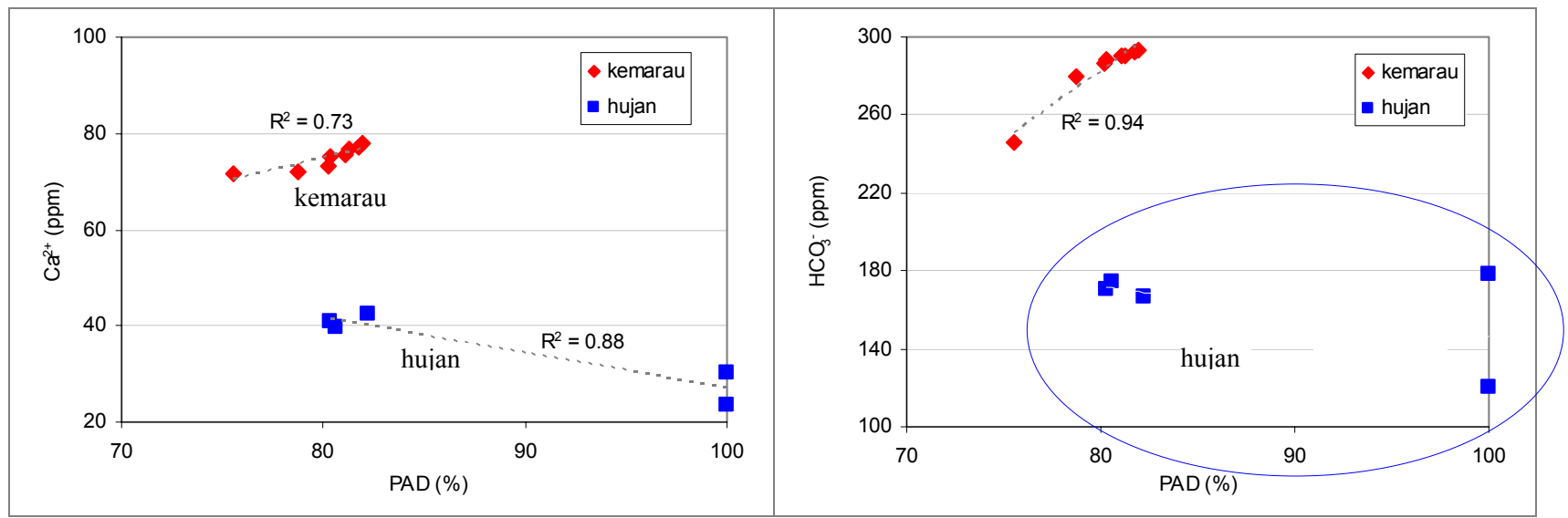

Gambar 4.54. Hubungan PAD-Kalsium Terlarut (kiri) dan PAD-Bikarbonat Terlarut (kanan) di Gua Ngreneng Sepanjang Tahun

Di Sungai Pentung, hal sedikit berbeda ditemukan pada hubungan antara PAD dan kandungan kalsium-bikarbonat terlarut pada saat musim hujan di Sungai Pentung mempunyai hubungan positif (Gambar 4.52) jika dibanding dengan yang ditemukan di Gua Gilap dan Gua Ngreneng. Pada saat musim kemarau hubungannya tetap positif, tetapi tidak sebesar yang dijumpai pada sungai bawah tanah. Hal ini disebabkan oleh perbedaan komposisi dan fluktuasi komponen aliran yang mengimbuh ke sistem perguaan, yaitu sifat conduit flow yang mempunyai waktu tunggu (timelag) yang lebih lama dibanding dengan overlandflow yang lebih cepat 
sampai ke Sungai Pentung. Hubungan PAD dan kalsium/bikarbonat terlarut yang dijumpai di Sungai Pentung karakteristiknya paling mirip dengan yang teramati di Gua Ngreneng yang pada musim hujan juga menerima overlandflow dari daerah sekitarnya.

Dari Gambar 4.53. terlihat bahwa PAD di Gua Gilap pada saat musim hujan sangat bervariasi dengan kisaran antara $47-88 \%$, sedangkan pada saat musim kemarau kisarannya adalah antara 73-83\%. Hal ini menunjukkan bahwa saluran conduit yang ada pada sistem pelorongan Gua Gilap berkontribusi memasok aliran conduit saat periode hujan. Dari scatter plot PAD dan kalsium-bikarbonat terlarut, terlihat bahwa terdapat hubungan yang positif antara karakteristik aliran dasar dan unsur terlarut utama yaitu kalsium dan bikarbonat. Hal ini terjadi baik pada saat musim hujan maupun musim kemarau yang menunjukkan bahwa PAD di Gua Gilap berkontribusi terhadap unsur utama terlarut. Hal yang sama juga dialami oleh Gua Ngreneng (Gambar 4.54.), meskipun dengan $\mathrm{R}^{2}$ yang lebih kecil saat musim hujan.

\section{f. Scatter plot PAD-log $\mathrm{PCO}_{2}$}

Scatter plot PAD - $\log \mathrm{PCO}_{2}$ di Sungai Pentung, Gua Gilap, dan Gua Ngreneng disajikan pada Gambar 4.55, 4.56, 4.57.

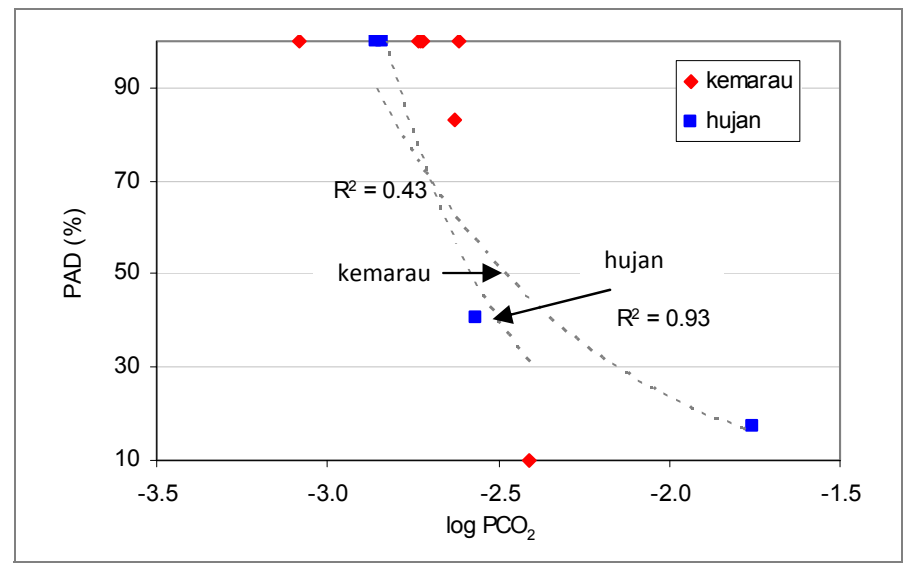

Gambar 4.55. Hubungan PAD-Tekanan Parsial Gas Karbondioksida Sepanjang Tahun di Sungai Pentung 


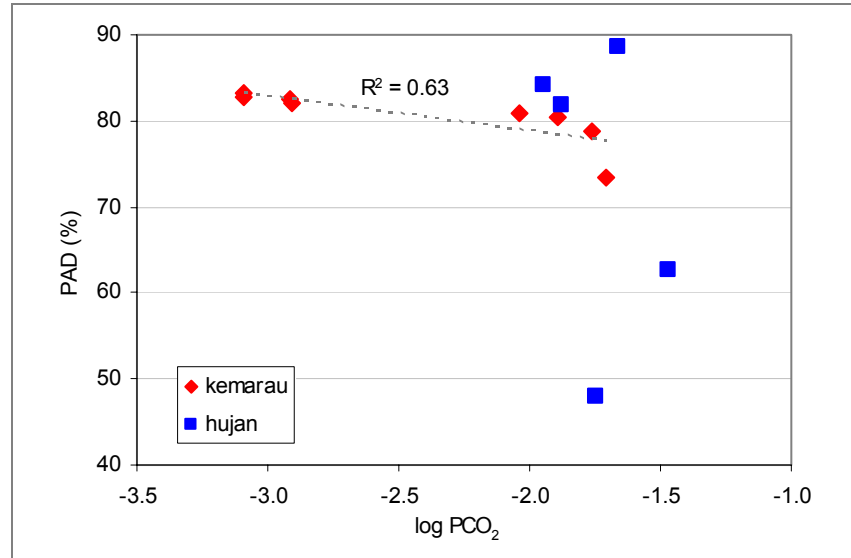

Gambar 4.56. Hubungan PAD-Tekanan Parsial Gas Karbondioksida Sepanjang Tahun di Gua Gilap

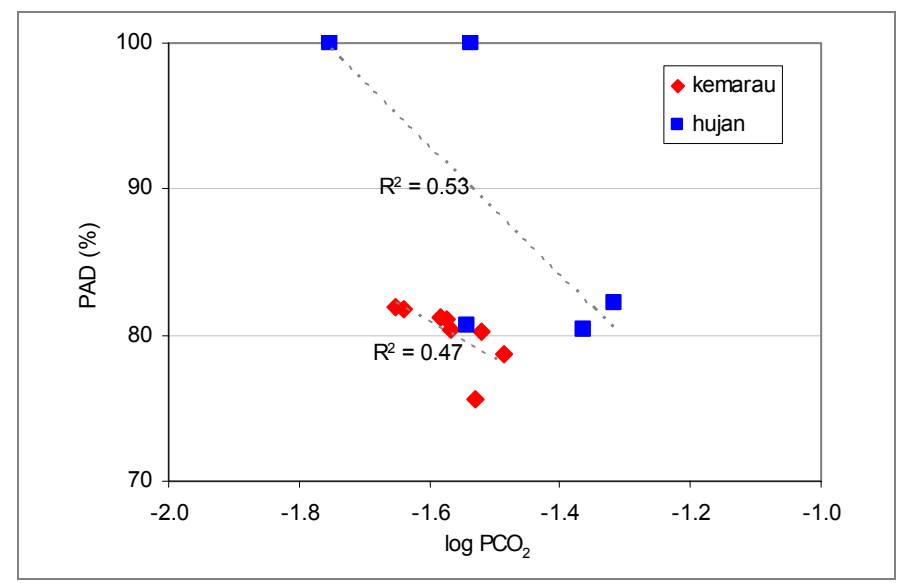

Gambar 4.57. Hubungan PAD-Tekanan Parsial Gas Karbondioksida Sepanjang Tahun di Gua Ngreneng

Di Sungai Pentung (Gambar 4.55), hubungan $\log \mathrm{PCO}_{2}$ dan $\mathrm{PAD}$ besar yaitu dengan nilai $\mathrm{R}^{2}$ sekitar 0,9, karena sistem interface udara dan air di Sungai Pentung bersifat terbuka sehingga setiap saat ada transfer gas karbondioksida ke dalam air, serta tidak ada gas karbondioksida yang dipergunakan untuk melarutkan batuan seperti halnya yang terjadi pada sistem sungai bawah tanah. Di Gua Gilap, variasi nilai $\log \mathrm{PCO}_{2}$ menunjukkan kecenderungan menurun dan mencapai level terendah pada saat waktu-waktu puncak musim kemarau (September-November) yang 
kemudian naik ketika mulai turun hujan dan berfluktuasi tergantung kepada variasi banjir di Gua Gilap. Jika dihubungkan dengan PAD, terlihat bahwa nilai log $\mathrm{PCO}_{2}$ dan PAD adalah mempunyai hubungan negatif, artinya nilai $\log \mathrm{PCO}_{2}$ akan turun saat persentase baseflow di Gua Gilap meningkat (Gambar 4.56). Pada saat musim kemarau, terdapat hubungan yang lebih signifikan antara tekanan parsial gas karbondioksida dan persentase baseflow pada air Sungai Gilap dibandingkan pada saat musim hujan (nilai $\mathrm{R}^{2}$ sebesar 0,63 dibandingkan sebesar 0,15 pada saat musim hujan). Hal ini menunjukkan bahwa proses water-rock interaction lebih dominan terjadi pada saat musim kemarau. Beberapa proses lain yang terjadi pada saat musim hujan adalah dilution by precipitation yang ditunjukkan dengan turunnya nilai PAD, serta masuknya gas karbondioksida melalui saluran conduit pada sistem karst terbuka (open system). Hal yang sama di musim kemarau juga dialami di Gua Ngreneng meskipun hubungannya tidak begitu besar yaitu dengan $\mathrm{R}^{2}$ hanya sekitar 0,5 (Gambar 4.57).

\section{f. Scatter plot unsur dominan terlarut-log $\mathrm{PCO}_{2}$}

Scatter plot unsur dominan terlarut- $\log \mathrm{PCO}_{2}$ di Sungai Pentung, Luweng Jomblangan, Gua Gilap, dan Gua Ngreneng disajikan pada Gambar 4.58, 4.59, 4.60, dan 4.61.

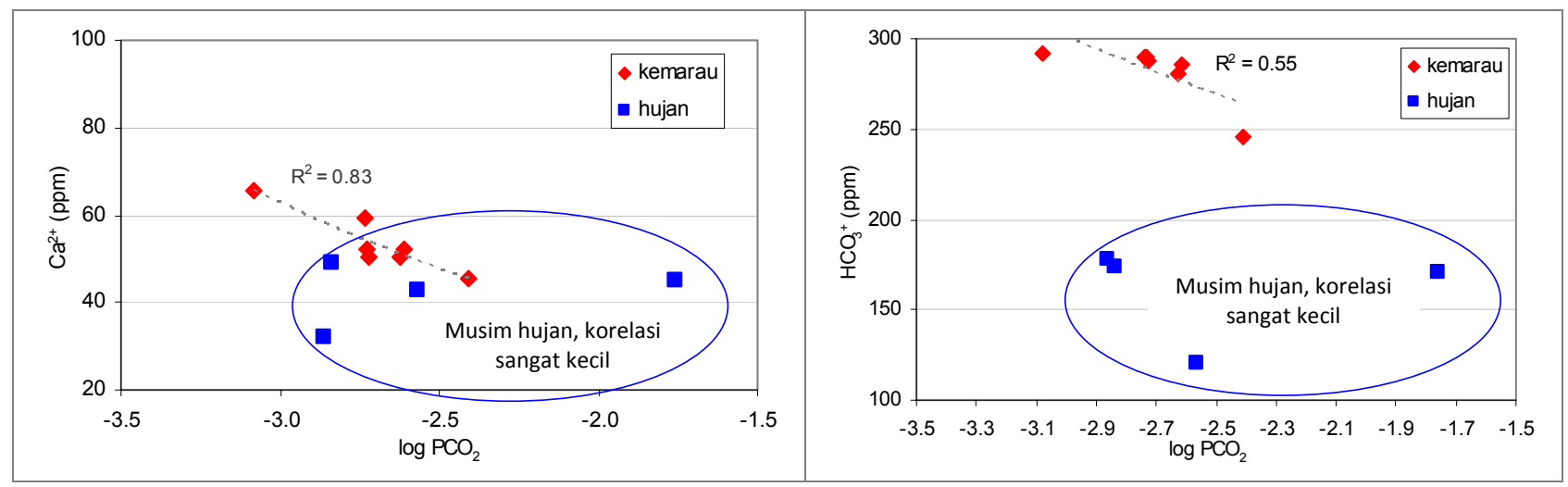

Gambar 4.58. Hubungan Nilai Log $\mathrm{PCO}_{2}$-Kalsium Terlarut (atas) dan Nilai Log $\mathrm{PCO}_{2^{-}}$ Bikarbonat Terlarut (bawah) di Sungai Pentung Sepanjang Tahun 

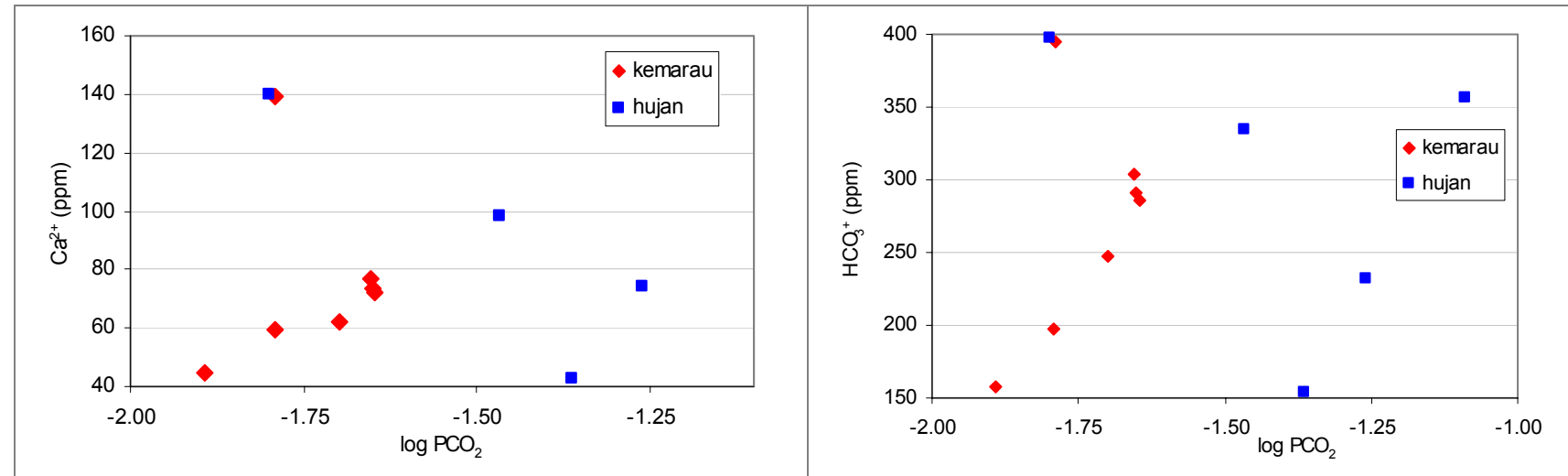

Gambar 4.59. Hubungan Nilai Log $\mathrm{PCO}_{2}$-Kalsium Terlarut (atas) dan Nilai $\log \mathrm{PCO}_{2}$ Bikarbonat Terlarut (bawah) di Luweng Jomblangan Sepanjang Tahun
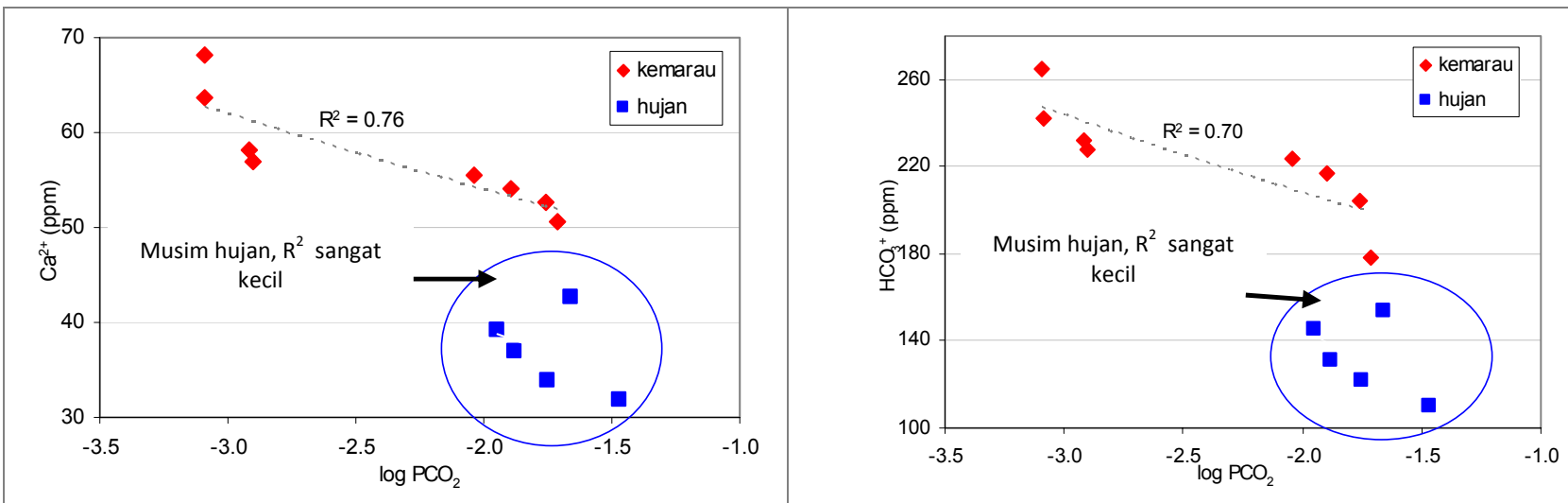

Gambar 4.60. Hubungan Nilai $\log \mathrm{PCO}_{2}$-Kalsium Terlarut (atas) dan Nilai $\log \mathrm{PCO}_{2}-$ Bikarbonat Terlarut (bawah) di Gua Gilap Sepanjang Tahun
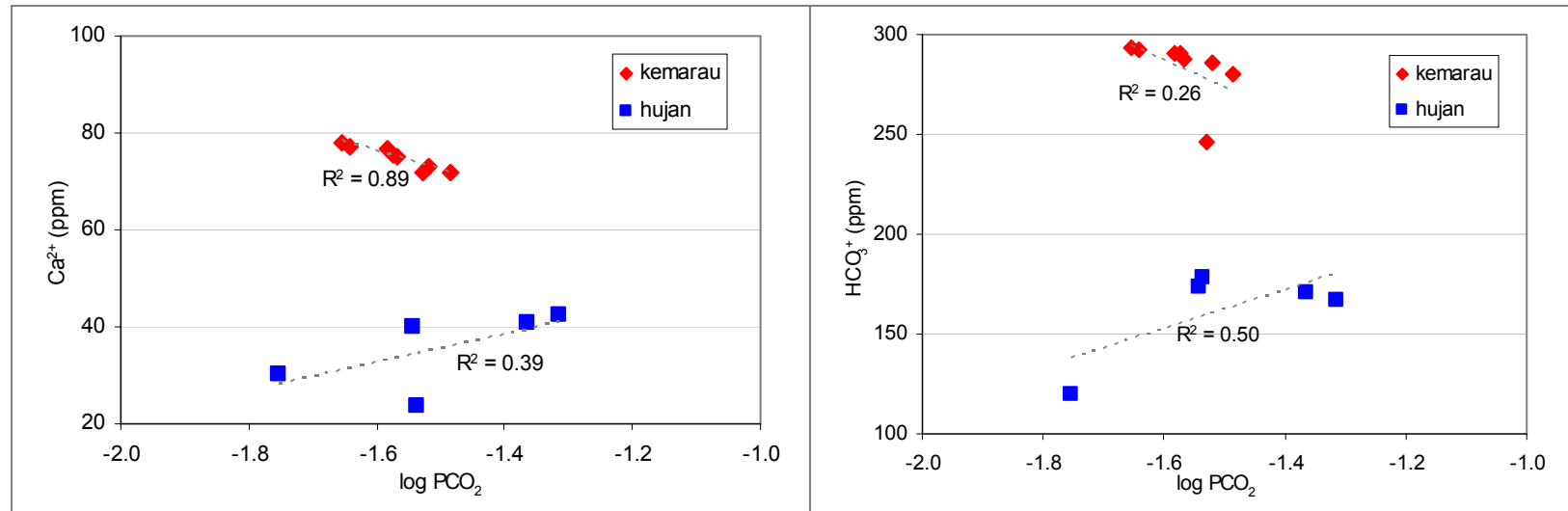

Gambar 4.61. Hubungan Nilai Log $\mathrm{PCO}_{2}$-Kalsium Terlarut (atas) dan Nilai $\log \mathrm{PCO}_{2}$ Bikarbonat Terlarut (bawah) di Gua Ngreneng Sepanjang Tahun 
Hubungan negatif juga terjadi pada hubungan antara kalsium dan bikarbonat terlarut dan $\log \mathrm{PCO}_{2}$. Nilai $\mathrm{R}^{2}$ yang rendah saat musim hujan menunjukkan dominasi aliran conduit yang cepat berubah, yaitu pada saat banjir yang membawa air dari permukaan karst mengisi sungai bawah tanah dan menurunkan PAD (baseflow). Bahkan, di Gua Ngreneng dijumpai hubungan positif. Perbedaan hubungan tersebut menunjukkan bahwa pengaruh gas karbondioksida lebih cenderung terjadi pada saat musim hujan dan mengecilkan pengaruh proses waterrock interaction. Hal ini didukung oleh besarnya aliran permukaan yang memasok Gua Ngreneng pada musim hujan. Secara umum, karakter dan variasi proses hidrogeokimia di Gua Gilap, Gua Ngreneng, Sungai Pentung, dan Luweng Jomblangan disajikan pada Tabel 4.26.

Tabel 4.26. Karakter dan Variasi Proses Hidrogeokimia di Sungai Pentung, Luweng Jomblangan, Gua Gilap, dan Gua Ngreneng Sepanjang Tahun

\begin{tabular}{|c|c|c|}
\hline Musim & Proses hidrogeokimia & Ciri-ciri parameter hidrogeokimia \\
\hline Kemarau & $\begin{array}{l}\text { Interaksi batuan dan air } \\
\text { (water-rock interaction) }\end{array}$ & $\begin{array}{l}\text { (1) Kadar unsur terlarut }\left(\mathrm{Ca}^{2+} \text { dan } \mathrm{HCO}_{3}^{-}\right) \text {meningkat menuju puncak kemarau } \\
\text { (2) Hubungan yang kuat antara penurunan debit dan kenaikan PAD } \\
\text { (3) Hubungan yang kuat antara kenaikan } \mathrm{Ca}^{2+} \text { dan } \mathrm{HCO}_{3}{ }^{-} \text {dan kenaikan PAD } \\
\text { (4) Kandungan gas karbondioksida yang minim dalam air saat puncak kemarau } \\
\text { (5) Komposisi kimia saat puncak kemarau bebeda dengan saat awal kemarau } \\
\text { (6) Hubungan yang kuat antara kenaikan } \mathrm{Ca}^{2+}-\mathrm{HCO}_{3}^{-} \text {dan penurunan karbondioksida dalam } \\
\text { air }\end{array}$ \\
\hline Hujan & $\begin{array}{l}\text { (1) Pengenceran oleh air hujan } \\
\text { (dilution by precipitation) } \\
\text { (2) Interaksi batuan dan air } \\
\text { (water-rock interaction) } \\
\text { (3) Difusi gas karbondioksida }\end{array}$ & $\begin{array}{l}\text { (1) Dominasi conduit flow saat banjir, dan dominasi difuse flow saat resesi dan non-banjir } \\
\text { (2) Turunnya } \mathrm{Ca}^{2+} \text { dan } \mathrm{HCO}_{3}^{-} \text {saat debit besar, dan kenaikannya saat debit kecil } \\
\text { (3) Naiknya gas karbondioksida saat debit besar } \\
\text { (4) Hubungan } \mathrm{DHL} \text { vs } \mathrm{Ca}^{2+} \text { dan } \mathrm{HCO}_{3}^{-} \text {dengan determinasi rendah } \\
\text { (5) Hubungan } \mathrm{PAD} \text { vs } \mathrm{Ca}^{2+} \text { dan } \mathrm{HCO}_{3}^{-} \text {dengan determinasi rendah saat debit besar } \\
\text { (6) Hubungan } \mathrm{PAD} \text { vs } \mathrm{Ca}^{2+} \text { dan } \mathrm{HCO}_{3}^{-} \text {dengan determinasi tinggi saat debit kecil } \\
\text { (7) Determinasi yang cukup kuat antara penurunan PAD dengan kenaikan } \mathrm{CO}_{2} \text { dalam air } \\
\text { sepanjang musim hujan }\end{array}$ \\
\hline
\end{tabular}




\section{Pembahasan karakteristik spasial dan temporal hidrogeokimia SBT Bribin dan hubungannya dengan sifat alirannya}

Pembahasan secara spasio-temporal hidrogeokimia SBT Bribin pada sub bab ini dimaksudkan untuk memberikan gambaran yang menyeluruh mengenai perbedaan karakter hidrogeokimia pada masing-masing lokasi pengambilan sampel yang mewakili alur SBT Bribin dari hulu menuju ke hilir. Pembahasan karakter hidrogeokimia lebih menekankan pada hubungan antara karakter hidrogeokimia dan karakteristik aliran pada masing-masing lokasi pengambilan sampel seperti yang sudah dibahas sebelumnya.

\section{a. Hubungan DHL-kalsium dan DHL-bikarbonat}

Hubungan antara Daya Hantar Listrik (DHL) yang merepresentasikan total unsur terlarut dalam air (Appelo and Postma, 1994) dan unsur penting terlarut pada sungai bawah tanah karst yaitu kation kalsium $\left(\mathrm{Ca}^{2+}\right)$ dan anion bikarbonat $\left(\mathrm{HCO}_{3}{ }^{-}\right)$ dapat digunakan untuk menjelaskan hubungan kuat tidaknya proses interaksi antara air dan batuan karst (water-rock interaction) di suatu tempat, karena persentase kalsium dan bikarbonat yang sangat besar dalam air (Karimi, et al, 2005). Secara temporal, hubungan DHL-kalsium dan DHL-bikarbonat akan dibahas pada musim hujan dan musim kemarau, sedangkan khusus untuk Gua Bribin ditambah pada saat 2 kali kejadian banjir. Selanjutnya, hubungan antara DHL-kalsium dan DHLbikarbonat gua-gua sepanjang aliran SBT Bribin saat musim kemarau disajikan pada Gambar 4.62. Gambar 4.63. Gua Bribin yang terletak di hilir SBT Bribin pada saat musim kemarau memiliki hubungan determinasi yang paling kuat yang juga didukung dengan nilai DHL dan kalsium dan bikarbonat terlarut yang paling tinggi dibandingkan dengan gua-gua lain. Jika mengacu hasil karakteristik aliran dasar yang sudah dibahas pada sub-bab sebelumnya, pada saat musim kemarau komposisi aliran 
dasar di Gua Bribin merupakan yang paling besar dan memiliki fluktuasi aliran dasar paling rendah dibanding gua-gua yang lain, yaitu mencapai angka sekitar 98\% dengan konstanta resesi aliran dasar $\left(\mathrm{K}_{\mathrm{b}}\right)$ sebesar 0,998 , sedangkan komposisi aliran dasar yang dijumpai di Gua Gilap yang berkisar pada angka $81 \%$. Sementara itu, Gua Ngreneng yang oleh MacDonalds and Partners (1984) disebutkan sebagai bocoran dari Gua Bribin mempunyai hubungan paling mirip dengan Gua Bribin dengan bentuk scatter plot kandungan DHL dan kalsium-bikarbonat yang juga mirip.

Gua-gua lain yang berada di wilayah hulu mempunyai hubungan yang lebih kecil dengan yang ditemukan di wilayah hilir, kecuali yang dijumpai di Sungai Pentung karena aliran dasar Sungai Pentung tidak bersifat karstik, sehingga hubungan hanya terpengaruh oleh oleh proses water-rock interaction saja, meskipun bukan dengan mineral yang berbatuan karbonat. Nilai $\mathrm{R}^{2}$ yang rendah di Luweng Jomblangan lebih disebabkan adanya proses mixing antara base flow dari Pentung dan baseflow dari akuifer Sungai Pentung yang mempunyai karakteristik yang berbeda tingkat interaksinya dengan batuan karbonat. Selanjutnya, persentase aliran antara (fissure flow) yang tinggi di Gua Gilap mengakibatkan proses water-rock interaction tidak seintensif yang dijumpai di Bribin dan Ngreneng, yang kemudian secara rinci disajikan pada Tabel 4.27. Sementara itu, hubungan pada saat musim hujan menunjukkan variasi yang jauh berbeda dibanding pada saat musim kemarau, seperti yang disajikan pada Gambar 4.64. dan 4.65. 


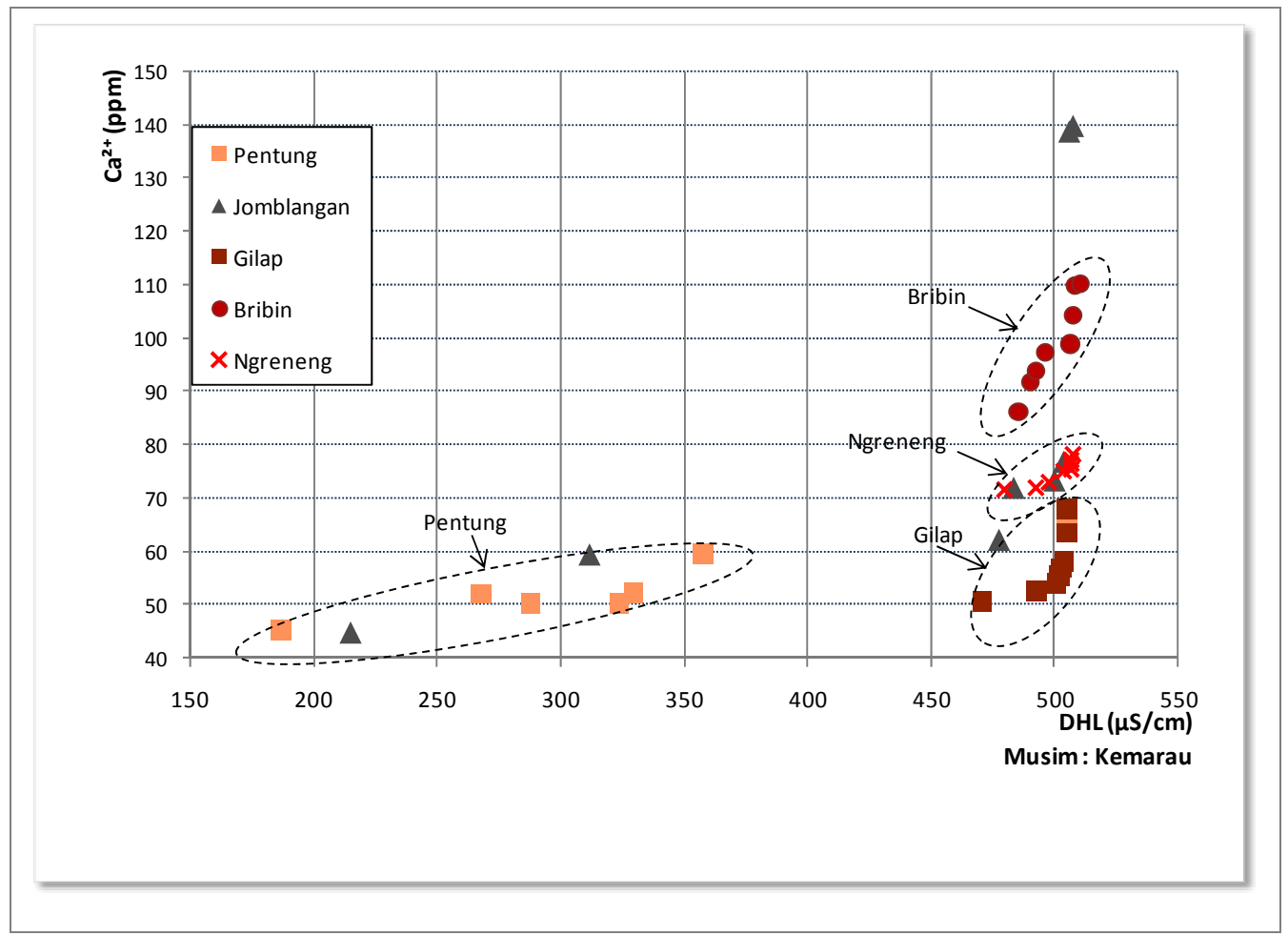

Gambar 4.62. Hubungan Kalsium dan DHL Gua-Gua di SBT Bribin pada Musim Kemarau

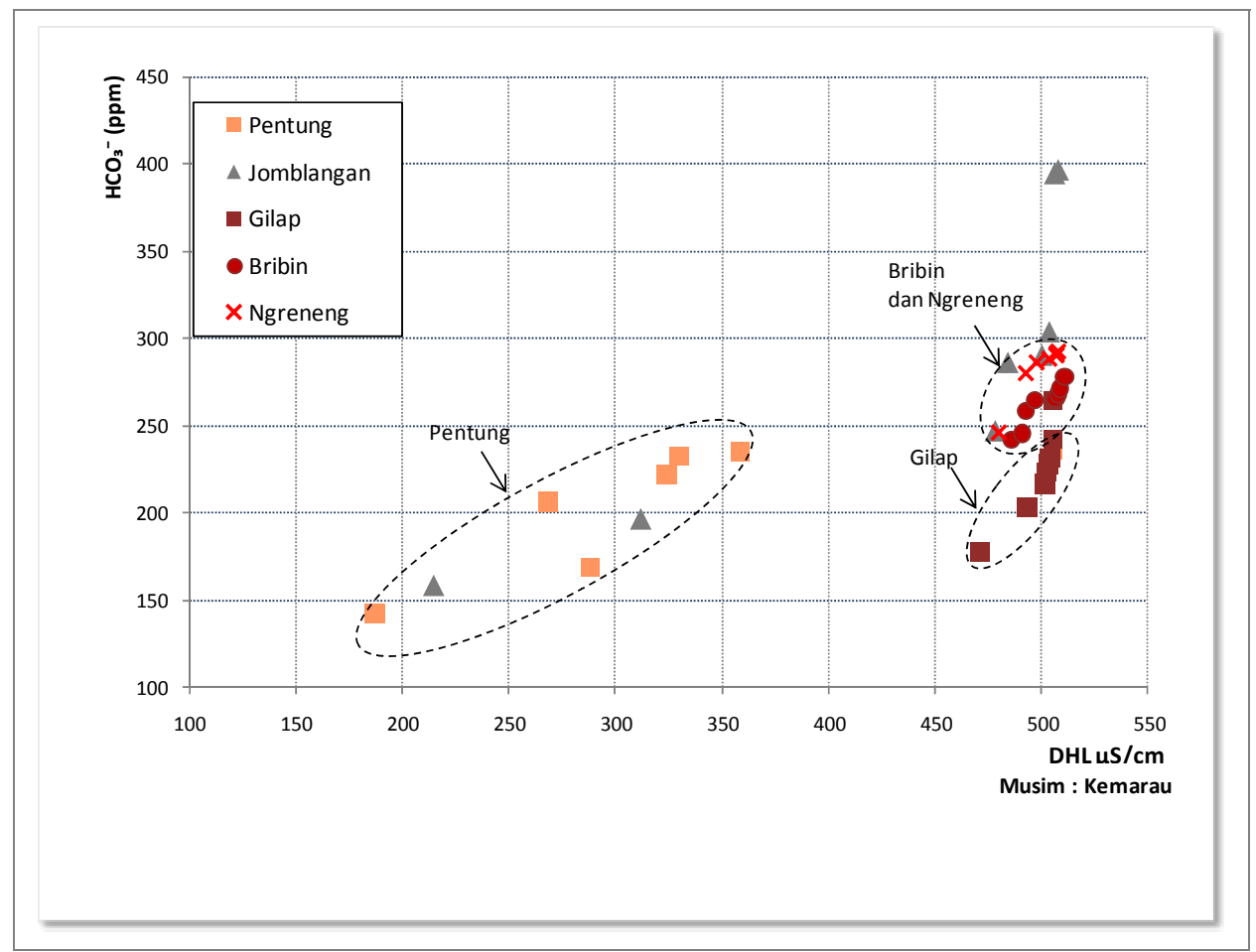

Gambar 4.63. Hubungan Bikarbonat-DHL Gua-Gua di SBT Bribin pada Musim Kemarau 
Pada saat hujan, gua-gua Bribin, Ngreneng dan Gilap ternyata menunjukkan hubungan Kalsium-DHL yang kecil, sedangkan hubungan Kalsium-DHL antara Gua Bribin dan Ngreneng tidak berbeda jauh. Jika dilihat dari rata-rata persentase aliran dasar (PAD) saat hujan, gua-gua tersebut mempunyai nilai aliran dasar yang lebih rendah jika dibandingkan saat musim kemarau, seperti yang disarikan pada Tabel 4.28 .

Tabel 4.27. Hubungan dan tingkat determinasi $\left(\mathrm{R}^{2}\right) \mathrm{DHL}$ vs kalsium dan bikarbonat sepanjang SBT Bribin pada musim kemarau

\begin{tabular}{|c|c|c|c|c|c|c|}
\hline Lokasi & Posisi & $\mathrm{Ca}^{2+}$ vs DHL & $\mathrm{HCO}_{3}^{-}$vs DHL & $\begin{array}{c}\text { Hubungan dan } \\
\text { tingkat } \\
\text { determinasi }\end{array}$ & Proses hidrogeokimia & Keterangan \\
\hline Sungai Pentung & Inlet hulu & $\mathbf{0 , 8 7 8}$ & 0,596 & $\begin{array}{c}\text { Positif } \\
\text { tinggi-sedang }\end{array}$ & $\begin{array}{l}\text { Water-rock interaction } \\
\text { bukan dengan akuifer } \\
\text { karbonat }\end{array}$ & $\begin{array}{l}\text { Sungai yang } \\
\text { input baseflow- } \\
\text { nya dari akuifer } \\
\text { vulkanik }\end{array}$ \\
\hline $\begin{array}{l}\text { Luweng } \\
\text { Jomblangan }\end{array}$ & hulu & $\mathbf{0 , 3 6 4}$ & 0,687 & $\begin{array}{c}\text { Positif } \\
\text { rendah-sedang }\end{array}$ & $\begin{array}{l}\text { Mixing antara air karbonat } \\
\text { dan bukan }\end{array}$ & $\begin{array}{l}\text { Gua yang } \\
\text { memperoleh } \\
\text { aliran langsung } \\
\text { dari Sungai } \\
\text { Pentung } \\
\end{array}$ \\
\hline Gua Gilap & $\begin{array}{l}\text { hulu- } \\
\text { tengah }\end{array}$ & 0,436 & 0,744 & $\begin{array}{c}\text { Positif } \\
\text { rendah-tinggi }\end{array}$ & $\begin{array}{l}\text { Persentase aliran dasar agak } \\
\text { rendah dibanding gua } \\
\text { Bribin dan Ngreneng, water } \\
\text { rock interaction dengan } \\
\text { batuan karbonat cukup kuat }\end{array}$ & $\begin{array}{l}\text { Persentase } \\
\text { Aliran Dasar } \\
\text { (PAD) sekitar } \\
80 \% \text { dan nilai } \mathrm{K}_{\mathrm{i}} \\
\text { kecil dan } \mathrm{K}_{\mathrm{c}} \\
\text { cukup tinggi } \\
\end{array}$ \\
\hline Gua Bribin & Hilir & $\mathbf{0 , 8 9 2}$ & 0,867 & $\begin{array}{l}\text { Positif } \\
\text { tinggi }\end{array}$ & $\begin{array}{l}\text { Persentase aliran dasar } \\
\text { paling tinggi, water rock } \\
\text { interaction dengan batuan } \\
\text { karbonat kuat }\end{array}$ & $\begin{array}{l}\text { PAD sekitar } \\
90 \%, \mathrm{~K}_{\mathrm{b}} \text { tinggi }\end{array}$ \\
\hline Gua Ngreneng & bocoran & $\mathbf{0 , 7 7 0}$ & 0,901 & $\begin{array}{l}\text { Positif } \\
\text { tinggi }\end{array}$ & $\begin{array}{l}\text { Persentase aliran dasar } \\
\text { cukup tinggi dan berlokasi } \\
\text { dekat dengan Gua Bribin, } \\
\text { water rock interaction } \\
\text { dengan batuan karbonat } \\
\text { kuat }\end{array}$ & $\begin{array}{l}\text { PAD mendekati } \\
\text { nilai di Gua } \\
\text { Bribin, } \mathrm{K}_{\mathrm{c}} \text { cukup } \\
\text { rendah }\end{array}$ \\
\hline
\end{tabular}




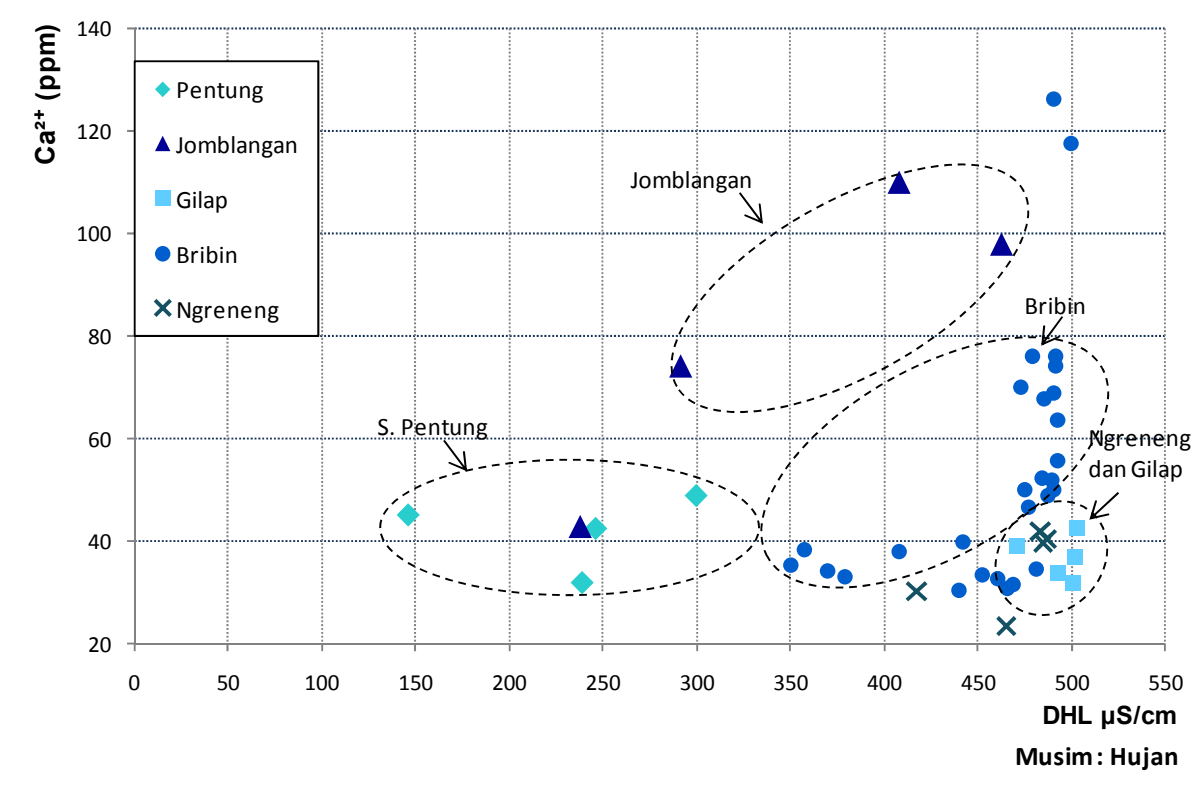

Gambar 4.64. Hubungan Kalsium dan DHL Gua-Gua di SBT Bribin pada Musim Hujan

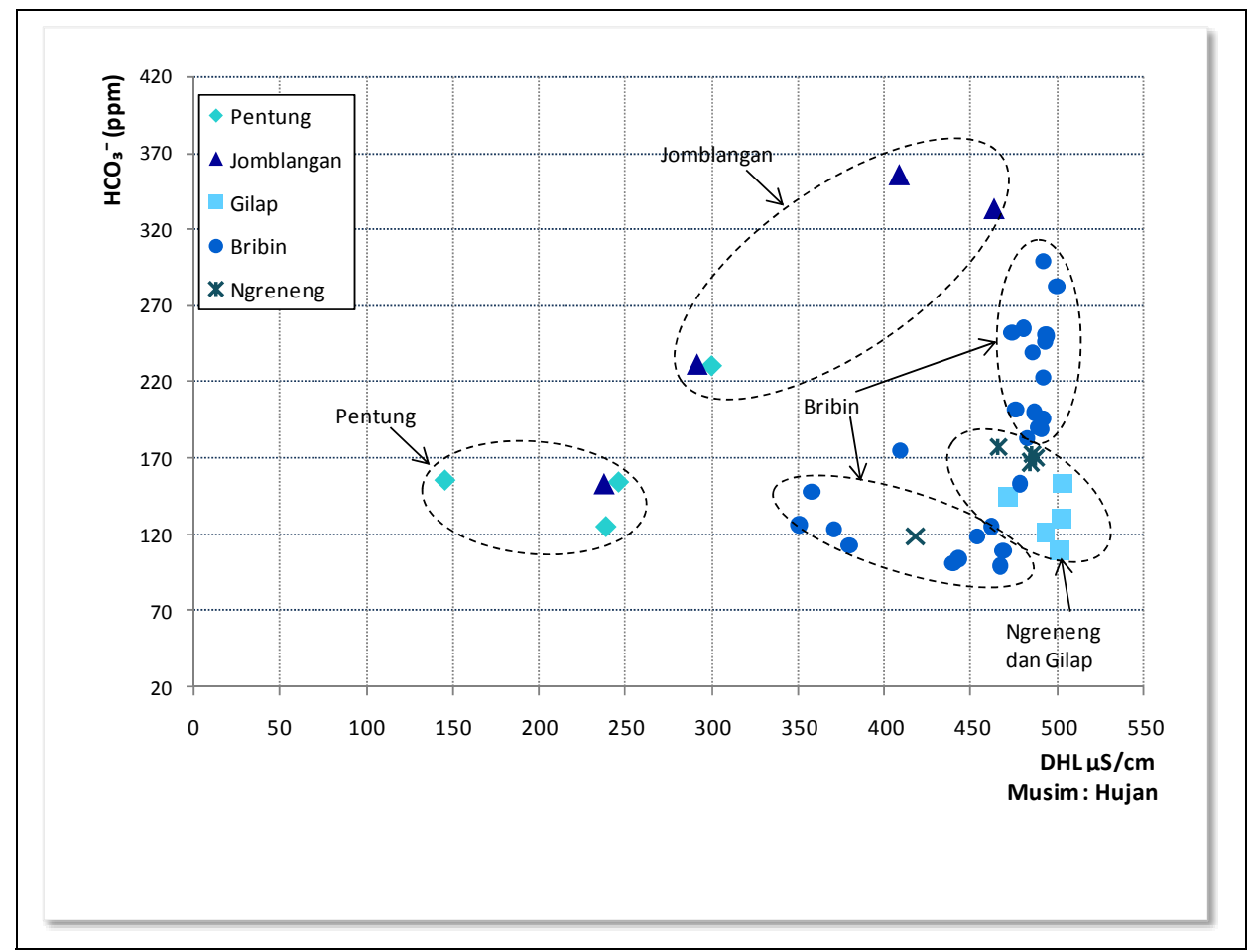

Gambar 4.65. Hubungan Bikarbonat dan DHL Gua-Gua di SBT Bribin pada Musim Hujan 
Tabel 4.28. Rerata Persentase Aliran Dasar Saat Pengambilan Sampel pada Musim Hujan

\begin{tabular}{|c|c|c|c|c|c|c|c|c|}
\hline \multicolumn{3}{|c|}{ Gua Gilap } & \multicolumn{3}{|c|}{ Gua Bribin } & \multicolumn{3}{|c|}{ Gua Ngreneng } \\
\hline \multicolumn{2}{|c|}{ Waktu } & \multirow{2}{*}{$\begin{array}{c}\text { PAD } \\
(\%)\end{array}$} & \multicolumn{2}{|c|}{ Waktu } & \multirow{2}{*}{$\begin{array}{c}\text { PAD } \\
\text { (\%) }\end{array}$} & \multicolumn{2}{|c|}{ Waktu } & \multirow{2}{*}{$\begin{array}{c}\text { PAD } \\
(\%)\end{array}$} \\
\hline Tanggal & jam & & Tanggal & jam & & Tanggal & jam & \\
\hline $20 / 12 / 06$ & $12: 30$ & 84,22 & $20 / 12 / 06$ & $10: 30$ & 100,0 & $20 / 12 / 06$ & $12: 30$ & 100,00 \\
\hline $1 / 2 / 07$ & $12: 30$ & 47,98 & $1 / 2 / 07$ & $10: 00$ & 99,5 & $1 / 2 / 07$ & $12: 30$ & 80,59 \\
\hline $23 / 2 / 07$ & $9: 30$ & 62,65 & $6 / 2 / 07$ & $19: 30$ & 98,0 & $23 / 2 / 07$ & $9: 30$ & 100,00 \\
\hline $30 / 3 / 07$ & 9:00 & 81,75 & $20 / 2 / 07$ & $10: 00$ & 95,5 & $30 / 3 / 07$ & 9:00 & 80,33 \\
\hline $20 / 4 / 07$ & 9:00 & 88,50 & $22 / 2 / 07$ & $21: 00$ & 71,0 & $20 / 4 / 07$ & 9:00 & 82,27 \\
\hline & & & $2 / 3 / 07$ & $11: 00$ & 99,0 & & & \\
\hline & & & $9 / 3 / 07$ & $10: 30$ & 99,6 & & & \\
\hline & & & $16 / 3 / 07$ & $14: 30$ & 98,1 & & & \\
\hline & & & $19 / 3 / 07$ & 4:00 & 85,5 & & & \\
\hline & & & $26 / 3 / 07$ & $21: 00$ & 96,0 & & & \\
\hline & & & $19 / 4 / 07$ & $20: 00$ & 98,5 & & & \\
\hline \multicolumn{2}{|c|}{ Rerata PAD } & 73,02 & \multicolumn{2}{|c|}{ Rerata PAD } & 94,60 & & PAD & 88,64 \\
\hline
\end{tabular}

Sumber : hasil analisis data 2006-2007

Sementara itu, Luweng Jomblangan mempunyai determinasi yang tinggi pada saat musim hujan jika dibandingkan dengan lokasi-lokasi lain, kemungkinan karena kecilnya pasokan conduit di daerah hulu karst (berbatasan dengan akuifer vulkanik), dan adanya input dari Sungai Pentung yang sifatnya intermitten saja (direct runoff hilang setelah hujan). Secara keseluruhan perbandingan hubungan dan kondisi aliran dasar saat periode hujan disajikan pada Tabel 4.29.

\section{b. Hubungan debit dan persentase aliran dasar (PAD)}

Debit aliran pada suatu sungai bawah tanah merupakan gabungan dari tiga komponen aliran yaitu komponen aliran diffuse, fissure dan conduit (White, 2004). Sepanjang tahun, komposisi aliran ini dapat berubah-ubah tergantung dari periode pengaliran suatu sungai bawah tanah. Karimi, et al. (2003) menjelaskan bahwa periode resesi (saat debit menurun) akan menyebabkan komposisi aliran diffuse meningkat dan merubah komposisi kimia air sungai bawah tanah karst, sehingga dapat disimpulkan bahwa persentase aliran dasar akan meningkat seiring dengan menurunnya debit aliran. Determinasi antara debit aliran dan persentase aliran dasar 
pada periode kemarau dan hujan sepanjang SBT Bribin disajikan pada Gambar 4.66.

dan 4.67.

Tabel 4.29. Hubungan dan Tingkat Determinasi $\left(\mathrm{R}^{2}\right)$ Antara DHL-Kalsium dan DHL

Karbonat di SBT Bribin pada Musim Hujan

\begin{tabular}{|c|c|c|c|c|c|c|}
\hline Lokasi & Posisi & $\mathrm{Ca}^{2+}$ vs DHL & $\mathrm{HCO}_{3}{ }^{-}$vs DHL & $\begin{array}{c}\text { Hubungan dan } \\
\text { tingkat } \\
\text { determinasi } \\
\end{array}$ & $\begin{array}{c}\text { Proses } \\
\text { hidrogeokimia }\end{array}$ & Keterangan \\
\hline Sungai Pentung & Inlet hulu & 0,013 & 0,311 & $\begin{array}{l}\text { Positif } \\
\text { rendah }\end{array}$ & $\begin{array}{l}\text { Proses water rock } \\
\text { interaction sangat } \\
\text { lemah }\end{array}$ & $\begin{array}{l}\text { Besarnya direct runoff } \\
\text { saat hujan }\end{array}$ \\
\hline $\begin{array}{l}\text { Luweng } \\
\text { Jomblangan }\end{array}$ & hulu & 0,812 & $\mathbf{0 , 8 8 9}$ & $\begin{array}{l}\text { Positif } \\
\text { tinggi }\end{array}$ & $\begin{array}{l}\text { Komponen aliran masih } \\
\text { didominasi diffuse } \\
\text { karena berada pada } \\
\text { boundary akuifer karst }\end{array}$ & $\begin{array}{l}\text { Secara visual tidak } \\
\text { terjadi fluktuasi debit } \\
\text { dan kekeruhan yang } \\
\text { mencolok sepanjang } \\
\text { waktu }\end{array}$ \\
\hline Gua Gilap & $\begin{array}{l}\text { hulu- } \\
\text { tengah }\end{array}$ & 0,020 & 0,071 & $\begin{array}{l}\text { Negatif } \\
\text { rendah }\end{array}$ & $\begin{array}{l}\text { Pasokan komponen } \\
\text { conduit sangat kuat, } \\
\text { rerata PAD paling } \\
\text { rendah, water rock } \\
\text { interaction sangat } \\
\text { lemah }\end{array}$ & $\begin{array}{l}\text { Rerata } \mathrm{PAD}=73 \% \\
\mathrm{~T}_{\mathrm{b}}=36,7 \mathrm{jam}\end{array}$ \\
\hline Gua Bribin & Hilir & 0,272 & 0,374 & $\begin{array}{l}\text { Positif } \\
\text { rendah }\end{array}$ & $\begin{array}{l}\text { Pasokan komponen } \\
\text { conduit kuat yang masih } \\
\text { cukup menyisakan } \\
\text { aliran dasar }\end{array}$ & $\begin{array}{l}\text { Rerata } \mathrm{PAD}=94 \% \\
\mathrm{~T}_{\mathrm{b}}=36,3 \text { jam }\end{array}$ \\
\hline Gua Ngreneng & bocoran & 0,370 & 0,810 & $\begin{array}{l}\text { Positif } \\
\text { Rendah- } \\
\text { tinggi }\end{array}$ & $\begin{array}{l}\text { Hampir mirip dengan } \\
\text { Bribin, tetapi dengan } \\
\text { time to base flow }\left(\mathrm{T}_{\mathrm{b}}\right) \\
\text { yang lebih cepat } \\
\text { dibanding Bribin, } \\
\text { karena morfometri gua }\end{array}$ & $\begin{array}{l}\text { Rerata } \mathrm{PAD}=88 \% \\
\mathrm{~T}_{\mathrm{b}}=16,8 \text { jam }\end{array}$ \\
\hline
\end{tabular}

Teori tersebut di atas selaras dengan yang terjadi di gua-ga sepanjang SBT Bribin. Gua Gilap, Bribin, dan Ngreneng, yaitu memiliki hubungan yang tinggi antara penurunan debit dan kenaikan PAD, khususnya pada saat musim kemarau, sehingga dikatakan bahwa determinasi debit dan PAD adalah negatif. Sementara itu, Sungai Pentung memiliki $\mathrm{R}^{2}$ yang paling kuat, karena sisa aliran sungai di musim kemarau diisi oleh aliran dasar saja. Lain halnya pada sungai bawah tanah, sisa komponen air sungai masih merupakan kombinasi antara aliran fissure dan diffuse, sehingga hubungan antara PAD vs debit sedikit lebih kecil dibanding yang dijumpai Sungai Pentung. Besarnya nilai $\mathrm{R}^{2}$ di Gilap, Bribin, dan Ngreneng ternyata juga dipengaruhi oleh cepat lambatnya akuifer karst melepaskan aliran fissure (nilai $\mathrm{K}_{\mathrm{i}}$ ), seperti yang disajikan pada Tabel 4.30. Selanjutnya dapat dijelaskan bahwa jika akuifer memiliki nilai $\mathrm{K}_{\mathrm{i}}$ besar (lambat melepaskan komponen fissure), maka 
hubungan debit-PAD akan lebih kecil dibanding akuifer yang lebih cepat melepas komponen aliran fissure $\left(\mathrm{K}_{\mathrm{i}}\right.$ kecil), sebagai contoh adalah fenomena yang ditemui di Gua Bribin.

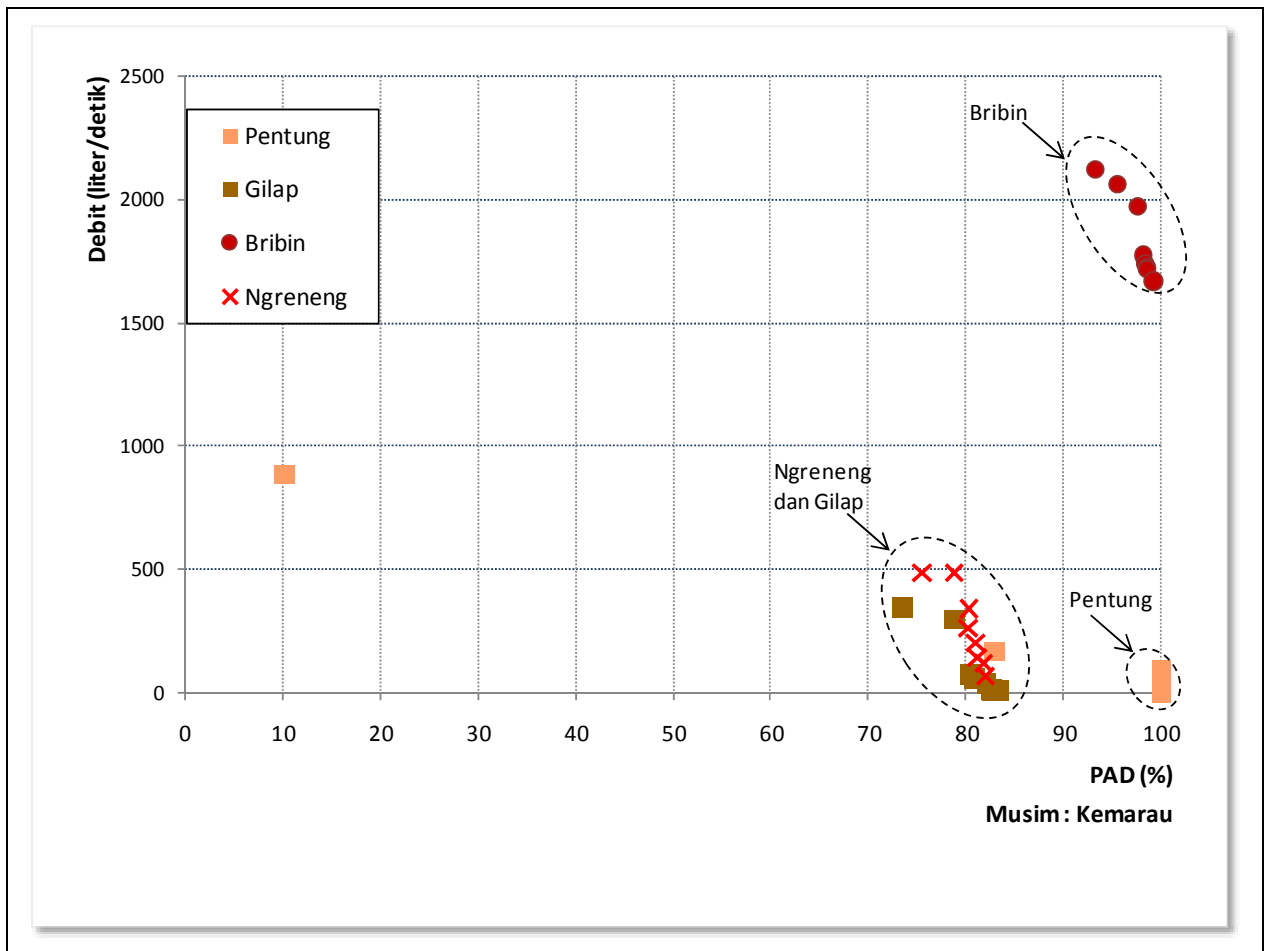

Gambar 4.66. Hubungan Debit dan Persentase Aliran Dasar (PAD) Gua-Gua di SBT Bribin pada Musim Kemarau

Tabel 4.30. Hubungan dan Tingkat Determinasi $\left(\mathrm{R}^{2}\right)$ antara PAD-Debit di Sepanjang SBT Bribin pada Musim Kemarau

\begin{tabular}{|l|c|c|c|l|}
\hline \multicolumn{1}{|c|}{ Lokasi } & Posisi & Debit vs PAD & $\begin{array}{c}\text { Hubungan dan } \\
\text { tingkat determinasi }\end{array}$ & \multicolumn{1}{|c|}{ Keterangan } \\
\hline Sungai Pentung & Inlet hulu & $\mathbf{0 , 9 8 8}$ & $\begin{array}{c}\text { Negatif } \\
\text { tinggi }\end{array}$ & $\begin{array}{l}\text { Determinasi paling kuat karena terisi aliran dasar } \\
\text { semata yang berasal dari akuifer non-karstic }\end{array}$ \\
\hline Gua Gilap & $\begin{array}{c}\text { hulu- } \\
\text { tengah }\end{array}$ & $\mathbf{0 , 8 5 2}$ & $\begin{array}{c}\text { Negatif } \\
\text { tinggi }\end{array}$ & $\begin{array}{l}\text { Determinasi kuat, dan aliran dasar merupakan } \\
\text { kombinasi dari aliran fissure dan diffuse, sehingga } \\
\text { lamanya akuifer melepaskan aliran fissure } \\
\text { berpengaruh terhadap nilai determinasi. Nilai } K_{\mathbf{i}} \text { di } \\
\text { Gua Gilap=0,767 }\end{array}$ \\
\hline Gua Bribin & Hilir & $\mathbf{0 , 8 5 5}$ & $\begin{array}{c}\text { Negatif } \\
\text { tinggi }\end{array}$ & Determinasi kuat, Nilai $\mathbf{K}_{\mathbf{i}}$ di Bribin=0,332 \\
\hline Gua Ngreneng & bocoran & $\mathbf{0 , 7 9 1}$ & $\begin{array}{c}\text { Negatif } \\
\text { tinggi }\end{array}$ & $\begin{array}{l}\text { Determinasi sedikit agak rendah dibanding Gua Gilap } \\
\text { dan Bribin, Nilai } \mathbf{K}_{\mathbf{i}} \text { di Ngreneng=0,877 }\end{array}$ \\
\hline
\end{tabular}




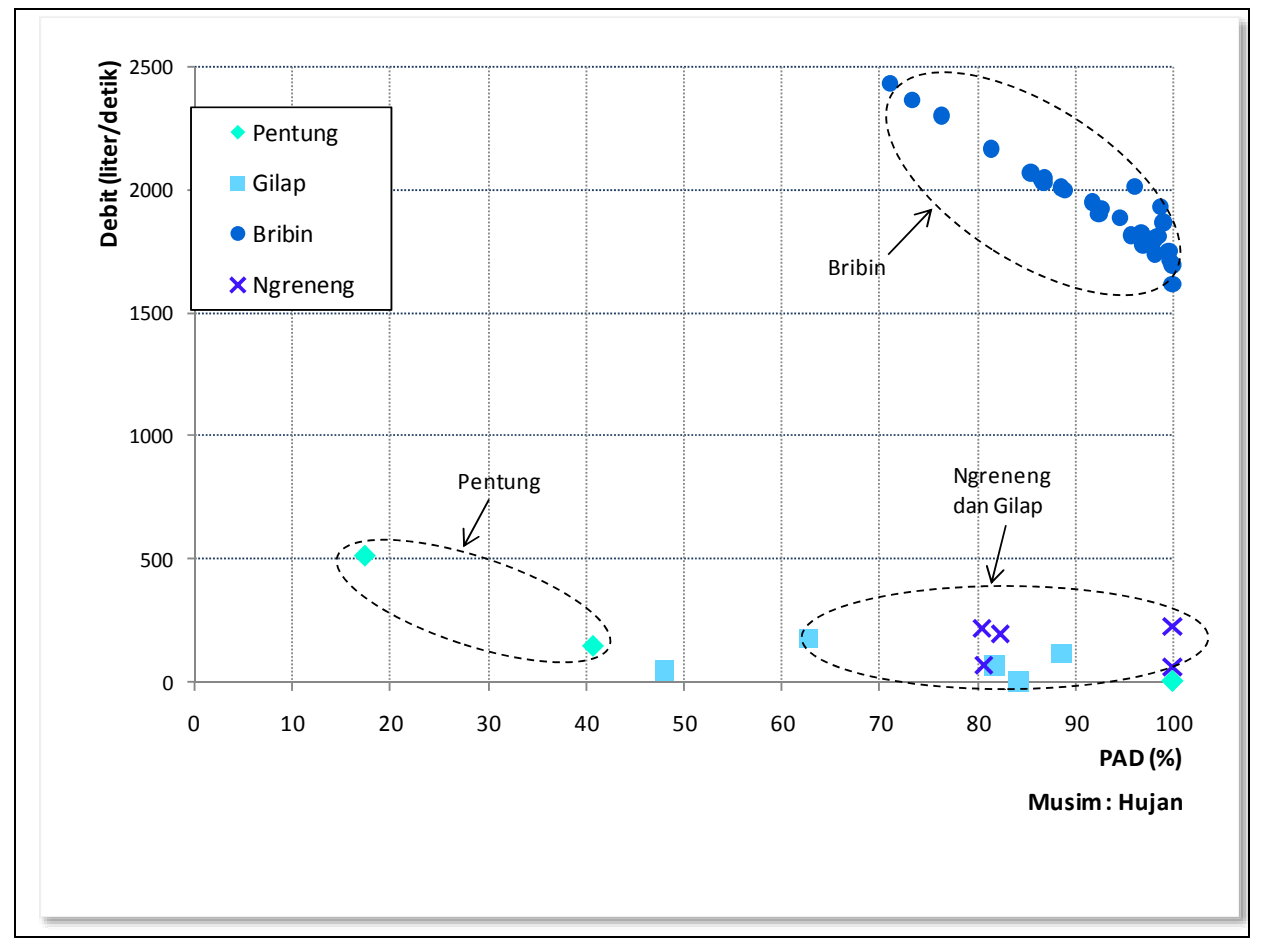

Gambar 4.67. Hubungan Debit dan Persentase Aliran Dasar (PAD) Gua-Gua di SBT Bribin pada Musim Hujan

Sebaliknya, pada saat periode hujan, terjadi penurunan nilai determinasi hingga mencapai nilai yang sangat kecil pada sungai bawah tanah di Gua Ngreneng dan Gua Gilap. Hal ini terjadi karena fluktuasi persentase aliran dasar (PAD) cukup besar. Selain itu, jika dihubungkan dengan data fluktuasi PAD selama kejadian banjir, tampak jelas bahwa julat PAD di Gua Gilap dan Ngreneng masing-masing 45-80\% dan 40-65\%, sedangkan julat PAD di Gua Bribin hanya berkisar antara 8090\% saja. Secara keseluruhan hubungan dan perbandingan tingkat determinasi antara PAD-debit pada gua-gua sepanjang SBT Bribin pada musim hujan disajikan pada Tabel 4.31. 
Tabel 4.31. Hubungan dan Tingkat Determinasi $\left(\mathrm{R}^{2}\right)$ antara PAD-Debit di Sepanjang SBT Bribin pada Musim Hujan

\begin{tabular}{|l|c|c|c|l|}
\hline \multicolumn{1}{|c|}{ Lokasi } & Posisi & Debit vs PAD & $\begin{array}{c}\text { Tingkat } \\
\text { determinasi }\end{array}$ & \multicolumn{1}{|c|}{ Keterangan } \\
\hline Sungai Pentung & Inlet hulu & $\mathbf{0 , 8 1 5}$ & $\begin{array}{c}\text { Negatif } \\
\text { tinggi }\end{array}$ & $\begin{array}{l}\text { Aliran dasar yang stabil saat musim hujan, dan sifat banjir } \\
\text { yang cepat hilang, sehingga hanya sedikit menurunkan } \\
\text { nilai determinasi }\end{array}$ \\
\hline Gua Gilap & $\begin{array}{c}\text { hulu- } \\
\text { tengah }\end{array}$ & $\mathbf{0 , 0 1 4}$ & $\begin{array}{c}\text { Negatif rendah (tanpa } \\
\text { hubungan) }\end{array}$ & $\begin{array}{l}\text { Fluktuasi aliran dasar yang tinggi pada periode hujan (45- } \\
80 \%)\end{array}$ \\
\hline Gua Bribin & Hilir & $\mathbf{0 , 9 1 3}$ & $\begin{array}{c}\text { Negatif } \\
\text { tinggi }\end{array}$ & $\begin{array}{l}\text { Fluktuasi aliran dasar yang stabil saat banjir(80-90\%), } \\
\text { bahkan beberapa kali pengambilan sampel dilakukan saat } \\
\text { periode resesi setelah banjir }\end{array}$ \\
\hline Gua Ngreneng & bocoran & $\mathbf{0 , 0 1 1}$ & $\begin{array}{c}\text { Negatif rendah (tanpa } \\
\text { hubungan) }\end{array}$ & $\begin{array}{l}\text { Fluktuasi aliran dasar yang tinggi saat periode hujan (40- } \\
\text { 65\%). Selain itu inlet Gua Ngreneng yang merupakan suatu } \\
\text { sinkhole selalu dipasok aliran konduit saat kejadian hujan. }\end{array}$ \\
\hline
\end{tabular}

\section{c. Hubungan PAD-kalsium dan PAD-bikarbonat}

Hubungan kalsium dan bikarbonat terlarut dengan variasi PAD sepanjang SBT Bribin pada periode kemarau disajikan pada Gambar 4.68. dan 4.69. Pada musim kemarau, terlihat perbedaan yang mencolok pada hubungan PAD-kalsium gua-gua di bagian hulu dan bagian hilir daerah tangkapan hujan SBT Bribin. Sebagai kation terlarut suatu sungai bawah tanah, besar kecilnya kalsium terlarut ditentukan oleh besar kecilnya aliran dasar. Gua Bribin dan Ngreneng pada bagian hilir yang lokasinya berdekatan mempunyai nilai determinasi yang sama dan cukup besar yaitu 0,730 (PAD-kalsium) dan nilai diatas 0,850 untuk PAD-bikarbonat. Kesamaan nilai pada musim kemarau ini kemungkinan dapat diakibatkan karena sebagian komponen aliran di Gua Ngreneng berasal dari Gua Bribin.

Sementara itu, di Sungai Pentung dijumpai hubungan yang kecil $(0,352)$ pada kalsium karena sebagian besar air bukan berasal dari akuifer karst, sehingga kalsium bukan merupakan kation dominan pada saat aliran dasar memasok aliran Sungai Pentung, lain halnya hubungan PAD-bikarbonat yang determinasinya besar karena ion bikarbonat dapat berasal dari mineral lain selain mineral kalsit. 
Selanjutnya, Gua Gilap mempunyai determinasi sedang (PAD-kalsium) yaitu $\mathrm{R}^{2}=0,588$ lebih disebabkan karena posisinya di daerah hulu, sehingga aliran dasar mempunyai time of residence (lama tinggal) yang relatif lebih singkat untuk melarutkan kalsium dalam air dibanding yang dialami oleh gua-gua di daerah hilir. Selain itu, Gua Gilap juga mempunyai sifat melepas aliran dasar $\left(\mathrm{K}_{\mathrm{b}}\right)$ lebih cepat dibanding Gua Bribin. Secara keseluruhan perbandingan hubungan antara PADkalsium dan bikarbonat terlarut pada gua-gua sepanjang SBT Bribin pada musim kemarau disajikan pada Tabel 4.32.

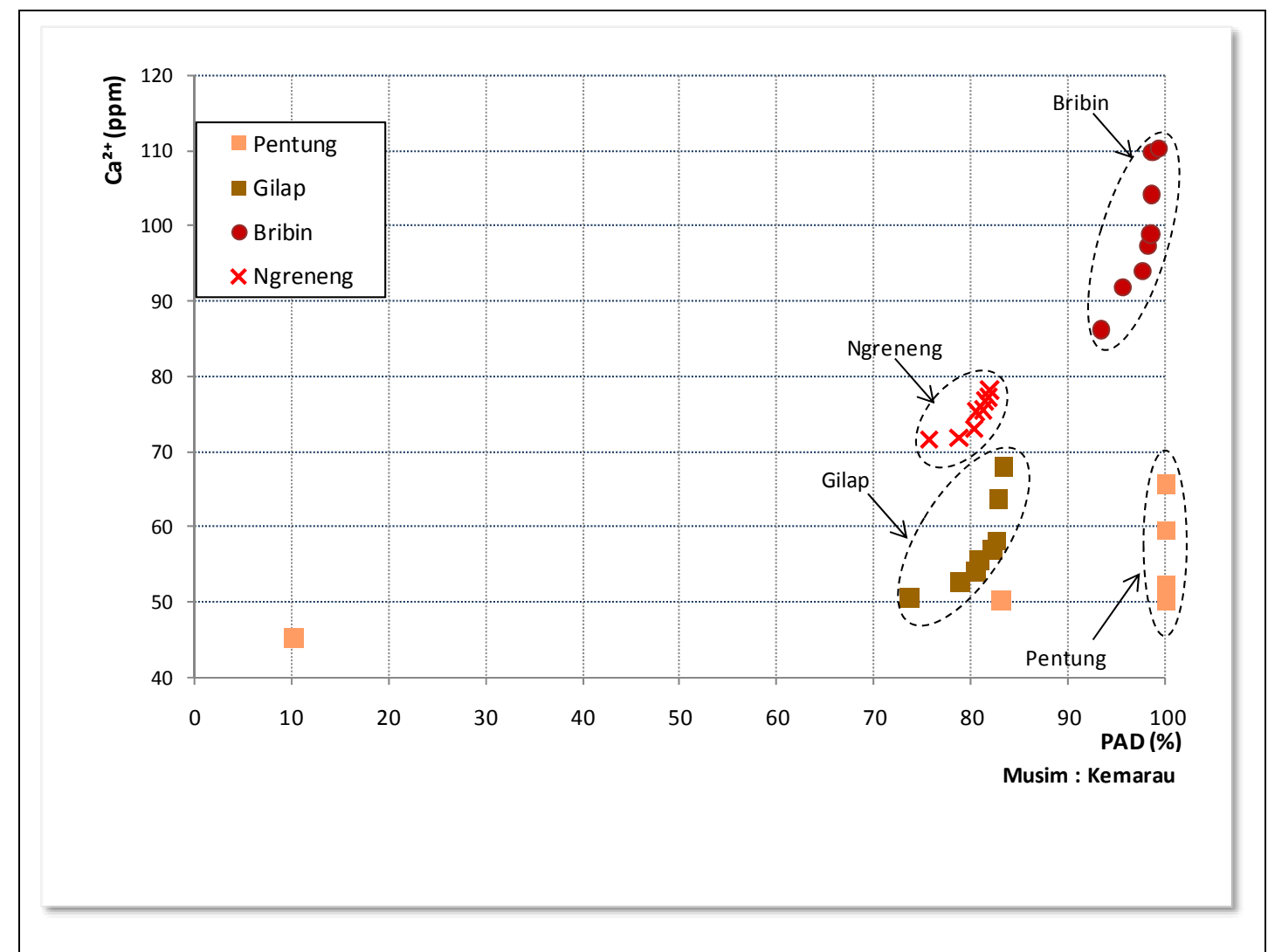

Gambar 4.68. Hubungan Kalsium Terlarut dan Persentase Aliran Dasar (PAD) Gua-Gua di SBT Bribin pada Musim Kemarau 


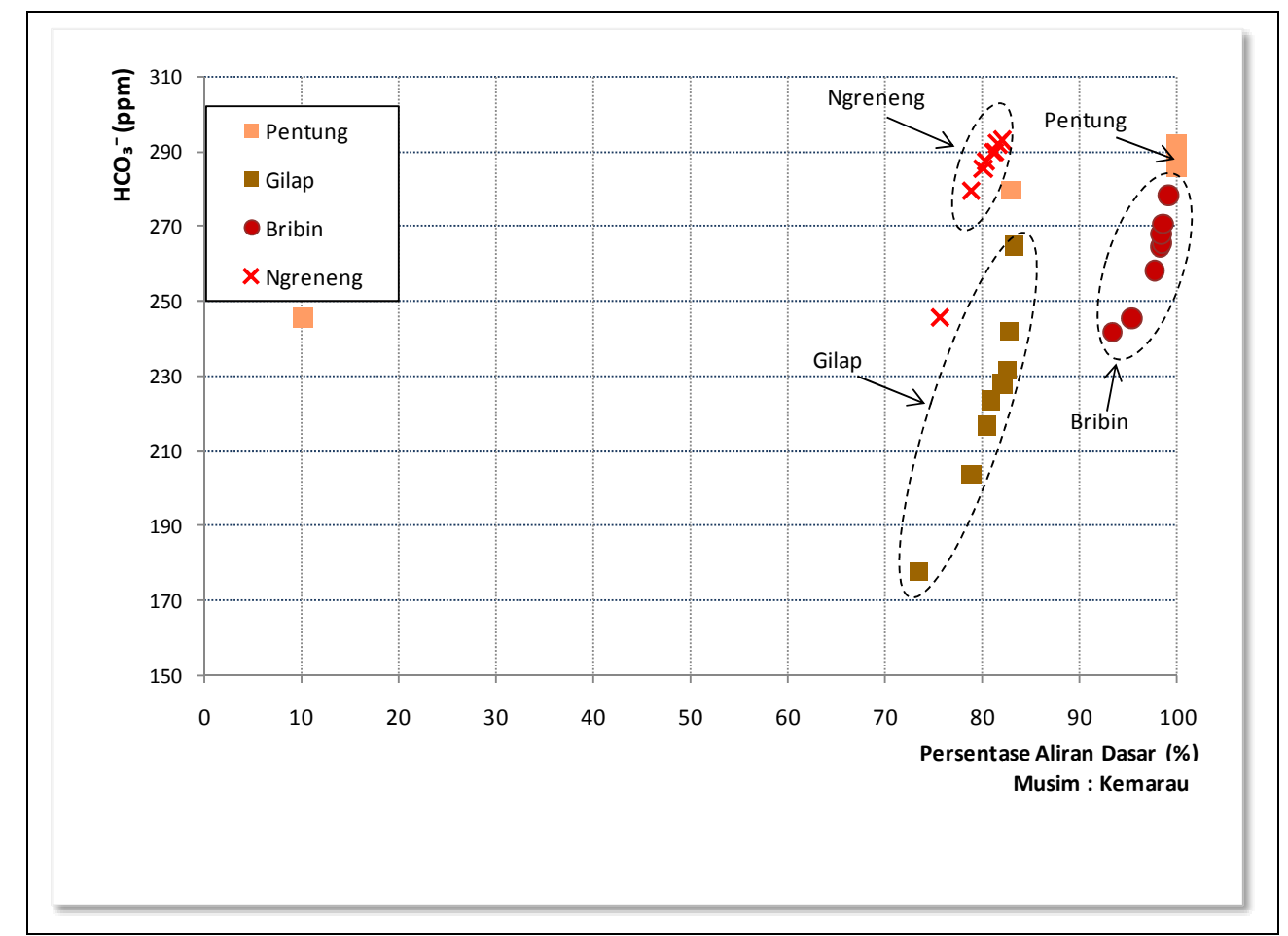

Gambar 4.69. Hubungan Bikarbonat Terlarut dan Persentase Aliran Dasar (PAD) Gua-Gua di SBT Bribin pada Musim Kemarau

Tabel 4.32. Hubungan dan Tingkat Determinasi $\left(\mathrm{R}^{2}\right)$ antara PAD-Kalsium dan PADKarbonat Di Sepanjang SBT Bribin pada Musim Kemarau

\begin{tabular}{|c|c|c|c|c|c|c|}
\hline Lokasi & Posisi & $\mathrm{Ca}^{2+}$ vs PAD & $\mathrm{HCO}_{3}{ }^{-}$vs PAD & $\begin{array}{c}\text { Hubungan dan } \\
\text { tingkat } \\
\text { determinasi }\end{array}$ & $\begin{array}{c}\text { Proses } \\
\text { hidrogeokimia }\end{array}$ & Keterangan \\
\hline Sungai Pentung & Inlet hulu & 0,352 & 0,985 & $\begin{array}{l}\text { Positif } \\
\text { rendah-tinggi }\end{array}$ & $\begin{array}{l}\text { Water-rock interaction } \\
\text { bukan dengan batuan } \\
\text { karbonat }\end{array}$ & $\begin{array}{l}\text { Determinasi dengan } \\
\text { bikarbonat tinggi karena } \\
\text { terdapat mineral sumber } \\
\text { karbonat pada akufer } \\
\text { vulkanik }\end{array}$ \\
\hline Gua Gilap & $\begin{array}{l}\text { hulu- } \\
\text { tengah }\end{array}$ & 0,588 & $\mathbf{0 , 8 5 5}$ & $\begin{array}{c}\text { Positif } \\
\text { sedang-tinggi }\end{array}$ & $\begin{array}{l}\text { Water-rock interaction } \\
\text { dengan batuan karbonat } \\
\text { dengan time residence } \\
\text { cukup singkat }\end{array}$ & $\begin{array}{l}\text { Daerah hulu, aliran } \\
\text { dasarnya waktunya lebih } \\
\text { singkat kontak dengan } \\
\text { batuan. Nilai } \mathrm{K}_{\mathrm{b}} \text { rendah, } \\
\text { pasokan fissure cukup } \\
\text { besar }\end{array}$ \\
\hline Gua Bribin & Hilir & 0,730 & 0,892 & $\begin{array}{r}\text { Positif } \\
\text { tinggi }\end{array}$ & $\begin{array}{l}\text { Water-rock interaction } \\
\text { dengan batuan karbonat } \\
\text { dengan time residence } \\
\text { lama }\end{array}$ & Nilai $\mathrm{K}_{\mathrm{b}}$ tinggi \\
\hline Gua Ngreneng & bocoran & $\mathbf{0 , 7 3 0}$ & 0,941 & $\begin{array}{r}\text { Positif } \\
\text { tinggi }\end{array}$ & $\begin{array}{l}\text { Water-rock interaction } \\
\text { dengan batuan karbonat } \\
\text { dengan time residence } \\
\text { lama dan sebagian } \\
\text { komponennya berasal } \\
\text { dari Gua Bribin }\end{array}$ & $\begin{array}{l}\text { Lokasi berdekatan, time } \\
\text { residence aliran dasar } \\
\text { lebih lama }\end{array}$ \\
\hline
\end{tabular}


Hubungan kalsium dan bikarbonat terlarut dengan variasi PAD sepanjang SBT Bribin pada musim hujan disajikan pada Gambar 4.70. dan 4.71. Dari gambargambar tersebut nampak bahwa secara umum hubungan antara unsur-unsur kalsiumbikarbonat dan PAD mengalami pengurangan karena besarnya pasokan air hujan saat musim hujan. Bahkan di Gua Ngreneng dan Sungai Pentung mempunyai hubungan negatif, berarti kenaikan kalsium atau karbonat terjadi pada saat PAD naik. Pada lokasi-lokasi tersebut memang terdapat karakteristik khusus, misalnya Sungai Pentung bukan merupakan sungai bawah tanah tetapi merupakan sungai permukaan dan bukan berasal dari akuifer karstik, sehingga kalsium terlarut tidak selalu dominan di dalam air. Sementara itu, Gua Ngreneng seperti sudah dijelaskan pada sub bab sebelumnya merupakan suatu sinkhole pada dasar sebuah lembah karst yang selalu memperoleh aliran conduit dengan cepat $\left(\mathrm{K}_{\mathrm{c}}=\mathrm{kecil}\right)$, setiap saat terjadi hujan yang menyebabkan aliran permukaan.

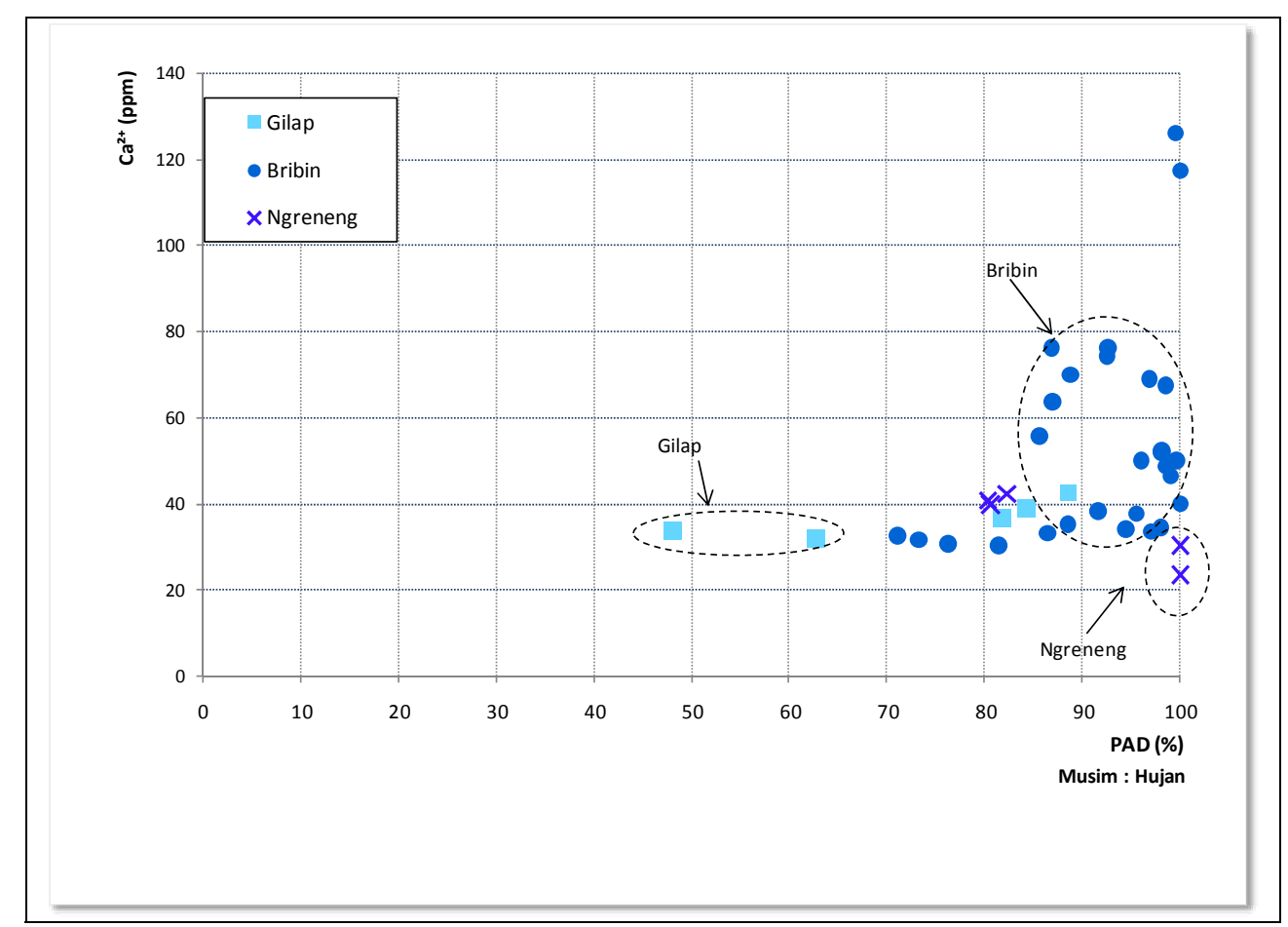

Gambar 4.70. Hubungan Kalsium Terlarut dan Persentase Aliran Dasar (PAD) Gua-Gua di SBT Bribin pada Musim Hujan 
Nilai determinasi kalsium dan bikarbonat dengan PAD di Gua Gilap paling stabil dibanding Gua Bribin dan Ngreneng. Kenyataan ini tidak terlepas karena Gua Gilap merupakan gua yang letaknya masih di bagian hulu dengan nilai $\mathrm{K}_{\mathrm{i}}$ yang paling besar (fissure flow lebih dominan dibanding gua-gua lain). Selain itu, nilai Kc di Gua Gilap paling stabil (lambat dilepaskan) dibanding gua-gua yang lain, sehingga kandungannya relatif lebih mirip dengan diffuse flow dibandingkan Gua Bribin dan Gua Ngreneng. Hubungan dan tingkat determinasi antara PAD-kalsium dan bikarbonat terlarut pada gua-gua sepanjang SBT Bribin pada musim hujan disajikan pada Tabel 4.33.

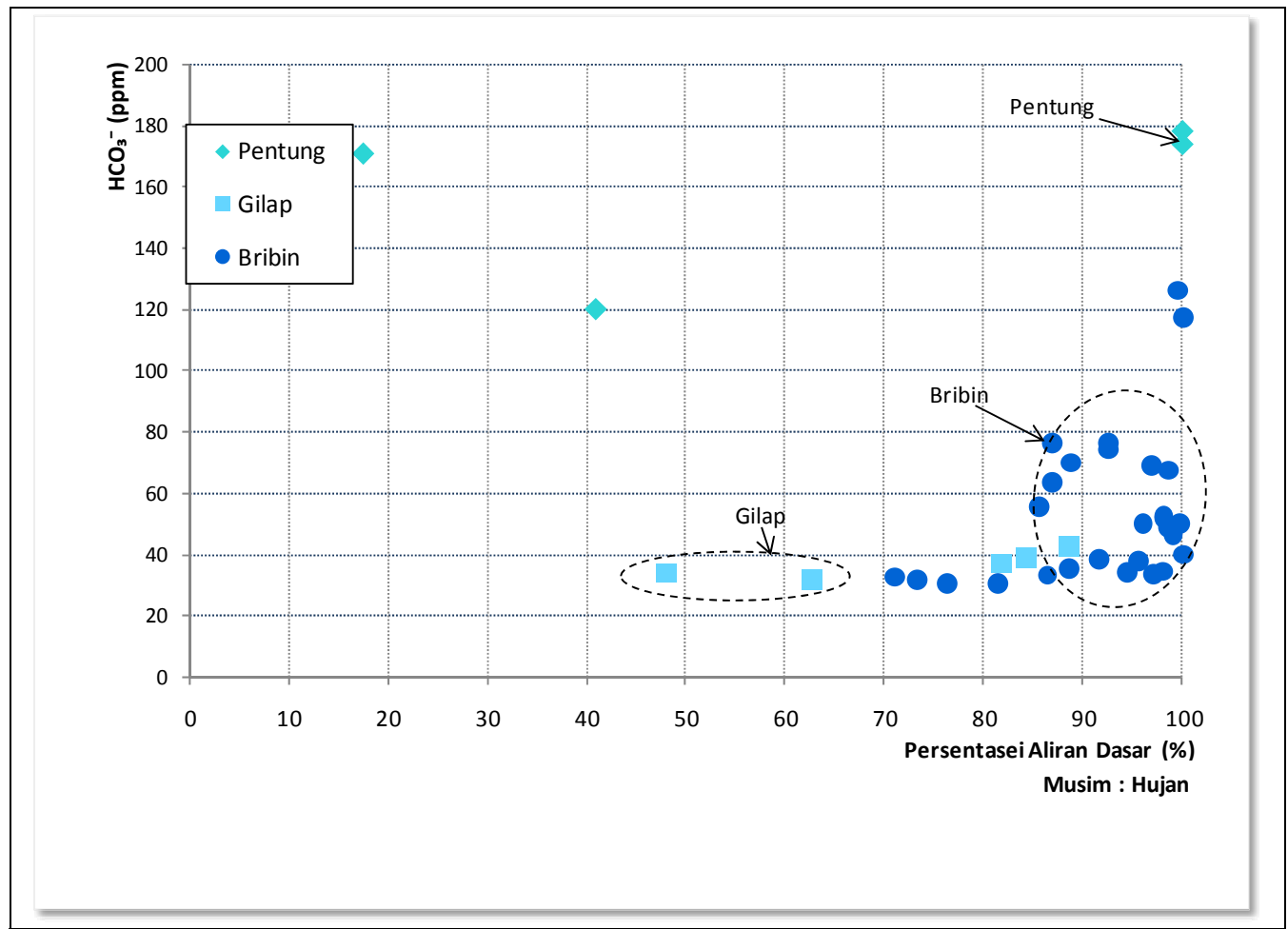

Gambar 4.71. Hubungan Bikarbonat Terlarut dan Persentase Aliran Dasar (PAD) Gua-Gua di SBT Bribin pada Musim Hujan 
Tabel 4.33. Hubungan dan Tingkat Determinasi $\left(\mathrm{R}^{2}\right)$ antara PAD-Kalsium dan PAD-

Karbonat di Sepanjang SBT Bribin pada Musim Hujan

\begin{tabular}{|c|c|c|c|c|c|c|}
\hline Lokasi & Posisi & $\mathrm{Ca}^{2+}$ vs PAD & $\begin{array}{c}\mathrm{HCO}_{3}^{-} \mathrm{vs} \\
\text { PAD }\end{array}$ & $\begin{array}{c}\text { Tingkat } \\
\text { determinasi }\end{array}$ & Proses hidrogeokimia & Keterangan \\
\hline $\begin{array}{l}\text { Sungai } \\
\text { Pentung }\end{array}$ & Inlet hulu & 0.080 & 0.207 & $\begin{array}{c}\text { Negatif-rendah } \\
\text { Positif rendah (tanpa } \\
\text { hubungan) }\end{array}$ & $\begin{array}{l}\text { Mixing antara proses water- } \\
\text { rock interaction akuifer non } \\
\text { karbonat dan aliran langsung } \\
\text { dari hujan. Aliran langsung } \\
\text { lebih cepat dibanding sungai } \\
\text { bawah tanah }(\mathrm{Tb}=\text { kecil). }\end{array}$ & $\begin{array}{l}\text { Sifat akuifer non-karst yang } \\
\text { membuat ion kalsium dan } \\
\text { bikarbonat tidak dominan. }\end{array}$ \\
\hline Gua Gilap & $\begin{array}{l}\text { hulu- } \\
\text { tengah }\end{array}$ & 0.690 & 0.628 & $\begin{array}{l}\text { Positif } \\
\text { sedang }\end{array}$ & $\begin{array}{l}\text { Kuatnya komponen fissure } \\
\text { yang cukup stabil }\left(\mathrm{K}_{\mathrm{i}}=\text { besar), }\right. \\
\text { kenaikan aliran conduit tidak } \\
\text { terlalu fluktuatif ketika terjadi } \\
\text { banjir, ( } \mathrm{K}_{\mathrm{c}} \text { besar). Proses } \\
\text { water-rock interaction paling } \\
\text { kuat dibanding gua-gua lain }\end{array}$ & $\begin{array}{l}\text { Gua Gilap posisinya agak } \\
\text { ke hulu, beda antara fissure, } \\
\text { diffuse dan conduit tidak } \\
\text { terlalu tegas, karena } \\
\text { singkatnya time of } \\
\text { residence dari diffuse flow. } \\
\text { Selain itu akuifer Gua Gilap } \\
\text { lebih lambat melepas } \\
\text { conduit dibanding gua-gua } \\
\text { lain }\left(\mathrm{K}_{\mathrm{c}} \text { besar). }\right.\end{array}$ \\
\hline Gua Bribin & Hilir & 0.143 & 0.149 & $\begin{array}{c}\text { Positif- rendah } \\
\text { (tanpa hubungan) }\end{array}$ & $\begin{array}{l}\text { Kejadian banjir membawa } \\
\text { aliran conduit } \\
\text { terjadi proses dilution by } \\
\text { precipitation }\end{array}$ & $\begin{array}{l}\text { Beda komposisi diffuse flow } \\
\text { dan conduit flow yang tegas } \\
\text { karena posisinya di hilir }\end{array}$ \\
\hline $\begin{array}{l}\text { Gua } \\
\text { Ngreneng }\end{array}$ & bocoran & 0.882 & 0.253 & $\begin{array}{l}\text { Negatif- tinggi } \\
\text { rendah (hubungan } \\
\text { terbalik) }\end{array}$ & $\begin{array}{l}\text { Pasokan conduit yang sering } \\
\text { terjadi dan nilai } \mathrm{K}_{\mathrm{c}} \text { yang kecil, } \\
\text { sehingga terjadi proses } \\
\text { dilution by precipitation yang } \\
\text { dominan }\end{array}$ & $\begin{array}{l}\text { Morfologi gua sebagai } \\
\text { sinkhole sehingga setiap } \\
\text { kejadian hujan akan } \\
\text { memasok aliran conduit ke } \\
\text { sungai bawah tanah }\end{array}$ \\
\hline
\end{tabular}

Dari telaahan nilai determinasi antar parameter kimia dengan kondisi aliran sepanjang aliran SBT Bribin baik secara spasial maupun temporal, maka:

(1)selama musim kemarau, terdapat hubungan yang kuat antara persentase aliran dasar (PAD) dengan besar kecilnya unsur terlarut dominan dalam air. Hal ini dapat dilihat dari tingginya nilai determinasi antara DHL dan unsur-unsur terlarut yang mengindikasinya kuatnya proses water-rock interaction (Desmarais dan Rojstaczer, 2002). Hal lain yang menunjukkan hubungan antara karakteristik hidrogeokimia dan besar kecilnya aliran dasar adalah tingginya determinasi antara PAD dan unsur-unsur terlarut. Besar kecilnya nilai determinasi saat musim kemarau juga dipengaruhi oleh letaknya pada daerah tangkapan hujan SBT Bribin (lokasinya di hilir, hulu, atau sebagai bocoran, atau bahkan kedudukannya sebagai 
sungai permukaan). Besar kecilnya variasi nilai konstanta resesi aliran baik itu aliran dasar-diffuse $\left(\mathrm{K}_{\mathrm{b}}\right)$, aliran antara-fissure $\left(\mathrm{K}_{\mathrm{i}}\right)$, serta aliran langsung-conduit $\left(\mathrm{K}_{\mathrm{c}}\right)$, juga berpengaruh terhadap karakter hidrogeokimia sepanjang SBT Bribin.

(2)Selama musim hujan, proses hidrogeokimia bergeser dari proses water-rock interaction ke arah dilution by precipitation karena adanya pasokan air hujan maupun hujan yang tertinggal pada sungai bawah tanah melalui saluran conduit. Hal ini ditandai dengan turunnya nilai determinasi antara PAD dan unsur-unsur dominan terlarut serta DHL-unsur-unsur dominan terlarut. Hal lain yang berpengaruh terhadap hidrogeokimia sungai bawah tanah saat hujan adalah perbedaan posisi spasial dan karakteristik aliran sepanjang SBT Bribin. Variasi spasial dan temporal karakter hidrogeokimia sepanjang SBT Bribin disajikan pada Gambar 4.72.

\section{Variasi dan Karakter Spasial dan Temporal Agresivitas Airtanah di SBT Bribin dan Hubungannya antar Parameter SKDnya}

\section{Variasi dan karakter spasial dan temporal agresivitas air SBT Bribin}

Tingkat agresivitas air terhadap batuan karbonat atau kemampuan air untuk melarutkan batuan karbonat merupakan salah satu faktor penting yang sering dikaji untuk mendeskripsikan proses pelarutan pada akuifer karst. Menurut Vesper and White (2004) derajat agresivitas ini lazim dinyatakan dalam suatu indeks yang dikenal sebagai indeks kejenuhan atau Saturation Indices (SI) terhadap mineral kalsit. Seperti yang sudah dijelaskan pada rumus (5), maka oleh White (1997) rumus tersebut dijabarkan lagi sebagai berikut:

$$
S I_{\mathrm{C}}=\log \frac{a_{\mathrm{Ca}^{2+}}}{P_{\mathrm{CO}_{2}}^{1 / 3}} \quad \frac{2^{2 / 3} \mathrm{~K}_{2}^{1 / 3} \gamma_{\mathrm{HCO}_{3}^{-}}^{2 / 3}}{\mathrm{~K}_{1}^{1 / 3} \mathrm{~K}_{\mathrm{CO}_{2}}^{1 / 3} \mathrm{~K}_{\mathrm{C}}^{1 / 3} \gamma_{\mathrm{Ca}^{2+}}^{2 / 3}}
$$




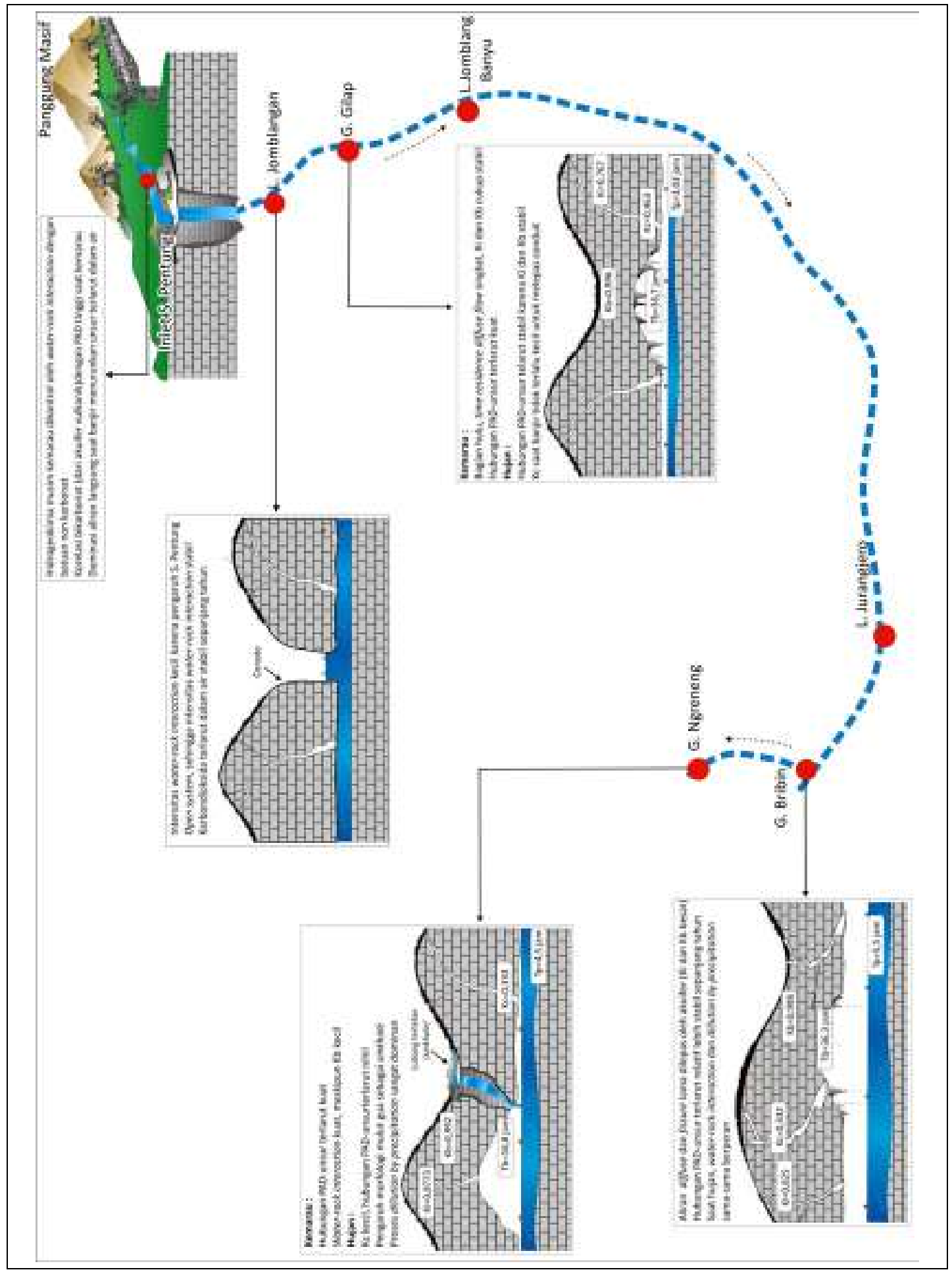

Gambar 4.72. Variasi Spasial dan Temporal Hidrogeokimia di SBT Bribin 
$\mathrm{K}_{1}, \mathrm{~K}_{2}$, adalah konstanta kesetimbangan pada penguraian $\mathrm{H}_{2} \mathrm{CO}_{3}$ yang pertama dan kedua, $\mathrm{K}_{\mathrm{C}}$ adalah konstanta pelarutan produk mineral kalsit, $\mathrm{K}_{\mathrm{CO} 2}$ adalah konstanta pelarutan gas karbondioksida di air, $\mathrm{a}_{\mathrm{Ca}}{ }^{2+}$ adalah aktivitas ion kalsium, $\mathrm{a}_{\mathrm{HCO} 3}{ }^{-}$adalah aktivitas ion bikarbonat, dan $\gamma$ koefisien aktivitas ion sampel yang akan dicari.

Klasifikasi nilai agresivitas disebutkan pada Tabel 3.3. yang menjelaskan bahwa nilai SI diatas 0 merupakan kondisi jenuh untuk melarutkan mineral kalsit (supersaturated), nilai $\mathrm{SI}=0$ adalah kondisi setimbang (equilibrium), dan nilai SI dibawah 0 air bersifat agresif untuk melarutkan mineral kalsit (undersaturated). Distribusi nilai agresivitas (SI) secara temporal dan spasial sepanjang SBT Bribin disajikan pada Gambar 4.73 .

Dari Gambar 4.73. terlihat bahwa secara temporal, umumnya air sungai bawah tanah gua-gua sepanjang SBT Bribin mempunyai pola yang sama yaitu mengalami peningkatan nilai indeks kejenuhan dari periode akhir musim hujan 2006 menuju puncak kemarau 2006, dan selanjutnya mengalami penurunan nilai dan pada beberapa tempat mengalami sedikit fluktuasi tergantung dari sifat dan fluktuasi banjir yang terjadi. Secara spasial nilai kenaikan dan penurunan nilai SI kalsit mempunyai julat yang berbeda-beda (Tabel 4.34.) 


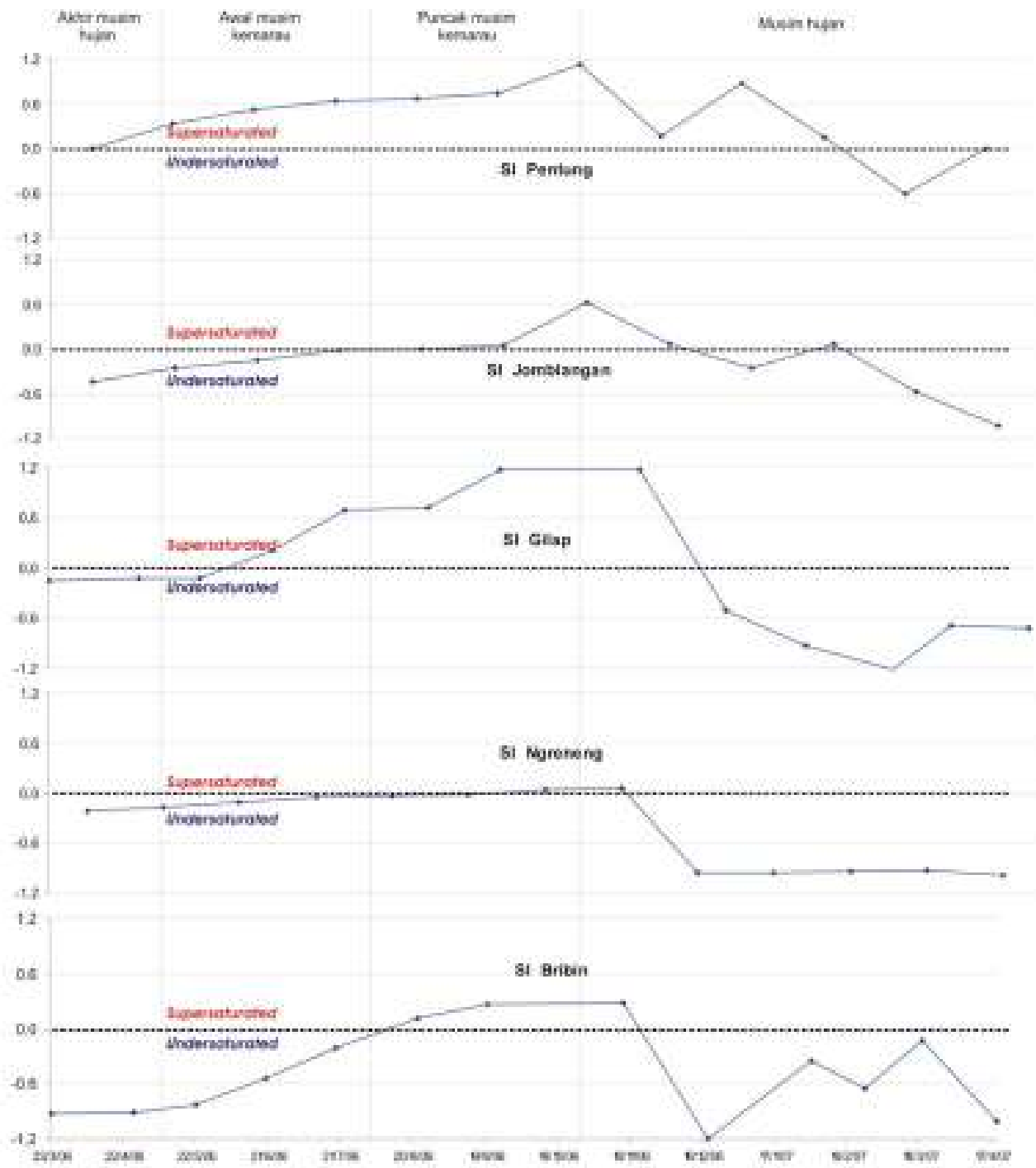

Gambar 4.73. Variasi Temporal Nilai Indeks Kejenuhan (SI) Gua-Gua di SBT Bribin

Tabel 4.34. Distribusi Nilai SI di SBT Bribin

\begin{tabular}{|l|l|c|c|c|c|}
\hline \multicolumn{1}{|c|}{ Lokasi } & \multicolumn{1}{|c|}{ Posisi } & Musim kemarau & Kriteria & Musim hujan & Kriteria \\
\hline Sungai Pentung & Masukan & $-0,01 \mathrm{~s} / \mathrm{d} 1,13$ & $\begin{array}{c}\text { Hampir jenuh s/d } \\
\text { sangat jenuh }\end{array}$ & $0,18 \mathrm{~s} / \mathrm{d}-0,61$ & Jenuh s/d agresif \\
\hline $\begin{array}{l}\text { Luweng } \\
\text { Jomblangan }\end{array}$ & Hulu & $-0,43 \mathrm{~s} / \mathrm{d} 0,63$ & $\begin{array}{c}\text { Sangat agresif s/d } \\
\text { jenuh }\end{array}$ & $0,06 \mathrm{~s} / \mathrm{d}-1,04$ & $\begin{array}{c}\text { Agak jenuh s/d } \\
\text { agresif }\end{array}$ \\
\hline Gua Gilap & Tengah-hulu & $-0,15 \mathrm{~s} / \mathrm{d} 1,18$ & $\begin{array}{c}\text { Agresif s/d sangat } \\
\text { jenuh }\end{array}$ & $-0,51 \mathrm{~s} / \mathrm{d}-1,21$ & $\begin{array}{c}\text { Agresif s/d sangat } \\
\text { agresif }\end{array}$ \\
\hline Gua Ngreneng & Bocoran-hilir & $-0,22 \mathrm{~s} / \mathrm{d} 0,05$ & $\begin{array}{c}\text { Agresif s/d agak } \\
\text { jenuh }\end{array}$ & $-0,96 \mathrm{~s} / \mathrm{d}-0,99$ & Sangat agresif \\
\hline Gua Bribin & Hilir & $-0,93 \mathrm{~s} / \mathrm{d} 0,29$ & $\begin{array}{c}\text { Agresif s/d agak } \\
\text { jenuh }\end{array}$ & $-0,12 \mathrm{~s} / \mathrm{d}-1,01$ & $\begin{array}{c}\text { Agresif s/d sangat } \\
\text { agresif }\end{array}$ \\
\hline
\end{tabular}


Dari Tabel 4.34. terlihat bahwa julat indeks kejenuhan (SI) pada tiap-tiap gua mempunyai perbedaan nilai. Jika dilihat dari posisi dan kedudukannya, pada musim kemarau dan penghujan gua-gua di bagian hilir (Gua Bribin dan Ngreneng) mempunyai nilai SI yang agresivitasnya lebih konstan dibanding gua-gua yang lain (julatnya tidak terlalu besar). Hal ini dapat dilihat di Gua Bribin yang memiliki persentase aliran dasar (PAD) paling stabil dibandingkan gua-gua yang lain. Meskipun demikian, sepanjang tahun air sungai bawah tanah di Gua Bribin mempunyai sifat paling agresif dibanding dengan tempat lain, bahkan nilai SI di Gua Bribin belum pernah melebihi angka 0 (setimbang) pada musim hujan (selalu agresif). Hal yang sama juga dijumpai di Gua Ngreneng. Jika dibandingkan dengan nilai SI di gua bagian hulu, sebagai contoh adalah Gua Gilap, maka Gua Gilap di musim kemarau mencapai nilai SI tertinggi sebesar 0,61, menunjukkan bahwa proses pelarutan sudah terhenti, bahkan pada awal musim kemarau nilai SI positif sudah tercapai. Hal yang sama juga dijumpai di Gua Jomblangan dan Sungai Pentung. Sebaliknya, hal demikian tidak ditemukan di gua-gua bagian hilir. Hal ini mengindikasikan bahwa proses pembentukan endapan gua (terutama saat kemarau) lebih intensif terjadi pada gua-gua di daerah hulu, sementara proses pelebaran lorong (pelarutan) yang lebih intensif yang ditandai dengan nilai SI negatif terjadi di guagua bagian hilir (Gua Bribin dan Ngreneng), meskipun pada saat musim hujan proses-proses tersebut lebih dipengaruhi oleh pasokan komponen aliran conduit dari air hujan. Kenyataan distribusi nilai SI ini mengindikasikan bahwa terdapat proses percampuran (mixing) yang lebih intensif antara komponen aliran diffuse dan fissure di gua-gua bagian hilir. Ford and Williams (1992), Bogli (1980), Plummer (1975), dan Jankowski and Jacobson (1991) menjelaskan bahwa percampuran antara dua air yang masing-masing sudah jenuh $(\mathrm{SI}=$ positif) terhadap mineral kalsit mampu menurunkan nilai SI kalsit dan menyebabkan air menjadi agresif untuk melarutkan 
batuan karbonat. Kenyataan yang dijumpai dari perhitungan nilai persentase aliran dasar (PAD) pada subbab sebelumnya adalah gua-gua di bagian hilir (khususnya Gua Bribin) mempunyai nilai PAD yang tinggi yang merupakan campuran dari komponen aliran diffuse dan fissure Hal inilah yang kemungkinan menyebabkan nilai agresifitas SBT Bribin di bagian hilir bersifat tidak jenuh (undersaturated) saat kemarau, disamping adanya faktor lain berupa sistem pelorongan sebagai open atau close system yang akan dibahas pada subbab selanjutnya.

\section{Karakter dan hubungan parameter SKD Air SBT Bribin hulu-hilir}

Menurut Daoxian (2005), parameter kualitas air karst yang biasa digunakan untuk mengetahui pola SKD di suatu daerah adalah variasi nilai $\mathrm{pH}$, SI, tekanan parsial gas karbondioksida, kandungan kalsium (atau bikarbonat) yang dilakukan pada komponen-komponen air sungai bawah tanah yaitu: (1) air hujan sebagai masukan, (2) air tetesan dari ornamen sebagai indikasi proses pelarutanpengendapan, dan (3) air sungai bawah tanah. Dari penjelasan yang sudah disampaikan pada Tabel 3.1, pengambilan sampel tetesan hanya dimungkinkan dilakukan pada Gua Gilap (hulu) dan Gua Bribin (hilir) karena faktor keberadaan dan morfometri gua, sehingga pada bahasan ini akan dibandingkan hubungan dan variasi komponen-komponen SKD pada 2 (dua) gua yaitu Gua Gilap yang mewakili daerah hulu dan Gua Bribin mewakili daerah hilir Tabel 4.35. dan 4.36. menyajikan julat besaran nilai parameter SKD di daerah hulu dan hilir. Khusus untuk hujan tidak dibedakan antara bagian hulu dan hilir dan tidak dibedakan antara musim hujan dan kemarau agar dapat diketahui perbedaan karakteristik parameter SKD air hujan dengan air tetesan dan air sungai bawah tanah. 
Tabel 4.35. Distribusi Nilai Paramater SKD SBT Bribin pada Musim Kemarau

\begin{tabular}{|l|c|c|c|c|c|c|}
\hline \multirow{2}{*}{ Komponen SKD } & \multicolumn{3}{|c|}{ Daerah Hulu (Gua Gilap) } & \multicolumn{3}{c|}{ Daerah Hilir (Gua Bribin) } \\
\cline { 2 - 7 } & Air hujan & Air tetesan & $\begin{array}{c}\text { Sungai bawah } \\
\text { tanah }\end{array}$ & \multicolumn{2}{c|}{$\begin{array}{c}\text { Air hujan } \\
\text { Air tetesan }\end{array}$} & $\begin{array}{c}\text { Sungai bawah } \\
\text { tanah }\end{array}$ \\
\hline $\mathbf{p H}$ & $6,29-6,55$ & $8,29-8,57$ & $7,06-8,42$ & $6,29-6,55$ & $7,06-7,72$ & $6,96-7,39$ \\
\hline Log $\mathbf{P}_{\mathbf{C O} 2}$ & $-1,59--1,87$ & $-3,03--3,31$ & $-1,71--3,09$ & $-1,59--1,87$ & $-1,88--2,47$ & $-1,53--2.13$ \\
\hline $\mathbf{S I ~ k a l s i t ~}^{*}$ & $-1,77--2,14$ & $0,56-1,25$ & $-0,15-1,18$ & $-1,77--2,14$ & $-0,52-0,29$ & $-0,83-0,26$ \\
\hline $\mathbf{C a}^{\mathbf{2 +}}$ (mg/lt) & $14,3-18,8$ & $62,6-80,0$ & $50,56-68,08$ & $14,3-18,8$ & $45,1-92,7$ & $86,13-110,3$ \\
\hline $\mathbf{H C O}_{\mathbf{3}}^{-} \mathbf{( m g / l t )}$ & $43,3-53,1$ & $183-248$ & $178-265$ & $43,3-53,1$ & $164-347$ & $242-278$ \\
\hline
\end{tabular}

Tabel 4.36. Distribusi Nilai Paramater SKD SBT Bribin pada Musim Hujan

\begin{tabular}{|l|c|c|c|c|c|c|}
\hline \multirow{2}{*}{ Komponen SKD } & \multicolumn{3}{|c|}{ Daerah Hulu (Gua Gilap) } & \multicolumn{3}{c|}{ Daerah Hilir (Gua Bribin) } \\
\cline { 2 - 7 } & Air hujan & Air tetesan & $\begin{array}{c}\text { Sungai bawah } \\
\text { tanah }\end{array}$ & \multicolumn{2}{c|}{$\begin{array}{c}\text { Air hujan } \\
\text { Air tetesan }\end{array}$} & $\begin{array}{c}\text { Sungai bawah } \\
\text { tanah }\end{array}$ \\
\hline pH & $6,29-6,55$ & $6,67-7,22$ & $6,52-7,12$ & $6,29-6,55$ & $6,93-7,18$ & $6,46-7,03$ \\
\hline $\mathbf{L o g} \mathbf{P}_{\mathbf{C O} 2}$ & $-1,59--1,87$ & $-1,37--2,00$ & $-1,47--1,95$ & $-1,59--1,87$ & $-1,65--1,98$ & $-1,19--1,79$ \\
\hline SI kalsit $^{2}$ & $-1,77--2,14$ & $-0,17--1,10$ & $-0,51--1,31$ & $-1,77--2,14$ & $-0,65--0,79$ & $-0,12--1,79$ \\
\hline $\mathbf{C a}^{2+}(\mathbf{m g} / \mathbf{l t})$ & $14,3-18,8$ & $12,0-57,5$ & $31,8-42,7$ & $14,3-18,8$ & $15,6-41,3$ & $67,7-134,4$ \\
\hline $\mathbf{H C O}_{\mathbf{3}}^{-}$(mg/lt) & $43,3-53,1$ & $111-187$ & $110-154$ & $43,3-53,1$ & $148-192$ & $149-300$ \\
\hline
\end{tabular}

Pada saat musim kemarau dan musim hujan, terlihat pengelompokan atau perbedaan nilai parameter-parameter SKD antara air tetesan dan sungai bawah tanah, dan bahkan jika dibandingkan dengan parameter SKD dari air hujan yang jatuh di daerah tangkapan SBT Bribin. Vesper and White (2004) dan Daoxian (2005) menjelaskan bahwa untuk mengkarakterisasi parameter-parameter SKD pada berbagai jenis air di daerah karst dan untuk mengetahui interaksi antar parameter, dapat menggunakan scatter plot analysis.

\section{a. Hubungan nilai SI kalsit dan $\log \mathbf{P}_{\mathrm{CO} 2}$ SBT Bribin bagian hulu}

Hubungan SI kalsit dan tekanan parsial gas karbondioksida di Gua Gilap (hulu) disajikan pada Gambar 4.74. dan 4.75. Tanda panah pada gambar-gambar tersebut menunjukkan evolusi komponen air karst dari air hujan ke air tetesan dan ke air sungai bawah tanah (masing-masing komponen air karst dibatasi dengan garis 
lingkaran). Pada saat musim hujan, komponen air hujan dapat mengimbuh langsung ke sungai bawah tanah melalui pelorongan conduit.

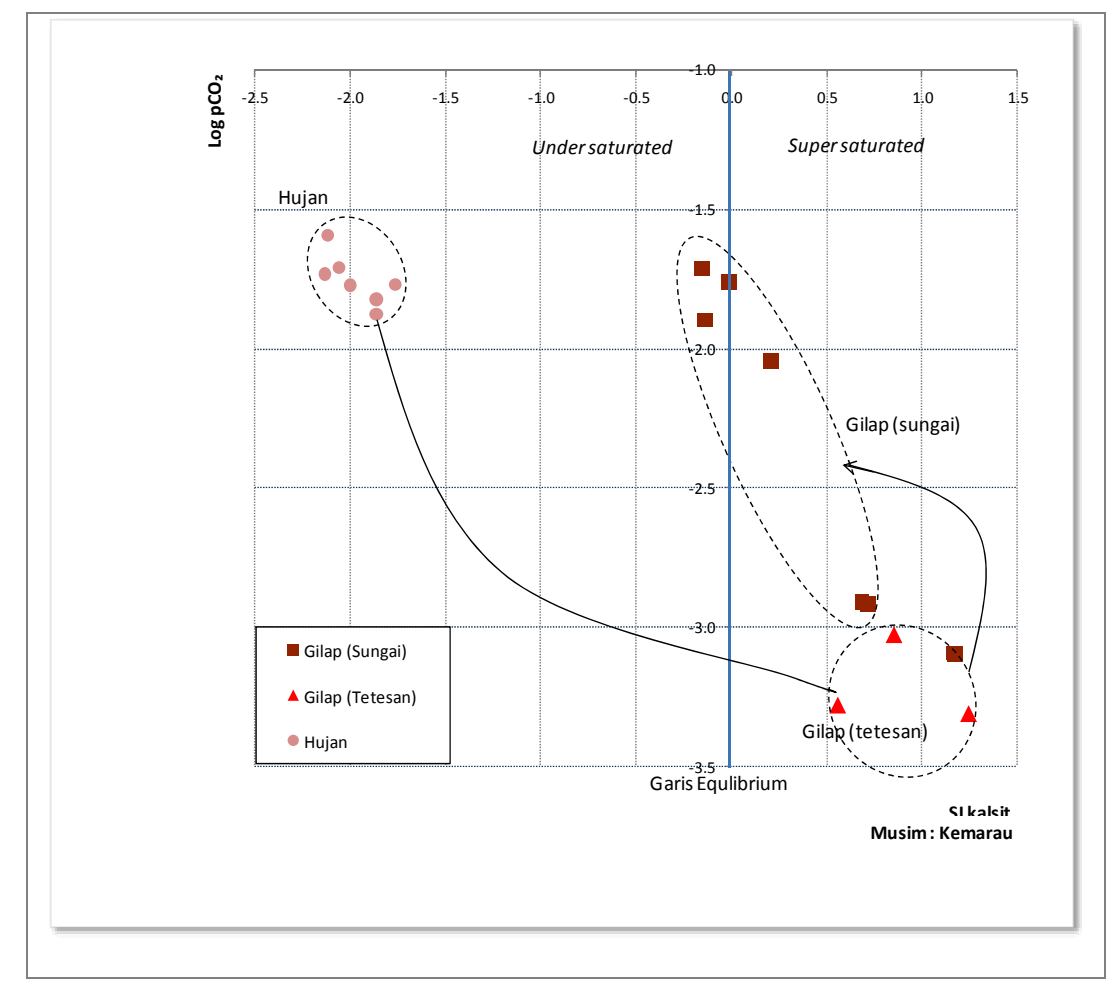

Gambar 4.74. Hubungan SI Kalsit dan $\log \mathrm{P}_{\mathrm{CO} 2}$ di Gua Gilap pada Musim Kemarau

Dari Gambar 4.74. terlihat bahwa pada saat musim kemarau, proses pelarutan dapat terjadi oleh sisa air hujan dan air sungai bawah tanah pada awal musim kemarau yang ditandai dengan nilai SI kalsit negatif dan $\log \mathrm{P}_{\mathrm{CO} 2}$ besar, sedangkan untuk air tetesan menunjukkan kondisi supersaturated atau tidak mampu melarutkan batuan karbonat (jenuh) dengan nilai SI kalsit positif, karena gas karbondioksida dalam air sudah digunakan untuk melarutkan batuan gamping selama perjalanan air menjadi tetesan, sehingga yang terjadi adalah proses pengendapan (precipitation) yang dicirikan dengan nilai SI positif. Panah yang ada pada gambar menunjukkan siklus yang dimulai dari air hujan (SI negatif), kemudian setelah terinfiltrasi berubah menjadi jenuh (SI positif) sebagai air tetesan (diffuse flow). Tandah panah kemudian 
menunjukkan air tetesan ini bercampur dengan air sungai bawah tanah sebagai komponen sungai bawah tanah saat kemarau, sehingga nilai SI sedikit turun. Pada musim hujan terdapat aliran langsung dari air hujan menuju saluran sungai bawah (ditunjukkan dengan panah langsung dari kelompok air hujan ke kelompok sungai bawah tanah tanah) melalui lorong-lorong conduit, yang menyebabkan nilai SI menjadi undersaturated.

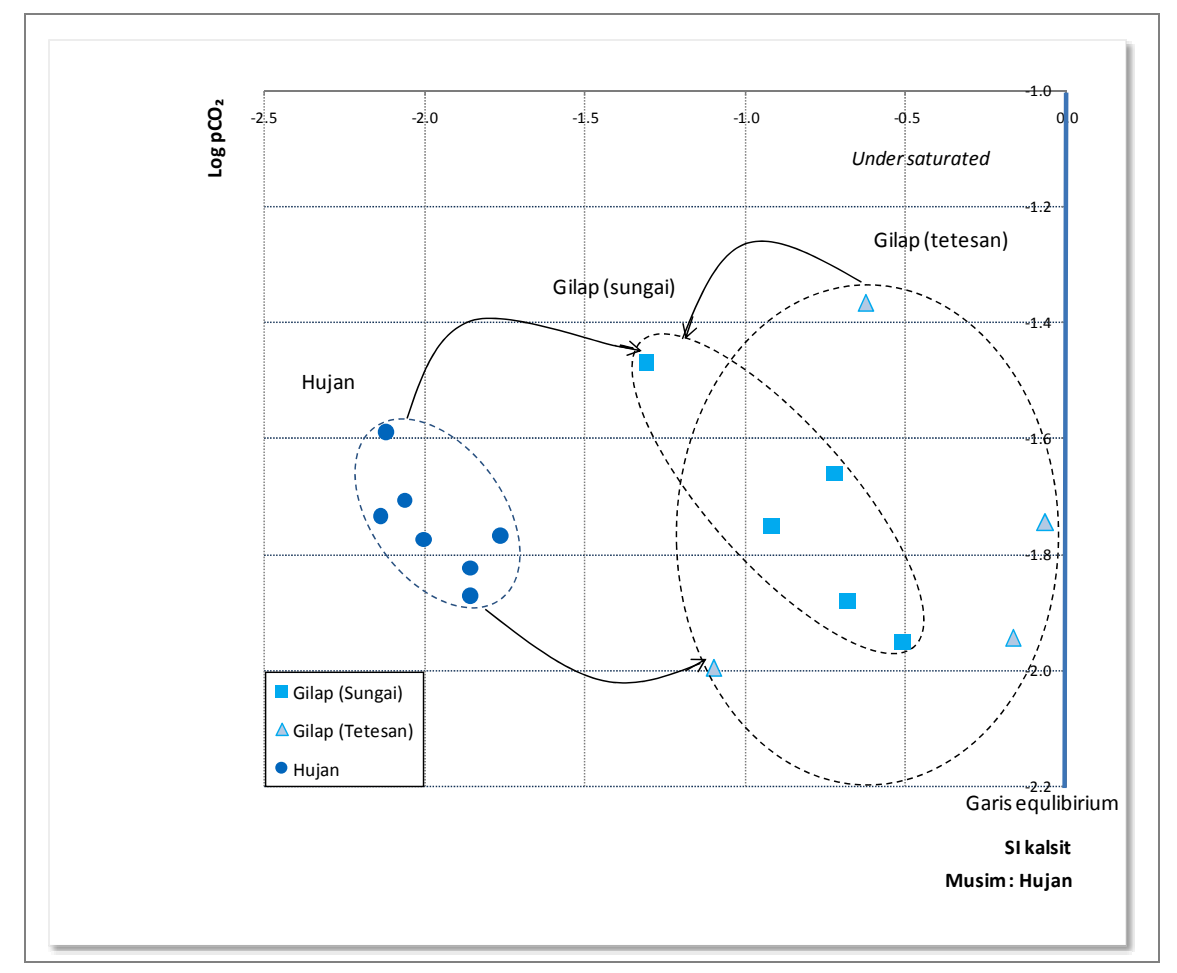

Gambar 4.75. Hubungan SI Kalsit dan log $\mathrm{P}_{\mathrm{CO} 2}$ di Gua Gilap pada Musim Hujan

Proses hidrogeokimia yang dapat dikenali dari plotting ini adalah water-rock interaction berupa pelarutan-pengendapan mineral kalsit yang kuat pada air sungai bawah tanah dengan nilai determinasi $\left(\mathrm{R}^{2}\right)$ diatas 90\%. Angka ini jauh diatas determinasi yang sama pada air hujan $(<50 \%)$ dan belum terjadi proses water-rock interaction. Fakta ini menunjukkan adanya proses percampuran (mixing) yang menyebabkan hubungan SI dan log PCO2 air sungai bawah tanah di Gua Gilap 
meningkat. Proses dan karakteristik hidrogeokimia yang hampir sama ditemukan pada saat periode hujan. Namun, semua sampel baik itu tetesan maupun air sungai bawah tanah mempunyai nilai SI dibawah nol (undersaturated) sehingga proses pelarutan lebih dominan dibandingkan saat kemarau. Hal ini karena adanya penambahan gas karbondioksida pada komponen aliran sungai bawah tanah. Ringkasan hubungan nilai SI kalsit dan tekanan parsial gas karbondioksida disajikan pada Tabel 4.37.

Tabel 4.37. Hubungan SI Kalsit dan $\log \mathrm{P}_{\mathrm{CO} 2}$ di Gua Gilap

\begin{tabular}{|c|c|c|c|}
\hline \multirow{2}{*}{ Musim } & \multicolumn{3}{|c|}{ Daerah Hulu (Gua Gilap) } \\
\hline & Air hujan & Air tetesan & Sungai bawah tanah \\
\hline Kemarau & & $\begin{array}{l}\text { 1. Determinasi }\left(\mathrm{R}^{2}\right) \text { yang sangat rendah } \\
\text { 2. SI positif }\end{array}$ & $\begin{array}{l}\text { 1. Hubungan negatif dengan } \mathrm{R}^{2}=0,94 \\
\text { 2. SI kalsit naik ketika } \mathrm{CO}_{2} \text { turun }\end{array}$ \\
\hline $\begin{array}{c}\text { Proses } \\
\text { Hidrogeokimia }\end{array}$ & & $\begin{array}{l}\text { 1. Water-rock interaction berupa } \\
\text { pengendapan mineral kalsit }\end{array}$ & $\begin{array}{l}\text { 1. Pelarutan (dissolution) di awal } \\
\text { kemarau } \\
\text { 2. Pengendapan pada puncak kemarau }\end{array}$ \\
\hline Hujan & 1. Hubungan negatif dengan $\mathrm{R}^{2}=0,5$ & $\begin{array}{l}\text { 1. Determinasi yang sangat rendah } \\
\text { 2. SI kalsit turun menjadi negatif }\end{array}$ & $\begin{array}{l}\text { 1. Hubungan negatif dengan } \mathrm{R}^{2}=0,80 \\
\text { 2. SI kalsit turun saat } \mathrm{CO}_{2} \text { naik saat } \\
\text { banjir }\end{array}$ \\
\hline $\begin{array}{c}\text { Proses } \\
\text { Hidrogeokimia }\end{array}$ & $\begin{array}{l}\text { 1. Sistem terbuka, } \\
\text { 2. Difusi gas } \mathrm{CO}_{2} \text { ke air }\end{array}$ & $\begin{array}{l}\text { 1. Water-rock interaction berupa } \\
\text { pelarutan mineral kalsit }\end{array}$ & $\begin{array}{l}\text { 1. Dissolution } \\
\text { 2. Dilution by precipitation } \\
\text { 3. Mixing }\end{array}$ \\
\hline
\end{tabular}

\section{b. Hubungan nilai SI kalsit dan log kalsium SBT Bribin bagian hulu}

Hubungan antara SI kalsit dan kandungan kalsium terlarut di Gua Gilap (hulu) disajikan pada Gambar 4.76. dan 4.77. 


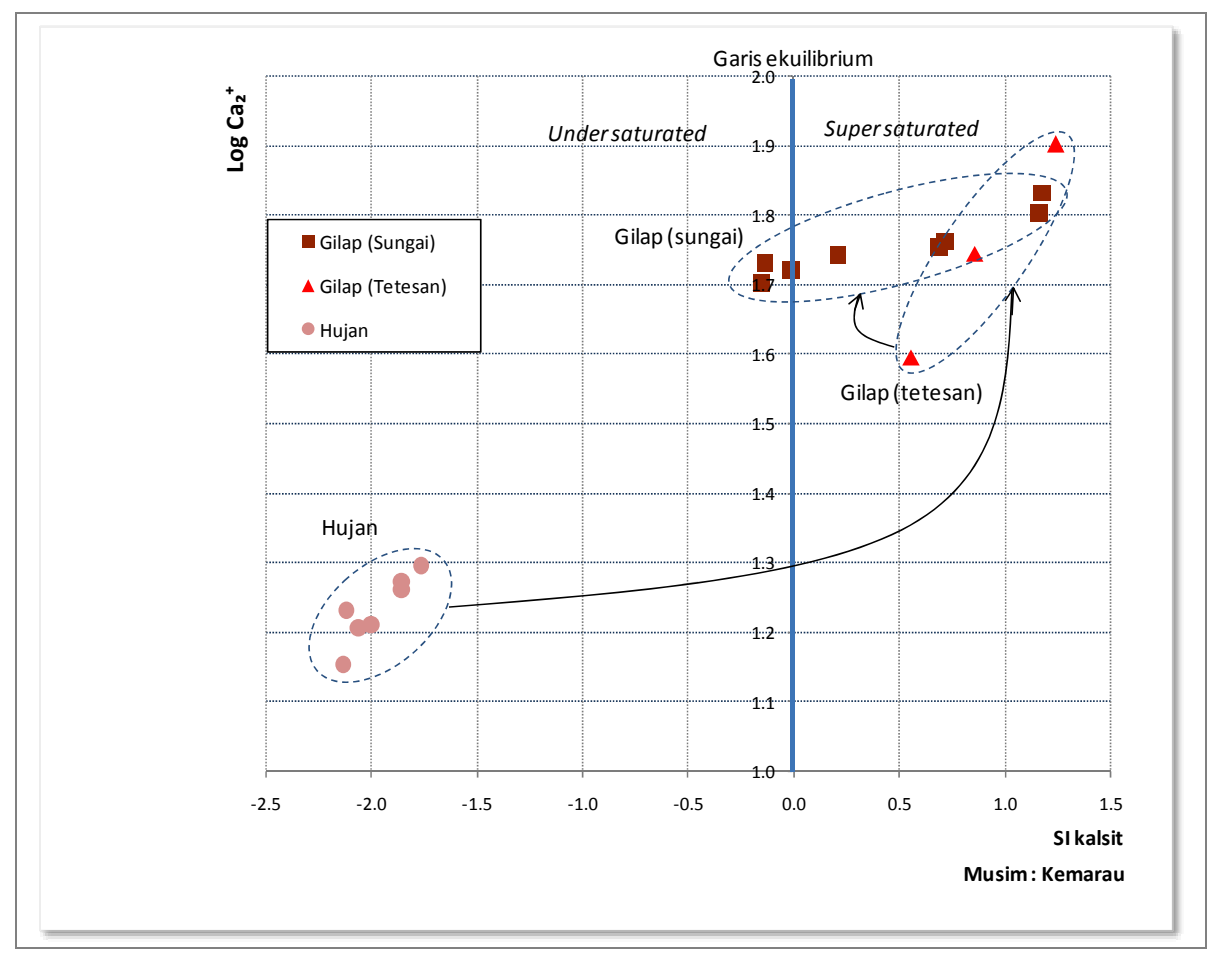

Gambar 4.76. Hubungan SI Kalsit dan Log Kalsium di Gua Gilap pada Musim Kemarau

Pada musim kemarau, hubungan antara nilai SI kalsit dan kandungan kalsium di Gua Gilap secara umum menunjukan hubungan yang positif dengan nilai determinasi $\left(\mathrm{R}^{2}\right)$ yang tinggi. Hal ini mengindikasikan bahwa kandungan kalsium terlarut dalam air berpengaruh terhadap besar kecinya nilai SI kalsit. Secara teoritis, Ford dan Williams (1992) menjelaskan bahwa nilai kalsium dan bikarbonat terlarut dalam air akan menaikkan atau menurunkan nilai SI karena adanya proses pelarutan atau pengendapan mineral kalsit. Dari Gambar 4.84. diketahui bahwa air tetesan mempunyai determinasi yang paling tinggi $\left(\mathrm{R}^{2}=0,996\right)$, karena proses pelarutan sudah sangat intensif dan mencapai tahap pengendapan (precipitation) mineral kalsit. Hidrokimia air tetesan ini dicirikan dengan nilai SI kalsit yang sudah jenuh (supersaturated) dan nilai kalsium yang tinggi. Garis berpanah warna biru dari kelompok air hujan menuju kelompok air tetesan menunjukkan bahwa air hujan memiliki nilai SI yang agresif (undersaturated) dan kandungan kalsium yang rendah, 
yang meningkat drastis ketika sampai pada air tetesan. Sementara itu, air sungai bawah tanah Gua Gilap yang merupakan campuran dari berbagai komponen aliran mempunyai nilai SI kalsit dan kalsium terlarut diantara air hujan dan air tetesan (perubahannya ditunjukkan dengan garis berpanah warna biru-pendek). Meskipun demikian, pada saat awal musim kemarau, air sungai bawah tanah mempunyai nilai SI kalsit yang agresif (undersaturated) karena masih ada pengaruh air hujan (bandingkan dengan nilai SI saat puncak kemarau). Hal ini menunjukkan bahwa secara umum terjadi proses pelarutan dan pengendapan pada lorong utama Gua Gilap meskipun intensitasnya lebih kecil jika dibandingkan dengan air tetesan.

Saat musim hujan, terjadinya penurunan determinasi antara SI kalsit dan kalsium lebih disebabkan karena adanya proses pengenceran oleh air hujan (dilution by precipitation) baik itu pada air tetesan maupun sungai bawah tanah. Secara umum terlihat pula bahwa semua sampel bersifat agresif untuk melarutkan mineral kalsit (undersaturated). Meskipun demikian, air tetesan tetap mempunyai nilai SI dan kalsium yang lebih tinggi dengan determinasi yang lebih tinggi dibanding air sungai bawah tanah, sehingga dapat dikatakan bahwa air hujan yang langsung mengisi sungai bawah tanah melalui lorong-lorong conduit menurunkan nilai SI, kalsium dan intensitas proses water-rock interaction (evolusi hidrogeokimia air hujan menuju air tetesan dan air hujan menuju sungai bawah tanah, serta dari air tetesan menuju sungai bawah tanah saat hujan dinyatakan dengan tanda panah). Ringkasan hubungan nilai SI kalsit dan kalsium terlarut disajikan pada Tabel 4.38. 


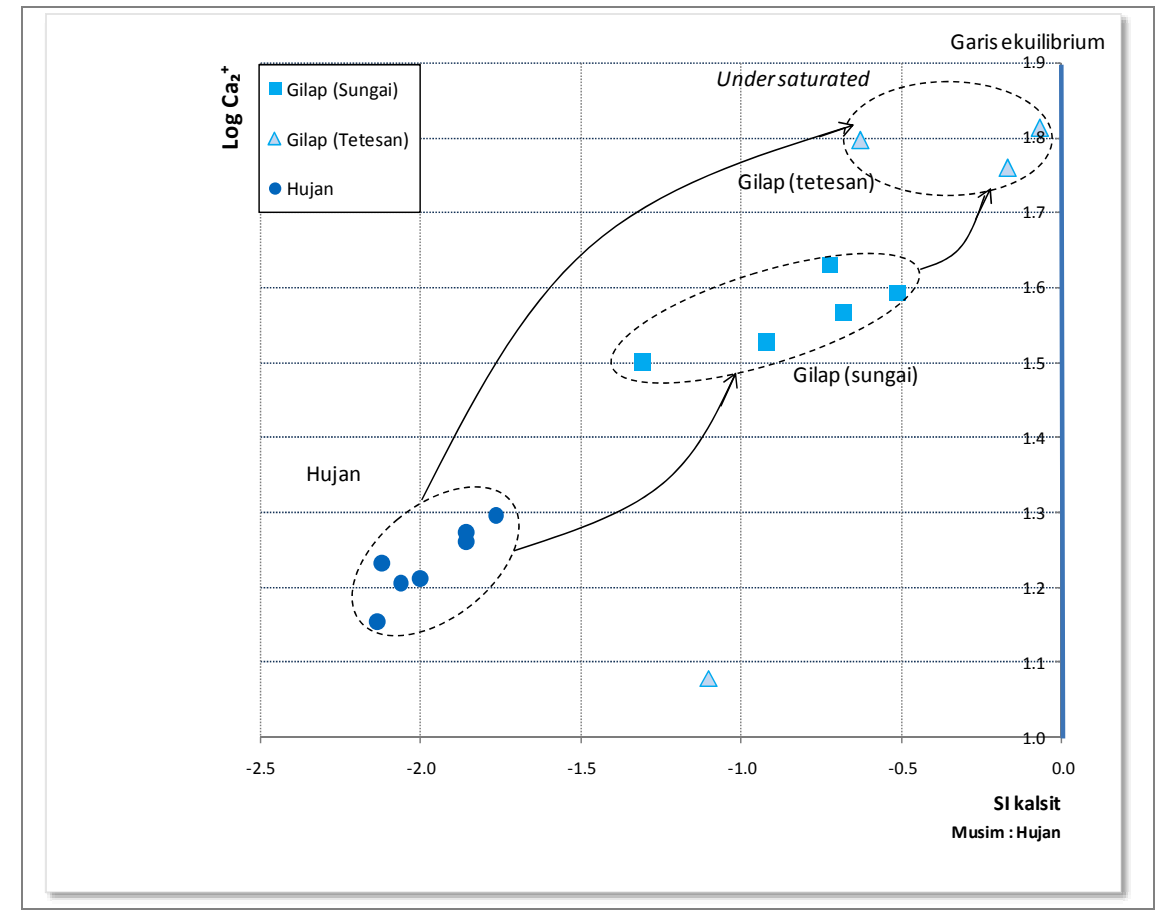

Gambar 4.77. Hubungan SI Kalsit dan log Kalsium di Gua Gilap pada Musim Hujan

Tabel 4.38. Hubungan SI Kalsit dan log Kalsium di Gua Gilap (hulu)

\begin{tabular}{|c|c|c|c|}
\hline \multirow{2}{*}{ Musim } & \multicolumn{3}{|c|}{ Daerah Hulu (Gua Gilap) } \\
\hline & Air hujan & Air tetesan & Sungai bawah tanah \\
\hline Kemarau & & $\begin{array}{l}\text { 1. Nilai SI dan kalsium yang tinggi. } \\
\text { 2. Hubungan positif dengan } \mathrm{R}^{2}=0,99\end{array}$ & $\begin{array}{l}\text { 1. Hubungan positif, } \mathrm{R}^{2} \text { lebih rendah dari } \\
\text { tetesan. } \\
\text { 2. SI dan kalsium turun di awal kemarau } \\
\text { 3. SI puncak kemarau naik mendekati SI } \\
\text { tetesan. }\end{array}$ \\
\hline $\begin{array}{c}\text { Proses } \\
\text { Hidrogeokimia }\end{array}$ & & $\begin{array}{l}\text { 1. Pengendapan mineral kalsit } \\
\text { 2. Membentuk ornamen gua }\end{array}$ & $\begin{array}{l}\text { 1. Pelarutan di awal kemarau } \\
\text { 2. Pengendapan di tengah kemarau }\end{array}$ \\
\hline Hujan & $\begin{array}{l}\text { Hubungan positif dengan } \mathrm{R}^{2}=0,78 . \\
\text { Air agresif untuk melarutkan mineral } \\
\text { kalsit }\end{array}$ & $\begin{array}{l}\text { 1. Determinasi sedikit turun } \\
\text { 2. Nilai SI dan kalsium turun drastis } \\
\text { 3. Air agresif }\end{array}$ & $\begin{array}{l}\text { 1. SI dan kalsium turun } \\
\text { 2. Determinasinya lebih rendah dibanding } \\
\text { saat kemarau. }\end{array}$ \\
\hline $\begin{array}{c}\text { Proses } \\
\text { Hidrogeokimia }\end{array}$ & Difusi karbondioksida kedalam air hujan & $\begin{array}{l}\text { 1. Perubahan dari proses pengendapan } \\
\text { menjadi pelarutan. } \\
\text { 2. Pengenceran oleh air hujan Intensitas } \\
\text { pelarutan meningkat. }\end{array}$ & $\begin{array}{l}\text { 1. Proses mixing dengan air hujan } \\
\text { 2. Perubahan dari proses pengendapan } \\
\text { menjadi pelarutan. } \\
\text { 3. Pengenceran oleh air hujan }\end{array}$ \\
\hline
\end{tabular}

\section{c. Hubungan nilai SI kalsit dan pH SBT Bribin bagian hulu}

Hubungan SI kalsit dan pH di Gua Gilap disajikan pada Gambar 4.78. dan 4.79. 


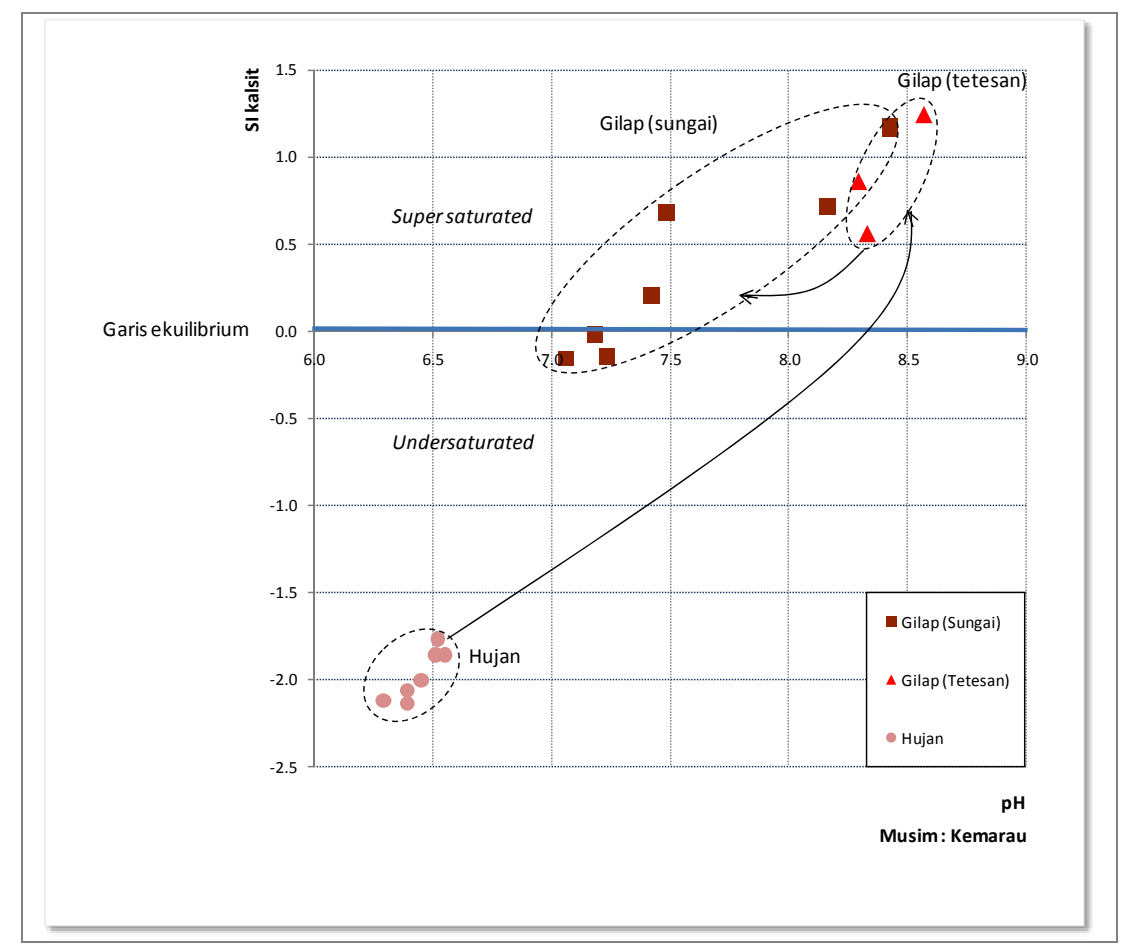

Gambar 4.78. Hubungan SI kalsit dan pH di Gua Gilap pada Musim Kemarau

Hubungan positif antara SI dan $\mathrm{pH}$ dengan $\mathrm{R}^{2}$ yang cukup besar ditemukan pada air tetesan dan sungai bawah tanah saat kemarau, meskipun nilai $\mathrm{R}^{2}$ pada sungai bawah tanah sedikit lebih tinggi (0,888 dibanding 0,700). Hal ini menunjukkan bahwa besar kecilnya nilai SI pada air tetesan lebih dipengaruhi oleh besar kecilnya unsur kalsium terlarut dalam air dibanding nilai $\mathrm{pH}$. Sementara itu, sungai bawah tanah mempunyai hubungan SI-pH yang lebih besar dibanding air tetesan, hal ini lebih disebabkan oleh adanya proses percampuran (mixing) antar komponen aliran yang mengisi sungai bawah tanah Vesper and White (2004).

Pada saat musim hujan (Gambar 4.79), masuknya aliran conduit ke sungai bawah tanah ternyata direspon dengan perubahan $\mathrm{pH}$ yang mempunyai determinasi tinggi $\left(\mathrm{R}^{2}=0,94\right)$ dengan naik-turunnya nilai SI. Sementara itu, air tetesan mempunyai determinasi pH-SI yang sangat rendah, bahkan lebih rendah dari 
hubungan tersebut yang pada air hujan. Hal ini menunjukkan fluktuasi aliran antara dan aliran dasar yang tidak stabil dan tergantung dari kejadian hujan (nilai $\mathrm{K}_{\mathrm{i}}$ dan $\mathrm{K}_{\mathrm{b}}$ Gua Gilap rendah). Ringkasan hubungan nilai SI kalsit dan $\mathrm{pH}$ di Gua Gilap disajikan pada Tabel 4.39.

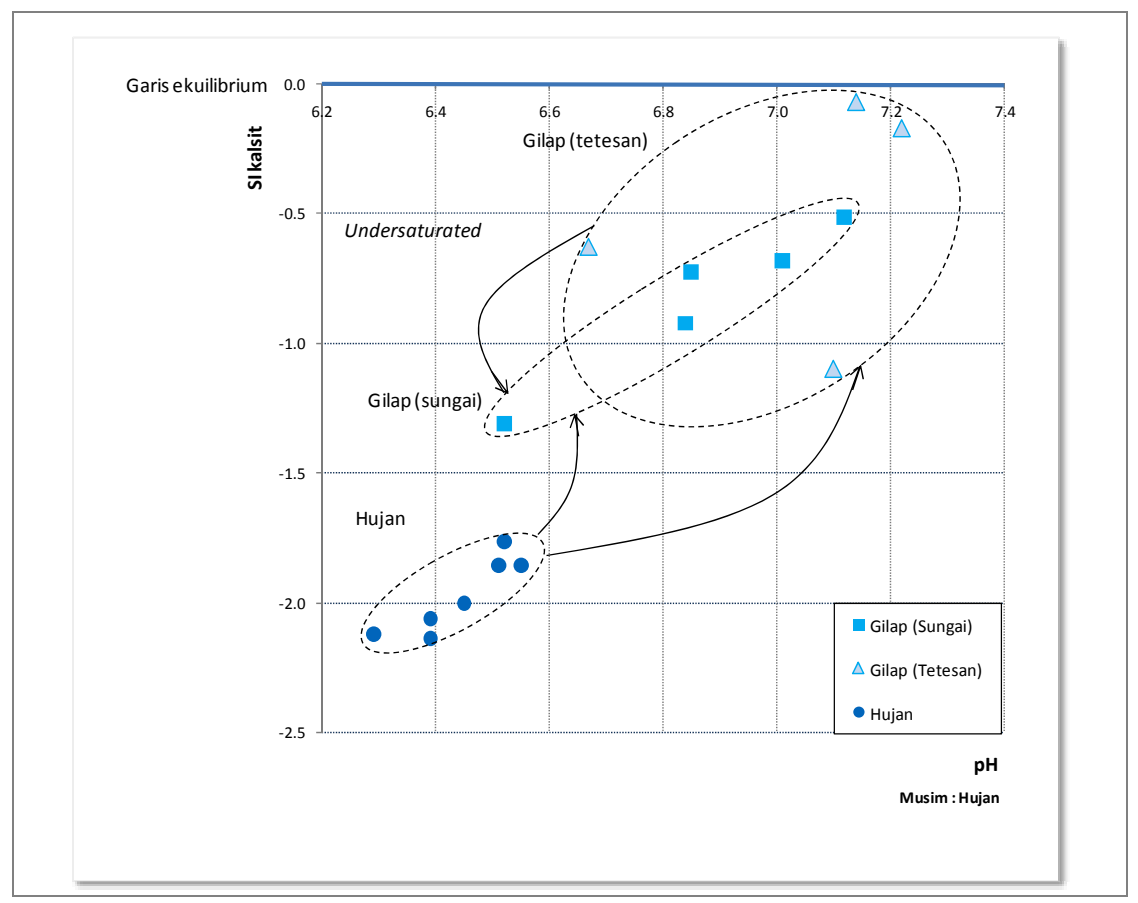

Gambar 4.79. Hubungan SI kalsit dan pH di Gua Gilap pada Musim Hujan

Tabel 4.39. Hubungan SI Kalsit dan pH di Gua Gilap (hulu)

\begin{tabular}{|c|c|c|c|}
\hline \multirow{2}{*}{ Musim } & \multicolumn{3}{|c|}{ Daerah Hulu (Gua Gilap) } \\
\hline & Air hujan & Air tetesan & Sungai bawah tanah \\
\hline Kemarau & & $\begin{array}{l}\text { 1. Nilai SI dan } \mathrm{pH} \text { yang tinggi. } \\
\text { 2. Hubungan positif denganR }{ }^{2}=0,70 \text {, cukup } \\
\text { tinggi }\end{array}$ & $\begin{array}{l}\text { 1. Nilai } \mathrm{R}^{2}=0,89 \text {, lebih tinggi dari air tetesan. } \\
\text { 2. SI dan } \mathrm{pH} \text { rendah di awal kemarau, di puncak } \\
\text { kemarau mendekati air tetesan. }\end{array}$ \\
\hline $\begin{array}{c}\text { Proses } \\
\text { Hidrogeokimia }\end{array}$ & & $\begin{array}{l}\text { 1. Pengendapan mineral kalsit } \\
\text { 2. Determinasi SI-kalsium lebih tinggi } \\
\text { dibanding SI-pH }\end{array}$ & $\begin{array}{l}\text { 1. Pelarutan (dissolution) di awal kemarau dan } \\
\text { pengendapan (precipitation) di puncak } \\
\text { 2. Determinasi SI-pH lebih tinggi dibanding } \\
\text { tetesan }\end{array}$ \\
\hline Hujan & $\begin{array}{l}\text { 1. Hubungan positif dengan } \mathrm{R}^{2}=0,79 \\
\text { 2. SI rendah dan } \mathrm{pH} \text { rendah }\end{array}$ & $\begin{array}{l}\text { 1. Determinasinya turun menjadi } \mathrm{R}^{2}=0,11 \text {. } \\
\text { 2. Nilai SI dan } \mathrm{pH} \text { turun drastis } \\
\text { 3. Air bersifat agresif ( } \text { undersaturated) }\end{array}$ & $\begin{array}{l}\text { 1. Air bersifat agresif (undersaturated). } \\
\text { Determinasinya lebih tinggi dibanding saat } \\
\text { kemarau. }\end{array}$ \\
\hline $\begin{array}{c}\text { Proses } \\
\text { Hidrogeokimia }\end{array}$ & $\begin{array}{l}\text { 1. Difusi karbondioksida kedalam air hujan, } \\
\text { Air ini bersifat agresif }\end{array}$ & $\begin{array}{l}\text { Proses pelarutan (dissolution). } \\
\text { Aliran diffuse dan fissure di Gilap yang cepat } \\
\text { merespon air hujan (Ki dan Kb kecil) }\end{array}$ & $\begin{array}{l}\text { 1. Proses mixing dengan air hujan } \\
\text { 2. Determinasi menjadi tinggi } \\
\text { 3. Air hujan merubah nilai } \mathrm{pH} \text { dan SI turun. }\end{array}$ \\
\hline
\end{tabular}




\section{d. Hubungan nilai SI kalsit dan $\log \mathbf{P}_{\mathrm{CO} 2}$ SBT Bribin bagian hilir}

Hubungan SI kalsit dan $\log \mathrm{P}_{\mathrm{CO} 2}$ di Gua Bribin disajikan pada Gambar 4.80. dan 4.81. Pada musim kemarau, determinasi antara SI kalsit- $\log \mathrm{P}_{\mathrm{CO} 2}$ di Gua hilir mempunyai hubungan positif dengan nilai $R^{2}$ yang cukup besar yaitu 0,95 untuk air sungai bawah tanah dan 0,73 untuk air tetesan, sedangkan air hujan mempunyai nilai $\mathrm{R}^{2}=0$,49. Jika dideskripsikan sesuai siklus hidrologinya (ditunjukkan dengan garis berpanah warna merah), maka air hujan yang masih bersifat agresif (nilai SI kalsit dan $\log \mathrm{P}_{\mathrm{CO} 2}$ kecil) yang terinfiltrasi, kemudian berkurang agresivitasnya atau nilai SI-nya meningkat setelah menjadi air tetesan, nilai SI-nya terhadap kalsit hanya sedikit diatas garis equilibrium (tebal-warna merah atau $\mathrm{SI}=0$ ). Hal ini menunjukkan bahwa proses pengendapan belum seintensif Gua Gilap $\left(\mathrm{CO}_{2}\right.$ sebagian masih digunakan untuk melarutkan mineral kalsit), sehingga nilai determinasinya dengan SI lebih kecil dari hubungan pada air sungai bawah tanah. Setelah mencapai sungai bawah tanah, nilai determinasi menjadi sedikit meningkat karena ada proses mixing dan masukan gas $\mathrm{CO}_{2}$ dari lorong-lorong conduit. Hal ini menunjukkan bahwa besar kecilnya pasokan gas karbondioksida dalam air berpengaruh terhadap naik turunnya intensitas pelarutan batuan karbonat. Akibatnya, pada musim kemarau, secara umum air sungai bawah tanah di Gua Bribin ada pada kondisi agresif (undersaturated) terhadap mineral kalsit.

Pada musim hujan, proses dilution by precipitation menyebabkan nilai SI kalsit turun dan $\log \mathrm{P}_{\mathrm{CO} 2}$ naik, dan sedikit menurunkan hubungan SI kalsit-log $\mathrm{P}_{\mathrm{CO} 2}$ dalam air. Determinasi SI- $\log \mathrm{P}_{\mathrm{CO} 2}$ antara banjir yang pertama dan banjir yang kedua memiliki nilai (negatif) yang hampir sama $\left(\mathrm{R}^{2}\right.$ sekitar 0,7-0,8), artinya menunjukkan besar kecilnya SI berbanding terbalik dengan tekanan gas karbondioksida dalam air. Hal yang menarik ditemukan pada nilai hubungan positif 
yang cukup kuat pada air tetesan yaitu dengan nilai $\mathrm{R}^{2}=0,8$ yang menunjukkan bahwa nilai SI kalsit naik ketika tekanan gas karbondioksida dalam air tetesan juga naik. Hal ini mirip dengan yang terjadi pada air tetesan di Gua Gilap yang mengindikasikan bahwa di Gua Bribin memiliki respon kimia tetesan yang hampir mirip dengan Gua Gilap. Ringkasan hubungan nilai SI kalsit dan $\log \mathrm{P}_{\mathrm{CO} 2}$ di Gua Bribin disajikan pada Tabel 4.40.

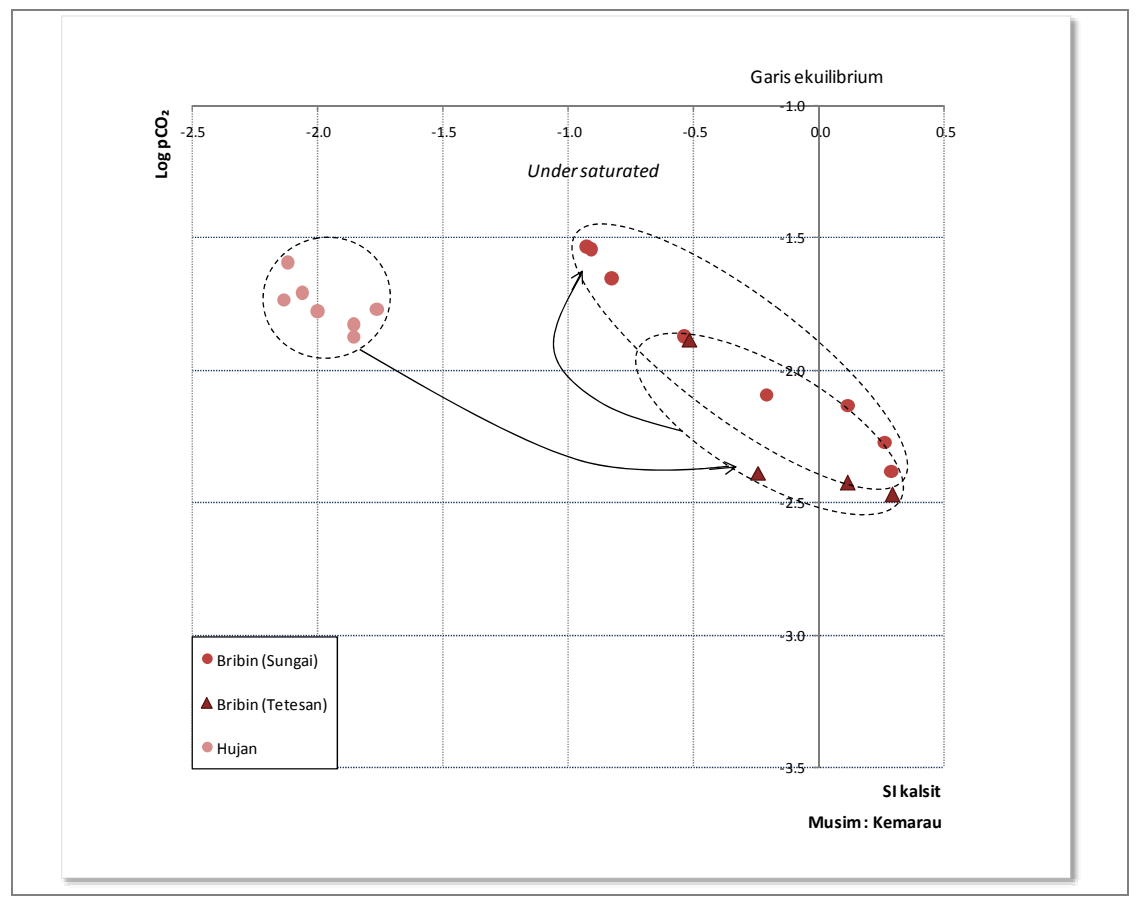

Gambar 4.80. Hubungan SI Kalsit dan log $\mathrm{P}_{\mathrm{CO} 2}$ di Gua Bribin pada Musim Kemarau

Tabel 4.40. Hubungan SI Kalsit dan log $\mathrm{P}_{\mathrm{CO} 2}$ di Gua Bribin (hilir)

\begin{tabular}{|c|c|c|c|}
\hline \multirow{2}{*}{ Musim } & \multicolumn{3}{|c|}{ Daerah Hilir (GuaBribin) } \\
\hline & Air hujan & Air tetesan & Sungai bawah tanah \\
\hline Kemarau & & $\begin{array}{l}\text { 1. SI positif dan } \log \mathrm{P}_{\mathrm{CO} 2} \text { rendah. } \\
\text { 2. Hubungan positif dengan } \mathrm{R}^{2}=0,7\end{array}$ & $\begin{array}{l}\text { 1. Hubungan positif dengan } \mathrm{R}^{2}=0,95 \\
\text { 2. SI tinggi dan log } \mathrm{P}_{\mathrm{CO} 2} \text { tinggi di awal kemarau } \\
\text { Di puncak kemarau mendekati air tetesan. }\end{array}$ \\
\hline $\begin{array}{c}\text { Proses } \\
\text { Hidrogeokimia }\end{array}$ & & $\begin{array}{l}\text { 1. Pelarutan mineral kalsit, pada nilai SI } \\
\text { kalsit negatif. } \\
\text { 2. Ada difusi gas karbondioksida dari } \\
\text { pelorongan. }\end{array}$ & $\begin{array}{l}\text { 1. Pelarutan di awal kemarau } \\
\text { 2. Pengendapan saat tengah kemarau, meskipun } \\
\text { fluktuasinya kecil, karena masih ada masukan } \\
\text { gas } \mathrm{CO}_{2} \text { dari pelorongan }\end{array}$ \\
\hline Hujan & $\begin{array}{l}\text { 1. Hubungan negatif } \\
\text { 2. Nilai SI rendah }\end{array}$ & $\begin{array}{l}\text { 1. Hubungan menjadi positif dengan } \mathrm{R}^{2}= \\
0,83 \text {. SI naik bersamaan dengan } \\
\text { kenaikan gas } \mathrm{CO}_{2} \text { dalam air }\end{array}$ & $\begin{array}{l}\text { 1. Nilai SI dan log } \mathrm{P}_{\mathrm{CO} 2} \text { turun } \\
\text { 2. Determinasinya lebih rendah dibanding saat } \\
\text { musim kemarau karena adanya percampuran } \\
\text { komponen aliran. }\end{array}$ \\
\hline $\begin{array}{c}\text { Proses } \\
\text { Hidrogeokimia }\end{array}$ & Difusi karbondioksida kedalam air hujan & $\begin{array}{l}\text { 1. Proses pelarutan (dissolution). } \\
\text { 2. Hubungan menjadi positif karena } \\
\text { respon aliran fissure }\end{array}$ & $\begin{array}{l}\text { 1. Proses mixing dengan air hujan menurunkan } \\
\text { determinasi } \\
\text { 2. masukan air hujan menaikkan nilai } \log \mathrm{P}_{\mathrm{CO} 2} \\
\text { dan menurunkan nilai SI. }\end{array}$ \\
\hline
\end{tabular}




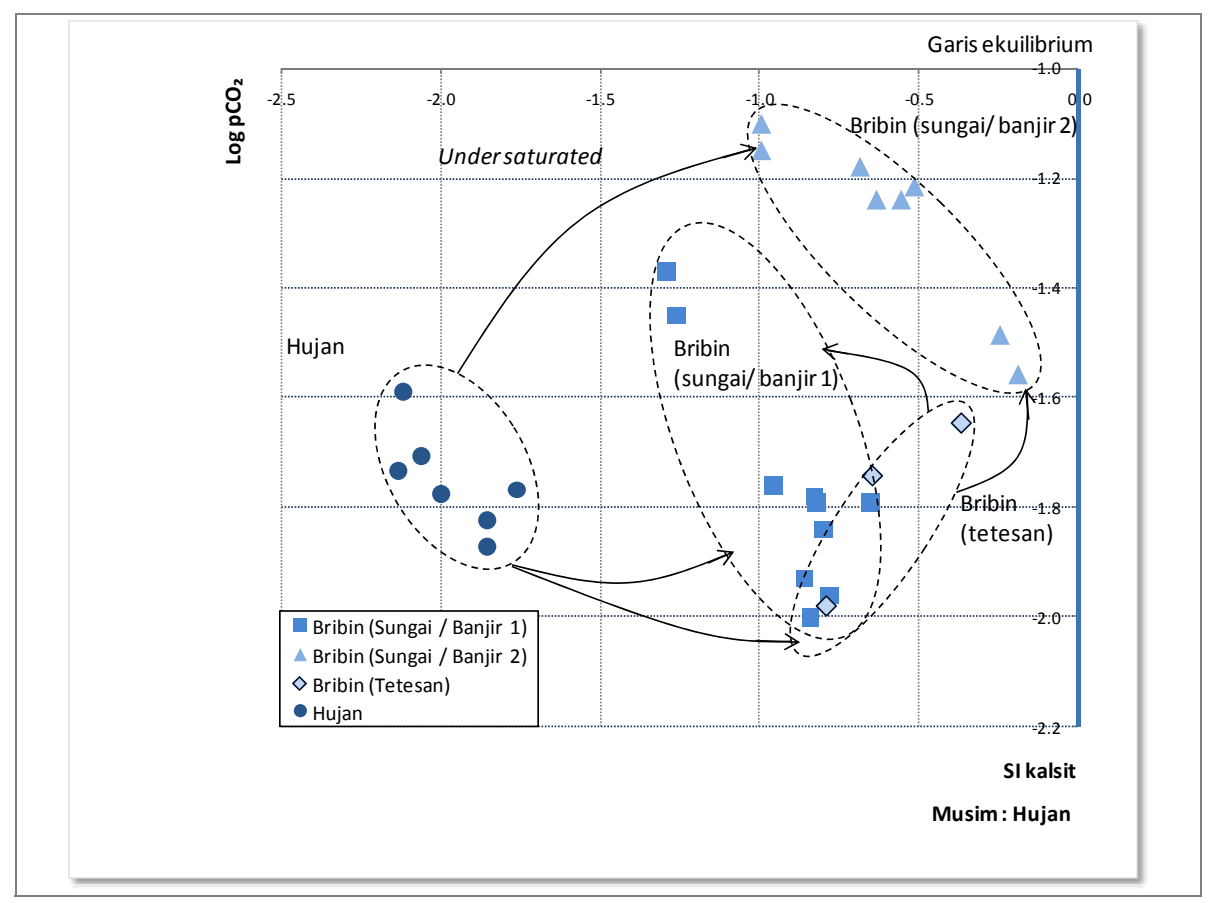

Gambar 4.81. Hubungan SI Kalsit dan $\log \mathrm{P}_{\mathrm{CO} 2}$ di Gua Bribin pada Musim Hujan

\section{e. Hubungan nilai SI kalsit dan log kalsium SBT Bribin bagian hilir}

Hubungan SI kalsit dan log kalsium di Gua Bribin disajikan pada Gambar 4.82. dan 4.83. Pada musim kemarau dijumpai nilai determinasi antara SI kalsit dan kalsium yang kecil pada air tetesan. Hal ini disebabkan oleh adanya waktu tunggu perjalanan air hujan menuju air tetesan, karena nilai koefisien aliran diffuse di Gua Bribin besar $\left(\mathrm{K}_{\mathrm{b}}=0,998\right)$. Sebagian sampel yang diamati mempunyai nilai SI dibawah 0 (undersaturated), sehingga menunjukkan kecenderungan adanya proses pelarutan, dan sebagian sampel yang lain menunjukkan nilai SI di atas 0 (oversaturated), yang menunjukkan adanya proses pengendapan (precipitation) mineral karbonat. Sementara itu air sungai bawah tanah di Gua Bribin menunjukkan hubungan antara SI kalsit dan kalsium yang kuat pada kondisi sebagian besar belum jenuh untuk melarutkan mineral kalsit (undersaturated). Evolusi sifat air dari kelompok air hujan 
menuju air tetesan dan dari air tetesan menuju air sungai bawah tanah ditunjukkan dengan garis berpanah warna biru.

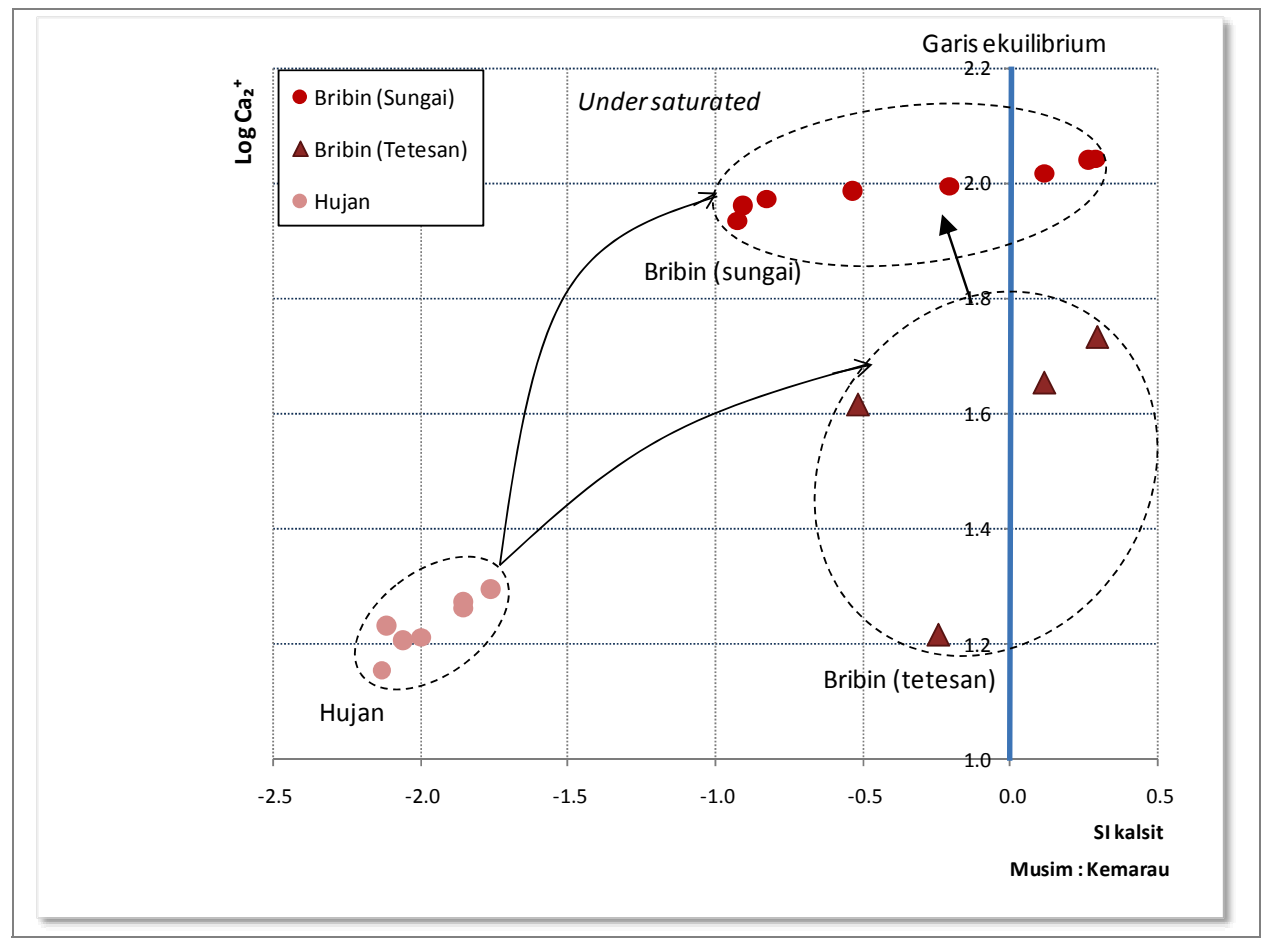

Gambar 4.82. Hubungan SI Kalsit dan log Kalsium di Gua Bribin pada Musim Kemarau

Pada musim hujan, determinasi antara SI kalsit dan kalsium meningkat dengan nilai determinasi $\left(\mathrm{R}^{2}\right)$ sebesar sekitar 0,75 pada kondisi air agresif (undersaturated). Hal ini mengindikasikan bahwa semakin besar nilai kalsium terlarut dalam air, maka nilai SI juga akan meningkat. Pada air sungai bawah tanah yang diwakili pada kejadian banjir, terjadi penurunan drastis nilai determinasi (semua air berada pada kondisi undersaturated). Jika melihat perjalanan air saat musim hujan, maka nilai determinasi SI kalsit dan kalsium pada air tetesan mirip dengan determinasi air hujan, sedangkan nilai determinasi saat banjir rendah karena perubahan kandungan kalsium terlarut dalam air tidak selalu sama dengan perubahan kandungan parameter-parameter SKD lain seperti log $\mathrm{PCO}_{2}$ dan $\mathrm{pH}$ (Vesper dan 
White, 2004). Ringkasan hubungan nilai SI kalsit dan log kalsium di Gua Bribin disajikan pada Tabel 4.41.

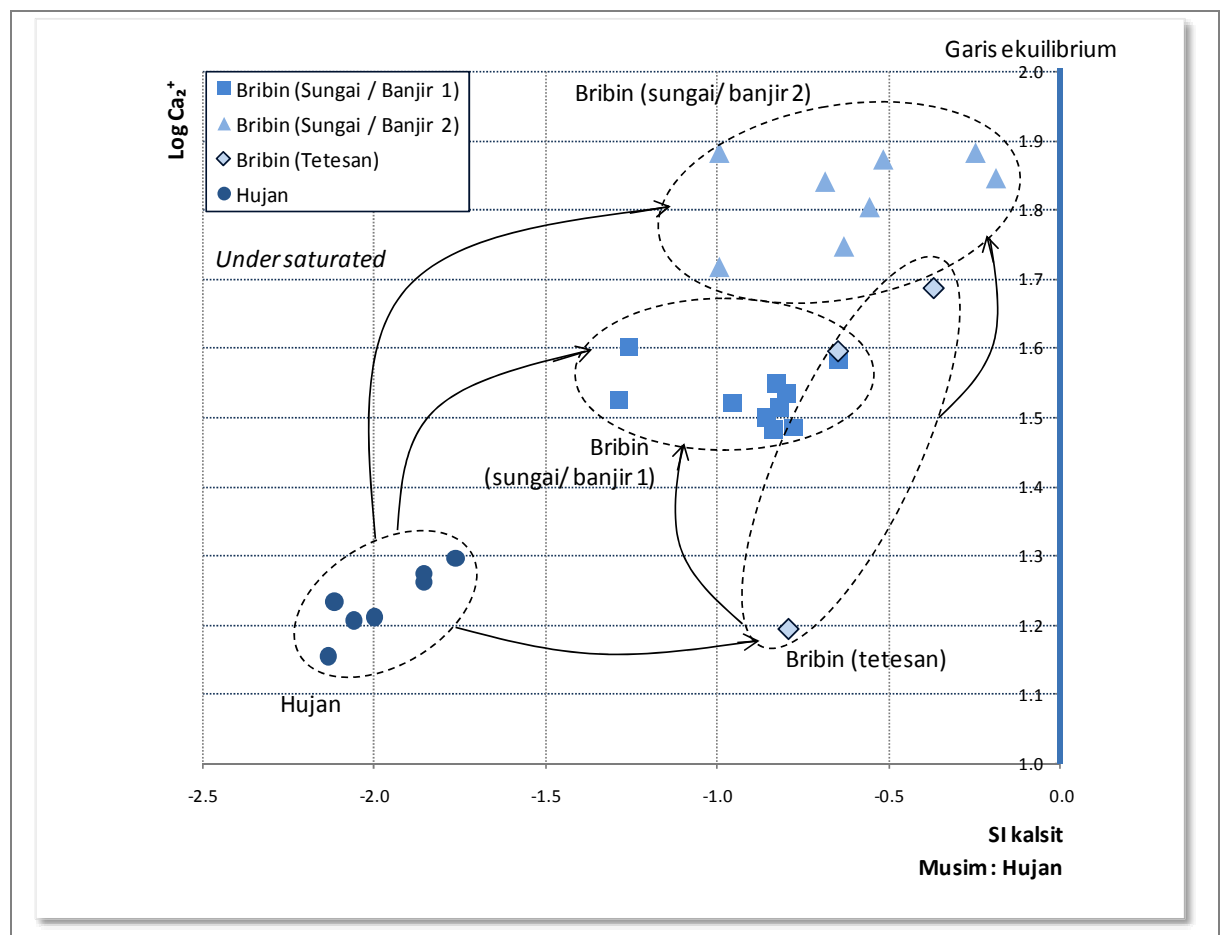

Gambar 4.83. Hubungan SI Kalsit dan log Kalsium di Gua Bribin pada Musim Hujan

Tabel 4.41. Hubungan SI Kalsit dan log Kalsium di Gua Bribin (hilir)

\begin{tabular}{|c|c|c|c|}
\hline \multirow{2}{*}{ Musim } & \multicolumn{3}{|c|}{ Daerah Hilir (GuaBribin) } \\
\hline & Air hujan & Air tetesan & Sungai bawah tanah \\
\hline Kemarau & & $\begin{array}{l}\text { 1. Nilai SI dan kalsium rendah. } \\
\text { 2. Hubungan positif dengan } R^{2}=0,21\end{array}$ & $\begin{array}{l}\text { 1. Hubungan positif dengan } \mathrm{R}^{2}=0,92 \\
\text { 2. Kondisi } \text { undersaturated. }\end{array}$ \\
\hline $\begin{array}{c}\text { Proses } \\
\text { Hidrogeokimia }\end{array}$ & & $\begin{array}{l}\text { 1. Pelarutan (dissolution) } \\
\text { 2. Pengendapan (precipitation) }\end{array}$ & $\begin{array}{l}\text { 1. Pelarutan (dissolution) } \\
\text { 2. Difusi } \mathrm{CO}_{2} \text { dari lorong terbuka }\end{array}$ \\
\hline Hujan & $\begin{array}{l}\text { 1. Hubungan positif dengan } \mathrm{R}^{2}=0,78 \text {, } \\
\text { 2. Air bersifat agresif (SI dan kalsium } \\
\text { rendah) }\end{array}$ & $\begin{array}{l}\text { 1. Hubungan positif dengan } \mathrm{R}^{2}=0,75 \text {. } \\
\text { 2. Nilai SI dan kalsium terlarut turun } \\
\text { 3. Air bersifat agresif (undersaturated). }\end{array}$ & $\begin{array}{l}\text { 1. Nilai SI dan kalsium turun } \\
\text { 2. Air bersifat agresif (undersaturated). }\end{array}$ \\
\hline $\begin{array}{c}\text { Proses } \\
\text { Hidrogeokimia }\end{array}$ & 1. Difusi $\mathrm{CO}_{2}$ kedalam air hujan & $\begin{array}{l}\text { 1. Perubahan dari proses pengendapan } \\
\text { menjadi pelarutan } \\
\text { 2. Pengenceran oleh air hujan } \\
\text { 3. Difusi } \mathrm{CO}_{2} \text { dari lorong terbuka }\end{array}$ & $\begin{array}{l}\text { 1. Pelarutan mineral kalsit } \\
\text { 2. Pengenceran oleh air hujan } \\
\text { 3. Difusi } \mathrm{CO}_{2} \text { dari lorong terbuka }\end{array}$ \\
\hline
\end{tabular}

\section{f. Hubungan nilai SI kalsit dan pH SBT Bribin bagian hilir}

Hubungan SI kalsit dan pH di Gua Bribin disajikan pada Gambar 4.84. dan 4.85. 


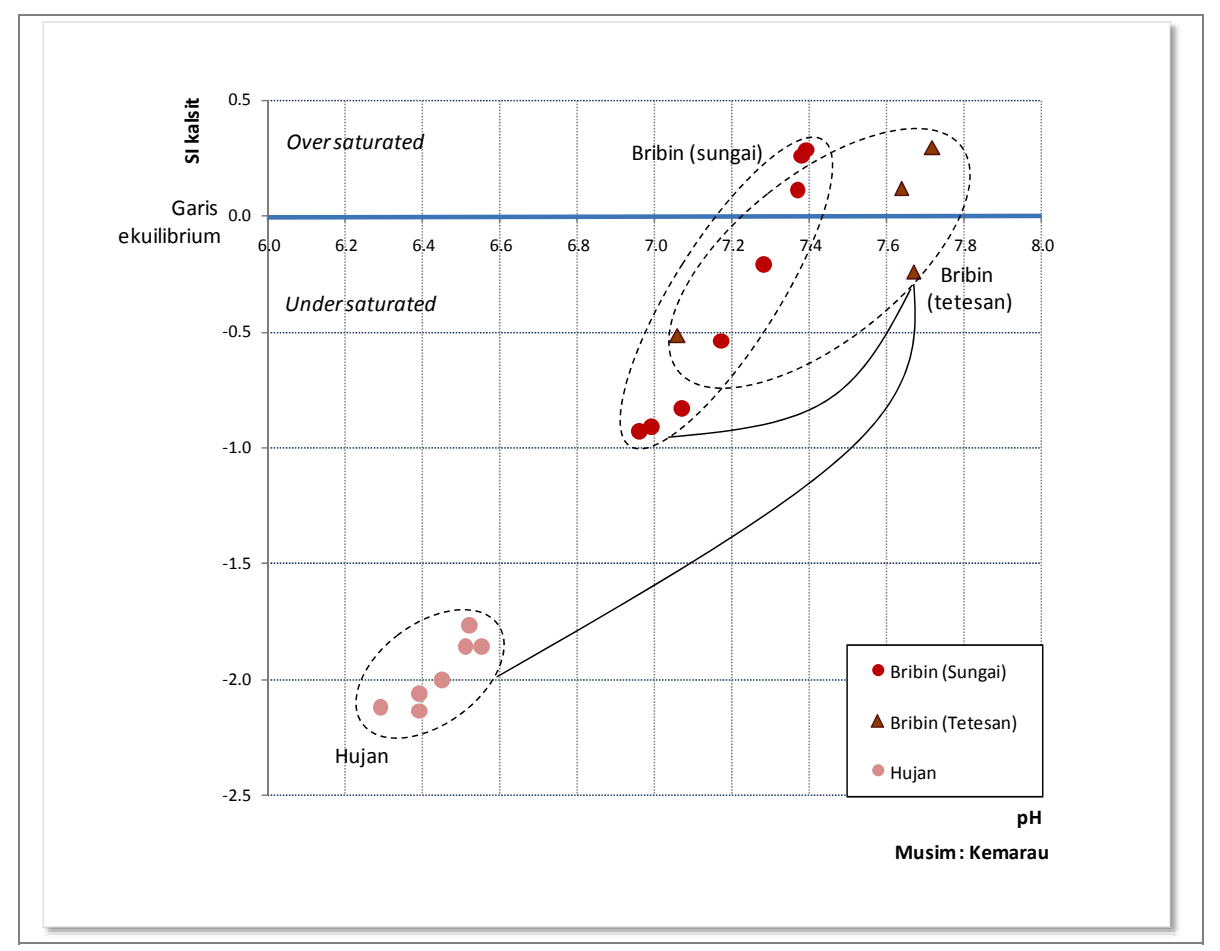

Gambar 4.84. Hubungan SI Kalsit dan pH di Gua Bribin pada Musim Kemarau

Hubungan positif yang besar $\left(\mathrm{R}^{2}=0,97\right)$ antara SI kalsit dan $\mathrm{pH}$ ditemukan pada air sungai bawah tanah saat kemarau, lebih besar dibanding pada air tetesan $\left(\mathrm{R}^{2}=0,66\right)$. Hal ini menunjukkan bahwa $\mathrm{pH}$ pada sungai bawah tanah yang merupakan gabungan dari berbagai komponen aliran, lebih berpengaruh terhadap besar kecilnya nilai SI, yang sebagian besar ada pada kondisi undersaturated. Jika dibandingkan dengan determinasi pada air hujan $\left(\mathrm{R}^{2}=0,79\right)$ sebagai masukan, tetap saja determinasinya lebih besar.

Pada musim hujan, masuknya aliran conduit ke sungai bawah tanah menyebabkan nilai determinasi sedikit turun $\left(\mathrm{R}^{2}=0,88\right)$ dan lebih mendekati nilai determinasi air hujan. Hal ini dapat dimungkinkan karena tidak adanya perubahan fase kejenuhan (dominasi undersaturated) atau agresifitas air karst untuk melarutkan 
batuan karbonat tetap di bawah angka 0 . Hal ini menunjukkan bahwa air sungai bawah tanah di Gua Bribin berfluktuasi stabil karena nilai koefisien resesi aliran dasar $\left(\mathrm{K}_{\mathrm{b}}=0,998\right)$ adalah paling tinggi dibanding lokasi-lokasi lain. Air tetesan di Gua Bribin mempunyai determinasi yang jauh berbeda dibanding saat kemarau, kemungkinan karena adanya waktu tunggu (time lag) yang lama dari hujan menjadi tetesan. Ringkasan hubungan nilai SI kalsit dan $\mathrm{pH}$ di Gua Bribin disajikan pada Tabel 4.42.

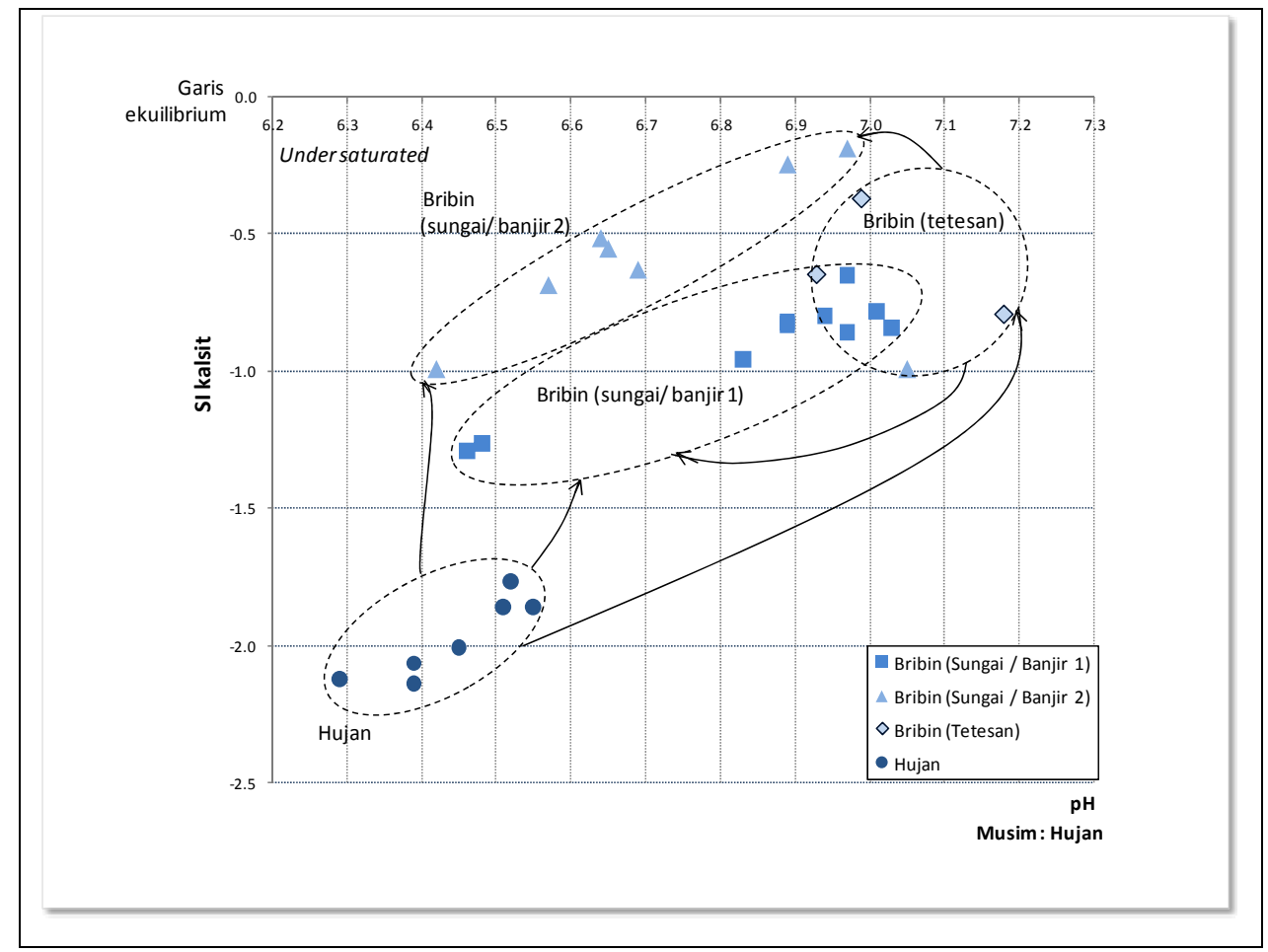

Gambar 4.85. Hubungan SI Kalsit dan pH di Gua Bribin pada Musim Hujan

Dari uraian perbedaan hubungan antara parameter SKD di SBT Bribin bagian hulu dan hilir, terdapat perbedaan pada nilai parameter SKD serta hubungan antar parameter pada saat musim kemarau dan penghujan yang dikontrol oleh proses hidrogeokimia, sifat aliran dan letaknya sepanjang SBT Bribin (secara lengkap disajikan dalam bentuk tabel pada Lampiran 2 dan 3). Dari kondisi parameter SKD 
di hulu dan hilir SBT Bribin baik pada saat kemarau maupun hujan, dapat dijelaskan bahwa secara prinsip terdapat perbedaan karakteristik nilai dan perilaku parameter SKD antara SBT Bribin bagian hulu dan hilir, yaitu sebagai berikut:

Tabel 4.42. Hubungan SI Kalsit dan pH di Gua Bribin (hilir)

\begin{tabular}{|c|c|c|c|}
\hline \multirow{2}{*}{ Musim } & \multicolumn{3}{|c|}{ Daerah Hilir (Gua Bribin) } \\
\hline & Air hujan & Air tetesan & Sungai bawah tanah \\
\hline Kemarau & & $\begin{array}{l}\text { 1. SI undersaturated } \\
\text { 2. } \mathrm{pH} \text { rendah (sekitar } 7 \text { ). } \\
\text { 3. Hubungan positif dengan } \mathrm{R}^{2}=0,67 \text {, cukup } \\
\text { tinggi }\end{array}$ & $\begin{array}{l}\text { 1. Hubungan positif dengan } \mathrm{R}^{2}=0,97 \\
\text { 2. SI positif ( ovesaturated) hanya tercapai saat } \\
3 \text { bulan terakhir musim kemarau. }\end{array}$ \\
\hline $\begin{array}{c}\text { Proses } \\
\text { Hidrogeokimia }\end{array}$ & & $\begin{array}{l}\text { 1. Dominan pelarutan } \\
\text { 2. Pengendapan ketika puncak kemarau }\end{array}$ & $\begin{array}{l}\text { 1. Dominan pelarutan } \\
\text { 2. Pengendapan ketika puncak kemarau } \\
\text { 3. Difusi } \mathrm{CO}_{2} \text { dari pelorongan }\end{array}$ \\
\hline Hujan & $\begin{array}{l}\text { 1. Hubungan positif dengan } \mathrm{R}^{2}=0,78, \\
\text { 2. Air bersifat agresif (SI dan kalsium } \\
\text { rendah) }\end{array}$ & $\begin{array}{l}\text { 1. Determinasinya turun menjadi } \mathrm{R}^{2}=0,35 \text {. } \\
\text { 2. SI dan } \mathrm{pH} \text { turun drastis } \\
\text { 3. Air bersifat lebih agresif }\end{array}$ & $\begin{array}{l}\text { 1. Determinasinya turun menjadi } \mathrm{R}^{2}=0,35 \text {. } \\
\text { 2. SI dan } \mathrm{pH} \text { turun drastis } \\
\text { 3. Air bersifat lebih agresif }\end{array}$ \\
\hline $\begin{array}{c}\text { Proses } \\
\text { Hidrogeokimia }\end{array}$ & 1. Difusi $\mathrm{CO}_{2}$ kedalam air hujan & $\begin{array}{l}\text { 1. Proses pelarutan (dissolution). } \\
\text { 2. Difusi } \mathrm{CO}_{2} \text { kedalam air }\end{array}$ & $\begin{array}{l}\text { 1. Dominan pelarutan (dissolution). } \\
\text { 2. Difusi } \mathrm{CO}_{2} \text { kedalam air } \\
\text { 3. Mixing, shg determinasi tinggi }\end{array}$ \\
\hline
\end{tabular}

(1) Pada saat kemarau, agresivitas air di bagian hulu SBT Bribin (Gua Gilap) sebagian besar berada pada kondisi jenuh (supersaturated-SI positif) yang dialami oleh air tetesan maupun air sungai bawah tanah. Ciri-ciri lain yang ditemukan adalah tingginya nilai $\mathrm{pH}$, kecilnya tekanan parsial gas karbondioksida, dan kalsium terlarut yang tinggi. Tingginya nilai SI kalsit di Gua Gilap mempunyai determinasi yang tinggi dengan minimnya pasokan gas karbondioksida dari lorong (closed system), karena gas karbondioksida sudah dimanfaatkan untuk proses pelarutan pada zone tak jenuh, serta nilai $\mathrm{pH}$ dan kalsium terlarut yang tinggi. Proses hidrogeokimia yang dominan adalah waterrock interaction berupa pengendapan mineral kalsit, yang menyebabkan terbentuknya ornamen bawah permukaan yang intensif.

(2) Kondisi agresivitas di bagian hilir SBT Bribin (Gua Bribin) cenderung bersifat agresif (undersaturated-SI negatif). Nilai $\mathrm{pH}$ di Gua Bribin tetap rendah sepanjang musim kemarau (berbeda dengan kondisi di Gua Gilap) dengan fluktuasi yang relatif stabil. Selain itu, nilai tekanan parsial gas karbondioksida 
jauh lebih tinggi dari yang ditemukan di Gua Gilap yang mengindikasikan adanya sistem pelorongan yang terbuka (open system) sehingga setiap saat tersedia pasokan gas karbondioksida yang menyebabkan air bersifat agresif. Akibatnya, proses yang dominan adalah pelarutan (dissolution) kalsit yang dicirikan secara fisik dengan lebarnya lorong sungai bawah tanah serta minimnya ornamen bawah permukaan karst.

(3) Pada musim hujan, karena adanya proses pengenceran oleh air hujan (dilution by precipitation), maka kondisi agresifitas air baik di hulu maupun di hilir mengalami penurunan menuju kondisi tidak jenuh (undersaturated) yang mengakibatkan dominasi proses pelarutan dan pelebaran lorong. Demikian juga yang dialami oleh parameter SKD lain, yaitu bertambahnya pasokan gas karbondioksida dari conduit flow, turunnya $\mathrm{pH}$ dan turunnya kalsium terlarut, meskipun kondisi agresifitas di Gua Bribin lebih tinggi jika dibandingkan dengan Gua Gilap. Selain itu proses lain yang dijumpai adalah percampuran (mixing) antara air tetesan dan air sungai bawah tanah, serta kuatnya difusi gas karbondioksida pada gua bagian hilir karena sifat pelorongannya yang mempunyai sistem terbuka (open system).

Secara konseptual, ilustrasi kondisi SKD dan tingkat pelarutan mineral kalsit sepanjang SBT Bribin disajikan pada Gambar 4.86. dan 4.87. 


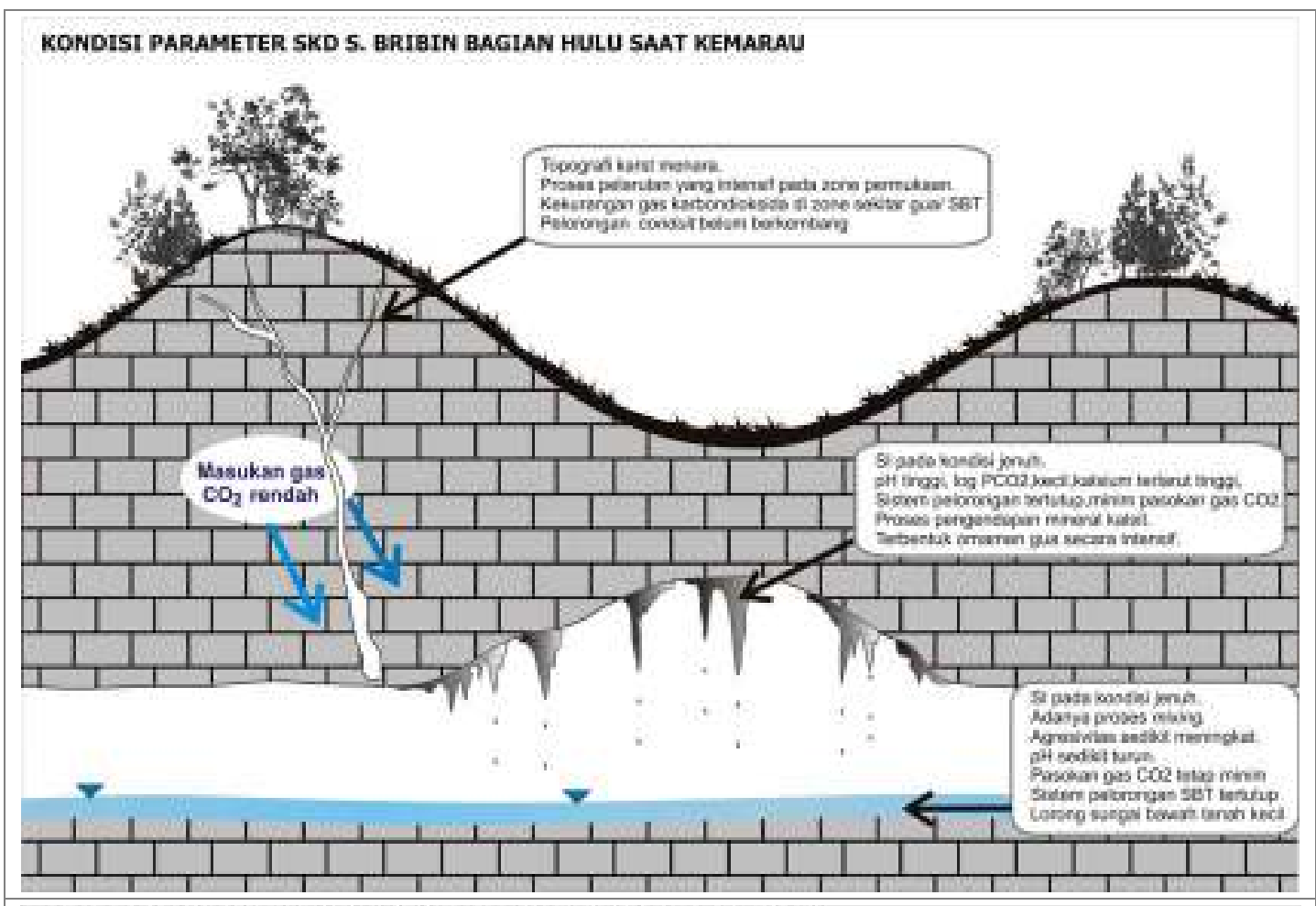

KONDISI PARAMETER SKD S. BRIBIN BAGIAN HILIR SAAT KEMARAU

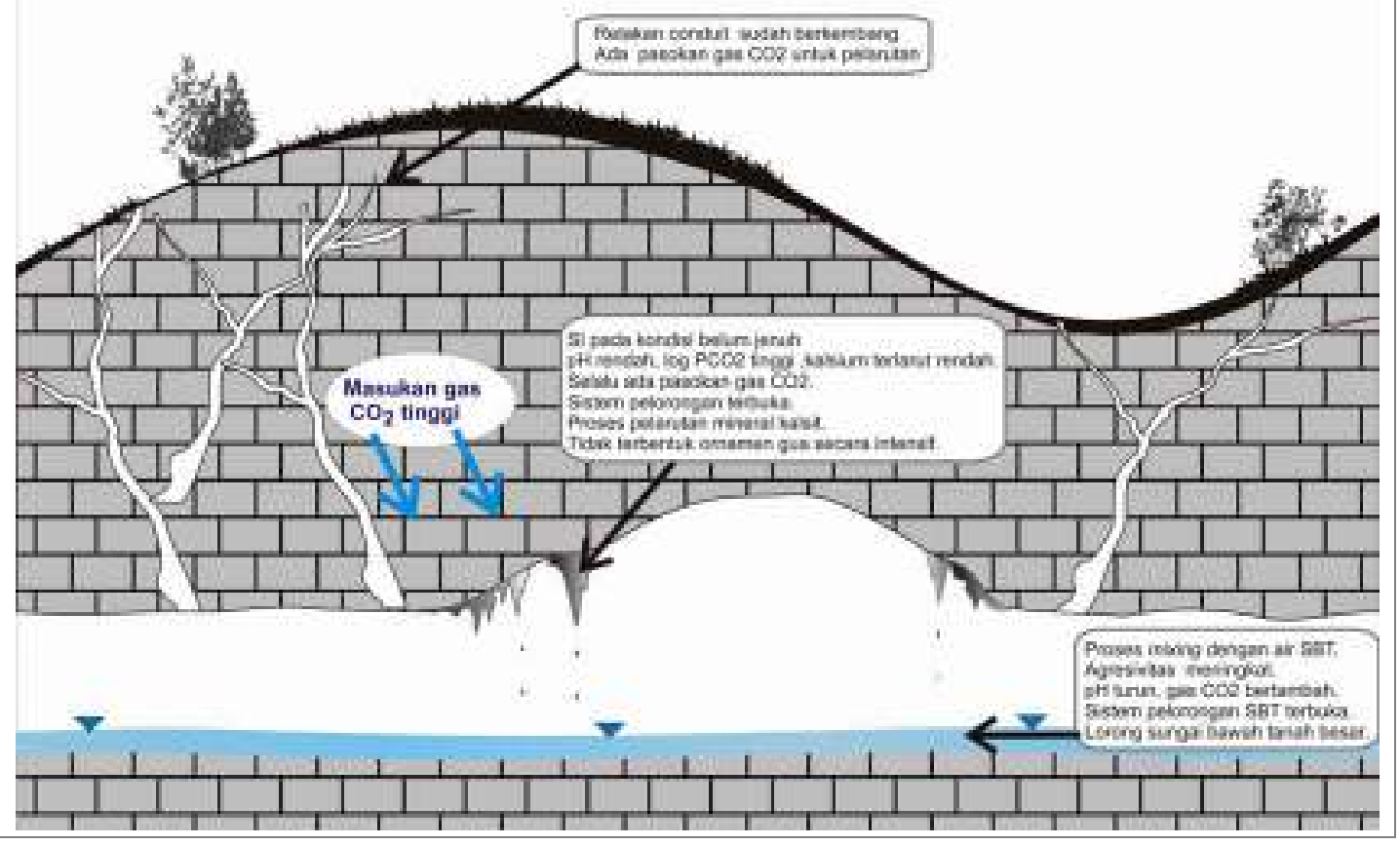

Gambar 4.86. Konseptual Model SKD di SBT Bribin pada Musim Kemarau 


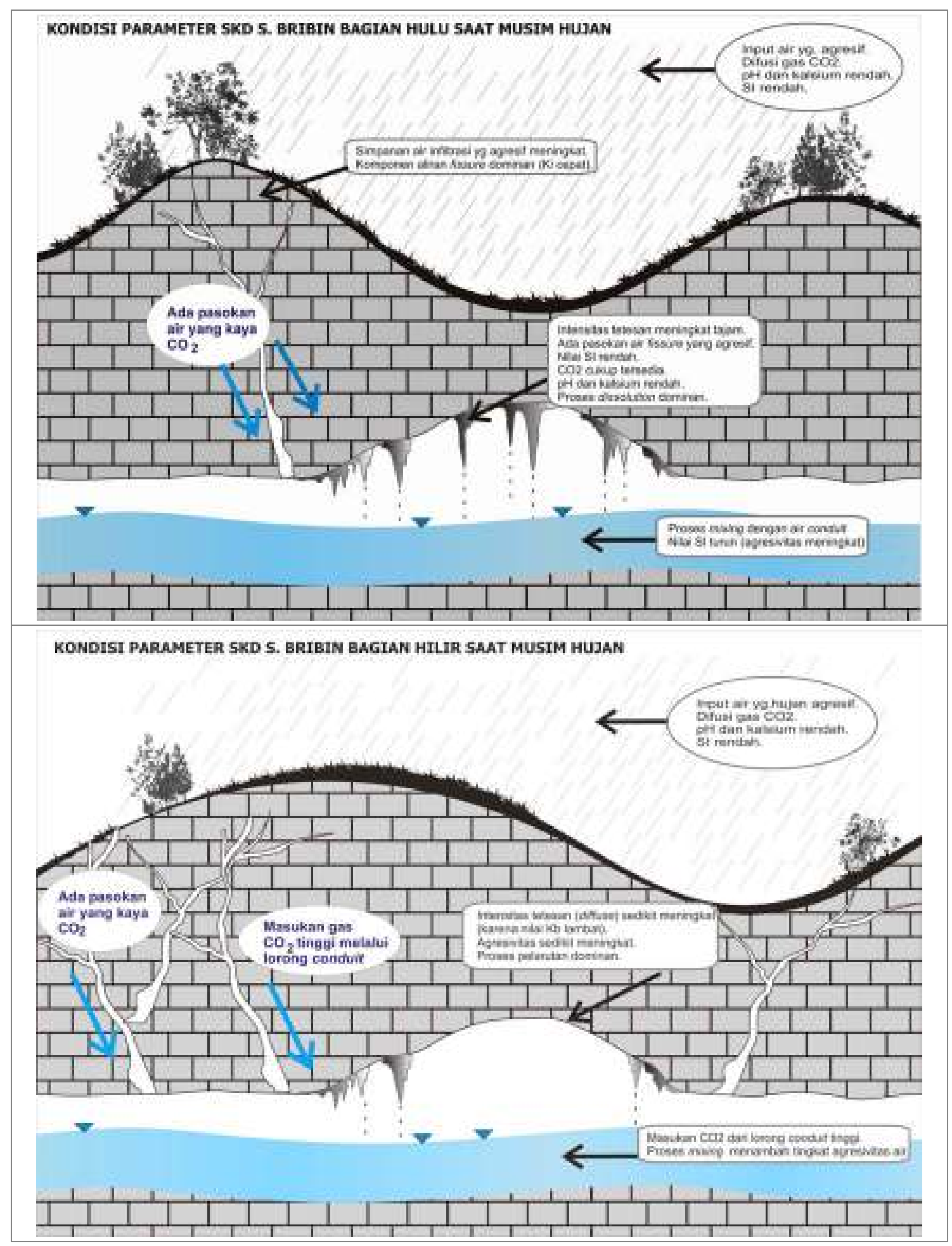

Gambar 4.87. Konseptual Model SKD di SBT Bribin pada Musim Hujan 


\section{E. Temuan Konsep dan Teori: Sifat Aliran, Hidrogeokimia, dan Perilaku Sistem Karst Dinamis (SKD) di SBT Bribin}

\section{Variasi spasial dan temporal sifat aliran akuifer karst}

Sepanjang SBT Bribin dari hulu ke hilir, dijumpai pola-pola yang menunjukkan perbedaan karakteristik aliran sungai bawah tanah. Perbedaan karakteristik aliran sungai bawah tanah tergantung dari letaknya sepanjang SBT Bribin, yang berarti dijumpai adanya variasi spasial, serta adanya variasi temporal karena karakteristiknya tergantung pada musim (kemarau dan hujan). Secara spasial, dari tiga lokasi yang diamati, yaitu (i) Gua Gilap yang terletak di daerah hulu; (ii) Gua Bribin yang terletak di bagian hilir; dan (iii) Gua Ngreneng yang merupakan bocoran utama dari SBT Bribin, terdapat perbedaan sifat aliran yang dilepaskan oleh akuifer karst yang didekati dengan parameter konstanta resesi yang meliputi konstanta-konstanta resesi aliran langsung-conduit $\left(\mathrm{K}_{\mathrm{c}}\right)$, antara-fissure (Ki), dasardiffuse, paramater hidrograf banjir berupa waktu menuju puncak banjir $\left(\mathrm{T}_{\mathrm{p}}\right)$ dan waktu menuju aliran dasar $\left(\mathrm{T}_{\mathrm{b}}\right)$, serta persentase aliran dasar (PAD).

Sifat aliran di Gua Gilap dikontrol oleh karakteristik akuifer karst yang lebih cepat melepaskan simpanan aliran dasar (diffuse) dibanding Gua Bribin, atau fungsi retakan kecil di Gua Gilap sudah lebih berkembang ke arah retakan yang lebih besar (fissure). Hal ini ditandai dengan nilai $\mathrm{K}_{\mathrm{i}}$ yang terkecil dibanding Gua Bribin dan Ngreneng atau berarti paling cepat melepaskan aliran antara (fissure). Sebaliknya, nilai konstanta aliran langsung $\left(\mathrm{K}_{\mathrm{c}}\right)$ di Gua Gilap mempunyai nilai yang terbesar, sehingga menunjukkan bahwa jenis retakan yang dominan di Gua Gilap adalah retakan menengah (fissure). Selain itu, analisis terhadap paramater $T_{p}$ dan $T_{b}$ juga menunjukkan bahwa retakan bertipe conduit belum begitu berkembang di Gua Gilap ( $\mathrm{T}_{\mathrm{b}}$ lama), meskipun nilai $\mathrm{T}_{\mathrm{p}}$-nya adalah yang paling cepat dan lebih disebabkan oleh luasan daerah tangkapannya yang paling kecil (daerah hulu). Jika dilihat dari 
paramater PAD, pada musim kemarau Gua Gilap mempunyai kisaran rata-rata PAD bulanan sekitar $80 \%$ dan sedikit menurun saat musim hujan. Saat kejadian banjir, nilai PAD di Gua Gilap menurun drastis menjadi sekitar $45-70 \%$ yang menunjukkan penambahan komponen aliran fissure atau conduit yang lebih besar dari penambahan aliran dasar.

Di Gua Bribin (bagian hilir), konstanta resesi aliran dasar $\left(\mathrm{K}_{\mathrm{b}}\right)$ menunjukkan nilai terbesar, artinya pelepasan aliran diffuse-nya paling lambat jika dibandingkan dengan gua-gua yang lain. Hal ini dibuktikan dengan fluktuasi debit aliran yang kecil antara musim hujan dan musim kemarau. Hal yang identik dijumpai pada pola retakan menengah yang ditunjukkan dengan nilai $\mathrm{K}_{\mathrm{i}}$ yang mempunyai tingkat pelepasan aliran fissure lambat. Sebaliknya, sifat pelepasan aliran conduit (nilai $\mathrm{K}_{\mathrm{c}}$ ) di Gua Bribin adalah yang paling cepat, menunjukkan bahwa retakan atau pelorongan yang berukuran besar sudah sangat berkembang di bagian hilir. Nilai Tp yang paling lambat di Gua Bribin menunjukkan bahwa luas daerah tangkapan hujan di gua ini paling luas, dan nilai Tb yang lama menunjukkan bahwa pelepasan aliran diffuse berlangsung dalam waktu yang relatif lama. Dari beberapa temuan tersebut, Gua Bribin menunjukkan perkembangan pola retakan pada akuifer yang menyebabkan pola alirannya bersifat campuran (mixed) antara komponen aliran diffuse dan conduit (Domenico and Schwartz, 1990). Hal tersebut selanjutnya menyebabkan stabilnya angka PAD di Gua Bribin, bahkan jika dibandingkan antara rerata bulanan saat kemarau $(\mathrm{PAD}=97 \%)$ dan saat kejadian banjir $(\mathrm{PAD}=90 \%)$.

Di Gua Ngreneng yang oleh MacDonald and Partners (1984) dijelaskan sebagai bocoran utama SBT Bribin ternyata mempunyai karakteristik pelepasan aliran dasar $\left(\mathrm{K}_{\mathrm{b}}\right)$ yang berbeda dibandingkan dengan yang ditemukan di Gua Bribin. Akuifer yang mengontrol sifat aliran di Gua Ngreneng bersifat cepat melepaskan 
aliran dasar (diffuse), tetapi lambat ketika melepaskan komponen aliran fissure, sementara sifat aliran langsungnya $\left(\mathrm{K}_{\mathrm{c}}\right)$ mirip dengan yang dijumpai di Gua Bribin (adanya koneksi dengan SBT Bribin). Hal ini menunjukkan bahwa tipe retakan yang dominan di Gua Ngreneng adalah tipe retakan berukuran menengah (fissure), sehingga debit aliran di Gua Ngreneng berkurang banyak saat puncak musim kemarau. Kondisi lain yang berpengaruh terhadap karakteristik aliran di Gua Ngreneng adalah morfologi gua yang terletak pada dasar suatu sinkhole (banyak menerima aliran langsung saat hujan) menyebabkan $T_{p}$ menjadi sangat singkat, serta faktor minimnya retakan bertipe diffuse yang berpengaruh terhadap singkatnya nilai $\mathrm{T}_{\mathrm{b}}$. Faktor-faktor tersebut berpengaruh terhadap fluktuasi PAD yang sangat besar antara musim kemarau dan saat kejadian banjir, yaitu $80 \%$ berbanding $45 \%$. Secara visual, kondisi aliran sepanjang SBT Bribin disajikan pada Gambar 4.88.

\section{Variasi spasial dan temporal hidrogeokimia dan hubungannya dengan sifat aliran akuifer karst}

Sepanjang SBT Bribin, terdapat perbedaan karakter hidrogeokimia yang terlihat secara spasial, dan adanya perbedaan yang berkaitan dengan perbedaan musim (temporal). Selain itu, kondisi dan proses hidrogeokimia yang bertanggungjawab terhadap karakter hidrogeokimia sungai bawah tanah mempunyai hubungan dengan sifat alirannya, terutama parameter persentase aliran dasar (PAD). Karakter hidrogeokimia sepanjang Sungai Bribin disajikan pada Gambar 4.89. 


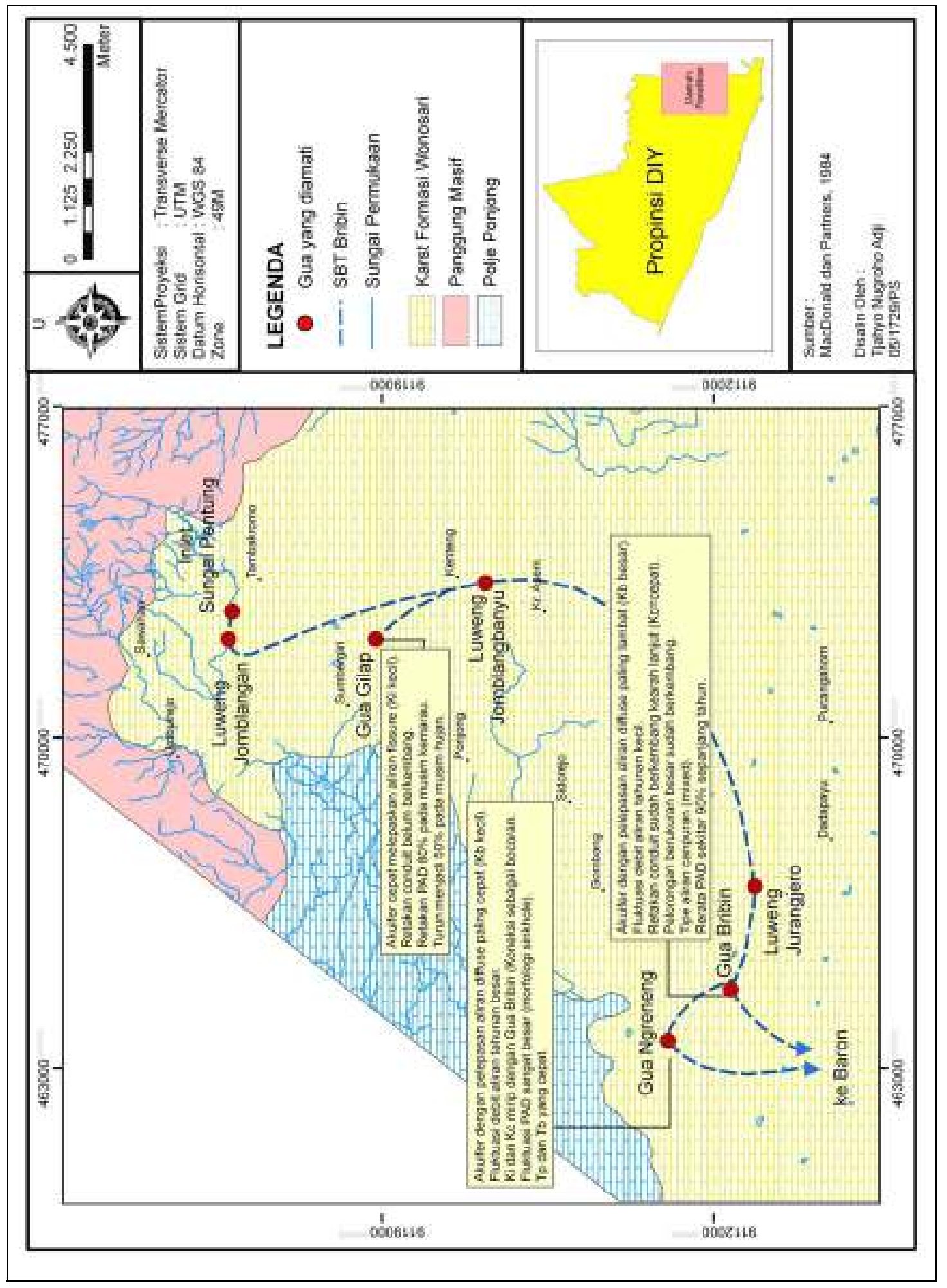

Gambar 4.88. Variasi Spasial dan Temporal Pelepasan Komponen Aliran Akuifer Karst di SBT Bribin 
Pada musim kemarau, hidrogeokimia di Gua Gilap dipengaruhi oleh besar kecilnya PAD meskipun hubungannya tidak begitu besar karena juga dipengaruhi oleh nilai $\mathrm{K}_{\mathrm{i}}$ yang kecil, sehingga sifat akuifernya cepat melepaskan aliran fissure. Dengan PAD saat kemarau sekitar $80 \%$, maka dijumpai proses hidrogeokimia berupa water-rock interaction yang ditunjukkan dengan determinasi yang cukup kuat antara unsur utama terlarut dan DHL. Pada musim hujan, karena adanya proses dilution by precipitation yang menyebabkan PAD di Gua Gilap menurun cukup signifikan, maka dijumpai proses hidrogeokimia berupa difusi gas karbondioksida ke dalam air yang merubah komposisi kimia air sungai bawah tanah, yaitu turunnya kandungan DHL, kalsium, bikarbonat, dan berkurangnya intensitas proses water-rock interaction.

Gua Bribin menunjukkan kecenderungan proses water-rock interaction musim kemarau lebih kuat dibanding yang ditemukan di Gua Gilap. Hal ini disebabkan oleh tingginya nilai $\mathrm{K}_{\mathrm{b}}$, sehingga PAD saat musim kemarau besar. Determinasi PAD-unsur terlarut dan determinasi DHL-unsur terlarut menunjukkan nilai yang lebih tinggi dibanding Gua Gilap. Di musim hujan, karena fluktuasi PAD yang tidak terlalu besar dengan saat kemarau, maka perubahan konsentrasi unsur terlarut juga tidak sebesar yang ditemukan di Gua Gilap, meskipun nilai determinasi antara PAD-unsur terlarut dan DHL-unsur terlarut turun karena adanya pasokan aliran conduit pada saat kejadian banjir yang menurunkan PAD. Di Gua Ngreneng, karakter hidrogeokimia saat kemarau mirip dengan yang ditemukan di Gua Bribin, sedangkan pada musim hujan, kondisi dan proses hidrogeokimia lebih dikontrol morfologi guanya yang mengakibatkan tingginya pasokan conduit saat kejadian banjir yang menurunkan PAD. 


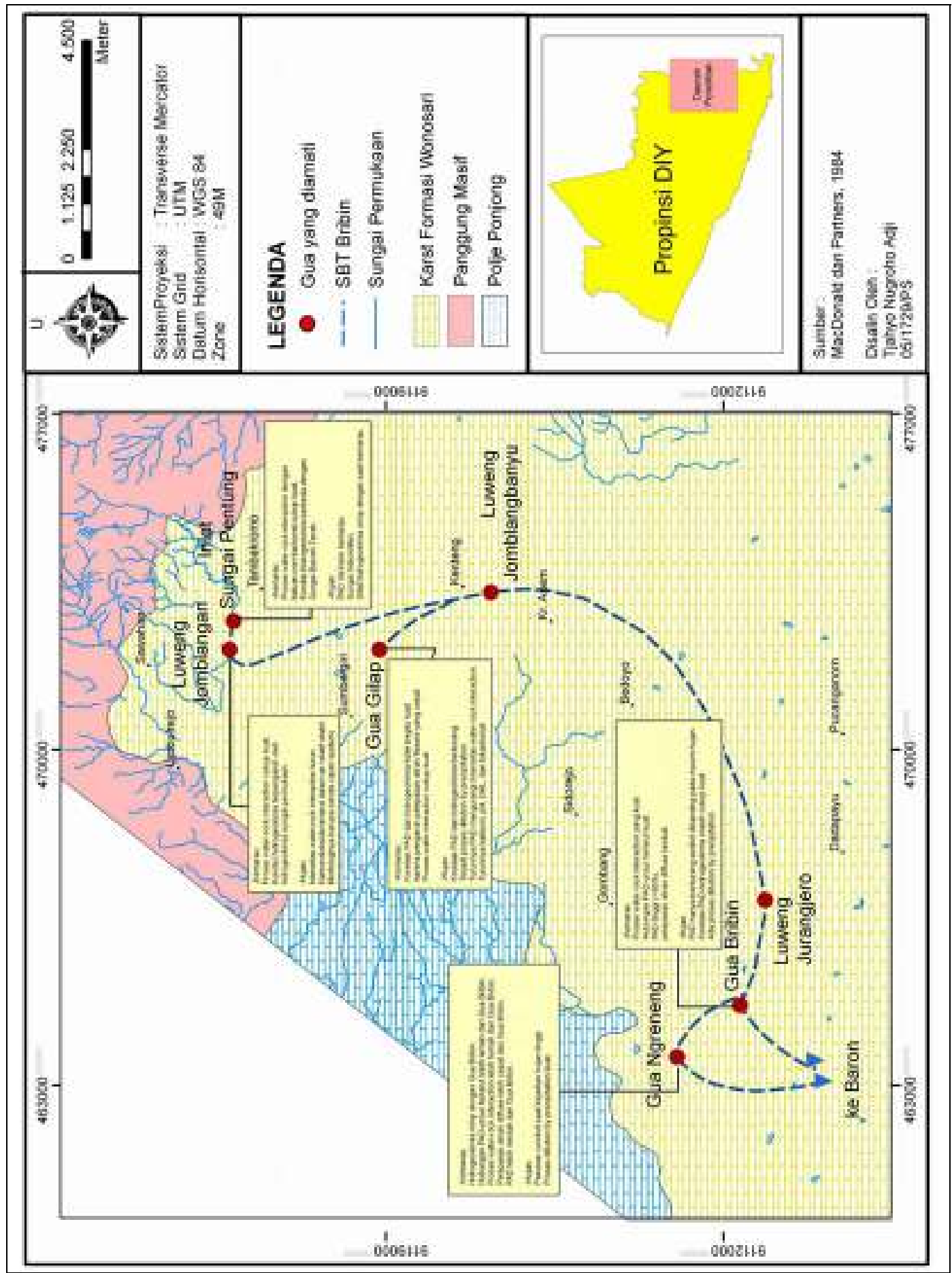

Gambar 4.89. Variasi Spasial Hidrogeokimia SBT Bribin 
Analisis hidrogeokimia yang dilakukan pada dua lokasi lain di bagian hulu yaitu pada sungai permukaan yang mengimbuh SBT Bribin (Sungai Pentung) dan sebuah gua yang jaraknya berdekatan dengan Sungai Pentung menunjukkan adanya perbedaan pola hubungan antar parameter hidrogeokimia jika dibandingkan dengan pola pada sungai bawah tanah karena sebagian besar input Sungai Pentung berasal dari akuifer non-karst. Faktor lain adalah sifat aliran sungai permukaan yang berbeda dengan sungai bawah tanah.

\section{Karakter SKD sepanjang SBT Bribin atas nilai agresivitas sungai bawah tanah dan hubungan antar parameter SKD hulu-hilir}

Terdapat perbedaan agresivitas airtanah karst untuk melarutkan batuan gamping antara daerah hulu dan hilir (variasi spasial) dan dipengaruhi pula oleh kondisi musim (variasi temporal). Pada saat kemarau, bagian hulu SBT Bribin menunjukkan bahwa air sudah tidak mampu untuk melarutkan batuan gamping. Sebaliknya, air sungai bawah tanah di bagian hilir bersifat agresif (mampu melarutkan batuan gamping). Perbedaan sifat agresivitas ini ditunjukkan dengan perbedaan tinggi-rendahnya nilai paramater-parameter SKD (SI kalsit, log $\mathrm{PCO}_{2}$, $\mathrm{Ca}^{2+}$, dan $\mathrm{pH}$ ) antara bagian hulu dan hilir, serta kuat tidaknya hubungan antar parameter tersebut. Perbedaan sifat agresivitas tersebut disebabkan oleh sifat pelorongan yang berbeda antara bagian hulu dan hilir. Di bagian hulu, sifat pelorongannya cenderung tertutup (closed system) dengan masukan gas karbondioksida terbatas, mengakibatkan terjadinya proses pengendapan (precipitation) mineral kalsit yang dicirikan dengan lebih berkembangnya ornamen gua sepanjang lorong sungai bawah tanah di Gua Gilap, serta tingginya nilai SI kalsit pada air tetesan. Di bagian hilir, lorong sungai bawah tanah yang besar serta sifatnya 
yang cenderung terbuka (open system), menyebabkan kandungan gas karbondioksida dalam air jauh lebih tinggi dibanding yang ditemukan di bagian hulu. Proses hidrogeokimia yang dominan adalah pelarutan (dissolution) mineral kalsit yang dicirikan dengan minimnya ornamen sepanjang lorong gua dan nilai SI kalsit yang rendah pada air tetesan.

Pada saat musim hujan, semua komponen air baik itu air hujan, air tetesan, maupun air sungai bawah tanah cenderung berada pada kondisi tak jenuh (undersaturated). Pada kondisi ini, proses hidrogeokimia yang terjadi adalah, dilution by precipitation yang meningkatkan kadar $\mathrm{CO}_{2}$ dalam air, water-rock interaction berupa pelarutan mineral kalit (dissolution), serta mixing pada sungai bawah tanah. Kondisi paramater SKD pada kondisi ini adalah $\mathrm{pH}$ rendah, $\mathrm{CO}_{2}$ tinggi, SI rendah dan kalsium rendah. Meskipun demikian, tetap terdapat perbedaan pada sifat agresivitas atau kemampuan batuan untuk melarutkan batuan karbonat, dimana air di bagian hilir cenderung lebih agresif yang ditunjukkan dengan kecilnya nilai SI kalsit. Konseptual model kondisi agresivitas dan parameter SKD sepanjang SBT Bribin dan hubungan dengan kondisi aliran dan hidrogeokimianya disajikan pada Gambar 4.90.

\section{Kemanfatan, keterbatasan metode dan dialog teori hasil penelitian}

Secara metodologi, kemanfaatan penelitian ini yang berbeda dengan penelitian-penelitian hidrogeokimia karst yang lain adalah terdapatnya pemisahan aliran dasar (diffuse flow) dari total aliran sungai bawah tanah yang kemudian dihubungkan dengan karakter hidrogeokimianya, meskipun secara sekilas prosedur scatter plot yang dilakukan hampir sama dengan yang dilakukan oleh Liu, et al. (2004a dan 2004b), Perrin, et al. (2003), Karimi, et al. (2004), Desmarais and Rojstaczer (2002), dan Vesper and White (2004). Semua penelitian hidrogeokimia 
yang sudah disebutkan tidak melakukan pemisahan aliran pada sungai bawah tanah dan menghubungkannya dengan karakter hidrogeokimia, sedangkan penelitian ini menemukan bahwa karakter hidrogeokimia tergantung dari besar kecilnya persentase aliran dasar (diffuse flow). Keterbaruan lain yang dihasilkan dari penelitian ini adalah menghubungkan karakteristik pelepasan komponen aliran dari akuifer karst dan posisinya pada SBT Bribin dengan karakter hidrogeokimia yang dipisahkan antara musim hujan dan musim kemarau. untuk mengkarakterisasi sifat SKD SBT Bribin. Penelitian ini juga membuat hubungan antara agresivitas dan parameter SKD diantaranya yaitu kandungan kalsium, karbondioksida dalam air dan $\mathrm{pH}$, meskipun hal ini sebagian sama dengan yang dilakukan oleh Vesper dan White (2004), tetapi menghubungkan parameter SKD dan membandingkannya pada air hujan, air tetesan dan air sungai bawah tanah belum dijumpai pada penelitian sebelumnya. Secara lokasi, penelitian ini akan mempunyai manfaat sebagai acuan penelitian hidrogeokimia karst di daerah tropis lain yang tidak penulis temukan pada telaahan pustaka.

Disamping kemanfaatan dan keterbaruan metode yang sudah disampaikan di atas, keterbatasan penelitian ini terutama adalah pada jumlah sampel yang diambil, terutama pada saat kejadian banjir pada beberapa gua tertentu karena tidak adanya alat pengambilan sampel air secara otomatis. Pengambilan sampel secara manual sulit dilakukan karena tingginya pasokan aliran conduit yang tidak memungkinkan bagi peneliti untuk masuk ke dalam gua. Tentu saja, jika sampel pada saat banjir dapat lebih sering diambil, maka akan dapat dihasilkan analisis yang lebih tajam. Keterbatasan lain adalah diabaikannya kondisi zona epikarst, terutama pengetahuan mengenai kondisi kandungan $\mathrm{CO}_{2}$ dalam tanah seperti Perrin (2003), meskipun banyak pula penelitian yang mengabaikan kondisi zone epikarst seperti Mudry (2004), Vesper dan White (2004), dan Raeisi dan Karami (1997). Manfaat dalam 
aspek penyediaan sumberdaya air dari penelitian ini adalah bahwa Gua Bribin mempunyai pelepasan komponen diffuse yang perlahan-lahan dengan fluktuasi tahunan yang kecil, sedangkan gua-gua lain di SBT Bribin umumnya mempunyai sifat pelepasan komponen diffuse yang lebih cepat sehingga pada puncak musim kemarau debitnya sangat kecil (Gua Gilap dan Gua Ngreneng). Pada gua-gua ini, hubungan antara PAD dan kandungan unsur terlarut pada musim kemarau tidak sekuat yang dijumpai di Gua Bribin. Selanjutnya, Tabel 4.43. menunjukkan matriks hubungan antara sifat pelepasan komponen aliran, hubungannya dengan karakter hidrogeokimia, dan agresivitasnya untuk melarutkan batugamping.

Tabel 4.43. Sifat Pelepasan Komponen Aliran Diffuse, Hubungannya dengan PAD, Jenis Pelorongan Gua dan Sifat Agresivitasnya

\begin{tabular}{|c|c|c|c|c|c|c|}
\hline $\begin{array}{c}\text { Pelepasan aliran } \\
\text { diffuse }\left(\mathrm{K}_{\mathrm{b}}\right)\end{array}$ & $\begin{array}{c}\text { Debit } \\
\text { andalan/PAD }\end{array}$ & $\begin{array}{l}\text { Hubungan PAD } \\
\text { dan unsur terlarut }\end{array}$ & $\begin{array}{c}\text { Proses } \\
\text { hidrogeokimia }\end{array}$ & $\begin{array}{c}\text { Jenis lorong } \\
\text { conduit }\end{array}$ & Agresivitas & Lokasi \\
\hline \multicolumn{7}{|c|}{ Musim kemarau } \\
\hline lambat & stabil & kuat & Pelarutan & terbuka & tinggi & Gua Bribin \\
\hline sedang & kecil & agak kuat & Pelarutan-pengendapan & terbuka & agak tinggi & Gua Ngreneng, Gua Jomblangan \\
\hline cepat & kering & agak kuat & Pengendapan & tertutup & rendah & Gua Gilap \\
\hline \multicolumn{7}{|c|}{ Musim hujan } \\
\hline lambat & cukup stabil & agak lemah & Pelarutan & terbuka & tinggi & Gua Bribin \\
\hline sedang & naik drastis & lemah & Pelarutan & terbuka & agak tinggi & Gua Ngreneng, Jomblangan \\
\hline cepat & naik & lemah & Pelarutan-pengendapan & tertutup & rendah & Gua Gilap \\
\hline
\end{tabular}

Dari Tabel 4.43. dan uraian sebelumnya, dapat diambil manfaat secara praktis bahwasanya Gua Bribin yang memiliki debit andalan atau PAD stabil karena pelepasan komponen aliran diffusenya paling lambat ternyata mempunyai agresivitas yang lebih tinggi dibanding gua-gua lain, sehingga proses pelebaran lorong SBT di masa depan masih dapat berlangsung, bahkan di musim kemarau ketika kondisi air SBT sudah jenuh dengan unsur terlarut. Selain itu, dari uraian bahwa perkembangan lorong conduit pada gua-gua SBT Bribin sudah membentuk sistem pelorongan yang sifatnya terbuka, maka potensi pencemaran dapat dengan mudah setiap saat mengancam kualitas air SBT Bribin. 


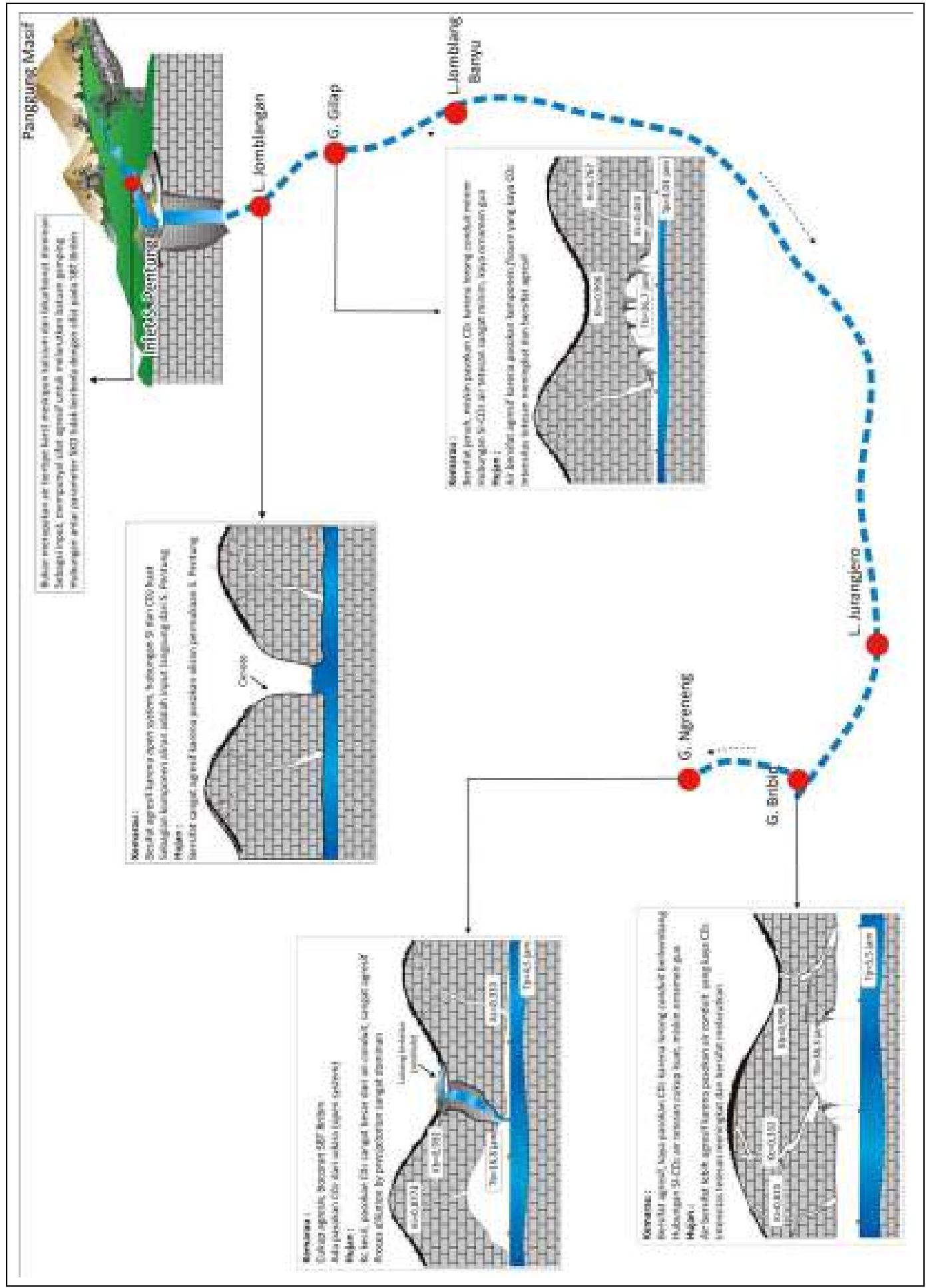

Gambar 4.90. Variasi Spasial dan Temporal SKD di SBT Bribin 
Disamping beberapa keterbaruan dan manfaat yang sudah disampaikan di atas, beberapa teori yang dihasilkan pada penelitian ini terkait dengan tujuan penelitian, tinjauan teoritis, dan kekhususan pada lokasi penelitian diantaranya adalah :

a. Gua Bribin yang terletak pada SBT Bribin bagian hilir, memiliki pelepasan komponen aliran dasar paling lambat $\left(\mathrm{K}_{\mathrm{b}}=\right.$ besar$)$, sehingga debit andalannya (PAD) paling stabil pada musim kemarau (hipotesis 1 terbukti). Hal ini memberikan gambaran bahwasanya terdapat dominasi retakan diffuse yang melepaskan air secara perlahan-lahan (diffuse flow karst aquifer).

Hasil ini mengkonfirmasi pernyataan White (1988) yang menyatakan bahwa pada diffuse flow karst aquifer air bergerak secara dominan pada retakan-retakan berukuran kecil yang tidak begitu terpengaruh oleh aktivitas pelarutan dan memiliki debit aliran yang fluktuasinya tidak terlalu besar. Akan tetapi, teori ini tidak tepat jika diterapkan pada saat kondisi banjir (flood events). Pada saat banjir, respon terhadap hujan cukup cepat debit peningkatan debit yang cukup tinggi mengindikasikan banyaknya sinkhole pada daerah tangkapannya dengan retakan berukuran conduit yang sudah berkembang seperti yang dijelaskan oleh Smart dan Hobbes (1996). Dengan dua kondisi berkaitan dengan pelepasan komponen aliran yang berbeda pada saat musim hujan dan musim kemarau, maka akuifer yang mengimbuh Gua Bribin dapat dikatakan mempunyai beberapa komponen aliran yang berperan sebagai input seperti yang dijelaskan oleh Perrin (2003), yaitu pada saat banjir di sungai bawah tanah diimbuh oleh beberapa sumber yang berbeda, di antaranya adalah air infiltrasi yang terkonsentrasi (point recharge), aliran diffuse, air yang tersimpan pada zone permeabilitas rendah, simpanan epikarst, air infiltrasi, 
simpanan conduit, lengas tanah, atau campuran dari komponen-komponen yang sudah disebutkan. Beberapa komponen aliran ini juga disebutkan oleh White (2004), dimana sifat pengimbuhannya dapat tergantung oleh kejadian hujan dan banyaksedikitnya sinkhole pada daerah tangkapan atau tingkat perkembangan pelorongan conduit. Sementara itu, diffuse flow masih dominan pada saat musim kemarau sebagai satu-satunya pengimbuh sungai bawah tanah, sehingga dapat dikatakan bahwa mayoritas pelorongan diffuse belum berkembang menjadi pelorongan conduit. Hal ini dibuktikan dengan nilai $\mathrm{K}_{\mathrm{b}}$ yang besar dan juga besarnya Persentase Aliran Dasar (PAD) yang masih di atas 90\% serta rata-rata bulanan PAD yang hanya turun sedikit ketika musim hujan. Akuifer dengan sifat pelepasan komponen aliran seperti yang dialami oleh Gua Bribin ini oleh Domenico dan Schwartz (1990) dan Gillieson (1996) dikenal sebagai akuifer karst yang bertipe campuran (mixed) antara diffuse aquifer dan conduit aquifer.

Secara spasial, kondisi yang agak berbeda dialami oleh Gua Gilap dan Gua Ngreneng yang mempunyai fluktuasi cukup besar antara PAD musim kemarau dan PAD musim hujan. Hal ini menunjukkan bahwa dominasi pelorongan diffuse lebih kecil dari yang dimiliki oleh SBT di Gua Bribin. Jika dirujuk pada teori yang diungkapkan oleh Perrin (2003), jenis akuifer di Gua Gilap dan terutama di Gua Ngreneng telah lebih berkembang ke arah dominasi pelorongan conduit, yang imbuhannya berasal dari batuan dengan permeabilitas rendah pada zona freatik yang sebenarnya merupakan volume dari lorong-lorong fissure atau saluran-saluran besar yang terhubung dengan saluran pengatus. Hal ini ditunjukkan dengan nilai $\mathrm{K}_{\mathrm{i}}$ yang lebih kecil dari Gua Bribin. Lebih jauh lagi, jika merujuk pada model "Tiga SubSistem Bertingkat yang Menghasilkan Perbedaan Hidrograf Aliran pada Mataair Karst" oleh Smart dan Hobbes (1986), maka dapat dijelaskan bahwa terdapat tiga 
model hidrograf aliran pada SBT Bribin, yaitu seperti yang dijelaskan pada Tabel 4.44 .

b. Tipikal Gua Bribin dengan PAD yang paling stabil mempunyai hubungan paling kuat dengan kandungan unsur terlarut, khususnya pada saat musim kemarau ketika proses water rock interaction dominan. Hubungan yang kuat ini tidak terjadi di musim hujan ketika aliran conduit mengisi SBT dengan debit yang besar, yang mengindikasikan jenis pelorongan berukuran besar juga sudah berkembang pada akuifer daerah tangkapan Gua Bribin (hipotesis 2 terbukti).

Temuan di Gua Bribin ini memperkuat argumen yang diungkapkan oeh Raeisi et al. (1993) bahwa akuifer yang didominasi oleh aliran diffuse akan mempunyai proses water-rock interaction yang kuat dan semakin melemahkan hasil berkebalikan yang dipublikasikan oleh Scanlon dan Thraikill (1987), yang sebenarnya menyelisihi teori-teori dasar hidrogeokimia karst yang diungkapkan oleh diantaranya Balakowics (1997), Shuster dan White (1971), dan Atkinson (1977a). Selain itu, temuan ini juga membuktikan bahwa dari sisi hidrogeokimia akuifer yang mengimbuh Gua Bribin pada saat musim kemarau dikontrol oleh diffuse aquifer, seperti halnya yang diungkapkan pula oleh Raeisi dan Karami (1997) yang melakukan penelitian di mataair Berghan, Iran. Secara spasial hal ini tidak dialami sepenuhnya oleh Gua Ngreneng maupun Gua Gilap yang mempunyai hubungan antara PAD dan unsur dominan terlarut yang lebih lemah dibanding Gua Bribin, karena kurangnya dominasi aliran diffuse. 
Tabel 4.44. Faktor-faktor Yang Berpengaruh Terhadap Hidrograf Aliran pada GuaGua di SBT Bribin

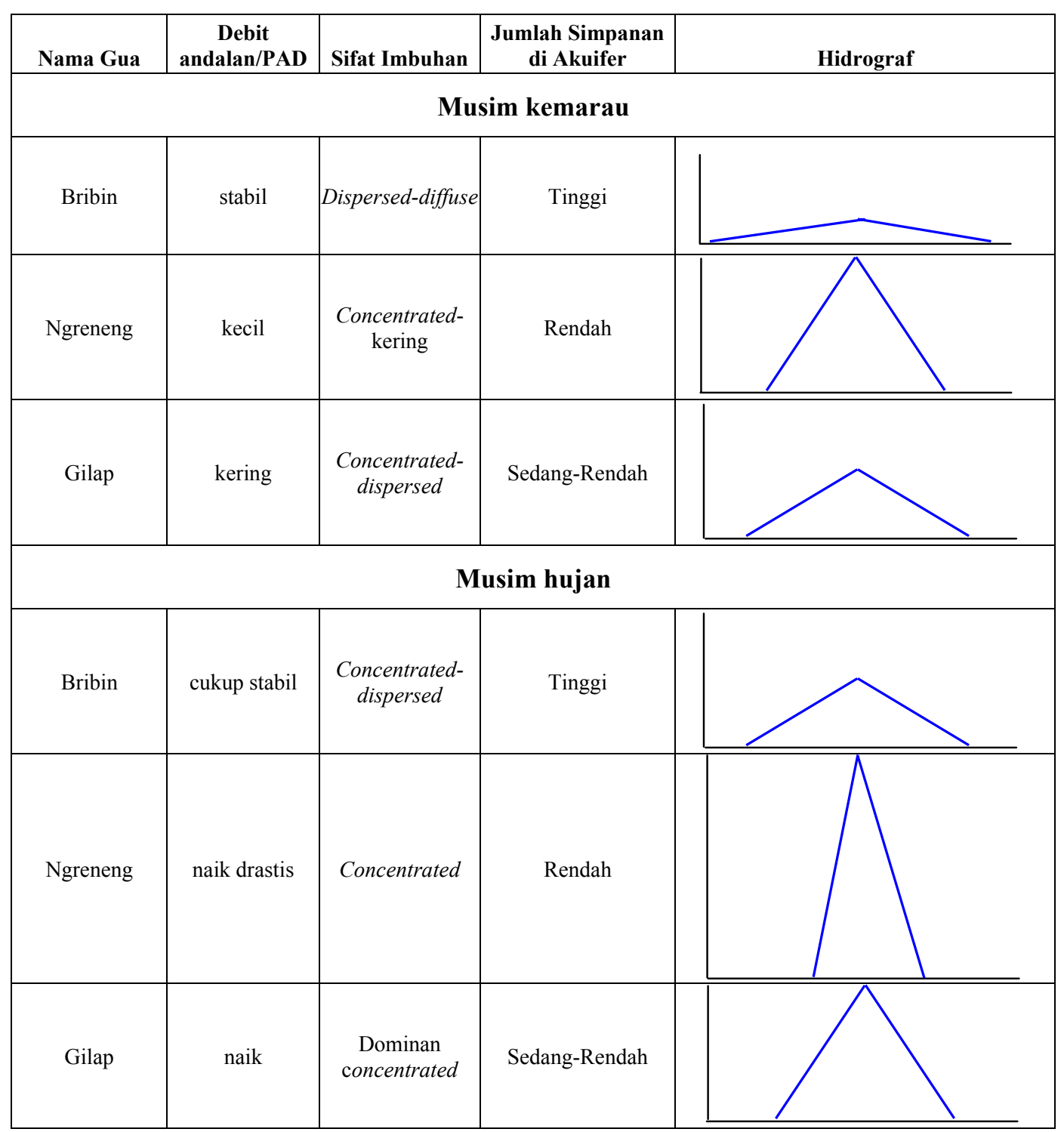

Pada kejadian banjir, seperti yang sudah diungkapkan oleh Perrin (2003), banyaknya komponen aliran yang mengimbuh Gua Bribin menyebabkan hubungan antara PAD dan unsur dominan menurun, meskipun penurunannya tidak sedrastis seperti yang dijelaskan oleh Liu et al. (2000a) dan Liu et al. (2004b). Hal ini diperkuat dengan fakta bahwa PAD di Gua Bribin fluktuasinya tidak besar sepanjang 
tahun. Selain itu, turunnya tingkat water-rock interaction menandakan bahwa jenis pelorongan conduit sudah berkembang di Gua Bribin, sehingga responnya dapat dijelaskan dengan menganggap bahwa perubahan tingkat water-rock interaction ini dikontrol oleh beberapa hal seperti yang sudah dijelaskan oleh Ashton (1966); Atkinson (1977b), Williams (1983), Hess dan White (1988), Ryan dan Meiman (1996), Halihan dan Wicks (1998), dan Brusca et al. (2001)., yaitu: (a) adanya variasi pada unsur dominan terlarut karena hasil dari pelarutan batuan gamping yang ditransfer melalui rekahan-rekahan; (b) adanya proses pengenceran oleh air hujan (dilution by precipitation); dan (c) interaksi dengan gas karbondioksida terlarut dalam air yang dipasok melalui lorong conduit. Beberapa teori inilah yang bertanggung jawab terhadap turunnya hubungan antara PAD dan unsur dominan terlarut seiring dengan berubahnya debit aliran ketika kejadian banjir.

Secara spasial, penurunan hubungan antara PAD dan unsur dominan terlarut di Gua Gilap dan Gua Ngreneng lebih drastis karena fluktuasi debit alirannya yang lebih tinggi (aliran diffuse tidak terlalu dominan seperti yang dialami oleh Gua Bribin). Penurunan hubungan antara PAD dan unsur dominan terlarut ini kemungkinan juga dialami pada penelitian yang dilakukan oleh Liu et al. (2004a), Liu et al. (2004b), dan Raeisi dan Karami (1997), meskipun dalam pubikasipublikasi tidak terdapat informasi mengenai besaran PAD pada waktu pengambilan sampel. Dari hal ini dapat diambil faedah, bahwasanya metode yang digunakan pada penelitian ini yaitu dengan menghubungkan PAD dan hidrogeokimia SBT dapat digunakan untuk menjelaskan karakteristik imbuhan komponen aliran oleh akuifer karst yang bertanggung jawab terhadap berubahnya kandungan unsur terlarut dan proses hidrogeokimia dalam air yang mengontrolnya. 
c. Secara teoritis, tipikal Gua Bribin dengan PAD yang besar dan stabil serta mempunyai kandungan unsur terlarut yang tinggi mempunyai tingkat agresivitas yang rendah karena sifat air SBT yang sudah jenuh (Appelo dan Postma,1993). Tetapi, hal sebaliknya justru ditemukan di Gua Bribin dimana sifat air pada musim kemarau lebih agresif dibanding gua-gua yang lain (berlawanan dengan hipotesis ke-3). Faktor yang berpengaruh adalah sifat pelorongan conduit yang terbuka (open system) yang sudah sangat berkembang di Gua Bribin, sehingga selalu ada pasokan gas karbondioksida ke SBT untuk proses pelarutan. Faktor lain yang berpengaruh adalah percampuran (mixing) antara dua jenis air jenuh (air conduit dan diffuse) yang mempunyai $\mathrm{PCO}_{2}$ berbeda menyebabkan air SBT di Gua Bribin lebih bersifat agresif untuk melarutkan batuan gamping.

Fakta yang terjadi di Gua Bribin ini sesuai dengan apa yang diungkapkan oleh Dreybort dan Gabrovsek (2003), meskipun karena dominasi aliran diffuse di Gua Bribin, maka dapat diasumsikan bahwa air akan bersifat jenuh untuk melarutkan batuan gamping seperti yang dijelaskan oleh Atkinson (1977a). Penjelasan dari kedua teori yang seolah-olah berlawanan ini adalah fakta bahwa akuifer yang mengimbuh Gua Bribin mempunyai sifat campuran (Domenico dan Schwartz,1990), yaitu dominasi retakan diffuse dengan lorong utama yang sudah sangat berkembang ke arah conduit. Melalui retakan conduit yang berukuran besar inilah (meskipun persentasenya sedikit) pasokan gas karbondioksida selalu ada untuk mendukung proses pelarutan (Jankowski, 2001). Sistem Karst Dinamis seperti ini diungkapkan oleh Bogli (1960; 1980), Sweeting (1972), Trudgill (1985), dan Ford dan Williams (1992) sebagai sistem yang bersifat terbuka (open system). Pada saat musim hujan, seperti yang dipublikasikan oleh Perrin, et al. (2003) dan Perrin (2003), adanya berbagai komponen aliran yang mengimbuh SBT menyebabkan tingkat agresivitas 
air karena berbagai komponen air yang mengimbuh SBT mempunyai kandungan gas karbondioksida yang tinggi, sehingga proses mixing seperti yang dijelaskan oleh Bogli (1960), Plummer (1975), Jankowski dan Jacobson (1991), serta Anthony, et al. (1997) berlangsung dan menurunkan nilai SI terhadap mineral kalsit. 


\section{KESIMPULAN}

1. PAD terbesar dijumpai di Gua Bribin (hilir) karena sifat akuifernya yang melepaskan komponen aliran diffuse $\left(\mathrm{K}_{\mathrm{b}}\right)$ paling lambat. Sementara itu, Gua Gilap di bagian hulu perkembangan lorong guanya cenderung kearah fissure $\left(\mathrm{K}_{\mathrm{i}}\right)$ dengan PAD yang lebih kecil dibanding daerah hilir. Pada saat kejadian banjir, penurunan PAD secara drastis terjadi khususnya di Gua Ngreneng karena mempunyai nilai $\mathrm{K}_{\mathrm{c}}$ paling kecil. Selain itu, berdasarkan fakta-fakta yang berkaitan dengan sifat komponen alirannya, temuan secara teoritis yang dapat dikemukakan adalah bahwa akuifer yang mengimbuh Gua Bribin dapat dikategorikan sebagai akuifer yang bertipe campuran (mixed), yaitu didominasi oleh imbuhan dari retakan yang bertipe diffuse pada musim kemarau, dengan debit andalan yang stabil, sifat imbuhannya tersebar (dispersed), dengan simpanan air di akuifernya tinggi, sedangkan pada musim hujan imbuhannya merupakan campuran dari komponen diffuse, fissure dan conduit. Secara spasial, Gua Ngreneng yang merupakan bocoran dari SBT Bribin, mempunyai akuifer bertipe campuran dengan perkembangan lorong fissure dan conduit yang lebih besar daripada yang dialami oleh akuifer yang mengimbuh Gua Bribin, sifat imbuhannya dominan terpusat (concentrated) dan simpanan aliran diffuse di akuifer rendah, sehingga debit alirannya turun drastis pada saat musim kemarau. Di bagian hulu, Gua Gilap mempunyai perkembangan akuifer lebih ke arah dominasi retakan menengah (fissure), imbuhannya campuran antara dispersed dan concentrated, dengan simpanan aliran diffuse di akuifer sedang, sehingga debit alirannya turun drastis hanya pada saat puncak musim kemarau.

2. Gua Bribin di hilir mempunyai hubungan antara PAD-hidrogeokimia paling kuat karena PADnya yang paling besar, sehingga proses water-rock interaction 
dominan, meskipun secara umum selama musim kemarau terdapat hubungan yang cukup kuat antara PAD-hidrogeokimia di sepanjang SBT Bribin. Pada saat musim hujan, hubungan PAD-hidrogeokimia di SBT Bribin menjadi lemah sebagai akibat tingginya pasokan komponen conduit, terutama pada gua-gua yang berfungsi sebagai sinkhole $\left(\mathrm{K}_{\mathrm{c}}=\mathrm{kecil}\right)$ seperti yang ditemukan di Gua Ngreneng. Dari fakta-fakta tersebut, penelitian ini menemukan bahwa Gua Bribin menunjukkan hubungan PAD-hidrogeokimia yang kuat karena dominasi komponen aliran diffuse pada musim kemarau. Sebaliknya, gua-gua lain di SBT Bribin mempunyai dominasi aliran diffuse yang lebih rendah, sehingga hubungan antara PAD-hidrogeokimia juga menjadi lebih lemah. Secara metodologis, penelitian ini menemukan bahwa hubungan PAD-hidrogeokimia dapat digunakan sebagai indikator karakteristik komponen aliran yang mengimbuh suatu SBT. Jika hubungan PAD-hidrogeokimia kuat, maka aliran yang dominan mengimbuh SBT adalah diffuse, sehingga proses hidrogeokimia yang terjadi adalah waterrock interaction, sedangkan jika hubungan PAD-hidrogeokimia lemah, maka diffuse flow menjadi tidak dominan dan proses hidrogeokimia yang mengontrol perkembangan SBT adalah dilution by precipitation dan campuran (mixing) dari berbagai komponen aliran. Pada saat musim hujan, hubungan PADhidrogeokimia juga dapat menjelaskan karakteristik imbuhan pada suatu SBT, meskipun saat kejadian banjir SBT diimbuh oleh berbagai komponen aliran. Secara umum hubungan PAD-hidrogeokimia di gua-gua sepanjang SBT Bribin saat periode hujan adalah menurun, meskipun penurunan paling sedikit tetap dialami oleh Gua Bribin karena PADnya yang lebih stabil (dominasi diffuse) dibanding gua-gua yang lain. Sebaliknya, gua-gua lain terutama yang morfologi entrancenya merupakan suatu sinkhole, ditemukan penurunan hubungan PAD- 
hidrogeokimia yang drastis karena tingginya pasokan aliran conduit (dilution by precipitation dominan).

3. Saat kemarau, air SBT di Gua Bribin (hilir) mempunyai sifat paling agresif dengan ciri-ciri tekanan gas $\mathrm{CO}_{2}$ yang lebih tinggi dibanding yang ditemukan pada gua-gua lain karena sifat pelorongan conduitnya yang bersifat terbuka (open system). Hal yang hampir sama dijumpai juga dengan tingkat agresivitas yang sedikit lebih rendah, yaitu di Luweng Jomblangan (morfologi=cenote). Hal lain yang berpengaruh adalah adanya teori percampuran (mixing) antara komponen conduit dan diffuse yang menurunkan tingkat kejenuhan air SBT meskipun PADnya besar dan sudah jenuh dengan unsur terlarut dalam air. Sebaliknya di bagian hulu, meskipun PADnya lebih kecil dengan unsur terlarut lebih sedikit, tetapi pasokan gas karbondioksidanya lebih sedikit karena sifat pelorongannya yang belum begitu berkembang (closed system), sehingga tingkat agresivitas airnya rendah. Pada saat musim hujan, tingkat agresivitas gua meningkat akibat tingginya pasokan komponen conduit, terutama pada gua-gua yang berfungsi sebagai sinkhole $\left(\mathrm{K}_{\mathrm{c}}=\right.$ kecil) seperti Gua Ngreneng dan Luweng Jomblangan, yang menaikkan tekanan parsial gas $\mathrm{CO}_{2}$ dalam air. Dari fakta-fakta tersebut ditemukan bahwa kontrol utama yang bertanggung jawab terhadap proses pelarutan batuan gamping di SBT Bribin cenderung pada sistem pelorongannya yang bersifat terbuka atau tertutup yang menentukan ketersediaan gas karbondioksida daripada sifat pelepasan atau imbuhan komponen aliran karst dari akuifer ke sungai bawah tanah. Faktor lain adalah percampuran (mixing) antara dua komponen air yang sudah jenuh terhadap mineral kalsit (air conduit dan diffuse) yang mempunyai $\mathrm{PCO}_{2}$ berbeda menyebabkan air SBT di Gua Bribin lebih bersifat agresif untuk melarutkan batugamping. 


\section{SARAN}

Untuk mencari tipologi pelepasan komponen aliran akuifer karst, model hidrogeokimia, dan perilaku SKD yang lebih rinci, perlu dipertimbangkan:

1. Waktu penelitian yang lebih panjang, minimal dua kali musim hujan dan dua kali musim kemarau dengan jumlah sampel yang lebih detail;

2. Penggunaan alat ukur hidrogeokimia dan sampling yang otomatis, sehingga tidak terkendala ketika mengambil sampel air pada saat kejadian banjir;

3. Perlu terintegrasi dengan riset pada lapisan epikarst, karena perubahan kandungan gas karbondioksida terjadi secara dinamis pada lapisan ini. 


\title{
VARIASI SPASIAL-TEMPORAL HIDROGEOKIMIA DAN SIFAT ALIRAN UNTUK KARAKTERISASI SISTEM KARST DINAMIS DI SUNGAI BAWAH TANAH BRIBIN, KABUPATEN GUNUNG KIDUL, DIY
}

\section{Ringkasan Disertasi}

Program Studi Geografi

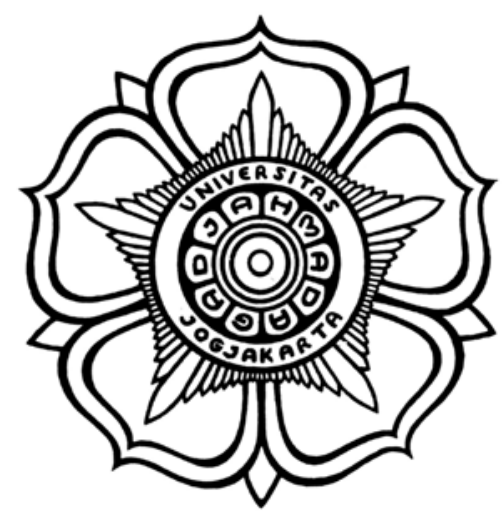

Oleh:

Tjahyo Nugroho Adji 05/1729/PS

\author{
PROGRAM PASCA SARJANA \\ FAKULTAS GEOGRAFI \\ UNIVERSITAS GADJAH MADA \\ YOGYAKARTA \\ 2010
}




\section{INTISARI}

Penelitian ini dilakukan pada kawasan bertopografi karst, yaitu daerah tangkapan Sungai Bawah Tanah (SBT) Bribin yang secara administratif terletak di Kabupaten Gunungkidul, Propinsi Daerah Istimewa Yogyakarta. Tujuan dari penelitian ini adalah: (1) menganalisis variasi spasial dan temporal karakteristik dan persentase aliran dasar (PAD) SBT Bribin; (2) mengevaluasi karakter hidrogeokimia SBT Bribin dan mencari hubungan dengan sifat alirannya; (3) mengkarakterisasi kondisi Sistem Karst Dinamis (SKD) SBT Bribin yang didekati dengan paramater tingkat agresivitas air terhadap batuan gamping dan hubungannya dengan kondisi paramater SKD SBT Bribin sepanjang tahun.

Untuk mengetahui karakteristik aliran dan PAD, tiga alat pencatat fluktuasi muka air SBT dipasang di hulu, hilir, dan bocoran SBT Bribin selama satu tahun, dan pengukuran debit aliran dilakukan untuk memperoleh kurva hubungan debit dan tinggi muka air SBT. Kemudian, dilakukan pemisahan aliran dasar dengan cara digital filtering untuk menghitung besarnya PAD setelah sebelumnya dihitung nilai konstanta resesi aliran diffuse, fissure, dan conduitnya. Untuk mengetahui karakter hidrogeokimia SBT, sebanyak 120 sampel air diambil dan dianalisis sepanjang tahun di SBT Bribin yang meliputi air tetesan gua, air hujan, dan air SBT. Scatter plot antar parameter hidrogeokimia kemudian dilakukan untuk mengetahui hubungan antara PAD dan hidrogeokimia, serta untuk mengetahui proses hidrogeokimia yang terjadi. Selanjutnya, untuk mengetahui tingkat agresivitas air SBT dilakukan analisis Indeks Kejenuhan terhadap mineral kalsit, sedangkan hubungan antar parameter SKD pada gua di bagian hulu dan hilir dilakukan untuk mengkarakterisasi kondisi SKD sepanjang SBT Bribin.

Hasil penelitian menunjukan bahwa terdapat perbedaan karakteristik aliran sungai bawah tanah secara temporal dan spasial di SBT Bribin karena adanya perbedaan sifat akuifer karst untuk melepaskan komponen aliran diffuse, fissure, dan conduit. Hal ini mengakibatkan adanya perbedaan karakteristik PAD di sepanjang SBT Bribin. Selanjutnya, karakteristik PAD berpengaruh terhadap karakter hidrogeokimia sungai bawah tanah terutama pada musim kemarau. Pada musim hujan, hidrogeokimia sungai bawah tanah lebih dipengaruhi oleh kejadian banjir yang mengakibatkan turunnya PAD karena adanya proses dilution by precipitation yang menaikkan kandungan $\mathrm{CO}_{2}$ dalam air. Secara umum, gua di hilir SBT Bribin lebih bersifat agresif untuk melarutkan batuan gamping dibandingkan gua di daerah hulu karena adanya perbedaan sifat pelorongan gua, dimana bagian hilir mempunyai sifat pelorongan terbuka sehingga selalu ada pasokan gas karbondioksida untuk mendukung proses pelarutan.

Kata kunci: Sifat aliran, diffuse, fissure, conduit, hidrogeokimia, agresivitas 


\section{A. Pendahuluan}

\section{Perumusan Masalah}

Istilah Karst Dynamic System atau Sistem Karst Dinamis (SKD) yang pertama kali dikenalkan oleh Daoxian (2005) sebenarnya bukan merupakan istilah baru. Bogli (1960, 1980), Sweeting (1972), Trudgill (1985), dan Ford dan Williams (1992), menjelaskan istilah ini sebagai suatu sistem yang didalamnya terjadi proses yang dinamis antara $\mathrm{H}_{2} \mathrm{O}, \mathrm{CO}_{2}$ dan $\mathrm{CaCO}_{3}$ yang dikontrol oleh karakteristik akuifer batuan gamping. White (1988), Ford dan Williams (1992), Smart dan Hobbes (1986) serta Gillieson (1996) secara prinsip membagi karakteristik aliran pada akuifer karst menjadi tiga yaitu: (1)aliran lorong (conduit); (2)celah (fissure), dan (3)rembesan (diffuse). Ketiga sifat aliran ini mempunyai karakteristik dan sumber yang berbeda dan berkaitan erat dengan 4 (empat) komponen utama imbuhan akuifer yang dideskripsikan oleh White (2004) yaitu berupa imbuhan allogenic recharge, internal runoff, diffuse infiltration, dan akuifer yang bertengger diatas akuifer karst. Sebagai akuifer yang berbatuan gamping, proses utama yang mengontrol karakteristik dan aliran pada akuifer karst adalah proses pelarutan (dissolution). Dreybort dan Gabrovsek (2003), mengungkapkan bahwa cepat atau lambatnya proses pelarutan batuan gamping tergantung dari besar kecilnya konsentrasi gas karbondioksida pada aliran airtanah karst. Selain itu faktor lain yang mengontrol adalah jenis pelorongan pada akuifer karst yang bersifat terbuka atau tertutup (Freeze dan Cherry, 1979).

Karena sifat pelorongannya yang anisotropis, penelitian untuk mengungkapkan sifat dan karakteristik akuifer karst di suatu kawasan umumnya dilakukan dengan pendekatan induktif. Salah satu pendekatan induktif yang dapat digunakan adalah pendekatan hidrogeokimia yang berasumsi bahwa komposisi kimia airtanah karst merupakan cerminan dari proses yang berlangsung dalam akuifer karst (Mudry, 2004). Metode ini dapat dikombinasikan dengan kajian sifat aliran sungai bawah dan merupakan metode yang dianggap paling representatif karena mampu mendeskripsikan sistem media penyimpan airtanah karst, termasuk sifat aliran pada akuifer berbatuan gamping yang berhubungan dengan sifat kimia airtanah karst, seperti yang dilakukan oleh Liu, et al. (2004a dan b), Etfimi (2005), Wang dan Luo (2001), Anthony, et al. (1997) serta Raeisi dan Karami (1997). Selanjutnya, Martin, et al. (2002) dan Karimi, et al. (2004) mengungkapkan bahwa interaksi antara diffuse flow dan conduit flow yang berperan banyak terhadap pelebaran celah pada batuan karbonat, ternyata juga dipicu oleh kadar agresivitas airtanah karst, sedangkan Taylor dan Greene (2001) 
mengungkapkan bahwa untuk mengkarakterisasi akuifer karst secara detail diperlukan pendekatan kuantitatif.

Sungai Bawah Tanah (SBT) Bribin merupakan salah satu sungai bawah tanah yang mempunyai potensi besar dan menjadi tumpuan pemenuhan air domestik masyarakat yang tinggal di kawasan karst Gunungsewu, Kabupaten GunungKidul yang dikenal sebagai daerah yang sulit air karena dalamnya lorong conduit yang mengontrol sungai bawah tanah mencapai 100 meter di bawah permukaan tanah sehingga sulit untuk dimanfaatkan. Pada periode tahun 2004 s.d. 2009 ini, kerjasama antara Pemerintah Provinsi (Pemprov) Daerah Istimewa Yogyakarta (DIY), Kab Gunung Kidul, BATAN, Kementerian Ristek, BMBF dan Universitas Kalsruhe, Jerman sudah hampir menyelesaikan proyek pemboran dan membuat bendung bawah tanah sistem mikrohidro di Gua Bribin. Bendungan baru ini diharapkan dapat menghasilkan listrik sebesar 250 sampai dengan $300 \mathrm{KW}$ yang kemudian akan digunakan untuk meningkatkan kapasitas layanan distribusi airtanah karst ini menjadi dua kali lipat dari sebelumnya, sehingga tampak bahwa harapan terhadap kelangsungan sumberdaya airtanah SBT Bribin dalam jangka waktu yang panjang. Tetapi, sampai saat ini belum ditemukan penelitian terkait dengan sifat aliran dan akuifer karst dan proses hidrogeokimia yang mengontrol perkembangan SBT Bribin. Terkait dengan hal tersebut, maka penelitian ini mengangkat permasalahan:

1. Bagaimanakah sifat aliran SBT Bribin yang tercermin dari pelepasan aliran akuifer karst dan persentase aliran dasar (PAD) SBT Bribin sepanjang tahun?

2. Bagaimanakah hubungan antara karakter hidrogeokimia SBT Bribin dan sifat alirannya sepanjang tahun?

3. Bagaimanakah karakteristik SKD SBT Bribin yang didekati dengan tingkat agresivitas untuk melarutkan batuan gamping dan juga hubungannya dengan perilaku paramater SKD sepanjang tahun?

\section{Tujuan Penelitian}

Tujuan penelitian ini adalah untuk :

1. menganalisis variasi spasial dan temporal karakteristik dan persentase aliran dasar (PAD) pada SBT Bribin;

2. mengevaluasi karakter hidrogeokimia pada SBT Bribin dan mencari hubungan dengan sifat alirannya;

3. mengkarakterisasi SKD pada SBT Bribin yang didekati dengan paramater tingkat agresivitas air terhadap batuan gamping dan hubungannya dengan kondisi paramater SKD SBT Bribin sepanjang tahun. 


\section{B. Metode Penelitian}

Karena sifat akuifer karst yang anisotropis (karakteristik permeabilitas ke segala arah tidak sama) karena terkontrol conduit dan tidak terdapatnya korelasi homogen dan gradual antara permukaan dan bawah permukaan, maka penelitian ini tidak menggunakan metode penelitian yang bersifat deduktif (mengunakan distribusi sifat permukaan untuk mengkarakterisasi sifat alirannya), tetapi lebih cenderung menggunakan metode induktif dengan sifat penelitian yang mendekati QuasiExperimental Research yang merupakan bagian dari Experimental Research (Dane, 1990). Tipe Quasi-Experimental riset ini dipilih atas dasar sulitnya beberapa faktor atau kondisi yang tidak dapat disurvei secara langsung seperti tebal dan perlapisan batuan karbonat pada akuifer karst, kandungan $\mathrm{CO}_{2}$ pada akuifer, jaringan retakan dan conduit di akuifer yang di lapangan tidak dapat dikorelasikan secara langsung dengan obyek utama penelitian ini, yaitu sungai bawah tanah. Selain itu, desain penelitian yang dipilih adalah Time Series Design of Quasi-Experimental Research, dengan metode FieldSurvey Research.

\section{Bahan dan Alat}

Bahan utama yang digunakan dalam penelitian ini adalah foto udara pankromatik hitam putih skala 1:20.000 dan 1:30.000 tahun 1992, 1993, dan 1994, peta rupa bumi digital skala $1: 25.000$ tahun 2001, peta sistem sungai bawah tanah karst Gunung Sewu oleh MacDonalds dan Partners (1984), dan citra satelit LANDSAT serta SRTM. Penelitian ini menggunakan peralatan utama a) HOBO-water level data logger untuk mencatat perubahan tinggi muka air sungai bawah tanah, b) current meter untuk mengukur debit aliran c) alat pengukur paramater kualitas air di lapangan ( $\mathrm{pH}, \mathrm{Eh}, \mathrm{EC}$, dan suhu), dan d) alat pengambilan sampel air.

\section{Pemilihan batas-batas daerah penelitian}

Batas daerah penelitian adalah estimasi semua wilayah permukaan yang merupakan daerah tangkapan hujan SBT Bribin. Sementara itu, batasan SBT Bribin mengacu pada MacDonalds dan Partners (1984) yaitu Gua Bribin dianggap sebagai outlet di hilir sungai yang hulunya adalah Sungai Pentung yang hilang ke beberapa ponor di daerah Sawah Ombo, yang kemudian ditemui lagi di Luweng Jomblangan, kemudian di Gua Gilap, Luweng Jomblangbanyu, Luweng Jurang Jero, dan terakhir di Gua Bribin dengan satu sistem bocoran yang dapat dijumpai di Gua Ngreneng. 


\section{Pengambilan dan pengumpulan data}

Data primer utama yang dikumpulkan pada penelitian ini adalah data fluktuasi debit sungai bawah tanah sepanjang tahun. Tiga alat pencatat fluktuasi muka air sungai bawah tanah dipasang di Gua Gilap (hulu), Gua Bribin (hilir), dan Gua Ngreneng (bocoran) selama satu tahun. Sepanjang periode pengamatan dilakukan beberapa kali pengukuran debit yang mewakili debit minimal, rerata dan besar untuk membuat kurva hubungan debit dan tinggi muka air sungai. Selama satu tahun pengamatan, pengambilan sampel air pada 5 (lima) lokasi di SBT Bribin yang dilakukan setiap 1 bulan sekali, dan pada musim penghujan pengambilan sampel disesuaikan dengan periode hidrograf banjir yang terjadi untuk memperoleh variasi sampling saat debit normal, debit puncak dan debit pelepasan (resesi).

\section{Cara Analisis}

Analisis yang dilakukan dalam penelitian ini meliputi:

a. Analisis spasial dan temporal dari sifat komponen aliran SBT Bribin selama satu tahun yang meliputi: (1) analisis hubungan debit dan TMA sungai bawah tanah; (2) analisis konstanta resesi dan hidrograf aliran; dan (3) analisis pemisahan aliran dasar;

b. Analisis variasi temporal dan spasial hidrogeokimia dan agresivitas airtanah karst yang meliputi: (1) analisis Charge Balance Calculation; (2) analisis Indeks Kejenuhan; (3) Analisis tekanan parsial gas karbondioksida dalam air;

c. Analisis terhadap perilaku komponen SKD, hubungan antar komponen, dan hubungannya dengan aliran dasar, yang meliputi: (1) analisis hidogeokimia bulanan selama 1 tahun; (2) analisis hidogeokimia pada saat hujan puncak atau banjir; (3) analisis longterm dan storm-scale hydrochemograph; (4) analisis hubungan variasi antara sifat hidrogeokimia dengan sifat komponen aliran; dan (5) analisis perilaku paramater SKD pada air hujan, air tetesan dan air sungai bawah tanah dan mencari hubungan antara agresivitas air dengan $\mathrm{pH}$, kalsium terlarut, dan tekanan parsial gas karbondioksida

\section{Hasil dan Pembahasan}

\section{Karakteristik spasial dan temporal karakteristik aliran dan PAD di SBT Bribin}

Uraian mengenai karakteristik aliran dan PAD di SBT Bribin meliputi: (1) konstanta resesi dan paramater hidrograf aliran, dan (2) Persentase Aliran Dasar dari 
tiga lokasi yang dipasang alat pencatat fluktuasi tinggi muka air sungai bawah tanah selama 1 tahun yaitu Gua Gilap (hulu), Gua Bribin (hilir), dan Gua Ngreneng (bocoran).

\section{a. Konstanta Resesi (K), waktu menuju puncak banjir $\left(T_{p}\right)$, dan waktu menuju aliran dasar $\left(T_{b}\right)$}

Konstanta resesi yang dibahas pada penelitian ini dibagi menjadi 3 (tiga) yaitu (i) konstanta resesi saluran-conduit $\left(\mathrm{K}_{\mathrm{c}}\right)$; (ii) antara-fissure $\left(\mathrm{K}_{\mathrm{i}}\right)$; dan (iii) dasar-diffuse $\left(\mathrm{K}_{\mathrm{b}}\right)$. Perbandingan nilai konstanta resesi antar tiga gua memberikan gambaran mengenai karakteristik akuifer karst untuk melepaskan ketiga komponen air yang dimilikinya. Sementara itu, parameter hidrograf aliran yang juga dibahas adalah waktu menuju puncak banjir $\left(T_{p}\right)$ yang memberikan gambaran terhadap seberapa cepat respon akuifer karst untuk mengimbuh sungai bawah tanah, dan waktu menuju aliran dasar $\left(\mathrm{T}_{\mathrm{b}}\right)$. Nilai paramater-parameter tersebut pada tiga gua di aliran SBT Bribin disajikan pada Tabel 1.

Tabel 1. Ringkasan julat nilai konstanta resesi dan paramater banjir SBT Bribin

\begin{tabular}{|l|c|c|c|c|c|}
\hline \multicolumn{1}{|c|}{ Nama gua } & $\mathbf{K}_{\mathbf{c}}$ & $\mathbf{K}_{\mathbf{i}}$ & $\mathbf{K}_{\mathbf{b}}$ & $\mathbf{T}_{\mathbf{p}}$ (jam) & $\mathbf{T}_{\mathbf{b}}$ (jam) \\
\hline Gua Gilap & $\begin{array}{c}0,14-0,88 \\
\text { (predominan=0,463) }\end{array}$ & $\begin{array}{c}0,39-0,92 \\
(\text { predominan=0,767) }\end{array}$ & $\begin{array}{c}0,94-0,99 \\
(\text { predominan=0,996) }\end{array}$ & $\begin{array}{c}1,5-5 \\
\text { (predominan=3,03) }\end{array}$ & $\begin{array}{c}7-192 \\
(\text { predominan=36,7) }\end{array}$ \\
\hline Gua Bribin & $\begin{array}{c}0,02-0,519 \\
\text { (predominan=0,332) }\end{array}$ & $\begin{array}{c}0,002-0,95 \\
(\text { predominan=0,825) }\end{array}$ & $\begin{array}{c}0,98-0,99 \\
(\text { predominan=0,998) }\end{array}$ & $\begin{array}{c}2-9,5 \\
\text { (predominan=5,5) }\end{array}$ & $\begin{array}{c}5-192 \\
(\text { predominan=36,3) }\end{array}$ \\
\hline $\begin{array}{l}\text { Gua } \\
\text { Ngreneng }\end{array}$ & $\begin{array}{c}0,188-0,748 \\
\text { (predominan=0,333) }\end{array}$ & $\begin{array}{c}0,732-0,971 \\
\text { (predominan=0,877) }\end{array}$ & $\begin{array}{c}0,978-0,999 \\
\text { (predominan=0,992) }\end{array}$ & $\begin{array}{c}2,5-7,5 \\
\text { (predominan=4,5) }\end{array}$ & $\begin{array}{c}9-240 \\
(\text { predominan=16,8) }\end{array}$ \\
\hline
\end{tabular}

$* \mathrm{~K}_{\mathrm{c}}=$ konstanta resesi conduit $; \mathrm{K}_{\mathrm{i}}=$ konstanta resesi fissure; $\mathrm{K}_{\mathrm{b}}=$ konstanta resesi diffuse

$* \mathrm{~T}_{\mathrm{p}}=$ time to peak; $\mathrm{T}_{\mathrm{b}}=$ time to baseflow

Dari Tabel 1. terlihat bahwa nilai konstanta resesi untuk komponen aliran diffuse, fissure, dan conduit pada tiga gua di SBT Bribin bervariasi. Rata-rata nilai konstanta resesi aliran diffuse $\left(\mathrm{K}_{\mathrm{b}}\right)$ tertinggi adalah di Gua Bribin $(0,998)$ dengan variasi yang kecil mengindikasikan bahwa dominasi diffuse flow pasca banjir pada skala waktu yang pendek maupun panjang masih bagus, dan terbukti dengan debit minimum masih diatas 1600 lt/dt. Gua Gilap mempunyai rerata konstanta resesi diffuse yang lebih kecil dibanding yang ditemukan di Gua Bribin, dengan variasi nilai sepanjang musim banjir cukup besar $(0,94-0,99)$, dengan rerata sebesar 0,996. Konstanta resesi diffuse di Gua Ngreneng menunjukkan angka rerata terkecil, yaitu sebesar 0,992. Melihat angka-angka tersebut, Gua Ngreneng melepaskan aliran dasar (diffuse) lebih cepat dibanding kedua gua yang lain. Fakta ini didukung pula dengan nilai waktu menuju aliran dasar $\left(\mathrm{T}_{\mathrm{b}}\right)$ di Gua Ngreneng yang lebih singkat yaitu sekitar 16,8 jam dibandingkan dengan Gua Gilap dan Bribin yaitu masing-masing 36,7 dan 36,3 jam pasca banjir puncak. 
Selanjutnya, nilai konstanta resesi untuk komponen aliran saluran atau conduit $\left(\mathrm{K}_{\mathrm{c}}\right)$ menunjukkan bahwa Gua Ngreneng, Gilap, dan Bribin mempunyai resesi yang curam dengan nilai rata-rata selama periode banjir dibawah 0,5. Menurut Schulz (1976), nilai resesi saluran yang kecil mempunyai karakteristik pelepasan komponen aliran conduit yang lebih cepat dibanding jika nilai $\mathrm{K}_{\mathrm{c}}$ nya lebih besar. Gua Ngreneng mempunyai nilai rata-rata $K_{c}$ yang kecil $(0,333)$ karena pada saat-saat hujan puncak memperoleh aliran permukaan setempat (sinkhole). Selain itu, sebagai aliran bocoran dari SBT Bribin, nilai $\mathrm{K}_{\mathrm{c}}$ di Gua Ngreneng juga terpengaruh oleh aliran Gua Bribin. Apabila melihat nilai waktu menuju puncak banjir $\left(\mathrm{T}_{\mathrm{p}}\right)$, Gua Ngreneng yang terletak di daerah tangkapan bagian hilir dan merupakan bocoran dari SBT Bribin, seharusnya mempunyai waktu menuju puncak banjir yang relatif sama dengan yang dimiliki oleh Gua Bribin. Tetapi, gua ini mempunyai $\mathrm{T}_{\mathrm{p}}$ yang 1 jam lebih cepat dari yang dimiliki oleh Gua Bribin. Hal ini berkaitan erat dengan morfologi Gua Ngreneng sebagai sebuah sinkhole. Sementara itu, Gua Gilap yang berlokasi di bagian hulu daerah tangkapan mempunyai nilai $\mathrm{K}_{\mathrm{c}}$ dan $\mathrm{T}_{\mathrm{p}}$ yang relatif lebih cepat dibanding yang dijumpai di Gua Ngreneng dan Bribin. Nilai konstanta resesi fissure atau aliran antara $\left(\mathrm{K}_{\mathrm{i}}\right)$ pada tiga gua di daerah penelitian tidak menunjukkan perbedaan yang cukup berarti dengan julat yang hampir seimbang $(0,767-0,877)$. Gua Gilap mempunyai rerata nilai $\left(\mathrm{K}_{\mathrm{i}}\right)$ yang paling rendah $(0,767)$, sementara Gua Bribin memiliki angka yang hampir sama dengan yang dijumpai di Gua Ngreneng (bocoran SBT Bribin) yaitu 0,825 di Bribin dan 0,877 di Ngreneng.

Melihat angka-angka terkait konstanta resesi pada berbagai komponen aliran dan parameter hidrograf banjir lainnya $\left(T_{p}\right.$ dan $\left.T_{b}\right)$, tampak bahwa Gua Gilap yang terletak pada SBT Bribin bagian hulu mempunyai respon yang paling cepat terhadap hujan $\left(\mathrm{T}_{\mathrm{p}}=3\right.$ jam$)$, karena letaknya berada di bagian hulu daerah tangkapan, meskipun mempunyai rerata nilai $\mathrm{K}_{\mathrm{b}}$ yang cukup tinggi $(0,996)$ jika dibandingkan yang dijumpai di Gua Ngreneng, sehingga masih tergolong baik dalam melepaskan air dari akuifer karst. Sementara itu, Gua Ngreneng yang memiliki nilai $\mathrm{K}_{\mathrm{b}}$ terkecil $(0,992)$, ternyata memiliki nilai waktu menuju puncak banjir $\left(\mathrm{T}_{\mathrm{p}}\right)$ yang relatif lama, tetapi mempunyai nilai $\mathrm{T}_{\mathrm{b}}$ yang cepat (16,8 jam) yang mengindikasikan bahwa Gua Ngreneng mempunyai sifat akuifer yang lebih cepat melepaskan komponen aliran dasar (diffuse) dan terpengaruh oleh fungsi Gua Ngreneng sebagai pengatus aliran permukaan langsung (point recharge) dari cekungan-cekungan di sekitarnya. Dari fakta ini terlihat bahwa kontrol morfologi permukaan berupa sinkhole berperan dalam mempengaruhi karakteristik parameter hidrograf banjir di Gua Ngreneng. Ringkasan kondisi paramater hidrograf banjir dan konstanta resesi di daerah penelitian disajikan pada Tabel 2. 
Tabel 2. Kondisi Komponen Aliran Akuifer Karst Atas Dasar Perbandingan Angka Paramater Hidrograf Banjir

\begin{tabular}{|c|c|c|c|}
\hline $\begin{array}{l}\text { Paramater } \\
\text { hidrograf }\end{array}$ & SBT & Perbandingan & Karakteristik \\
\hline $\mathrm{K}_{\mathrm{b}}=0,996$ & \multirow{5}{*}{ Gilap } & $\begin{array}{l}>\text { Ngreneng } \\
<\text { Bribin }\end{array}$ & $\begin{array}{l}\text { - akuifer melepaskan aliran diffuse lebih cepat daripada G. Bribin tapi lebih } \\
\text { lambat daripada G. Ngreneng } \\
\text { - fungsi retakan kecil (diffuse) masih lebih baik dari G. Ngreneng }\end{array}$ \\
\hline $\mathrm{K}_{\mathrm{i}}=0,767$ & & $\begin{array}{l}<\text { Ngreneng } \\
<\text { Bribin }\end{array}$ & $\begin{array}{l}\text { - simpanan air pada retakan berukuran menengah (fissure) paling cepat } \\
\text { dilepaskan dibanding di G. Bribin dan Ngreneng }\end{array}$ \\
\hline $\mathrm{K}_{\mathrm{c}}=0,463$ & & $\begin{array}{l}>\text { Ngreneng } \\
>\text { Bribin }\end{array}$ & $\begin{array}{l}\text { - simpanan air pada retakan berukuran besar (conduit) paling lama dilepas } \\
\text { oleh akuifer } \\
\text { - luasan daerah tangkapannya paling kecil dibanding G. Bribin dan Ngreneng }\end{array}$ \\
\hline $\mathrm{T}_{\mathrm{p}}=3,03 \mathrm{jam}$ & & $\begin{array}{l}<\text { Ngreneng } \\
<\text { Bribin }\end{array}$ & - jarak tangkapan hujan paling dekat karena berada di bagian hulu \\
\hline $\mathrm{T}_{\mathrm{b}}=36,7 \mathrm{jam}$ & & $\begin{array}{l}>\text { Ngreneng } \\
>\text { Bribin }\end{array}$ & $\begin{array}{l}\text { - simpanan diffuse lama dilepas oleh akuifer } \\
\text { - retakan conduit belum berkembang sebaik G. Bribin dan Ngreneng }\end{array}$ \\
\hline $\mathrm{K}_{\mathrm{b}}=0,998$ & \multirow{5}{*}{ Bribin } & $\begin{array}{l}>\text { Ngreneng } \\
>\text { Gilap }\end{array}$ & $\begin{array}{l}\text { - potensi simpanan diffuse paling baik karena paling lama dilepas oleh akuifer } \\
\text { - debit masih besar di musim kemarau }\end{array}$ \\
\hline $\mathrm{K}_{\mathrm{i}}=0,825$ & & $\begin{array}{l}<\text { Ngreneng } \\
>\text { Gilap }\end{array}$ & $\begin{array}{l}\text { - simpanan pada retakan fissure relatif paling baik (hampir sama dengan di } \\
\text { Ngreneng }\end{array}$ \\
\hline $\mathrm{K}_{\mathrm{c}}=0,332$ & & $\begin{array}{l}<\text { Ngreneng } \\
<\text { Gilap }\end{array}$ & $\begin{array}{l}\text { - adanya point recharge saat hujan yang mengimbuh langsung ke sungai, } \\
\text { sehingga konstanta resesi saluran besar }\end{array}$ \\
\hline $\mathrm{T}_{\mathrm{p}}=5,5 \mathrm{jam}$ & & $\begin{array}{l}>\text { Ngreneng } \\
>\text { Gilap }\end{array}$ & - luas tangkapan hujan paling besar \\
\hline $\mathrm{T}_{\mathrm{b}}=36,3 \mathrm{jam}$ & & $\begin{array}{l}>\text { Ngreneng } \\
<\text { Gilap }\end{array}$ & $\begin{array}{l}\text { - komponen aliran conduit dan diffuse sama-sama dominan pada saat banjir } \\
\text { - simpanan diffuse lama dilepas oleh akuifer }\end{array}$ \\
\hline $\mathrm{K}_{\mathrm{b}}=0,992$ & \multirow{5}{*}{ Ngreneng } & $\begin{array}{l}<\text { Gilap } \\
<\text { Bribin }\end{array}$ & $\begin{array}{l}\text { - akuifer melepaskan komponen aliran diffuse paling cepat dibanding G. Gilap } \\
\text { dan Bribin }\end{array}$ \\
\hline $\mathrm{K}_{\mathrm{i}}=0,877$ & & $\begin{array}{l}>\text { Gilap } \\
>\text { Bribin }\end{array}$ & - simpanan pada retakan fissure paling lama dilepas oleh akuifer \\
\hline $\mathrm{K}_{\mathrm{c}}=0,333$ & & $\begin{array}{l}<\text { Gilap } \\
>\text { Bribin }\end{array}$ & $\begin{array}{l}\text { - mulut gua merupakan point recharge aliran permukaan saat hujan } \\
\text { - merupakan bocoran dari SBT Bribin sehingga nilainya hampir identik }\end{array}$ \\
\hline $\mathrm{T}_{\mathrm{p}}=4,5 \mathrm{jam}$ & & $\begin{array}{l}>\text { Gilap } \\
<\text { Bribin }\end{array}$ & $\begin{array}{l}\text { - seharusnya nilainya identik dengan di Bribin, tetapi terpengaruh aliran } \\
\text { langsung ke mulut gua pada saat kejadian hujan }\end{array}$ \\
\hline $\mathrm{T}_{\mathrm{b}}=16,8 \mathrm{jam}$ & & $\begin{array}{l}<\text { Gilap } \\
<\text { Bribin }\end{array}$ & $\begin{array}{l}\text { - simpanan aliran dasar paling cepat dilepas oleh akuifer } \\
\text { - retakan conduit kemungkinan sudah dominan }\end{array}$ \\
\hline
\end{tabular}

${ }^{*} \mathrm{~K}_{\mathrm{c}}=$ konstanta resesi conduit $; \mathrm{K}_{\mathrm{i}}=$ konstanta resesi fissure; $\mathrm{K}_{\mathrm{b}}=$ konstanta resesi diffuse

$* \mathrm{~T}_{\mathrm{p}}=$ time to peak; $\mathrm{T}_{\mathrm{b}}=$ time to baseflow

Dari Tabel 2. dapat diketahui bahwa sungai di Gua Bribin mempunyai simpanan aliran dasar (aliran mantap) yang paling besar dan simpanan tersebut dilepaskan paling perlahan-lahan dibanding yang ditemukan di Gua Ngreneng dan Gua Gilap. Daerah hulu tangkapan hujan SBT Bribin yang diwakili oleh Gua Gilap juga menunjukkan tingkat pelepasan aliran dasar (baseflow) yang lambat, sehingga berkontribusi positif bagi kelangsungan debit SBT Bribin pada musim kemarau. Hanya saja, karena letaknya di bagian hulu, maka respon terhadap banjir termasuk yang paling cepat, dan debit aliran mantap pada musim kemarau tergolong kecil. Sementara itu, Gua Ngreneng yang berdekatan dan merupakan bocoran dari SBT Bribin ternyata mempunyai sifat pelepasan akuifer yang berbeda dengan yang ditemukan di G. Bribin karena 
karakteristik banjirnya dipengaruhi oleh morfologinya sebagai suatu point recharge cekungan-cekungan karst di sekitarnya .

\section{b. Persentase Aliran Dasar (PAD)}

PAD atau perbandingan antara debit aliran dasar yang dipisahkan dari hidrograf banjir dibagi dengan debit total aliran dapat digunakan untuk mengkarakterisasi simpanan atau potensi akuifer untuk mengimbuh sungai bawah tanah sepanjang tahun. Distribusi PAD bulanan gua-gua di di aliran SBT Bribin disajikan pada Tabel 3, dan ilustrasinya disajikan pada Gambar 1. Secara umum, rasio aliran dasar bulanan pada ketiga gua menunjukkan pola yang hampir sama, yaitu meningkat secara perlahan-lahan ketika menuju puncak musim kemarau, kemudian berfluktuasi pada saat musim hujan dengan kecenderungan rasio yang lebih kecil dibanding pada saat musim hujan karena pengaruh meningkatnya kontribusi aliran conduit saat hujan. PAD menunjukkan semakin ke arah hilir, PAD cenderung meningkat (Gilap<Bribin) dan Gua Bribin mempunyai PAD yang paling tinggi (>95\%) jika dibanding Gua Ngreneng dan Gilap (80\%). Fakta lain yang menarik adalah kenyataan bahwa pola kecenderungan rasio aliran dasar bulanan di Gua Ngreneng pada saat musim hujan yang menunjukkan kecenderungan meningkat, sementara di Gua Gilap dan Bribin memiliki pola kecenderungan menurun

Tabel. 3. PAD di SBT Bribin

\begin{tabular}{|c|c|c|c|c|c|}
\hline NO & BULAN & GILAP & $\begin{array}{l}\text { PAD }(\% \\
\text { BRIBIN }\end{array}$ & NGRENENG & MUSIM \\
\hline 1 & Mei 2006 & 80,41 & 97,03 & 80,35 & kemarau \\
\hline 2 & Juni 2006 & 80,47 & 98,40 & 80,36 & kemarau \\
\hline 3 & Juli 2006 & 80,93 & 98,53 & 80,37 & kemarau \\
\hline 4 & Agustus 2006 & 81,66 & 98,64 & 80,38 & kemarau \\
\hline 5 & September 2006 & 81,77 & 98,70 & 80,38 & kemarau \\
\hline 6 & Oktober 2006 & 82,09 & 99,14 & 80,38 & kemarau \\
\hline 7 & November 2006 & 82,36 & 99,40 & 80,38 & kemarau \\
\hline 8 & Desember 2007 & 80,11 & 97,44 & 81,78 & hujan \\
\hline 9 & Januari 2007 & 84,86 & 98,87 & 82,93 & hujan \\
\hline 10 & Pebruari 2007 & 77,49 & 97,22 & 83,48 & hujan \\
\hline 11 & Maret 2007 & 82,94 & 97,07 & 82,41 & hujan \\
\hline 12 & April 2007 & 82,85 & 98,26 & 81,78 & hujan \\
\hline
\end{tabular}

Sumber : hasil analisis data 2006-2007

. Fakta ini memperkuat argumentasi sebelumnya bahwa karena morfologi mulut Gua Ngreneng merupakan sinkhole dari cekungan karst, maka dominasi aliran conduit 
hanya sesaat $\left(\mathrm{K}_{\mathrm{c}}\right.$ dan $\mathrm{T}_{\mathrm{b}}$ kecil), sehingga jika dirata-rata dalam sebulan terlihat bahwa peran aliran conduit di gua ini kecil yang menyebabkan rasio aliran dasarnya justru meningkat. Tetapi, jika analisis rasio aliran dasar ini dilakukan pada saat-saat kejadian banjir saja, maka persentase aliran dasar pada semua gua cenderung menurun yang menunjukkan adanya penambahan kontribusi komponen aliran conduit yang besar (Tabel 4.).

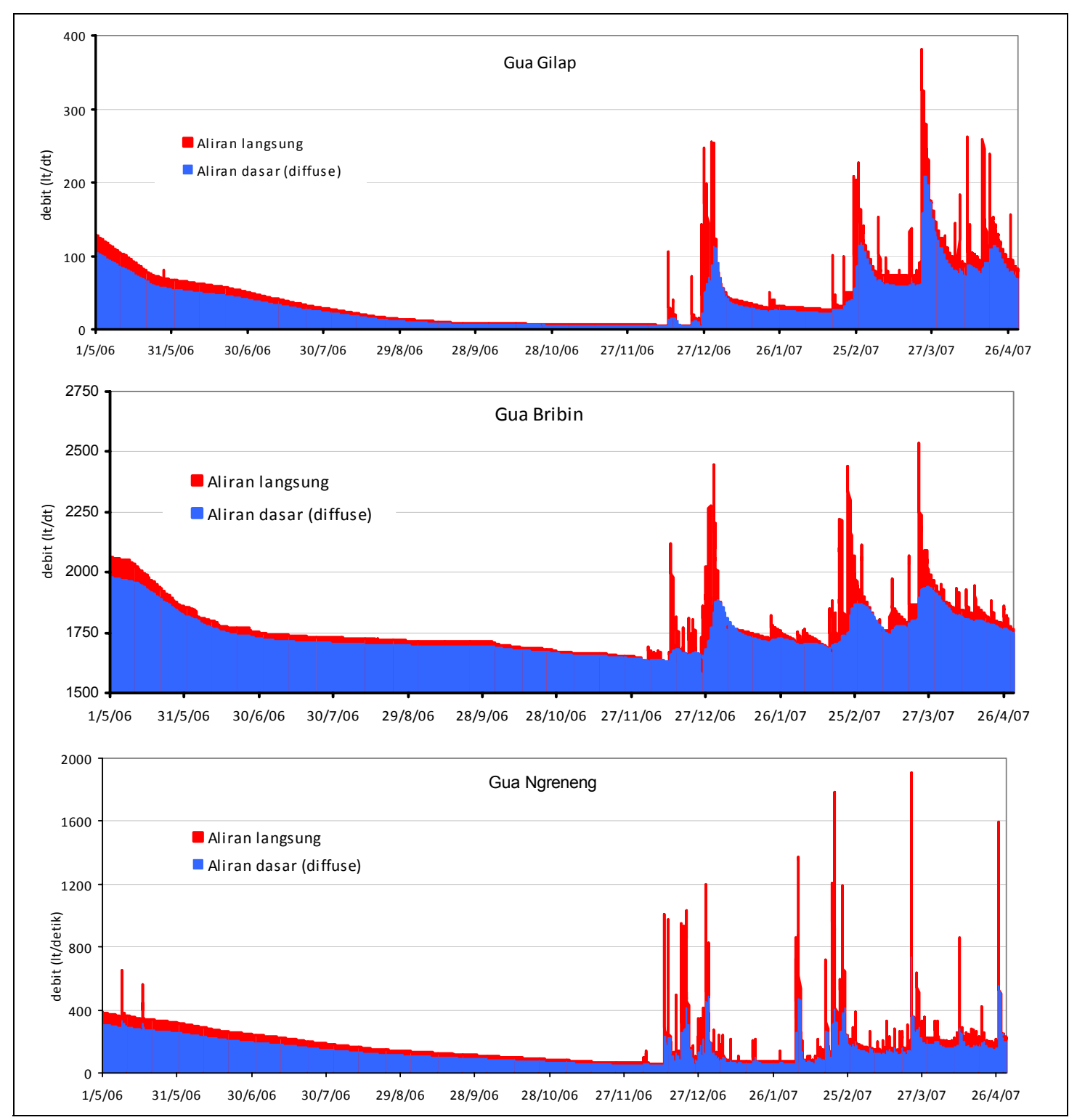

Gambar 1. Pemisahan Aliran Dasar Gua-Gua di SBT Bribin

Dari Tabel 4. terlihat bahwa Gua Ngreneng memiliki PAD paling kecil (46,5 \%). Hal ini menunjukkan bahwa penambahan aliran dasar (diffuse) pada saat kejadian banjir 
jauh lebih sedikit dibawah penambahan aliran langsung (conduit). Gua Bribin memiliki PAD yang tidak berbeda jauh jika dibandingkan dengan PAD bulanannya. Hal ini mengindikasikan dominasi aliran dasar di Gua Bribin lebih baik dibanding Gua Ngreneng dan Gua Gilap. Sementara itu, rasio saat banjir di Gua Gilap memiliki rerata nilai sebesar $65,41 \%$, lebih kecil dibanding rasio bulanannya tetapi lebih signifikan dengan yang ditemukan di Gua Ngreneng. Hal ini menunjukkan bahwa pola retakan conduit di Gua Gilap belum begitu berkembang dibandingkan dengan yang dijumpai di Gua Ngreneng.

Tabel. 4. Rasio Aliran Dasar dan Total Aliran Saat Kejadian banjir

\begin{tabular}{|c|c|c|c|c|c|c|}
\hline \multirow[b]{2}{*}{$\mathrm{NO}$} & \multicolumn{2}{|c|}{ GUA GILAP } & \multicolumn{2}{|c|}{ GUA BRIBIN } & \multicolumn{2}{|c|}{ GUA NGRENENG } \\
\hline & WAKTU BANJIR & $\begin{array}{c}\text { RASIO } \\
(\%)\end{array}$ & WAKTU BANJIR & RASIO (\%) & WAKTU BANJIR & RASIO (\%) \\
\hline 1 & 13/12/06 jam 19:00 & 45,08 & 6/12/06 jam 22:30 & 98,38 & 13/12/06 jam 19:30 & 41,43 \\
\hline 2 & $22 / 12 / 06$ jam $15: 30$ & 55,52 & 7/12/06 jam 23:00 & 99,02 & 15/12/06 jam 18:30 & 44,68 \\
\hline 3 & 31/12/06 jam 06:30 & 57,75 & 13/12/06 jam 19:30 & 86,16 & 18/12/06 jam 13:30 & 50,85 \\
\hline 4 & 16/2/07jam 16:30 & 57,25 & 29/12/06 jam 00:30 & 77,72 & 20/12/06 jam 18:30 & 43,88 \\
\hline 5 & 24/2/07 jam 19:00 & 51,25 & 30/12/06 jam 17:00 & 82,69 & $22 / 12 / 06$ jam $20: 30$ & 44,68 \\
\hline 6 & 26/2/07 jam 18:00 & 58,55 & 16/2/07 jam 18:00 & 92,29 & 5/2/07 jam 17:00 & 45,68 \\
\hline 7 & 6/3/07 jam 21:00 & 79,91 & 22/2/07 jam 21:00 & 81,81 & 19/2/07 jam 20:30 & 40,79 \\
\hline 8 & 9/3/07 jam 19:00 & 78,18 & 23/2/07 jam 20:00 & 84,51 & 20/2/07 jam 20:00 & 59,77 \\
\hline 9 & 14/3/07 jam 02:00 & 78,92 & 28/2/07 jam 01:30 & 89,91 & & \\
\hline 10 & 19/3/07jam 00:00 & 72,75 & 7/3/07 jam 05:00 & 99,05 & & \\
\hline 11 & 21/3/07jam 08:00 & 77,20 & 7/4/07 jam 22:00 & 95,50 & & \\
\hline 12 & 23/3/07 jam 08:00 & 50,88 & 27/4/07 jam 20:00 & 97,25 & & \\
\hline 13 & 7/4/07 jam 01:30 & 70,33 & & & & \\
\hline 14 & 10/4/07 jam 18:00 & 62,94 & & & & \\
\hline 15 & 11/4/07 jam 15:00 & 76,30 & & & & \\
\hline 16 & 16/4/07 jam 23:30 & 73,80 & & & & \\
\hline & Rerata & 65,41 & & 90,36 & & 46,47 \\
\hline
\end{tabular}

Sumber : hasil analisis data 2006-2007

\section{Karakteristik spasial-temporal hidrogeokimia dan hubungannya dengan kondisialiran di SBT Bribin}

Karakteristik hidrogeokimia secara spasio-temporal di SBT Bribin memberikan gambaran yang menyeluruh mengenai perbedaan karakter hidrogeokimia pada masingmasing lokasi pengambilan sampel yang mewakili alur SBT Bribin dari hulu menuju ke hilir, dan menekankan pada hubungan antara karakter hidrogeokimia dan karakteristik aliran pada masing-masing lokasi pengambilan sampel. 


\section{a. Hubungan DHL-kalsium dan DHL-bikarbonat}

Gua Bribin yang terletak pada posisi paling hilir pada saat musim kemarau memiliki hubungan yang paling kuat dan memiliki nilai DHL dan kalsium \& bikarbonat terlarut yang paling tinggi dibandingkan dengan gua-gua lain. Jika mengacu hasil karakteristik aliran dasar yang sudah dibahas, pada saat musim kemarau komposisi aliran dasar di Gua Bribin adalah yang paling besar dan memiliki fluktuasi aliran dasar paling rendah dibanding gua-gua yang lain, yaitu mencapai angka sekitar 98\% dengan konstanta resesi aliran dasar $\left(\mathrm{K}_{\mathrm{b}}\right)$ sebesar 0,998 , sedangkan komposisi aliran dasar yang dijumpai di Gua Gilap berkisar pada angka 81 \%. Sementara itu, Gua Ngreneng yang oleh MacDonalds dan Partners (1984) disebutkan sebagai bocoran dari Gua Bribin mempunyai nilai hubungan paling mirip dengan Gua Bribin dengan plotting kandungan DHL dan kalsium-bikarbonat yang juga mirip. Gua-gua lain yang berada di wilayah hulu mempunyai nilai hubungan yang lebih kecil dengan yang ditemukan di wilayah hilir, kecuali yang dijumpai di Sungai Pentung karena aliran dasar Sungai Pentung tidak bersifat karstik, sehingga nilai hubungan hanya terpengaruh oleh oleh proses water-rock interaction saja, meskipun bukan dengan mineral yang berbatuan karbonat. Nilai hubungan yang kecil di L. Jomblangan lebih disebabkan adanya proses mixing antara baseflow dari Sungai Pentung dan baseflow dari akuifer karst yang mempunyai karakteristik yang berbeda tingkat interaksinya dengan batuan karbonat. Selanjutnya, aliran antara (fissure flow) yang tinggi di Gua Gilap mengakibatkan proses water-rock interaction tidak seintensif yang dijumpai di Bribin dan Ngreneng.

Tabel 5. Perbandingan determinasi $\left(\mathrm{R}^{2}\right)$ DHL vs kalsium dan bikarbonat di SBT Bribin musim kemarau

\begin{tabular}{|c|c|c|c|c|c|c|}
\hline LOKASI & POSISI & $\begin{array}{l}\mathrm{CA}^{2+} \mathrm{VS} \\
\mathrm{DHL}\end{array}$ & $\mathrm{HCO}_{3}{ }^{-} \mathrm{VS} \mathrm{DHL}$ & $\begin{array}{c}\text { TINGKAT } \\
\text { DETERMINASI }\end{array}$ & $\begin{array}{c}\text { PROSES } \\
\text { HIDROGEOKIMIA }\end{array}$ & KETERANGAN \\
\hline SBT Pentung & Inlet hulu & 0,878 & 0,596 & Positif- tinggi-sedang & $\begin{array}{l}\text { Water-rock interaction } \\
\text { bukan dengan akuifer } \\
\text { karbonat }\end{array}$ & $\begin{array}{l}\text { Sungai yang input } \\
\text { baseflow- nya dari } \\
\text { akuifer vulkanik }\end{array}$ \\
\hline L. Jomblangan & hulu & 0,364 & 0,687 & $\begin{array}{l}\text { Positif-rendah- } \\
\text { sedang }\end{array}$ & $\begin{array}{l}\text { Mixing antara air karbonat } \\
\text { dan bukan }\end{array}$ & $\begin{array}{l}\text { Gua yang } \\
\text { memperoleh aliran } \\
\text { langsung dari Sungai } \\
\text { Pentung }\end{array}$ \\
\hline G. Gilap & hulu-tengah & 0,436 & 0,744 & Positif- rendah-tinggi & $\begin{array}{l}\text { Persentase aliran dasar agak } \\
\text { rendah dibanding gua } \\
\text { Bribin dan Ngreneng, water } \\
\text { rock interaction dengan } \\
\text { batuan karbonat cukup kuat }\end{array}$ & $\begin{array}{l}\text { Persentase Aliran } \\
\text { Dasar (PAD) sekitar } \\
80 \% \text { dan nilai } \mathrm{K}_{\mathrm{i}} \\
\text { kecil dan } \mathrm{K}_{\mathrm{c}} \text { cukup } \\
\text { tinggi }\end{array}$ \\
\hline G. Bribin & Hilir & 0,892 & 0,867 & Positif-tinggi & $\begin{array}{l}\text { Persentase aliran dasar } \\
\text { paling tinggi, water rock } \\
\text { interaction dengan batuan } \\
\text { karbonat kuat }\end{array}$ & $\begin{array}{l}\text { PAD sekitar } 90 \%, \mathrm{~K}_{\mathrm{b}} \\
\text { tinggi }\end{array}$ \\
\hline G. Ngreneng & bocoran & 0,770 & 0,901 & Positif-tinggi & $\begin{array}{l}\text { Persentase aliran dasar } \\
\text { cukup tinggi dan berlokasi } \\
\text { dekat dengan G. Bribin, } \\
\text { water rock interaction } \\
\text { dengan batuan karbonat } \\
\text { kuat }\end{array}$ & $\begin{array}{l}\text { PAD mendekati nilai } \\
\text { di Gua Bribin, } \mathrm{K}_{\mathrm{c}} \\
\text { cukup rendah }\end{array}$ \\
\hline
\end{tabular}

Sumber : hasil analisis data 2006-2007 
Pada saat hujan, gua Bribin, Ngreneng dan Gilap menunjukkan hubungan Kalsium-DHL yang rendah, sedangkan hubungan yang sama antara Gua Bribin dan Ngreneng tidak berbeda jauh. Saat hujan, gua-gua tersebut mempunyai PAD yang jauh lebih rendah dibanding saat musim kemarau. Tabel 6. menunjukkan bahwa Gua Gilap mempunyai hubungan negatif karena mempunyai PAD yang paling rendah dibanding G. Bribin dan G. Ngreneng. Sementara itu, Luweng Jomblangan mempunyai hubungan yang besar pada saat musim hujan jika dibandingkan dengan lokasi-lokasi lain, yang kemungkinan karena kecilnya pasokan conduit di daerah hulu karst (berbatasan dengan akuifer vulkanik), dan adanya input dari Sungai Pentung yang sifatnya intermitten saja (direct runoff hilang setelah hujan).

Tabel 6. Perbandingan determinasi $\left(\mathrm{R}^{2}\right)$ antara DHL-kalsium dan DHL karbonat di di SBT Bribin musim hujan

\begin{tabular}{|c|c|c|c|c|c|c|}
\hline LOKASI & POSISI & $\begin{array}{l}\mathrm{CA}^{2+} \mathrm{VS} \\
\mathrm{DHL}\end{array}$ & $\mathrm{HCO}_{3}^{-} \mathrm{VS}$ DHL & $\begin{array}{c}\text { TINGKAT } \\
\text { DETERMINASI }\end{array}$ & $\begin{array}{c}\text { PROSES } \\
\text { HIDROGEOKIMIA }\end{array}$ & KETERANGAN \\
\hline Sungai Pentung & Inlet hulu & 0,013 & 0,311 & Positif-rendah & $\begin{array}{l}\text { Proses water rock } \\
\text { interaction sangat } \\
\text { lemah }\end{array}$ & $\begin{array}{l}\text { Besarnya direct runoff } \\
\text { saat hujan }\end{array}$ \\
\hline $\begin{array}{l}\text { Luweng } \\
\text { Jomblangan }\end{array}$ & hulu & 0,812 & 0,889 & Positif-tinggi & $\begin{array}{l}\text { Komponen aliran masih } \\
\text { didominasi diffuse } \\
\text { karena berada pada } \\
\text { boundary akuifer karst }\end{array}$ & $\begin{array}{l}\text { Secara visual tidak } \\
\text { terjadi fluktuasi debit } \\
\text { dan kekeruhan yang } \\
\text { mencolok sepanjang } \\
\text { waktu }\end{array}$ \\
\hline Gua Gilap & hulu-tengah & 0,020 & 0,071 & Negatif-rendah & $\begin{array}{l}\text { Pasokan komponen } \\
\text { conduit sangat kuat, } \\
\text { rerata PAD paling } \\
\text { rendah, water rock } \\
\text { interaction sangat } \\
\text { lemah }\end{array}$ & $\begin{array}{l}\text { Rerata } \mathrm{PAD}=73 \% \\
\mathrm{~T}_{\mathrm{b}}=36,7 \text { jam }\end{array}$ \\
\hline Gua Bribin & Hilir & 0,272 & 0,374 & Positif-rendah & $\begin{array}{l}\text { Pasokan komponen } \\
\text { conduit kuat yang masih } \\
\text { cukup menyisakan } \\
\text { aliran dasar }\end{array}$ & $\begin{array}{l}\text { Rerata } \mathrm{PAD}=94 \% \\
\mathrm{~T}_{\mathrm{b}}=36,3 \mathrm{jam}\end{array}$ \\
\hline Gua Ngreneng & bocoran & 0,370 & 0,810 & Positif rendah-tinggi & $\begin{array}{l}\text { Hampir mirip dengan } \\
\text { Bribin, tetapi dengan } \\
\text { time to base flow }\left(\mathrm{T}_{\mathrm{b}}\right) \\
\text { yang lebih cepat } \\
\text { dibanding Bribin, } \\
\text { karena morfometri gua }\end{array}$ & $\begin{array}{l}\text { Rerata } \mathrm{PAD}=88 \% \\
\mathrm{~T}_{\mathrm{b}}=16,8 \mathrm{jam}\end{array}$ \\
\hline
\end{tabular}

Sumber : hasil analisis data 2006-2007

\section{b. Hubungan debit dan persentase aliran dasar (PAD)}

Karimi, et al. (2003) menjelaskan bahwa periode resesi (saat debit turun setelah kejadian banjir) akan menyebabkan komposisi aliran diffuse meningkat dan merubah komposisi kimia air sungai bawah tanah karst, sehingga dapat disimpulkan bahwa persentase aliran dasar akan meningkat sering dengan menurunnya debit aliran. Teori tersebut diatas selaras dengan yang terjadi di gua-ga di SBT Bribin. Gua Gilap, Bribin, dan Ngreneng memiliki hubungan yang tinggi antara penurunan debit dan kenaikan PAD, khususnya pada saat musim kemarau, atau hubungan debit dan PAD adalah negatif. 
Tabel 7. Perbandingan determinasi $\left(\mathrm{R}^{2}\right)$ antara PAD-debit di SBT Bribin musim kemarau

\begin{tabular}{|l|c|c|c|l|}
\hline \multicolumn{1}{|c}{ LOKASI } & POSISI & $\begin{array}{c}\text { DEBIT VS } \\
\text { PAD }\end{array}$ & $\begin{array}{c}\text { TINGKAT } \\
\text { DETERMINASI }\end{array}$ & \multicolumn{2}{c|}{ KETERANGAN } \\
\hline Sungai Pentung & Inlet hulu & 0,988 & Negatif-tinggi & $\begin{array}{l}\text { Determinasi paling kuat karena terisi aliran dasar semata } \\
\text { yang berasal dari akuifer non-karstic }\end{array}$ \\
\hline Gua Gilap & hulu-tengah & 0,852 & Negatif-tinggi & $\begin{array}{l}\text { Determinasi kuat, dan aliran dasar merupakan kombinasi } \\
\text { dari aliran fissure dan diffuse, sehingga lamanya akuifer } \\
\text { melepaskan aliran fissure berpengaruh terhadap nilai } \\
\text { determinasi. Nilai } \mathrm{K}_{\mathrm{i}} \text { di Gilap=0,767 }\end{array}$ \\
\hline Gua Bribin & Hilir & 0,855 & Negatif-tinggi & Determinasi kuat, Nilai $\mathrm{K}_{\mathrm{i}}$ di Bribin=0,332 \\
\hline Gua Ngreneng & bocoran & 0,791 & Negatif-tinggi & $\begin{array}{l}\text { Determinasi sedikit agak lemah dibanding Gilap dan } \\
\text { Bribin, Nilai } \mathrm{K}_{\mathrm{i}} \text { di Ngreneng=0,877 }\end{array}$ \\
\hline
\end{tabular}

Sumber : hasil analisis data 2006-2007

Sementara itu, Sungai Pentung (akuifer vulkanik) memiliki hubungan yang paling kuat, karena sisa aliran sungai di musim kemarau diisi oleh aliran dasar saja. Lain halnya pada sungai bawah tanah, sisa komponen air sungai masih merupakan kombinasi antara aliran fissure dan diffuse, sehingga nila determinasi $\left(\mathrm{R}^{2}\right)$ antara PAD vs debit sedikit lebih kecil dibanding yang dijumpai Sungai Pentung. Besarnya determinasi di Gilap, Bribin, dan Ngreneng ternyata juga dipengaruhi oleh cepat lambatnya akuifer karst melepaskan aliran fissure (nilai $\mathrm{K}_{\mathrm{i}}$ ), seperti yang disajikan pada Tabel 7 . Selanjutnya, dapat disimpulkan bahwa akuifer dengan nilai $\mathrm{K}_{\mathrm{i}}$ besar (lambat melepaskan komponen fissure), maka determinasi debit-PAD akan lebih kecil dibanding akuifer yang lebih cepat melepas komponen aliran fissure $\left(\mathrm{K}_{\mathrm{i}}\right.$ kecil), sebagai contoh adalah fenomena yang ditemui di Gua Bribin. Sebaliknya, pada saat periode hujan, terjadi penurunan nilai determinasi hingga mencapai nilai yang sangat kecil pada sungai bawah tanah di Gua Ngreneng dan Gua Gilap. Hal ini terjadi karena fluktuasi persentase aliran dasar (PAD) cukup besar. Selain itu, jika dihubungkan dengan data fluktuasi PAD selama kejadian banjir, tampak jelas bahwa julat PAD di Gua Gilap dan Ngreneng masing-masing 45-80\% dan 40-65\%, sedangkan julat PAD di Gua Bribin hanya berkisar antara $80-90 \%$ saja. Perbandingan determinasi antara PAD-debit pada gua-gua di SBT Bribin pada musim hujan disajikan pada Tabel 8.

Tabel 8. Perbandingan determinasi $\left(\mathrm{R}^{2}\right)$ antara PAD-debit di di SBT Bribin musim hujan

\begin{tabular}{|c|c|c|c|c|}
\hline LOKASI & POSISI & $\begin{array}{l}\text { DEBIT VS } \\
\text { PAD }\end{array}$ & $\begin{array}{c}\text { TINGKAT } \\
\text { DETERMINASI }\end{array}$ & KETERANGAN \\
\hline Sungai Pentung & Inlet hulu & 0,815 & Negatif-tinggi & $\begin{array}{l}\text { Aliran dasar yang stabil saat musim hujan, dan sifat banjir } \\
\text { yang cepat hilang, sehingga hanya sedikit menurunkan } \\
\text { nilai determinasi }\end{array}$ \\
\hline Gua Gilap & $\begin{array}{l}\text { hulu- } \\
\text { tengah }\end{array}$ & 0,014 & $\begin{array}{c}\text { Negatif rendah (tanpa } \\
\text { hubungan) }\end{array}$ & $\begin{array}{l}\text { Fluktuasi aliran dasar yang tinggi saat periode hujan ( } 45- \\
80 \%)\end{array}$ \\
\hline Gua Bribin & Hilir & 0,913 & Negatif-tinggi & $\begin{array}{l}\text { Fluktuasi aliran dasar yang stabil saat banjir }(80-90 \%) \text {, } \\
\text { bahkan beberapa kali pengambilan sampel dilakukan saat } \\
\text { periode resesi setelah banjir }\end{array}$ \\
\hline Gua Ngreneng & bocoran & 0,011 & $\begin{array}{l}\text { Negatif rendah (tanpa } \\
\text { hubungan) }\end{array}$ & $\begin{array}{l}\text { Fluktuasi aliran dasar yang tinggi saat periode hujan (40- } \\
65 \%) \text {. Selain itu inlet G. Ngreneng yang merupakan suatu } \\
\text { sinkhole selalu dipasok aliran konduit saat kejadian hujan. }\end{array}$ \\
\hline
\end{tabular}

Sumber : hasil analisis data 2006-2007 


\section{c. Hubungan PAD-kalsium dan PAD-bikarbonat}

Saat musim kemarau, terlihat perbedaan yang mencolok pada hubungan PADkalsium gua-gua di bagian atas dan bagian bawah daerah tangkapan hujan SBT Bribin. Sebagai kation terlarut suatu sungai bawah tanah, besar kecilnya kalsium terlarut ditentukan oleh besar kecilnya aliran dasar. Gua Bribin dan Ngreneng pada bagian hilir yang lokasinya berdekatan mempunyai nilai determinasi yang sama dan cukup besar yaitu 0,730 (PAD-kalsium) dan nilai diatas 0,850 untuk PAD-bikarbonat. Kesamaan nilai pada musim kemarau ini kemungkinan dapat diakibatkan karena sebagian komponen aliran di Gua Ngreneng berasal dari Gua Bribin. Sementara itu, di Sungai Pentung dijumpai hubungan yang kecil $(0,352)$ pada kalsium karena sebagian besar air bukan berasal dari akuifer karst, sehingga kalsium bukan merupakan kation dominan pada saat aliran dasar memasok aliran Sungai Pentung, lain halnya hubungan PADbikarbonat yang determinasinya besar karena ion bikarbonat dapat berasal dari mineral lain selain mineral kalsit. Selanjutnya, Gua Gilap mempunyai determinasi sedang (PAD-kalsium) yaitu 0,588 yang lebih disebabkan karena posisinya di daerah hulu sehingga aliran dasar mempunyai time of residence (lama tinggal) yang relatif lebih singkat untuk melarutkan kalsium dalam air dibanding yang dialami oleh gua-gua di daerah hilir. Selain itu, Gua Gilap juga mempunyai sifat melepas aliran dasar $\left(\mathrm{K}_{\mathrm{b}}\right)$ lebih cepat dibanding Gua Bribin. Secara keseluruhan perbandingan determinasi antara PADkalsium dan bikarbonat terlarut pada gua-gua di SBT Bribin pada musim kemarau disajikan pada Tabel 9.

Saat periode hujan, secara umum hubungan antara unsur-unsur kalsiumbikarbonat dan PAD mengalami pengurangan karena besarnya pasokan air hujan saat musim hujan. Bahkan di G. Ngreneng dan Sungai Pentung mempunyai hubungan negatif, berarti kenaikan kalsium atau karbonat terjadi pada saat PAD naik. Pada lokasilokasi tersebut memang terdapat karakteristik khusus. Sebagai contoh adalah bahwa Sungai Pentung bukan merupakan sungai bawah tanah tetapi merupakan sungai permukaan dan bukan berasal dari akuifer karstik, sehingga kalsium terlarut tidak selalu dominan di dalam air. Sementara itu, Gua Ngreneng seperti sudah dijelaskan pada sub bab sebelumnya merupakan suatu sinkhole pada dasar sebuah lembah karst yang selalu memperoleh aliran conduit dengan cepat $\left(\mathrm{K}_{\mathrm{c}}=\right.$ kecil pada setiap terjadi hujan yang menyebabkan aliran permukaan. 
Tabel 9. Perbandingan determinasi $\left(\mathrm{R}^{2}\right)$ antara PAD-kalsium dan PAD- karbonat di SBT Bribin musim kemarau

\begin{tabular}{|c|c|c|c|c|c|c|}
\hline LOKASI & POSISI & $\mathrm{CA}^{2+} \mathrm{VS}$ PAD & $\mathrm{HCO}_{3}^{-} \mathrm{VS} \mathrm{PAD}$ & $\begin{array}{c}\text { TINGKAT } \\
\text { DETERMINASI }\end{array}$ & $\begin{array}{c}\text { PROSES } \\
\text { HIDROGEOKIMIA }\end{array}$ & KETERANGAN \\
\hline Sungai Pentung & Inlet hulu & 0,352 & 0,985 & Positif-rendah-tinggi & $\begin{array}{l}\text { Water-rock interaction } \\
\text { bukan dengan batuan } \\
\text { karbonat }\end{array}$ & $\begin{array}{l}\text { Determinasi dengan } \\
\text { bikarbonat tinggi karena } \\
\text { terdapat mineral sumber } \\
\text { karbonat pada akufer } \\
\text { vulkanik }\end{array}$ \\
\hline Gua Gilap & hulu-tengah & 0,588 & 0,855 & Positif-sedang-tinggi & $\begin{array}{l}\text { Water-rock interaction } \\
\text { dengan batuan karbonat } \\
\text { dengan time residence } \\
\text { cukup singkat }\end{array}$ & $\begin{array}{l}\text { Daerah hulu, aliran } \\
\text { dasarnya waktunya lebih } \\
\text { singkat kontak dengan } \\
\text { batuan. Nilai } \mathrm{K}_{\mathrm{b}} \text { rendah, } \\
\text { pasokan fissure cukup } \\
\text { besar }\end{array}$ \\
\hline Gua Bribin & Hilir & 0,730 & 0,892 & Positif- tinggi & $\begin{array}{l}\text { Water-rock interaction } \\
\text { dengan batuan karbonat } \\
\text { dengan time residence } \\
\text { lama }\end{array}$ & Nilai $K_{b}$ tinggi \\
\hline Gua Ngreneng & bocoran & 0,730 & 0,941 & Positif- tinggi & $\begin{array}{l}\text { Water-rock interaction } \\
\text { dengan batuan karbonat } \\
\text { dengan time residence } \\
\text { lama dan sebagian } \\
\text { komponennya berasal } \\
\text { dari Gua Bribin }\end{array}$ & $\begin{array}{l}\text { Lokasi berdekatan, time } \\
\text { residence aliran dasar } \\
\text { lebih lama }\end{array}$ \\
\hline
\end{tabular}

Sumber : hasil analisis data 2006-2007

Tabel 10. Perbandingan determinasi $\left(\mathrm{R}^{2}\right)$ antara PAD-kalsium dan PAD- karbonat di SBT

Bribin musim hujan

\begin{tabular}{|c|c|c|c|c|c|c|}
\hline LOKASI & POSISI & $\begin{array}{l}\mathrm{CA}^{2+} \mathrm{VS} \\
\mathrm{PAD}\end{array}$ & $\begin{array}{c}\mathrm{HCO}_{3}^{-} \mathrm{VS} \\
\mathrm{PAD}\end{array}$ & $\begin{array}{c}\text { TINGKAT } \\
\text { DETERMINASI }\end{array}$ & $\begin{array}{c}\text { PROSES } \\
\text { HIDROGEOKIMIA }\end{array}$ & KETERANGAN \\
\hline $\begin{array}{l}\text { Sungai } \\
\text { Pentung }\end{array}$ & Inlet hulu & 0.080 & 0.207 & $\begin{array}{l}\text { Negatif-rendah } \\
\text { Positif rendah (tanpa } \\
\text { hubungan) }\end{array}$ & $\begin{array}{l}\text { Mixing antara proses water- } \\
\text { rock interaction akuifer non } \\
\text { karbonat dan aliran langsung } \\
\text { dari hujan. Aliran langsung } \\
\text { lebih cepat dibanding sungai } \\
\text { bawah tanah ( } \mathrm{Tb}=\text { kecil). }\end{array}$ & $\begin{array}{l}\text { Sifat akuifer non-karst yang } \\
\text { membuat ion kalsium dan } \\
\text { bikarbonat tidak dominan. }\end{array}$ \\
\hline Gua Gilap & hulu-tengah & 0.690 & 0.628 & Positif-sedang & $\begin{array}{l}\text { Kuatnya komponen fissure } \\
\text { yang cukup stabil }\left(\mathrm{K}_{\mathrm{i}}=\text { besar }\right) \text {, } \\
\text { kenaikan aliran conduit tidak } \\
\text { terlalu fluktuatif ketika terjadi } \\
\text { banjir, ( } \mathrm{K}_{\mathrm{c}} \text { besar). Proses } \\
\text { water-rock interaction paling } \\
\text { kuat dibanding gua-gua lain }\end{array}$ & $\begin{array}{l}\text { Gua Gilap posisinya agak } \\
\text { ke hulu, beda antara fissure, } \\
\text { diffuse dan conduit tidak } \\
\text { terlalu tegas, karena } \\
\text { singkatnya time of } \\
\text { residence dari diffuse flow. } \\
\text { Selain itu akuifer G. Gilap } \\
\text { lebih lambat melepas } \\
\text { conduit dibanding gua-gua } \\
\text { lain }\left(\mathrm{K}_{\mathrm{c}} \text { besar). }\right.\end{array}$ \\
\hline Gua Bribin & Hilir & 0.143 & 0.149 & $\begin{array}{l}\text { Positif- rendah (tanpa } \\
\text { hubungan) }\end{array}$ & $\begin{array}{l}\text { Kejadian banjir membawa } \\
\text { aliran conduit } \\
\text { terjadi proses dillution by } \\
\text { precipitation }\end{array}$ & $\begin{array}{l}\text { Beda komposisi diffuse flow } \\
\text { dan conduit flow yang tegas } \\
\text { karena posisinya di hilir }\end{array}$ \\
\hline Gua Ngreneng & bocoran & 0.882 & 0.253 & $\begin{array}{l}\text { Negatif- tinggi } \\
\text { rendah (hubungan } \\
\text { terbalik) }\end{array}$ & $\begin{array}{l}\text { Pasokan conduit yang sering } \\
\text { terjadi dan nilai } \mathrm{K}_{\mathrm{c}} \text { yang kecil, } \\
\text {,sehingga terjadi proses } \\
\text { dillution by precipitation yang } \\
\text { dominan }\end{array}$ & $\begin{array}{l}\text { Morfologi gua sebagai } \\
\text { sinkhole sehingga setiap } \\
\text { kejadian hujan akan } \\
\text { memasok aliran conduit ke } \\
\text { sungai bawah tanah } \\
\end{array}$ \\
\hline
\end{tabular}

Sumber : hasil analisis data 2006-2007

Sementara itu, nilai determinasi kalsium \& bikarbonat dengan PAD di Gua Gilap saat musim hujan paling stabil dibanding G. Bribin dan Ngreneng. Kenyataan ini tidak terlepas karena G. Gilap merupakan gua yang letaknya pada bagian hulu dengan nilai $\mathrm{K}_{\mathrm{i}}$ yang paling besar (fissure flow dominan). Selain itu, nilai Kc di Gua Gilap 
paling stabil (lambat dilepaskan) dibanding gua-gua yang lain, sehingga kandungannya relatif lebih mirip dengan diffuse flow dibandingkan G. Bribin dan G. Ngreneng (Tabel 10).

Dari telaahan nilai determinasi antar parameter kimia dengan kondisi aliran di aliran SBT Bribin baik secara spasial maupun temporal, maka dapat dijelaskan bahwa:

(1) selama musim kemarau, terdapat hubungan yang kuat antara persentase aliran dasar (PAD) atau besar kecilnya diffuse flow dalam air dengan besar kecilnya unsur terlarut dominan dalam air (hidrogeokimia). Hal ini dapat dilihat dari tingginya nilai determinasi antara DHL dan unsur-unsur terlarut yang mengindikasinya kuatnya proses water-rock interaction (Desmarais dan Rojstaczer, 2002). Hal lain yang menunjukkan hubungan antara karakteristik hidrogeokimia dan besar kecilnya aliran dasar adalah tingginya determinasi antara PAD dan unsur-unsur terlarut. Lebh jauh lagi, besar kecilnya determinasi saat musim kemarau juga dipengaruhi oleh posisi spasialnya pada daerah tangkapan hujan SBT Bribin (lokasinya di hilir, hulu, atau sebagai bocoran, atau bahkan kedudukannya sebagai sungai permukaan atau sungai bawah tanah). Besar kecilnya variasi nilai konstanta resesi aliran baik itu aliran dasar-diffuse $\left(\mathrm{K}_{\mathrm{b}}\right)$, aliran antara-fissure $\left(\mathrm{K}_{\mathrm{i}}\right)$, serta aliran langsung-conduit $\left(\mathrm{K}_{\mathrm{c}}\right)$, juga berpengaruh terhadap karakter hidrogeokimia di SBT Bribin.

(2) Selama musim hujan, proses hidrogeokimia bergeser dari proses water-rock interaction ke arah dillution by precipitation karena besarnya pasokan air hujan maupun hujan yang tertinggal pada sungai bawah tanah. Hal ini ditandai dengan turunnya nilai determinasi antara PAD dan unsur-unsur dominan terlarut serta DHL-unsur-unsur dominan terlarut. Hal lain yang berpengaruh terhadap hidrogeokimia sungai bawah tanah saat hujan adalah perbedaan posisi spasial dan karakteristik aliran seperti yang sudah dijelaskan sebelumya.

\section{Kondisi spasial dan temporal agresivitas airtanah terhadap batuan gamping dan hubungannya dengan kondisi SKD di SBT Bribin}

\section{a. Tingkat agresivitas air SBT Bribin}

Menurut Vesper dan White (2004) tingkat agresivitas di daerah karst lazim dinyatakan dalam suatu indeks yang dikenal sebagai indeks kejenuhan atau Saturation Indices (SI) terhadap mineral kalsit. Secara spasial dan temporal nilai kenaikan dan penurunan nilai SI kalsit di daerah penelitian disajikan pada Tabel 11. 
Tabel 11. Distribusi Nilai SI di SBT Bribin

\begin{tabular}{|c|c|c|c|c|c|}
\hline LOKASI & POSISI & $\begin{array}{c}\text { MUSIM } \\
\text { KEMARAU }\end{array}$ & KRITERIA & MUSIM HUJAN & KRITERIA \\
\hline Sungai Pentung & Masukan & $-0,01 \mathrm{~s} / \mathrm{d} 1,13$ & $\begin{array}{l}\text { Hampir jenuh s/d } \\
\text { sangat jenuh }\end{array}$ & $0,18 \mathrm{~s} / \mathrm{d}-0,61$ & Jenuh s/d agresiv \\
\hline $\begin{array}{l}\text { Luweng } \\
\text { Jomblangan }\end{array}$ & Hulu & $-0,43 \mathrm{~s} / \mathrm{d} 0,63$ & $\begin{array}{l}\text { Sangat agresiv s/d } \\
\text { jenuh }\end{array}$ & $0,06 \mathrm{~s} / \mathrm{d}-1,04$ & $\begin{array}{l}\text { Agak jenuh s/d } \\
\text { agresiv }\end{array}$ \\
\hline Gua Gilap & Tengah-hulu & $-0,15 \mathrm{~s} / \mathrm{d} 1,18$ & $\begin{array}{c}\text { Agresiv s/d sangat } \\
\text { jenuh }\end{array}$ & $-0,51 \mathrm{~s} / \mathrm{d}-1,21$ & $\begin{array}{l}\text { Agresif s/d sangat } \\
\text { agresiv }\end{array}$ \\
\hline Gua Ngreneng & Bocoran-hilir & $-0,22 \mathrm{~s} / \mathrm{d} 0,05$ & $\begin{array}{l}\text { Agresiv s/d agak } \\
\text { jenuh }\end{array}$ & $-0,96 \mathrm{~s} / \mathrm{d}-0,99$ & Sangat agresiv \\
\hline Gua Bribin & Hilir & $-0,93 \mathrm{~s} / \mathrm{d} 0,29$ & $\begin{array}{l}\text { Agresiv s/d agak } \\
\text { jenuh }\end{array}$ & $-0,12 \mathrm{~s} / \mathrm{d}-1,01$ & $\begin{array}{l}\text { Agresif s/d sangat } \\
\text { agresiv }\end{array}$ \\
\hline
\end{tabular}

Sumber : hasil analisis data 2006-2007

Dari Tabel 11. terlihat bahwa julat indeks kejenuhan (SI) pada tiap-tiap gua mempunyai perbedaan nilai. Jika dilihat dari posisi dan kedudukannya, pada musim kemarau dan penghujan gua-gua di bagian hilir (G.Bribin dan Ngreneng) mempunyai nilai SI yang agresivitasnya lebih konstan dibanding gua-gua yang lain (julatnya tidak terlalu besar). Kenyataan ini bisa dilihat di Gua Bribin yang memiliki PAD paling stabil dibandingkan gua-gua yang lain. Meskipun demikian, sepanjang tahun air sungai di Gua Bribin mempunyai sifat paling agresif dibanding dengan tempat lain, bahkan nilai SI di Gua Bribin belum pernah melebihi angka 0 (setimbang) pada musim hujan (selalu agresif). Hal yang sama juga dijumpai di Gua Ngreneng. Jika dibandingkan dengan nilai SI di gua bagian hulu, sebagai contoh adalah Gua Gilap, maka Gua Gilap di musim kemarau mencapai nilai SI tertinggi sebesar 0,61, menunjukkan bahwa proses pelarutan sudah terhenti, bahkan pada awal musim kemarau nilai SI positif sudah tercapai. Hal yang sama juga dijumpai di Luweng Jomblangan dan Sungai Pentung. Sebaliknya, hal demikian tidak ditemukan di gua-gua bagian hilir. Hal ini mengindikasikan bahwa proses pembentukan endapan gua (terutama saat kemarau) lebih intensif terjadi pada gua-gua di daerah hulu, sementara proses pelebaran lorong (pelarutan) yang lebih intensif yang ditandai dengan nilai SI negatif terjadi di gua-gua bagian hilir (G. Bribin dan Ngreneng), meskipun pada saat musim hujan proses-proses tersebut lebih dipengaruhi oleh pasokan komponen aliran conduit dari air hujan. Kenyataan distribusi nilai SI ini mengindikasikan bahwa terdapat proses percampuran (mixing) yang lebih intensif antara komponen aliran diffuse dan fissure di gua-gua bagian hilir. Ford dan Williams (1992), Bogli (1980), Plummer (1975), dan Jankowski dan Jacobson (1991) menjelaskan bahwa percampuran antara dua air yang masing-masing sudah jenuh (SI=positif) terhadap mineral kalsit mampu menurunkan nilai SI kalsit dan menyebabkan air menjadi agresif untuk melarutkan batuan karbonat. Kenyataan yang dijumpai dari perhitungan nilai persentase aliran dasar (PAD) pada pembahasan 
sebelumnya adalah bahwa gua-gua di bagian hilir (khususnya Gua Bribin) mempunyai nilai PAD yang tinggi yang merupakan campuran dari komponen aliran diffuse dan fissure Hal inilah yang kemungkinan menyebabkan nilai agresivitas SBT Bribin di bagian hilir bersifat undersaturated saat kemarau.

\section{b. Karakter parameter SKD di SBT Bribin}

Menurut Daoxian (2005), parameter-parameter kualitas air karst yang biasa digunakan untuk mengetahui pola SKD di suatu daerah adalah variasi nilai $\mathrm{pH}$, SI, tekanan parsial gas karbondioksida, kandungan kalsium (atau bikarbonat) yang dilakukan pada komponen-komponen air sungai bawah tanah yaitu: (1) air hujan sebagai masukan, (2) air tetesan dari ornamen sebagai indikasi proses pelarutanpengendapan, dan (3) air sungai bawah tanah. Tabel 12. dan Tabel 13. menyajikan julat besaran nilai parameter-parameter SKD di daerah hulu dan hilir. Khusus untuk hujan tidak dibedakan antara bagian hulu dan hilir dan tidak dibedakan antara musim hujan dan kemarau agar dapat diketahui perbedaan karakteristik parameter SKD air hujan dengan air tetesan dan air sungai bawah tanah.

Tabel 12. Distribusi Nilai Komponen SKD SBT Bribin Saat Kemarau

\begin{tabular}{|c|c|c|c|c|c|c|}
\hline \multirow[b]{2}{*}{ KOMPONEN SKD } & \multicolumn{3}{|c|}{ DAERAH HULU (GUA GILAP) } & \multicolumn{3}{|c|}{ DAERAH HILIR (GUA BRIBIN) } \\
\hline & AIR HUJAN & AIR TETESAN & $\begin{array}{c}\text { SUNGAI } \\
\text { BAWAH } \\
\text { TANAH }\end{array}$ & AIR HUJAN & AIR TETESAN & $\begin{array}{l}\text { SUNGAI } \\
\text { BAWAH } \\
\text { TANAH }\end{array}$ \\
\hline pH & $6,29-6,55$ & $8,29-8,57$ & $7,06-8,42$ & $6,29-6,55$ & $7,06-7,72$ & $6,96-7,39$ \\
\hline $\log P_{\mathrm{CO} 2}$ & $-1,59--1,87$ & $-3,03--3,31$ & $-1,71--3,09$ & $-1,59--1,87$ & $-1,88--2,47$ & $-1,53--2.13$ \\
\hline SI kalsit & $-1,77--2,14$ & $0,56-1,25$ & $-0,15-1,18$ & $-1,77--2,14$ & $-0,52-0,29$ & $-0,83-0,26$ \\
\hline $\mathrm{Ca}^{2+}$ (mg/lt) & $14,3-18,8$ & $62,6-80,0$ & $50,56-68,08$ & $14,3-18,8$ & $45,1-92,7$ & $86,13-110,3$ \\
\hline $\mathrm{HCO}_{3}^{-}(\mathrm{mg} / \mathrm{lt})$ & $43,3-53,1$ & $183-248$ & $178-265$ & $43,3-53,1$ & $164-347$ & $242-278$ \\
\hline
\end{tabular}

Sumber : hasil analisis data 2006-2007

Tabel 13. Distribusi Nilai Komponen SKD SBT Bribin Saat Musim Hujan

\begin{tabular}{|c|c|c|c|c|c|c|}
\hline \multirow[b]{2}{*}{ KOMPONEN SKD } & \multicolumn{3}{|c|}{ DAERAH HULU (GUA GILAP) } & \multicolumn{3}{|c|}{ DAERAH HILIR (GUA BRIBIN) } \\
\hline & AIR HUJAN & AIR TETESAN & $\begin{array}{c}\text { SUNGAI } \\
\text { BAWAH } \\
\text { TANAH }\end{array}$ & AIR HUJAN & AIR TETESAN & $\begin{array}{l}\text { SUNGAI } \\
\text { BAWAH } \\
\text { TANAH }\end{array}$ \\
\hline pH & $6,29-6,55$ & $6,67-7,22$ & $6,52-7,12$ & $6,29-6,55$ & $6,93-7,18$ & $6,46-7,03$ \\
\hline $\log \mathrm{P}_{\mathrm{CO} 2}$ & $-1,59--1,87$ & $-1,37--2,00$ & $-1,47--1,95$ & $-1,59--1,87$ & $-1,65--1,98$ & $-1,19--1,79$ \\
\hline SI kalsit & $-1,77--2,14$ & $-0,17--1,10$ & $-0,51--1,31$ & $-1,77--2,14$ & $-0,65--0,79$ & $-0,12--1,79$ \\
\hline $\mathrm{Ca}^{2+}(\mathrm{mg} / \mathrm{lt})$ & $14,3-18,8$ & $12,0-57,5$ & $31,8-42,7$ & $14,3-18,8$ & $15,6-41,3$ & $67,7-134,4$ \\
\hline $\mathrm{HCO}_{3}^{-}(\mathrm{mg} / \mathrm{lt})$ & $43,3-53,1$ & $111-187$ & $110-154$ & $43,3-53,1$ & $148-192$ & $149-300$ \\
\hline
\end{tabular}

Sumber : hasil analisis data 2006-2007 
Pada saat musim kemarau dan musim hujan, terlihat pengelompokan atau perbedaan nilai parameter-parameter SKD antara air tetesan dan sungai bawah tanah, dan bahkan jika dibandingkan dengan parameter SKD dari air hujan yang jatuh di daerah tangkapan SBT Bribin. Vesper dan White (2004) dan Daoxian (2005) menjelaskan bahwa untuk mengkarakterisasi parameter-parameter SKD pada berbagai jenis air di daerah karst dan untuk mengetahui interaksi antar parameter, dapat menggunakan scatter plot analysis. Dari hasil analisis scatter plot antara SI kalsit dan $\log \mathrm{P}_{\mathrm{CO} 2}$, SI kalsit dan log kalsium, SI kalsit dan $\mathrm{pH}$, serta SI kalsit dan log $\mathrm{P}_{\mathrm{CO} 2}$ pada gua di bagian hulu dan gua bagian hilir pada musim kemarau dan penghujan (Lampiran 2 dan Lampiran 3), maka dapat dijelaskan bahwa:

(1) Pada saat kemarau, kondisi agresivitas air di bagian hulu SBT Bribin (Gua Gilap) sebagian besar berada pada kondisi jenuh (supersaturated-SI positif) yang dialami oleh air tetesan maupun air sungai bawah tanah. Ciri-ciri lain yang ditemukan adalah tingginya nilai $\mathrm{pH}$, sedikitnya tekanan parsial gas karbondioksida, dan kalsium terlarut yang tinggi. Tingginya nilai SI kalsit di Gua Gilap mempunyai determinasi yang kuat dengan minimnya pasokan gas karbondioksida dari lorong (closed system), karena gas karbondioksida sudah dimanfaatkan untuk proses pelarutan pada zone tak jenuh, serta nilai $\mathrm{pH}$ dan kalsium terlarut yang tinggi. Proses hidrogeokimia yang dominan adalah water-rock interaction berupa pengendapan mineral kalsit, yang menyebabkan terbentuknya ornamen bawah permukaan yang intensif.

(2) Kondisi agresivitas di bagian hilir SBT Bribin (Gua Bribin) cenderung bersifat agresif (undersaturated-SI negatif). Berbeda dengan yang ditemukan di Gua Gilap, nilai $\mathrm{pH}$ di Gua Bribin tetap rendah sepanjang musim kemarau dengan fluktuasi yang relatif stabil. Selain itu, nilai tekanan parsial gas karbondioksida tercatat jauh lebih tinggi dari yang ditemukan di Gua Gilap yang mengindikasikan adanya sitem pelorongan yang terbuka (open system) sehingga setiap saat selalu ada pasokan gas karbondioksida yang menyebabkan air bersifat agresif. Akibatnya, proses yang dominan adalah pelarutan (dissolution) kalsit yang dicirikan secara fisik dengan lebarnya lorong sungai bawah tanah serta minimnya ornamen bawah permukaan karst.

(3) Pada musim hujan, karena adanya proses pengenceran oleh air hujan (dillution by precipitation), maka kondisi agresivitas air baik di hulu maupun di hilir mengalami penurunan menuju kondisi tidak jenuh (undersaturated) yang mengakibatkan dominasi proses pelarutan dan pelebaran lorong. Demikian juga yang dialami oleh paramater-parameter SKD lain, yaitu bertambahnya pasokan 
gas karbondioksida dari conduit flow, turunnya $\mathrm{pH}$ dan turunnya kalsium terlarut, meskipun kondisi agresivitas di Gua Bribin lebih tinggi jika dibandingkan dengan Gua Gilap. Selain itu, proses lain yang dijumpai adalah percampuran (mixing) antara air tetesan dan air sungai bawah tanah, serta kuatnya difusi gas karbondioksida pada gua bagian hilir karena sifat pelorongannya yang mempunyai sistem terbuka (open system). Konseptual model kondisi agresivitas dan parameter SKD SBT Bribin bagian hulu dan hilir saat musim hujan disajikan pada Gambar 2. dan Gambar 3.

\section{Kesimpulan}

1. PAD terbesar dijumpai di Gua Bribin (hilir) karena sifat akuifernya yang melepaskan komponen aliran diffuse $\left(\mathrm{K}_{\mathrm{b}}\right)$ paling lambat. Sementara itu, Gua Gilap di bagian hulu perkembangan lorong guanya cenderung kearah fissure $\left(\mathrm{K}_{\mathrm{i}}\right)$ dengan PAD yang lebih kecil dibanding daerah hilir. Pada saat kejadian banjir, penurunan PAD secara drastis terjadi khususnya di Gua Ngreneng karena mempunyai nilai $\mathrm{K}_{\mathrm{c}}$ paling kecil. Selain itu, berdasarkan fakta-fakta yang berkaitan dengan sifat komponen alirannya, temuan yang dapat dikemukakan adalah bahwa akuifer yang mengimbuh Gua Bribin dapat dikategorikan sebagai akuifer yang bertipe campuran (mixed), yaitu didominasi oleh imbuhan dari retakan yang bertipe diffuse pada musim kemarau, dengan debit andalan yang stabil, sifat imbuhannya tersebar (dispersed), dengan simpanan air di akuifernya tinggi, sedangkan pada musim hujan imbuhannya merupakan campuran dari komponen diffuse, fissure dan conduit. Secara spasial, Gua Ngreneng yang merupakan bocoran dari SBT Bribin, mempunyai akuifer bertipe campuran dengan perkembangan lorong fissure dan conduit yang lebih besar daripada yang dialami oleh akuifer yang mengimbuh Gua Bribin, sifat imbuhannya dominan terpusat (concentrated) dan simpanan aliran diffuse di akuifer rendah, sehingga debit alirannya turun drastis pada saat musim kemarau. Di bagian hulu, Gua Gilap mempunyai perkembangan akuifer lebih ke arah dominasi retakan menengah (fissure), imbuhannya campuran antara dispersed dan concentrated, dengan simpanan aliran diffuse di akuifer sedang, sehingga debit alirannya turun drastis hanya pada saat puncak musim kemarau. 


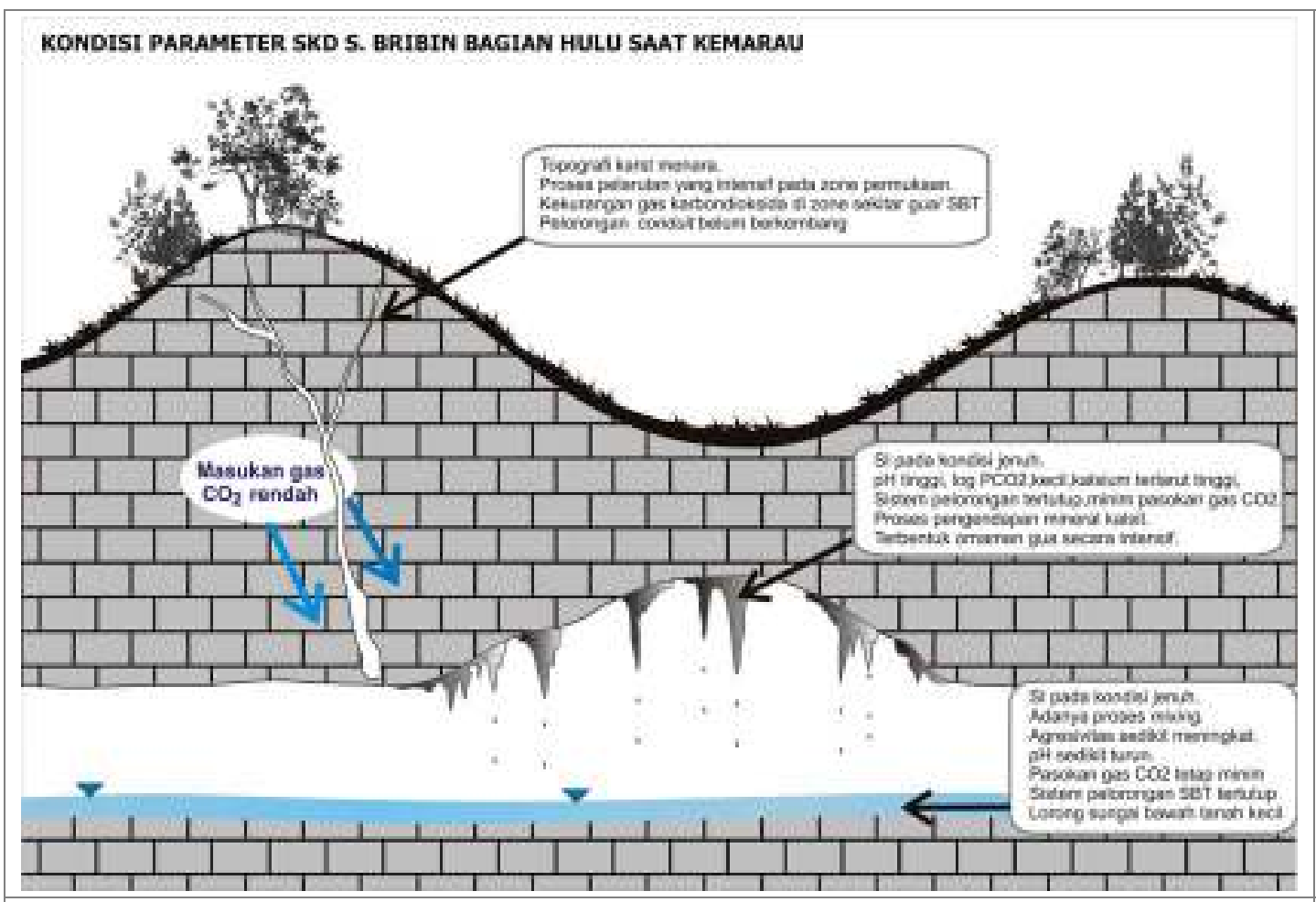

KONDISI PARAMETER SKD S. BRIBIN BAGIAN HILIR SAAT KEMARAU

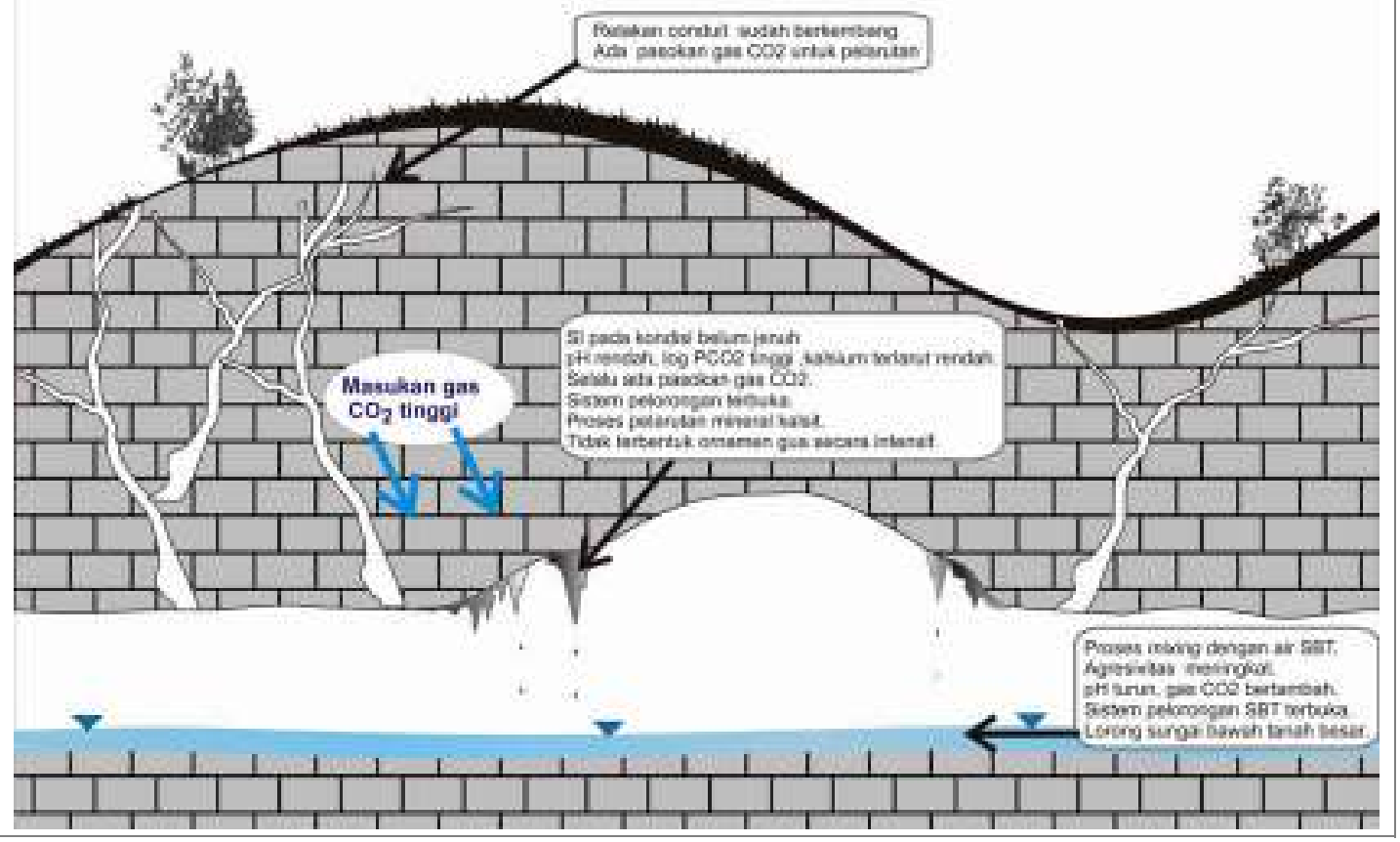

Gambar 2. Model tingkat agresivitas airtanah karst di musim kemarau 


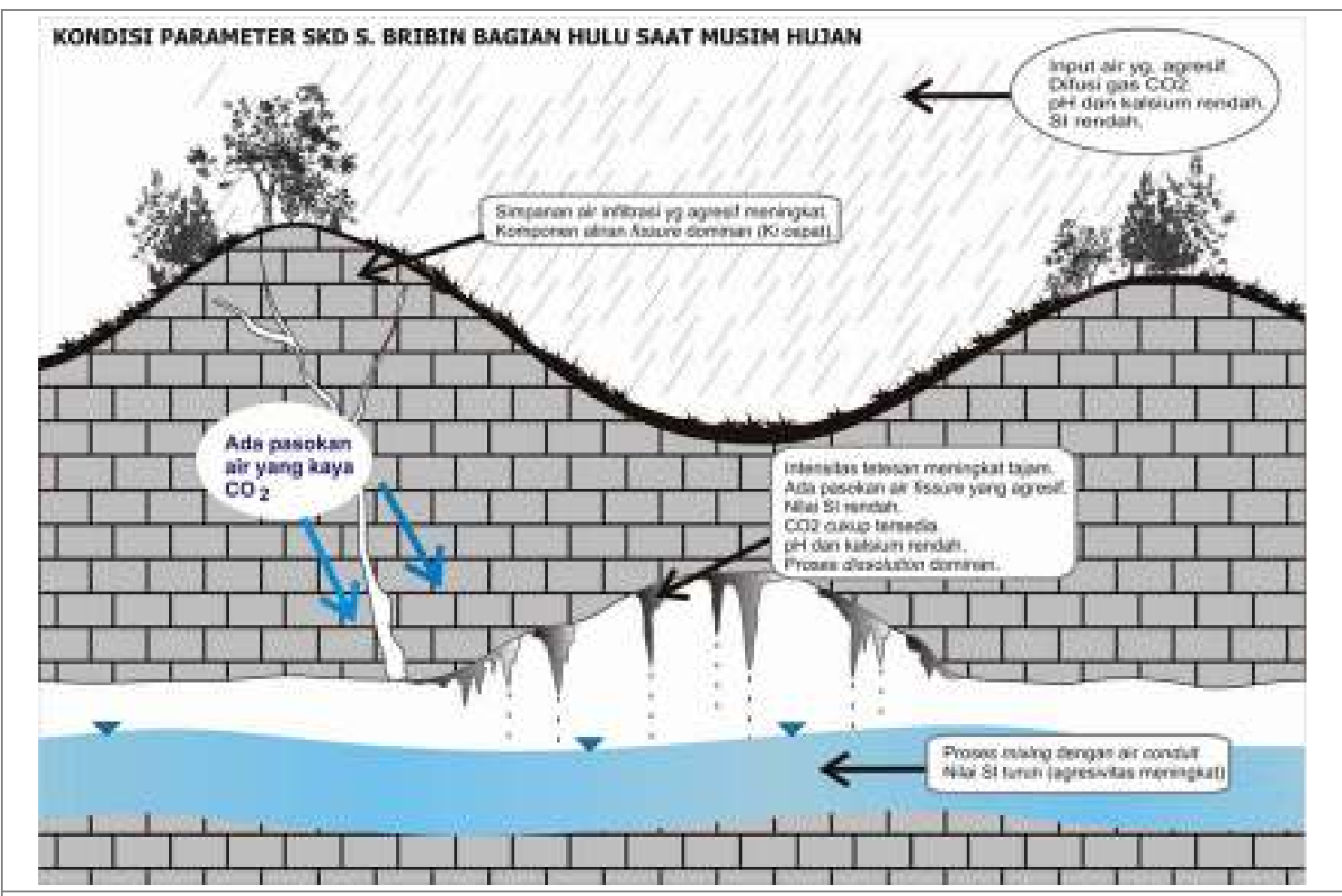

KONDISI PARAMETER SKD S. BRIBIN BAGIAN HILIR SAAT MUSIM HUJAN

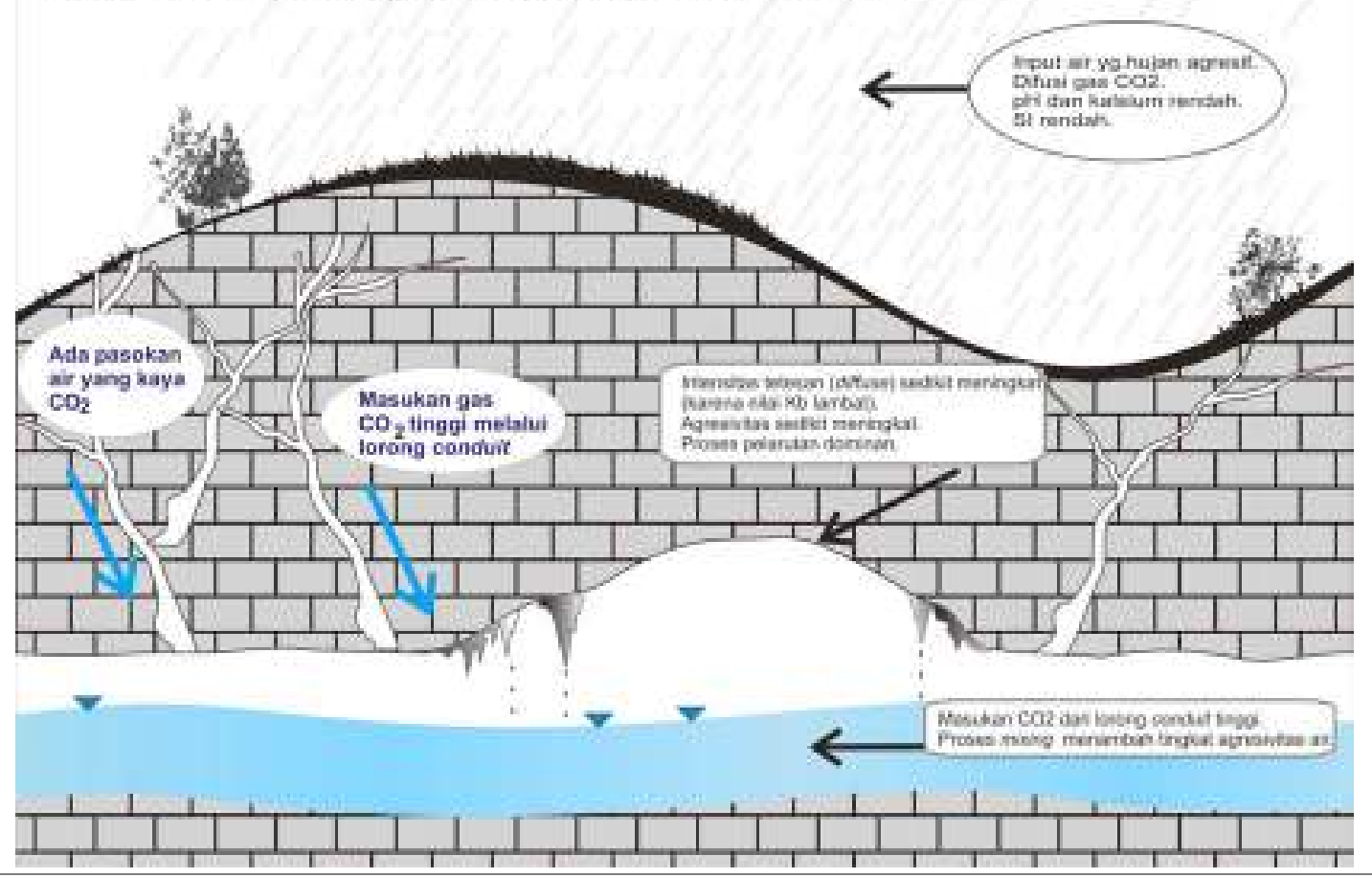

Gambar 3. Model tingkat agresivitas airtanah karst di musim hujan 
2. Gua Bribin di hilir mempunyai hubungan antara PAD-hidrogeokimia paling kuat karena PADnya yang paling besar, sehingga proses water-rock interaction dominan, meskipun secara umum selama musim kemarau terdapat hubungan yang cukup kuat antara PAD-hidrogeokimia di sepanjang SBT Bribin. Pada saat musim hujan, hubungan PAD-hidrogeokimia di SBT Bribin menjadi lemah sebagai akibat tingginya pasokan komponen conduit, terutama pada gua-gua yang berfungsi sebagai sinkhole $\left(\mathrm{K}_{\mathrm{c}}=\right.$ kecil) seperti yang ditemukan di Gua Ngreneng. Dari faktafakta tersebut, penelitian ini menemukan bahwa Gua Bribin menunjukkan hubungan PAD-hidrogeokimia yang kuat karena dominasi komponen aliran diffuse pada musim kemarau. Sebaliknya, gua-gua lain di SBT Bribin mempunyai dominasi aliran diffuse yang lebih rendah, sehingga hubungan antara PAD-hidrogeokimia juga menjadi lebih lemah. Secara metodologis, penelitian ini menemukan bahwa hubungan PAD-hidrogeokimia dapat digunakan sebagai indikator karakteristik komponen aliran yang mengimbuh suatu SBT. Jika hubungan PAD-hidrogeokimia kuat, maka aliran yang dominan mengimbuh SBT adalah diffuse, sehingga proses hidrogeokimia yang terjadi adalah water-rock interaction, sedangkan jika hubungan PAD-hidrogeokimia lemah, maka diffuse flow menjadi tidak dominan dan proses hidrogeokimia yang mengontrol perkembangan SBT adalah dilution by precipitation dan campuran (mixing) dari berbagai komponen aliran. Pada saat musim hujan, hubungan PAD-hidrogeokimia juga dapat menjelaskan karakteristik imbuhan pada suatu SBT, meskipun saat kejadian banjir SBT diimbuh oleh berbagai komponen aliran. Secara umum hubungan PAD-hidrogeokimia di gua-gua sepanjang SBT Bribin saat periode hujan adalah menurun, meskipun penurunan paling sedikit tetap dialami oleh Gua Bribin karena PADnya yang lebih stabil (dominasi diffuse) dibanding gua-gua yang lain. Sebaliknya, gua-gua lain terutama yang morfologi entrancenya merupakan suatu sinkhole, ditemukan penurunan hubungan PADhidrogeokimia yang drastis karena tingginya pasokan aliran conduit (dilution by precipitation dominan).

3. Saat kemarau, air SBT di Gua Bribin (hilir) mempunyai sifat paling agresif dengan ciri-ciri tekanan gas $\mathrm{CO}_{2}$ yang lebih tinggi dibanding yang ditemukan pada gua-gua lain karena sifat pelorongan conduitnya yang bersifat terbuka (open system). Hal yang hampir sama dijumpai juga dengan tingkat agresivitas yang sedikit lebih rendah, yaitu di Luweng Jomblangan (morfologi=cenote). Hal lain yang berpengaruh adalah adanya percampuran (mixing) antara komponen conduit dan diffuse yang menurunkan tingkat kejenuhan air SBT meskipun PADnya besar dan sudah jenuh dengan unsur terlarut dalam air. Sebaliknya di bagian hulu, meskipun 
PADnya lebih kecil dengan unsur terlarut lebih sedikit, tetapi pasokan gas karbondioksidanya lebih sedikit karena sifat pelorongannya yang belum begitu berkembang (closed system), sehingga tingkat agresivitas airnya rendah. Pada saat musim hujan, tingkat agresivitas gua meningkat akibat tingginya pasokan komponen conduit, terutama pada gua-gua yang berfungsi sebagai sinkhole $\left(\mathrm{K}_{\mathrm{c}}=\mathrm{kecil}\right)$ seperti Gua Ngreneng dan Luweng Jomblangan, yang menaikkan tekanan parsial gas $\mathrm{CO}_{2}$ dalam air. Dari fakta-fakta tersebut ditemukan bahwa kontrol utama yang bertanggung jawab terhadap proses pelarutan batuan gamping di SBT Bribin cenderung pada sistem pelorongannya yang bersifat terbuka atau tertutup yang menentukan ketersediaan gas karbondioksida daripada sifat pelepasan atau imbuhan komponen aliran karst dari akuifer ke sungai bawah tanah. 


\section{SPATIAL AND TEMPORAL VARIATION OF HIDROGEOCHEMISTRY AND KARST FLOW PROPERTIES TO CHARACTERIZE KARST DYNAMIC SYSTEM IN BRIBIN UNDERGROUND RIVER, GUNUNG KIDUL REGENCY, DIY PROVINCE}

\section{Summary}

Geography Study Program

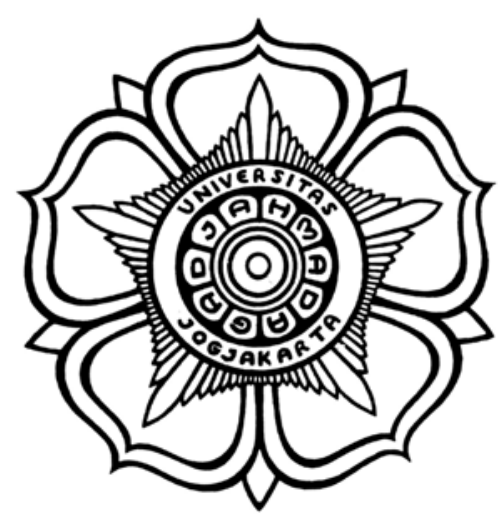

By:

Tjahyo Nugroho Adji

05/1729/PS

\section{GRADUATE SCHOOL FACULTY OF GEOGRAPHY \\ GADJAH MADA UNIVERSITY \\ YOGYAKARTA \\ 2010}




\begin{abstract}
This research is conducted in karst area, which is particularly enclosed by Bribin Underground River Catchment, Gunungkidul Regency. The objectives of this study are: (1) to understand spatial and temporal variation of flow characteristic as well as Diffuse Flow Proportion (PAD) of Bribin River; (2) to assess hydrogeochemistry and to recognize the relationship between hydrogeochemistry and flow characteristics of Bribin River, and (3) to define water agressivity of Bribin River with respect to carbonate mineral and to express the components of Karst Dynamic System (KDS) one-year behavior.

To define flow characteristic and PAD, three water level data loggers are installed within upper, lower and the leakage point along Bribin River continued by discharge measurement with the purpose of attaining stage-discharge rating curve. Afterwards, PAD is defined by conducting digital filtering baseflow separation approach after calculation of diffuse, fissure, and conduit recession constant. Next, to figure out hydrogeochemical condition, 120 sample of karst water are analyzed including rain, underground-river, and drip water. After that, scatter plots between hydrogeochemical parameters are conducted to achieve the correlation between PAD and hydrogeochemistry as well as to figure out hydrogeochemical processes to occur. Subsequently, Saturation Indices analysis with respect to calcite mineral and KDS components correlation is carried out to define karst water agressivity and its manners along flowpath of Bribin River.

The research's result demonstrates that there is spatial and temporal differentiation of flow characteristics along Bribin River attributable to the comportment of karst aquifer toward discharging its diffuse, fissure, or conduit flow components, which consequence to the dissimilarity of PAD distribution along Bribin River. Accordingly, PAD characteristics result to dry season hydrogeochemical condition of Bribin River. However, wet season hydrogeochemical condition is more influenced by means of dilution by precipitation process within flood events, which exaggerates $\mathrm{CO}_{2}$ content of water. Generally, the upper-stream cave tend to more aggressive in dissolving limestone, contrast to down-steam cave that be inclined to precipitate carbonate mineral as a result of their differentiation of cavities configuration. In addition, down-stream cave is characterized by open system cavities, subsequent to the $\mathrm{CO}_{2}$ discharge to preserve dissolution process.
\end{abstract}

Keywords : Flow characteristic, diffuse, fissure, conduit, hydrogeochemistry, aggressivity 


\section{A. Introduction}

\section{Problem statement}

Karst Dynamic Systems (SKD) term introduced by Daoxian (2005) actually is not the new term. Previously, Bogli (1960, 1980), Sweeting (1972), Trudgill (1985), Ford and Williams (1992) had explained this word as a system that covers dynamic processes among $\mathrm{H}_{2} \mathrm{O}, \mathrm{CO}_{2}$, and $\mathrm{CaCO}_{3}$ controlled by the limestone aquifer environment. White (1988), Ford and Williams (1992), Smart and Hobbes (1986), as well as Gillieson (1996) principally divide the characteristics of karst aquifer flows into three components, i.e. conduit; fissure, and diffuse. Each part has different characteristic and resource that is highly associated with 4 major components of aquifer to recharge (White, 2004). Those are allogenic recharge, internal runoff, diffuse infiltration and perched aquifer overlying karst aquifer. Within karst aquifer, the major process to control characteristic and karst aquifer flow is dissolution. In addition, Dreybort and Gabrovsek (2003) states that the rate of dissolution process is highly correlated with the concentration level of $\mathrm{CO}_{2}$ within karst groundwater. Also, the type of conduit, whether it is open or close system, also controls the rate of dissolution process (Freeze and Cherry, 1979).

In general, the research to disclose the nature and characteristics of karst aquifer employs inductive approaches since the type of conduit is anisotropic. According to Mudry (2004), one of inductive approaches is hydrogeochemical method assuming that chemical constituents of karst groundwater reflect to the process inside karst aquifer. This method is typically collective with the nature of underground flow to acquire the most representative method, to describe the system of groundwater karst storage media and the flow nature of limestone aquifer that is correlated with chemical characteristics of karst groundwater (Liu, et al, 2004a and 2004b, Etfimi, 2005, Wang and Luo, 2001, Anthony, et al, 1997, as well as Raeisi and Karami, 1997). Martin et al. (2002) and Karimi et al. (2004) opine that beside the interaction between diffuse flow and conduit flow, it turns out that the aggressivity of karst groundwater also plays important role on fissure carbonate rock development. On the other hand, Taylor and Greene (2001) conclude that quantitative approach is needed to describe the characteristic of karst aquifer in detail.

Bribin Underground River (SBT Bribin) has high potency as the primary water resource to fulfill the need of domestic community at Gunungsewu Karst, Gunungkidul Regency. This area is famous as a water deficiency region due to the depth conduit 
system to be achieved. In 2004 to 2009, The Government of Gunungkidul cooperates with The Government of DIY Province, Ministry of Research and Technology, BATAN, Federal Misnistry and Education-Universitas Kalsruhe, Germany has finished to drill and to dam SBT Bribin to be used as micro-hydro systems. This dam is expected to produce 250 to $300 \mathrm{KW}$ of electricity to double the service capacity of groundwater distribution. However, the research on the nature of flow, karst aquifer and hydrogeochemical processes to control the development of SBT Bribin channel has not been conducted yet. Thus, some issues raise:

1. How are the SBT Bribin flow properties to release its karst flow components and its dependable flow (PAD) along the year?;

2. How is the relationship between hydrogeochemical condition and SBT Bribin karst flow properties?;

3. How is the SKD characteristic that is approached by aggressivity level to dissolve carbonate rock and its relationship to the SKD parameters along the year?

\section{Research objective}

The objectives of this research are as follows:

1. To analyze the spatial and temporal in terms of characteristic and PAD of SBT Bribin;

2. To evaluate the hydrogeochemical condition along SBT Bribin and to find its relationship with the karst flow nature;

3. To characterize SKD within SBT Bribin that is approached by aggressivity level to dissolve limestone and its relationship to SKD parameters during the year;

\section{B. Research Method}

This research uses inductive approach that is similar with Quasi-Experimental Research as a part of Experimental Research (Dane, 1990) because the nature of karst aquifer is anisotropic (permeability to every directions different)-the uncontrolled conduit. Also, no homogeny and gradual correlation between surface and underground surface is another reason that this research does not apply deductive approach.

In addition, the difficulty to survey the karst aquifer condition, such as the thickness of carbonate rock, the $\mathrm{CO}_{2}$ content within aquifer, the fissure network, and conduit on karst aquifer that can not be directly correlated with the condition of SBT 
Bribin, supports the using of the Quasi-Experimental Research to be applied in this research. The research design is Time Series Design of Quasi-Experimental Research, using Field- Survey Research Method.

\section{The materials and tools}

The principal materials is white and blank panchromatic aerial photo-scale 1:20.000 and 1:30.000 year 1992, 1993, and 1994, digital topographical map scale 1 : 25.000 year 2001, Gunungsewu karst underground river map by MacDonalds and Partners (1984), as well as LANDSAT and SRTM satellite image.

The major tools used in this research are stated below.

a. HOBO-water level data logger to record the SBT Bribin water level fluctuation

b. Current meter to measure the underground river discharge

c. Some tools to measure the field water quality parameters $(\mathrm{pH}, \mathrm{Eh}, \mathrm{EC}$, and temperature)

d. Water sampling tools

\section{The boundary of the research area}

The research area covers all rainfall catchments area of SBT Bribin. The boundary is based on MacDonalds and Partners (1984) that Bribin cave is assumed to be an outlet at the lower part of this river.

\section{Data}

The primary data in this research is discharge fluctuation of SBT Bribin during a year. The tools to record the water surface fluctuation are placed at 3 locations: Gilap Cave (upper course), Bribin Cave (under course), and Ngreneng Cave (leakage), for one year time period. During observation period, discharge measurement is conducted several times to get the data of minimum, average and maximum discharge. The data is needed to construct the stage discharge rating curve. During one year, the sample of 5 points along SBT Bribin is taken once a month. In period of rain season, the number of the sampling taken is adjusted with the flood hydrograph period to get sampling variation at normal, peak, and recession stage.

\section{Data analysis}

Some analyses are conducted in this research as follows. 
a. Spatial and temporal analysis of SBT Bribin flow components characteristic during one year that cover: (1)analysis of the relationship between underground river discharge and water level; (2)analysis of recession constant and hydrograph; (3)analysis of baseflow separation

b. Spatial and temporal variation analysis of hydrogeochemical and aggressivity of karst groundwater. This analysis consists of: (1)Charge Balance Error Calculation analysis; (2)Saturation Indices analysis; (3)partial carbon dioxide water pressure analysis

c. Analysis of SKD components behavior, correlation between components, and correlation with baseflow that consists of (1) monthly hydrogeochemical analysis; (2)hydrogeochemical analysis at peak hydrograph or flood events; (3) long-term and storm-scale hydrochemograph analysis; (4)correlation analysis of variation between hydrogeochemical with flow component characteristics; (5) behavior analysis of SKD indicator (parameter) on rain, drip water of speleothem and water of underground river and correlation analysis between water aggressivity with $\mathrm{pH}$, dissolved calcium, and partial carbondioxide pressure.

\section{Result and Analysis}

\section{Spatial and temporal characteristics of flow and PAD along SBT Bribin}

The flow and PAD characteristics along Bribin Underground River covers: (1) recession constant and flow hydrograph parameter; and (2) the baseflow percentage from Gilap Cave (upper course), Bribin Cave (under course) and Ngreneng Cave (leakage) in which the tools to record the fluctuation of water surface of underground river is installed.

\section{a. Recession constant $(K)$, time to peak $\left(T_{p}\right)$, and time to baseflow $\left(T_{b}\right)$}

The recession constant studied in this research is divided into 3 parts. Those are: (i) recession constant for conduit $\left(\mathrm{K}_{\mathrm{c}}\right)$; (ii) recession constant for fissure $\left(\mathrm{K}_{\mathrm{i}}\right)$; and (iii) recession constant for diffuse $\left(\mathrm{K}_{\mathrm{b}}\right)$. The comparison of recession constant among the three caves (Bribin, Gilap, and Ngreneng caves) describes the karst aquifer characteristics to release the water components inside the karst aquifer. The hydrograph parameter discussed in this research is time to peak $\left(T_{p}\right)$, that describes how fast the karst aquifer response to recharge the underground river, and time to baseflow $\left(T_{b}\right)$. The parameter index of the three caves along SBT Bribin is presented in Table 1. 
Table 1. Summary of Recession Constant and Flood Parameter at SBT Bribin

\begin{tabular}{|l|c|c|c|c|c|}
\hline \multicolumn{1}{|c|}{ Caves } & $\mathbf{K}_{\mathbf{c}}$ & $\mathbf{K}_{\mathbf{i}}$ & $\mathbf{K}_{\mathbf{b}}$ & $\mathbf{T}_{\mathbf{p}}(\mathbf{h o u r})$ & $\mathbf{T}_{\mathbf{b}}$ (hour) \\
\hline Gilap & $\begin{array}{c}0.14-0.88 \\
(\mathrm{avg}=0.463)\end{array}$ & $\begin{array}{c}0.39-0.92 \\
(\mathrm{avg}=0.767)\end{array}$ & $\begin{array}{c}0.94-0.99 \\
(\operatorname{avg}=0.996)\end{array}$ & $\begin{array}{c}1.5-5 \\
(\mathrm{avg}=3.03)\end{array}$ & $\begin{array}{c}7-192 \\
(\operatorname{avg}=36.7)\end{array}$ \\
\hline Bribin & $\begin{array}{c}0.02-0.519 \\
(\mathrm{avg}=0.332)\end{array}$ & $\begin{array}{c}0.002-0.95 \\
(\mathrm{avg}=0.825)\end{array}$ & $\begin{array}{c}0.98-0.99 \\
(\mathrm{avg}=0.998)\end{array}$ & $\begin{array}{c}2-9.5 \\
(\mathrm{avg}=5.5)\end{array}$ & $\begin{array}{c}5-192 \\
(\mathrm{avg}=36.3)\end{array}$ \\
\hline Ngreneng & $\begin{array}{c}0.188-0.748 \\
(\mathrm{avg}=0.333)\end{array}$ & $\begin{array}{c}0.732-0.971 \\
(\mathrm{avg}=0.877)\end{array}$ & $\begin{array}{c}0.978-0.999 \\
(\mathrm{avg}=0.992)\end{array}$ & $\begin{array}{c}2.5-7.5 \\
(\mathrm{avg}=4.5)\end{array}$ & $\begin{array}{c}9-240 \\
(\mathrm{avg}=16.8)\end{array}$ \\
\hline
\end{tabular}

$* \mathrm{~K}_{\mathrm{c}}=$ recession constant conduit $; \mathrm{K}_{\mathrm{i}}=$ recession constant fissure; $\mathrm{K}_{\mathrm{b}}=$ recession constant diffuse

$* \mathrm{~T}_{\mathrm{p}}=$ time to peak; $\mathrm{T}_{\mathrm{b}}=$ time to baseflow

Based on the Table 1, it turns out that the recession constant for diffuse, fissure, and conduit flows have variation. The highest average of diffuse flow recession constant is found at Bribin Cave (0.998) with a diminutive variation, indicates that the domination of diffuse flow after flood events on the short and long term period is still tremendous with a minimum discharge of 1600 lt/second. On the other hand, Gilap Cave has a slightly lower average of diffuse recession constant to Bribin's. The variation during flood season is significantly high (0.94-0.99) with 0.996 as the average. Next, the diffuse recession constant at Ngreneng caves has the lowest average (0.992). It designates that Ngreneng caves release the diffuse component faster compared to Bribin Cave and Gilap Cave. This fact is supported by the value of time to peak and time to baseflow (16.8 hours) compared to Gilap Cave and Bribin Cave, 36.7 hours and 36.3 hours, respectively.

Furthermore, the conduit recession constant shows that those three caves have a steep recession for below 0.5 during flood period. The lower recession constant the faster the release of conduit flow component (Schulz, 1976). Ngreneng Cave has a low average of $K_{c}(0.333)$ since within the rain peak period it accepts additional flow from sinkhole. Additionally, the $\mathrm{K}_{\mathrm{c}}$ at Ngreneng Cave is also affected by the flow from Bribin Cave (as a leakage point). Based on time to peak $\left(T_{p}\right)$, this cave should have similar period of time to reach flood peak as Bribin Cave. However, the research shows that the $T_{p}$ of Ngreneng Cave is one hour faster than Bribin Cave's due to its morphology as a sinkhole. Meanwhile, Gilap Cave that is located at the upper course has the highest $\mathrm{K}_{\mathrm{p}}$ and $\mathrm{T}_{\mathrm{p}}$ among other two caves.

On the other hand, the fissure recession constant $\left(\mathrm{K}_{\mathrm{i}}\right)$ for those three caves do not differ significantly with the range between 0.767 and 0.877 . Gilap Cave has the lowest $\mathrm{K}_{\mathrm{i}}(0.767)$, while Bribin Cave and Ngreneng Cave have parallel $\mathrm{K}_{\mathrm{i}}$ amounting at 0.825 and 0.877 , respectively. Table 1 explains that Gilap Cave has the fastest responds to rain ( $\mathrm{Tp}=3$ hours) due to its location at the upper of catchment area. The average $\mathrm{K}_{\mathrm{b}}$ 
of this cave is high enough (0.996) compared to Ngreneng Cave (0.992). Thus, Gilap cave is still in fine condition to release its water storage from karst aquifer.

Having the lowest $\mathrm{K}_{\mathrm{b}}$, Ngreneng Cave has relatively long period of time to peak (Tp) but a short period of time to baseflow $(\mathrm{Tb})$ for 16.8 hours. It indicates that the baseflow component diffused by aquifer is fast due to its function as a point recharge from the basin neighboring. This also proves that sinkhole has significant relationship with flood hydrograph parameter at Ngreneng Cave. The summary of flood hydrograph parameter and recession constant is shown below.

Table 2. Condition of Karst Aquifer Flow Component Based on Comparison of Flood Hydrograph Parameter

\begin{tabular}{|c|c|c|c|}
\hline $\begin{array}{l}\text { Hydrograph } \\
\text { Parameter }\end{array}$ & Caves & Comparison & Characteristics \\
\hline $\mathrm{K}_{\mathrm{b}}=0.996$ & \multirow{5}{*}{ Gilap } & $\begin{array}{l}>\text { Ngreneng } \\
<\text { Bribin }\end{array}$ & $\begin{array}{l}\text { - aquifer releases diffuse storage faster than Bribin, but slower than } \\
\text { Ngreneng } \\
\text { - Better diffuse flow storage (small fracture) than Ngreneng }\end{array}$ \\
\hline $\mathrm{K}_{\mathrm{i}}=0.767$ & & $\begin{array}{l}<\text { Ngreneng } \\
<\text { Bribin }\end{array}$ & - the fastest fissure storage releasing \\
\hline $\mathrm{K}_{\mathrm{c}}=0.463$ & & $\begin{array}{l}>\text { Ngreneng } \\
>\text { Bribin }\end{array}$ & $\begin{array}{l}\text { - the slowest conduit releasing by aquifer } \\
\text { - the smalest catchment area covered }\end{array}$ \\
\hline $\mathrm{T}_{\mathrm{p}}=3.03$ hour & & $\begin{array}{l}<\text { Ngreneng } \\
<\text { Bribin }\end{array}$ & - the shortest distance to reach flood peak (upper catchment) \\
\hline $\mathrm{T}_{\mathrm{b}}=36.7$ hour & & $\begin{array}{l}>\text { Ngreneng } \\
>\text { Bribin }\end{array}$ & $\begin{array}{l}\text { - aquifer releases diffuse storage in slow manner } \\
\text { - relatively poor conduit development compared to Bribin and } \\
\text { Ngreneng }\end{array}$ \\
\hline $\mathrm{K}_{\mathrm{b}}=0.998$ & \multirow{5}{*}{ Bribin } & $\begin{array}{l}>\text { Ngreneng } \\
>\text { Gilap }\end{array}$ & $\begin{array}{l}\text { - the best diffuse flow storage (slowest diffuse flow releasing by } \\
\text { aquifer) } \\
\text { - significant discharge within peak of dry season }\end{array}$ \\
\hline$K_{i}=0.825$ & & $\begin{array}{l}<\text { Ngreneng } \\
>\text { Gilap }\end{array}$ & - relatively abundant fissure storage (similar to Ngreneng) \\
\hline $\mathrm{K}_{\mathrm{c}}=0.332$ & & $\begin{array}{l}<\text { Ngreneng } \\
<\text { Gilap }\end{array}$ & $\begin{array}{l}\text { - the occurrence of point recharge to increase conduit recession } \\
\text { constant }\end{array}$ \\
\hline $\mathrm{T}_{\mathrm{p}}=5.5$ hour & & $\begin{array}{l}>\text { Ngreneng } \\
>\text { Gilap }\end{array}$ & - the largest catchment area covered \\
\hline $\mathrm{T}_{\mathrm{b}}=36.3$ hour & & $\begin{array}{l}>\text { Ngreneng } \\
<\text { Gilap }\end{array}$ & $\begin{array}{l}\text { - the domination both conduit and diffuse flow components within flood } \\
\text { events } \\
\text { - the slowest diffuse flow component }\end{array}$ \\
\hline $\mathrm{K}_{\mathrm{b}}=0.992$ & \multirow{5}{*}{ Ngreneng } & $\begin{array}{l}<\text { Gilap } \\
<\text { Bribin }\end{array}$ & - the fastest diffuse flow component releasing by aquifer \\
\hline $\mathrm{K}_{\mathrm{i}}=0.877$ & & $\begin{array}{l}>\text { Gilap } \\
>\text { Bribin }\end{array}$ & - the slowest fissure flow component releasing by aquifer \\
\hline $\mathrm{K}_{\mathrm{c}}=0.333$ & & $\begin{array}{l}<\text { Gilap } \\
>\text { Bribin }\end{array}$ & $\begin{array}{l}\text { - cave entrance as apoint recharge to overland flow } \\
\text { - leakage og Bribin main channel }\end{array}$ \\
\hline $\mathrm{T}_{\mathrm{p}}=4.5$ hour & & $\begin{array}{l}>\text { Gilap } \\
<\text { Bribin }\end{array}$ & $\begin{array}{l}\text { - influenced by overlandflow characteristic within flood events to } \\
\text { shorten } T_{p}\end{array}$ \\
\hline $\mathrm{T}_{\mathrm{b}}=16.8$ hour & & $\begin{array}{l}<\text { Gilap } \\
<\text { Bribin }\end{array}$ & $\begin{array}{l}\text { - the fastest releasing diffuse flow component } \\
\text { - development of conduit cavities }\end{array}$ \\
\hline
\end{tabular}

$* \mathrm{~K}_{\mathrm{c}}=$ recession constant conduit $; \mathrm{K}_{\mathrm{i}}=$ recession constant fissure; $\mathrm{K}_{\mathrm{b}}=$ recession constant diffuse

$* \mathrm{~T}_{\mathrm{p}}=$ time to peak; $\mathrm{T}_{\mathrm{b}}=$ time to baseflow 
According to Table 2, it seems the river at Bribin Cave performs the most significant baseflow storage and confirms the slowest releasing compared to Ngreneng and Gilap Caves. The upper point within catchment at SBT Bribin, represented by Gilap Cave, has a slow baseflow release that graciously contributes to the sustainability of SBT Bribin discharge within dry season. Due to its position at upper course, nevertheless, it has the fastest response to flood and low discharge within dry season. In addition, Ngreneng Cave has different characteristics. Although it is a leakage from and located closed to SBT Bribin, it performs different aquifer releasing characteristics from Bribin's due to its entrance morphology as a recharge point for some karst basins surrounding.

\section{b. Baseflow Percentage (PAD)}

PAD is a ratio of baseflow discharge separated from flood hydrograph and total flow. Usually, it is used widely to characterize a water storage or aquifer potency to recharge underground river during the year. Table 3 and Figure 1 below show the PAD distribution along SBT Bribin.

Tabel. 3. PAD Condition along SBT Bribin

\begin{tabular}{|c|l|r|r|r|c|}
\hline \multirow{2}{*}{ NO } & \multicolumn{1}{|c|}{ Month } & \multicolumn{3}{|c|}{ PAD (\%) } & SEASON \\
\cline { 5 - 7 } & \multicolumn{1}{|c|}{ GILAP } & \multicolumn{1}{c|}{ BRIBIN } & NGRENENG & SE \\
\hline 1 & May 2006 & 80.41 & 97.03 & 80.35 & dry \\
\hline 2 & June 2006 & 80.47 & 98.40 & 80.36 & dry \\
\hline 3 & July 2006 & 80.93 & 98.53 & 80.37 & dry \\
\hline 4 & Augustus 2006 & 81.66 & 98.64 & 80.38 & dry \\
\hline 5 & September 2006 & 81.77 & 98.70 & 80.38 & dry \\
\hline 6 & October 2006 & 82.09 & 99.14 & 80.38 & dry \\
\hline 7 & November 2006 & 82.36 & 99.40 & 80.38 & dry \\
\hline 8 & December 2007 & 80.11 & 97.44 & 81.78 & wet \\
\hline 9 & January 2007 & 84.86 & 98.87 & 82.93 & wet \\
\hline 10 & February 2007 & 77.49 & 97.22 & 83.48 & wet \\
\hline 11 & March 2007 & 82.94 & 97.07 & 82.41 & wet \\
\hline 12 & April 2007 & 82.85 & 98.26 & 81.78 & wet \\
\hline
\end{tabular}

Sumber : data analysis (2006-2007)

Generally, monthly baseflow ratios at the three caves show a similar pattern. Initially, it increases gradually to achieve crest value within the peak of dry season. Afterward, it tends to fluctuate at rainy season by having a lower ratio since it is affected by the increasing conduit flow contribution. Along flowpath of SBT Bribin, the PAD is always augment (Bribin $>$ Gilap). In this case, Bribin has the highest PAD 
(around 95\%) among Ngreneng and Gilap Caves (around 80\%). Interestingly, the monthly PAD pattern at Ngreneng Cave tends to increase, while it tends to decrease at Gilap and Bribin Caves. This fact supports the previous argument that due to the cave entrance as a sinkhole, it appears that the monthly average PAD increases. On the other hand, the percentage of baseflow for all caves tends to decline in flood period, indicates immense additional conduit flow to append (Table 4).

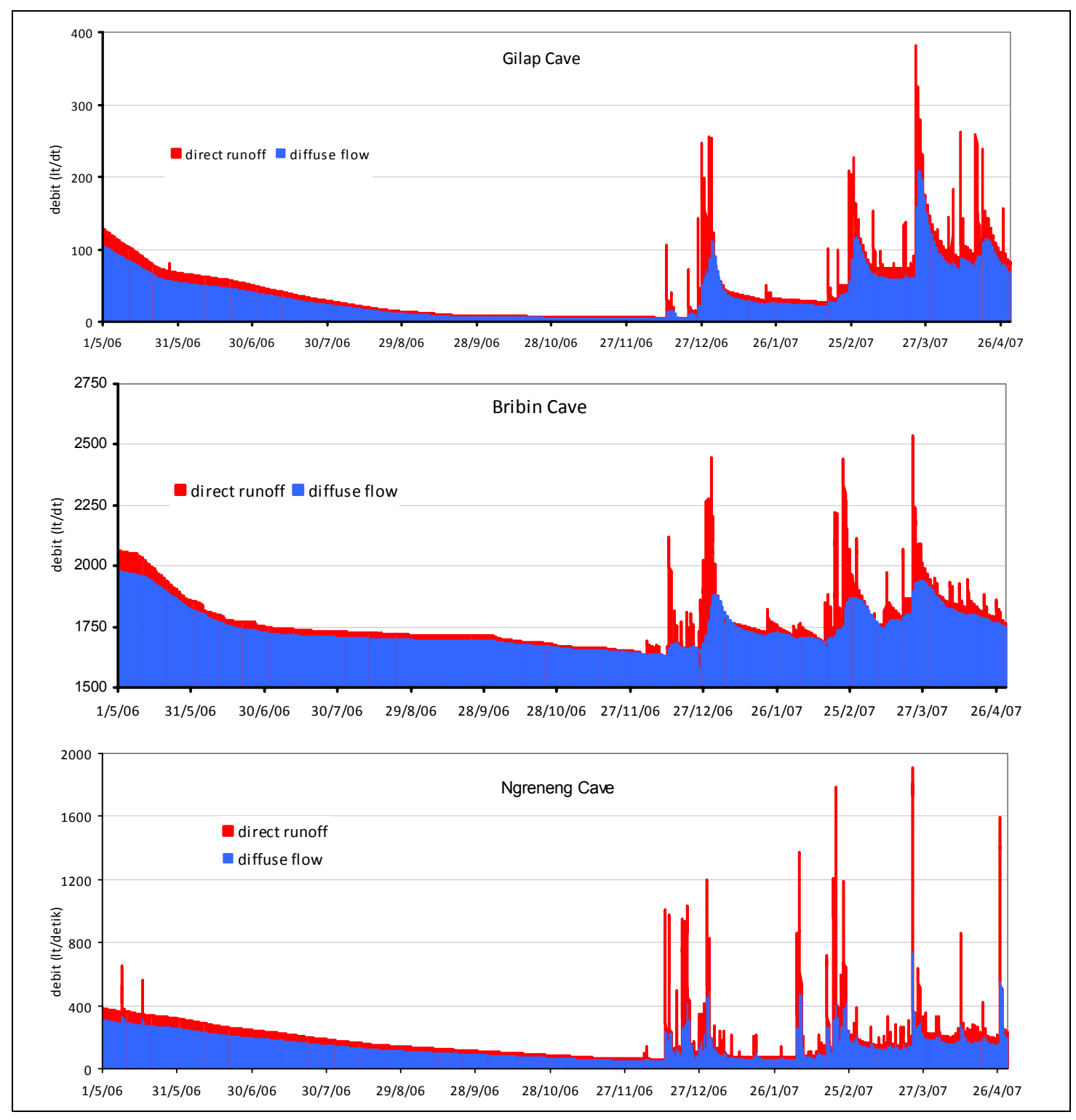

Figure 1. Baseflow Separation of SBT Bribin

According to the above table, Ngreneng Cave has the lowest PAD amounting at $46.5 \%$. It shows that the addition of diffuse flow within flood events is significantly 
lower than the conduit flow addition. Next, Bribin cave encompasses similar PAD compared to its monthly average. It indicates that PAD domination is better than other caves. Meanwhile, the Gilap cave's flood event average PAD is lower than its monthly average $(65.41 \%)$ but it is more significant compared to Ngreneng Cave. This shows that the conduit fracture pattern at Gilap cave does not develop as Ngreneng Cave yet.

Table. 4. Baseflow Ratio and Total Flow in Flood Period

\begin{tabular}{|c|c|c|c|c|c|c|c|}
\hline \multirow{2}{*}{ NO } & \multicolumn{2}{|c|}{ GILAP CAVE } & \multicolumn{3}{|c|}{ BRIBIN CAVE } & \multicolumn{2}{|c|}{ NGRENENG CAVE } \\
\hline & TIME FLOODING & PAD (\%) & TIME FLOODING & PAD & $(\%)$ & TIME FLOODING & PAD (\%) \\
\hline 1 & $13 / 12 / 06$ at $19: 00$ & 45.08 & $6 / 12 / 06$ at $22: 30$ & & 98.38 & $13 / 12 / 06$ at $19: 30$ & 41.43 \\
\hline 2 & $22 / 12 / 06$ at $15: 30$ & 55.52 & $7 / 12 / 06$ at $23: 00$ & & 99.02 & $15 / 12 / 06$ at $18: 30$ & 44.68 \\
\hline 3 & $31 / 12 / 06$ at $06: 30$ & 57.75 & $13 / 12 / 06$ at $19: 30$ & & 86.16 & $18 / 12 / 06$ at $13: 30$ & 50.85 \\
\hline 4 & $16 / 2 / 07$ at $16: 30$ & 57.25 & $29 / 12 / 06$ at $00: 30$ & & 77.72 & $20 / 12 / 06$ at $18: 30$ & 43.88 \\
\hline 5 & $24 / 2 / 07$ at $19: 00$ & 51.25 & $30 / 12 / 06$ at $17: 00$ & & 82.69 & $22 / 12 / 06$ at $20: 30$ & 44.68 \\
\hline 6 & $26 / 2 / 07$ at $18: 00$ & 58.55 & $16 / 2 / 07$ at $18: 00$ & & 92.29 & $5 / 2 / 07$ at $17: 00$ & 45.68 \\
\hline 7 & $6 / 3 / 07$ at $21: 00$ & 79.91 & $22 / 2 / 07$ at $21: 00$ & & 81.81 & $19 / 2 / 07$ at $20: 30$ & 40.79 \\
\hline 8 & $9 / 3 / 07$ at $19: 00$ & 78.18 & $23 / 2 / 07$ at $20: 00$ & & 84.51 & $20 / 2 / 07$ at $20: 00$ & 59.77 \\
\hline 9 & $14 / 3 / 07$ at $02: 00$ & 78.92 & $28 / 2 / 07$ at $01: 30$ & & 89.91 & & \\
\hline 10 & 19/3/07at 00:00 & 72.75 & $7 / 3 / 07$ at $05: 00$ & & 99.05 & & \\
\hline 11 & 21/3/07at 08:00 & 77.20 & $7 / 4 / 07$ at $22: 00$ & & 95.50 & & \\
\hline 12 & $23 / 3 / 07$ at $08: 00$ & 50.88 & $27 / 4 / 07$ at $20: 00$ & & 97.25 & & \\
\hline 13 & $7 / 4 / 07$ at $01: 30$ & 70.33 & & & & & \\
\hline 14 & $10 / 4 / 07$ at $18: 00$ & 62.94 & & & & & \\
\hline 15 & $11 / 4 / 07$ at $15: 00$ & 76.30 & & & & & \\
\hline 16 & $16 / 4 / 07$ at $23: 30$ & 73.80 & & & & & \\
\hline & Average & 65.41 & & & 90.36 & & 46.47 \\
\hline
\end{tabular}

Source : data analisis 2006-2007

\section{Hydrogeochemical spatial-temporal characteristics and its relationship with the SBT Bribin flow condition}

\section{a. The Relationship of EC-Calcium and EC-Bicarbonate}

Bribin cave that is located at the under course has the strongest relationship and the highest EC and dissolved Calcium-Bicarbonate among other caves within dry season. Based on the baseflow characteristic, Bribin Cave encompasses the highest baseflow and exposes the lowest baseflow fluctuation among other caves, amounting at approximately $98 \%$ and $\mathrm{K}_{\mathrm{b}}$ at 0.998 , while it is only $81 \%$ found at Gilap Cave. Ngreneng cave as a leakage of Bribin Cave (MacDonalds and Patners, 1984) has similar correlation, EC and calcium-bicarbonate as Bribin's.At upper course, other caves have lower correlation but Pentung River due to its baseflow contributed by non-karstic 
aquifer. Thus, the correlation is affected only by water-rock interaction process. The low correlation at Luweng Jomblangan is more affected by the mixing process between Pentung River and karst aquifer baseflow that has different interaction stage with carbonate rock. On the other hand, at Gilap Cave, the water-rock interaction process is not as intensive as found at Bribin and Ngreneng caves due to its high fissure flow. On rainy season, Bribin, Ngreneng, and Gilap caves have low Calcium-EC correlation; even it is lower than it in dry season. Table 6 shows that Gilap Cave has a negative correlation as a result of its lower PAD than other caves. Interestingly, Luweng Jomblangan has different pattern. It has high correlation on rainy season that may due to low conduit flow at upper course and the intermittent input from Pentung River (the direct runoff disappears after rainfall events).

Table 5. $\mathrm{R}^{2}$ Value of EC vs Calcium and Bicarbonate of SBT Bribin in Dry Season

\begin{tabular}{|c|c|c|c|c|c|c|}
\hline SITE & POSITION & $\mathrm{Ca}^{2+}$ VS EC & $\mathrm{HCO}_{3}^{-} \mathrm{VS} \mathrm{EC}$ & CORRELATION & $\begin{array}{l}\text { HYDROGEOCHEMICAL } \\
\text { PROCESSES }\end{array}$ & NOTE \\
\hline Pentung & Inlet & 0,878 & 0,596 & $\begin{array}{l}\text { Positive- high- } \\
\text { medium }\end{array}$ & $\begin{array}{l}\text { Water-rock interaction with } \\
\text { respect to non-carbonate rock }\end{array}$ & $\begin{array}{l}\text { The river with } \\
\text { baseflow input from } \\
\text { volcanic aquifer }\end{array}$ \\
\hline L. Jomblangan & upper & 0,364 & 0,687 & $\begin{array}{l}\text { Positive-low- } \\
\text { medium }\end{array}$ & $\begin{array}{l}\text { Mixing between carbonate and } \\
\text { non-carbonate water }\end{array}$ & $\begin{array}{l}\text { Direct overland flow } \\
\text { from Pentung }\end{array}$ \\
\hline G. Gilap & $\begin{array}{l}\text { Upper- } \\
\text { centre }\end{array}$ & 0,436 & 0,744 & Positive- low - high & $\begin{array}{l}\text { PAD slightly lower than Bribin } \\
\text { and Ngreneng, strong water- } \\
\text { rock interaction with respect to } \\
\text { carbonate rock }\end{array}$ & $\begin{array}{l}\mathrm{PAD} \text { around } 80 \% \text {, } \\
\text { low } \mathrm{K}_{\mathrm{i}} \text { and high } \mathrm{K}_{\mathrm{c}}\end{array}$ \\
\hline G. Bribin & under & 0,892 & 0,867 & Positive-high & $\begin{array}{l}\text { The highest PAD, strongest } \\
\text { water-rock interaction with } \\
\text { respect to carbonate rock }\end{array}$ & $\begin{array}{l}\text { PAD around } 90 \%, \mathrm{~K}_{\mathrm{b}} \\
\text { high }\end{array}$ \\
\hline G. Ngreneng & leakage & 0,770 & 0,901 & Positive-high & $\begin{array}{l}\text { High PAD, located adjacent to } \\
\text { Bribin Cave, strong water-rock } \\
\text { interaction with respect to } \\
\text { carbonate rock }\end{array}$ & $\begin{array}{l}\text { PAD similar to } \\
\text { Bribin, with } K_{c} \text { low }\end{array}$ \\
\hline
\end{tabular}

\section{b. The relationship of discharge and PAD}

Karimi, et al. (2003) explains that recession period (when discharge decline after period of flood) cause the diffuse flow component increases and changes the chemical composition of karst underground river. Consequently, the PAD increases when the discharge decreases. The phenomenon at Gilap, Bribin and Ngreneng and all caves along SBT Bribin supports this theory. All those caves have significant negative correlation between discharge and PAD, especially in dry season. Pentung River (volcanic aquifer) has the strongest correlation because the discharge in dry season is filled by baseflow only. On the other hand, underground river correlation $\left(\mathrm{R}^{2}\right)$ is slightly lower than Pentung's since the residual river component is a combination between fissure and diffuse. The high correlation $\left(\mathrm{R}^{2}\right)$ at Gilap, Bribin, and Ngreneng caves are also affected by how fast the karst aquifer release the fissure flow $\left(\mathrm{K}_{\mathrm{i}}\right)$, as shown at Table 7. It is concluded that the higher the $\mathrm{K}_{\mathrm{i}}$, the lower correlation of discharge-PAD as Bribin shows. 
Table 6. $\mathrm{R}^{2}$ Value of EC vs Calcium and Bicarbonate of SBT Bribin in Wet Season

\begin{tabular}{|c|c|c|c|c|c|c|}
\hline SITE & POSITION & $\mathrm{Ca}^{2+}$ VS EC & $\mathrm{HCO}_{3}{ }^{-} \mathrm{VS} \mathrm{EC}$ & CORRELATION & $\begin{array}{c}\text { HYDROGEOCHEMICAL } \\
\text { PROCESSES }\end{array}$ & NOTE \\
\hline Pentung & Inlet & 0.013 & 0.311 & Positive-low & Low water rock interaction & $\begin{array}{l}\text { Large direct runoff in } \\
\text { flood events }\end{array}$ \\
\hline L. Jomblangan & upper & 0.812 & 0.889 & Positive-low & $\begin{array}{l}\text { Domination of diffuse flow due } \\
\text { to its position within karst } \\
\text { boundary (mixing) }\end{array}$ & $\begin{array}{l}\text { Visually. no strong } \\
\text { discharge fluctuation } \\
\text { along the year }\end{array}$ \\
\hline G. Gilap & $\begin{array}{l}\text { Upper- } \\
\text { centre }\end{array}$ & 0.020 & 0.071 & Negative-low & $\begin{array}{l}\text { High conduit contribution, } \\
\text { lowest PAD, low water rock } \\
\text { interaction }\end{array}$ & $\begin{array}{l}\text { Average } \mathrm{PAD}=73 \% \\
\mathrm{~T}_{\mathrm{b}}=36.7 \text { hour }\end{array}$ \\
\hline G. Bribin & under & 0.272 & 0.374 & Positive-low & $\begin{array}{l}\text { High conduit contribution, very } \\
\text { well diffuse storage }\end{array}$ & $\begin{array}{l}\text { Average } \mathrm{PAD}=94 \% \\
\mathrm{~T}_{\mathrm{b}}=36.3 \text { hour }\end{array}$ \\
\hline G. Ngreneng & leakage & 0.370 & 0.810 & Positive low-high & $\begin{array}{l}\text { Similar to Bribin, with faster } \\
\text { time to base flow }\left(T_{b}\right) \text { due to its } \\
\text { entrance cave's morphology }\end{array}$ & $\begin{array}{l}\text { Average } \mathrm{PAD}=88 \% \\
\mathrm{~T}_{\mathrm{b}}=16.8 \text { hour }\end{array}$ \\
\hline
\end{tabular}

Tabel 7. $\mathrm{R}^{2}$ Value of PAD vs. Discharge of SBT Bribin in Dry Season

\begin{tabular}{|l|c|c|c|l|}
\hline \multicolumn{1}{|c}{ SITE } & POSITION & $\begin{array}{l}\text { DISCHARGE } \\
\text { VS PAD }\end{array}$ & CORRELATION & NOTE \\
\hline Pentung & Inlet & $\mathbf{0 . 9 8 8}$ & Negative-high & $\begin{array}{l}\text { Highest correlation, filled by 100\% baseflow from non- } \\
\text { karstic aquifer }\end{array}$ \\
\hline G. Gilap & $\begin{array}{l}\text { Upper- } \\
\text { centre }\end{array}$ & $\mathbf{0 . 8 5 2}$ & Negative-high & $\begin{array}{l}\text { High correlation, baseflow contributed by diffuse and } \\
\text { fissure flow. Correlation valued affected by fissure storage } \\
\text { releasing. } \mathrm{K}_{\mathrm{i}} \text { value in Gilap=0.767 }\end{array}$ \\
\hline G. Bribin & under & $\mathbf{0 . 8 5 5}$ & Negative-high & High correlation. $\mathrm{K}_{\mathrm{i} \text { value in Bribin=0.332 }}$ \\
\hline G. Ngreneng & leakage & $\mathbf{0 . 7 9 1}$ & Negative-high & Slightly low correlation,. $\mathrm{K}_{\mathrm{i}}$ value in Ngreneng=0.877 \\
\hline
\end{tabular}

Conversely, in wet season, the correlation declines and reaches a very low amount at Ngreneng and Gilap Caves due to the high fluctuation of PAD. The PAD fluctuation ranges from $45-80 \%$ at Gilap Cave, while it is $40-60 \%$ at Ngreneng Cave. However, Bribin Cave confirms different condition with PAD fluctuation between 80 $90 \%$. The wet season correlation comparison of PAD-discharge along SBT Bribin is clearly presented in Table 8.

Table $8 . \mathrm{R}^{2}$ Value of PAD vs. Discharge of SBT Bribin in Wet Season

\begin{tabular}{|l|c|c|c|l|}
\hline \multicolumn{1}{|c|}{ SITE } & POSITION & $\begin{array}{c}\text { DISCHARGE } \\
\text { VS PAD }\end{array}$ & CORRELATION & NOTE \\
\hline Pentung & Inlet & 0.815 & Negative-high & $\begin{array}{l}\text { Stable baseflow in wet season, flash flooding behavior only } \\
\text { a little decrease the dry season correlation }\end{array}$ \\
\hline G. Gilap & $\begin{array}{l}\text { Upper- } \\
\text { centre }\end{array}$ & $\mathbf{0 . 0 1 4}$ & Negative-very low & High fluctuation of baseflow (45-80\%) \\
\hline G. Bribin & under & $\mathbf{0 . 9 1 3}$ & Negative-high & Stable fluctuation of baseflow in flood events (80-90\%) \\
\hline G. Ngreneng & leakage & $\mathbf{0 . 0 1 1}$ & Negative-low & $\begin{array}{l}\text { High fluctuation of baseflow (40-65\%). High conduit } \\
\text { contribution due to its entrance cave's morphology }\end{array}$ \\
\hline
\end{tabular}

\section{c. The PAD-calcium and PAD-bicarbonate correlation}

In the dry season, there are significant differences on PAD-Calcium correlation of upper and lower part of caves along SBT Bribin. As a dissolved cation in underground river, the Calcium dissolved constituent is much affected by the PAD contribution. Bribin and Ngreneng caves have a similar PAD-Calcium and PAD- 
Bicarbonate correlation amounting at 0.73 and more than 0.85 , respectively. The similar amount of correlation for those caves may be caused by part of flow component of Ngreneng Cave comes from Bribin Cave.

Pentung River encompasses low PAD-Calcium correlation (0.352) because the water source is not primarily derived from karst aquifer. Hence, Calcium is not a dominant cation when baseflow dominates Pentung River. However, it performs high correlation of PAD-Bicarbonate because the bicarbonate ion can be originated as of some minerals but Calcite. On the other hand, Gilap Cave presents medium PADcalcium correlation (0.588) because of its position at upper course. Subsequently, the baseflow has shorter time to baseflow to dissolved Calcium as experienced by under course caves. Additionally, Gilap Cave has a quicker baseflow releasing compared to Bribin Cave. In summary, the correlation of PAD-Calcium and Bicarbonate comparison of caves along SBT Bribin is illustrated in Table 9.

Tabel 9. $\mathrm{R}^{2}$ Value of PAD vs. Calcium and Bicarbonate of SBT Bribin in Dry Season

\begin{tabular}{|c|c|c|c|c|c|c|}
\hline SITE & POSITION & $\mathrm{Ca}^{2+} \mathrm{VS}$ EC & $\mathrm{HCO}_{3}^{-} \mathrm{VS} \mathrm{EC}$ & CORRELATION & $\begin{array}{l}\text { HYDROGEOCHEMICAL } \\
\text { PROCESSES }\end{array}$ & NOTE \\
\hline Pentung & Inlet & 0.352 & 0.985 & Positive-low-high & $\begin{array}{l}\text { Water-rock interaction with } \\
\text { respect to non-carbonate rock }\end{array}$ & $\begin{array}{l}\text { High correleation of } \\
\text { PAD-Bicarbonate as } \\
\text { derives from non- } \\
\text { carbonate aquifer }\end{array}$ \\
\hline G. Gilap & $\begin{array}{l}\text { Upper- } \\
\text { centre }\end{array}$ & 0.588 & 0.855 & $\begin{array}{l}\text { Positive-medium- } \\
\text { high }\end{array}$ & $\begin{array}{l}\text { Water-rock interaction with } \\
\text { respect to non-carbonate rock in } \\
\text { short time residence }\end{array}$ & $\begin{array}{l}\text { The shortest time } \\
\text { residence of baseflow, } \\
\text { low } \mathrm{K}_{\mathrm{b}} \text { value rendah } \\
\text { with medium } \\
\text { contribution of fissure } \\
\text { flow }\end{array}$ \\
\hline G. Bribin & under & 0.730 & 0.892 & Positive- high & $\begin{array}{l}\text { Water-rock interaction with } \\
\text { respect to non-carbonate rock in } \\
\text { long time residence }\end{array}$ & High $\mathrm{K}_{\mathrm{b}}$ value \\
\hline G. Ngreneng & leakage & 0.730 & 0.941 & Positive- high & $\begin{array}{l}\text { Water-rock interaction with } \\
\text { respect to non-carbonate rock in } \\
\text { long time residence, and } \\
\text { influenced from Bribin flow (as } \\
\text { a leakage) }\end{array}$ & $\begin{array}{l}\text { Adjacent location to } \\
\text { Bribin }\end{array}$ \\
\hline
\end{tabular}

In wet season, the relationship between Calcium-Bicarbonate and PAD generally decreases due to the high supply of conduit flow. Additionally, Ngreneng Cave and Pentung River perform negative correlation due to the increasing constituent of Calcium or Bicarbonate as PAD inclines. Those location, indeed, have special characteristics. Pentung River as surface stream, hence the dissolved Calcium is not always foremost in the water. Ngreneng Cave, as previously mentioned, is a sinkhole at the base of karst valley that always catches fast conduit flow since the $\mathrm{K}_{\mathrm{c}}$ value is low in rainy season. On the other hand, Gilap Cave confirms the most stable correlation of Calcium andbBcarbonate with PAD compared to Bribin's and Ngreneng's. These facts are supported by its location that is adjacent to upper course that presents dominant fissure 
flow $\left(\mathrm{K}_{\mathrm{i}}\right)$. In addition, it has the most stable $\mathrm{Kc}$ among other caves so its content is relatively similar with diffuse flow (see Table 10).

Tabel 10. $\mathrm{R}^{2}$ Value of PAD vs. Calcium and Bicarbonate of SBT Bribin in Wet Season

\begin{tabular}{|c|c|c|c|c|c|c|}
\hline SITE & POSITION & $\mathrm{Ca}^{2+} \mathrm{VS} \mathrm{EC}$ & $\mathrm{HCO}_{3}^{-} \mathrm{VS} \mathrm{EC}$ & CORRELATION & $\begin{array}{l}\text { HYDROGEOCHEMICAL } \\
\text { PROCESSES }\end{array}$ & NOTE \\
\hline Pentung & Inlet & 0.080 & 0.207 & $\begin{array}{l}\text { Negative-low } \\
\text { Positive-low }\end{array}$ & $\begin{array}{l}\text { Mixing between water-rock } \\
\text { interaction in non-carbonate } \\
\text { aquifer and overland flow. } \\
\text { Faster overland flow respond } \\
\text { than underground river. } \\
\text { ( } \mathrm{Tb}=\text { short). }\end{array}$ & Non-karstic aquifer. \\
\hline G. Gilap & $\begin{array}{l}\text { Upper- } \\
\text { centre }\end{array}$ & 0.690 & 0.628 & Positive-medium & $\begin{array}{l}\text { Strong fissure flow and stable } \\
\left(\mathrm{K}_{\mathrm{i}}=\text { high }\right) \text {, slow conduit flow } \\
\text { escalating within flood events } \\
\left(\mathrm{K}_{\mathrm{c}} \text { high). Strongest water-rock }\right. \\
\text { interaction process }\end{array}$ & $\begin{array}{l}\text { Shortest time of residence } \\
\text { of diffuse flow to dissolve } \\
\text { carbonate rock. Sloe aquifer } \\
\text { to release conduit storage } \\
\text { lain }\left(\mathrm{K}_{\mathrm{c}} \text { high). }\right.\end{array}$ \\
\hline G. Bribin & under & 0.143 & 0.149 & Positive- low & $\begin{array}{l}\text { The contribution of conduit flow } \\
\text { (dilution by precipitation } \\
\text { process) }\end{array}$ & $\begin{array}{l}\text { Diffrent diffuse flow and } \\
\text { conduit flow due to its } \\
\text { under-course position }\end{array}$ \\
\hline G. Ngreneng & leakage & 0.882 & 0.253 & Negative- high-low & $\begin{array}{l}\text { High conduit flow contribution } \\
\text { and Low } \mathrm{K}_{\mathrm{c}} \text { value to generate } \\
\text { dilution by precipitation } \\
\text { domination }\end{array}$ & $\begin{array}{l}\text { High conduit contribution } \\
\text { due to its entrance cave's } \\
\text { morphology }\end{array}$ \\
\hline
\end{tabular}

Based on the spatial and temporal analysis of hydrochemical parameter correlation and flow condition along SBT Bribin, it turns out that:

(1) In dry season, there is significant correlation between PAD (diffuse flow) with the level of the dominant constituent of karst water). The high correlation between EC and the dissolved constituent indicates the strong water-rock interaction processes (Desmarais and Rojstaczer, 2002). The fact that there is high correlation between PAD and the dissolved part supports the relation between hydrogeochemical and PAD contribution. Furthermore, the correlation is also affected by its spatial position by the side of Bribin cacthment area and the level of $\mathrm{K}_{\mathrm{b}}, \mathrm{K}_{\mathrm{i}}$ and $\mathrm{Kc}$.

(2) In wet season, hydrogeochemical processes moves from water-rock interaction process to dilution by precipitation since there is a high rain supply through conduit. The decline of PAD-dominant dissolved constituent and also ECdominant dissolved constituent correlations support the hydrochemical process movement. As previously explained, the spatial position and baseflow characteristic also affect the hydrogeochemistry of underground river.

3. Spatial and temporal karst water aggressiveness condition of limestone and its relationship with SKD condition along SBT Bribin.

a. The water aggressiveness level of SBT Bribin

According to Vesper and White (2004), the aggressiveness level on karst region is usually stated in an index known as Saturation Indices (SI) with respect to calcite 
mineral. The spatial and temporal distribution of SI along SBT Bribin is presented in Table 11.

Table 11. SI Distribution along SBT Bribin

\begin{tabular}{|l|l|c|c|c|c|c|}
\hline \multicolumn{1}{|c}{ LOCATION } & POSITION & DRY SEASON & CONDITION & WET SEASON & $\begin{array}{c}\text { CONDITION } \\
\text { saturated to } \\
\text { aggressive }\end{array}$ \\
\hline Pentung & Inlet & -0.01 to 1.13 & $\begin{array}{c}\text { almost saturated to } \\
\text { super saturated }\end{array}$ & $\begin{array}{c}\text { very aggressive to } \\
\text { saturated }\end{array}$ & 0.06 to -1.04 & -0.61 \\
aggressive \\
\hline Gilap & Upper & -0.43 to 0.63 & $\begin{array}{c}\text { aggressive to super } \\
\text { saturated }\end{array}$ & -0.51 to -1.21 & $\begin{array}{c}\text { aggressive to very } \\
\text { aggressive }\end{array}$ \\
\hline Ngreneng & Upper-centre & -0.15 to 1.18 & -0.22 to 0.05 & $\begin{array}{c}\text { aggressive to almost } \\
\text { saturated }\end{array}$ & -0.96 to -0.99 & $\begin{array}{c}\text { very aggressive } \\
\text { aggressive to almost } \\
\text { saturated }\end{array}$ \\
\hline Bribin & Under & -0.93 to 0.29 & -0.12 to -1.01 & $\begin{array}{c}\text { aggressive to very } \\
\text { aggressive }\end{array}$ \\
\hline
\end{tabular}

From the above table, it turns out that SI at each cave has a different value. According to its position, on dry and rainy season, the caves at under course (Bribin and Ngreneng Caves) have indices to more constant compared to other caves, and Bribin Cave confirms the most stable PAD. However, the river at Bribin Cave has the most aggressive characteristic during all the year (SI level never exceed the level of zero on rainy season) as Ngreneng's. As a comparison, the SI at upper course, e.g. Gilap Cave, reaches the highest level of SI in dry season at amount of 0.61. Even on the beginning of dry season, the SI is positive. This indicates that dissolution process has stopped. This reality is found also at Luweng Jomblangan and Pentung River. Conversely, this phenomenon does not appear at under course caves. It indicates that in dry season, the process of cave development is more intensive for upper course caves, while the process of widening tunnel in dissolution process is more intensive for under course caves (SI is negative) as shown by Bribin and Ngreneng Caves, though in rainy season, those processes are affected primarily by conduit flow component.

The distribution level of SI proves that the more intensive mixing process between diffuse and fissure flow comes to pass at under course caves. Ford and Williams (1992), Bogli (1980), Plummer (1975), and Jankowski and Jacobson (1991) state that the mixing between water with high SI to calcite is able to decrease the SI value and causes the water becomes aggressive to dissolve carbonate rock. The previous analysis of PAD illustrates that the under course caves, especially Bribin, have high PAD to cause aggressivity level of Bribin becomes undersaturated in dry season. 


\section{b. The condition of SKD along SBT Bribin}

Daoxian (2005) states that some parameters of karst water quality is able to identify SKD pattern such as: variation of $\mathrm{pH}$; SI; with respect to calcite mineral; carbordioxide partial pressure; and dissolved calcium or bicarbonate that are conducted in karst underground river components, such as (1) rain water as an input; (2) drip water from cave ornament/speleothem as an indicator of dissolution-precipitation processes, and (3) the water of underground river. Table 12 and 13 below present the condition of SKD parameter at SBT Bribin upper and under course. The analysis does not separate rainwater between upper and under course and between dry and rainy season so the different characteristics of SKD parameter between drip water, rainwater, and underground river are known clearly.

Table 12. The Distribution of SKD Parameters of SBT Bribin in Dry Season

\begin{tabular}{|c|c|c|c|c|c|c|}
\hline \multirow{2}{*}{$\begin{array}{c}\text { SKD } \\
\text { PARAMETER }\end{array}$} & \multicolumn{3}{|c|}{ UPPER COURSE (GILAP CAVE) } & \multicolumn{3}{|c|}{ UNDER COURSE (BRIBIN CAVE) } \\
\hline & RAINWATER & DRIP WATER & $\begin{array}{l}\text { UNDERGROUND } \\
\text { RIVER }\end{array}$ & RAINWATER & DRIP WATER & $\begin{array}{c}\text { UNDERGROUND } \\
\text { RIVER }\end{array}$ \\
\hline pH & $6.29-6.55$ & $8.29-8.57$ & $7.06-8.42$ & $6.29-6.55$ & $7.06-7.72$ & $6.96-7.39$ \\
\hline $\log P_{\mathrm{CO} 2}$ & $-1.59--1.87$ & $-3.03--3.31$ & $-1.71--3.09$ & $-1.59--1.87$ & $-1.88--2.47$ & $-1.53--2.13$ \\
\hline SI kalsit & $-1.77--2.14$ & $0.56-1.25$ & $-0.15-1.18$ & $-1.77--2.14$ & $-0.52-0.29$ & $-0.83-0.26$ \\
\hline $\mathrm{Ca}^{2+}$ (mg/lt) & $14.3-18.8$ & $62.6-80.0$ & $50.56-68.08$ & $14.3-18.8$ & $45.1-92.7$ & $86.13-110.3$ \\
\hline $\mathrm{HCO}_{3}^{-}(\mathrm{mg} / \mathrm{lt})$ & $43.3-53.1$ & $183-248$ & $178-265$ & $43.3-53.1$ & $164-347$ & $242-278$ \\
\hline
\end{tabular}

Table 13. The Distribution of SKD Parameters of SBT Bribin in Wet Season

\begin{tabular}{|c|c|c|c|c|c|c|}
\hline \multirow{2}{*}{$\begin{array}{c}\text { SKD } \\
\text { PARAMETER }\end{array}$} & \multicolumn{3}{|c|}{ UPPER COURSE (GILAP CAVE) } & \multicolumn{3}{|c|}{ UNDER COURSE (BRIBIN CAVE) } \\
\hline & RAINWATER & DRIP WATER & $\frac{\text { UNDERGROUND }}{\text { RIVER }}$ & RAINWATER & DRIP WATER & $\frac{\text { UNDERGROUND }}{\text { RIVER }}$ \\
\hline pH & $6.29-6.55$ & $6.67-7.22$ & $6.52-7.12$ & $6.29-6.55$ & $6.93-7.18$ & $6.46-7.03$ \\
\hline $\log P_{\mathrm{CO} 2}$ & $-1.59--1.87$ & $-1.37--2.00$ & $-1.47--1.95$ & $-1.59--1.87$ & $-1.65--1.98$ & $-1.19--1.79$ \\
\hline SI kalsit & $-1.77--2.14$ & $-0.17--1.10$ & $-0.51--1.31$ & $-1.77--2.14$ & $-0.65--0.79$ & $-0.12--1.79$ \\
\hline $\mathrm{Ca}^{2+}$ (mg/lt) & $14.3-18.8$ & $12.0-57.5$ & $31.8-42.7$ & $14.3-18.8$ & $15.6-41.3$ & $67.7-134.4$ \\
\hline $\mathrm{HCO}_{3}^{-}(\mathrm{mg} / \mathrm{lt})$ & $43.3-53.1$ & $111-187$ & $110-154$ & $43.3-53.1$ & $148-192$ & $149-300$ \\
\hline
\end{tabular}

Based on the tables above, it appears out that in both dry and rainy season, there is a difference among SKD parameters for drip water and underground river, even when it is compared to SKD parameters for rainwater in Bribin catchment's area. Vesper and White (2004) and Daoxian (2005) explain that scatter plot analysis is used to characterize SKD parameter on many type of water at karst area and to understand the interaction among parameter. Based on scatter plot analysis between SI calcite and log $\mathrm{PCO}_{2}$, SI calcite and log calcium, SI calcite and $\mathrm{pH}$, SI calcite and $\log \mathrm{PCO}_{2}$ in upper and under course caves, on dry and rainy season, it turns out that: 
(1) In dry season, the water aggressiveness condition at upper course of SBT Bribin (Gilap Cave) is mostly on supersaturated condition (the SI is positive). This condition is experienced by both speleothem drip water and underground river. Another characteristic found is high $\mathrm{pH}$ value, low partial $\mathrm{CO}_{2}$ pressure, and high dissolved calcium. The high SI calcite at Gilap Cave has significant correlation with the low $\mathrm{CO}_{2}$ supply from cave tunnel (closed system), since it is already used on dissolution process within unsaturated zone. Additionally, Gilap Cave also performs strong correlation between the high SI calcite with $\mathrm{pH}$ and dissolved calcium. The dominant hydrogeochemical process is water-rock interaction (precipitation of calcite mineral) to develop cave speleothem, intensively.

(2) The aggressivity condition at under course of SBT Bribin tends to be aggressive and undersaturated (negative SI). The $\mathrm{pH}$ value on this area is low in dry season with a slight fluctuation. The value of partial $\mathrm{CO} 2$ pressure is much higher than it of Gilap Cave. It shows that the open system of karst aquifer causes the water becomes aggressive due to the continuous supply of $\mathrm{CO} 2$. As a result, the dominant process is calcite dissolution. The widening of the underground river tunnel and the minimum ornament proves this domination of dissolution process.

(3) Due to dilution by precipitation in rainy season, the aggressiveness of water at upper and under course experience a declining SI to undersaturated condition that causes a domination of dissolution and widening of karst channel. The aggressiveness condition at Bribin Cave is higher than Gilap's, nevertheless; the same phenomenon is also experienced by some parameters, i.e the addition of $\mathrm{CO}_{2}$ from conduit flow, the decline of $\mathrm{pH}$ and dissolved calcium. Another process to contribute dissolution process are: mixing between drip water and underground river water and strong $\mathrm{CO}_{2}$ diffusion at under course caves due to the open system to occur. The concept of aggressiveness condition and SKD parameter of Bribin underground river on upper and under course are illustrated in Figure 2 and 3. 


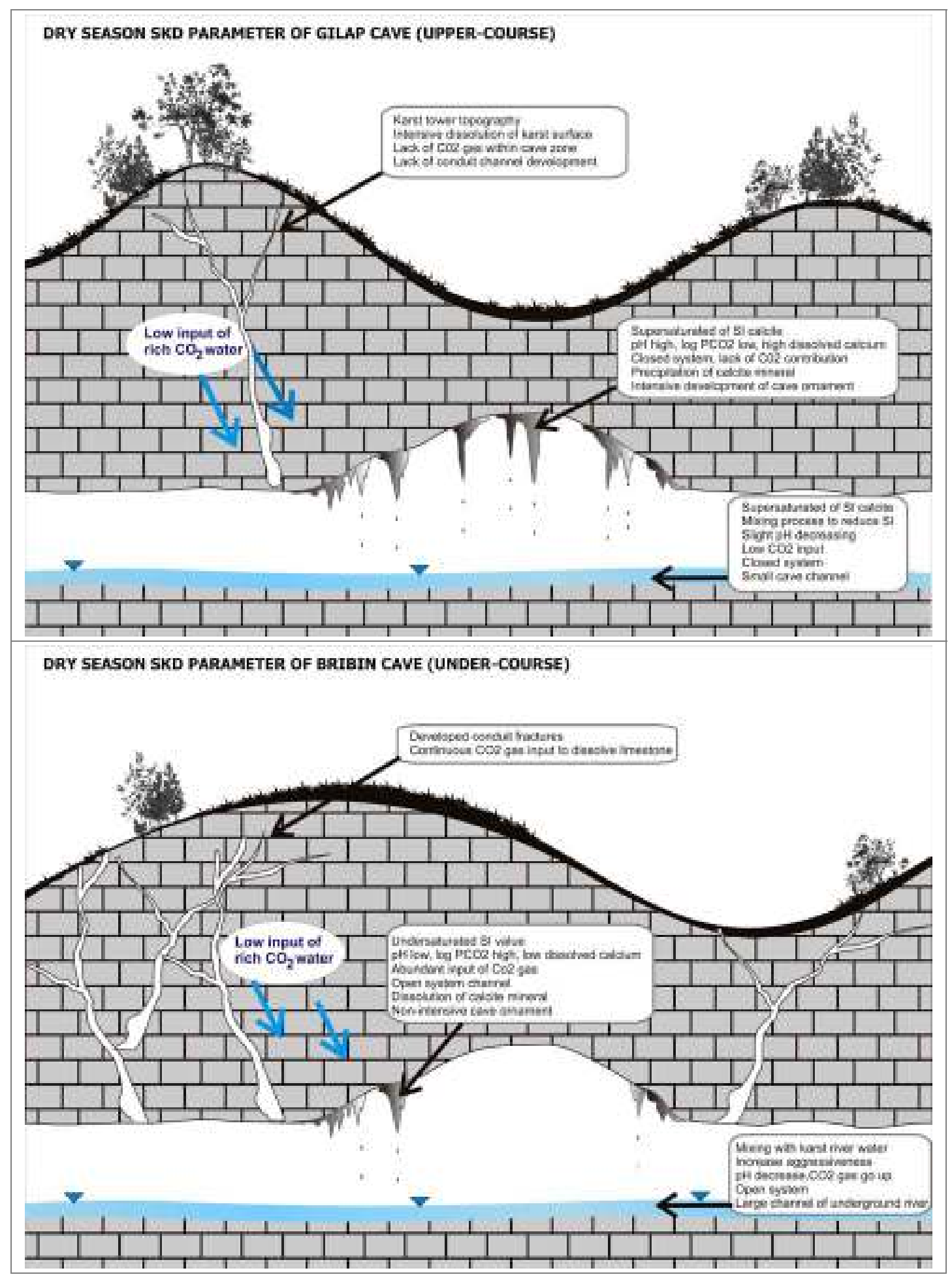

Figure 2. Karst Water Aggressiveness Conceptual Model of SBT Bribin in Dry Season 

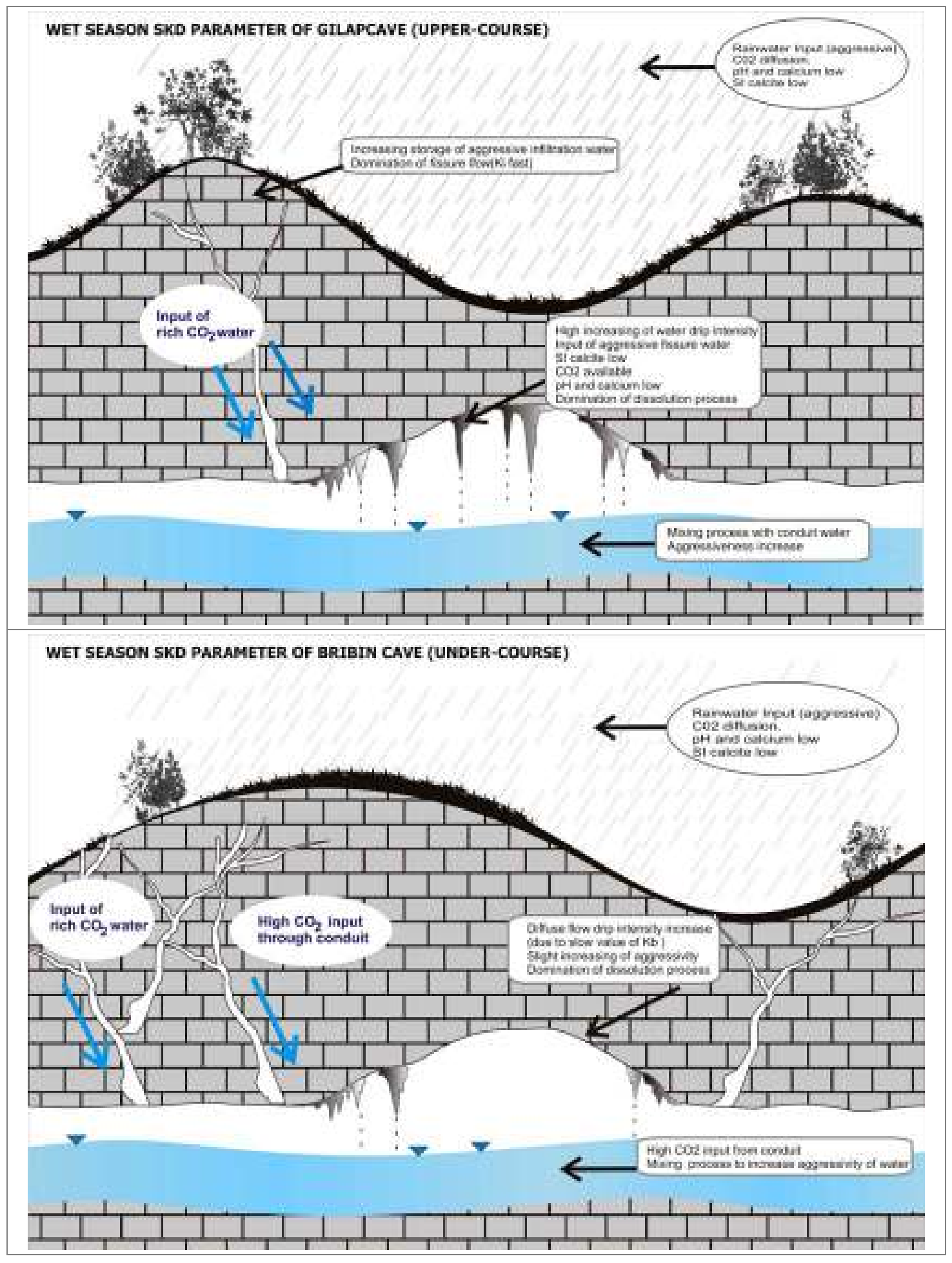

Figure 3. Karst Water Aggressiveness Conceptual Model of SBT Bribin in Wet Season 


\section{Conclusion}

1. The highest PAD is found at Bribin Cave (under-course) due to its aquifer character to release diffuse flow component very slowly. Meanwhile, Gilap Cave (uppercourse) performs the development of fissure fractures with PAD value lesser compare to under-course cave. In flood events, the significant PAD confirmed in Ngreneng Cave, subsequent to its smallest $\mathrm{K}_{\mathrm{c}}$ value.

2. Bribin Cave (under-course) performs the strongest correlation between PAD and dissolved chemical constituent due to its largest PAD. In consequences, water-rock interaction process is dominant. In wet season, the correlation between PAD and hydrogeochemistry becomes weak as a result of conduit flow contribution, especially takes place in sinkhole caves $\left(\mathrm{K}_{\mathrm{c}}=\right.$ fast$)$, such as Ngreneng and Jomblangan Caves.

3. In dry season, Bribin Cave (under-course) performs the most aggressive cave to dissolve carbonate rock, characterized by higher partial pressure of $\mathrm{CO}_{2}$ gas and open-system channel to present. Similar condition also found in Jomblangan Cave as an open-system cave (morphology as a cenote). Another factor to increase aggressiveness is mixing process between conduit and diffuse flow that consequence to reduce the SI value inside the water. On the other hand, the upper-course cave (Gilap Cave) confirms higher value of SI Calcite (low aggressivity) due to the lack of $\mathrm{CO} 2$ gas contribution through the cave channel (closed system). In wet season, all caves confirm decreasing value of SI Calcite (high aggressivity), especially in Ngreneng and Jomblangan Caves, due to their morphology as a sinkhole that always obtained large volume of conduit flow. 


\section{GLOSARIUM}

agresivitas air, kondisi atau kemampuan air untuk melarutkan suatu mineral batuan (Jankowski, 2001)

air jenuh, tidak agresif, (super) saturated, kondisi air yang secara termodinamika sudah tidak mampu melarutkan batuan atau mineral tertentu (Appelo dan Postma, 1994)

air tidak jenuh, agresif, undesaturated, kondisi air yang secara termodinamika masih mampu melarutkan batuan atau mineral tertentu (Appelo dan Postma, 1994)

akuifer, batuan, sedimen, formasi, sekumpulan formasi, atau bagian dari suatu formasi jenuh air yang mampu menyimpan dan mengalirkan airtanah dalam jumlah yang cukup untuk mensuplai sumur atau mataair sepanjang tahun pada suatu kondisi kemiringan hidraulik tertentu (Acworth, 2001)

aliran laminer, sifat aliran pada suatu sungai dimana kecepatan alirannya relatif sama pada semua bagian penampang airnya (Linsley, et al, 1975)

aliran turbulen, sifat aliran pada suatu sungai dimana kecepatan alirannya memiliki kecepatan aliran yang berbeda pada bagian-bagian penampang airnya (Linsley, et al, 1975)

allogenic recharge, imbuhan yang berasal dari aliran permukaan berupa sungai dari luar daerah karst yang masuk ke akuifer karst melalui ponor (White 2004)

anisotropis-akuifer, akuifer yang mempunyai porositas atau permeabilitas tidak sama/beraturan ke segala arah (Fetter, 1994)

annual discharge hydrograph, debit hidrograf tahunan, grafik berskala yang menunjukkan hubungan antara waktu selama satu tahun pada sumbu horisontal dan data debit aliran pada sumbu tegak (Schulz, 1976)

autoogenic recharge, imbuhan yang berasal dari aliran permukaan dari tangkapan hujan pada daerah karst yang masuk ke dalam sistem sungai bawah tanah melalui ponor (White 2004)

banjir, kedaaan pada suatu hidrograf aliran, dimana debit aliran lebih tinggi dari debit biasanya (Schulz, 1976)

baseflow maximum indices, suatu angka yang menunjukkan persentase aliran dasar maksimal suatu aliran sungai yang dipengaruhi oleh kondisi akuifernya (Eckhardt, 2005)

baseflow separation, pemisahan aliran dasar, suatu metode untuk memisahkan komponen aliran pada suatu sungai menjadi komponen aliran dasar dan komponen aliran langsung (Schulz, 1976)

batuan gamping, batuan karbonat, batuan sedimen yang didominasi oleh kalsium karbonat yang merupakan hasil rombakan dari binatang dan vegetasi laut (Ford dan Williams, 1992)

cockpit, bagian pada sela antar bukit kerucut karst yang membentuk cekungan dengan bentuk seperti bintang (Lehmann, 1936)

conduit flow, komponen aliran pengisi sungai bawah tanah dari akuifer yang mengalir melalui retakan-retakan pada batuan gamping yang berukuran $10^{2}-10^{4} \mathrm{~mm}$ atau lebih (Bonacci, 1990) 
cutaneous zone, bagian permukaan dan tanah permukaan dari zona epikarst (Perrin, 2003)

daerah tangkapan hujan, daerah aliran sungai, suatu kawasan berupa cekungan yang dibatasi oleh pembatas topografi berupa igir yang didalamnya terdapat jaringan sungai, dimana hujan yang jatuh kedalam kawasan ini dikeluarkan melalui satu keluaran (outlet) (Linsley et al,1975)

data logger, suatu alat yang dapat diprogram dengan menggunakan komputer yang berfungsi untuk menyimpan data terkait dengan parameter lingkungan seperti suhu, tekanan udara, tingi muka air, dll

debit aliran, hasil perkalian antara luas penampang air yang basah dengan kecepatan alirannya pada suatu penampang tertentu baik berupa sungai atau saluran yang berisi air (Linsley, et al, 1975)

debit andalan, baseflow, aliran dasar, debit aliran pada suatu sungai yang masih mengalir pada saat musim kemarau yang berasal dari simpanan airtanah pada suatu akuifer (Fetter, 1994)

debit puncak, debit aliran dengan magnitude terbesar yang dicapai pada waktu-waktu tertentu, biasanya dijumpai saat muka air tertinggi pada suatu hidrograf aliran (Schulz, 1976)

deep phreatic, zona freatik dalam, zona jenuh dalam suatu akuifer yang letaknya jauh lebih dalam dari muka airtanahnya (Ford dan Ewers, 1978)

diffuse flow, komponen aliran pengisi sungai bawah tanah dari akuifer yang mengalir melalui retakan-retakan pada batuan gamping yang berukuran $10^{-3}-10 \mathrm{~mm}$ (Bonacci, 1990)

diffuse infiltration, proses masuknya air hujan yang jatuh ke permukaan tanah dan terinfiltrasi secara perlahan-lahan melalui pori-pori tanah yang mampu disimpan dalam kurun waktu mingguan pada zone epikarst sebelum kemudian turun ke bawah melalui rekahan atau matriks batuan menuju ke muka airtanah (White 2004)

difusi, proses perpindahan antar fase melalui suatu interface, dalam hal ini adalah perpindahan gas karbondioksida dari udara ke air (Bogli, 1980)

digital filtering, angka yang diperoleh dari konstanta resesi yang digunakan untuk memisahkan komponen aliran pada suatu hidrograf aliran (Eckhardt, 2005)

dilution by precipitation, proses pengenceran air dari unsur terlarut oleh air hujan ynag miskin unsur terlarut (Appelo dan Postma, 1994)

doline, dolin, cekungan tertutup yang berukuran kecil atau sedang pada suatu kawasan karst yang berhubungan dengan sungai bawah tanah sebagai akibat proses pelarutan batuan gamping, runtuhan gua ataupun pengaruh iklim (Ford dan Williams, 1992)

drainase, sistem pengaliran air atau pengeringan yang ada pada suatu daerah melalui jaringan saluran atau sungai (Bahagiarti, 2005)

eksokarst, bagian atas permukaan dari suatu bentangalam karst(White, 1988)

endokarst, bagian bawah permukaan dari suatu bentangalam karst (White, 1988)

epikarst, suatu zone dekat permukaan daerah karst yang mempunyai porositas yang tinggi dan berfungsi sebagai media penyimpan air hasil infiltrasi di daerah karst (Perrin, 2003) 
equilibrium, kesetimbangan, kondisi dimana sifat agresivitas air berada dalam kondisi setimbang yaitu tidak dapat melarutkan dan tidak pula dapat mengendapkan suatu mineral batuan (Appelo dan Postma, 1994)

fissure flow, komponen aliran pengisi sungai bawah tanah dari akuifer yang mengalir melalui retakan-retakan pada batuan gamping yang berukuran 10-10² $\mathrm{mm}$ (Bonacci, 1990)

flood hydrograph, hidrograf banjir, grafik berskala yang menunjukkan hubungan antara waktu pada sumbu horisontal dan data debit aliran pada saat kejadian banjir pada sumbu tegak (Schulz, 1976)

formasi geologi, suatu strata atau perlapisan batuan yang mempunyai jenis batuan dan fasies yang memiliki kesamaan karakteristik

freatik, zona freatik, zona jenuh air dalam suatu akuifer atau formasi yang permukaan airnya bebas (Bahagiarti, 2005)

gua, ruang alamiah di dalam bumi yang kebanyakan memiliki ruangan-ruangan dan loronglorong yang merupakan hasil proses pelarutan (Ford dan Cullingford, 1976)

heterogen- akuifer, akuifer yang sebagai suatu formasi batuan terdiri dari lebih dari satu jenis batuan (Fetter, 1994)

hidrogeokimia, pendekatan yang mengkaji proses dan reaksi yang terjadi karena adanya interaksi antara airtanah dan batuan pada akuifer (Mudry, 2004)

hidrokemograf, gambar atau grafik berskala yang berisi informasi perubahan debit aliran dan perubahan sifat kimia air secara temporal (Plagnes dan Balakowicz, 2001)

homogen-akuifer, akuifer yang sebagai suatu formasi batuan terdiri dari satu jenis batuan saja (Fetter, 1994)

hukum darcy, hukum tentang gerakan airtanah yang menerangkan bahwa debit airtanah berbanding lurus dengan konduktivitas hidraulik, kemiringan akuifer, dan luas penampang akuifernya (Fetter, 1994)

indeks kejenuhan, saturation indices, angka atau bilangan yang menunjukkan tingkat kejenuhan atau agresivitas air untuk melarutkan suatu mineral batuan (Appelo dan Postma, 1994)

internal runoff, aliran permukaan dan hujan yang jatuh ke suatu cekungan karst tertutup dan kemudian masuk ke akuifer karst melalui sinkhole atau ponor (White 2004)

karst labirin, bentukan permukaan karst yang dicirikan oleh lembah-lembah kering memanjang sebagai akibat proses pelarutan yang terkontrol oleh kekar mayor atau sesar (White, 1988)

karst poligonal, bentukan permukaan karst yang dicirikan oleh dolin atau cekungancekungan yang berhubungan antara satu dengan yang lain, sehingga membentuk dolin yang saling bersambungan (White, 1988)

karst, istilah untuk medan dengan batuan gamping yang dicirikan oleh drainase permukaan yang langka, solum tanah yang tipis dan hanya setempat-setempat, terdapatnya cekungan-cekungan tertutup (doline), serta keberadaan sistem drainase bawah permukaanyang lebih dominan dibandingkan dengan sistem aliran permukaannya (Summerfield, 1991) 
karstifikasi, proses pelarutan, proses korosi batuan secara kimia oleh air pada batuan gamping, gipsum, batugaram atau batuan lain yang mudah larut yang bertanggung jawab terhadap terbentuknya fenomena karst baik di permukaan maupun bawah permukaan bumi (Summerfield, 1991)

kegel karst, tipe karst tropis yang dicirikan dengan bentukan bukit-bukit yang tumpul dan tidak terjal (Lehmann, 1936)

konstanta resesi, recession constant, suatu angka yang biasa digunakan sebagai indikator keberlangsungan aliran dasar, dapat diperoleh secara eksponensial dari kurva resesi suatu hidrograf aliran (Nathan and McMahon, 1990)

kubah karst, cone karst, connical,kenampakan permukaan karst yang berbentuk seperti kerucut berupa bukit sisa proses pelarutan (White, 1988)

luweng, gua vertikal, ruang alamiah di dalam bumi yang kebanyakan memiliki ruanganruangan dan lorong-lorong yang merupakan hasil proses pelarutan, dengan mulut gua berbentuk vertikal dengan sudut mendekati $90^{\circ}$ (Ford dan Cullingford, 1976)

menara karst, tower karst, kenampakan permukaan karst, khususnya pada karst di daerah tropis berupa bukit sisa proses pelarutan dengan sisi-sisi bukit yang vertikal atau mendekati vertikal (White, 1988)

meteoric water, air yang jatuh dari udara yang kaya akan gas karbondioksida (Fetter, 1994)

mixing, percampuran, proses percampuran dari dua jenis air yang sudah jenuh dengan tingkat tekanan parsial gas karbondioksida berbeda akan merubah sifat air menjadi tidak jenuh/agresif (Bogli, 1980)

muka airtanah, water table, suatu garis dimana kita pertama kali menemukan airtanah, dikenal juga sebagai batas atas suatu akuifer bebas (Fetter, 1994)

perched aquifer, akuifer yang bertengger karena bagian bawahnya dibatasi lapisan kedap air yang tidak kontinyu (Fetter, 1994)

percolated water, air perkolasi, air yang mengalir secara menyebar (diffuse) dari zone epikarst menuju lorong-lorong conduit di sebelah bawahnya (Ford dan Williams, 1992)

pinacle, blok batugamping yang tersisa di permukaan karena proses pelarutan di sekitar retakan batuan (White, 1988)

pipe flow, sifat aliran yang mengalir melalui saluran atau pipa dengan sifat aliran yang turbulen, sehingga tidak mengikuti kaidah hukum Darcy (White, 1988)

polje, cekungan di daerah karst yang luas dengan diameter antara1-5 km dengan panjang dapat mencapai $60 \mathrm{~km}$, mempunyai struktur yang datar di dasarnya dan tersusun dari materi alluvial (White, 1988)

ponor, point recharge, sinkhole, lubang pada suatu cekungan karst yang merupakan penghubung antara aliran permukaan dan bawah permukaan (White, 1988)

porositas primer, intergranuler, porositas yang berasal dari sifat asli batuan itu sendiri (Fetter, 1994)

porositas sekunder, porositas yang bukan berasal dari sifat asli batuan itu sendiri, tetapi karena adanya proses lain yang menyebabkan terjadinya porositas pada suatu batuan (Fetter, 1994) 
precipitation, pengendapan mineral, lanjutan proses pelarutan yaitu pada kondisi jenuh dimana air menyisakan padatan sebagai endapan mineral batuan (Appelo dan Postma, 1994)

proses pelarutan, dissolution, bagian dari proses hidrogeokimia berupa interaksi antara air dan mineral batuan yang menyebabkan sebagian dari unsur mineral terlarut dalam air (Appelo dan Postma, 1994)

sistem karst dinamis (SKD), sistem yang dibatasi oleh interface udara-air-batuan yang didalamnya terjadi proses perpindahan massa yang dinamis antara $\mathrm{H}_{2} \mathrm{O}, \mathrm{CO}_{2}$ dan $\mathrm{CaCO}_{3}$ yang dikontrol oleh karakteristik akuifer batuan gamping (Daoxian, 2005)

sistem sungai bawah tanah, gabungan dari jaringan lorong-lorong hasil proses pelarutan antar gua-gua yang terisi oleh aliran air secara permanen (Ford dan Cullingford, 1976)

sistem terbuka, open system, sistem pelorongan pada akuifer karst, dimana lorongnya terhubung secara langsung dengan permukaan, sehingga selalu ada pasokan gas karbondioksida (Bogli, 1980)

sistem tertutup, closed system, sistem pelorongan pada akuifer karst, dimana lorongnya tidak terhubung secara langsung dengan permukaan, sehingga tidak ada pasokan gas karbondioksida (Bogli, 1980)

speleothem, ornamen gua, bentukan yang indah pada dinding gua sebagai hasil dari proses pelarutan dan pengendapan mineral kalsit oleh aliran air (Ford dan Cullingford, 1976)

stage discharge rating curve, kurva yang menunjukkan rumus dan hubungan antara tinggi muka air sungai dan debit alirannya (Schulz, 1976)

stage hydrograph, hidrograf tinggi muka air, grafik berskala yang menunjukkan hubungan antara waktu pada sumbu horisontal dan tinggi muka air pada sumbu tegak (Schulz, 1976)

subcutaneous zone, bagian yang mengalami pelebaran rekahan akibat proses pelarutan pada zone epikarst (Perrin, 2003)

tracer test, suatu cara untuk melacak jarigan sistem sungai bawah tanah dengan menggunakan garam, larutan kimia, pewarna, atau radioaktif (Ford dan Williams, 1992)

uvala, gabungan dari beberapa doline yang membentuk cekungan yang luas dengan bentuk tidak beraturan dengan banyak lubang infiltrasi ke dalam tanah (White, 1988)

vadose, zona vadose, zona dalam suatu akuifer atau formasi yang tidak jenuh air atau tidak mengandung air (Bahagiarti, 2005)

waktu tunda, timelag, jeda waktu antara kejadian hujan pada suatu daerah aliran sungai dengan debit puncak yang terjadi pada hidrograf aliran di sungai (Schulz, 1976)

water-rock interaction, hubungan berupa proses kimia antara mineral penyusun suatu akuifer dengan airtanah yang mengalir didalamnya (Appelo dan Postma, 1994) 


\section{DAFTAR PUSTAKA}

Acworth, R.I., 2001. Groundwater Hydrology, Short Course Note, School of Civil and Environmental Engineering, University of New South Wales, Sydney, Australia

Adji T.N. dan Nurjani, E., 1999. Optimasi Airtanah karst Sebagai Pemasok Air Domestik Pada Kawasan Kritis Air di Gunung Kidul, Laporan Penelitian, Fakultas Geografi UGM (tidak dipublikasikan)

Adji, T.N., 1997. Kualitas Air Goa-Goa Karts di Sekitar Cekungan Wonosari: Studi Kasus; DAS Bawah Tanah Bribin, Kabupaten Gunung Kidul, Daerah Istimewa Yogyakarta, Skripsi Sarjana, Fakultas Geografi UGM.

Agusman, M. A., Kertonegoro, B.D., Siradz, S.A., 2006. Karakterisasi tanah-tanah berwarna hitam hingga merah di atas formasi karst Kabupaten Gunung Kidul, Jurnal Ilmu Tanah dan Lingkungan, Vol. 6. no. 1, Fakultas Pertanian, UGM

Ahmad, M.L., Haryono, E., Suprojo, S.W., 2005, Geomorfologi Karst Mayor antara Telaga Sanglen dan Kamal, Kabupaten Gunung Kidul, DIY, Gunung Sewu-Indonesian Cave and Karst Journal, Vol. 1 No. 1, HIKESPI, Indonesia

Alekin, O.A., 1970. Principles of Hydrochemistry. Hydromet. Izdat., pp 443

Anthony, D.M., Groves, C., Meiman, J., 1997. Preliminary investigations of seasonal changes in the geochemical evolution of Logdson River, Mammoth Cave, Kentucky, Proceedings of the 4th Mammoth Cave Science Conf., Mammoth Cave, KY, 15-23.

Appelo, C.A.J., Postma, D., 1994. Geochemistry, groundwater and pollution. A.A. Balkema, Rotterdam, 536p.

Ashton, K., 1966. The analysis of flow data from karst drainage systems. Transactions of the Cave Research Group of Great Britain 7:161-203.

Atkinson, T.C., 1977a. Carbon dioxide in the atmosphere of the unsaturated zone: an important control of groundwater hardness in limestones. Journal of Hydrology 35: $111-125$.

Atkinson, T.C.,1977b. Diffuse flow and conduit flow in limestone terrain in the Mendip Hills, Somerset (Great Britain). Journal of Hydrology 35: 95-110.

Bakalowicz, M., 1977. Etude du degre d'organisation des ecoulements souterrains dans les aquiferes carbonates par une methode hydrogeochimique nouvelle. Academy of Science, Paris, 284D: 2463-2466.

Balazs, D., 1968. Karst Regions in Indonesia: Karszt-Es Barlangkutatas, Volume V. Budapest, Globus nyomda, $61 \mathrm{p}$.

Balazs, D., 1971, Intensity of the Tropical Karst Development Based on Cases of Indonesia, Karszt-Es Barlangkutatas, Volume VI. Budapest, Globus nyomda, 67 p.

Ball, J.W., Nordstrom, D.K., 1991. User's manual for WATEQ4F with revised thermodynamic database and test cases for calculating speciation of major, trace, and redox elements in natural water. USGS open fil rept. 91-183. http://h2o.usgs.gov/software/

Bappeda Kab. Gunung Kidul, 2007. Penyusunan Neraca Sumberdaya Air Kab. Gunung Kidul, DIY, Laporan Akhir, Gunung Kidul. 
Bemmelen, R.W. van, 1970. The Geology of Indonesia. General Geology of Indonesia and Adjacent Archipelagoes. Government Printing Office. The Haque

Bintarto, R., Hadisumarno, H., 1987. Metode Analisa Geografi, LP3ES, Jakarta

Blair, R.W., 2008. Karst Landforms and Lakes, National Aeronautics and Space Administration, http://disc.sci.gsfc.nasa.gov/geomorphology/GEO 7

Bonacci, O., 190, Regionalization in karst regions, Proceedings of the Ljubljana Symposium, April 1990, IAHS Publ. no. 191, 1990.

Bogli, 1980. Karst Hydrology and Physical Speleology. Springler-Verlag

Bogli, A., 1960. Kalklosung und Karrenbildung.- Z.Geomorph., Suppl.2, Internationale Beitrage zur Karstmorphologie: 4-21.

Brusca, L., Aiuppa, A., D’Alessandro, W., Parello, F., Allard, P., Michel, A., 2001. Geochemical mapping of magmatic gas-water-rock interactions in the aquifer of Mount Etna volcano. Journal of Volcanology and Geothermal Research 108: 199218.

Budel, J. K. 1975. The Ice Age In The Tropics. Universitas, 1, 183-192.

Currens, J.C., 1999. A sampling plan for conduit flow karst springs, minimizing sampling cost and maximizing statistical utility, Engineering Geology, 52.121-128.

Dam, M. A. C. 1994. The Late Quaternary Evolution Of The Bandung Basin, West-Java, Indonesia. Department Of Quaternary Geology, Faculty Of Earth Science, Vrije Universiteit, De Belelaan 1085, Amsterdam, 252 Pp.

Dane, F.C. 1990. Research Methods, Brooks/Cole Publishing Company, Pacific Grove, California

Danes, J.V., 1910. Die Karstphanomene in Goenoeng Sewoe auf Java, Tjdschrift van het kon. Ned. Aardrijksk. Gen. Tweede Serie, deel XXVII, 247-260

Daoxian, Y, 2005, The Carbon Cycle in Karst, Karst Dynamic Laborartory, China, http://www.karst.edu.cn/carbon/car-cyc.htm

Desmarais, K., and Rojstaczer, S., 2002. Inferring groundwater flow paths from measurements of carbonate spring response to storms, Journal of Hydrology, v. 260, $118-134$

Doerfliger, N. and Zwahlen, F. 1995. National report from Switzerland. In: COST Action 65 Report Hydrogeological aspects of groundwater protection in karstic areas. European Commission. 446p.

Domenico,P.A. and Schwartz, F.W., 1990. Physical and Chemical Hydrogeology. $2^{\text {nd }}$ Ed. John Wiley \& Sons

Drever, J.I. 1988. The Geochemistry of Natural Water, $2^{\text {nd }}$ edition. Englewood Cliffs, New Jersey: Prentice Hall

Drew, D. 1995. Glossary of karstic terminology. In: COST Action 65 Report .

Dreybrodt, W. and Gabrovsek, F., 2003. Basic Processes and Mechanism Governing the Evolution of Karst./Speleogenesis and Evolution of Karst Aquifers 1 (1), www.speleogenesis.info, 26 pages.

Eckhardt K, 2005. How to construct recursive digital filters for baseflow separation. Hydrological Processes 19, 507-515. 
Etfimi, R., 2005. Use of hydrochemical studies to identify the recharge sources of karst Spring; example of Poceme springs in Albania, Geophysical Research Abstracts, Vol.7, 04063

Fakultas Kehutanan, 1993. Penyusunan Arahan Konservasi Tanah dan Air di Daerah Tangkapan Air Gua Bribin Kabupaten Gunung Kidul DIY. Kerjasama antara Dinas Kehutanan DIY - Fakultas Kehutanan UGM Yogyakarta

Fetter, C.W., 1994, Applied Hydrogeology. $3^{\text {rd }}$ Ed. Macmillan Publishing Company, New York

Flathe, H. \& Pfeiffer, D., 1965. Grundzuge der morphologie, Geology und Hydrogeologie im Karstgebiet Gunung Sewu (Java, Indonesien): Geologisches Jahrbuch, v. 83, p. 533562.

Ford, D. and Williams, P. 1992. Karst Geomorphology and Hydrology, Chapman and Hall, London

Ford, T.D., Cullingford, C.H.D. 1986. The Science of Speleology, Academic Press, London, New York, San Francisco

Ford, T.D., Ewers, R.O., 1971. The development of limestone caves in the dimensions of length and depth, Can. J Earth Sci 15:1783-1798

Freeze, R.A. and Cherry, J.A., 1979. Groundwater. Prentice Hall.

Gillieson, D., 1996, Caves: Processes, Development, and Management, Blackwell, Oxford

Haggett, P.1975. Geography, A Modern Synthesis, Harper \& Row Publisher, London

Halihan, T., Wicks, C.M., 1998. Modeling of storm responses in conduit flow aquifers with reservoirs. Journal of Hydrology 208: 82-91.

Harvey, D., 1969. Explanation in Geography, Edward Arnold, London.

Haryono, E. Day,M. , 2004. Landform differentiation within the Gunung Kidul Kegel karst, Java, Indonesia, Journal of Cave and Karst Studies, 66-August

Haryono, E., 2001. Nilai Hidrologis Bukit Karst, Makalah pada seminar Nasional, EkoHidrolik, 28-29 Maret 2001, Jurusan Teknik Sipil , UGM

Haryono, E., 2008. Model Perkembangan Karst Berdasarkan Morfometri Jaringan Lembah Di Karangbolong, Gunungsewu. Blambangan dan Rengel, Disertasi, Fakultas Geografi Universitas gadjah Mada, Yogyakarta

Hess, J.W., White, W.B., 1988. Storm response of the karstic carbonate aquifer of southcentral Kentucky. Journal of Hydrology 99: 235-252.

Jankowski, J. , Jacobson, G., 1990. Hydrochemical processes in groundwater-discharge playas, Central Australia. Hydrological Processes, 4, 59-70

Jankowski, J., 2001. Groundwater Environment, Short Course Note, School of Geology, University Of New South Wales, Sydney, Australia

Karimi, H., Raeisi , E., Zare, M. 2003. Hydrodynamic behavior of the Gilan karst spring, west of Zagros, Iran. BCRA Cave and Karst Science. Vol 30 (1) pp 15 - 22

Karimi, H., Raeisi, E., Bakalowicz, M., 2004. Characterising the main karst aquifers of the Alvand Basin, northwest of Zagros, Iran, by a hydrogeochemical approach, Hydrogeology Journal, Vol.13 nr. 5-6 
Ko, R.K.T., MD.DV., 1984. Peranan Ilmu Speleologi Dalam Penyelidikan Fenomena Karstik dan Sumberdaya Tanah dan Air - Sebuah Informasi Soal Speleologi, Ceramah Pada Pusat Penelitian Tanah -Bogor, Bogor.

Kusumayudha, S.B., 2005, Hidrogeologi Karst dan Geometri Fraktal di Daerah Gunungsewu, Adicita Karya Nusa, Yogyakarta

Kusumayudha, S.B., Zen, M.T., Notosiswoyo, S., Gautama, R.S., 2000. Fractal analysis of the Oyo River, cave system and topography of the Gunung Sewu karst area, Central Java, Indonesia, Hydrogeology Journal, 8, 337-345

Lehmann, H., 1936. Morfologiche Studien auf Java, Gohr, Abh, 3, Stutgart

Linsley, R.K., Kohler, M.A., Paulhus, J.L., 1975. Hydrology for Engineers. $2^{\text {nd }}$. Ed. Mac Graw Hill Kogakusha Ltd. Tokyo, Japan

Liu, Z.,Groves,C., Yuan,D., Meiman, J., 2004(a). South China Karst Aquifer Storm-Scale Hydrochemistry, Ground Water. 42, Jul/Agt 2004

Liu, Z.,Groves,C., Yuan,D., Meiman,J., Jiang, D., He, S., Li,Q., 2004(b). Hydrochemical variation during flood pulses in the south-west peak cluster karst : impacts of $\mathrm{CaCO}_{3}$ $\mathrm{H}_{2} \mathrm{O}-\mathrm{CO}_{2}$ interactions, Hydrological Processess. 18, 2423-2437

MacDonalds and Partners. 1984. Greater Yogyakarta - Groundwater Resources Study. Vol 3C: Cave Survey. Yogyakarta, Directorate General of Water Resources Development Project (P2AT)

Martin, J.B., Wicks, C.M. Sasowky, J.D. 2002. Interaction of Fracture and Conduit Flow in the Evolution of Karst Aquifers, Hydrogeology and Biology of Past-Paleozoic Carbonate Aquifers. KWI Special Publ. 7., Charles Town, Virginia

Morley, J. 1982. Palaeoecological Interpretation Of A 10,000 Year Pollen Record From Danau Padang, Central Sumatra, Indonesia. Journal Of Biogeography, 9, 151-190.

Mudry, J., 1990. Les courbes flux chimique-débit et le fonctionnement des aquifères karstiques. Journal of Hydrology, 120: 283-294.

Mudry, J., 2004. Hydrochemical Characterization of Karst Aquifers, University of FrancheComté, BESANÇON, France Page 2. http://lsbb.unice.fr/sms us/Mudry.pdf

Mulyanto, D. 2006. Genesis dan keragaman warna tanah di batuan karbonat jalur BaronWonosari. Disertasi S-3 (tidak dipublikasikan), Fakultas Pertanian, UGM

Nathan RJ, McMahon TA, 1990. Evaluation of automated techniques for baseflow and recession analysis. Water Resources Research. 26(7):1465-1473.

Perrin J., Jeannin P.Y., Zwahlen F., 2000. Spatial variability of groundwater chemistry within a karst aquifer (Milandre test site, Swiss Jura).In Karst 2000: New trends in karst studies, Marmaris Turkey.

Perrin J., Jeannin P.Y., Zwahlen F., 2003. Implication of the spatial variability of infiltrationwater chemistry for the investigation of a karst aquifer a field study at Milandre test site, Swiss Jura. Hydrogeology Journal, 11:673-686

Perrin, J., 2003. A conceptual model of flow and transport in a karst aquifer based on spatial and temporal variation of natural tracers, PhD Thesis, Centre D'Hydrogeologie, University de Neuchatel 
Plagnes, V. and Bakalowicz, M., 2001. May it propose a unique interpretation for karstic spring chemographs? In: J. Mudry and F. Zwahlen (Editors), 7th Conference on Limestone Hydrology and Fissured Media. Franche-Comté University, Besançon, pp. 293-298.

Plummer, L.N., 1975. Mixing of sea water with calcium carbonate groundwater: quantitative studies in geological sciences. Geol. Soc. Am. Mem., 142, 219-236

Plummer,L.N., Prestemon,E.C. and Parkhurst, D.L., 1991. An Interactive Code (NETPATH) for modelling NET geochemical reactions along a flowPATH. U.S. Geological Survey, Water Resources Investigation. Rep. 91-4078, pp 130., http://h2o.usgs.gov/software/

Raeisi, E., Pezeshkpoor, P. , Moor, F., 1993. Characteristics of karst aquifers as indicated by temporal changes of the spring's physico-chemical properties. Iranian Journal of Science andTechnology 17(1): 17-28.

Raeisi, R., Karami,G., 1997. Hydrochemographs of Berghan karst spring as indicators of aquifer characteristics, Journal of Cave and Karst Studies 59(3), 112-118

Rahardjo, W., Rumidi, S., Rosidi, H.M.D.,1977, Peta Geologi Lembar Jogjakarta, skala 1:100.000, Pusat Pengembangan dan Penelitian Geologi, Bandung

Ryan, M., Meiman, J., 1996. An examination of short-term variations in water quality at a karst spring in Kentucky. Ground Water 34: 23-30.

Samodra, H., 2005. Monografi Kars Gunung Sewu, Pusat Penelitian dan Pengembangan Geologi, Badan Geologi, Departemen Energi dan Sumberdaya Mineral

Scanlon, B.R., Thrailkill, J. 1987. Chemical similarities among physically distinct spring types in a karst terrain. Journal of Hydrology 89: 259-279.

Schulz, E.F., 1976. Problems in Applied Hydrology. Water Resources Publication, Colorado

Short, N.M., Blair, R.W. 1986. Geomorphology from Space, NASA Publication. http://geoinfo.amu.edu.pl/wpk/geos/GEO HOME_PAGE.html

Shuster, E.T. , White, W.B., 1971. Seasonal fluctuations in the chemistry of limestone springs: A possible means for characterizing carbonate aquifers. Journal of Hydrology 14: 93-128.

Smakhtin, V.Y., 2001. Low flow hydrology: a review. Journal of Hydrology, 240:147-86.

Smart, P.L. and Hobbes, S.L., 1986. Characteristics of Carbonate Aquifers: A conceptual basis. In Proceedings, Environmental Problem in Karst Terrains and Their Solution. Bowling Green, KY: National Well Water Association, 1-4

Srijono dan Aldilla, N., 2006. Geogenesis Polje-Purba Ponjong Kabupaten Gunungkidul, Daerah Istimewa Yogyakarta, Gunung Sewu-Indonesian Cave and Karst Journal, Vol. 2 No. 1, HIKESPI, Indonesia

Strahler, A.N., 1989. Introduction to Physical Geography, John Wiley \& Sons, New York.

Stumn W., and J.J. Morgan. 1981. Aquatic Chemistry, $2^{\text {nd }}$ edition. New York:John Wiley and Sons

Summerfield, M.A., 1991, Global Geomorphology, John Wiley and Sons, New York.

Surono, Toha, B., Sudarno, I., Wiryosujono, S., 1992, Geologi Lembar Surakarta-Giritontro, Jawa, Pusat Penelitian dan Pengembangan Geologi, Bandung 
Suryanta, G., 2001, Kajian Karakteristik Hidrograf Satuan Daerah Karst Gunung Kidul (Studi Kasus: Daerah Tangkapan Air Sungai Bawahtanah Bribin, Kabupaten Gunung Kidul, Propinsi DIY), Skripsi Sarjana, Fakultas Geografi, UGM, Yogyakarta

Sutikno dan Tanudrijo, D., 2006. Kajian Geoarkeologi Kawasan Gunungsewu Sebagai Dasar Pengembangan Model Pelestarian Lingkungan Karst, Laporan Hasil Penelitian Hibah Penelitian Pasca Sarjana-HPTP, Universitas Gadjah Mada

Sweeting, M.M., 1972. Karst Landforms, Macmillan, London.

Taylor, J.T., Greene, E.A.2001. Quantitative Approaches in Characterizing Karst Aquifers, in Eve L. Kuniansky, ed., USGS Karst Interst Group Proceedings, Water Resources Investigation Report 01-4011, p. 164-166.

Toha, B., Purtyasti, R.D., Sriyono, Sutoto, Rahardjo, W., dan Pramumijoyo, S., 1994. Geologi Dearah Pegunungan Selatan, Suatu Kontribusi, Prosiding Geologi dan Geoteknik Pulau Jawa sejak Akhir Mesozoik hingga Kuarter, hal. 19-36, Jurusan Teknik Geologi, Universitas Gadjah Mada

Trudgil, S., 1985. Limestone Geomorphology, Longman, New York.

Urushibara-Yoshino, K. 1995. Environmental Change In The Karst Areas On The Island Of Java. Journal Of The Faculty Of Letters, Komazawa University, 53, 85-97.

Urushibara-Yoshino, K., Yoshino,M., 1997. Palaeoenvironmental change in Java Islands and its surrounding areas, Journal of Quaternary Science, 12 (5), 435-442

Verstappen, H. Th. 1975. On Palaeoclimates And Landform Development In Malesia. Modern Quaternary Research SE Asia, 1, 3-35.

Verstappen, H. Th. 1997. The effect of climatic change on southeast Asian geomorphology. J. Quaternary Sci., Vol. 12, 413-418.

Verstappen, H. Th., 1994. Climatic Change and Geomorphology In S. And Se Asia. Proceedings, Colloquim Royal Academy Of Overseas Sciences, Brussels, 1992. GeoEco-Trop 16, 101-147.

Verstappen, H.Th., 1969. The state of karst research in Indonesia, in Stelcl, O., (ed.), Problems of the Karst Research, Brno, Ceskoslovenska Akademia Sciencias, p. 139148.

Vesper, D.J., White, W.B., 2004. Storm pulse chemograf of saturation index and carbondioxide pressure:implication for shifting recharge sources during storm events in the karst aquifer at Fort Campbell, Kentucky/Tenessee, USA. Hydrogeology Journal, Vol. 12:135-143

Waltham, A.C., Smart, P.L., Friederich, H., Eavis, A.J. \& Atkinson, T.C., 1983, The caves of Gunung Sewu, Java: Cave Science, v. 10, no. 2, p. 55-96.

Wang,Y., Ma, T., Luo,Z., 2001. Geostatistical and geochemical analysis of surface water leakage into groundwater on a regional scale: a case study in the Liulin karst system, northwestern China, Journal of Hydrology 246, 223-234

White, W.B., 1988. Geomorphology and Hydrology of Karst Terrain. Oxford University Press, New York

White, W.B., 1993. Analysis of Karst Aquifer. In:Alley, W.M. (editor), Regional Groundwater Quality. Van Nostrand Reinhold, New York

White, W.B., 2004. Conceptual Models for Karstic Aquifers, www.speleogenesis.info 
White, W.B., 2004. Thermodynamic equilibrium, kinetics, activation barriers, and reaction mechanisms for chemical reactions in karst terrains. Environmental Geology 30:4658

Williams, P.W., 1983. The role of the subcutaneous zone in karst hydrology. Journal of Hydrology 61: 45-67.

Wiyono, Siradz, S.A. dan Hanudin, E., 2006. Aplikasi Soil Taxonomy pada tanah-tanah yang berkembang dari bentukan karst Gunung Kidul. Jurnal Ilmu Tanah dan Lingkungan, Vol. 6. no.1, Fakultas Pertanian, UGM

Yunus, H.S., 2008. Konsep dan Pendekatan Gografi: Memaknai Hakekat Keilmuannya, Makalah dalam Sarasehan Forum Pimpinan Pendidikan Tinggi Geografi Indonesia, Fakultas Geografi UGM, Yogyakarta. 


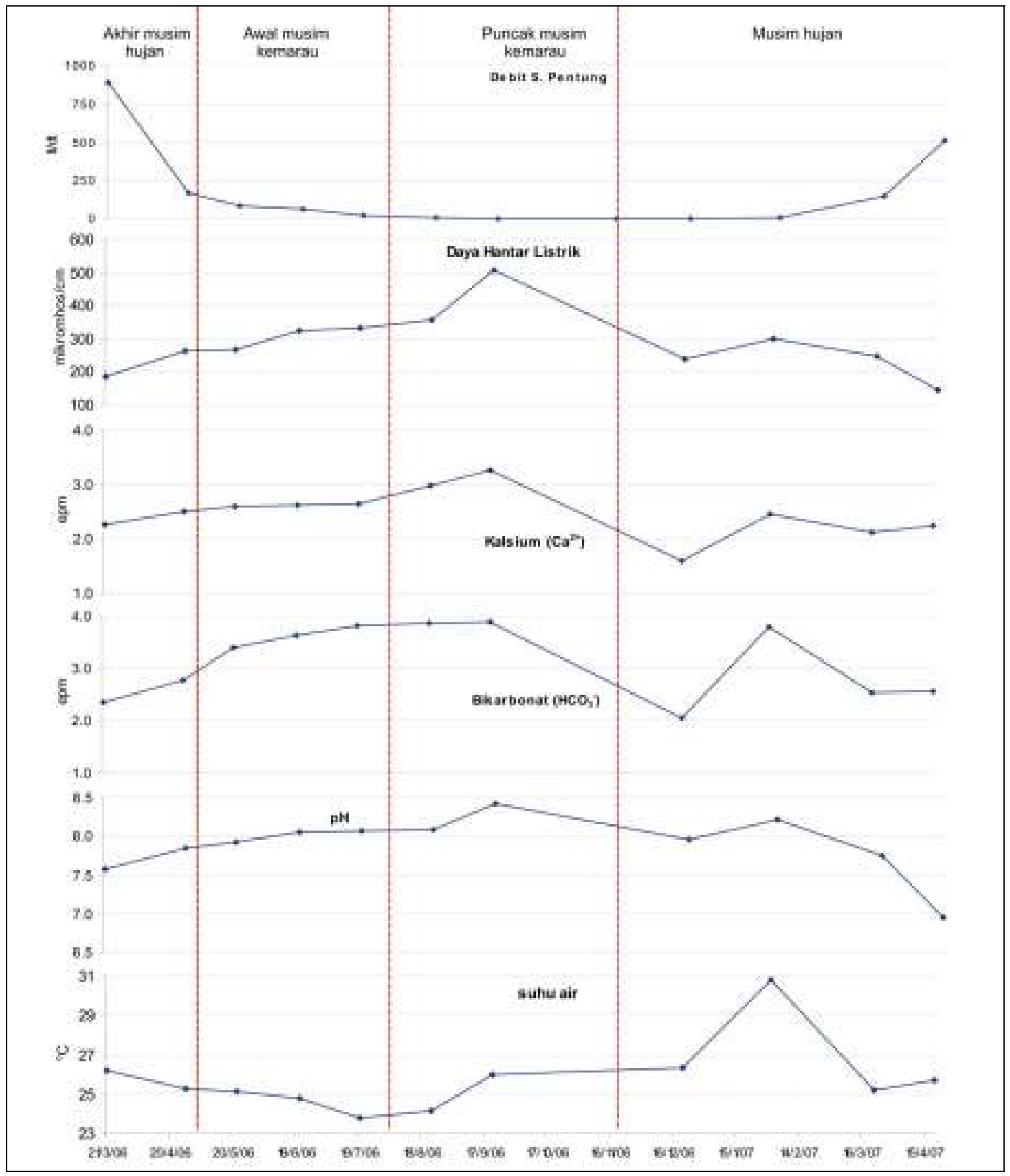

Lampiran 1-a. Hidrokemograf Sungai Pentung sepanjang tahun (sumbu x tidak diskalakan) 


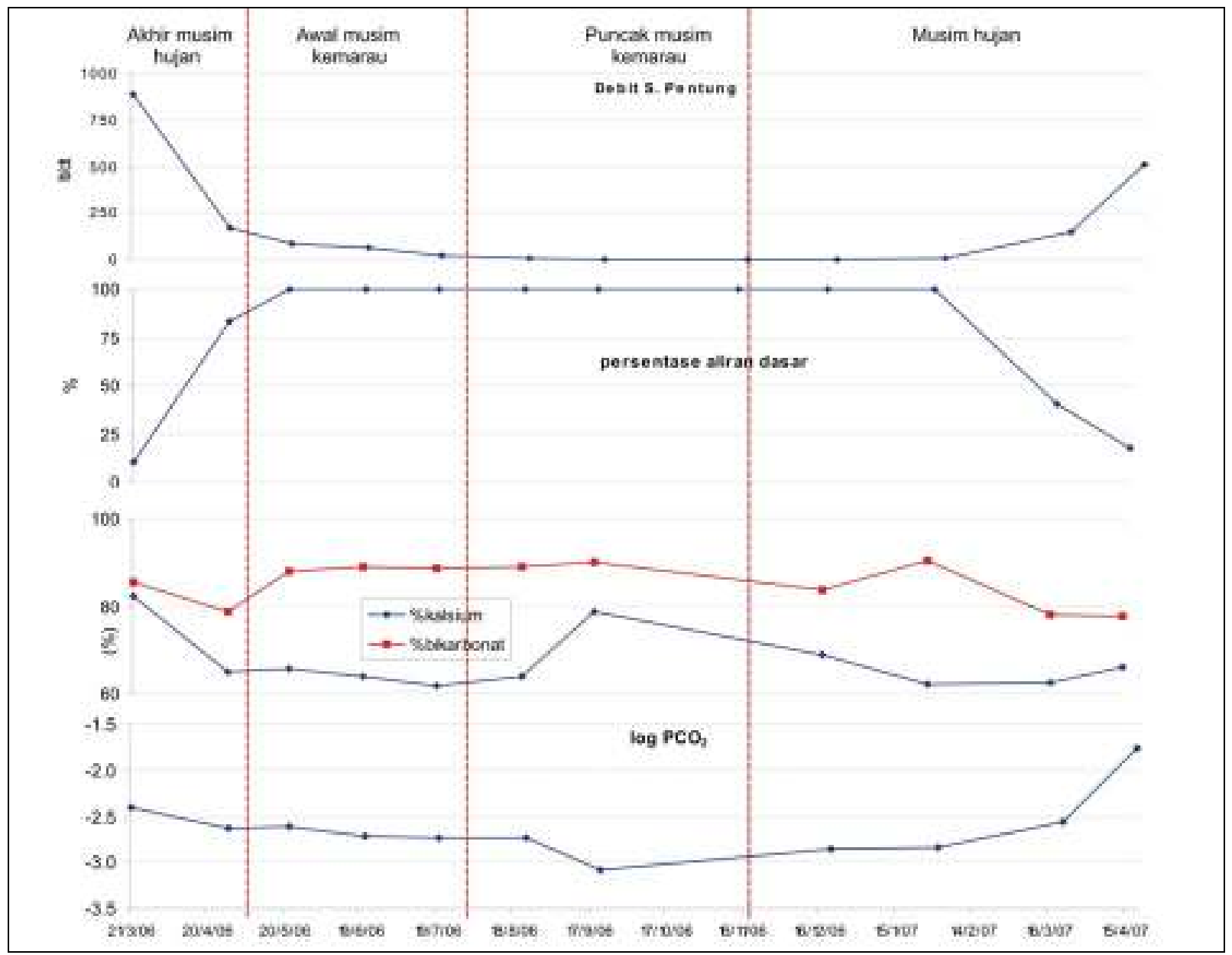

Lampiran 1-b. Variasi debit, persentase aliran dasar, $\log \mathrm{PCO}_{2}$ dan persentase kalsium dan bikarbonat Sungai Pentung sepanjang tahun (sumbu x tidak diskalakan) 


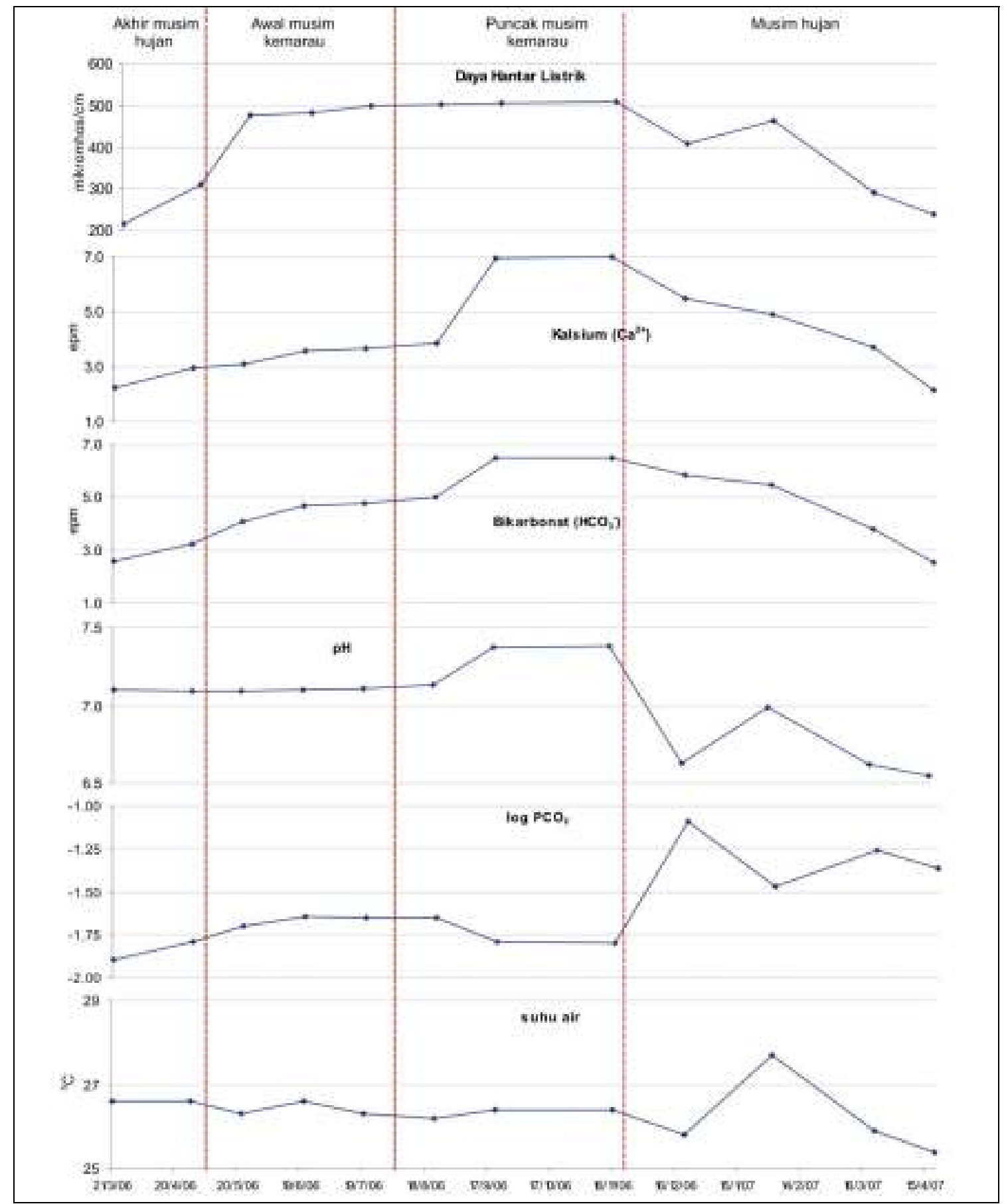

Lampiran 1-c. Hidrokemograf Luweng Jomblangan sepanjang tahun (sumbu x tidak diskalakan) 


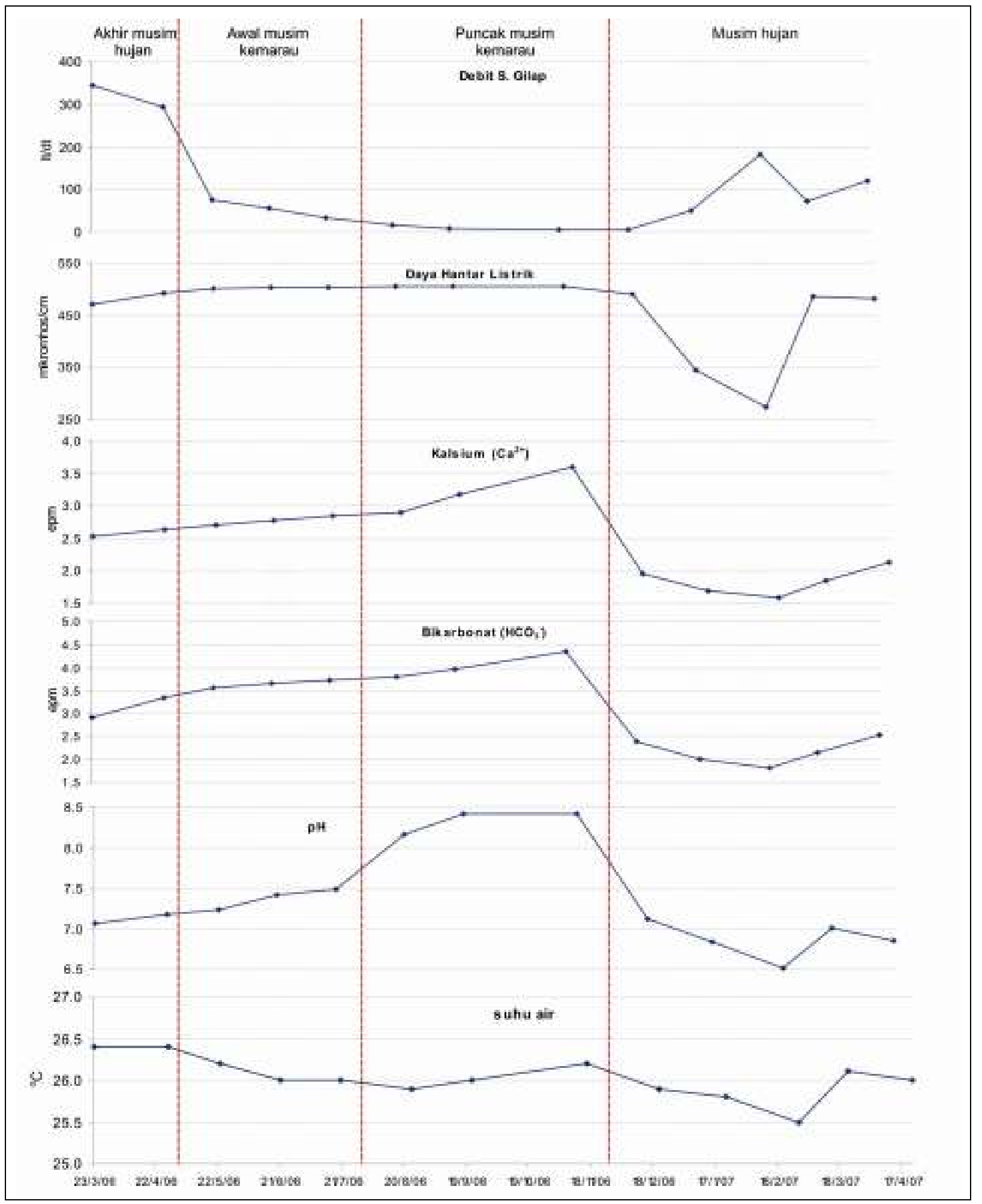

Lampiran 1-d. Hidrokemograf Gua Gilap sepanjang tahun (sumbu x tidak diskalakan) 


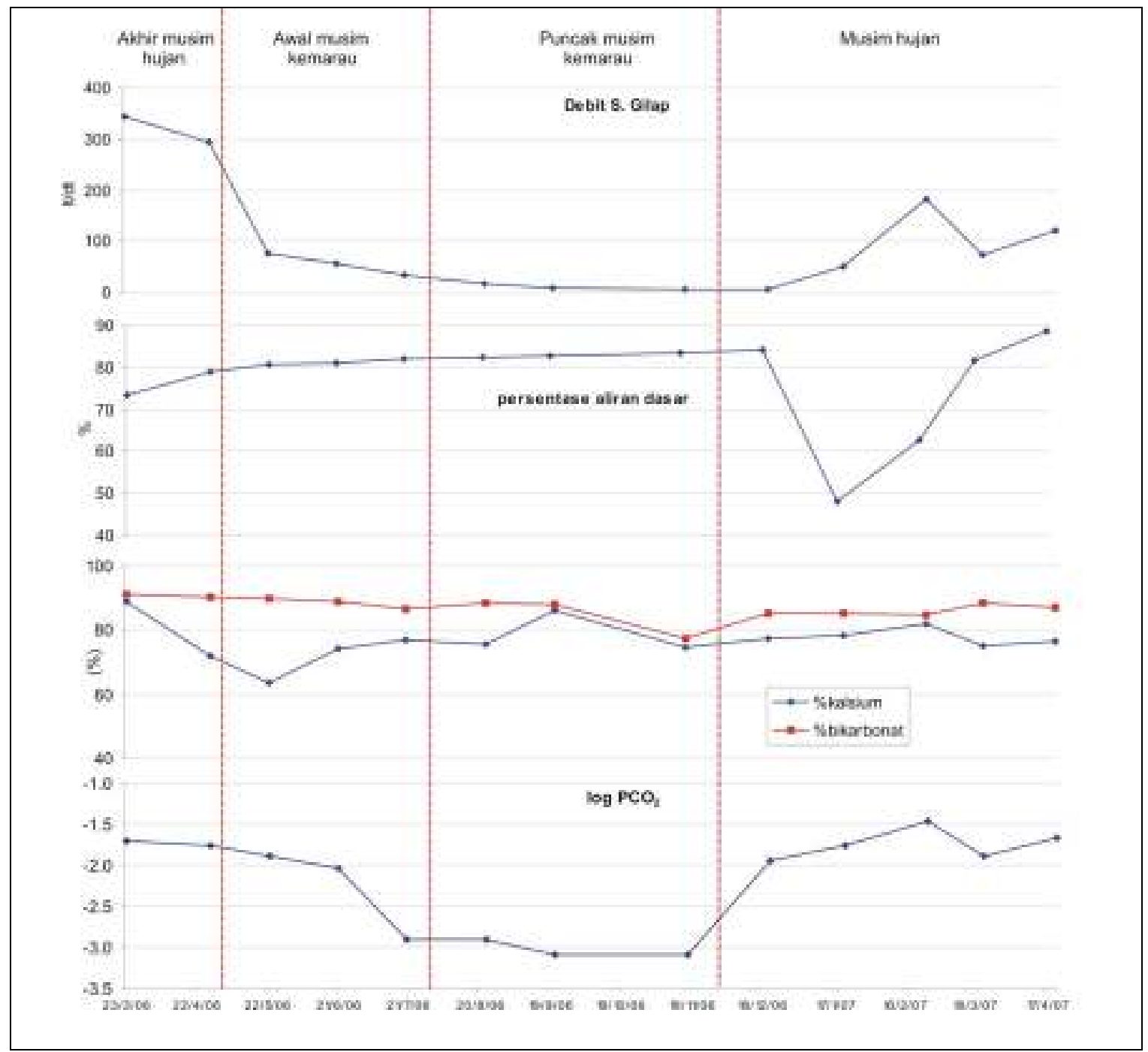

Lampiran 1-e. Variasi debit, persentase aliran dasar, $\log \mathrm{PCO}_{2}$ dan persentase kalsium dan bikarbonat Gua Gilap sepanjang tahun (sumbu x tidak diskalakan) 


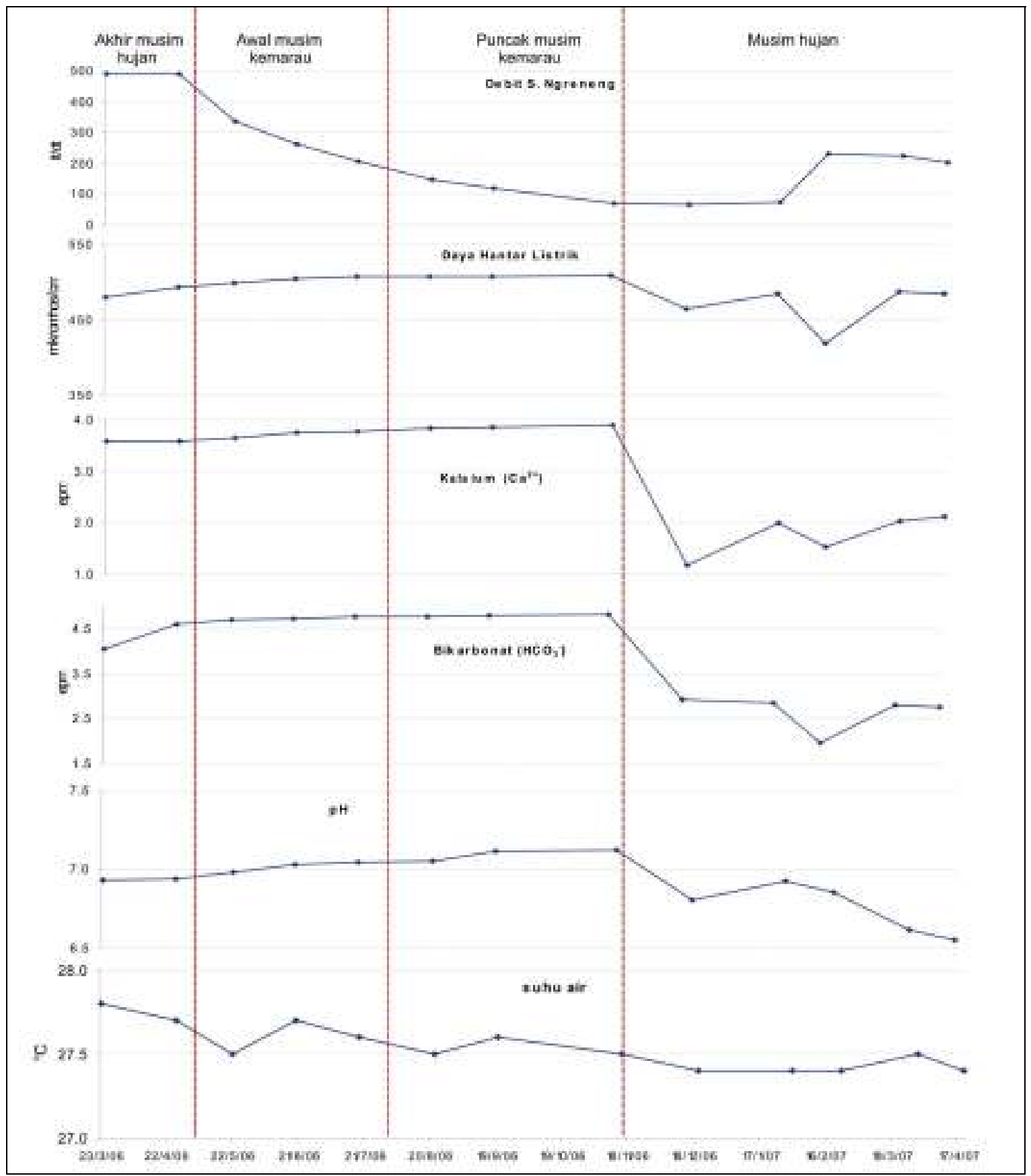

Lampiran 1-f. Hidrokemograf Gua Ngreneng sepanjang tahun (sumbu x tidak diskalakan) 


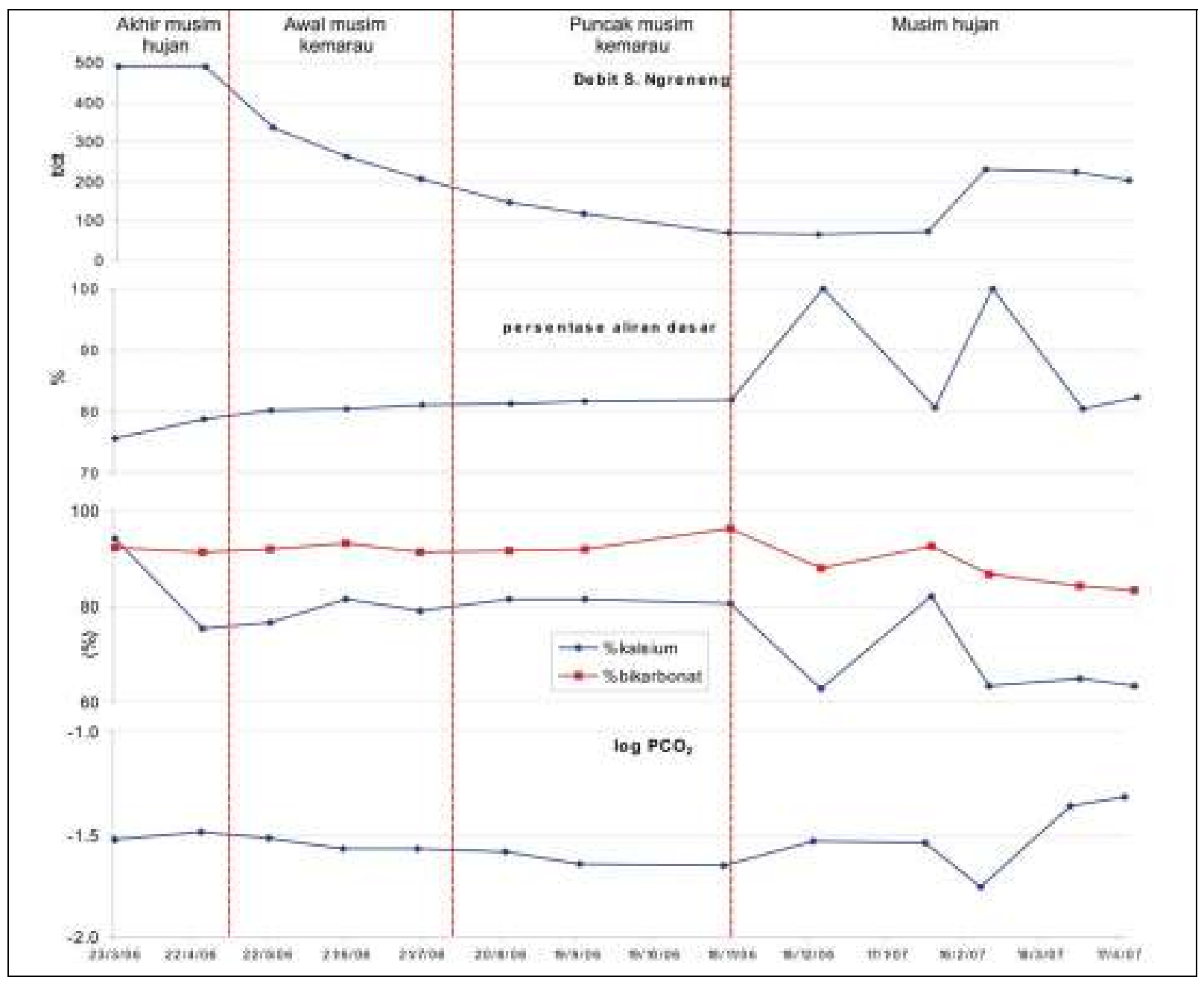

Lampiran 1-g. Variasi debit, persentase aliran dasar, $\log \mathrm{PCO}_{2}$ dan persentase kalsium dan bikarbonat Gua Ngreneng sepanjang tahun (sumbu x tidak diskalakan) 
Lampiran 2. Kondisi dan Hubungan Antar Parameter SKD di Hulu dan Hilir SBT Bribin Musim Kemarau

\begin{tabular}{|c|c|c|c|c|c|c|c|c|}
\hline \multicolumn{9}{|c|}{ Air tetesan } \\
\hline & Hulu (G. Gilap) & Hilir (G. Bribin) & Hulu (G. Gilap) & Hilir (G. Bribin) & Hulu (G. Gilap) & Hilir (G. Bribin) & Hulu (G. Gilap) & Hilir (G. Bribin) \\
\hline 1 & \multicolumn{2}{|c|}{ SI kalsit } & \multicolumn{2}{|r|}{$\mathrm{pH}$} & \multicolumn{2}{|c|}{$\log P_{\mathrm{cO} 2}$} & \multicolumn{2}{|c|}{$\mathrm{Ca}^{2+}(\mathrm{ppm})$} \\
\hline Nilai & \multirow{2}{*}{$\begin{array}{l}\quad 0,56 \text { s/d } 1,25 \\
\text { Dominan jenuh } \\
\text { (supersaturated) }\end{array}$} & $-0,52 \mathrm{~s} / \mathrm{d} \quad 0,29$ & \multirow{2}{*}{$\begin{array}{c}\text { 8,29 s/d 8,57 } \\
\text { Tinggi saat kemarau }\end{array}$} & $7,06 \mathrm{~s} / \mathrm{d} 7,72$ & \multirow{2}{*}{$\begin{array}{l}\quad-3,03 \text { s/d }-3,31 \\
\text { Sedikit cadangan } \\
\text { karbondioksida (closed } \\
\text { system) }\end{array}$} & $-1,88 \mathrm{~s} / \mathrm{d}-2,47$ & \multirow{2}{*}{\begin{tabular}{l}
\multicolumn{1}{c}{62,6 s/d 80,0} \\
Jumlah kalsium \\
terlarut lebih sedikit
\end{tabular}} & $45,1 \mathrm{~s} / \mathrm{d} 92,7$ \\
\hline kondisi & & $\begin{array}{l}\text { Dominan agresif } \\
\text { (undersaturated) }\end{array}$ & & $\begin{array}{l}\text { Tetap rendah saat puncak } \\
\text { kemarau }\end{array}$ & & $\begin{array}{l}\text { Masukan karbondiksida } \\
\text { lebih besar (open } \\
\text { system) }\end{array}$ & & $\begin{array}{l}\text { Fluktuasi kalsium } \\
\text { terlarut besar }\end{array}$ \\
\hline 2 & \multicolumn{2}{|c|}{$\begin{array}{c}\text { Hubungan }\left(\mathbf{R}^{2}\right) \text { antara } \mathrm{SI} \text { kalsit dan Log } \\
\mathrm{P}_{\mathrm{cO} 2}\end{array}$} & \multicolumn{2}{|c|}{$\begin{array}{c}\text { Hubungan }\left(\mathrm{R}^{2}\right) \text { antara SI kalsit dan Log } \\
\mathrm{Ca}^{2+}\end{array}$} & \multicolumn{2}{|c|}{ Hubungan $\left(\mathrm{R}^{2}\right)$ antara $\mathrm{SI}$ kalsit dan $\mathrm{pH}$} & & \\
\hline Nilai & \multirow{3}{*}{$\begin{array}{l}\quad 0,026 \text { (negatif) } \\
\text { Hampir tidak ada } \\
\text { hubungan antara } \\
\text { besar kecilnya Log } \\
\text { Pco2 dan naik } \\
\text { turunnya SI kalsit } \\
\text { Water-rock interaction } \\
\text { berupa pengendapan } \\
\text { mineral kalsit, gas } \\
\text { karbondiksida sudah } \\
\text { digunakan untuk } \\
\text { melarutkan batuan } \\
\text { karbonat }\end{array}$} & 0,731 (negatif) & \multirow{3}{*}{$\begin{array}{l}\quad 0,996 \text { (positif) } \\
\text { Naik/turun-nya nilai SI } \\
\text { tergantung dari } \\
\text { naik/turun-nya nilai } \\
\text { kalsium terlarut } \\
\text { (determinasinya kuat) } \\
\text { Water-rock interaction } \\
\text { (pengendapan } \\
\text { mineral kalsit). } \\
\text { Membentuk ornamen } \\
\text { gua secara intensif }\end{array}$} & 0,206 (positif) & \multirow{3}{*}{$\begin{array}{l}\quad 0,701 \text { (positif) } \\
\text { Naik/turun-nya nilai SI } \\
\text { tergantung dari } \\
\text { naik/turun-nya pH } \\
\text { (determinasinya cukup } \\
\text { kuat) } \\
\text { Water-rock interaction } \\
\text { berupa pengendapan } \\
\text { mineral kalsit. } \\
\text { Determinasi SI-kalsium } \\
\text { lebih tinggi dibanding } \\
\text { SI-pH }\end{array}$} & 0,661 (positif) & & \\
\hline kondisi & & $\begin{array}{l}\text { Semakin besar nilai } \mathrm{SI} \\
\text { maka semakin kecil } \\
\text { nilai Log } \mathrm{P}_{\mathrm{CO} 2} \\
\text { (determinasi cukup } \\
\text { kuat) }\end{array}$ & & $\begin{array}{l}\text { Hampir tidak ada } \\
\text { hubungan antara kalsium } \\
\text { terlarut dan naik turunnya } \\
\text { SI kalsit }\end{array}$ & & $\begin{array}{l}\text { Naik/turun-nya nilai SI } \\
\text { tergantung dari } \\
\text { naik/turun-nya pH } \\
\text { (determinasinya cukup } \\
\text { kuat) }\end{array}$ & & \\
\hline $\begin{array}{l}\text { Proses } \\
\text { hidrogeokimia }\end{array}$ & & $\begin{array}{l}\text { Water-rock interaction } \\
\text { berupa pelarutan } \\
\text { mineral kalsit saat nilai } \\
\text { SI kalsit negatif. } \\
\text { Ada masukan gas } \\
\text { karbondioksida yang } \\
\text { memicu proses } \\
\text { pelarutan. } \\
\end{array}$ & & $\begin{array}{l}\text { Water-rock interaction, } \\
\text { tetapi tidak banyak } \\
\text { merubah nilai kalsium } \\
\text { terlarut di air }\end{array}$ & & $\begin{array}{l}\text { Terjadi proses water- } \\
\text { rock interaction berupa } \\
\text { pelarutan mineral kalsit } \\
\text { saat nilai SI negatif dan } \\
\text { pengendapan mineral } \\
\text { kalsit, pada nilai SI kalsit } \\
\text { positif. }\end{array}$ & & \\
\hline \multicolumn{9}{|c|}{ Air sungai bawah tanah } \\
\hline 1 & \multicolumn{2}{|c|}{ SI kalsit } & \multicolumn{2}{|r|}{$\mathrm{pH}$} & \multicolumn{2}{|c|}{$\log P_{\mathrm{cO} 2}$} & \multicolumn{2}{|c|}{$\mathrm{Ca}^{2+}(\mathrm{ppm})$} \\
\hline Nilai & \multirow{2}{*}{$\begin{array}{l}\quad-0,15 \mathrm{~s} / \mathrm{d} \quad 1,18 \\
\text { Dominan jenuh } \\
\text { (supersaturated) }\end{array}$} & $-0,83 \mathrm{~s} / \mathrm{d} \quad 0,26$ & \multirow{2}{*}{$\begin{array}{c}7,06 \text { s/d } 8,42 \\
\text { pH lebih dari } 8 \text { pada } \\
\text { puncak kemarau }\end{array}$} & $6,96 \mathrm{~s} / \mathrm{d} 7,39$ & \multirow{2}{*}{$\begin{array}{c}-1,71 \text { s/d }-3,09 \\
\text { Kurang masukan } \\
\text { karbondioksida (closed } \\
\text { system) }\end{array}$} & $-1,53 \mathrm{~s} / \mathrm{d}-2.13$ & \multirow{2}{*}{$\begin{array}{l}50,56 \text { s/d } 68,08 \\
\text { Jumlah dan } \\
\text { fluktuasi sedikit }\end{array}$} & $86,13 \mathrm{~s} / \mathrm{d} 110,3$ \\
\hline kondisi & & $\begin{array}{l}\text { Dominan agresif } \\
\text { (undersaturated) }\end{array}$ & & $\begin{array}{l}\text { Tetap rendah saat } \\
\text { kemarau }\end{array}$ & & $\begin{array}{l}\text { Lebih banyak masukan } \\
\text { dari sistem pelorongan } \\
\text { (open system) }\end{array}$ & & $\begin{array}{l}\text { Jumlah dan fluktuasi } \\
\text { kalsium terlarut besar }\end{array}$ \\
\hline 2 & \multicolumn{2}{|c|}{$\begin{array}{c}\text { Hubungan }\left(\mathbf{R}^{2}\right) \text { antara SI kalsit dan Log } \\
\mathbf{P}_{\mathrm{cO} 2}\end{array}$} & \multicolumn{2}{|c|}{$\begin{array}{l}\text { Hubungan }\left(\mathrm{R}^{2}\right) \text { antara } \mathrm{SI} \text { kalsit dan Log } \\
\mathrm{Ca}^{2+}\end{array}$} & \multicolumn{2}{|c|}{ Hubungan $\left(\mathrm{R}^{2}\right)$ antara $\mathrm{SI}$ kalsit dan $\mathrm{pH}$} & & \\
\hline & \multirow{3}{*}{$\begin{array}{l}\quad 0,936 \text { (negatif) } \\
\text { SI kalsit naik ketika } \\
\text { pasokan gas } \\
\text { karbondioksida turun } \\
\text { (determinasi kuat) } \\
\text { Dominan } \\
\text { pengendapan mineral } \\
\text { kalsit, kurang } \\
\text { pasokan gas } \\
\text { karbondioksida }\end{array}$} & 0,953 (negatif) & \multirow{3}{*}{$\begin{array}{l}\quad 0,881 \text { (positif) } \\
\text { Determinasi cukup } \\
\text { kuat, SI kalsit } \\
\text { tergantung fluktuasi } \\
\text { kalsium terlarut } \\
\text { Water- rock } \\
\text { interacton berupa } \\
\text { pengendapan kalsit, } \\
\text { memicu pertumbuhan } \\
\text { ornamen }\end{array}$} & 0,922 (positif) & \multirow{2}{*}{$\begin{array}{l}\quad 0,888 \text { (positif) } \\
\text { Determinasi cukup } \\
\text { kuat, SI kalsit } \\
\text { tergantung fluktuasi pH } \\
\text { dalam air }\end{array}$} & 0,968 (positif) & & \\
\hline kondisi & & $\begin{array}{l}\text { SI kalsit naik ketika } \\
\text { pasokan gas } \\
\text { karbondioksida turun } \\
\text { (determinasi kuat) }\end{array}$ & & $\begin{array}{l}\text { Determinasi cukup kuat, } \\
\text { SI kalsit tergantung } \\
\text { fluktuasi kalsium terlarut }\end{array}$ & & $\begin{array}{l}\text { Determinasi cukup kuat, } \\
\text { SI kalsit tergantung } \\
\text { fluktuasi pH dalam air }\end{array}$ & & \\
\hline $\begin{array}{l}\text { Proses } \\
\text { hidrogeokimia }\end{array}$ & & $\begin{array}{l}\text { Ada masukan } \\
\text { karbondioksida dari } \\
\text { pelorongan, pelarutan } \\
\text { mineral kalsit }\end{array}$ & & $\begin{array}{l}\text { Water- rock interacton } \\
\text { berupa pelarutan kalsit, } \\
\text { memicu perkembangan } \\
\text { lorong gua }\end{array}$ & $\begin{array}{l}\text { Pengendapan mineral } \\
\text { kalsit pada pH tinggi }\end{array}$ & $\begin{array}{l}\text { Pelarutan mineral kalsit } \\
\text { pada pH sekitar } 7\end{array}$ & & \\
\hline
\end{tabular}


Lampiran 3. Kondisi dan Hubungan Antar Parameter SKD di Hulu dan Hilir SBT Bribin Musim Hujan

\begin{tabular}{|c|c|c|c|c|c|c|c|c|}
\hline \multicolumn{9}{|c|}{ Air tetesan } \\
\hline & Hulu (G. Gilap) & Hilir (G. Bribin) & Hulu (G. Gilap) & Hilir (G. Bribin) & Hulu (G. Gilap) & Hilir (G. Bribin) & Hulu (G. Gilap) & Hilir (G. Bribin) \\
\hline 1 & \multicolumn{2}{|c|}{ SI kalsit } & \multicolumn{2}{|c|}{$\mathrm{pH}$} & \multicolumn{2}{|c|}{$\log P_{\mathrm{CO} 2}$} & \multicolumn{2}{|c|}{$\mathrm{Ca}^{2+}(\mathrm{ppm})$} \\
\hline Nilai & $-0,17 \mathrm{~s} / \mathrm{d}-1,10$ & $-0,65 \mathrm{~s} / \mathrm{d}-0,79$ & $6,67 \mathrm{~s} / \mathrm{d} 7,22$ & $6,93 \mathrm{~s} / \mathrm{d} 7,18$ & $-1,37 \mathrm{~s} / \mathrm{d}-2,00$ & $-1,65 \mathrm{~s} / \mathrm{d}-1,98$ & $12,0 \mathrm{~s} / \mathrm{d} 57,5$ & $15,6 \mathrm{~s} / \mathrm{d} 41,3$ \\
\hline kondisi & $\begin{array}{l}\text { Dominan agresiv } \\
\text { (undersaturated) }\end{array}$ & $\begin{array}{l}\text { Dominan agresiv } \\
\text { (undersaturated) }\end{array}$ & Fluktuasi cukup tinggi & Fluktuasi rendah & $\begin{array}{l}\text { Cukup masukan gas } \\
\text { karbondioksida dari } \\
\text { conduit }\end{array}$ & $\begin{array}{l}\text { Banyak masukan gas } \\
\text { karbondioksida dari } \\
\text { conduit }\end{array}$ & $\begin{array}{l}\text { Jumlah kalsium } \\
\text { terlarut sedikit }\end{array}$ & $\begin{array}{l}\text { Jumlah kalsium } \\
\text { terlarut sedikit }\end{array}$ \\
\hline 2 & \multicolumn{2}{|c|}{$\begin{array}{l}\text { Hubungan }\left(\mathbf{R}^{2}\right) \text { antara SI kalsit dan Log } \\
\mathbf{P}_{\mathrm{CO} 2}\end{array}$} & \multicolumn{2}{|c|}{ Hubungan $\left(R^{2}\right)$ antara SI kalsit dan Log } & \multicolumn{2}{|c|}{ Hubungan $\left(\mathrm{R}^{2}\right)$ antara $\mathrm{SI}$ kalsit dan $\mathrm{pH}$} & & \\
\hline Nilai & 0,008 (negatif) & 0,834 (negatif) & 0,729 (positif) & 0,745 (positif) & 0,700 (positif) & 0,354 (positif) & & \\
\hline kondisi & $\begin{array}{l}\text { Hampir tidak ada } \\
\text { hubungan antara } \\
\text { besar kecilnya Log } \\
\text { P co2 dan naik } \\
\text { turunnya SI kalsit }\end{array}$ & $\begin{array}{l}\text { Semakin besar nilai SI } \\
\text { maka semakin kecil } \\
\text { nilai Log } \mathrm{P}_{\mathrm{CO} 2} \\
\text { (determinasi kuat) }\end{array}$ & $\begin{array}{l}\text { Naik/turun-nya nilai SI } \\
\text { tergantung dari } \\
\text { naik/turun-nya nilai } \\
\text { kalsium terlarut } \\
\text { (determinasi cukup } \\
\text { kuat) }\end{array}$ & $\begin{array}{l}\text { Naik/turun-nya nilai SI } \\
\text { tergantung dari } \\
\text { naik/turun-nya nilai } \\
\text { kalsium terlarut } \\
\text { (determinasi cukup kuat) }\end{array}$ & $\begin{array}{l}\text { Naik/turun-nya nilai SI } \\
\text { tergantung dari } \\
\text { naik/turun-nya pH } \\
\text { (determinasinya cukup } \\
\text { kuat) }\end{array}$ & $\begin{array}{l}\text { Naik/turun-nya nilai SI } \\
\text { ada hubungannya } \\
\text { dengan naik/turun-nya } \\
\mathrm{pH} \text { (determinasinya } \\
\text { lemah) }\end{array}$ & & \\
\hline $\begin{array}{c}\text { Proses } \\
\text { hidrogeokimia }\end{array}$ & $\begin{array}{l}\text { Water-rock interaction } \\
\text { berupa pelarutan } \\
\text { mineral kalsit. Musim } \\
\text { ini tidak terbentuk } \\
\text { ornamen gua. }\end{array}$ & $\begin{array}{l}\text { Water-rock interaction } \\
\text { berupa pelarutan } \\
\text { mineral kalsit. Kecil } \\
\text { kemungkinan terbentuk } \\
\text { ornamen gua yang } \\
\text { spektakuler. }\end{array}$ & $\begin{array}{l}\text { Water-rock interaction } \\
\text { (pelarutan mineral } \\
\text { kalsit). }\end{array}$ & $\begin{array}{l}\text { Water-rock interaction, } \\
\text { tetapi tidak banyak } \\
\text { merubah nilai kalsium } \\
\text { terlarut di air }\end{array}$ & $\begin{array}{l}\text { Water-rock interaction } \\
\text { berupa pelarutan } \\
\text { mineral kalsit. }\end{array}$ & \begin{tabular}{|l|} 
Fluktuasi $\mathrm{pH}$ dan $\mathrm{SI}$ \\
tidak sama saat kejadian \\
banjir.
\end{tabular} & & \\
\hline \multicolumn{9}{|c|}{ Air sungai bawah tanah } \\
\hline 1 & \multicolumn{2}{|c|}{ SI kalsit } & \multicolumn{2}{|c|}{$\mathrm{pH}$} & \multicolumn{2}{|c|}{ Log $\mathrm{P}_{\mathrm{cO} 2}$} & \multicolumn{2}{|c|}{$\mathrm{Ca}^{2+}(\mathrm{ppm})$} \\
\hline Nilai & $-0,51 \mathrm{~s} / \mathrm{d}-1,31$ & $-0,12 \mathrm{~s} / \mathrm{d}-1,79$ & $6,52 \mathrm{~s} / \mathrm{d} 7,12$ & $6,46 \mathrm{~s} / \mathrm{d} 7,03$ & $-1,47 \mathrm{~s} / \mathrm{d}-1,95$ & $-1,19 \mathrm{~s} / \mathrm{d}-1,79$ & $31,8 \mathrm{~s} / \mathrm{d} 42,7$ & $67,7 \mathrm{~s} / \mathrm{d} 134,4$ \\
\hline kondisi & $\begin{array}{l}\text { Dominan agresiv } \\
\text { (undersaturated) }\end{array}$ & $\begin{array}{l}\text { Dominan agresiv } \\
\text { (undersaturated) }\end{array}$ & $\begin{array}{l}\text { Relatif stabil pada } \mathrm{pH} \\
\text { rendah }\end{array}$ & $\begin{array}{l}\text { Fluktuasi rendah pada } \mathrm{pH} \\
\text { rendah }\end{array}$ & $\begin{array}{c}\text { Cukup masukan } \\
\text { karbondioksida dari } \\
\text { conduit }\end{array}$ & $\begin{array}{l}\text { Banyak masukan gas } \\
\text { karbondioksida dari } \\
\text { conduit }\end{array}$ & $\begin{array}{l}\text { Jumlah dan } \\
\text { fluktuasi sedikit }\end{array}$ & $\begin{array}{l}\text { Jumlah dan fluktuasi } \\
\text { kalsium terlarut besar }\end{array}$ \\
\hline 2 & \multicolumn{2}{|c|}{$\begin{array}{c}\text { Hubungan }\left(\mathbf{R}^{2}\right) \text { antara SI kalsit dan Log } \\
\mathrm{P}_{\mathrm{CO} 2}\end{array}$} & \multicolumn{2}{|c|}{ Hubungan $\left(R^{2}\right)$ antara SI kalsit dan Log } & \multicolumn{2}{|c|}{ Hubungan $\left(R^{2}\right)$ antara $S I$ kalsit dan $\mathrm{pH}$} & & \\
\hline & 0,806 (negatif) & 0,843 (negatif) & 0,641 (positif) & 0,161 (positif) & 0,940 (positif) & 0,892 (positif) & & \\
\hline kondisi & $\begin{array}{l}\text { SI kalsit naik ketika } \\
\text { pasokan gas } \\
\text { karbondioksida turun } \\
\text { (determinasi kuat) }\end{array}$ & $\begin{array}{l}\text { SI kalsit naik ketika } \\
\text { pasokan gas } \\
\text { karbondioksida turun } \\
\text { (determinasi kuat) }\end{array}$ & $\begin{array}{l}\text { Determinasi cukup } \\
\text { kuat, SI kalsit } \\
\text { tergantung fluktuasi } \\
\text { kalsium terlarut }\end{array}$ & $\begin{array}{l}\text { Hampir tidak ada } \\
\text { determinasi, SI kalsit tidak } \\
\text { tergantung fluktuasi } \\
\text { kalsium terlarut }\end{array}$ & $\begin{array}{l}\text { Determinasi kuat, } \mathrm{SI} \\
\text { kalsit tergantung } \\
\text { fluktuasi pH dalam air }\end{array}$ & $\begin{array}{l}\text { Determinasi kuat, } \mathrm{SI} \\
\text { kalsit tergantung } \\
\text { fluktuasi pH dalam air }\end{array}$ & & \\
\hline $\begin{array}{l}\text { Proses } \\
\text { hidrogeokimia }\end{array}$ & $\begin{array}{l}\text { Dominan pelarutan } \\
\text { mineral kalsit, } \\
\text { karbondioksida dari } \\
\text { aliran conduit }\end{array}$ & $\begin{array}{l}\text { Dominan pelarutan } \\
\text { mineral kalsit, } \\
\text { karbondioksida dari } \\
\text { aliran conduit }\end{array}$ & $\begin{array}{l}\text { Water- rock } \\
\text { interacton berupa } \\
\text { pelarutan kalsit, tidak } \\
\text { terjadi pertumbuhan } \\
\text { ornamen }\end{array}$ & $\begin{array}{l}\text { Pelarutan mineral kalsit. } \\
\text { Determinasi rendah } \\
\text { karena perubahan } \\
\text { kandungan kalsium } \\
\text { terlarut tidak selalu } \\
\text { sama dengan } \\
\text { perubahan parameter } \\
\text { yang mempengaruhi SI }\end{array}$ & $\begin{array}{l}\text { Pelarutan mineral kalsit } \\
\text { pada } \mathrm{pH} \text { rendah }\end{array}$ & $\begin{array}{l}\text { Pelarutan mineral kalsit } \\
\text { pada } \mathrm{pH} \text { rendah }\end{array}$ & & \\
\hline
\end{tabular}

